\title{
COMMERCIAL REPUBLICANISM IN THE DUTCH GOLDEN AGE
}

\author{
THE POLITICAL THOUGHT OF \\ JOHAN \& PIETER DE LA COURT
}

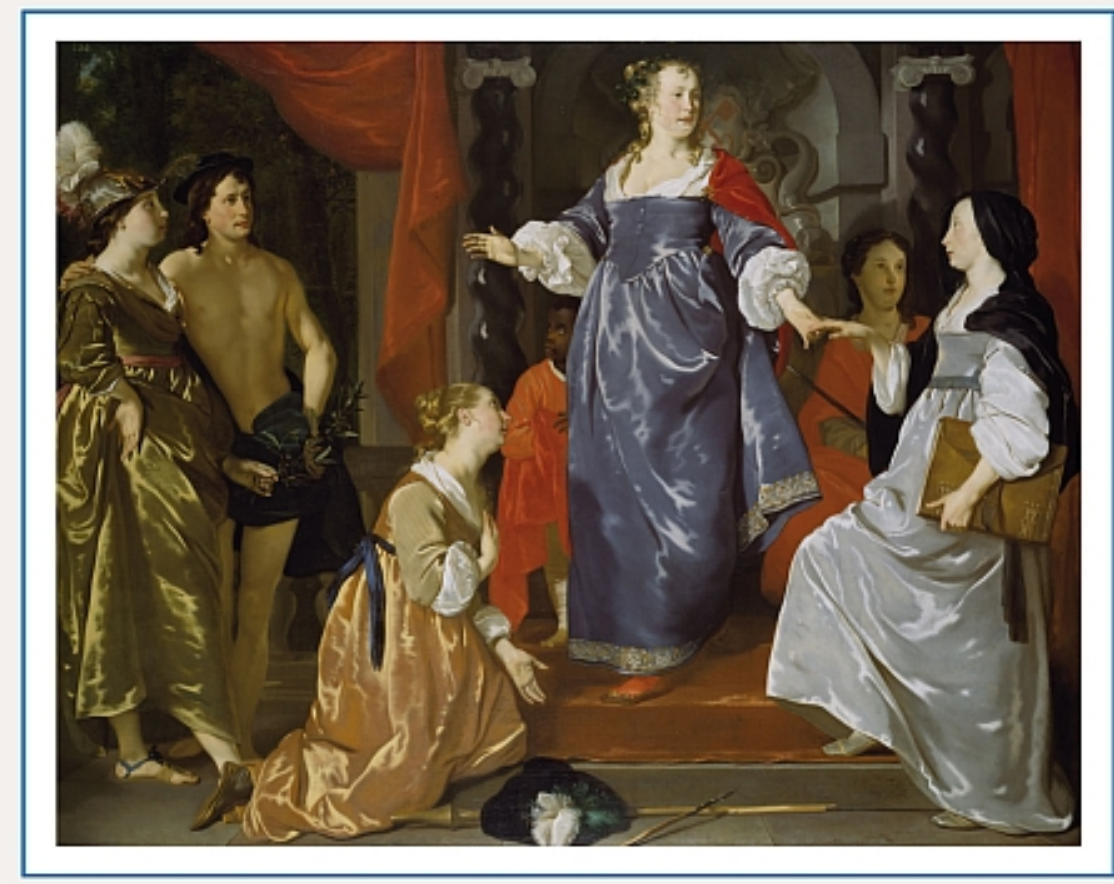

\section{By}

ARTHUR WESTSTEIJN

Series Editors: TERENCE BALL, JÖRN LEONHARD \& WYGER VELEMA 
Commercial Republicanism in the Dutch Golden Age 


\title{
Studies in the History of Political Thought
}

\author{
Edited by \\ Terence Ball, Arizona State University \\ Jörn Leonhard, Albert-Ludwigs-Universität Freiburg \\ Wyger Velema, University of Amsterdam \\ Advisory Board \\ Janet Coleman, London School of Economics \\ and Political Science, UK \\ Vittor Ivo Comparato, University of Perugia, Italy \\ Jacques Guilhaumou, CNRS, France \\ John Marshall, Johns Hopkins University, Baltimore, USA \\ Markku Peltonen, University of Helsinki, Finland
}

VOLUME 7 


\title{
Commercial Republicanism in the Dutch Golden Age
}

The Political Thought of Johan \& Pieter de la Court

\author{
By \\ Arthur Weststeijn
}

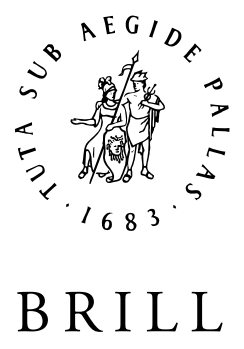

LEIDEN • BOSTON

2012 
The digital edition of this title is published in Open Access.

Cover illustration: Abraham van den Tempel, The City of Leiden Receives the Textile Industry, 1651. Museum de Lakenhal, Leiden.

This book is printed on acid-free paper.

Library of Congress Cataloging-in-Publication Data

Weststeijn, Arthur.

Commercial republicanism in the Dutch Golden Age : the political thought of Johan \& Pieter de la Court / by Arthur Weststeijn.

p. cm. -- (Studies in the history of political thought, ISSN $1873^{-6} 648$; v. 7)

Includes bibliographical references and index.

ISBN 978-90-04-22139-o (hbk. : acid-free paper) 1. Netherlands--Politics and

government--1648-1795. 2. Court, Johan de la, 1622-166o--Political and social views. 3. Court, Pieter de la, 1618?-1685--Political and social views. 4. Republicanism--Netherlands--History--17th century. 5. Merchants--Political activity--Netherlands--History--17th century. 6. Netherlands--Commercial policy. 7. Netherlands--Intellectual life--17th century. 8. Political culture--Netherlands--History-17th century. 9. Political science--Netherlands--History--17th century. 10. Economics-Netherlands--History--17th century. I. Title.

JA84.N2W48 2012 321.8'6--dc23

2011042155

This publication has been typeset in the multilingual "Brill" typeface. With over 5,100 characters covering Latin, IPA, Greek, and Cyrillic, this typeface is especially suitable for use in the humanities. For more information, please see www.brill.nl/brill-typeface.

ISSN $1873-6548$

ISBN 9789004221390

ISBN 9789004221406 (e-book)

Copyright 2012 by Koninklijke Brill NV, Leiden, The Netherlands.

Koninklijke Brill NV incorporates the imprints Brill, Global Oriental, Hotei Publishing, IDC Publishers, Martinus Nijhoff Publishers and VSP.

All rights reserved. No part of this publication may be reproduced, translated, stored in a retrieval system, or transmitted in any form or by any means, electronic, mechanical, photocopying, recording or otherwise, without prior written permission from the publisher.

Authorization to photocopy items for internal or personal use is granted by Koninklijke Brill NV provided that the appropriate fees are paid directly to The Copyright Clearance Center, 222 Rosewood Drive, Suite 910, Danvers, MA 01923, USA.

Fees are subject to change. 
Volli, e volli sempre, e fortissimamente volli (Vittorio Alfieri, 1783) 



\section{CONTENTS}

List of Illustrations........................................................................................... ix

Acknowledgments...........................................................................................

A Note on References .........................................................................................ii

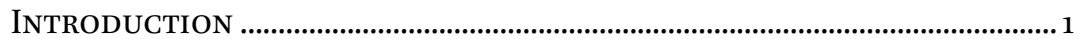

I The MAKING OF AN OEUVRE ................................................................ 25

A Humanist Education ............................................................................226

The Dutch Debate....................................................................................... 37

The Making of an CEuvre ........................................................................... $5^{0}$

Conclusion: Politics as a Ballgame .............................................................. 63

II The RHetoric of THE MARKet ..........................................................69

Persuading the Passions.................................................................................... 71

In the Public Arena: Rhetoric in Action .................................................... 87

Fables and Frankness .......................................................................... 114

Conclusion: The Rhetoric of the Market ...............................................133

III WISE MERCHANTS ................................................................................. 141

Hobbes \& the Foundation of the Commonwealth..............................142

Citizenship in Theory and Practice ...........................................................157

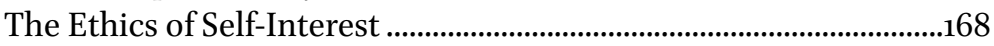

Representing the Wise Merchant.........................................................184

Conclusion: Commercial Citizenship in Perspective ..........................200

IV The Commercial Commonwealth....................................................205

The Batavian Athens......................................................................................206

The Politics of Free Trade.........................................................................224

Monarchy Dethroned ..........................................................................242

Towards a Merchant Democracy …......................................................261

Conclusion: The Radical Republic ......................................................2279 


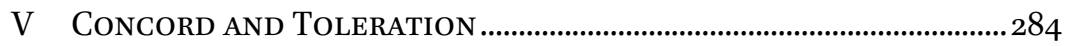

The Erasmian Moment.......................................................................286

The Relation between Church and State ............................................298

Toleration: Pluralism for the Sake of Unity ............................................316

Epilogue: From Freedom of Religion to Freedom

of Speech?

Conclusion: The Brothers De la Court and the Commercial

Republican Tradition.

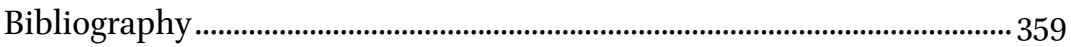

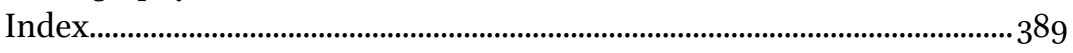




\section{LIST OF ILLUSTRATIONS}

The colour plates can be found after p.178.

Plate A. Abraham van den Tempel, Pieter de la Court, 1667. Collection Rijksmuseum, Amsterdam. Acquisition with support of the Vereniging Rembrandt.

Plate B. Abraham van den Tempel, Catharina van der Voort, 1667. Collection Rijksmuseum, Amsterdam. Acquisition with support of the Vereniging Rembrandt.

Plate C. Godfried Schalcken, Pieter de la Court, 1679. Museum de Lakenhal, Leiden.

Plate D. Abraham van den Tempel, The City of Leiden Receives the Textile Industry, 1651. Museum de Lakenhal, Leiden.

Fig. 1. Frontispiece to Johan and Pieter de la Court, Consideratien van Staat, ofte Polityke Weeg-schaal, 1661.

Amsterdam University Library, OTM: OG 63-822.

Fig. 2. Joost van den Vondel, Op de Waeg-schaal, 1618.

Amsterdam University Library, OTM: Pr. G16a

Fig. 3. Frontispiece to Johan and Pieter de la Court, Politike

Discoursen, 1662. Amsterdam University Library, OTM:

OG 63-7504

Fig. 4. Frontispiece to Pieter de la Court, Historie der Gravelike Regering in Holland, 1662. Amsterdam University Library, OTM: OK 61-565.

Fig. 5. Frontispiece to Pieter de la Court, Aanwysing der heylsame politike gronden en maximen, 1669. Amsterdam University Library, OTM: O 63-3745 
Fig. 6. "A Frenchman and a Dutchman in the Kingdom of Apes," from Pieter de la Court, Sinryke Fabulen, 1685. Amsterdam University Library, OTM: OK 63-2796 .112

Fig. 7. "The frogs and a log," from Pieter de la Court, Sinryke Fabulen, 1685. Amsterdam University Library, OTM: OK 63-2796.

Fig. 8. "A boatman's tale," from Pieter de la Court, Sinryke Fabulen, 1685. Amsterdam University Library, OTM: OK 63-2796.

Fig. 9. "The charcoal burner and the textile entrepreneur," from Pieter de la Court, Sinryke Fabulen, 1685. Amsterdam University Library, OTM: OK 63-2796 126

Fig. 10. "The fox and the mask," from Pieter de la Court, Sinryke Fabulen, 1685. Amsterdam University Library, OTM: OK 63-2796

Fig. 11. Godaert Kamper, Pieter de la Court and Elisabeth Tollenaar, 1657/58. Formerly Utrecht, Diaconessenhuis. Present location unknown

Fig. 12. "The guilds and a city," from Pieter de la Court, Sinryke Fabulen, 1685. Amsterdam University Library, OTM: OK 63-2796. 


\section{ACKNOWLEDGMENTS}

Late in his life, when John Milton looked back upon the travels of his youth, one place in particular nourished his nostalgia: Florence, "a city which I have always valued above the rest for the elegance of its dialect and of its genius". Milton especially remembered his frequent visits to one of Florence's principal delights, its "private academies - an institution which deserves the highest commendation, as calculated to preserve at once polite letters and friendly intercourse". Much has changed in the centuries since, and I doubt whether anyone these days would share Milton's praise for the Florentine dialect. Nonetheless, the commendable phenomenon of the private academy has luckily endured the whips and scorns of time: in the green hills overlooking Florence, in the villas where Milton's humanist predecessors escaped the heat and fever of the city below, the European University Institute still cultivates the blessed combination of polite letters and friendly intercourse.

This book is based on a doctoral thesis largely researched and written in this unrivalled setting, and first of all I am grateful to the European University Institute for, simply, its mere existence. I have been particularly fortunate to be supervised at the EUI by Martin van Gelderen, whose intellectual guidance has been vital for my tentative steps on the academic path, and whose exceptionally stimulating seminars, workshops, and convegni offered a continuous source of inspiration in the best Florentine tradition. Many others at the EUI have also played an important role in the development of my research. In particular, I would like to thank Tony Molho for his encouraging comments at the start of the project, and Rainer Bauböck for similar support at the very end when he kindly agreed to be a member of the examining jury of my doctoral thesis. I am also greatly indebted to Susan Karr for her exemplary critical eye, and to three occasional visitors, Jonathan Scott, Kevin Sharpe, and Tim Stanton, who provided a listening ear and subsequent valuable advice. Meanwhile, all members of the Irish-Iberian-Italian axis in Florence proved day by day (and often night by night) that Europe, like any empire, is at its best in the peripheries.

At the other side of the Atlantic, I had the opportunity to spend a few months in the very different but equally thrilling scenery of the frozen lakes that surround the University of Wisconsin at Madison. Johann 
Sommerville offered me a warm welcome in wintry Madison as well as very helpful comments on an early draft of my argument. I am equally grateful to the questions, criticism and enthusiasm of audiences at conferences in both the Old World and the New, from Budapest to Los Angeles and from Chicago to Berlin. Back in The Netherlands, Alex Bick, Jan Hartman and Eric Schliesser suddenly turned up as fellow De la Courtwatchers with lots of insights and inspiration. I would also like to express my deepest gratitude to Jonathan Israel for generously sharing his knowledge and criticism on numerous crucial stages throughout the making of this book.

A special word of thanks goes to my colleagues at the Faculty of Philosophy at the University of Groningen, in particular to Lodi Nauta, whose exceptional ability to combine scholarly rigour with intellectual openness stands as a model to academics worldwide. My new home and my new colleagues at the Royal Netherlands Institute in Rome have meanwhile provided a setting of polite letters and friendly intercourse that even Florence can hardly match. Yet my largest debt of all is to Wyger Velema, who first suggested the topic of this book to me, and whose characteristic enthusiasm (and unparalleled wine cellar by Dutch standards) has been crucial in keeping me on the track ever since. For once, therefore, the commonplace tribute is true: without Wyger this book would never have been written.

I dedicate this book to my parents, who from the earliest days have taught me the power and the glory of the written word - by showing not only that the pen is the mightiest sword, but also that books, read or unread, are by far the nicest wallpaper. 


\section{A NOTE ON REFERENCES}

The history behind the œuvre of Johan (1620-1660) and Pieter de la Court (1618-1685) is a complex tale of brotherly collaboration, sudden death, and endless revisions. This tale, told in full in chapter 1 below, requires some preliminary remarks.

The lack of historical evidence makes it in many cases impossible to assert with utter certainty who of the two brothers wrote what exactly. Therefore, I consistently speak of 'the De la Courts' in plural, and only of 'De la Court' in singular when there is actual proof that the author was Pieter de la Court. This means that all references to the original argument from the Politike Weeg-schaal, to the Politike Discoursen, and to Welvaren speak of the two De la Courts as authors, whereas all references to the revisions in the Politike Weeg-schaal and to the treatises Interest van Holland, Aanwysing, and Sinryke Fabulen speak of a single De la Court.

Besides, for the sake of clarity I refer always to the most complete editions of the brothers' works, or, in the case of manuscripts, to the available published editions. This means that all short references to their treatises stand for the following:

- Politike Weeg-schaal refers to the fourth, revised edition of Consideratien van Staat, ofte Politike Weeg-schaal (Amsterdam: Dirk Dirksz, 1662), with the respective part, book, and chapter.

- Politike Discoursen refers to the second, revised edition of Politike Discoursen, handelende in Ses onderscheide Boeken van Steeden, Landen, Oorlogen, Kerken, Regeeringen en Zeeden (Amsterdam: 'Ciprianus vander Gracht', 1662), with the respective part, book, and chapter.

- Interest van Holland refers to Interest van Holland, ofte gronden van Hollands-welvaren (Amsterdam: 'Cyprianus vander Gracht', 1662), with the respective chapter.

- Aanwysing refers to the first edition of Aanwysing der heilsame politike Gronden en Maximen van de Republike van Holland en West-Vriesland (Leiden and Rotterdam: Hakkens, 1669), with the respective part and chapter.

- Sinryke Fabulen refers to Sinryke Fabulen, verklaart en toegepast tot alderley zeede-lessen, dienstig om waargenoomen te werden in het menschelijke en burgerlijke leeven (Amsterdam: Hieronymus Sweerts, 1685). 
- Welvaren refers to Hetwelvaren van Leiden. Handschrift uit hetjaar 1659, ed. F. Driessen (The Hague: Martinus Nijhoff, 1911), with the respective chapter.

When quoting from these works I maintain in translation the typography, including capitals and italics, of the original Dutch version that appears in full in the footnotes; unless stated otherwise, translations are mine. Full details of the entire oeuvre of the brothers De la Court are listed in the bibliography. 


\section{INTRODUCTION}

New Year's Eve 1672. On the threshold of what would become the most disastrous year in the Dutch Golden Age, Pieter de la Court, a textile entrepreneur from Leiden, was in Hamburg. Business had brought him there, but De la Court's expertise went well beyond the intricacies of the market: in the wee hours of the night he took up his pen and wrote a long letter to a like-minded author on the other side of the North Sea, the English republican James Harrington. De la Court told Harrington that the plans being laid for a future French-English attack against the Dutch Republic were unlikely to be successful. War, he argued, would only serve the hegemonic cause of Louis XIV, and the English people would therefore "rather see the king of France reduced than the states of the United Netherlands". Moreover, even if England did attack, its armies would be no match for the Dutch, who had "with small means, but because of greater frugality, wisdom and resolution - which are generally to be found in all republics - endured and humiliated the remarkably larger resources and power of the king of England."

With these words De la Court claimed the superiority of the Dutch Republic, which was prospering because of its commerce, liberty and concord, qualities not to be found in England: "Since England is ruled by a king and all powerful kingdoms are mostly restrained by interior or foreign wars that their kings deliberately wage against neighbours, therefore it is apparent that during those times trade and navigation could not be maintained there at all." ${ }^{\prime 2}$ In short, the English, subjected to the arbitrary

\footnotetext{
${ }^{1}$ Pieter de la Court, "Consideratiën over den gevreesden oorlog, die de koningen van Engeland ende Vrankrijk souden mogen ofte konnen aandoen," addressed to James Harrington, written on 31 December 1671 and signed on 1 January 1672 . The original draft of this letter is in the The Hague Royal Library, Ms 75 C37, fols. 273-282. Apparently, De la Court wrote the letter at the explicit request of Harrington, but there is no evidence of any other correspondence. The letter is published in J.H. Kernkamp (ed.), "Twee 'niet ter drukperse bereide' geschriften van Pieter de la Court," Bijdragen en mededelingen van het historisch genootschap 56 (1935), 195-214, 198-199: “... veel liever den koning van Vrankrijk als de staten der Vereenigde Neederlanden verminderd sagen ... met kleine geldmiddelen, door grotere spaarsaam-, wijs- en standvastigheid - die gemeenelik in alle republiken gevonden werden - die merkelik meerdere subsidiën en magt des konings van Engeland verduurd ende te schande gemaakt hebben."

2 Ibidem, 205: "Want vermits Engeland geregeerd werd van eenen koning ende alle magtige koningryken den meesten tijd onderworpen zijn binnenlandse oorlogen, ofte ook
} 
greed of a monarch, would never be able to achieve the same commercial splendour as the United Provinces. And therefore, as De la Court went on to explain to Harrington, England should not try to subdue the Dutch but rather join them in a coalition against France, a state with a comparable outlook and therefore England's real adversary. As De la Court concluded:

According to the interest of the king of England and his subjects it is totally unadvisable to form an alliance with the king of France to subdue the Free Netherlands. On the contrary, it very well suits the interests of the king of England and his subjects to form with other close neighbours and especially with the State of the Free Netherlands an alliance for mutual protection against that all-powerful and otherwise all-swallowing France. ${ }^{3}$

The further events of the following year would prove that De la Court had been far too optimistic in his assumptions. England (or at least its king) did find it in its interest to join the French in their assault on the United Provinces, eventually with catastrophic results for the Dutch. That summer, when almost the whole country was occupied by the invading troops and only the province of Holland could stand firm by flooding part of the land as a natural barrier against the enemy armies, the republican government of 'True Liberty' collapsed and the Prince of Orange was called back to power by an outraged populace. Four days after Grand Pensionary Johan de Witt survived a first assault on his life (only to be massacred in an orgy of violence two months later), De la Court started to make safe his belongings and fled for Antwerp. He did so for good reason: according to legend, on one of those hot days of the summer of 1672 an unruly group of Orangists gathered in front of De la Court's former house in Leiden. When they did not find who they were looking for, the aggressors bound a dog with its belly cut-open to the tree in front of the house, put a candle in its

buitenlandse, die hunne koningen teegen de naburen moedwilliglik voeren, soo is kennelik, dat gedurende denselven tijd de koopmanschap ende zeevaart aldaar gansch niet gehanteerd soude kunnen warden."

3 Ibidem, 213: “... dat volgens het interest des konings van Engeland ende syner onderdanen gansch ongeraden is met den koninge van Vrankrijk een verbond aan te gaan ter verdrukkinge der Vrye Neederlanden. Ende dat het in teegendeel met des konings van Engeland ende syner onderdanen interessen seer wel overeenkomt met andere omleggende naburen ende insonderheid met den Staat der Vrye Neederlanden te maken verbonden ter gemeene bescherminge teegen dat oovermagtige ende andersins alles inslokken willende Vrankrijk." De la Court's argument is strikingly similar to a pamphlet of the English republican Slingsby Bethel, written almost exactly a year before, The Present Interest of England Stated (London, 1671), which in turn explicitly refers to De la Court's Interest van Holland (1662). 
cloven body and left a note saying "De la Court, if you won't shut your mouth, we'll treat you as we did this dog". ${ }^{4}$ Not eager to verify the truth of this menace, De la Court chose the surest way out.

De la Court's reputation as a spokesman of the previous regime, which so firmly discredited him in the eyes of the Orangist populace, dated back to the 1660 s. At the beginning of that decade, he had published a series of political treatises about the nature of good government and its practical implications for the situation in Holland, treatises that were partly written by his younger brother Johan, who died in 1660 before any of them had been published, and partly by Pieter de la Court himself. Together, the brothers De la Court had thus constructed an ouvre that was highly contested and debated throughout the Republic. With their radical plea for a truly republican government devoid of any monarchical element such as a Stadholder, for far-reaching religious toleration and comprehensive economic liberty, the brothers were seen by many as advocates of the disputed government in power, the oligarchic regime of regents gathered around De Witt. In the heated political debate of the period, a stream of pamphlets followed which denounced the "false calumnies and adorned lies", the "never sufficiently despised", "rebellious" writings of De la Court, this "new born Dutch Cromwell alias Leiden Quaker". ${ }^{5}$ Such insinuations were particularly powerful in 1672 when the country, on the brink of total collapse, needed a scapegoat to blame for its downfall.

Yet the works of the brothers De la Court are not only of interest in the context of this turbulent era. Above all, they stand out as a highly significant contribution to early-modern European political thought in general. Merging various elements from natural law theory, reason of state literature, the 'new philosophy' of the age and classical and contemporary historical writing, their œuvre provides a distinct argument for a republican

\footnotetext{
4 "La Court zoo je niet snoert Uw mond, Doen we je als deezen hond." The story is told in B.W. Wttewaall, Proeve uit een onuitgegeven staathuishoudkundig geschrift, het Welvaren der stad Leyden (Leiden, 1845), xxiv-Xxv, but its sources are unclear.

5 Haeghs Hof-Praetje, ofte 't samen-spraeck tusschen een Hagenaer, Amsterdammer, ende Leyenaar. Op ende tegens de valsche calumnien ende versierde leugenen van Pieter la Court, gestelt in sijn alsoo genoemde Intrest van Holland ende gronden van 't Hollands welvaren (Leiden, 1662); Een onverwelckbare kroon, gevlochten op het noyt-genoegh verachte boeck, genaemt de Hollantsche Intrest, door Pieter la Court [1662]; Op de op-roerige schriften van Pieter la Court, door hem uyt-gegeven onder de naem van V.D.H. en D.C. [1662]; De gansche distructie van den nieuw-gebooren Hollantschen Cromwel alias Leydtschen Quaker; genaemt t'Intrest van Hollandt, ofte gronden van's Hollants welvaren (Schiedam, [1663]); Helle-vreucht over den herbooren, ende nieu-regeerende Hollantschen Cromwel alias s'Hollandts Intrest ende Stadthouders Regeringh Beschrijver [1662].
} 
society in which liberty and commerce intertwine. Their ideal republic is a commonwealth of free citizens who engage in virtuous trade, harnessing their self-love to the common good in a harmony of public and private interests - a harmony that is not constrained by the arbitrary powers of others (as happened, according to De la Court, in Harrington's England) but rationally regulated by the rule of law. In a highly rhetorical style, crammed with popular expressions and jokes, vivid historical examples and Aesopian fables, the brothers De la Court set out their theory in the vernacular, clearly addressing a broad contemporary audience. Nonetheless, the appeal of their works has reached wider horizons. Though obviously being a product of the time and place in which it was formulated, the political thought of the De la Courts transcends its relevance within this context as it amounts to the most passionate republican theory in all of Dutch history - and one of the most radical critiques of monarchy in Ancien Régime Europe.

This book provides a comprehensive, strongly contextualized analysis and interpretation of the political thought of the brothers De la Court. Starting from the letter to Harrington in which De la Court emphasized the intrinsic link between republican liberty and commercial splendour, it argues that their œuvre pivots on the unconditional embrace of commerce as the mainstay of republican politics. Through their selfrepresentation as 'wise merchants', outspoken truth-tellers schooled in political insight and mercantile expertise, the De la Courts maintained that a true republic could only be a commercial commonwealth, and that trade could only prosper under a truly republican government. As the letter to Harrington reveals, this commercial republicanism originated from the mercantile culture of the Dutch Republic, yet within a context of international comparison, collaboration and competition, crossing the North Sea from Hamburg to London, discussing the combined fate of England, France and the Netherlands, employing the international concept of 'interest' as the general measure of the res publica, the common good. Accordingly, the republican thought of the De la Courts must be studied by looking at the interaction between the Dutch and European contexts of their intellectual endeavour.

The general purpose of this book is therefore twofold. First, I intend to show how the brothers De la Court, armed with a large theoretical arsenal of international political languages, engaged in a wide-ranging critique of the Dutch republican experience during the seventeenth century. The rhetorical characteristics of this critique reveal in particular the importance of rhetoric and ideological conflict in the political culture of the 
Dutch Golden Age. Secondly, I aim to argue that the commercial core of the republican thought of the De la Courts, formulated in the most successful early-modern republic at the height of its power, is of fundamental significance for our understanding of the development of republicanism in Europe at large between the Renaissance and the Enlightenment. As an ideology of active civic participation in politics, free of any form of arbitrary domination, seventeenth-century republicanism was strongly informed by the rise of commercial society.

\section{RepubliCANism: The DebATE}

Was there ever a single unitary tradition of republican thought in earlymodern Europe? Whoever considers the recent historiographical debate on the 'republican heritage' should hesitate to answer this question in the affirmative. On the one hand, grand-scale attempts to give an all-encompassing overview of the republican tradition have been rightly disputed because of their one-sidedness and lack of attention to geographical variety. On the other, fruitful research of the diverse and dispersed aspects of this tradition has apparently fragmented an unequivocal concept of what republicanism then actually means. Therefore, one may wonder whether it still makes sense to speak about early-modern republicanism at all. This introductory section argues that the answer to this last question is a far more straightforward 'yes'.

By far the most important and influential representative of the idea that one large tradition of republican thought can be excavated from below the surface of early-modern political thought is John Pocock. In his epoch-making study The Machiavellian Moment. Florentine Political Thought and the Atlantic Republican Tradition, first published in 1975, Pocock gives a grand-scale overview of a paradigmatic language of republicanism that originated in classical antiquity, was revived in the Florentine Renaissance, transported to Civil War England and ultimately came to a close with the American Revolution. It has often been remarked that Pocock's dense argument defies any attempt to summarization, but given the absolute predominance of the work in the historiographical debate, such a short synopsis is nonetheless indispensable.

According to Pocock, the republican tradition dates back to the Aristotelian portrayal of man as a zoon politikon, a political animal that actively participates in the public life of the city-state. This characterization of the good life as a vita activa civile was revived in the Florentine 
Renaissance, in particular by Niccolò Machiavelli, for whom the virtù of the free citizen who engages in the defence and expansion of liberty, formed the foundation upon which a republic can confront unpredictable fortuna. ${ }^{6}$ This Machiavellian republicanism, Pocock insists, did not entail a political program with a clearly defined objective but rather a political language that survived the downfall of the Florentine republic. Lingering on as an alternative discourse amidst natural law and reason of state theory, it re-emerged in England in the mid-seventeenth century. James Harrington is the central character in Pocock's analysis of this English resurgence and adaptation of the language of republican virtue. In his major work, The Commonwealth of Oceana (1656), Harrington argued as an English Machiavelli for an expansionist republic of land-owning citizens who participate actively in politics and are thus empowered to confront the corruptive sirens of commercial wealth. From Harrington on, the republican discourse of virtue would continue to dominate political debate in the Anglophone world until it reached its apogee across the Atlantic with the American Constitution - in Pocock's famous remark "the last act of the civic Renaissance". ${ }^{7}$ With this portrayal of a longue durée republican tradition, Pocock clearly challenged the hegemonic position of liberalism as the dominant force in seventeenthand eighteenth-century political thought. Indeed, Pocock sees liberalism, rooted in a jurisdictional language that emphasizes the rights of the citizen, as diametrically opposed to the republican language of

\footnotetext{
${ }^{6}$ In Pocock's own words: "On the one hand virtú is that by which we innovate, and so let loose sequences of contingency beyond our prediction or control so that we become prey to fortuna; on the other hand, virtú is that internal to ourselves by which we resist fortuna and impose upon her patterns of order, which may even become patterns of moral order. ... It was the virtue, as it was the end, of man to be a political animal; the polity was the form in which human matter developed its proper virtue, and it was the function of virtue to impose form on the matter of fortuna. The republic or polity was in yet another sense a structure of virtue: it was a structure in which every citizen's ability to place the common good before his own was the precondition of every other's, so that every man's virtue saved every other's from that corrupt part of whose time-dimension was fortuna.... [S] uccess was a function of virtú and virtú was a matter of the autonomy of personalities mobilized for the public good. Only in republics could it be mobilized, and every republic was a finite particular in which only a finite number of individuals could be trained and assembled to display virtú. However defined, the virtú of every individual depended on the virtú of every other; its decline was impossible to arrest once it was well started; and it must be manifested in arms as well as in citizenship, in the external world of war as well as in the civic world of justice." J.G.A. Pocock, The Machiavellian Moment. Florentine Political Thought and the Atlantic Republican Tradition, 2d. ed. (Princeton: Princeton University Press, 2003), 167, 184, 213.
}

7 Ibidem, 462. 
civic virtue. ${ }^{8}$ By highlighting the importance of this republican language for the ideological origins of the American Revolution, Pocock deliberately downplayed the role of liberalism in the creation of the modern world.

Like all great books, Pocock's The Machiavellian Moment was not only highly influential but also much debated and passionately criticized and this remains the case to this day. As Pocock remarks in the afterword to a recent new edition of his masterpiece: "I notice in the historical profession generally, and among historians of political thought in particular, a low level of tolerance, even after thirty years, toward the notion that civic virtue as studied in The Machiavellian Moment enjoys a history of its own; there is a fairly constant desire to diminish or dismiss its presence." ${ }^{9}$ This desire has appeared in various guises, and importantly, much of the resulting debate has been, like Pocock's own position, intensely politically coloured. ${ }^{10}$ All in all, though it was argued in 1992 that the study of republicanism was by then "perceptibly thinning out, like a nova entering its red giant phase", " this prophecy has proved far too hasty. Twenty years later the study of republicanism is still at the forefront of discussions of early-modern political thought, and it does not seem very close to becoming a black hole of past memories.

The historiographical criticism of Pocock's sweeping overview of the Atlantic republican tradition has, very generally, deviated into two

\footnotetext{
8 See Pocock, "Virtues, Rights, and Manners: a Model for Historians of Political Thought," in Idem, Virtue, Commerce, and History. Essays on Political Thought and History, Chiefly in the Eighteenth Century (Cambridge: Cambridge University Press, 1985), 37-50. Later, Pocock has toned down his earlier claims. Cf. the recent afterword to The Machiavellian Moment, 561: "The sharp distinction I aimed to draw was one between two conceptual premises: between a right to which one may lay claim (perhaps because it is imminent in one's nature) and a virtue which one must find in oneself and express in actions undertaken with one's equals. ... This distinction is not "hard and fast", since the two modes of understanding have constantly overlapped and interacted; but it has to be insisted on if we are to understand the tensions which have arisen in the course of this interaction."

9 Pocock, The Machiavellian Moment, 562.

${ }_{10}$ Pocock's emphasis on a distinctive Atlantic (i.e. British-American) tradition of political thought clearly follows from his view on the position of the British Commonwealth vis-à-vis continental Europe. According to Pocock, "the concept of 'Europe' is in danger of fetishization": Pocock, "Clergy and Commerce. The Conservative Enlightenment in England," in R. Ajello (ed.), L'Età dei Lumi. Studi storici sul Settecento europeo in onore di Franco Venturi 2 vols. (Naples: Jovene, 1985), vol. I: 530, note 10. See on this topic also Pocock, The Discovery of Islands. Essays in British History (Cambridge: Cambridge University Press, 2005).

" Daniel T. Rodgers, "Republicanism: the Career of a Concept," The Journal of American History 79 (1992), 11-38: 11.
} 
different directions. ${ }^{12}$ The first direction, notably pursued by Quentin Skinner, maintains the emphasis on one long-standing republican tradition from antiquity to the modern age, but with some important adjustments. These adjustments entail in particular the claim that the roots of the humanist plea for an active civic life and participatory politics do not stem principally from Aristotle, but rather from Roman theories of virtue, justice and liberty that had remained current throughout the Middle Ages. ${ }^{13}$ Above all, Skinner stresses the republican ideal of liberty in the sense of non-domination as the central characteristic of this Roman legacy, which amounted to a grand tradition of European political thought that offers a historical alternative to contemporary liberalism. ${ }^{14}$ While Skinner thus continues along the lines set by Pocock, a second line of critique, especially associated with Paul Rahe, has sought to disclaim Pocock's entire project. Rahe contends that there is an almost complete rupture between classical and Renaissance republicanism, a rupture exemplified by Machiavelli who radically departed from his classical predecessors. ${ }^{15}$ Moreover, he argues that Machiavelli's ambiguous legacy within the Anglophone Atlantic disproves the existence of a single paradigmatic language of early-modern republicanism as opposed to liberalism. ${ }^{16}$

The increasing attention over the past two decades to the role of rhetoric in political thought has resulted in a further blurring of Pocock's unitary republican tradition. One particularly important exponent of this 'rhetorical turn' is Victoria Kahn's Machiavellian Rhetoric, which again

${ }^{12}$ For an overview of the various critiques of John Pocock and of the concept of 'civic humanism', coined by Hans Baron and explicitly used by Pocock as the basis of his work on republicanism, see James Hankins, "Introduction," and William J. Connell, "The Republican Idea," in Hankins (ed.), Renaissance Civic Humanism. Reappraisals and Reflections (Cambridge: Cambridge University Press, 2000) 1-29.

${ }_{13}$ See Quentin Skinner, The Foundations of Modern Political Thought, 2 vols. (Cambridge: Cambridge University Press, 1976), vol. I, esp. 69-112; Idem, "Machiavelli's Discorsi and the Pre-humanist Origins of Republican Ideas" and "The Republican Ideal of Political Liberty," in Gisela Bock, Quentin Skinner and Maurizio Viroli (eds.), Machiavelli and Republicanism (Cambridge: Cambridge University Press, 1990), 121-141, 293-309.

${ }^{14}$ Skinner, Liberty before Liberalism (Cambridge: Cambridge University Press, 1998), and Idem, Hobbes and Republican Liberty (Cambridge: Cambridge University Press, 2008).

15 See Paul A. Rahe, Republics Ancient and Modern, 3 vols. (Chapel Hill: University of North Carolina Press, 1992). Rahe's interpretation of Machiavelli is summarized in Idem, "Situating Machiavelli," in Hankins (ed.), Renaissance Civic Humanism, 270-308.

${ }^{16}$ Rahe (ed.), Machiavelli's Liberal Republican Legacy (Cambridge: Cambridge University Press, 2006); Idem, Against Throne and Altar. Machiavelli and Political Theory under the English Republic (Cambridge: Cambridge University Press, 2008). See also the comparable argument of Vickie B. Sullivan, Machiavelli, Hobbes, and the Formation of a Liberal Republicanism in England (Cambridge: Cambridge University Press, 2004). 
highlights the ambivalence of Machiavelli's early-modern legacy. Arguing directly against Pocock, Kahn maintains that the "Machiavellian moment of Renaissance culture is a rhetorical moment": a moment that involved the claim that politics is all about contingency, and that contingency can only be mastered by the art of persuasion. Machiavelli, according to Kahn, "offered a rhetoric for dealing with the realm of de facto political power, rather than a political theory with a coherent thematic content". Accordingly, Machiavellianism did not primarily entail a republican language of virtù, but rather a way of writing about politics that emphasized the predominance of fortuna, of de facto power and the unsettling potential of language. In particular in seventeenth-century England, so Kahn maintains, this Machiavellian politics "offered a rhetoric not only for constituting but also for challenging the status quo" - a combination of political commitment and ideological critique which, with its attention for dissimulation and fraud, disconcertingly merged republicanism and tyranny. ${ }^{17}$

Following Kahn, the study of the role of rhetoric in politics has led to different appraisals of English republicanism in the seventeenth century. Thus, David Norbrook contends that the English republican experience did not suddenly come about with the beheading of Charles I, but that it was deeply rooted in the humanist rhetorical culture of earlier decades which poetically imagined republican practice. For Norbrook, therefore, republicanism already enjoyed a powerful presence before the actual establishment of the English Commonwealth. In an elegant move to reconcile Pocock and his critics, he states: "Republicanism before the $1640 \mathrm{~s}$ may not have had the practical option of being a programme rather than a language; but a distinctively republican emphasis on language could become a programme. ${ }^{18}$ At the other side of the debate, Kevin Sharpe powerfully maintains that English republicanism failed precisely because of this relation between ideology and aesthetics. Both as a language and as a programme, Sharpe argues, English republicanism did not offer a coherent alternative for the powerful set of representative images that constituted the Stuart monarchy. ${ }^{19}$

\footnotetext{
${ }^{17}$ Victoria Kahn, Machiavellian Rhetoric. From the Counter-Reformation to Milton (Princeton: Princeton University Press, 1994), ix, 4, 238.

${ }_{18}$ David Norbrook, Writing the English Republic. Poetry, Rhetoric and Politics, 1627-166o (Cambridge: Cambridge University Press, 1999), 13. See also Markku Peltonen, Classical Humanism and Republicanism in English Political Thought, 1570-1640 (Cambridge: Cambridge University Press, 1995).

19 See Kevin Sharpe, "A Commonwealth of Meanings: Languages, Analogues, Ideas and Politics," in Idem, Remapping Early Modern England. The Culture of Seventeenth-Century
} 
The issue of rhetoric has thus opened up different vistas that deviate from the path set out by Pocock. In contrast, another dominant topic in the historiographical debate on early-modern republicanism follows directly in Pocock's footsteps. This is the issue of commerce. Pocock characterizes the republican tradition as highly critical of, if not openly antagonistic to, the rise of commercial society and its capacity to distract the virtuous citizen with the temptations of private wealth and luxury. For Pocock, republican virtue was intrinsically linked to ownership of land, and 'the ideals of virtue and commerce could not therefore be reconciled to one another'. ${ }^{20}$ Nonetheless, other historians have claimed in reply that the relation between republican ideology and commercial society was not necessarily antagonistic. ${ }^{21}$ In a particularly important article, Steve Pincus has argued that many seventeenth-century English republicans merged a commitment to the common good with an embrace of commercial society. While Pocock's role model Harrington fiercely opposed commercialization, a range of other supporters of the English Commonwealth, according to Pincus, came to see "the creation and increase of commercial wealth as an unequivocal social good". ${ }^{22}$ These authors pleaded for a republic based on trade and an "economics of abundance",

Politics (Cambridge: Cambridge University Press, 2000), 38-123; and Idem, “'An Image Doting Rabble': The Failure of Republican Culture in Seventeenth-Century England," in Idem and Steven N. Zwicker (eds.), Refiguring Revolutions. Aesthetics and Politics from the English Revolution to the Romantic Revolution (Berkeley etc.: University of California Press, 1998), 25-56.

${ }^{20}$ Pocock, "Virtues, Rights, and Manners," 48. Cf. also Idem, The Machiavellian Moment, 460-461, 463-464: "We have found that a 'bourgeois ideology,' a paradigm for capitalist man as a zoon politikon, was immensely hampered in its development by the omnipresence of Aristotelian and civic humanist values which virtually defined rentier and entrepreneur as corrupt, and that if indeed capitalist thought ended by privatizing the individual, this may have been because it was unable to find an appropriate way of presenting him as citizen. ... [R] eal, inheritable, and, so to speak, natural property in land was the paradigmatic case [within republican theory]. ... The landed man, successor to the master of the classical oikos, was permitted the leisure and autonomy to consider what was to others' good as well as his own; but the individual engaged in exchange could discern only particular values - that of the commodity which was his, that of the commodity for which he exchanged it. His activity did not oblige or even permit him to contemplate the universal good as he acted upon it, and he consequently continued to lack classical rationality."

${ }^{21}$ See esp. David Wootton (ed.), Republicanism, Liberty, and Commercial Society, 16491776 (Stanford: Stanford University Press, 1994). Cf. as well Hiram Caton, The Politics of Progress. The Origins and Development of the Commercial Republic, 1600-1835 (Gainesville: University of California Press, 1988). For a wholly different argument against Pocock focusing on the related issue of collective vs. private property, see Eric Nelson, The Greek Tradition in Republican Thought (Cambridge: Cambridge University Press, 2004).

${ }^{22}$ Steven Pincus, "Neither Machiavellian Moment nor Possessive Individualism: Commercial Society and the Defenders of the English Commonwealth," The American Historical Review 103 (1998), 705-736: 722. 
with commercial Athens as the primary classical example. Within this new political economy, the concept of interest partly displaced that of civic virtue: as Marchamont Nedham, one of its most prominent representatives, observed, "Interest is the true zenith of every state and person" ${ }^{23}$ Mercantile interests and commercial activity as the basis of active political participation became the central elements of this strand of republican thought, which, as Pincus contends against Pocock, lay at the roots of liberal political philosophy.

Overall, then, Pocock's notion of a unitary republican language of Machiavellian virtù has been criticized and revised from many different angles. Yet for all their disagreements, these angles of critique share one important common feature: a fairly restricted geographical focus on the Italian Renaissance and the Anglophone Atlantic. In particular the period of the English Commonwealth dominates the scholarly debate on earlymodern republicanism. However broad or narrow one envisages the republican tradition to be, the focus is often purely English. Thus, Blair Worden, who claims that there were only a few true republicans in the seventeenth century, also states that these republicans are first and foremost to be found in England. "It was in England", Worden writes, "that the classical vision of Italian Renaissance humanists was preserved (and adapted) in the seventeenth century, and it was from there that it subsequently reentered political thought elsewhere. ${ }^{{ }_{24} 4}$ Other scholars like Skinner or Norbrook, who perceive republicanism to be present on a much larger scale, deeply rooted in humanist culture and rhetoric, also focus predominantly on the English case.

There is, however, an alternative and more international approach that does not only concentrate on republican theory but also on actual republican practice in early-modern Europe. This approach, arguably initiated by Franco Venturi's elegant series of lectures from the early 1970 , ${ }^{25}$ has recently been developed further, for example in Thomas Maissen's exceptionally comprehensive overview of the early-modern republican Werdegang of the Swiss Confederation. ${ }^{26}$ In line with Maissen's impressive and successful attempt to situate the local Swiss experience within a

${ }^{23}$ Quoted in Ibidem, 729.

${ }^{24}$ Blair Worden, "English Republicanism," in J.H. Burns and Mark Goldie (eds.), The Cambridge History of Political Thought, 1450-1700 (Cambridge: Cambridge University Press, 1991), 434-475: 444.

${ }_{25}$ See Franco Venturi, Utopia and Reform in the Enlightenment (Cambridge: Cambridge University Press, 1971).

${ }^{26}$ Thomas Maissen, Die Geburt der Republic. Staatsverständnis und Repräsentation in der frühneutzeitlichen Eidgenossenschaft (Göttingen: Vandenhoeck \& Ruprecht, 2006). 
broad international framework, the republican tradition might be defined as a 'shared European heritage', as a set of ideals and practices that spread throughout the continent. This consciously pan-European focus is central to an important two-volume collection of essays, edited by Martin van Gelderen and Quentin Skinner, which discusses early-modern republicanism over a wide continental scale, paying attention to the various local contexts in which republican ideals were formulated, from the Castilian monarchy to the Polish-Lithuanian Commonwealth. ${ }^{27}$ This broad, international approach has thus opened up a range of republican perspectives - yet not without risks. As David Wootton argues with particularly pertinent criticism, a too inclusive approach to republicanism can easily result in conceptual vagueness and erode the meaning and significance of the term 'republican' ${ }^{28}$ In the words of Johann Sommerville: "The wider the definition of republicanism we employ, the easier we will find it to discover early modern republicans. But there is a price to pay for this, since if we are too liberal in giving recognition to our republican forebears, we are in danger of granting undue acknowledgment to some other dubious characters." ${ }^{29}$

A diversified approach to republicanism, then, involves the risk of incoherence. Among the most successful and rewarding attempts to overcome that risk is the work of Jonathan Scott. ${ }^{30}$ Focusing on seventeenthcentury republicanism in England from a comparative perspective, with particular attention to the Dutch Republic, Scott establishes a convincing synthesis of republican thought that highlights its eclectic moral and

${ }^{27}$ Martin van Gelderen and Quentin Skinner (eds.), Republicanism: a Shared European Heritage, 2 vols. (Cambridge: Cambridge University Press, 2002).

${ }_{28}$ David Wootton, "Review of Republicanism: a Shared European Heritage," English Historical Review 120 (2005), 135-139. See also the careful and rewarding analyses of the classical and early-modern conceptualizations of 'republic' in Wootton, "The True Origins of Republicanism: the Disciples of Baron and the Counter-Example of Venturi," in Manuela Albertone (ed.), Il repubblicanesimo moderno. L'idea di repubblica nella riflessione storica di Franco Venturi (Napels: Bibliopolis, 2006), 271-304; and James Hankins, "Exclusivist Republicanism and the Non-Monarchical Republic," Political Theory 38 (2010), $45^{2}-482$.

${ }^{29}$ Johann P. Sommerville, "English and Roman Liberty in the Monarchical Republic of Early Stuart England," in John F. McDiarmid (ed.), The Monarchical Republic of EarlyModern England. Essays in Response to Patrick Collinson (Aldershot: Ashgate, 2007), 201-216.

${ }^{30}$ Jonathan Scott, "Classical Republicanism in Seventeenth-Century England and the Netherlands," in Van Gelderen and Skinner (eds.), Republicanism, vol. I: 61-81; Idem, Commonwealth Principles. Republican Writing of the English Revolution (Cambridge: Cambridge University Press, 2004). 
political contents. "No seventeenth-century republican", he argues, "wrote in one political language only, and most combined several, spanning the intellectual terrains of humanism, Christianity, science and law." ${ }^{11}$ These different languages mutually established the programmatic core of republicanism as a reformation of manners, a moral philosophy of selfgovernment within the commonwealth and the individual soul. Given their connected yet divergent backgrounds, English and Dutch republicans stressed different aspects of this philosophy but shared its underlying principle that such a moral reformation is only possible in a free society where no man is enslaved by the arbitrary rule of a king.

The main merit of Scott's synthesis is that he has kept the child of republicanism while throwing away the lukewarm bathwater of Pocock's approach. By emphasizing the moral core of republican thought, Scott moves beyond the narrow confines of republicanism as a unitary language, yet without succumbing to the conceptual vagueness that a broad definition has occasionally brought about. Moreover, Scott's analysis has another merit for turning attention to the experience of the seventeenthcentury Dutch Republic, after all the only genuine and long-lasting republic in the Atlantic world before the American Revolution. As the most powerful republican polity in an essentially monarchical age, the United Provinces played a pivotal role in keeping the republican heritage alive between the Renaissance and the Enlightenment. Throughout the seventeenth century, the Dutch 'republican alternative' had a significant impact on republican thought throughout Europe, including Switzerland, Italy and England, ${ }^{32}$ while its highly successful but decentralized political system has recently been heralded "as a refutation of the assumption that a 'modern' or effective state must necessarily be a centralized state". ${ }^{33}$ How did seventeenth-century Dutch political thinkers theorize about this republican prominence?

${ }^{31}$ Ibidem, 9 .

${ }^{32}$ See André Holenstein, Thomas Maissen and Maarten Prak (eds.), The Republican Alternative. The Netherlands and Switzerland Compared (Amsterdam: Amsterdam University Press, 2008). On the Dutch impact in seventeenth-century Italy, see Salvo Mastellone, "I repubblicani del Seicento e il modello politico olandese," Il pensiero politico 28 (1985), 145-163; Vittorio Conti, "Modelli repubblicani nel primo Seicento," Filosofia politica 12 (1998), 57-65; and Vittor Ivo Comparato, "La repubblica napoletana del 1647/48: Partiti, idee, modelli politici," Il pensiero politico 21 (1998), 205-238.

33 James D. Tracy, The Founding of the Dutch Republic. War, Finance, and Politics in Holland, 1572-1588 (Oxford: Oxford University Press, 2008), esp. 297-314, quote on 314 . 


\section{The Dutch Experience \& The Brothers De la CourT}

Dutch historiography has traditionally paid relatively little attention to the intellectual and ideological dimensions of politics. Consequently, the history of political thought has, unlike in the Anglophone world or in Italy, never been a thriving discipline in Dutch academia. It should therefore not come as a surprise that Pocock himself was the first to ask how Dutch republicanism could fit into the overall picture of The Machiavellian Moment. In a lecture of 1981, Pocock addressed this question fairly straightforwardly: Dutch republicanism, he argued, was dominated by jurisdictional language, it centred on sovereignty rather than virtue, and therefore it should be judged as fundamentally different from the 'Atlantic' republican tradition - if it was to be judged as republicanism at all. ${ }^{34}$ Indeed, in a later article Pocock argued that Spinoza, as the most important representative of seventeenth-century Dutch political thought, was hardly a true republican since he employed the language of rights, thus unable to stand the comparison with the virtuous republicanism of Harrington. ${ }^{35}$

In reaction to Pocock's claims, a number of Dutch intellectual historians have reassessed this rigid dichotomy between the republican thought at either side of the North Sea. The first to reply, Eco Haitsma Mulier, underlined that seventeenth-century Dutch republicans like the brothers De la Court and Spinoza used elements of both natural law discourse and the Machiavellian language of virtue at the same time, thus discrediting Pocock's paradigm of two conflicting political languages. ${ }^{36}$ Hans Blom, another specialist on Dutch early-modern political thought, equally argued against Pocock that juristic vocabularies and the language of virtue went hand in hand in the work of the De la Courts and Spinoza. ${ }^{37}$ Finally, the most extensive reply to Pocock came from the hand of Ernst

${ }^{34}$ J.G.A. Pocock, "The Problem of Political Thought in the Eighteenth Century: Patriotism and Politeness," Theoretische geschiedenis 9 (1982), 3-24. See also Idem, "Virtues, Rights, and Manners," 46-47; Idem, "The Dutch Republican Tradition," in Margaret C. Jacob and Wijnand W. Mijnhardt (eds.), The Dutch Republic in the Eighteenth Century. Decline, Enlightenment, and Revolution (Ithaca and London: Cornell University Press, 1992), 188-193; and most recently Idem, "The Atlantic Republican Tradition: The Republic of the Seven Provinces," Republics of Letters: A Journal for the Study of Knowledge, Politics and the Arts 2, 1 (2010), from http://rofl.stanford.edu/node/72 [retrieved 22 June 2011].

35 Pocock, "Spinoza and Harrington: An Exercise in Comparison," Bijdragen en mededelingen betreffende de geschiedenis der Nederlanden 102 (1987), 435-449.

${ }^{36}$ E.O.G. Haitsma Mulier, "J.G.A. Pocock and Seventeenth-Century Dutch Republicanism: A Reconsideration," Theoretische geschiedenis 9 (1982), 24-29.

${ }_{37}$ Hans W. Blom, Spinoza en De la Court. Politieke wetenschap in de zeventiende eeuw, Mededelingen vanwege het Spinozahuis, nr. 42 (Leiden: Brill, 1981). 
Kossmann. In a broad overview of Dutch republican thought in the seventeenth and eighteenth centuries, Kossmann maintained that the particularDutchrepublicanexperiencehardlymatchedPocock'scharacterization. However, he also warned that this should not to lead to the conclusion that there existed a uniquely Dutch intellectual tradition. As Kossmann stressed, "the theoretical explanation and justification of Dutch republicanism was in fact firmly based on conceptions developed outside the Netherlands and deeply influenced by foreign intellectual innovation"..$^{8}$ Dutch republicans, in short, were not constrained by their narrow national borders but made an eclectic use of a range of internationally constituted political languages. ${ }^{39}$

In the past two decades, research on Dutch republican thought within this international framework has been developed further, often clearly inspired by (though not necessarily following) the path set out by Pocock. As a result, certain key figures and periods have received the attention they deserve, particularly the period of the Dutch Revolt, the towering figure of Spinoza, and the later eighteenth century. ${ }^{40}$ Yet surprisingly, when it comes to the brothers De la Court, the historical research to date has been somewhat meagre, inconclusive, and one-sided. In particular, the few existing studies on the De la Courts all share a comparable focus

${ }_{3}^{8}$ E.H. Kossmann, "Dutch Republicanism" in Idem, Political Thought in the Dutch Republic. Three Studies (Amsterdam: KNAW, 2000), 167-193: 193. On the historiography of Dutch republicanism in its international context, see also the lively debate between Wijnand Mijnhardt and Wyger Velema in De Achttiende Eeuw 37 (2005), 75-89, 193-205.

39 Wyger Velema, “'That a Republic is Better than a Monarchy': Anti-Monarchism in Early Modern Dutch Political Thought," in Van Gelderen and Skinner(eds.), Republicanism, vol. I: $9-25$.

${ }^{40}$ For the Dutch Revolt, see Martin van Gelderen, "The Machiavellian Moment and the Dutch Revolt," in Bock, Skinner and Viroli (eds.), Machiavelli and Republicanism, 205-223; and Van Gelderen, The Political Thought of the Dutch Revolt, 1555-159o (Cambridge: Cambridge University Press, 1992). For Spinoza, see Hans Blom, "Virtue and Republicanism. Spinoza's Political Philosophy in the Context of the Dutch Republic," in Helmut G. Koenisgberger (ed.), Republiken und Republikanismus im Europa der Frühen Neuzeit (München: R. Oldenbourg Verlag, 1988), 195-212; Blom, Morality and Causality in Politics. The Rise of Naturalism in Dutch Seventeenth-Century Political Thought (PhD dissertation Utrecht University, 1995), 183-239; and Raia Prokhovnik, Spinoza and Republicanism (Basingstoke and New York: Palgrave, 2004). For the eighteenth century, see Wyger Velema, Republicans. Essays on Eighteenth-Century Dutch Political Thought (Leiden: Brill, 2007); and S.R.E. Klein, Patriots republikanisme: politieke cultuur in Nederland (1766-1787) (Amsterdam: Amsterdam University Press, 1995). One of the few general overviews in English of Dutch republican thought is Herbert A. Rowen, "The Dutch Republic and the Idea of Freedom," in Wootton (ed.), Republicanism, Liberty, and Commercial Society, 310340 ; an article that abounds in superficial statements, only to conclude that the Dutch are by nature no great philosophers. 
on the institutional aspects of their thought, without paying attention to the central issues of rhetoric, commerce, and republican morals which are not only of most relevance in the historiographical debate on earlymodern republicanism, but arguably also the most distinctive characteristics of the brothers' republican endeavour.

The main existing interpretations of the work of the brothers De la Court are those of the three Dutch historians mentioned above:Kossmann, Haitsma Mulier, and Blom. Kossmann's pioneering contribution, dating back to 1960, broke new ground with a general overview of the development of Dutch political thought in the seventeenth century. ${ }^{41}$ After half a century Kossmann's study is still inspiring, but also rather superficial and dated. In particular, it lacks Kossmann's later insight that Dutch political thought should be studied against its international background, and hence it offers no coherent discussion of the way in which the brothers De la Court employed international languages in a Dutch context. This neglect of contextualization arguably informs Kossmann's awkward remarks about the 'modernity' of the thought of the De la Courts. Searching for a Dutch tradition of political thought in evolutionary terms, for a Dutch way of thinking about politics that in the end necessarily had to lead to democratic modernity, Kossmann was tempted to do away with anyone who seemed to lack such modernizing intentions. The De la Courts, for Kossmann, could not pass this test. According to his interpretation, they were in fact "reactionary" political theorists who "took a step backward in the evolution of political theory" because they did not envisage the establishment of a "democratic-liberal government". ${ }^{2}$ In Kossmann's eyes, this amounted to a cardinal sin, but it goes without saying that his was a highly anachronistic interpretation.

In the late 1970s, the issue of Dutch seventeenth-century political thought was taken up by Haitsma Mulier in his important dissertation on The Myth of Venice and Dutch Republican Thought in the Seventeenth Century. A major chapter of this book, which in general deals with the reception of the Venetian republican example in the Dutch Republic, is dedicated to the case of the brothers De la Court. ${ }^{43}$ Haitsma Mulier focuses

${ }^{41}$ It is printed in English in Kossmann, Political Thought in the Dutch Republic, 25-129.

${ }^{42}$ Ibidem, $72-73$.

${ }^{43}$ E.O.G. Haitsma Mulier, The Myth of Venice and Dutch Republican Thought in the Seventeenth Century (Assen: Van Gorcum, 1980), 120-169. See also Idem, "A Controversial Republican: Dutch Views on Machiavelli in the Seventeenth and Eighteenth Centuries," in Bock, Skinner and Viroli (eds.), Machiavelli and Republicanism, 247-263; and Idem, "The Language of Seventeenth-Century Republicanism in the United Provinces: Dutch or 
on the way the brothers adopted the legacy of Italian Renaissance political thought and practice: he accurately discusses their extensive discussion of the institutional structures of Venice and Genoa, he highlights the influence of Machiavelli, points to the similarities with Harrington and also refers to the importance of neo-stoicism for the development of their ideas. Yet in spite of this careful contextualization, Haitsma Mulier's perspective, confined to only a part of the works of the De la Courts, has very little to say about how the brothers employed this international intellectual framework in the lively Dutch political debate of their day. ${ }^{44}$ In short, though Haitsma Mulier's interpretation is far more balanced and sophisticated than Kossmann's, it is a long way from offering the last word on the subject.

The same applies to the work of Blom. Over the last three decades, Blom has published a vast number of articles on Dutch seventeenth-century political thought which from the outset have sought to reveal, as he says, an "affinity between seventeenth and twentieth century political thought". ${ }^{45}$ An important consequence of this approach is that the historical context of the work of the brothers De la Court does not receive its due share in Blom's work. That said, Blom convincingly characterizes the core of their thought as the "interdependence of passions and institutions" or

European?" in A. Pagden (ed.), The Languages of Political Theory in Early-Modern Europe (Cambridge: Cambridge University Press, 1987), 179-195.

${ }^{44}$ See for this debate especially Pieter Geyl, "Het Stadhouderschap in de partijliteratuur onder De Witt," in Idem, Pennestrijd over staat en historie (Groningen: Wolters-Noordhoff, 1971), 3-71; M. van der Bijl, "Pieter de la Court en de politieke werkelijkheid," in H.W. Blom and I.W. Wildeberg (eds.), Pieter de la Court in zijn tijd. Aspecten van een veelzijdig publicist (1616-1685) (Amsterdam and Maarssen: APA-Holland University Press, 1986), 65-91; G.O. van de Klashorst, "'Metten schijn van monarchie getempert'. De verdediging van het Stadhouderschap in de partijliteratuur, 1650-1686," in Ibidem, 93-136; Idem, "De "Ware Vrijheid' ", in E.O.G. Haitsma Mulier and W.R.E. Velema (eds.), Vrijheid: een geschiedenis van de vijftiende tot de twintigste eeuw (Amsterdam: Amsterdam University Press, 1999), 157-185; and most recently Jill Stern, Orangism in the Dutch Republic in Word and Image, 1650-1675 (Manchester: Manchester University Press, 2010).

${ }^{45}$ Hans W. Blom, "Political Science in the Golden Age. Criticism, History and Theory in Dutch Seventeenth Century Political Thought," The Netherlands' Journal of Sociology 15 (1979), 47-71: 48. Blom's recent work on the De la Courts includes the articles "Burger en belang: Pieter de la Court over de politieke betekenis van burgers," in J. Kloek and K. Tilmans (eds.), Burger. Een geschiedenis van het begrip 'burger' in de Nederlanden van de Middeleeuwen tot de 21ste eeuw (Amsterdam: Amsterdam University Press, 2002), 99-112; "The Republican Mirror: The Dutch Idea of Europe," in A. Pagden (ed.), The Idea of Europe. The Politics of Identity from Antiquity to the European Union (Cambridge: Cambridge University Press, 2002), 91-115; and "Spinoza on Res Publica, Republics, and Monarchies," in Blom et al. (eds.), Monarchisms in the Age of Enlightenment. Liberty, Patriotism, and the Common Good (Toronto etc.: University of Toronto Press, 2007), 19-44. 
of "private and public interest": the De la Courts constructed a political theory which, on the basis of the passionate human condition, arrives at a plea for republican government where efficiency is the main standard. As Blom summarizes their endeavour: "Political effectiveness lies in the evolutionary development of an institutional structure in which the 'right' passions are promoted, rather than in the accidental and uncertain presence of virtue. ${ }^{n} 4$

On the whole, each of these three interpretations has their own distinctive value - Kossmann's vivid characterizations, Haitsma Mulier's contextual sophistication, Blom's theoretical profundity. Yet they all share certain crucial shortcomings. First and foremost, they focus on the institutional dimension of the thought of the brothers De la Court. Republicanism, so all three seem to argue, involves primarily an institutional concern, and the De la Courts are therefore of specific importance for their theory of government. However, the historiographical debate to date has shown that early-modern republicanism entailed much more than mere institutionalism: republicans envisaged a reformation of manners, they discussed personal virtue, common liberty and the role of commerce, they rhetorically engaged in political debate and ideological criticism. Clearly, then, the most fruitful way to reveal the international relevance of the brothers De la Court is to look at their thought through this prism of morals, commerce and rhetoric, a prism that thus far has been largely neglected.

Moreover, the interpretations by Kossmann, Haitsma Mulier and Blom suffer from being part of a teleological narrative of seventeenth-century Dutch political thought. Instead of being dealt with as valuable authors in themselves, the brothers De la Court figure in all three interpretations as mere pawns in a larger development, paving the way for later authors, in particular for Spinoza, who is seen as the culmination of a long century of republican writing in the Dutch Republic. This teleological approach has been largely adopted by the few scholars outside of the Netherlands who have discussed the De la Courts, in particular Noel Malcolm, who analyzes the brothers' intermediary position between Hobbes and Spinoza, ${ }^{47}$ and Stefano Visentin, who focuses on their reading of Machiavelli in the light of Spinoza. ${ }^{4}$ Obviously, the De la Courts did not publish their

\footnotetext{
46 Blom, Morality and Causality, 178.

47 Noel Malcolm, "Hobbes and Spinoza," in Idem, Aspects of Hobbes (Oxford: Oxford University Press, 2002), 27-52: 42-44.

$4^{8}$ Stefano Visentin, "Assolutismo e libertà. L'orizzonte repubblicano nel pensiero politico olandese del XVII secolo," Filosofia politica 12, 1 (1998), 67-85; Idem, "Passioni
} 
treatises to supply Spinoza with a source of inspiration, yet the existing narratives suggest that they did, that their significance lies primarily in their impact on Spinoza's politics.

Spinoza is also the central character of Jonathan Israel's recent work on the 'Radical Enlightenment', which dominates much of the debate on early-modern political philosophy since the start of this century. According to Israel, the mainstream tradition of moderate Enlightened thought is of only secondary importance when compared to a far more significant and radical strand of philosophy that, mainly originating in the Dutch Republic, spread throughout Europe as a largely underground movement. It was this radical tradition, Israel argues, that would ultimately cause the revolutionary epoch at the end of the eighteenth century and thus shape modernity. At its roots stood the towering figure of Spinoza, but also a range of other authors, including the brothers De la Court. Highlighting their essentially urban and commercial concerns, Israel claims that the republicanism of the De la Courts and Spinoza, "with its uncompromising anti-monarchism and egalitarian tendency ... leads in direct line of descent to the revolutionary rhetoric of Robespierre and the French Jacobins". ${ }^{49}$ Their thought, he stresses, was "totally at odds with, and inherently unlikely to influence, any generally approved and received moderate mainstream tradition of political thought anywhere in early modern Europe". Highly anti-establishment, egalitarian and "fundamentally incompatible with Christianity and all forms of revealed religion", this Dutch republican strand offered something "dramatically new in the history of European and wider western thought" and would in the

\footnotetext{
collettive e leggi politiche nel repubblicanesimo olandese del XVII secolo: dai fratelli De la Court a Spinoza," Giornale di Storia Costituzionale 8 (2004), 239-258; Idem, "Acutissimus o prudentissimus? Intorno alla presenza di Machiavelli nel Trattato politico di Spinoza," Etica \& Politica/Ethics \& Politics 6, 1 (2004), from http://www2.units.it/ etica/2004_1/ visentin.htm [retrieved May 13, 2011]; Idem, "La virtù dei molti. Machiavelli e il repubblicanesimo olandese della seconda metà del seicento," in Fillipo del Lucchese et al. (eds.) Machiavelli: immaginazione e contingenza (Pisa: ETS, 2006), 217-252. The 'encounter' between Machiavelli and Spinoza has also been highlighted in a number of other recent Italian studies: see Vittorio Morfino, Il tempo e l'occasione. L'incontro Spinoza Macchiavelli (Milan: Edizioni Universitarie di Lettere, Economia, Diritto, 2002); and Filippo Del Lucchese, Tumulti e indignatio. Conflitto, diritto e moltitudine in Machiavelli e Spinoza (Milan: Edizioni Ghibli, 2004).

${ }^{49}$ Jonathan Israel, Radical Enlightenment. Philosophy and the Making of Modernity, 1650-1750 (Oxford: Oxford University Press, 2001), 22. Cf. for a comparable argument Heinz Schilling, "Der libertär-radikale Republikanismus der Holländischen Regenten," Geschichte und Gesellschaft 10 (1984), 498-533; and Idem "Dutch Republicanism in its Historical Context," in Idem, Religion, Political Culture and the Emergence of Early Modern Society (Leiden etc.: Brill, 1992), 413-427.
} 
end have lasting consequences for the outlook of modern-day societies..$^{50}$ Israel's decidedly polemical argument, clearly directed against Pocock and his followers, opens up a very important field, namely the impact of the brothers De la Court and their controversial Dutch contemporaries throughout eighteenth-century Europe. However, given the fairly rudimentary existing interpretations of the De la Courts, Israel has arguably raised this issue a bit too early. For how can we fully assess the reception of a body of thought when its roots and range have not yet been analyzed comprehensively?

\section{APPROACH \& CONTENTS}

This book, as the first comprehensive study of the republicanism of the brothers De la Court, aims to provide such an analysis. Following the sharpening focus in the historiography on republican rhetoric, morals and commerce, it uncovers the commercial foundation of the brothers' republican endeavour, dissecting the different facets of their central claim that commerce and republicanism are intrinsically correlated. I will not start from the assumption that theirs was an inherently radical theory, intended to anticipate the democratic constitutionalism of a later age. Instead, my aim is to show what was conventional in their thought and what was not, to reveal how the De la Courts employed existing vocabularies to arrive at an innovative argument that can only be explained in the context of their own times, the context of late humanist European culture and the seventeenth-century Dutch political debate.

In general, the approach that underlies this attempt can be subdivided into two related elements of contextualization. The first is the context of the various languages that shaped early-modern political thought, from late humanist rhetoric to religious discourse, from natural law to reason of state theory, from Renaissance republicanism to the 'new philosophy' of the age. Regarding these various, partly overlapping, languages, it is useful to stress what Annabel Brett has felicitously called the "intellectual promiscuity" of the author, the unscrupulous eclecticism of any writer, unbound by marital fidelity to one distinctive Pocockian language.

\footnotetext{
$5^{5}$ Israel, "The Intellectual Origins of Modern Democratic Republicanism (166o-1720)," European Journal of Political Theory 3 (2004), 7-36: 14-15, elaborated further in Idem, Enlightenment Contested. Philosophy, Modernity, and the Emancipation of Man 1670-1752 (Oxford: Oxford University Press, 2006), 240-263.
} 
This promiscuity, as Brett emphasizes, does not so much result from deliberate authorial intentions as it is a necessary consequence of language-use as such. "Words", she states, "do not limit themselves to particular language games: they travel, carrying their semantic baggage with them, undermining the closure of language games and thus of linguistic context". ${ }^{11}$ This opening up of linguistic contexts implies that these contexts are by definition international. In another eloquent phrase that prolongs the metaphor, now by Stephen Greenblatt: "Language is the slipperiest of human creations; like its speakers, it does not respect borders. ${ }^{{ }^{2} 2}$ In line with this dictum, I will highlight the eclecticism with which the brothers De la Court moved across various internationally constituted discursive terrains. The crucial question, of course, is what the De la Courts did with this broad horizon, a horizon that set the borders of their intellectual enterprise while leaving room for new roads to explore.

A main assumption of this book is that the answer to this question lies in the brothers' participation in the contemporary political debate of the Dutch Republic, the undisputed centre of seventeenth-century global trade. This second contextual element might be defined as that of practice: it entails the rhetoric with which the De la Courts engaged in the controversies of their day, and the civic, mercantile and religious practices that shaped the framework in which they conceived and published their works - from the advent of commercial society to the challenges of religious pluralism and the rise of absolutist state power. Ideas matter because they adopt and apply various normative languages to such a social, political and economic framework. This does not mean that the content of ideas can be traced back directly to a non-textual background, for such a form of reductionism would imply a far too simplistic, onedirectional relation of influence between practice and theory. Instead, it means that ideas are not articulated in the thin air of a reified, self-contained linguistic realm, but rather that they attain meaning in relation to, and interaction with, a much denser sphere of various contexts. With regard to the brothers De la Court, this sphere includes, first of all, the underlying norms of participation in the public debate, set by the prescripts of late humanist rhetoric; ${ }^{53}$ and secondly, the civic politics,

\footnotetext{
${ }^{51}$ Annabel Brett, "What is Intellectual History Now?" in David Cannadine (ed.), What is History Now? (Basingstoke etc.: Palgrave Macmillan, 2002), 113-131: 123.

${ }^{52}$ Stephen Greenblatt, "Racial Memory and Literary History," PMLA 116 (2001), 48-63: 62 .

${ }_{53}$ On rhetoric as the core of contextualized intellectual history, see Anthony J. La Vopa, "Doing Fichte. Reflections of a Sobered (But Unrepentant) Contextual Biographer,"
} 
corporatist economy and religious diversity that characterized the urban centres of the seventeenth-century Dutch Republic.

Overall, this double contextualization results in a narrative that explores the commercial republicanism of the De la Courts on four different levels: rhetoric, citizenship, commercial society and religious toleration. After a first chapter that introduces the brothers' early life, academic education and the making of their œuvre within the Dutch political debate of the mid-seventeenth century, chapters two to five each focus on one of these four levels of analysis. Chapter two discusses the issue of rhetoric. Starting from the prominence of the passions in late humanist rhetoric, this chapter examines the De la Courts' ideas about human nature and speech, and then continues to analyze in detail the different features of their rhetorical practice, in particular their employment of emblematic fables. The core of this rhetorical practice, so the chapter argues, is the embrace of outspokenness, of frank and honest speech to counter courtly and clerical demagogy: a rhetoric of the market that merges commercial candour with anti-monarchical criticism.

Following this analysis of the way in which the De la Courts participated in the public debate, the third chapter turns to the nucleus of their republican politics, the citizen. It starts by analyzing how the brothers De la Court appropriated Hobbesian contract theory for their idiosyncratic claim that a true civil society is necessarily non-monarchical. It then continues to show how exclusivist civic practices in the Dutch Golden Age informed the De la Courts' critical account of the citizen as an independent adult male who, recipient of rights and performer of duties, is capable of free speech. The ethics that underlie this concept of citizenship follow from a notion of well-understood self-interest as the disciplined pursuit of honour, the prime characteristic of the 'wise merchants' who embody the De la Courts' mercantile reformation of manners.

Chapter four moves from the individual level of the citizen to the general level of society al large - the commercial commonwealth. Focusing on the brothers' criticism of the economic policies of their hometown, Leiden, the centre of Europe's textile industry, this chapter examines their republican model of an open and free society, mirrored by the classical paragon of Ancient Athens. The notion of liberty that underlies this model merges freedom of trade with the 'True Liberty' of republican

in Hans Erich Bödeker (ed.), Biographie schreiben (Göttingen: Wallstein Verlag, 2003), 107-171: $145^{-150 .}$ 
independence. Accordingly, the ideal republic of the brothers De la Court is a polity where self-interested commerce fosters the common good, unadulterated by arbitrary domination. Any form of monarchical government amounts to tyranny, the brothers argued, and they combined this radical anti-monarchism with a tentative plea for democratic government - a move that is particularly important in comparison with their English republican contemporaries. The fifth and last chapter focuses on the way in which this commercial commonwealth can persist through the maintenance of social concord and religious toleration. Rejecting revolutionary change and clerical interference in politics, the brothers De la Court adhered to the ideal of a broad public church that is supervised by the secular authorities. On account of both moral necessity and political expediency, this public church leaves room for the dissent of private congregations, which amounts to an inclusive notion of religious toleration, especially as regards Catholicism, for the sake of economic prosperity, social concord, and the purity of faith.

Finally, the conclusion assesses the significance of the thought of the brothers De la Court for the development of early-modern republicanism, followed by a short and rudimentary overview of the international reception of their ideas throughout the late seventeenth and eighteenth centuries. The De la Courts maintained that the Dutch republican experience was part of a long-standing tradition that originated in antiquity, yet they gave a distinctive commercial twist to this tradition, championing the mercantile model of Athens and Holland over the militant model of Rome and England. This commercial twist would become an important element of political thought in Europe and beyond during the Enlightenment. Thus, the focus of this thesis significantly expands our knowledge of what early-modern republicanism was all about. It offers a glance at the fault line where humanist rhetoric began its gradual demise, where the classical notion of honour merged with the modern language of interest, where free trade meant the safeguarding of self-reliance, and where toleration implied an evangelical pursuit to impose secular control over the church. The commercial republic of the brothers De la Court stood at these crossroads between old and new, with one foot firmly set in the past, yet the other tentatively moving into a different direction. 



\section{THE MAKING OF AN OEUVRE}

From the beginning, Johan and Pieter de la Court were outsiders. Their father, Pieter de la Court senior, was born near Ypres in the southern Netherlands, and migrated in his early twenties to the Dutch Republic. He settled in Leiden, Holland's second biggest town, and within a few years he became a successful independent entrepreneur in Leiden's thriving textile business. As a result, not long after his marriage with Jeanne de Plancke, also of southern origin, De la Court sr. was able to purchase citizenship rights of the city in $1618 .{ }^{1}$ In that same year, their son Pieter was born, and four years later came Johan. ${ }^{2}$ The two brothers would become the most prolific children of the family, and echoes of their origins would resonate throughout their lives and work. As the sons of a self-made man, they would plead for unrestricted immigration and economic freedom; as members of a successful but much despised minority within the Dutch Republic, they continually behaved like uninvited guests with a certain aversion to conformity. In the eyes of resentful critics, they were basically "garlic eaters", the scornful term applied to anyone from the south, an inference that definitely did not leave the brothers unaffected. ${ }^{3}$ As a passage in their work notes, doubtless reflecting the brothers' own experience: "The separation between Flemish and Hollanders is a too large and well-known rupture that should be healed, for truly to make someone a

${ }^{1}$ Th. van Tijn, "Pieter de la Court, zijn leven en zijn economische denkbeelden," Tijdschrift voor geschiedenis 69 (1956), 304-370: 304-306. For the wider background of the large Flemish immigration to Leiden, see J. Briels, Zuid-Nederlanders in de Republiek, 1572-1630 (Sint-Niklaas: Danthe, 1985), esp. 125-134; and Leo Lucassen and Boudien de Vries, "Leiden als middelpunt van een Westeuropees textiel-migratie-systeem, 1586-1650," Tijdschrift voor Sociale Geschiedenis 22 (1996), 138-167.

${ }^{2}$ Jeanne de Plancke gave birth to seven children, of whom only four would reach adulthood: Jacob (1617-1687), Pieter (1618-1685), Johanna (1620-1678), and Johan (1622$1660)$.

${ }^{3}$ See the pamphlet Een nieuw liedeken van een hoere-waerts soon buyten Yperen [1648], a satirical song mocking De la Court sr., "die knuf-look vreter.../Hoe komt nu rijck die quant?/Hy nam, hy loogh, onthiel, bedrooch,/Ontkend' zijn eyghen handt." Evidently, the De la Courts were not only resented because of their descent but also because of their economic success, allegedly attained through greed, lies and deceit. For the background of this pamphlet, see chapter 2 below. 
stranger in his own birthplace is a great offence against the right of nature." ${ }^{4}$ Strangers in their own country: this is how the De la Courts must have felt until the very end.

This first chapter introduces the life and works of the brothers De la Court by analyzing how their common ouvre came about in the context of late humanist culture and Dutch political debate around 1650 . It does not entail a comprehensive biographical overview of their entire life or an exhaustive critical bibliography of their works. ${ }^{5}$ Rather, my aim in this chapter is to shed light on those aspects of their education and of seventeenth-century Dutch debating culture that are essential for understanding the various dimensions of their thought. The chapter discusses not only what the brothers De la Court published and when, but especially why and how they entered the public debate and how their contemporaries reacted to their writings. It will show that the making of the brothers' œuvre involved an attempt to move Dutch republican politics in a new direction - an attempt that, for all its boldness, was eventually doomed to fail.

\section{A HuMANist EDUCATION}

\section{Grand Tour}

Thanks to the economic success of their father, who was by 1630 one of the main entrepreneurs in the Leiden textile industry, the brothers De la Court enjoyed a thorough humanist education that was a privilege of the elite. In his early teens, Pieter de la Court was enrolled at the Latin School in Leiden, the institution that prepared young adolescents for university. He entered school on the same day as Nicolaas Heinsius, ${ }^{6}$ whose father, the famous poet and philologist Daniel Heinsius, taught Greek and history at Leiden University. Heinsius was the editor of, among many other works, an influential edition of Aristotle's Politics, and his son Nicolaas

\footnotetext{
${ }^{4}$ Welvaren 72 , p. 158: “... die separatie tussen Vlamingen en Hollanders is te grooten bekenden scheuringh, die men behoorde te heelen, want voorwaer ijmand in sijn eigen geboorteplaetse een vreemdelingh te maecken is een groot gewelt tegen 't reght der nature strijdende."

${ }^{5}$ For the latter, see Ivo W. Wildenberg, Johan \& Pieter de la Court (1662-1660 \& $1618-$ 1685). Bibliografie en receptiegeschiedenis (Amsterdam: APA-Holland University Press, 1986).

${ }^{6}$ Willem Frijhoff, "Pieter de la Courts reisjournaal (1641-1643) als ego-document," in Blom and Wildenberg (eds.), Pieter de la Court, 11-34: 21-22, esp. note 24.
} 
later became a prolific poet in the service of the Swedish Court. ${ }^{7}$ De la Court and Nicolaas remained friends for some time, and so, from an early age, the De la Courts came into close contact with the humanist culture that dominated Dutch intellectual society, particularly in Leiden, the bulwark of Protestant late humanism. ${ }^{8}$ Indeed, De la Court senior envisaged a more prestigious and dignified future for his youngest sons than the textile business. As an elder of the Walloon church in Leiden, he persuaded them to study theology in order to become preachers, one of the means for the moneyed classes to gain further social mobility. Hence, in the autumn of 1641, Johan de la Court enrolled at Leiden University as a student in theology. ${ }^{9}$

Pieter de la Court's destiny, for the moment, lay elsewhere. Some days before Johan entered university, Pieter had left the harbour of Brielle, near Rotterdam, to set sail to Yarmouth. This was the beginning of his Grand Tour, the study trip that was a standard element of a true humanist education. ${ }^{10}$ De la Court's trip would last for more than two years, taking him to England, France, Switzerland, the Rhine cities and the soil where his roots lay, the southern Netherlands. During his voyage, he kept a diary, which makes it possible to follow his journey in some detail." After his arrival in England, De la Court went on to London, where he would stay for over five months. He took English classes, bought a number of books in St. Paul's Churchyard to enrich his small library and wondered at local peculiarities such as the exceptional preference, especially among women, "for sweets and Spanish wine", the enjoyment of "many perilous exercises" such as wrestling and football, and the strange habit of drinking

\footnotetext{
7 See Frans Felix Blok, Nicolaas Heinsius in dienst van Christina van Zweden (Delft, 1949). Daniel Heinsius's edition of Aristotle's Politica, published by Elzevier in 1621, comprises the original Greek with a Latin translation and extensive paraphrases of the argument by Heinsius.

${ }^{8}$ See the characteristically colourful description by Anthony Grafton, "Civic Humanism and Scientific Scholarship at Leiden," in Idem, Bring Out Your Dead. The Past as Revelation (Cambridge, Mass.: Harvard University Press, 2001), 118-137.

9 Van Tijn, "Pieter de la Court," 309-311; and Frijhoff, "Reisjournaal," note 35.

10 See A. Frank van Westrienen, De Groote Tour. Tekening van de educatiereis der Nederlanders in de zeventiende eeuw (Amsterdam: Noord-Hollandsche Uitgeversmaatschappij, 1983).

"The diary is preserved in the archive of the De la Court family in the Regional Archive Leiden (hereafter RAL FA De la Court), inv. nr. 14. The standard, chronological part of the diary is published in F. Driessen (ed.), De reizen der De la Courts 1641-1700-1710 (Leiden, 1928), 1-30. The remaining part, which consists of more personal, detached notes, is published in Willem Frijhoff (ed.), "De reisnotities (1641-1643) van Pieter de la Court," in Blom and Wildenberg (eds.), Pieter de la Court, 34-64. Frijhoff's article "Reisjournaal" gives an extensive analysis of Pieter's Grand Tour.
} 
beer with breakfast. ${ }^{12}$ With friends, among them his schoolmate Nicolaas Heinsius, De la Court visited the important sights, and he attentively observed all the latest political developments. At the end of November 1641, when Charles I entered London, De la Court could hardly hide his surprise when he saw how the king turned once to "laugh at the quarrelling rabble, doing their best to get at the wine, both white and red, that was poured through three leaden pipes out of the fountain". ${ }^{13}$ It was the first time that this young son of a sober Calvinist merchant was confronted with these consequences of monarchical rule. Arguably, De la Court's visit to England, on the brink of the Civil War, thus left a significant mark on his later radical republican engagement.

A number of important meetings during his Grand Tour are also likely to have impressed De la Court. The first of these took place in January 1642, when De la Court, still in London, met several times with the famous Czech philosopher Jan Amos Comenius. The initiative for this contact had come from Adriaan Heereboord, a young professor of philosophy and rhetoric at Leiden University who had possibly taught Pieter before. ${ }^{14}$ Heereboord, an important member of Cartesian circles in Dutch academia, showed a deep interest in Comenius' writings and had instructed De la Court to get in touch with the Czech philosopher. De la Court visited Comenius at his home, and, clearly impressed by this "very friendly and talkative man", ${ }^{5}$ he scrutinized Comenius's latest work, in particular his 'pansophic' treatises which aimed for a universal pedagogical and scientific reform, developed together with Samuel Hartlib from Francis Bacon's Instauratio magna. ${ }^{16}$ The contact would prove to be fruitful since

${ }^{12}$ Frijhoff (ed.), "Reisnotities," 37: "De Engelschen en voorneemelick de vrouwen sijn seer tot sueticheit genegen en tot Spaenschen wijn. Hebben veel perijkeleuse exercitien die sij op feest- en sondagen in het velt doen als worstelen, schermen, naer de voet bal te lopen."

${ }_{13}$ Driessen (ed.), Reizen, 6: “... soo keerde hy sich eens om ende lachten om t' graw dat twistede ende een igelyck daer van syn best doende om den wyn soo witten als roden die men door drie loode goten wt de fonteyne een tyt lanck liet vlieten."

${ }^{14}$ See Frijhoff, "Reisjournaal," note 35.

15 Driessen (ed.), Reizen, 8: “... een heel vriendelyck gespraecksaem man.”

${ }^{16}$ In the winter of 1642 , Comenius was working on the treatise that later would be published as Via lucis, vestigata et vestiganda (Amsterdam, 1668), dedicated to the English Royal Society. See also Comenius, Pforte der Dinge/Janua rerum, ed. and trans. Erwin Schadel (Hamburg: Felix Meiner Verlag, 1989), esp. xxix-xli. The library of De la Court's son, Pieter de la Court van der Voort, had a large folio edition of Comenius's pedagogical works, the Opera omnia didactica (Amsterdam, 1657), as well as the 1645 Leiden edition of Bacon's Augmentis Scienticarum. Both works had possibly belonged to his father. See the inventory of the library, drafted in 1739, in RAL FA De la Court, inv. nr. 59, vol. III (hereafter Library): fol. 17, 33. Cf. also the inventory from 1749 in RAL FA De la Court, inv. nr. 116. 
Comenius went on to visit the Dutch Republic later that year, meeting, among many others, Heereboord and Descartes. ${ }^{17}$

By then, De la Court had continued his journey to France, passing through Rouen, Paris and Orléans to descend along the Loire, with as eventual destination the famous Protestant Academy in Saumur. This was the location of some further important meetings, in particular with the local professors of theology, among whom Louis Cappel, expert in Hebrew textual criticism, and the famous theologians Josué de la Place and Moyse Amyraut, whose teachings on predestination and original sin challenged Huguenot orthodoxy. ${ }^{18}$ De la Court paid a great deal of attention to all aspects of daily religious life in Saumur, on which he left extensive notes in his diary. ${ }^{19}$ Arguably, this experience and the irenicist theology taught at Saumur had a significant influence on his later tolerationist stance. One of De la Court's travel companions in France was the young controversial preacher Johannes de Mey, who later became an important representative of the Dutch Calvinist endeavour to integrate the study of the Bible with the newest developments in natural philosophy. ${ }^{20}$ De Mey's treatise Euzooia, written around 1675 and explicitly inspired by Thomas More's Utopia, argues among much else for the secular control over the church, the unity of Christianity on the basis of a few fundamental articles of faith, and the freedom of private worship - issues also prominent in the writings of the brothers De la Court (see chapter 5 below). In his treatise, De Mey refers to an unidentified author from Saumur as the source of his statements, and it is likely that his and De la Court's shared view on these

\footnotetext{
${ }_{17}$ See Willem Frijhoff, "Pieter de la Court and Comenius' Third Visit to Holland (1642)," Acta Comeniana. Revue Internationale des Études Coméniologiques 7 (1987), 183-192, which includes the letters that De la Court sent from London to inform Heereboord about his meetings with Comenius. On Comenius' later stay in the Dutch Republic, see Wilhelmus Rood, Comenius and the Low Countries (Amsterdam: Van Gendt \& Co., 1970).

18 See Frijhoff (ed.), "Reisnotities," 42-45. For the teaching of theology at Saumur, see Brian G. Armstrong, Calvinism and the Amyraut Heresy. Protestant Scholasticism and Humanism in Seventeenth-Century France (Madison etc.: University of Wisconsin Press, 1969), and F.P. van Stam, The Controversy over the Theology of Saumur, 1635-1650. Disrupting Debates among the Huguenots in Complicated Circumstances (Amsterdam and Maarssen: APA-Holland University Press, 1988). For Cappel, see also François Laplanche, L'écriture, le sacré et l'histoire. Érudits et politiques protestants devant la bible en France au XVIIe siécle (Amsterdam and Maarssen: APA-Holland University Press, 1986), 181-290.

19 Driessen (ed.), Reizen, 17-21. Cf. Frijhoff, "Reisjournaal," 18, 20, 31-32.

${ }^{20}$ See Eric Jorink, Het Boeck der Nature. Nederlandse geleerden en de wonderen van Gods Schepping, 1575-1715 (Leiden: Primavera Pers, 2007), esp. 386-405; and H.J. Zuidervaart, "Het natuurbeeld van Johannes de Mey (1617-1678), hoogleraar filosofie aan de Illustere School te Middelburg," Archief. Mededelingen van het Koninklijk Zeeuwsch genootschap der Wetenschappen 99 (2001), 1-40.
} 
matters stemmed from the period they spent together at the Protestant Academy in Saumur. ${ }^{21}$

De la Court left Saumur in the summer of 1642 and continued his trip through the Rhone valley towards Marseille, and from there to Geneva. Again, as earlier during his voyage, he was clearly fascinated (and at times horrified) by all the peculiarities of local confessional religious practice from the execution of an "atheist and ridiculer of Scripture" to the burning of various witches and of a "Jew who feigned being Christian". In an English side note in his diary, De la Court revealed his sceptical attitude as regards such enforced dogmatism, asking "The divel [sic] was he ever seene?" ${ }^{22}$ Possibly, De la Court's ongoing engagements with all the diverse manifestations of Catholic, Huguenot and Calvinist confessional culture along his Grand Tour laid at the origin of this rising scepticism about the possibility of confessional unity, elaborated in his later writings. More in general, De la Court's diary testifies to a levelheaded mind with a great affection for practicalities, numbers and measures, textiles and colours. Of course, this was not surprising for the son of a cloth entrepreneur, but it also shows that the prospect of being a preacher was not reserved for this future merchant. In the end, when returning to Leiden via the Rhine cities and the Southern Netherlands, De la Court must have made up his mind about his future. As Willem Frijhoff concludes in his lucid and suggestive analysis of the diary: "From a theologian in the making he has become a prospective cloth entrepreneur and political thinker. His grand tour has assisted him to find his way. He has set himself rules for life and rules for work: his education is fulfilled." ${ }^{23}$

\section{Academic Politics at Leiden University}

Nonetheless, one further essential element of De la Court's humanist upbringing was still lacking: a university education. Immediately after his homecoming, in the autumn of 1643, De la Court therefore joined his younger brother Johan and enrolled as a student in theology at Leiden University, shortly before his twenty-fifth birthday. Eventually, Johan and Pieter would follow the same educational path, but vice versa: when

${ }^{21}$ Johannes de Mey, Euarchia of tweede vervolg van Euzooia, in Al de Nederduistche wercken (Middelburg, 1681), esp. 782-783.

${ }^{22}$ Frijhoff (ed.), "Reisnotities," $5^{1-52}, 56$ : "Een Joden die sich christen veinsde en tot predicant beropen was levendich verbrant te Geneven. Item een atheist en bespotter van de schriftuer gecondemneert het hooft te verliesen."

${ }^{23}$ Frijhoff, "Reisjournaal," 34. 
Johan graduated from university around the end of 1645, he left for his own Grand Tour, which also brought him to Geneva. ${ }^{24}$

In the 1640s, Leiden was the largest and most important university in the Protestant world, characterized by a distinctively international student population. ${ }^{25}$ As students in theology, the brothers De la Court first had to follow a preliminary propaedeusis in the faculty of arts, a preparatory curriculum that included courses in rhetoric, Classical languages, history and philosophy. It was during this first stage of their studies that the De la Courts were introduced to politics as an academic subject. In particular, politica was an important element of the study of rhetoric and of the field of moral philosophy, which was subdivided into three categories, ethics, economics (literally the 'study of the household'), and politics. ${ }^{26}$ It is thus to rhetoric and philosophy that we must turn to understand the scope of the education in politics that the De la Courts received.

During the first decades of the seventeenth century, the dominating shadow of Aristotle continued to colour the philosophical scene at Leiden, although the first Cartesian cracks in the wall became visible exactly in those years when the brothers De la Court spent their days in the classroom. ${ }^{27}$ A particularly influential representative of Dutch neo-Aristotelianism in this period was Franco Burgersdijk, whose textbooks on logic, moral philosophy and politics long remained the standard material for students in the Dutch Republic and abroad. ${ }^{28}$ Burgersdijk had died in 1635 , but his legacy was continued by the two most important teachers of the brothers De la Court, Adriaan Heereboord and Marcus Zuerius Boxhorn. Heereboord, the man who had brought Pieter de la Court into contact with Comenius, became professor of philosophy at Leiden in 1641 .

${ }^{24}$ Ibidem, 12.

${ }^{25}$ Jonathan Israel, The Dutch Republic. Its Rise, Greatness, and Fall 1477-1806 (Oxford: Oxford University Press, 1995), 572. On Leiden University in this period, see Willem Otterspeer, Het bolwerk van de vrijheid: de Leidse universiteit, 1575-1672 (Amsterdam: Bert Bakker, 2000).

${ }^{26}$ See for a general overview Jill Kraye, "Conceptions of Moral Philosophy," in The Cambridge History of Seventeenth-Century Philosophy, ed. Daniel Gaber and Michael Ayers, 2 vols. (Cambridge: Cambridge University Press, 2003), vol. II: 1279-1316. On the teaching in politics at Leiden in particular, see H. Wansink, Politieke wetenschappen aan de Leidse Universiteit $1575^{ - \pm 1650}$ (Utrecht: HES, 1981).

${ }_{27}$ A still valuable and authoritative source is Paul Dibon, La philosophie néerlandaise au Siècle d'Or. L'enseignement philosophique dans les universités a l'époque précartésienne (1575-1650) (Paris etc.: Elsevier, 1954), esp. 90-119 on Burgersdijk.

${ }_{28}$ For Burgersdijk, see E.P. Bos and H.A. Krop (eds.), Franco Burgersdijk (1590-1635) (Studies in the History of Ideas in the Low Countries I) (Amsterdam: Rodopi, 1993), particularly the contribution by Hans Blom, also in his Morality and Causality, 67-100. 
His teachings, based on the method of disputations according to which the students had to defend different theses, largely followed Burgersdijk's textbook Idea philosophia moralis, sive compendiosa instititutio, a fairly conventional compendium in moral philosophy first published in $1623 .{ }^{29}$ Though clearly Aristotelian in inspiration, Burgersdijk's account used diverse authorities to construct a philosophical system independent from theology. ${ }^{30}$ Heereboord followed this neo-Aristotelian attempt to separate philosophy and theology, publicly defending the freedom to philosophize. Importantly, this stance brought him close to Descartes, whose controversial writings, following the Discours de la méthode (1637), enjoyed an immediate and heated reception in Dutch academic circles. ${ }^{31}$ Heereboord openly supported Descartes in the Leiden academic community, although this support was not so much based on a rigorous acceptance of the Cartesian 'new philosophy' as on the endeavour to construct an eclectic philosophia novantiqua unrestrained by theological interference. ${ }^{32}$

Heereboord would play an important role in the life of the De la Court family (see chapter 2 below), but more significant for the study of politics at Leiden was Boxhorn, professor of rhetoric and, from 1648, the successor to Heinsius as the chair of history. Around 1643, Boxhorn's students asked him to give a series of private lectures on Dutch politics, outside of the official curriculum. Possibly, one of these students was Johan de la Court, for a copy of the notes of these lectures later ended up in the possession of his brother Pieter, then still on his Grand Tour. ${ }^{33}$ In any case, Boxhorn's

${ }^{29}$ Cf. Franco Burgersdijk, Idea philosophiae moralis, sive compendiosa institutio (Leiden, 1644) with the collection of disputations held under Heereboord's professoriate, Collegium Ethicum, seu Philosophia Moralis (London, 1658). See also the remarks in Kraye, 'Conceptions of Moral Philosophy', 1285-1286.

3o Blom, Morality and Causality, 71-73.

$3^{31}$ See for a clear and concise analysis: Wiep van Bunge, From Stevin to Spinoza. An Essay on Philosophy in the Seventeenth-Century Dutch Republic (Leiden etc: Brill, 2001), 34-64; and Theo Verbeek, Descartes and the Dutch: Early Reactions to Cartesian Philosophy, 16371650 (Carbondale: Southern Illinois University Press, 1992). More extensive, but also rather unstructured, is C.L. Thijssen-Schoute, Nederlands Cartesianisme (Amsterdam: NoordHollandsche Uitgevers Maatschappij, 1954).

$3^{2}$ Herman de Dijn, "Adriaan Heereboord en het Nederlands Cartesianisme," Algemeen Nederlands Tijdschrift voor Wijsbegeerte 75 (1983), 56-69; and Van Bunge, From Stevin to Spinoza, 48-49.

${ }_{33}$ See the manuscript "Status Foederatorum Belgii Provinciarum, excerptos ex ore clarissimi viri D.M. Zuerii Boxhornii Eloquentiae in Academia Lugduno Batava professoris ordinaris. Anno 1643," Royal Library The Hague, Ms 70 G12. On the cover, a later hand has added "P.J. Delacourt" as the presumed author. The text of the lecture notes is in an unknown hand, but on the blank pages in between the text, later notes have been added 
teachings and writings in politics and history were to be very influential, from his stress on the empirical use of contemporary political examples to his popularization of Tacitism and reason of state. Following the groundwork by Burgersdijk, Boxhorn developed an elaborate academic politica in connection with a practical commentary on the actual political situation in the Dutch Republic and abroad. ${ }^{34}$

Boxhorn's series of private lectures from 1643, later published as Commentariolus de statu Confoederatorum Provinciarum Belgii and also translated into Dutch, entails an almost purely descriptive rationalization of the administrative and economic complexities of the United Provinces. ${ }^{35}$ As such it evidently answered to a large demand in Dutch society for a comprehensible analysis of the obscure political constellation of this newly born European anomaly. Boxhorn explained to his students the intricacies of Dutch provincial sovereignty, following Grotius with the claim that the summum imperium lied with the States of each individual province and not with the States-General, the central assembly of representatives of the different provinces. He also clarified the role of the Stadholder, the monarchical element in the Dutch republican constitution fulfilled by a member of the House of Orange, whose powers as a supremus gubernator were in Boxhorn's account clearly restricted. Most importantly, Boxhorn entered into direct debate with the Italian Cardinal Guido Bentivoglio, who had argued in his famous Relationi (1630) that the Republic's chances of survival were small. For Bentivoglio, Dutch republican liberty and concord were compromised by the large authority of the Stadholder and the overall "diversity of interests", especially the animosity between the different provinces and the unsettling religious pluralism. These seeds of conflict meant that the Republic would "eventually be put

which are unmistakeably by Pieter de la Court, as a comparison with his autograph letters in the Amsterdam Stadsarchief, Family archive Backer, inv. nrs. 465, 470, reveals. Possibly, De la Court had inherited the manuscript from Johan after his death in 1660 (see below), but this is impossible to claim with utter certainty. Cf. Wansink, Politieke wetenschappen, 150-151.

${ }^{34}$ See Wansink, Politieke wetenschappen, 93-107, and Jaap Nieuwstraten, "Why the Wealthy Should Rule: Marcus Zuerius Boxhorn's Defence of Holland's Aristocratic Mercantile Regime," in Jan Hartman et al. (eds.), Public Offices, Personal Demands. Capability in Governance in the Seventeenth-Century Dutch Republic (Newcastle: Cambridge Scholars Publishing, 2009), 126-149.

${ }^{35}$ [M.Z. Boxhorn], Commentariolus de statu Confoederatarum Provinciarum Belgii (The Hague, 1649). This Latin edition is almost entirely similar to the manuscript owned by De la Court. I have also used the Dutch translation, Politijck hant-boecxken, van de Staet van 't Nederlandt (s.l., 1650). 
once more under the government of one man". ${ }^{6}$ Boxhorn countered with the fundamental claim that since the Dutch were no Romans, they had taken care that the power of the Stadholder was duly subordinated to the authority of the provincial States. Moreover, thanks to its commercial prosperity the Republic would continue to thrive in concord and liberty. ${ }^{37}$ Bentivoglio's assessment of the Dutch fate would continue to obsess the brothers De la Court (see chapter 5 below), who doubtless studied Boxhorn's text closely and must have been highly receptive to his optimistic counterargument.

Apart from these considerations on the current situation in and future of the United Provinces, Boxhorn also taught his students the contours of a more abstract political theory in the tradition of political Aristotelianism. During the first decades of the seventeenth century, politics became increasingly identified as an independent academic discipline with its own methodology. In particular at German universities numerous treatises were published that systematically analyzed the origin, goal and functioning of political societies. ${ }^{38}$ Burgersdijk had also contributed to this development with the uncharacteristically short textbook Idea oeconomicae et politicae doctrinae, published posthumously in 1644 . This treatise, part of the teaching material at Leiden, neatly divided economics, the subject of which was the domus or household, from politics, which concerned the constitution and the government of the respublica, "a society of many families living under the same magistrate and the same laws". ${ }^{39}$

${ }^{36}$ Guido Bentivoglio, Relatione delle Provincie Unite, ed. S. Mastellone and E.O.G. Haitsma Mulier (Florence: Centro Editoriale Toscano, 1983), 128-129: "diversità d'interessi ... che finalmente sia per ridursi di nuovo sotto il governo d'un solo."

37 Boxhorn, Commentariolus, 146-149; Idem, Politijck hant-boecxken, 141-144. In his classes, Boxhorn paid close attention to Rome's demise from a republic into a principality. See the collection of disputations, held by his students in the 1640 s as training in rhetoric, appended to Boxhorn, Emblemata politica. Accedunt dissertationes politicae de Romanorum Imperio (Amsterdam, 1651).

${ }^{38}$ For a characterization of the academic politica, see Horst Dreitzel, "Der Aristotelismus in der politischen Philosophie Deutschlands im 17. Jahrhundert," in Echard Kessler et al. (eds.), Aristotelismus und Renaissance. In memoriam Charles B. Schmitt (Wiesbaden: Otto Harrassowitz, 1988), 163-192; and Wolfgang Weber, Prudentia gubernatoria. Studien zur Herrschaftslehre in der deutschen politischen Wissenschaft des 17. Jahrhunderts (Tübingen: Max Niemeyer, 1992), esp. 340. For its impact in the Netherlands, cf. Martin van Gelderen, "Aristotelians, Monarchomachs and Republicans: Sovereignty and respublica mixta in Dutch and German Political Thought, 1580-1650," in Van Gelderen and Skinner (eds.), Republicanism, vol. I: 195-217.

${ }_{39}$ Burgersdijk, Idea oeconomicae et politicae doctrinae (Leiden, 1644) II.I.2, p. 32: "Respublica est societas plurium familiarum sub eodem magistratu, iisdemque legibus tegentium." See the extensive analysis in Blom, Morality and Causality, 89-100. 
In a conventional Aristotelian way, Burgersdijk argued that man is by nature a political animal, and he claimed that a mixed government of the three classical forms, monarchy, aristocracy, and democracy, is the best. More significantly, one of the few authors mentioned by Burgersdijk apart from Aristotle was Machiavelli. Burgersdijk refuted Machiavelli's Principe, which he read as an immoral advice for monarchs not to take care of their subjects. ${ }^{40}$ But in spite of this refutation, young students at Leiden were, when reading Burgersdijk's textbook, obliquely introduced to the disquieting writings of Machiavelli.

Boxhorn followed in Burgersdijk's footsteps, yet eventually he departed from the latter's essentially Aristotelian trail. His key work is the Institutiones politicae, first published in 1657 but probably largely based on Boxhorn's teachings from the early 1640 s onwards. ${ }^{41}$ Subdivided into two books, the Institutiones first discuss the origin and goal of political society and then the three classical forms of government. This structure was typical for the politica genre, but on a couple of important issues Boxhorn entered into a less conventional direction. First of all, the notion of human sociability as the foundation of society, prominent in Burgersdijk and also, for instance, in the political thought of Hugo Grotius, is entirely absent from Boxhorn's work. Instead, Boxhorn emphasized the free, selfinterested yet needy natural state of human beings, and therefore maintained that the commonwealth does not find its origin in sociability, but in necessity and fear (I.2-3). As a result, the maintenance of obedience becomes the main pillar of good government. One particularly forceful means to establish such civil obedience is religion - in Boxhorn's words, echoing his predecessor at Leiden Justus Lipsius, "the bond, the tie, and indeed the foundation of the Republic". ${ }^{42}$ Another means is the upholding of the rule of law, a third a broad level of political participation (I.8, II.1). This last claim leads to the fundamental question of which form of government should be considered best. Here again, Boxhorn departed from the conventional preference, such as that of Burgersdijk, for the mixed

${ }^{40}$ Burgersdijk, Idea oeconomicae et politicae doctrinae II.I.15, p. 35-36.

${ }^{41}$ I have used the edition with commentary by Georg Hornius, Institutiones Politicae (Utrecht, 1702). My interpretation of this work is greatly indebted to Jaap Nieuwstraten's groundbreaking analysis of Boxhorn's political thought, History and Politics in SeventeenthCentury Dutch Political Thought. The Case of Marcus Zuerius Boxhorn (1612-1653) (PhD dissertation Erasmus University Rotterdam, forthcoming). I am very grateful to Jaap for generously sharing his work with me before publication.

${ }_{42}$ Boxhorn, Institutiones, ed. Hornius, I.8 Exp., p. 85: "Diximus Religionem esse vinculum ac nexum adeoque fundamentum Reip." Cf. Lipsius, Monita et exempla politica (Leiden, 1630) I.2, p. 6: "Esto igitur vinculum \& firmamentum Reipublicae, Religio." 
regime. He argued that a perfect balance between a monarchical, an aristocratic and a democratic element would be utterly unachievable, since one of these three elements would inevitably come to dominate over the other two. In particular, one man could easily seize all powers and thus establish tyranny (II.4). At the same time, an aristocracy would lapse into the tyranny of a few, Tacitus's paucorum dominatio ${ }^{43}$ while a democracy meant for Boxhorn the eventual triumph of licence and anarchy (I.5, II.810). Boxhorn's model of good government was therefore a broad, open aristocratic regime where the wealthy ruled - a clear allusion to the current situation in the Dutch Republic. The keyword of this model was concord, the fundamental link between rulers and ruled based on the rule of law and the pursuit of mutual interests (II.5).

Overall, Boxhorn's teachings in politics were fairly traditional, but with his denial of natural sociability and of the feasibility of a balanced mixed regime, he clearly contributed to what has been called "the crisis of political Aristotelianism". ${ }^{44}$ It remains an open question whether Boxhorn thus paved the way for the radicalization of Dutch political thinking later in the century. In any case, his possible influence on the brothers De la Court should not be overlooked, for key notions in their work at times echo Boxhorn's teachings, from their view on the foundation of the commonwealth to their argument for a broad aristocratic government (see below, chapters 3 and 4). It is beyond doubt that the De la Courts were first introduced to these issues during the 1640s in Boxhorn's classes at Leiden, where they also must have been schooled thoroughly in the reading of other representatives of early seventeenth-century politica, from the sweeping treatises by Henning Arnisaeus, Christoph Besold and Adam Contzen to the idiosyncratic Politica generalis by Johannes Werdenhagen. ${ }^{45}$ Later, Pieter de la Court would loudly expound his disgust of all these academic Latin treatises, "boasting with high-flown Titles such as Politica, Systema Politicum, Doctrina Civilis, Prudentia

43 Boxhorn, Institutiones I.3 Exp., p. 21, quoting Tacitus, Annals VI.42.2.

44 Horst Dreitzel, "Reason of State and the Crisis of Political Aristotelianism: An Essay on the Development of 17th Century Political Philosophy," History of European Ideas 28 (2002), 163-187.

45 The library of Pieter de la Court van der Voort included only a few classical works of Latin politica which had possibly belonged to his father as a student: Adam Contzen, De perfecta republica (Cologne, 1629); Henning Arnisaeus, De jure majestatis (Straatsburg, 1635); Idem, De republica (Straatsburg, 1636), Christoph Besold, De incrementis imperiorum (Straatsburg, 1623); and Johannes Angelius Werdenhagen, Universalis introductio in omnes respublicas sive politica generalis (Amsterdam, 1632): Library, fols. 10, 18-19, 31. 
Politica, de Republica, Arcana Rerumpublicarum, Aphorismi Politici, Axiomata Politica, \&c, written by some Germanic Professors, Doctors, Preachers and Schoolteachers". These works, De la Court insisted, are "so Pedantically cowardly, tasteless, scholastic, full of ignorance and of wrong or harmful and seditious Opinions, that all those Germanic writers seem to have practised their judgment nowhere less than in matters of State".$^{4}$ Yet in spite of this flamboyant rebuttal of the conventional politics as taught at Leiden, the writings of the brothers De la Court were, as this book will show throughout, rooted much more firmly in the tradition of academic politica than they themselves were willing to acknowledge. ${ }^{47}$

\section{The Dutch Debate}

\section{Between the Academy and the Agora}

Following De la Court's own colourful judgment, it is tempting to consider the academic teaching at Leiden as far removed from the daily concerns of Dutch political and institutional practice. However, such a characterization would not do justice to the breadth and extent of the public debate in the Republic..$^{48}$ In fact, Boxhorn himself is a case in point of an academic who actively participated in the political debate, not only with his Commentariolus on the Dutch constitution, but also, for instance, by commenting on the turbulent political developments across the North Sea. In reaction to the execution of Charles I in 1649, Boxhorn wrote a pamphlet in defence of the Royalist cause. A few years later he also published a compendium on English history which portrayed England as a country plagued by incessant upheavals, now subdued under the yoke of

\footnotetext{
${ }^{46}$ Politike Discoursen, "Voor-Reeden, Aen den Leeser," sig. *2: “... de Latijnse boeken, pronkende met hoogdravende Tituls, als; Politica, Systema Politicum, Doctrina Civilis, Prudentia Politica, de Republica, Arcana Rerumpublicarum, Aphorismi Politici, Axiomata Politica, \&c. beschreeven door eenige Duitse Professoren, Doctoren, Predikers en Schoolmeesters. Maarvermits onse Autheur ter Contrarie meende, alle de selve schriften soo Pedantisch laf, ongesult, schoolsiek, vol van onweetendheid, en verkeerde ofte schadelike, ende oproerige, Opinien te weesen; dat alle die Duitse Schryvers, hun oordeel nergens min, als in saaken van Staat schynen wel geoeffend te hebben."

47 Van Gelderen, “Aristotelians, Monarchomachs and Republicans," 214-216.

${ }^{48}$ Cf. Wansink, Politieke wetenschappen, 146-154. For a somewhat hesitating attempt to establish a theoretical framework to analyze the connection between political debate and institutional practice in the early-modern period, see Luise Schorn-Schütte, "Einleitung," in Idem (ed.), Aspekte der politischen Kommunikation im Europa des 16. und 17.Jahrhunderts (Munich: R. Oldenbourg Verlag, 2004), 1-12.
} 
an illegitimate and treacherous republican regime. ${ }^{49}$ Other professors at Leiden, most prominently the French scholar Claudius Salmasius (who soon fell victim to the sharp pen of John Milton), similarly chose sides in the English debate. In short, Leiden University was anything but an ivory tower.

This academic concern with current political issues reveals the broad nature of the Dutch public debate, as well as its international impact. Since the early days of the Revolt against Spain, the cities of the Netherlands had nurtured a fervent debating culture where all sorts of pressing questions were constantly discussed in an endless stream of pamphlets, poems, songs, petitions, pasquilles and the occasional elaborate treatise. ${ }^{50}$ Dutch literacy was relatively very high, ${ }^{51}$ the Republic enjoyed a thriving publishing industry, and the cheap prices of print and the numerous peddlers in the urban centres enabled large segments of society to participate in the political debate..$^{2}$ In recent years, this vibrant discussion culture has at times been characterized as an early instance of a Habermasian 'public sphere', the roots of which are commonly located in the late seventeenth-century Republic of Letters, where all participants allegedly contributed to a shared endeavour of rational, disinterested critical inquiry. ${ }^{53}$ Numerous historians have tried to situate the rise of such an Enlightened public sphere in an earlier age, in particular in the Netherlands. For example, an authoritative analysis of the political culture of the Dutch Golden Age portrays the Dutch discussion culture of

49 Boxhorn, De successione et iure primogenitorum in adeundo principatu dissertatio (Leiden, 1649); Idem, Metamorphosis Anglorum, sive mutationes variae regum, regni, rerumque Angliae (s.l., 1653). See the extensive analysis in Nieuwstraten, History and Politics, ch. 5 .

$5^{\circ}$ See Craig E. Harline, Pamphlets, Printing and Political Culture in the Early Dutch Republic (Dordrecht etc.: Martinus Nijhoff, 1987), and Femke Deen, David Onnekink and Michel Reinders (eds.), Pamphlets and Politics in the Dutch Republic (Leiden and Boston: Brill, 2011).

${ }^{51}$ Israel, Dutch Republic, 686-69o.

$5^{2}$ See Jeroen Salman, "Het nieuws op straat. Actueel drukwerk in het vroegmoderne distributienetwerk," in: José de Kruif et al. (eds.), Het lange leven van het pamflet. Boekhistorische, iconografische, literaire en politieke aspecten van pamfletten, 1600-190o (Hilversum: Verloren, 2oo6), 56-67. Cf. for the English case Joad Raymond, Pamphlets and Pamphleteering in Early Modern Britain (Cambridge: Cambridge University Press, 2003), which also sporadically refers to the importance of the Dutch printing and distribution networks.

${ }^{53}$ Jürgen Habermas, Strukturwandel der Öffentlichkeit. Untersuchungen zu einer Kategorie der bürgerlichen Gesellschaft, 2d. ed. (Frankfurt: Suhrkamp, 1990). After its translation into English in 1989, Habermas's work has enjoyed much influence in English historiography. For an illustrative example, see T.C.W. Blanning, The Culture of Power and the Power of Culture. Old Regime Europe, 1660-1789 (Oxford: Oxford University Press, 2002). 
around 1650 as a "neutral" public sphere with "respect for everyone's opinion", where "everybody was welcome, and all remained debatable". ${ }^{4}$

Such a classification of the Dutch debate is overly idealistic, as has been pointed out by more recent studies that emphasize conflict instead of compromise as the main characteristic of seventeenth-century Dutch political culture. ${ }^{55}$ Instead of being neutral and value-free, the Dutch public debate was dominated by partisan propaganda and irrational libel, an untameable many-headed monster beyond the control of the authorities. In times of particular political or religious turbulence, such as the dénouement of the Arminian controversy in 1618-19, polemics and biting satire proliferated, with results like Den Arminiaenschen dreck-waghen ["The Arminian Shitcar"], an infamous caricature with a message as unsubtle as its title. ${ }^{6}$ Confronted with these excrescences of the public debate, many distinguished publicists could hardly hide their anxiety and openly proclaimed their preference for a much more effective policy of censorship. As for instance Grotius remarked, all the pasquilles and libels that overflowed the Dutch market were merely fomenta discordiae, the "fomenters of discord". ${ }^{57}$

The crucial question for an aspiring author in the Dutch political debate was therefore how to manœuvre in this pulsating arena, how to engage the public while avoiding instant refutation or even slander. Consequently, the essential objective since the start of the Revolt was to appeal to the middle ground in society, the large 'middle groups' who, cherishing common norms and values, shunned an extremist minority position. ${ }^{5}$ Political success depended on the ability to address these

${ }_{54}$ Willem Frijhoff et al., 1650. Bevochten eendracht (The Hague: SdU, 1999), 218-224. More sensitive to the difficulties of using the Habermasian concept are Judith Pollmann and Andrew Spicer, "Introduction," in Idem (eds.), Public Opinion and Changing Identities in the Early Modern Netherlands (Leiden: Brill, 2007), 1-9. Cf. also Jason Peacey, Politicians and Pamphleteers. Propaganda During the English Civil Wars and Interregnum (Aldershot: Ashgate, 2004), esp. 303-332; and Peter Lake and Steve Pincus, "Rethinking the Public Sphere in Early Modern England," Journal of British Studies 45 (2006), 270-292.

55 See esp. Michel Reinders, Printed Pandemonium. The Power of the Public and the Market for Popular Political Publications in the Early Modern Dutch Republic (PhD dissertation Erasmus University Rotterdam, 2008); and Freya Sierhuis, "A Babel Full of Confusion". Politics, Literature and the Stage During the Arminian Controversy, 1610-1630 (PhD dissertation European University Institute, Florence, 2009).

${ }_{5}^{6}$ Den Arminiaenschen dreck-waghen (Amsterdam, 1618).

57 Hugo Grotius, Annales et historiae de rebus Belgicis (Amsterdam, 1657), 549: "et quotidie novi libelli aderant, fomenta discordiae", a remark in the context of the debate on the proposals for peace with Spain in 1608 .

$5^{8}$ See J.J. Woltjer, Tussen vrijheidsstrijd en burgeroorlog (Amsterdam: Balans, 1994), esp. 58-63, 87-88. 
shared principles effectively, to make the middle groups believe that the general public opinion was identical to one's own particular cause. As a result, rhetorical self-presentation was absolutely decisive, while a too radical argumentation often proved to be counterproductive. Yet as in England, the ultimate consequence of both sides of the debate trying to win over the middle groups was merely a further politicization of commonly held values and thus, the eventual polarization of the public realm..$^{59}$ In this sense, the attempt to appeal to the middle ground arguably fomented political discord still further.

At the same time, the extent and capriciousness of the Dutch public debate also proved to be a lucrative asset for authors and publishers alike, who could play upon the impulses of the market to sell their ideas and products to as large an audience as possible. A particularly successful example of this strategy was the large series of 'Republics' published by the famous editorial house of Elzevier in Leiden in the course of the 1620s-1640s. These treatises, descriptive surveys of the geography, history and politics of various countries, were prepared in close cooperation with the scholar Johannes de Laet, one of the governors of the Dutch West India Company. Some of the treatises were written by De Laet himself, others were merely new editions of already existing texts. Overall the series entailed a comprehensive overview of all polities of any importance, from classical antiquity to contemporary Europe and the exotic world overseas. ${ }^{60}$ Some of the texts contained significant political contents, such as the two works on Venice by Gasparo Contarini and Donato Gianotti - important propagators of the 'Myth' that portrayed Venice as the ultimate republican regime. ${ }^{61}$ Published in Latin and in cheap, handy duodecimo format, the series proved to be a huge success, both in the Dutch Republic and abroad. Pieter de la Court van der Voort, the son of Pieter de la Court, still owned the entire series (possibly inherited from his father) at the time of his death in $1739 .{ }^{62}$ The 'Republics' of Elzevier

59 Tim Harris, "Propaganda and Public Opinion in Seventeenth-Century England," in Jeremy D. Popkin (ed.), Media and Revolution. Comparative Perspectives (Lexington: University Press of Kentucky, 1995), 48-73, esp. $5^{2}$.

${ }^{60}$ For an overview of the series, see J.A. Gruys, "De reeks 'Republieken' van de Elzeviers en Johannes de Laet," in B.P.M. Dongelmans et al. (eds.), Boekverkopers van Europa. Het $17^{d e}$-eeuwse Nederlandse uitgevershuis Elzevier (Zutphen: Walburg Pers, 2000), 77-114.

${ }^{61}$ See for a suggestive analysis Vittorio Conti, Consociatio Civitatum. Le Repubbliche nei testi elzeviriani (1625-1649) (Florence: Centro Editoriale Toscano, 1997). On the impact of Contarini and Gianotti in the Dutch Republic, see also Haitsma Mulier, Myth of Venice.

${ }^{62}$ Library, fol. 31. On the international dissemination of the publications by Elzevier, see e.g. Frans Korsten, "The Elzeviers and England," in Lotte Hellinga et al. (eds.), 
thus show how the Dutch discussion and printing culture opened up a market for political works that combined theoretical insight with practical concerns, alluring the curiosity of a large audience in between the academy and the agora. Moreover, the series reveals the international inspiration and impact of the Dutch political debate. The Elzevier 'Republics' not only introduced many foreign authors to the Dutch market, but also circulated throughout Europe at large. The importance of the Dutch debate went far beyond the narrow Dutch borders.

\section{Debating True Liberty: The Sovereignty \& The Interest of the Republic}

Fuelled by the range of historical and international examples from the Elzevier series, the political debate in the Dutch Republic throughout the seventeenth century concentrated largely on two fundamental issues: the issue of the origin and location of sovereignty, and the issue of the country's true interest. In other words, the Dutch debate was taken hostage by the combined legacy of Jean Bodin and the heterogeneous tradition of reason of state. ${ }^{63}$ In order to situate the writings of the brothers De la Court within the shared assumptions of their day, this section will give a short overview of the way in which this double legacy dominated the debate in the Republic. Far from aiming to give a comprehensive analysis of all seventeenth-century Dutch theories of sovereignty and reason of state, this overview concentrates on the way in which these abstract theoretical notions and concrete political developments shaped the mainstream debate during the 1650 s, as exemplified by pamphlets and other popular publications that formed the core of the vibrant Dutch debating culture. ${ }^{64}$

The Bookshop of the World. The Role of the Low Countries in the Book-Trade 1473-1941 ('t GoyHouten: Hes \& De Graaf, 2001), 131-143.

${ }_{3}$ Cf. J.H.M. Salmon, "The Legacy of Jean Bodin: Absolutism, Populism or Constitutionalism?," History of Political Thought 17 (1996), 500-522. For useful surveys of the reason of state literature, see esp. Peter Burke, "Tacitism, Scepticism, and Reason of State," in J.H. Burns and Mark Goldie (eds.), The Cambridge History of Political Thought, 1450-170o (Cambridge: Cambridge University Press, 1991), 479-498; and Michael Stolleis, Staat und Staatsräson in der frühen Neuzeit. Studien zur Geschichte des öffentlichen Rechts (Frankfurt: Suhrkamp, 1990).

${ }_{64}$ See on the Dutch political debate in this period especially Geyl, "Stadhouderschap in de partijliteratuur"; Van de Klashorst, “'Metten schijn van monarchie getempert' "; Idem, "De 'Ware Vrijheid'"; and Stern, Orangism. On the role of the stage in the debate, see H. Duits, Van Bartholomeusnacht tot Bataafse opstand. Studies over de relatie tussen politiek en toneel in het midden van de zeventiende eeuw (Hilversum: Verloren, 1990), esp. 95-153. Cf. also Guido de Bruin, "Political Pamphleteering and Public Opinion in the Age of De Witt (1653-1672)," in Deen et al. (eds.), Pamphlets and Politics, 63-95. 
The central author in the appropriation of Bodin's theory of sovereignty to the Dutch context was Grotius. In his De antiquitate reipublicae Batavicae (1610), Grotius made the forceful and influential claim that ever since Roman antiquity, sovereignty in Holland had remained with the States - a representative council of noblemen and magistrates elected from the common people. This Batavian imperium optimatium, a truly aristocratic government, was 'tempered' by a primus optimatium, an individual authority who, unlike a monarch, was subjected to the rule of law. ${ }^{65}$ In this way, Grotius tried to ground the current political situation in Holland and the Dutch Republic at large on a well-established and glorious historical foundation. His argument was clear: sovereignty, originating from the common people, had always resided with the States, who shared the government with a principate. Like Boxhorn after him, Grotius thus attempted to come to terms with the complex political reality of the United Provinces, in particular with the crucial role of the Stadholder. This institutional remnant from the times before the Revolt was, in theory, merely a public servant for the various provincial States by which he was appointed, yet in practice he played a much more influential part in Dutch politics. On the basis of an opaque set of old privileges and informal influences, the Stadholder could exercise a strong hold on Dutch political life, embodying one of the few 'national' elements within the highly decentralized confederation of provinces that had formed a defensive union against Spain. ${ }^{6}$ Through his historical overview, Grotius explained that the Stadholder was an essential element of this political amalgam, yet he also insisted that sovereignty remained at all times with the provincial States. Moreover, a principate would turn into monarchy if not demarcated by the rule of law. Quoting from Tacitus's Annals, Grotius defined monarchy as the direct opposite of republican liberty, the most significant asset of the legacy of the ancient Batavians. ${ }^{67}$

Grotius's elaboration of the 'Batavian Myth' celebrated the province of Holland and the Dutch Republic as a time-honoured example of good

\footnotetext{
${ }^{65}$ Hugo Grotius, The Antiquity of the Batavian Republic, ed. and trans. Jan Waszink (Assen: Van Gorcum, 2000) I.4, II.4, II.14, p. 54, 58, 64. Grotius's early republicanism is analyzed in more detail in Richard Tuck, Philosophy and Government, 1572-1651 (Cambridge: Cambridge University Press, 1993), 154-166. For its international impact, see also Conti, Consociatio Civitatum.

${ }^{66}$ See Herbert H. Rowen, "Neither Fish nor Fowl: The Stadholderate in the Dutch Republic," in Idem and Andrew Lossky (eds.), Political Ideas and Institutions in the Dutch Republic (Los Angeles: Clark Library, 1985), 3-31.

${ }_{67}$ Grotius, Antiquity II.3, p. 58.
} 
government, and as such it greatly influenced the way in which the Dutch defined their anomalous republican polity throughout the seventeenth century. However, two crucial historical episodes revealed that Grotius's carefully constructed account of provincial sovereignty hardly corresponded to the harsh political reality on the ground. The first of these episodes was the climax of the Arminian controversy in 1618/19, when the Stadholder, Prince Maurice of Orange, openly defied the authority of the States of Holland and thus directly disclaimed Grotius's defence of the Batavian republican model. ${ }^{68}$ Indeed, Grotius was himself imprisoned by the Stadholder for his role in the entire controversy and his outspoken political stance (see chapter 5 below). Grotius escaped, went into exile, and continued to dominate the debate, yet a first strong blow had been delivered not only to his account of sovereignty, but to the precarious Dutch political system as such. The crisis of 1618/19 entailed a trauma that would continue to haunt the Dutch political debate for the rest of the century.

The second blow, after decades of relative tranquillity, came in 1650. In that year, the new Stadholder William II, the grandson of the pater patriae William the Silent, staged what was seen by many as a monarchical coup d'état against the States of Holland. Again, the Grotian republican model trembled. The public debate was inundated with an endless stream of pamphlets that argued for and against the actions of the Prince of Orange. ${ }^{69}$ One characteristic pamphlet, which represented the heated general debate by staging a spirited discussion between four people, invoked Grotius to argue that there was no authority above the States, and that the Stadholder, unlike the late English king, therefore did not enjoy any sovereign powers. ${ }^{70}$ On the other side, many supporters of the Stadholder maintained, pace Grotius, that the Dutch Republic at large

68 See for a clear and concise analysis Israel, Dutch Republic, 433-46o.

${ }_{69}$ Ibidem, 595-609. For a detailed overview of the resulting pamphlet war, see Simon Groenveld, De Prins voor Amsterdam. Reacties uit pamfletten op de aanslag van 1650 (Bussum: Fibula-Van Dishoeck, 1967). Cf. also Roeland Harms, "Thievery of Literature. Consequences of the Interaction Between Politics and Commerce for the Form and Contents of Pamphlets," in Deen et al. (eds.), Pamphlets and Politics, 37-62.

$7^{\circ}$ Hollands praatjen, tusschen vier personen ... aangaande de souverainiteyt van Syn Hoogheyt, en tot justificatie van de Ed. Mog. Heeren Staten van Hollandt (Antwerp, 1650 ), 7 . Grotius is likewise invoked in, for instance, Nootwendige aenmerkinge op een fameus libel, ghenaemt de Bickerse beroerte (Antwerp, 1650). On the phenomenon of such pamphlets that stage a discussion between various persons as a rhetorical mirror of the general debate, see Clazina Dingemanse, Rap van tong, scherp van pen. Literaire discussiecultuur in Nederlandse praatjespamfletten (circa 1600-1750) (Hilversum: Verloren, 2008), esp. 112-177. 
had one 'supreme sovereign', namely the States-General together with the Stadholder. According to this view, all the Dutch provinces had entered a political covenant with the 1576 Union of Utrecht by which they relinquished their sovereign rights, not unlike the agreement between various individuals to form a civil society. Just as citizens were not permitted to rebel against the lawful government, so the States of Holland had no right to claim any special authority above the Stadholder. ${ }^{71}$ Numerous refutations followed back and forth, and before long, the Dutch political debate became deeply polarized.

Both sides appropriated the same historical and contemporary examples of republican government to substantiate their particular cause. Doubtless informed by the successful 'Republics' of Elzevier, the opponents as well as the supporters of the Stadholder's coup contended that their interpretation of the Dutch institutional framework wholly corresponded to the republican paradigms of classical Greece, Renaissance Italy, or the Swiss Cantons. A particularly popular strategy among those who defended provincial sovereignty was to compare the Dutch Republic with the Delian League or the Swiss Eidgenossenschaft as a purely defensive union of sovereign entities. ${ }^{72}$ In contrast, supporters of the Stadholder insisted that the mainstay of true republican government, as in the Hebrew Republic, Sparta, or Venice, was a primus in Republica who perfected the mixed regime by balancing aristocratic preponderance with a monarchical element. ${ }^{73}$ As with the theoretical notion of sovereignty, the abstract vocabulary from the Aristotelian politica thus entered mainstream public debate, lending academic lustre to an increasingly perverse pamphlet war.

At the same time, the polarized attempts to win over the middle ground resulted in a gradual radicalization of republican principles. Given the Stadholder's coup, the Grotian middle way between provincial sovereignty and princely dignity had lost its persuasiveness. Little by little the

${ }^{71}$ Bickerse beroerten, ofte Hollandtschen eclypsis, teghen den Helderen dageraedt der Provintie van Hollandt (s.l., 165o), sig. $\mathrm{B}_{2}-3 \mathrm{v}$. Similar claims for example in Oogen-salve, voor de blinde Hollanders (Rotterdam, 1650); and Het recht der souverainiteyt van Hollandt, ende daer tegens de welgefundeerde redenen ... tot weder-legginge van de Hollantsche souverainiteyt (s.l., 1650).

$7^{2}$ See for instance Het tweede deel van 't Hollands praatjen ... aangaande het bedrijf van Zyn Hoogheidt (Antwerp, 1650); Extract eens briefs uyt Vlissingen, inhoudende een roefpraatje (The Hague, 1650).

73 'Galeacus de Rivo Ursino', Grondich bericht, nopende den interest van desen staet (Rotterdam, 1651), 5. For a detailed analysis, see Van de Klashorst, "'Metten schijn van monarchie getempert'". 
Batavian model started to collapse. Was a Stadholder really an essential element of a true republican government? One noteworthy pamphlet from 1650 argued that the experience of other republics, like the Italian city-states, the German Imperial Towns, and now also England, revealed that in a republic individual servants to the state could always be dismissed. "That is Liberty! Of which we have had here nothing but a shadow", the pamphlet exclaimed. "It is an absurdity and it goes against nature and natural reason that we have Stadholders here. All Nations, in particular Republics, laugh at us like at Children and fools who knowingly walk into servitude." ${ }^{74}$ With this highly rhetorical remark, the pamphlet insisted that true republican liberty as opposed to servitude entails the absence of any monarchical element in the state. Moreover, its author argued that the principle of a Stadholder opposed the country's general interest, since the Princes of Orange only pursued their own "particular interest ... as happens in all Courts" under the monarchical motto semper augustus. A political role for the House of Orange would imply that their family's interests "will be altogether preferred above those of our State, our Commerce ... and our own welfare". ${ }^{75}$

This language of 'interest', a key concept of the reason of state literature from the middle decades of the century, had recently entered the Dutch debate during the negotiations that resulted in the Peace of Westphalia. Confronted with numerous French and Spanish diplomats and documents infused with the terminology of the 'true interests' of states, the Dutch political discourse gradually adopted this vocabulary. ${ }^{76}$ As a result, in the wake of the Stadholder's attempted coup from 1650, the debate on

${ }^{74}$ Trouwhartige aenspraeck, aen alle goede patriotten van desen staet (Leiden, 1650), unpag.: "Dat is Vryheyt! Van de welcke wy hier niet als een schaduwe hebben gehadt ... 't is een absurditeyt ende 't strijdt teghen de natuyr ende alle natuurlijcke reden, dat wy hier Stadthouders hebben. Alle Natien, bysonder Republijcken bespotten ende belacchen ons, als Kinders ende dwasen: die willens ende wetende tot de slavernye loopen."

75 Ibidem, unpag.: “... hebben sy niet van begin aen en geduyrich oock haer particulier interest daer onder gesocht ende gevonden ... gelijcket in alle Hoven toe-gaet? ... d'Interesten van sijn Moeders Huys sullen allesins ghepraefereert worden boven die van onsen Staet, onse Commercien ... ende eygen welvaert." A similar argument in Het rechte derde deel van 't Hollands praatje, aangaande de wettige souverayniteyt van de GrootMogende Heeren Staten van Hollandt (s.l., 1650), 8 ('16').

${ }^{76}$ See e.g. [Antoine de Brun], Pierre de touche, des veritables interests des ProvincesUnies du Pais-Bas (Dordrecht, 1647). The language of 'interest' was further popularized by the work of Lieuwe van Aitzema, whose influential compendia of contemporary history, particularly the 14 massive volumes of Historie of verhael van saken van staet en oorlogh (1657-1671) incorporated many French documents filled with reason of state terminology. For Aitzema, see Gees van der Plaat, Eendracht als opdracht. Lieuwe van Aitzema's bijdrage aan het publieke debat in de zeventiende-eeuwse Republiek (Hilversum: Verloren, 2003). 
the sovereignty in the Republic merged with a debate on the country's general interest, the indisputable main concern of the United Provinces irrespective of their constitutional complexities. The key question was whether the Dutch should engage in further war to advance their republican cause against Spanish domination, and the related issue of how to promote the country's welfare. Were the liberty, safety and the commercial success of the Republic best safeguarded by an aggressive foreign policy, strengthened by a large standing army? Or would peace and a strong navy promote the further enhancement of the Republic in the European balance of power and trade?

Again, these issues were fundamentally linked to the figure of the Stadholder. Since William the Silent had assumed the military command in the Revolt against Philip II, warfare had been one of the major sources of the authority and standing of the successive Princes of Orange, who, as Stadholders, also obtained the office of Captain-General over the Dutch troops. Accordingly, the Stadholder and many of his supporters generally favoured the resumption of war, while their opponents, particularly in the cities of Holland, where most of the taxes were raised to pay for the army, pleaded for peace. With the Peace of Westphalia, the latter prevailed. The Stadholder's warlike designs were now painted in the black terms of selfinterest at the cost of the public interest, the main threat to republican liberty. In contrast, the 'Orangists' insisted that the interest of the United Provinces could only be furthered by the Stadholder, "the Scourge of Spain, the gate to our Liberty, the Support of our State, the Pride of all our Friends, and the fear for all our Enemies". ${ }^{77}$

Both sides of the debate hence claimed that they were defending true republican liberty. While Orangists argued that the majesty and military experience of the Stadholder were necessary to protect Dutch liberty and independence against foreign domination, the counterargument was that there is not much difference between "a Spaniard, a Barbarian, or a Native when I lose my Liberty and become enslaved": domination, either foreign or internal, is and remains domination. ${ }^{78}$ The debate thus revolved around

77 [Jacob Stermont], Lauweren-krans gevlochten voor Syn Hoocheyt Wilhelm, de Heervan Oranjen (s.l., 1650), sig. A2: “...den Geessel van Spanjen, de poort onser Vryheyt, de Schraeg onser Staet, den Trots van alle onse vrienden, ende een schrik voor alle onse Vianden." See also Grondich bericht, 4.

${ }_{78}$ 'Wel-hem Recht-hert van Vry-Land', Brief, rakende het vangen der ses leden van de Groot-mogende Heeren Staten van Hollandt en West-vrieslandt (s.l., 1650), sig. A3: "of 't dan is een Spangiaart, een Barbaar, of een Inlander, als ick mijn Vryheyt quijt, en een slaaf moet zijn; soo en kan 't my niet verscheelen, wie het doet." 
the pivotal question of how to define true liberty, phrased in the characteristic Roman idiom of liberty as independence in opposition to servitude. The antagonism between the two blocs arguing for and against the Stadholder should therefore not be mistaken as an ideological struggle between Orangist 'monarchists' on the one hand and 'true' republicans on the other. As several recent studies have made clear, such a rigid, dualistic view collapses in view of the shared vocabularies and the common goal of republican liberty that both Orangists and their adversaries pretended to pursue. ${ }^{79}$ Far from constituting an anti-republican 'party', the miscellaneous front of Orangists merely envisaged a republican polity of sorts, a perfectly balanced, mixed regime fulfilled by the figure of the Stadholder. Unlike across the North Sea, the main adversaries in the Dutch political arena did not clash over royalist versus commonwealth rule; instead, the Dutch debate was one between two different republicanisms.

Yet like 1649 in England, where the execution of Charles I prompted a wave of republican writings that sought to legitimize the new political order, $165^{\circ}$ was a watershed in the ideological history of the Dutch Republic. Shortly after his attempted coup d'état, William II suddenly died from smallpox, leaving no direct adult heirs. Terrified by his example, the States of Holland seized the opportunity and, soon followed by other provinces, they decided not to appoint a new Stadholder. Thus began a period heralded by some as an epoch of 'True Liberty' (known in the historiography, somewhat less empathically, as the 'First Stadholderless Era') - a new political framework that asked for a reformulation of republican principles. ${ }^{80}$ Amidst a devastating war with England and vehement Orangist resistance, which characterized the recent developments as a 'cancer' that infected the entire Dutch body politic, ${ }^{81}$ the powerful regents of Holland's towns decided to formalize the absence of a Prince of Orange as Stadholder with the 1654 Act of Exclusion. Sealed on Cromwell's instigation as a secret annexe to the peace treaty with England, this Act officially excluded all members of the House of Orange from any

\footnotetext{
${ }^{79}$ See in particular Jonathan Israel, Monarchy, Orangism, and Republicanism in the Later Dutch Golden Age, Second Golden Age Lecture (Amsterdam: Amsterdams Centrum voor de Studie van de Gouden Eeuw, 2004); Charles-Edouard Levillain, "William III's Military and Political Career in Neo-Roman Context, 1672-1702," The Historical Journal 48, 2 (2005), 213-350; Jill Stern, "The Rhetoric of Popular Orangism, 1650-72," Historical Research 77 (2004), 202-224; and Idem, Orangism.

8o See Israel, Dutch Republic, 700-726.

${ }^{81}$ Ontdeckinghe van den Nederlantschen cancker. Waer mede 't gehele lichaem van onsen staet deerlijck is besmet ('Heyl-Stadt', 1653).
} 
high political office. A theoretical justification of the Act followed soon with the elaborate Deductie, ofte declaratie van de Staten van Hollandt ende West-Vrieslandt ["Deduction or Declaration of the States of Holland and West-Friesland"], written by the most powerful man in the new political constellation: the Grand Pensionary of the States of Holland, Johan de Witt.

De Witt's Deductie directly challenged the central Orangist claim that the United Provinces had lost their truly balanced republican liberty and splendour now that no member of the House of Orange occupied the offices of Stadholder and Captain-General. Referring to the gruesome fate of other republics such as Rome under Caesar and Augustus, Florence under the De Medici and Milan under the Visconti, De Witt insisted that "in a Republic, such offices cannot be assigned to those whose Ancestors held these posts before, without considerable peril to liberty". Indeed, so De Witt continued, "all Republics in the entire world, not one excluded, who have ever fallen into such maxims or habits ... have thereby been brought under subjection and been reduced into a Monarchical state". ${ }^{2}$ In short, to safeguard republican liberty, political and military power should not be made hereditary. De Witt asserted that this stance was substantiated by the experience of a range of shining republican examples, from Venice, Genoa, Lucca and Ragusa to the Swiss Cantons and the Hebrew Republic - standard references employed by both sides of the Dutch political debate. Stressing provincial sovereignty, De Witt also appropriated the fashionable language of reason of state to maintain that the United Provinces were no formal constitutional unity but rather a confederation of different republics, connected through a mutual connection of commercial and military interests. This delicate harmony could only be torn apart by the preponderance of an "eminent Head", De Witt warned. ${ }^{83}$ Yet overall, the Deductie remained within the boundaries of the Batavian model: De Witt carefully sought not to deride the

${ }^{82}$ [Johan de Witt], Deductie, ofte declaratie van de Staten van Hollandt ende WestVrieslandt (The Hague, 1654), 48: “...dat in eene Republijcque soodanighe charges niet sonder merckelijck perijckel vande vryheydt konnen werden gheconfereert op die geene welckers Ouders de selve charges daer bevoorens hebben bekleedt ... dat alle de Republijcquen vande gantsche Werelt, geene uytghesondert, die oyt tot soodanige maximes, ofte gewoonten zijn vervallen ... daer door onder subjectie ghebracht, ende tot een Monarchicquen staet ghereduceert zijn."

${ }^{8}$ Ibidem, 52-64. Cf. J.C. Boogman, "De raison d'état-politicus Johan de Witt," in Idem, Van spel en spelers (The Hague: Martinus Nijhoff, 1982), 162-189. 
Stadholdership as such, but only to justify the exclusion of the family of the reviled William II from the office.

This principle of non-hereditary political and military power entailed the core of the official claim that the Republic had entered a stage of True Liberty which overshadowed the earlier republican achievements. Yet, for all its bombast, it was a rather weak assertion, precisely because it did not offer a compelling theoretical alternative to the ideal of the balanced mixed regime. In the absence of a persuasive vindication of the status quo, the debate continued. An Orangist rebuttal of the Deductie insisted that "the Act of Exclusion violates the dearly bought freedom of the Country", for true republican liberty would entail the possibility to appoint a Prince of Orange as Stadholder. The self-proclaimed successes of the De Witt regime were in fact highly detrimental, so the pamphlet maintained: the peace with England did not further the Republic's cause "because our liberty can only be maintained by War", and "as regards liberty of Commerce, that is just a private and slavish liberty, which is profitable but not generous". ${ }^{84}$ A subsequent reaction in turn defended the Act of Exclusion, extensively discussing how free republics of the past had lost their liberty because of a hereditary military command. ${ }^{85}$ Another pamphlet challenged the Orangists with the Grotian argument that "the States represent the Community of the entire Country"; if the Prince of Orange would have more authority than the States, "then he would be Sovereign, and we would not be free, as we are now, but unfree" ${ }^{86}$ But the authority of Grotius was also appropriated by the other side. In the province of Zeeland, in particular, there was much resentment about Holland's self-centred ideological course. Adriaan Veth, the Pensionary of Zeeland, forcefully substantiated this criticism with a lengthy quote from Grotius's De antiquitate in favour of the 'moderation' of the mixed regime. In the absence of a Stadholder and Captain-General as monarchical

\footnotetext{
${ }^{84}$ Bedenckingen op de Deductie van de Ed. Gr. Mog. Staten van Hollandt (s.l., 1654), 71-73: “... de Acte van Seclusie, strijt tegen de diergekochte vryheydt des Landts ... onse vryheyt niet anders als met den Oorloge is behouden. Wat aengaet de vryheydt van Negotie, dat's maer een particuliere ende slaefachtige vryheydt, die wel profijtelijck is, maer niet genereus."

${ }_{5}$ Korte aenteeckeninge, dienende tot antwoort op seker libel, genoemt Bedenckingen op de Deductie (s.l., 1655), esp. 36-39.

${ }^{86}$ Noodig bericht aan alle oprechte patriotten en beminders van de duer-gekochte vryheyt (Amsterdam, 1654), sig. B: "De Staten representeren de Gemeente of 't geheele Landt; en indien de Prins dan meerder als sy waren, of dat sijn gesag daar boven strekte, soo was hy immers Souverayn, en wy niet vry, als we nu zijn, maar onvry."
} 
counterweight, Veth prophesied, the United Provinces gradually degenerated into a nepotistic oligarchy, utterly powerless to preserve republican independence. $^{87}$

Accordingly, at the close of the decade of the 1650 os, the debate on the political order of the Dutch Republic remained fundamentally undecided. The ideal of the mixed regime still dominated as the most powerful ideological framework to rationalize the Dutch political constellation, yet it hardly corresponded to the reality of the oligarchic government in power. Was this new phase in Dutch history really an era of True Liberty? The issues of provincial sovereignty and the interest of the state, of war and peace and the extent of free trade, continued to rouse fervent public debate. Meanwhile, the United Provinces were anything but independent of the outside world. When the Stuarts were restored to the English throne in 166o, the Act of Exclusion was revoked, and in an attempt to offset a new Orangist revival, the States of Holland agreed to undertake the education of the young Prince of Orange, the future William III. For those haunted by the traumas of 1618 and 1650, this was not a promising sign. They required an alternative, more radical approach to authenticate the claim that this Stadholderless era was an epoch of True Liberty.

\section{The MAKING OF AN OEUVRE}

\section{From Ideological Testament to Political Campaign}

From the outset, the brothers De la Court were deeply aware that 1650 and its aftermath necessitated a new foundation of republican principles. With the death of the Stadholder, they contended, "Rulers and Subjects, as well as all thoughts, Tongues, Writing pens, and Printing presses" were free again. This enticing sense of freedom not only enabled the brothers to write down and publish their thoughts, but also required a fresh theoretical elaboration of what was at stake in the Republic. ${ }^{88}$ And this was

\footnotetext{
${ }^{87}$ Adriaan Veth, Propositie door den Heer Raedt Pensionaris, der Heeren Staten van Zeelandt ... Aengaende de designatie van den Heere Prince van Orangien, tot Capiteyn, en Admirael, der Vereenighde Nederlanden, mitsgaders Stadhouder (Middelburg, 166o), sig. A4. See also the earlier pamphlet Copia van de resolutie ende motiven der Ed. Moog. Heeren Staten van Zeelandt teghens d'Acte van Seclusie (s.l., 1654).

${ }_{88}$ Politike Discoursen, "Voor-Reeden," sig. *2v.: “... maar dat warelik alle de Regeerders, ende Onderdanen, als meede alle de gedagten, Tongen, Schrijf-pennen, ende Druk-persen, seederd de dood des laatsten Stad-houders en Kapitains Generaal in Holland, hebben bekoomen meer vryheids."
} 
exactly what the De la Courts attempted to bring about. Worldly-wise after their Grand Tour, schooled in the intricacies of academic politics at Leiden, and by now deeply involved in the Leiden textile industry with their own successful firm, Johan and Pieter de la Court decided to try their luck in what was by far the most challenging public arena: the political debate.

The first steps in this ambitious project were taken by Johan. As his brother would later explain, around 1654, the year of the Act of Exclusion, Johan no longer needed to "spend his time to accumulate his goods" and instead decided to use "his superfluous time, which many waste in shallow company", for putting "without hate, love, fear, and hope, sincerely his inner thoughts of all occurring Political and Moral matters on the paper". ${ }^{89}$ But after a few productive years and at a time when he was still actively engaged in writing, Johan fell ill. At the start of 166o, he made his testament and authorized his brother Pieter to take over all his property should he fail to recover. Nearly a month later, Johan died. The bequest that he left to his brother consisted not only of a large number of printed books, but also of his own unfinished manuscripts, which ought to remain unpublished. ${ }^{90}$

Yet Pieter de la Court was to disregard this last wish, deciding instead to disclose his brother's ideological testament. That same year, he prepared an edition of a part of Johan's papers that together comprised a more or less finished work, eventually published in 1660 under the title Consideratien en exempelen van staat, omtrent de fundamenten van allerley regeringe ["Considerations and Examples of State, Concerning the Foundations of All Sorts of Governments"]. Given the provocative potential of the work, De la Court clearly trod carefully: the book was printed in Amsterdam under a fake editorial name and according to the title page written by a certain 'V.H.' ${ }^{\prime 1}$ As contemporaries were quick to find out,

${ }^{89}$ Ibidem, sig. *3: “... naademaal onse Autheur sig bevond in soodaanige gelegentheid, dat hy niet seer behoefde bekommerd te zijn, ofte sijn tijd te besteeden, om sijn goederen te vermeerderen ... sijn overtollige tijd, die veelen in ligtvaardige geselschappen quisten, te besteeden ... sonder haat, en liefde, vreese, ende hoope, opregtelik sijn binnenste gedagten van alle voorkomende Politike, en Morale saken op het papier te stellen."

${ }^{\circ}$ J.H. Kernkamp (ed.), "Brieven uit de correspondentie van Pieter de la Court en zijn verwanten (1667-1685), met bijlagen (1657-1685)," Bijdragen en mededelingen van het historisch genootschap 72 (1958), 3-195: 160-161, note 2 .

${ }^{11}$ The publisher concealed behind 'Ian Iacobsz Dommekracht' [= 'hulk'] was Jan Jacobsz Schipper, active between 1637 and 1669. See M.M. Kleerkooper and W.P. van Stockum, De boekhandel te Amsterdam, voornamelijk in de 17e eeuw, 2 vols. (The Hague: Martinus Nijhoff, 1914-16), vol. I: 188-189. For a detailed bibliographical description of this work, see Wildenberg, Bibliografie, nr. 1031. 
'V.H.' stood for 'Van Hove', the literal Dutch translation of 'De la Court'. Apparently, De la Court hesitated to divulge his brother's identity, but he was equally unwilling to maintain total silence about the author's name. Using his initials in Dutch as a pseudonym appeared to be a convenient middle way.

This first work of the brothers De la Court comprises an outwardly conventional examination, in the tradition of the neo-Aristotelian politica, of the three classical forms of government, monarchy, aristocracy and democracy. It discusses the details of these governmental structures, and extensively analyzes three prototypical cases: the Ottoman Empire, employed to prove that all monarchical rule is necessarily tyrannical, the Venetian republic, an example of a thriving yet conservative aristocracy, and classical Athens, the flourishing, commercial city-state where law and liberty ruled. Of these three examples, the latter is heralded as the best form of government, and the work concludes accordingly that "the Popular government is the most natural, rational, peaceful, and advantageous for the Inhabitants". ${ }^{2}$ This unequivocal conclusion, explicitly connected to the political situation in the Dutch Republic, entailed a clear departure from the Aristotelian conventions and the ideal of the mixed regime. However, the principal aspect that set the work apart from more traditional treatises was its use of the vernacular and distinctive rhetoric: crammed with jokes, fables and vivid metaphors, the work merged its academic background with a popular, lay discourse, thus manifestly trying to intervene in the public debate.

It remains unknown whether this first work enjoyed any success, but the next year, De la Court decided to bring out a second edition, with a new publisher and under a new title: Consideratien van staat ofte Polityke Weeg-schaal ["Considerations of State or Political Balance"], again by 'V.H.' ${ }^{93}$ De la Court changed more than the title and the publisher though. Adding around a hundred pages and adjusting the order of some chapters, he revised the whole work, and, importantly, modified its main conclusions. Where the first edition had ended with its explicit defence of popular government, De la Court appended some chapters to explain the "Reasons why the Popular Government has been depicted so favourably

${ }^{22}$ Politike Weeg-schaal III.I.6, p. 577: "Ende dienvolgende dunkt my, ik nu wel zoude mogen besluiten, dat alles wel overwogen zijnde, de Populare Regeering de naturelikste, reedelikste, vreedsamighste, en voordeeligste voor de Ingeseetenen is."

${ }_{93}$ Published in Amsterdam by Iacob Volckertsz Zinbreker, active between 1654 and 1672. See Wildenberg, Bibliografie, nr. 1032. 
until now; although it is truly not the best one". Instead, this second edition argued "that an Aristocracy that is closest to the Popular Government is surely the best Government". ${ }^{44}$ De la Court continued to add new passages to subsequent editions of the work, which was issued another six times during the following year, 1662. Again, different publishers were involved, all from Amsterdam, though two of these editions might have been brought out without De la Court's consent and cooperation - pirated copies issued with the intention to profit from the book's apparent success. ${ }^{95}$ All in all, the work was enlarged with another hundred pages, and there still exists a copy in which De la Court made further amendments and additions for another re-edition which, however, would never be published..$^{6}$ In comparison to the first edition, the book eventually almost doubled in size. For the ultimate result De la Court's modifications had therefore been at least as important as his brother Johan's groundwork. However, since the original manuscript of the first edition is lost, it is impossible to determine with utter certitude the exact contributions of each of the two brothers.

Thanks to his brother's bequest, 1662 proved to be a highly productive year for Pieter de la Court. Apart from the six different editions of the Politike Weeg-schaal, he would also publish fifteen editions of three other works. First, he edited a collection of essays out of the documents left by Johan as Politike Discoursen, handelende in ses onderscheide boeken van steeden, landen, oorlogen, kerken, regeeringen, en zeeden ["Political

${ }_{94}$ Politike Weeg-schaal III.III.3, III.III.5, p. 652, 661: "Reedenen waarom de Populare Regeering voor desen zo gunstig is voorgestelt geweest; hoewel die warelik de beste niet zy ... Dat een Aristokratie, die allernaast aan de Populare komt, gewisselik de beste Regeering is."

95 The third, modified, edition of the Politike Weeg-schaal was published by Dirk Dirksz., and another copy of this edition, probably unauthorized, appeared with a fictitious place and publisher given ('Ysselmonde, voor Querinus Overal, alias: Dwaal-star'). A fourth, further modified edition, to which I refer, was published again by Dirk Dirksz, and a next one (also called the fourth edition, but slightly different from the latter), by Abraham and Jan van Wees. Another copy of this edition, again probably unauthorized, was issued by Jacob Vinckel, and a fifth edition, with only very few modifications, by the publisher called 'Joan. Cyprianus vander Gracht', probably a pseudonym of a publisher close to the famous editorial house of Johannes Blaeu (see below). See Wildenberg, Bibliografie, nrs. 1033-1038.

${ }_{96}$ This copy, preserved in the Amsterdam University Library as Ms XXV C41, is the fourth edition by Dirk Dirksz, with marginal notes which are unmistakeably by Pieter de la Court, as a comparison with his autographic letters in the Amsterdam Stadsarchief has confirmed. It is arguably the most extensive and therefore most definitive copy of the Politike Weeg-schaal since the amount of additions makes it much larger than the fifth edition. I refer to these additions whenever appropriate. 
Discourses, Dealing in Six Different Books with Cities, Countries, Wars, Churches, Governments and Morals"]. This title clearly reveals the influence of reason of state literature, from the Discorsi politici (1599) by Paolo Paruta to the Discours politiques (1646) by the Duke of Rohan. ${ }^{97}$ A first edition of the Politike Discoursen, written by 'D.C.', De la Court's original initials, was published in Leiden, followed by a slightly modified version in Amsterdam that was published again the next year, probably in an unauthorized edition. ${ }^{8}$ The work, subdivided into six different books all loosely centred on an equal number of themes, comprises a large number of divergent topics, from an analysis of urban economics and a clearly Machiavellian-inspired discussion of power politics and warfare, to a provocative and highly anti-clerical part on religious and ecclesiastical affairs and a concluding section on moral philosophy. As in the case of the Politike Weeg-schaal, the manuscript of the work has not survived, which again makes it difficult to decipher its conception. However, according to the preface, which gives some details about the story behind the making of the work, the text was all Johan's, while Pieter only structured the work and gave it its title. In any case, it seems that De la Court saw no reason to carry out large amendments as in the Politike Weeg-schaal, and apparently he largely concurred with its contents.

The other papers that De la Court inherited from his brother included an unfinished manuscript on the economic and political situation in Leiden, the brothers' hometown. Ten different versions exist of this manuscript, none of which is in De la Court's hand, so the attribution of this work is rather difficult. Yet following the analysis of all these manuscripts by Jan Lucassen, it is possible to reconstruct the work's formation. ${ }^{99}$ The principal part of the text, a fairly radical plea for economic de-regularization and a sharp critique of the monopolist conduct of Leiden University, clearly the work of a well-informed mind with inside

97 The library of Pieter de la Court van der Voort had a copy of both works. See Library, fols. 19, 32 .

$9^{8}$ The Leiden edition was by Pieter Hackius and the Amsterdam one by 'I. Ciprianus vander Gracht', the same editor of the fifth edition of the Politike Weeg-schaal. The 1663 edition was by Jacob Venkel or Vinckel, notorious for his disputed reprints. See Wildenberg, Bibliografie, nrs. 1061-1063, and Paul van Heck, "In het spoor van Machiavelli: de Politike Discoursen, 1662, van Johan en Pieter de la Court," LIAS. Sources and Documents Relating to the Early Modern History of Ideas 27 (2000), 277-318: 278-279, notes 5-7.

99 Jan Lucassen, "Het Welvaren van Leiden $(1659-1662)$ : de wording van een economische theorie over gilden en ondernemerschap," in B. de Vries et al. (eds.), De kracht der zwakken. Studies over arbeid en arbeidersbeweging in het verleden (Amsterdam: IISG, 1992), 13-48. 
knowledge of such matters, was most probably written by Johan, perhaps assisted by his brother. It bears the title Aenmerkinge op het welvaren en Intrest der Stad Leyden ["Comments on the Welfare and Interest of the City of Leiden"] and was finished around August 1659. ${ }^{100}$ After Johan's death, Pieter would continue working on the text for about two years, adding chapters on politics, defence, religious freedom and the history of the city. He dedicated the work to the Leiden regent Johannes Eleman, explicitly referring to their close friendship since De la Court's marriage with Eleman's sister-in-law, Elisabeth Tollenaar, in 1657. Yet when the final version of the work was ready, titled Het welvaren der stad Leyden ["The Welfare of the City of Leiden"], De la Court left it in his desk, unpublished..$^{101}$ By then, De la Court had decided to extend the ideological testament of his late brother into a full-fledged political campaign.

Probably at the instigation of Eleman, the manuscript of Het welvaren had been circulated among the members of the Leiden political establishment. As a result, De la Court's writings entered the inner governing circles of the Republic and eventually attracted the attention of Johan de Witt himself. Persuaded by this new powerful audience, De la Court developed the work on Leiden into a more general study, applied to the case of the entire province of Holland. A first draft of this work-in-progress was consulted by De Witt in July 1661. From then on, De la Court's writings were subjected to the interference of a number of important regents, who intended to use the work as propaganda for the policies of the States of Holland, in particular vis-à-vis the opposition of Zeeland. ${ }^{102}$ Apart from De Witt, those involved were above all Pieter de Groot, the son of Hugo Grotius and by then Pensionary of Amsterdam, and the Leiden regent Hendrick van Willighen. All three paid meticulous attention to the work, suggesting modifications and enlargements. Epecially De Witt meddled heavily in the matter, carrying out a large number of corrections in line with his own ideas. In particular, De la Court's frequent

${ }^{100}$ The manuscript of this first version is now in the Amsterdam University Library, Ms $\mathrm{XV} \mathrm{B}_{3}$. I have also consulted the later manuscripts in the libraries of Groningen University, Ms 233, Leiden University, Ms LTK 784-785, and the Royal Library in The Hague, Ms 75 J65.

${ }^{101}$ It was eventually published by F. Driessen as Het Welvaren van Leiden. Handschift uit het jaar 1659 (The Hague: Martinus Nijhoff, 1911).

${ }^{102}$ This interference is analyzed in detail in an unpublished MA-thesis by Leo van Rossum, "Het aandeel van Johan de Witt aan het Interest van Holland" (Utrecht University, 1964). Van Rossum has carefully examined the printer's copy of the work in the The Hague Royal Library, Ms 73 B17, in which he has retrieved a total of five different hands. A copy of this thesis can be consulted in the Netherlands Economic Historical Archive, Amsterdam, Bijzondere collecties 542 . 
criticism of the existing oligarchy that was in power - De Witt's own regime - was toned down by the statesman, who even deleted an entire passage, too critical in his eyes, and replaced it with two chapters that vindicated his rule. ${ }^{103}$

The resulting work comprises a lengthy discussion of the economic situation in Holland and a passionate attack on the Stadholder's rule in line with the Politike Weeg-schaal, though now stated more explicitly and, thanks to De Witt's interference, clearly defending the existing powers. Shortly before publication, De Groot suggested carrying out yet a further addition, focusing on Holland's sovereignty and independence from the other provinces and on its foreign policy. ${ }^{104}$ De la Court complied with this proposal and when the work was finally ready, it was published by 'Joan. Cyprianus van der Gracht', a pseudonym of an unknown printer who used the presses of the famous Amsterdam editor Johannes Blaeu.$^{105}$ Issued in the summer of 1662 as Interest van Holland, ofte gronden van Hollandswelvaren ["Interest of Holland, or Foundations of Holland's Welfare"], written by 'V.D.H.' (i.e. Van den Hove), the book proved to be a huge and immediate success, and it went through at least eight further editions dated in the same year. ${ }^{106}$

Profiting from this success, De la Court, perhaps at the suggestion of his publisher, decided to issue some new editions of the Politike Weeg-schaal and the Politike Discoursen, of which respectively the fifth and the second reprint were by the same 'Cyprianus van der Gracht'. But this was not all. He also published yet another work that year, the Historie der Gravelike Regering in Holland ["History of the Count's Government in Holland"], a long historical overview of the rule of the various Counts of Holland up to the start of the Dutch Revolt, which served as a historiographical foundation of the anti-Stadholder argument. This work, again by 'V.H.', went

${ }^{103}$ The deleted passage is published in D. Veegens, "Johan de Witt als publicist," in Veegens, Historische Studien, 2 vols. (The Hague: Van Stockum, 1884), vol. II: 54-56. As Van Rossum has argued, the chapters that took its place, 29 and 30 of the published work, are most probably based on a concept written by De Witt himself. For the contacts between De la Court and De Witt, see Herbert H. Rowen, John de Witt, Grand Pensionary of Holland, 1625-1672 (Princeton: Princeton University Press, 1978), 391-398; and Luc Panhuysen, De Ware Vrijheid. De levens van Johan en Cornelis de Witt (Amsterdam: Atlas, 2005), 296-298.

${ }^{104}$ See the letter of De Groot to De Witt, d.d. 2 June 1662, published in Brieven aan Johan de Witt, ed. N. Japikse, 2 vols. (Amsterdam, 1910-1922), vol. II: 107-109. De Groot's proposed additions would form chapters 39-43 of the work.

${ }^{105}$ This assumption is based on the testimony of De la Court's friend, the lawyer Simon van Leeuwen, who said he had seen the work under Blaeu's presses. See Wildenberg, Bibliografie, 39.

${ }^{106}$ Ibidem, nrs. 1041-1049. 
through four editions. ${ }^{107}$ Surprising, furthermore, was the publication of a book called Nauwkeurige consideratie van staet, wegens de heerschappye van een vrye en geheymen staets-regering over de gantsche aertbodem ["Careful Consideration of State, on Account of the Dominion of a Free and Secret State-Government over the Entire Earth"], again with 'Cyprianus van der Gracht' under the name 'V.D.H.' This text was an almost completely identical reprint of a work published in 1657 by the jurist Gerard van Wassenaer, a member of the Utrecht political and intellectual establishment. Apparently, De la Court, or at least his publisher, found it worthwhile or lucrative to publish this book again under his nowfamous pseudonym. ${ }^{108}$

\section{In the Maelstrom of the Debate}

The works of the brothers De la Court spread among large groups within Dutch society, and they caused a vigorous political controversy that triggered a new, radical phase in the public debate. Franciscus van den Enden, Latin teacher to Spinoza, revealed in October 1662, just months after the first publication of the Interest van Holland, that the different books of the De la Courts had enjoyed "large success among the Common people and not less among Persons of High standing". Van den Enden emphasized that he did not know the authors of these works and frequently he expressed his disagreement with the "contemporary writers of loose Discourses and mutilated Holland's Interest". However, "encouraged by their invitation or seduction on the way of a modest exercise of Freedom", he decided to entrust his own political opinions to the printing press. $^{109}$ The writings of the brothers De la Court thus prompted the first political publication of the group of freethinkers around Spinoza.

${ }^{107}$ Three of these editions do not mention a publisher, the fourth, probably unauthorized, edition was by Jacob Vinkel. See Ibidem, nrs. 1051-1054. In one of his own copies, De la Court made extensive notes: see Leiden University Library Ms LTK 679.

${ }_{108}$ See E.O.G. Haitsma Mulier, "De Naeuwkeurige consideratie van staet van de gebroeders De la Court. Een nadere beschouwing," Bijdragen en Mededelingen betreffende de Geschiedenis der Nederlanden 99 (1984), 396-407. The possible influences of this work on the De la Courts are further analyzed in Blom, Morality and Causality, 168-173.

${ }^{109}$ Franciscus van den Enden, Kort verhael van Nieuw-Nederlants gelegentheit (1662), ed. F. Mertens, from http://users.telenet.be/fvde/WorksP/KortVerhael.pdf [retrieved May 13, 2011], "Voor-Reeden,” p. iv: “... ziende hun goet succes in der Gemeintens en niet min Hooge stants Personen gretigh ontfangen haerder schriften, ook al meede dear toe aenleidingh gegeven, en te meer aengemoedicht om hare nodingh of aenlokkingh ter baan van bescheide Vryheits-betrachting niet geheel Vruchteloos te laten passeren." Ibidem, "Na-Reeden," p. 69: “... zoo en hebben wy niet en minder als de hedendaeghze losse 
Van den Enden did not exaggerate, for the treatises of the De la Courts, and especially the Interest van Holland, proved to be true bestsellers, widely diffused among the urban populace and said to be read and discussed even on canal boats. Pamphlets such as the 1662 Haeghs HofPraetje ["The Hague's Court Talk"] critically dramatized such discussions by staging a debate between diverse opponents of Pieter de la Court, already mentioned by his true name. ${ }^{110}$ Other Orangist pasquilles followed, defaming in much harsher language this devilish "new-born Dutch Cromwell alias Leiden Quaker". "With the odd blend of vulgar yet humanist reproach that was typical for such libels, De la Court was scorned for his alien origins and his riches, and admonished to

Go, you Bastard, go to Pluto's dark dwelling

Maybe Pluto will make you the King of Hell

Go, Nero's brother, go to Aeneas's cavern

Receive there forever the fire that never chills. ${ }^{12}$

Such opposition to De la Court did not remain limited to anonymous pamphlets. Shortly after the publication of the Interest van Holland, the fervently orthodox Leiden consistory decided to investigate the contents of this work and of the Politike Discoursen since it was rumoured that they were "offensive", a claim fully confirmed after a closer examination. The consistory temporarily excluded the alleged author from the Lord's

Discourse, en verminkte Hollandtze Interest-schrijvers, enz. de vrymoedigheit derven nemen." For Van den Enden, see Israel, Radical Enlightenment, 175-184.

${ }^{110}$ Haeghs Hof-Praetje, ofte 't samen-spraeck tusschen een Hagenaer, Amsterdammer, ende Leyenaar. Op ende tegens de valsche calumnien ende versierde leugenen van Pieter la Court, gestelt in sijn alsoo genoemde Intrest van Holland ende gronden van 't Hollands welvaren (Leiden, 1662). This pamphlet was countered by a reaction that repudiated De la Court as much as his opponents: 't Afgeruckte masker van den Haegsen Hofprater (Leiden, 1663).

"i1 De gansche distructie van den nieuw-gebooren Hollantschen Cromwel alias Leydtschen Quaker; genaemt t'Intrest van Hollandt, ofte gronden van 's Hollants welvaren (Schiedam, [1663]); Helle-vreucht over den herbooren, ende nieu-regeerende Hollantschen Cromwel alias s'Hollandts Intrest ende Stadthouders Regeringh beschrijver [1662].

${ }_{112}$ Een onverwelckbare kroon, gevlochten op het noyt-genoegh verachte boeck, genaemt de Hollantsche Intrest, door Pieter la Court [1662]: "Gaat dan gy Rotsack, gaat in Plutoos duyster wooning/Misschien dat Pluto u wel maakt de Helsche Coning,/Gaat Neros broeder, gaat in Aetneas bergspelonck,/Ontfanckt daar eeuwiglijck de noyt verkoude vonck." Surprisingly, this pamphlet, as another anonymous pasquille rebuking De la Court, $O p$ de op-roerige schriften van Pieter la Court, door hem uyt-gegeven onder de naem van V.D.H. en D.C. [1662], were published by De la Court's own publisher, 'Cyprianus van der Gracht'. These two pamphlets were countered by one vindicating De la Court, also anonymously: Den rechten Hollander, tegen de twee pasquillen op de heer Pieter la Court, of syn boeck genaemt Hollantsche Intrest [1662]. 
Supper and called upon the urban magistracy to take further measures. De la Court admitted that he was the author of the Interest van Holland, though not of its offensive passages, nor of the at least as scandalous Politike Discoursen. Yet, when the second edition of the Politike Discoursen was issued around December 1662, the further distribution of the work was prohibited and De la Court's exclusion from the Lord's Supper was reconfirmed. To overcome this situation, De la Court tried to obtain the backing of De Witt, but in vain. Having lost his powerful patronage, he had to grovel before the ecclesiastical authorities. Only when he had declared "that he did not approve all the things in the published books of which he was charged", was De la Court again accepted at the Lord's Supper, that prime locus of early-modern social life. ${ }^{113}$

Yet De la Court also encountered support. A notably like-minded and equally productive author was the The Hague jurist Johan Uytenhage de Mist, who in 1662 published five editions of a provocative anti-Stadholder treatise with 'Cyprianus vander Gracht', De la Court's publisher in Amsterdam. ${ }^{114}$ The next year, a refutation, directed against both this work and the Interest, appeared with the same publisher under the title Den Herstelden Prins ["The Restored Prince"]. ${ }^{115}$ De la Court was happy to find that its author "shows more his good disposition or will in favour of the prince, than any competence to defend such matters well". ${ }^{116} \mathrm{He}$ also welcomed a subsequent rebuttal by a certain 'Aesopus Stomachatus', perhaps a pseudonym of Uytenhage, ${ }^{117}$ as well as another large pamphlet that

${ }^{113}$ See the excerpts from the 1662-1663 meetings of the Leiden consistory and magistrate in Brieven aan Johan de Witt, ed. Japikse, vol. II: 110-111: “... verklarende, dat hy al de dingen, die in de uitgegeven boeken hem werden ten laste gelegd, niet approbeerde."

${ }^{114}$ De Stadhouderlijcke Regeeringe in Hollandt ende West-Vrieslant (Amsterdam, 1662), soon followed by a rebuttal: Toetze op het laster-schrift, 't onrecht genaamt Stadhouderlyke Regeeringe van Holland en West-Vriesland (Leiden, 1662).

${ }_{15}$ Den Herstelden Prins tot Stad-houder ende Capiteyn Generaal ... tegens de boekjens onlangs uyt gegeven met den naem van Interest van Hollandt, ende Stadthouderlijcke Regeringe in Hollandt (Amsterdam, 1663), dedicated to William III by a certain 'D.C.'

${ }_{16}$ Pieter de la Court to the brothers Van der Voort, 9 March 1663, in J.H Kernkamp (ed.), "Brieven uit de correspondentie van Pieter de la Court en zijn verwanten (1661-1666)," Bijdragen en mededelingen van het historisch genootschap 70 (1956), 82-156: 98: "De autheur laat meer blijken sijn goeden aard of wil ten voordeele der prinsen, alswel eenige bequaamheid om soodaanige sake wel te defenderen."

${ }_{117}$ 'Aesopus Stomachatus', Apologie ofte verantwoordinge van den ondienst der stadthouderlyke regeeringe (Amsterdam, 1663), published again by 'Cyprianus van der Gracht'. See Wildenberg, Bibliografie, nr. 1091. A year earlier, another pamphlet had been published under the title Aesopus Defensor sig erbarmende over de diepe sugten van den Klagenden Veenboer (The Hague, 1662). It has been argued that De la Court himself was this 'Aesopus', but this assumption is not based on any convincing evidence. See for a discussion of the authorship: Wildenberg, Bibliografie, 29-30. 
he characterized as "speaking more straightforwardly in favour of liberty and against the particular interest of the Princes of Orange, than has been done by any private pens until today". ${ }^{18}$ All in all, De la Court had become the centre of the public debate and he and his allies were besieged by a virtually endless stream of further poems, pamphlets and pasquilles that flooded the Dutch market for the next two years. ${ }^{119}$ De la Court had clearly unleashed the untameable beast of Dutch public opinion.

The intensity of the debate and the forceful opposition of the church made De la Court decide to maintain silence for a while. Yet he still engaged in a continuous rethinking of his conclusions, he further adjusted his copies of the Politike Weeg-schaal and the Gravelike Regeeringe for possible re-editions in the future, and he made numerous notes of historical documents that contained relevant information. ${ }^{120} \mathrm{He}$ also initiated (and quickly abandoned) a new work entitled Hollandse Chronijk ["Dutch Chronicle"], a geographical, social, religious and political description of Holland during the times of Charlemagne, to be based on a historical survey from the classical period onwards. ${ }^{121}$ Another of his manuscripts comprises a huge series of loose historical data, ranging from the year 691 to 1583 , followed by some notes of financial and military resolutions taken between 1664 and $1667 \cdot{ }^{122}$ In the end, having collected new information and references with the assistance of his friend Uytenhage de Mist, De la Court decided to try again and prepare a new publication. ${ }^{123}$

${ }_{118}$ Pieter de la Court to the brothers Van der Voort, 6 May 1663, in Kernkamp (ed.), "Brieven (1661-1666)," 107-108: "Het spreekt ronder voor de vrijheid ende teegen het interest der princen van Oranjen, als door eenige privee pennen tot heeden is geschiet." De la Court refers to De gulde legenden van de Stadthouders in Hollant ende West-Vrieslandt (Amsterdam, 1663). See also 'H. van V.', Hollandse Vrijheid verdedigt tegen de usurpatie der Stadhouders ('Loevestein', 1663).

${ }^{119}$ See e.g. 'F.J.A.', Wederleggingh tegens eenige poincten, de welcke soo lasterlijck verhaelt worden in het boeck genaemt de Hollandtsche Intrest (Amsterdam, 1662); [Jean Nicolas de Parival], Le vray l'interêt de la Hollande, elevé sur les ruines de celuy qui voit les jour sous le nom de V.D.H. ([Amsterdam], 1662); Tafel-praetje ... over de schendige boecken genaemt den Intrest van Hollandt, mitsgaders de Consideratien van Staet, ende Politijcque Discourssen (Dordrecht, [1662]); A. Van den Berg, Verdediging, of antwoort op het schandaleuze en monstreuze boek, genaamt Hollandts Intrest (Dordrecht, 1663).

${ }^{120}$ See De la Court's large manuscript of loose notes, Amsterdam University Library Ms XIV E16.

${ }^{121}$ "Kort Begrijp van eene Hollandse Chronik," part of a large manuscript titled "Hollandse Chronijk," Amsterdam University Library Ms XVI B1.

${ }^{122}$ Ibidem, fols. 91-632; fols. 633-634. See also the various copies of resolutions of the States of Holland, some in De la Court's hand, compiled in Ms 75 C 37 in the Royal Library in The Hague.

${ }^{123}$ For Uytenhage's assistance, see the unpublished chapter "Wat goede vrugten de beginselen eener Vrye Regeeringe albereids gebaard hebben sedert den jare 1662 tot den 
In 1667, following the resounding triumph over England in the Second Anglo-Dutch war, De Witt cum suis had enforced the signing of the Perpetual Edict whereby the States of Holland formally abolished the office of the Stadholder. Confident that his message would now encounter a more favourable response, De la Court again dived into the maelstrom of the public debate.

His new contribution to the debate entailed an adjusted and extensively enlarged re-edition of the Interest van Holland, with a new preface, a different chapter sequence and some up-to-date information to actualize the contents. Yet before the work was issued, De la Court attempted to tread very carefully, since the memory of what had happened in 1662 was still fresh. First, he sought to obtain the permission of the States of Holland to publish the book, a request which was granted in December 1668. Then, in the preface to the work, he excused himself for the publication of the Interest van Holland with the argument that "the acquisitive Printers had reprinted this wholly imperfect Work, which was by its Writer never designed for the Press ... repeatedly without my knowledge and against my wishes". ${ }^{124}$ In short, De la Court claimed that he was not to blame for the public outcry in the wake of 1662 .

The treatise was eventually issued in the spring of 1669 with the Leiden editor Hackius, who had also published the first edition of the Politike Discoursen back in 1662. ${ }^{125}$ Under the new, resounding title of Aanwysing der heilsame politike Gronden en Maximen van de Republike van Holland en West-Vriesland ["Demonstration of the Beneficial Political Foundations and Maxims of the Republic of Holland and West-Friesland"], but with no mention of any author, it ran to a total of 2500 copies, of which 1500 had already been sold by the beginning of June. ${ }^{126}$ However, despite or maybe because of this success, the precautionary measures that De la Court had taken proved to be useless. Immediately after the publication, the ecclesiastical authorities approached the States of Holland to complain about its contents, arguing that De la Court's tolerationist stance

\footnotetext{
jare 1669," in J.H. Kernkamp (ed.), "Twee "niet ter drukperse bereide” geschriften van Pieter de la Court', Bijdragen en mededelingen van het historisch genootschap 56 (1935), 160-195.

${ }^{124}$ Aanwysing, "Voor-Reeden des Aucteurs," *3v.: “... de baatsugtige Drukkers gemeld gansch onvolmaakt Werk, welk door sijnen Schryver ter Drukkerye niet bescheyden was ... te meermalen sonder mijn weten, en teegen mijne genegentheid, herdrukt hebben."

${ }^{125}$ On the Hackius printing house, see Paul G. Hoftijzer, "Sic Transit Gloria ... The End of the Officina Hackiana," Quaerendo 26, 4 (1996), 258-273.

${ }^{126}$ See Wildenberg, Bibliografie, nr. 1111, and for the distribution Ibidem, 37.
} 
undermined religious stability. After discussing the work, the States of Holland declared it to be "injurious, libellous and highly detestable", withdrew the granted permission for publication and prohibited its further sale and distribution. ${ }^{127}$ Nonetheless, this ban did not really obtain the intended results, for a new edition of the work was published with the same publisher and under the same title in $1671 .{ }^{128}$

Given the events of the following year, when the regime of True Liberty collapsed and the Prince of Orange, William III, was installed as Stadholder, De la Court was ultimately forced to desist from publishing further. Only years later, towards the end of his life, did he decide to entrust his views to paper again. His opinions had remained the same, yet the form in which he now couched them was new: the emblematic fable. This popular literary subgenre, consisting of a small image and corresponding allegorical story, followed by an explanation of its meaning, offered De la Court the appropriate means to expose his opinions one more time under a thin, almost transparent veil of metaphors and parables. In hundred different emblematic fables, explicitly employed for their rhetorical value in combining word and image, he enunciated once more his views on the human condition and the ideal organization of society. De la Court died at the end of April 1685, and shortly after, the Sinryke Fabulen, verklaart en toegepast tot alderley zeede-lessen, dienstig om waargenoomen te werden in het menschelijke en burgerlijke leeven ["Significant Fables, Explained and Applied to All Sorts of Moral Lessons, Useful to be Observed in Human and Civil Life"] was published by the Amsterdam printer Hieronymus Sweerts. It is likely that the work was deliberately kept unpublished during its author's life since the concealed references to the Stadholder's regime were much too blatant and, needless to say, unlikely to please the existing powers. ${ }^{129}$ Even from the grave, De la Court continued to intervene in the political debate.

${ }^{127}$ See J.H. Kernkamp, “De “Aanwysing” op de lijst van verboden boeken,” Bijdragen voor Geschiedenis en Oudheidkunde 7, 6 (1935), 102-110; quotes on 105-106.

${ }_{128}$ See Wildenberg, Bibliografie, 1112. De la Court also prepared yet another edition of the work, rewriting the first and fifteenth chapters of the first part. The manuscript of these revisions, inserted within a copy of the first edition of the Aanwysing, is preserved in the Royal Library in The Hague, Ms 393 C22. Probably due to the events of 1672, this new edition would never be published.

${ }^{129}$ The title page mentions no author, but the work is signed by 'P.C.P' (i.e. Pieter de la Court Pieterszoon). See Wildenberg, Bibliografie, nr. 1131. 


\section{Conclusion: Politics as a Ballgame}

The core of the provocative attempt of the brothers De la Court to establish a new foundation for Dutch republican politics in the wake of $165^{\circ}$ was their radical departure from the ideal of the Batavian model. Throughout their œuvre, from the first edition of the Politike Weeg-schaal in 1660 to the Sinryke Fabulen in 1685 , the De la Courts insisted that in politics, speculative conceptions of an idealistic state of affairs are utterly worthless. Such speculations, like "Rempublicam Platonis, Aristotelis, Eutopiam Mori", are nothing more than the building of "a Philosophical Republic in the air". ${ }^{130}$ In contrast, what truly matters is the harsh political reality on the ground. Human wickedness and ignorance are unavoidable, no country consists of virgin soil, and "in Politics, like in a ballgame, one ought never to set the ball where one wishes, but one must strike it as it lies". ${ }^{11}$ Wishful thinking is therefore to no avail, and all a good patriot can do in politics is making society a bit less imperfect by choosing the least of two evils. ${ }^{132}$

This pragmatic stance against utopian speculation was of course a commonplace argument in early-modern political thinking. In Il Principe, Machiavelli dismissed people who imagined nonexistent republics, and about a century later, the French skeptic Pierre Charron disclaimed in particular the republics of Plato and Thomas More as "castles in the aire" - a verdict echoed by De la Court. ${ }^{133}$ Spinoza would continue to ridicule those who "have generally written satire instead of ethics, and have never conceived a political system which can be applied in practice" ${ }^{134}$ Yet De la Court's metaphor of politics as a ballgame clearly involves more than just a commonplace. Its underlying message is that the body politic is no predictable, quantifiable mechanism that can be analyzed scientifically. Rather, it is a complex set of rules that leave room for competition,

\footnotetext{
${ }^{130}$ Aanwysing I.II., p. 16: “... Rempublicam Platonis, Aristotelis; Eutopiam Mori, in de lugt eene Philosophise Republijk."

${ }^{131}$ Ibidem, 17-18: “... dat men in de Politie nooit vermag, gelijk wel somtijds in het kolfspel, den bal schoon naar wensch te setten, maar dat men die altijds soo als hy legd moet slaan."

${ }^{132}$ Politike Weeg-schaal III.I.6, p. 561.

${ }_{133}$ Niccolò Machiavelli, Il Principe, ed. Giorgio Inglese (Turin: Einaudi, 1995) XV, p. 102-103; Pierre Charron, Of Wisdome (Amsterdam and New York: Da Capo Press, 1971) I.51, p. 197 .

${ }^{134}$ Spinoza, Tractatus Politicus, in The Political Works, ed. and trans. A.G. Wernham (Oxford: Clarendon, 1958) I.1, p. 261.
} 
contingency and individual ingenuity. Thomas Hobbes insisted that the "skill of making and maintaining commonwealths consisteth in certain rules, as doth arithmetic and geometry, not (as tennis-play) on practice only" ${ }^{135}$ Harrington argued that in politics it is better to play "as it were at billiards ... unless your ribs be so strong that you think better of football" ${ }^{136}$ Yet whatever the game of politics is called, its ultimate result is always determined by fortune.

Confronted with the crises and political contingencies of the 1650 s, this Machiavellian obsession with the power of fortune made the brothers De la Court depart from the conventional approach to the Dutch constitutional framework in the terms of the ideal Batavian model. Following a gradual development in the public debate that had started around 1650 , the De la Courts moved from a theoretical discussion of provincial sovereignty and institutional complexities to the language of interest. For what do speculative arguments matter if politics is all about de facto power and the law of necessity? In the wake of the Orangist coup d'état and the subsequent debates about the Act of Exclusion, the De la Courts became convinced that the only feasible argument against the Stadholder and in favour of True Liberty was not so much a question of sovereignty, but one of interest. In a realm of de facto politics, where imperious Princes suddenly died and secretly signed treaties had to legitimate the new order, the interest of the state seemed to be the only indisputable foundation upon which republican politics could be built. Academic disputations and thorough scholarly treatises in Latin now had little appeal, and the De la Courts eagerly turned to alternative sources that taught how to cope with political contingency: to Machiavelli and Traiano Boccalini, to French and Spanish theorists of reason of state, and eventually also to the new star on the firmament of de facto politics, Hobbes.

Nonetheless, this attempt to push the political debate into a new direction did not mean that the brothers De la Court could entirely discard the conventions of the Dutch discussion culture. As all pamphleteers, they had to maneuver carefully in the public arena to appeal to the middle ground. On the one hand, if they wanted their ideas to be heard then they had to address as large an audience as possible; on the other, if they wanted to become truly influential, they had to reach the higher echelons

${ }^{135}$ Thomas Hobbes, Leviathan, ed. C.B. MacPherson (London etc.: Penguin, 1968) XX, p. 135 .

${ }^{136}$ James Harrington, The Commonwealth of Oceana and A System of Politics, ed. J.G.A. Pocock (Cambridge: Cambridge University Press, 1992), 147. 
where political decisions were taken. This tension between two opposing approaches pervades the form and contents of the works of the De la Courts. It is a tension between a popular discourse, deliberately set down in the vernacular, and a more distinguished, sophisticated attitude, infused with Latin quotes and academic terminology that betray the brothers' cultured background. Time and again, specific passages in their work suggest that the brothers not only attempted to call upon "the judgment of all modest Readers", the common citizenry of the Dutch urban centres, but particularly hoped to reach the eyes and ears of the "Lawful Rulers" so as to "raise the speculation and thoughts of those who have any share in Government in my free Fatherland". ${ }^{137}$ In short, the De la Courts were trapped in between the vulgarity of the agora and the decorum of the academy.

Still more than its provocative contents, the form of this slippery attempt to please two audiences at once reveals why the works of the brothers De la Court met with such a fierce public outcry. Shocked by the impropriety of their language, the aristocratic author of one opposing pamphlet asserted that "I have never believed that Holland could have reached such an absolute freedom that everyone would be allowed to discuss matters of State and to defame the name of the laudable dead Princes". "No, Holland", he exclaimed, "your liberty does not involve consent to libel". ${ }^{138}$ Another reaction to the De la Courts insisted similarly that "such things ought not to be made public among the people and the rabble". ${ }^{39}$ These reactions reveal that the Orangist opponents of the De la Courts were particularly upset by the popular language that the brothers used, by the openness and outspokenness of their anti-Stadholder criticism. As noted above, these Orangists were no monarchists that disclaimed the legitimacy of the De Witt regime. Instead, they argued that

\footnotetext{
${ }^{137}$ Aanwsying III.8, p. 522: “... naar het oordeel aller bescheiden Leeseren, ende voorneementlik der Wettige Regeerderen.” Politike Weeg-schaal III.III.6, p. 665: “... om de speculatie en gedagten op te wekken, der geenen, die, in mijn vry Vaderland eenig deel aan de Regeering hebbende." See also the dedication of Welvaren, p. 1-2.

${ }^{138}$ Den klagenden veen-boer, over de faem-roovende pasquillen tegens sijn Hoogheyt den Heere Prince van Orangie, en de selfs loffelijcke voorvaderen (The Hague, 1662), sig. A2: “... ick hadde noyt gelooft dat Hollandt tot soo een absoluten vryheyt soude gheraeckt hebben, dat het een yder geoorloft soude zijn, te bedisputeeren de saken van Staet, en te diffameeren de namen der lofbaere doode Princen ... neen Hollant uwe vryheydt bestaet niet in consent tot laster."

${ }_{39}$ 'W.H.', Den oprechten Stadthouder in Hollant, waer in oock aengewesen wort de ydelheydt van de Interest van Hollant (Amsterdam, 1663), sig. A5: “... dusdanige dingen niet en behoorde onder al het volck ende het graeuw gemeen gemaeckt te worden.”
} 
the liberty and the interest of the Republic were not promoted by the harsh, blunt political speech of the brothers De la Court. As a certain Jasper Cattenbaert aptly explained the position of many moderate Orangists in his 1662 rebuttal of De la Court's Interest van Holland:

Our goal is not to agitate against the current Government, which pleases us most, yes we dare to say openheartedly that it is the best and most secure ever enjoyed by any Country or Empire since the beginning of the World. We only oppose those vehement and ongesoute ['unsalted', i.e. plain] proposals which the Writer brings up against Persons, Offices, States, and Positions that can very well coexist with the current Government and Peace of the Country, whereby Liberty will not be violated, but placed in the highest Seat. For such a Lord or Head is fully bearable and coincides very well with the Interest of Holland. ${ }^{140}$

Thus, before long the principled anti-Stadholder argument of the De la Courts was depicted as an extremist position, and the Orangists eventually succeeded in arguing that they represented the moderate middle ground. In the course of the 1660 s and 1670 s, they continued to take the Batavian model of Grotius as their authoritative starting point. ${ }^{141}$ While the brothers De la Court and their few allies rallied behind the radical claim that a true republic is free of any monarchical element, the Orangist interpretation in the end won over the middle groups in society. After 1672, Dutch republicanism would merge this support for the House of Orange with the language of commercial interest that was put at centre stage in the work of the brothers De la Court. ${ }^{142}$ And so, their attempt to

${ }^{140}$ [Jasper Cattenbaert], Hollands op-komst, oft bedenkingen, op de schaadelijke schriften, genaamt Graafelyke Regeeringe en Interest van Holland, uit-gegeven door V.D.H. (Leiden, 1662), "Voor-reeden," p. 123-124: "Eyndelijk, ons doel-wit is niet, yets te ageeren, tegens de tegenwoordige Regeeringe, dese behaagt ons meest: ja derven vrymoedig seggen, datse is de beste, en zekerste, die ooit eenige Landen oft Rijken, sedert, de aanvang des Werelts heeft genooten: maar gaan alleen tegen, die vehemente en ongesoute propoosten, welke den Schrijver voert, tegen Persoonen, Ampten, Staaten, en Bedieninge, die seer wel, met de hedendaagsche Regeeringe en Ruste der Landen konnen bestaan; waar door de Vryheidt niet verkragt, maar in 'er hoogste zetel gestelt werdt. Wijl sulk een Heer en Hooft een gans verdragelijke zake is, en seer wel met de Interest van Holland over een komt."

${ }^{141}$ See e.g. [P. de Huybert], Apologie, tegens de algemeene, en onbepaelde vryheyd, voor de oude Hollandsche regeeringe (Middelburg, 1669); Consideratien ende redenen, daer by de nootsaeckelijckheyt van de Stadthouderlijcke regeringe in desen staet ende republique wordt aengewesen (The Hague, 1677).

${ }_{142}$ See esp. the large treatise by Petrus Valkenier, ' $t$ Verwerd Europa (Amsterdam, 1675). On Valckenier, see E.O.G. Haitsma Mulier, "Die politisch-historischen Ideeen von Petrus Valkenier," in Albert de Lange and Gerhard Schwinge (eds.), Pieter Valkenier und das Schicksal der Waldenser um 1700 (Heidelberg: Regionalkultur, 2004), 109-122; and Thomas Maissen, "Petrus Valkeniers republikanische Sendung. Die niederländische Prägung des 
reach two audiences failed: the establishment turned its back to the brothers' fanaticism, while their appeal to the middle ground was never truly committed, as is revealed by the disdainful references in their work to the 'ignorant rabble'. The brothers De la Court played the game of politics - and in due course, they lost.

All in all, the common œuvre of Johan and Pieter de la Court came about in the twilight zone between the autumn of late humanist culture and the gradual dawn of a new age. During their early years at Latin School and Leiden University, the brothers enjoyed a standard humanist education that schooled them thoroughly in the study of the classics, of history, philosophy, and academic politics. Meanwhile, their Grand Tour revealed to them an exotic world outside Leiden's walls, the international community of famous scholars like Comenius and Amyraut, the political intricacies of pre-Civil War England, and all the diverse aspects of religious pluralism in France and Geneva. The De la Courts were trained to become cosmopolitan humanists, and they would never renounce this background entirely.

Yet in the course of their lives, some of these earlier feathers were shaken off. In Het welvaren van Leiden, the critical eulogy for their hometown, the brothers regretted the days that they had spent in the classroom. "Can one think of anything more ridiculous and more capable to extinguish all human wisdom than Philosophy, as it has been taught all over Europe and is still taught at many Academia?", they asked. Academic philosophy is only good for armchair pedantry, and the same goes for another prime element of late humanist university education, the study of Roman law - which offers "mere historical knowledge" but is utterly useless for a modern public life. ${ }^{143}$ Indeed, De la Court emphatically ridiculed all academic treatises of Latin politica that could not cope with the practical realities of seventeenth-century politics. Instead of these elements of a humanist training, something different was required to deal with the challenges of an era when constant political change undermined past certainties. Swept away in the broad public debate that characterized Dutch urban culture, the brothers De la Court realized that humanist

neuzeitlichen schweizerischen Staatsverständnis," Schweizerische Zeitschrift für Geschichte 48 (1998), 149-176.

${ }_{143}$ Welvaren 6, p. 15: "Jae dat meer is kan er wel ietwas meer bespottelijck, en bequamer, om alle menschelijke wijsheid uijtteblusschen, bedaght werden, als de Philosophie, soo als sij door geheel Europa onderwesen is geweest, ende op veel Akademiën als nogh onderweesen werd." Ibidem 9, p. 21: "De Roomsche reghtsgeleerdheid is maer een historische kennis." 
values had begun to loose their utility and persuasiveness. The eventual result was their common œuvre, which, written in the vernacular, stands out for its attempt to break new ground in Dutch republican politics. It involves a clear departure from the pillars of late humanism, but its foundation was built on exactly those pillars. The brothers De la Court tried to reform humanism with humanist means. 


\section{CHAPTER TWO}

\section{THE RHETORIC OF THE MARKET}

The crucial criterion for successful participation in the seventeenthcentury Dutch public debate was the establishment of authority. Confronted with the limits imposed by convention and censorship, authors had to search for powerful patronage to support their publications and overcome potential opposition. The history behind the œuvre of the brothers De la Court reveals that this was no easy task: though he was initially backed by De Witt and the political establishment, De la Court quickly lost this support after the publication of the Interest van Holland, he was scorned by the public and his works were banned by the church. Yet apart from official patronage, there was also a second, more powerful way to establish one's authority and thereby undermine the authority of others: the power of language. ${ }^{1}$ With their humanist education, the brothers De la Court, like all seventeenth-century authors, knew how to apply that power most effectively thanks to the study of rhetoric.

Since antiquity, the teaching and practice of rhetoric had played a central role in public life, offering the foremost comprehensive system for the creation and evaluation of speech - and thus, for society's most important feature: human communication. Famous Roman orators and theorists such as Cicero and Quintilian, who elaborated on a rich Greek rhetorical legacy, left hugely influential treatises that would dominate discussions on the subject for centuries. With the advent of humanism, this rhetorical tradition received new attention and emphasis. In line with the teachings of the classics, rhetoric came to be seen as an essential element of the ideal of a vir bonus dicendi peritus, the virtuous citizen who engages actively in the public life of the polity by eloquently advising his sovereign and instructing his fellow citizens to pursue truth and reason. ${ }^{2}$

\footnotetext{
${ }^{1}$ See Kevin Sharpe, Reading Revolutions. The Politics of Reading in Early Modern England (New Haven and London: Yale University Press, 2000), 27-34.

${ }^{2}$ For two useful introductions to humanist rhetoric, see Brian Vickers, "Rhetoric and Poetics," in Charles B. Schmitt et al. (eds.), The Cambridge History of Renaissance Philosophy (Cambridge: Cambridge University Press, 1988), 715-745, and Quentin Skinner, Reason and Rhetoric in the Philosophy of Hobbes (Cambridge: Cambridge University Press, 1996). Needless to say, the humanist reception of Classical rhetorical theory was much more complex and much less uncritical than my short remarks might suggest. See e.g. for
} 
This humanist project continued to dominate the teaching of rhetoric in the seventeenth-century Dutch Republic. A popular collection of different treatises on the elements of a good education, introduced by Grotius and published in 1645 by Elzevier in Amsterdam, repeatedly emphasized the importance of rhetoric for a successful life both in public and in private. ${ }^{3}$ Rhetoric was also a central element of the academic teaching at Leiden University, in particular of the introductory curriculum of the faculty of arts. During the 1640 s, these classes in rhetoric were taught by Heereboord and, especially, Boxhorn, who as professor in eloquence organized public practical exercises in oratorical delivery for his students. ${ }^{4}$ The texts that Heereboord and Boxhorn used in their courses included the treatises on rhetoric by the prolific Dutch scholar Gerard Vossius, whose textbooks were a standard source for the teaching of rhetoric at all Dutch schools and universities from 1625 onwards. ${ }^{5}$ Hence, we must turn to Vossius to analyze the kind of rhetorical education that taught students like the brothers De la Court how to participate in the public debate.

Starting from a detailed analysis of the work of Vossius, this chapter aims to show how the rhetoric of the brothers De la Court was formed by

Ramus's dialectic defiance of the Classical tradition: Kees Meerhoff, "Ramus en tijdgenoten: de humanistische receptie van de retorica," Lampas. Tijdschrift voor Nederlandse classici 34 (2001), 351-372. For other important theorists such as Trebizond, Agricola and Erasmus see also Thomas M. Conley, Rhetoric in the European Tradition (Chicago and London: The University of Chicago Press, 1990), esp. 111-133.

3 Hugo Grotius et al., Dissertationes de studiis instituendis (Amsterdam, 1645). This collection includes treatises by humanists like Erasmus and Leonardo Bruni and more recent authors such as Tomasso Campanella, Gabriel Naudé, Arnold Clapmarius, and the Dutch scholar Caspar Barlaeus. The library of Pieter de la Court van der Voort owned a copy of this collection: Library, fol. 33. See also Anthony Grafton, "The New Science and the Traditions of Humanism," in Idem, Bring Out Your Dead, 97-117. On the social and cultural importance of rhetoric in the Dutch Golden Age, see Jeroen Jansen, "Het geslaagde spreken: welsprekendheid als beroepsbekwaamheid in de zeventiende eeuw," De zeventiende eeuw 18 (2002): 31-42; and Thijs Weststeijn, The Visible World. Samuel van Hoogstraten's Art Theory and the Legitimation of Painting in the Dutch Golden Age (Amsterdam: Amsterdam University Press, 2008), esp. 65-78.

${ }^{4}$ See Chris L. Heesakkers, "An Lipsio licuit et Cunaeo quod mihi non licet? Petrus Francius and Oratorical Delivery in the Amsterdam Athenaeum Illustre," in Gilbert Tournoy and Dirk Sacré (eds.), Ut granum sinapis. Essays on Neo-Latin Literature in Honour ofJozefIJsewijn (Leuven: Leuven University Press, 1997), 324-349. There is no general study of rhetorical education in the Dutch Republic, but see for some introductory remarks A. Frank-Van Westrienen, Het schoolschrift van Pieter Teding van Berkhout: vergezicht op het gymnasiaal onderwijs in de zeventiende-eeuwse Nederlanden (Hilversum: Verloren, 2007); and cf. for the English case Peter Mack, Elizabethan Rhetoric. Theory and Practice (Cambridge: Cambridge University Press, 2002).

5 See the extensive biography by C.S.M. Rademaker, Life and Work of Gerardus Joannes Vossius (1577-1649) (Assen: Van Gorcum, 1981), esp. 177-181, 193-196. 
their education and their gradual involvement in the Dutch debate. I will argue that the role of the passions in persuasion, emphasized by Vossius, is an essential element of the way in which the De la Courts thought about the dangers and possibilities of human speech. Through a careful examination of the various rhetorical devices with which they approached their audience, from the establishment of authorial 'ethos' to the use of fables, the chapter clarifies the form of rhetoric the brothers employed. Thereby it reveals the form of rhetoric that the De la Courts postulated as the best way to speak in public: a 'mercantile' rhetoric, characterized by outspokenness and rejection of dissimulation, which engendered a deliberate departure from humanist rhetorical conventions.

\section{Persuading the Passions}

\section{The Aristotelian Rhetoric of Vossius}

At the start of the seventeenth century, Gerard Vossius was one of the most important protagonists in the humanist rhetorical tradition. In 1606, whilst employed as the rector of the Latin School in the Dutch town of Dordrecht, Vossius published his Institutiones oratoriae, a substantial erudite encyclopaedia of rhetorical theory. ${ }^{6}$ With the subsequent advances in his career - he was appointed professor in rhetoric and history at Leiden University 1622 , and in 1632 he became the first professor of the newly opened 'Athenaeum Illustre' in Amsterdam - Vossius's work on rhetoric was republished in numerous revised editions and enjoyed growing international influence. In 1621 a compendium version of the earlier work was published under the title Rhetorices contractae sive partitionum oratoriarum libri $V$, which soon became the standard textbook for the teaching of rhetoric in the province of Holland. ${ }^{7}$ A far more concise edition, the Elementa rhetorica, also translated into Dutch, summarized the main topics in a few pages. ${ }^{8}$ Both works spread through the Dutch Republic and

\footnotetext{
6 This work is analysed in more detail by Jeroen Jansen, "De Institutiones oratoriae van G.J. Vossius (1577-1649)," Lampas. Tijdschrift voor Nederlandse classici 34 (2001), 373-39o.

7 See for a short synopsis Wilfried Barner, Barockrhetorik. Untersuchungen zu ihren geschichtlichen Grundlagen (Tübingen: Max Niemeyer Verlag, 1970), 265-274. For some general remarks on the nature of such rhetoric textbooks, see Brian Vickers, "Some Reflections on the Rhetoric Textbook," in Peter Mack (ed.), Renaissance Rhetoric (New York: St. Martin's Press, 1994), 81-102.

${ }^{8}$ Vossius, Elementa rhetorica, oratoriis ejusdem partitionibus accomodata, inque usum scholarum Hollandiae et West-Frisiae edita (Leiden, 1626); Idem, Elementa rhetorica, Dat is be-ghinselen der redden-riik-konst (Amsterdam, 1648).
} 
abroad, and they were to dominate the study of rhetoric throughout the following decades. By the end of the seventeenth century, the Rhetorices contractae had run to 33 editions, of which 14 German and 7 from Oxford. ${ }^{9}$

The work of Vossius stood firmly in the tradition of humanist rhetoric that paid increasing attention to the orator's capacity to arouse the various passions of the audience, the various movements in the soul which make us perceive some things as good and others as evil. In the later Renaissance, theorists increasingly emphasized this element of affectus, or passion, in the art of persuasion, and the various devices with which an orator could play upon the passions of his auditors in order to mobilize their wills. In the seventeenth century, the era of Baroque, this development resulted in an ever more systematic treatment of the role of affectivity in rhetorical theory. ${ }^{10}$ For the German humanist Bartholomeus Keckermann, the primary function of rhetoric was motum cordis, "the moving of the heart". " As the French moralist La Rochefoucauld claimed, the passions were "the only orators who always persuade". ${ }^{12}$

The principal authority to which Vossius turned for his analysis of rhetoric and affectus was Aristotle. In the course of the sixteenth century, Aristotle had emerged from the large shadow of his Roman followers Cicero and Quintilian and was reappraised on the basis of the elaborate discussion of the passions in his Rhetoric. ${ }^{13}$ Vossius followed this trend. His first work, the Institutiones oratoriae, aimed to give a comprehensive introduction to Aristotle with the commentary of later theorists, and as such it was welcomed by other scholars. Daniel Heinsius, the father of De la Court's school friend and travelling companion Nicolaas, wrote to Vossius that the work was not hampered by Aristotle's own "obscurity" and "pernicious conciseness", and therefore it would reveal "the important secrets of Aristotle". ${ }^{14}$ The paramount presence of Aristotle was toned down somewhat in the Rhetorices contractae, but the work has

\footnotetext{
9 Jansen, 'Institutiones oratoriae', 388-389; Conley, Rhetoric, 16o. I have used the Oxford 1651 edition.

${ }^{10}$ See Brian Vickers, In Defence of Rhetoric (Oxford: Clarendon Press, 1989), 276-286; and Conley, Rhetoric, 151-162.

${ }^{11}$ Quoted in Conley, Rhetoric, 158.

${ }_{12}$ "Les passions sont les seuls orateurs qui persuadent toujours", quoted in Gisèle Mathieu-Castellani, La rhétorique des passions (Paris: Presses Universitaires de France, 2000), 29.

${ }_{13}$ See Lawrence D. Green, "Aristotle's Rhetoric and Renaissance Views of the Emotions," in Mack (ed.), Renaissance Rhetoric, 1-26.

${ }^{14}$ Quoted in Jansen, "Institutiones oratoriae," 374.
} 
nonetheless been characterized as "the most 'Aristotelian' of any treatise on rhetoric of the time". ${ }^{15}$

This Aristotelian influence is indeed dominant from the outset of the Rhetorices contractae. It starts with Vossius's definition of rhetoric as a "faculty of finding in each thing that which is appropriate to persuade", directly taken from Aristotle. ${ }^{16}$ With this emphasis on the nature of rhetoric as a mere faculty and not as an art or science, Vossius clearly distinguished himself from the Ramist tradition, which subordinated rhetoric to dialectic in a comprehensive system of imparting knowledge. For Vossius, the goal was not the instruction of knowledge, but persuasion, the stimulation to action. Accordingly, Vossius stated that the threefold nature of rhetoric is "that which the Greeks call logos, ethos, and pathos": the correspondence between the argumentation of the orator, his personal ethos and the emotions that he might arise in the audience. ${ }^{17}$ This Aristotelian inspired interaction between logos, ethos, and pathos forms the core principle underlying Vossius's treatment of the faculty of persuasion, and hence the core principle of rhetorical education in the seventeenth-century Dutch Republic. How are these three elements of rhetoric connected? In order to answer this question, I will turn to the outline and contents of Vossius's textbook Rhetorices contractae work in some detail.

After his introduction of the goal and nature of rhetoric, Vossius discusses the orator's first and foremost task, inventio. He defines this central activity in basic terms as "the devising of arguments that are appropriate to persuade" ${ }^{18}$ In other words, inventio entails the skill of finding the various 'commonplaces', the loci communes, which offer the arguments that are most likely to convince and stimulate the audience. It depends on the sort of oration which arguments are appropriate for such persuasion. Again in line with the Classical tradition, Vossius heads all possible orations under three different genera or sorts, with each genus corresponding to a set of characteristic passions: first, the genus demonstrativum, which comprises epideictic orations of praise and blame to be attained by

15 Conley, Rhetoric, 160.

${ }_{16}$ Vossius, Rhetorices contractae, sive partitionum oratoriarum libri V(Oxford, 1651) I.I.3, p. 3: "Definitur Rhetorice ab Aristotele, facultas utendi in unaquaque re, quod in ea est ad persuadendum idoneum." Cf. Aristotle, The "Art" of Rhetoric, trans. John Henry Freese (Cambridge, Mass.: Harvard University Press, 1926) I.II.1, p. 14.

${ }_{17}$ Vossius, Rhetorices contractae I.II.5, p. 18: "Loci Rhetorum proprii sunt triplices, alii argumentorum docentium, alii conciliantium, alii permoventium. Graeci ea vocant, $\lambda$ ó $\gamma o s$, $\dot{\eta} \theta \eta, x \alpha \iota \pi \dot{\alpha} \theta \eta$ (rationes, mores, \& affectus)." Cf. Aristotle, Rhetoric I.II.4, p. 16.

${ }_{18}$ Ibidem I.II.1, p. 15: "Inventio est excogitatio argumentorum, quae ad persuadendum idonea sunt." 
delighting the audience; secondly, the genus deliberativum, the utterances with which the orator persuades or dissuades the audience from doing something by arousing either hope or fear; and third, the genus juridiciale, entailing the pleas of accusation and defence in the courtroom, to be achieved by playing upon the audience's compassion or rage. Of these three genera, the deliberative one is of most relevance for it concerns the "contingent issues" that are central to public life and politics, such as (and here Vossius follows again Aristotle) "taxes, war and peace, the custody of countries, importations and exportations, and the making of laws". ${ }^{19}$

In the second book of his treatise, Vossius discusses in detail the various ways in which an orator can arouse the appropriate passions in order to achieve total persuasion on these deliberative issues. In this way, he shows how the logos, the orator's argumentation, is intrinsically connected to the pathos of the audience, the passions that "God has implanted within our souls so that they are stimuli to honest deeds". ${ }^{20}$ Vossius invokes the Stoics, in particular Cicero, for the claim that human nature is dominated by four basic passions - pleasure, hope, distress, and fear. ${ }^{21}$ Yet in contrast to the Stoics, he continues to stress the Aristotelian idea that the passions should not be extirpated, but rather channelled towards a useful purpose. Accordingly, Vossius also adopts the larger list of passions from Aristotle's Rhetoric, insisting on their use for rhetorical persuasion. ${ }^{22}$ Explicitly following Aristotle's example, Vossius shows that every genus within the faculty of rhetoric corresponds to a number of pairs of contrary passions. In deliberative oratory, there are two sets of opposite passions which the orator should try to provoke: either fear for a future evil, or confidence in a positive outcome, and either shame, a "disturbance of the soul" because of an offensive judgment, or impudence, the disregard of possible ignominy. ${ }^{23}$ When talking about politics, an

\footnotetext{
${ }^{19}$ Ibidem I.V.2-3, p. 49-50: "Materia in hoc genere sunt res contingentes ... Speciatim autim, si causa sit publica, quinque sunt, de quibus, juxta Aristotelem, suleat institui deliberatio: vectigalia, bellum \& pax, custodia regionum, ea quae importantur \& exportantur, \& ratio ferendarum legum." Cf. Aristotle, Rhetoric I.IV.7, p. 40.

${ }^{20}$ Ibidem II.I, p. 117: "Atqui Deus animis nostris insevit adfectus, ut stimuli sint ad actiones honestas." For the use of a 'pathetic style', cf. Aristotle, Rhetoric III.VII.3, p. 378.

${ }^{21}$ Cf. Cicero, Tusculan Disputations, trans. J.E. King (Cambridge, Mass.: Harvard University Press, 1927) III.XI.24-25, p. 254.

${ }^{22}$ Vossius, Rhetorices contractae II.I, p. 119, and cf. Aristotle, Rhetoric, II.I.8-9, p. 172. On the difference between the Stoic and the Aristotelian conceptions of the passions, see Susan James, "Reason, the Passions, and the Good Life," in Gaber and Ayers (eds.), The Cambridge History of Seventeenth-Century Philosophy, vol. II: 1358-1396, esp. 1374-1376.

${ }^{23}$ Vossius, Rhetorices contractae II.II-IV, p. 120-134, and cf. the extensive analysis of these passions in Aristotle, Rhetoric II.V-VI, p. 200-220. For a lucid overview of
} 
orator should, dependent on his subject matter and intentions, try to mobilize the audience to action by evoking fear, confidence, shame or impudence.

Vossius emphasizes the various ways in which these four passions can be aroused. To provoke fear, an orator should use imaginative language that makes the coming evil look imminent. He should thus 'put the case before the eyes' of the audience, especially by referring to examples of situations where the evil in question has already been established. In contrast, he can create confidence by stressing that the danger can be easily avoided, for example by claiming divine favour. Shame is obviously provoked by highlighting scandalous behaviour or facts, a strategy that is particularly employed in satire, while impudence is gained through the contempt of such scandal. Finally, Vossius provides an extensive discussion of a range of specific speeches in which these considerations can prove their practical value. The speeches of deliberative rhetoric are subdivided into four parts, again based on different sets of passions. Vossius stresses in particular the establishment of love or hate through speeches of commendation, monition and conciliation. ${ }^{24}$ Through numerous examples of such speeches from Classical literature, Vossius gives his student readers a practical overview of how to arouse the passions when speaking on public occasions.

Having thus established the interaction between logos and pathos, Vossius continues with the third element of the faculty of persuasion: ethos. This element concerns the morality of the oration, the impression that the orator leaves on the audience. "For an oration to be moral", Vossius states, "an orator should above all perform in such a way that prudence, probity and benevolence glitter within it." ${ }^{25}$ A prudent speech will be the most comprehensible and therefore easily trusted, its probity will make it not seem too studious or suspect, while its benevolence will simply achieve that the orator is embraced by his audience. As Vossius says: "If the orator is loved, he has at his disposal a kind of helepolis ['destroyer of cities', a fortified wheeled tower in Ancient Greece] with which he,

seventeenth-century classifications of and theorizing about the passions and their place in the explanation of action, see Susan James, "The Passions in Metaphysics and the Theory of Action," in Gaber and Ayers (eds.), The Cambridge History of Seventeenth-Century Philosophy, vol. I: 913-949, and, more extensively, Idem, Passion and Action. The Emotions in Seventeenth-Century Philosophy (Oxford: Clarendon Press, 1997).

${ }^{24}$ Vossius, Rhetorices contractae II.XXI-XXII, p. 227-239.

${ }^{25}$ Ibidem II.XV.2, p. 168-169: "Quo morata sit oratio, ante omnia id agendum est oratori, ut in oratione ejus reluceant prudentia, probitas, benevolentia." 
without any violence, can invade the souls of the auditors. ${ }^{{ }^{6} 6}$ Yet ethos entails more than this combative morality of the orator himself: a good speech should also reckon with the mores of the audience and change its form accordingly. In a monarchy, a different approach is needed than in an aristocracy or in a democracy, and whatever the kind of government, people will always differ in passions, habits, age and fortunes. The skilful orator should know how to deal with this diversity. In short, a successful establishment of ethos is of paramount importance for winning the support of the audience.

According to the Classical rhetorical tradition, the second part of the orator's task, after inventio, is the structuring of the speech, the dispositio. Vossius deals with this aspect in the third book of the Rhetorices contractae. He begins this discussion with a lengthy treatment of the exordium, the introduction to a speech, which is together with the conclusion the most appropriate part for arousing the emotions of the audience. While the exordium should indicate the scope of the oration and prepare the audience for its contents, it should above all try to achieve that "the soul of the auditor is made ready, just as by some kind of drugs, for benevolence and attention". ${ }^{27}$ For this purpose, it might be appropriate to start with an historical example, a fable or a metaphorical story, and it is also useful to address the audience directly, Vossius states. Adversaries are to be refuted from the beginning, and they should not get any opportunity to turn that which is said to their advantage. Therefore, the exordium ought not to be commutabile, liable to opposite reasoning, and it should maintain a certain degree of surprise and distinctiveness. However, it should not turn out to be swollen or arrogant, since this will be fatal for the orator's ethos and will eventually make the audience far from benevolent towards him. ${ }^{28}$

The exordium of a speech is followed by the narratio, the part that entails the unfolding of the facts to be dealt with, and then the perspicuous and brief proposition of the case followed by the contentio, the juxtaposition of the opposing arguments of the orator and his adversaries. According to Vossius, such contentio should be performed by first arguing one's own case via syllogism or its more rhetorical form enthymeme, the

\footnotetext{
${ }^{26}$ Ibidem II.XV.3-5, p. 169: “... si ametur Orator, habet quasi helepolin quandam, qua, absque violentia, animos auditorum invadat."

${ }_{27}$ Ibidem III.II.7, p. 283: "Alterum exordii munus erat, ut auditoris animus, velut medicamentis quibusdam, ad benevolentia \& attentionem, praeparetur.”

${ }^{28}$ Ibidem III.III.4-5, p. 293; III.IV.4-9, p. 311-312.
} 
Aristotelian device for arousing passions by letting premises speak for themselves; ${ }^{29}$ and then refuting the case of one's opponent. For this purpose, an argument can be either negated or twisted back to the adversary, while subsequent interrogation and indignant reproach then may serve to achieve total confutation. The speech finally ends with the peroratio or conclusion. Together with the exordium, this is the most important part since it recapitulates all the strongest arguments which will thus "cleave to the auditors' souls". Moreover, the conclusion is very well suited for pathopeia, the excitement of the passions: the last words are those in which "the orator must especially open up the sources of eloquence, so that the judge [i.e. the audience] seems not only to kindle, but even to burn". ${ }^{30}$

In the fourth book of the Rhetorices contractae, Vossius gives an ample overview of all these different sources of eloquence that can ignite the passions of the audience under the general banner of elocutio, the style of the speech. Following the Classical definition, Vossius states that the elocutio should be elegant by using pure and appropriate language, and plain and lucid by avoiding ambiguity and long-windedness. Above all, good elocutio consists of dignitas: the quality that provides the oration with "pictures" and "lights", also called the ornatus, the fully equipped, armoured language with which the orator can mobilize the inherent persuasive qualities of speech in order to triumph on the rhetorical battlefield. ${ }^{31}$ Such ornatus is divided into two different parts: first, the various tropes, which alter the proper signification of a word to a different one, and secondly the figures of speech, by which a part of speech "is changed from its ordinary usage to a better one". ${ }^{32}$ It would go far beyond the purpose of this study to fully analyze Vossius's extensive and elaborate discussion of all these tropes and figures, which range from various forms of metaphor, metonymy, and synecdoche to figures such as transitio,

\footnotetext{
${ }^{29}$ Ibidem III.VII.1-10, p. 327-334. Cf. Aristotle, Rhetoric I.II.8, p. 18-20, and see Skinner, Reason and Rhetoric, 36 .

${ }^{30}$ Ibidem III.IX.5-10, p. 345-346: "In enumeratione ... observare oportet ... ut ea tantum repetamus, in quibus causae potissimum consistit, quaeque propterea maxime velimus auditorum animis inhaerere. ... Hac in parte orator imprimis aperire debet fontes eloquentiae: sic ut non solum incendere judicem, sed ardere ipse videatur."

${ }^{31}$ Ibidem IV.III.1, p. 387: “... undique ornata sit oratio, tum ea eligi debent, quae picturarum instar per se habent ornatum; ut sunt verborum sententiarumque lumina, de quibus tractat Dignitas." For the metaphorical sense of ornatus as offering the orator the weapons in a war of words, see Skinner, Reason and Rhetoric, 48-51.

$3^{2}$ Ibidem IV.XI.1, p. 427: "Altera Dignitatis pars in schematibus, sive figuris versatur. Est vero schema, forma orationis, quae haec alio quopiam modo, quam inversione significationis, a vulgari consuetudine immutatur in meliorem."
} 
rejectio, and revocatio, in total running to almost a third part of his treatise. Yet a sample of some tropes and figures with special importance may suffice to show how Vossius deals with ornatus within the faculty of persuasion.

These tropes and figures of speech are particularly important because they present the ideas of the orator in adorned, sensible, and imaginative language and thereby play upon the imagination and the passions of the audience. ${ }^{33}$ One such trope that entices the imagination is irony, which Vossius defines as a device "by which is understood the contrary of what is said". The proper signification of a word is thus altered for the sake of wit, and Vossius states that "when we want it to bite as sharply as possible, its use is highest" ${ }^{34}$ Other useful tropes are litotes (when, deliberately, less is said than actually understood) and hyperbole to give emphasis to a phrase. Ridicule is also discussed by Vossius in the part on tropes, though he adds that it should actually be seen as a distinctive form of speech. In his analysis, there are six different sorts of ridicule, from sarcasm ("a hostile mockery of someone already dead, or certain to die soon") to the more subtle asteismus, "an urbane joke". ${ }^{35}$ Clearly, these six forms of ridicule can be used for provoking various passions, making the audience laugh and therefore love the orator and detest the object of laughter.

The second part of ornatus consists of the figures of speech, each of which can be employed for provoking the passions of the audience. For example, asyndeton gives an oration pace and impulse, while its opposite polysyndeton "makes that the case itself which is at stake, is perceived to a higher degree". ${ }^{6}$ The use of synonyms brings about weight (gravitas) and sharpness (acrimonia), and a device such as anaphora (the repetition of a word at the start of successive sentences) adds force to the oration. Vossius further mentions a number of important figures of speech that enhance the orator's argumentation, such as prolepsis and hypobole, by which the possible objections of the adversary are anticipated and

33 Cf. James, Passion and Action, 218.

${ }_{34}$ Vossius, Rhetorices contractae IV.VII.1-3, p. 409-411: "Ironia est tropus, quo intelligitur contrarium ejus, quod dicitur. Ironiae ... cum acrius mordere volumus, usus est maximus. Atque interdum in exordio etiam aedhibetur, quod securitatem causae ostendit." For various notions, definitions and discussions of irony in Medieval and Renaissance rhetorical theory, including the one of Vossius, see Dilwyn Knox, Ironia. Medieval and Renaissance Ideas on Irony (Leiden etc.: Brill, 1989).

35 Ibidem IV.X.1-7, p. 423-425: "Sarcasmus est hostilis irrisio super jam mortuo, aut certo morituro ... Acteismus est jocus urbanus."

${ }^{36}$ Ibidem IV.XI.7-11, p. 429-430: "Asyndeton autem valet ad celeritatem, atque animi impetum significandum ... Polysyndeton facit, ut res ipsa, de qua agitur, videatur major.” 
answered, or the range of anacoinosis, paramologia, and epitrope, which entail consultation with or concessions to the opponent to move the auditor's souls and gain their confidence. When this is done in an ironical way, Vossius adds, the adversary will become truly disliked. ${ }^{37}$

A different species of figure are those used for explanation, such as sententiae, general proverbs that instruct and delight, especially when applied to a specific person, exempla (either true or invented), and parables such as fables to illustrate the speech. The device of paradiastole, the redescribing of certain actions by altering their conventional moral connotations, enjoys a particular rhetorical force. This technique is especially useful for refutation and reprehension. ${ }^{38}$ The same is true for paralepsis, when the orator states that he will not deal with a certain issue which is then nevertheless mentioned in passing. Ekphonesis, a forceful exclamation which reveals "the passion of the soul and the magnitude of the case", is said to be especially appropriate at the end of the oration. ${ }^{39}$ Finally, when the orator wants to catch the audience's full attention, he should use a device such as aporia, stating he does not know what to do or how to continue, or interrogatio, posing a question directly to the audience or the adversary. ${ }^{40}$ Vossius's Rhetorices contractae makes clear that once able to deploy all these rhetorical devices, the orator owns a powerful linguistic arsenal to entice the imagination, arouse all sorts of passions, and thus win over and mobilize the audience.

Taken as a whole, then, these are the various features of rhetorical instruction that students like the brothers De la Court practiced and learnt by heart at Latin School and university, with the emphasis on the correspondence between argumentation, ethos and the passions. Far from offering a range of dry devices to bring about exaggerated artificial reasoning, as modern disgust of stylistic rhetoric might suggest, these features entailed a dynamic conception of how language reveals the inner human condition, of how rhetorical figures reflect, and can thus manipulate, human psychology and actual linguistic behaviour. The classification

37 Ibidem IV.XIV.6-21, p. 450-457.

${ }^{38}$ Ibidem IV.XVIII.2-4, p. 472: "П $\alpha \rho \alpha \delta\llcorner\alpha \sigma \tau 0 \lambda \eta \dot{~ e s t, ~ c u m ~ e o r u m, ~ q u a ~ v u l g o ~ o b ~ v i c i n i t a t e m ~}$ confundi solent, remoto uno, alterum ponitur ... Convenit haec figura refellenti, \& reprehendenti." For the importance of this kind of rhetorical redescription, see the analysis in Skinner, Reason and Rhetoric, 142-153.

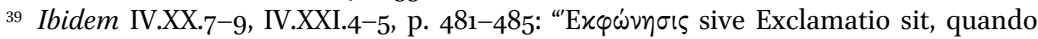
oratio interjectionem habens epressam, aut intellectam, animi affectum, ac rei magnitudinem significat."

${ }^{40}$ Ibidem IV.XXI.6-7, 24-25, p. 485-496. 
of all these figures was meant as a codification of real life, of all feelings as expressed in language. ${ }^{41}$ Its teaching and performance were essential to late humanist culture, and therefore the analysis of rhetoric is crucial to every study that deals with the written word within that culture.

\section{Cartesian Passions? Human Nature and the Ambivalence of Speech}

Vossius's rhetorical account of the passions was not particularly exceptional in the seventeenth century. The passions were a standard element of many treatises in moral and political philosophy, and an ongoing debate on the usefulness and dangers of the passionate human condition dominated European Baroque culture. In this debate, the view that the passions have a positive function because they can be mobilized as incentives to honest deeds, was often countered with a description of the passions as unruly and treacherous elements, to be curtailed as much as possible. Around the middle of the century, these conflicting theories continued to dictate the 'new philosophy' of the age, from Descartes to Hobbes. ${ }^{42}$ In the Dutch Republic, the Utrecht jurist Gerard van Wassenaer discussed in intricate detail the arousal of all human passions in his 1657 treatise which was later republished under De la Court's pseudonym. ${ }^{43}$ More famously, Spinoza put the passions at the centre of his philosophy, not only in part III of the Ethics, but also in his political works. Indeed, Spinoza's intervention in the Dutch political debate can be characterized as a rhetorical attempt to play upon the imagination of his audience in an ethical way by the proper motivation of key passions such as ambition, fear and hope. As Spinoza made clear in the opening chapter of his Tractatus Politicus, the recognition of the passions as essential properties of human nature is a necessary condition for making sense of politics.

\footnotetext{
${ }^{41}$ A point stressed repeatedly by Vickers, In Defence, esp. 294-334.

${ }^{42}$ See in particular James, Passion and Action. For positive assessments of the passions see Richard Strier, "Against the Role of Reason: Praise of Passion from Petrarch to Luther to Shakespeare to Herbert," in Gail Kern Paster et al. (eds.), Reading the Early Modern Passions. Essays in the Cultural History of Emotions (Philadelphia: University of Pennsylvania Press, 2004), 23-42. The opposite attitude is often identified with the Neostoicism of Justus Lipsius, particularly his famous De Constantia (1584). For Lipsius's influence, see Gerhard Oestreich, Neostoicism and the Early Modern State (Cambridge: Cambridge University Press, 1982), and cf. the critique by Martin van Gelderen, "Holland und das Preußentum: Justus Lipsius zwischen niederländischem Aufstand und brandenburgpreußischem Absolutismus," Zeitschrift für historische Forschung 23 (1996), 29-56. See also Tuck, Philosophy and Government, 45-119.

${ }_{43}$ 'V.D.H.', Naeuwkeurige consideratie van staet, wegens de heerschappye van een vrye en geheymen staets-regering over de gantsche aertbodem (Amsterdam, 1662), esp. 103-112.
} 
Accordingly, the successful political thinker knows how to use the passions in order to persuade the audience. ${ }^{44}$

A similar acknowledgment of the importance of language for the arousal of the passions pervades the thought of the brothers De la Court. The very first lines of their first treatise, published in 166o, state how a different use of speech, either tearful or cheerful, can cause different passions in the audience, from sadness and compassion to joy and laughter. Moreover, telling "a sharp truth" might very well provoke wrath and hate, especially when the object of that truth is a monarch. ${ }^{45}$ From the very start of their œuvre, the brothers De la Court showed that they were acutely aware of the power of speech in the motivation of passions. As Vossius had taught, they realized that a rhetorician should always consider the mores of the audience, while successful persuasion is always dependent on the proper use of pathos. Affectus pro effectu, as a maxim in the introduction of the Aanwysing has it, "passion goes before the effect". ${ }^{4}$

How did the De la Courts portray the passions that define human nature? In general, their depiction of the passions mirrors much of the ambivalence in mainstream seventeenth-century conceptions of the passions as on the one hand useful, yet on the other dangerous elements of human conduct. First of all, the brothers fully recognized the unavoidability of the passions: "The passions of men, which in short could be called joy and grief, are so necessary that one cannot understand how the world's order and course could exist without these passions." ${ }^{47}$ The De la Courts thus adopted the conventional idea that our passionate condition stems from the very moment of conception, an idea popularized for example in the influential treatise De la sagesse (1601) by the French ecclesiastic Pierre Charron. In their standard definition of the passions as urges that assist the soul in pursuing good or fleeing from evil, the De la Courts

\footnotetext{
${ }_{44}$ Spinoza, Tractatus Politicus I, p. 260-264. See for rhetoric in Spinoza: F. Akkerman, "Le caractère rhétorique du Traité théologico-politique," in Idem, Met iets van eeuwigheid, eds. G.C. Huisman et al. (Groningen: Universiteitsbibliotheek, 1995), 67-79; Steven Frankel, "Politics and Rhetoric: The Intended Audience of Spinoza's Tractatus TheologicoPoliticus," The Review of Metaphysics 52 (1999), 897-924; and Michael A. Rosenthal, "Persuasive Passions: Rhetoric and the Interpretation of Spinoza's Theological-Political Treatise," Archiv für die Geschichte der Philosophie 85 (2003), 249-268.

45 Politike Weeg-schaal, "Inleyding," p. 1: "alzoo verwekt een scherpe waarheid, en het tergen, gramschap en haat." Cf. Nauwkeurige consideratie, 159-16o.

${ }_{46}$ Aanwysing, "Voor-Reeden," sig. *****3.

47 Politike Discoursen II.VI.1, p. 166-167: "De passien der menschen, diemen in 't kort blydschap en droefheid soude konnen noemen, sijn soo noodsaakelik, datmen niet begrypen kan, hoe des weerelds ordre en loop, sonder die passien, soude konnen bestaan."
} 
equally followed Charron. ${ }^{48}$ They also shared his sceptical unease with the possible consequences of the passions for sound human judgment. "The passions are first in possession", as their argument goes,

and who pays attention will realize that they also stick with man until the end of his life. Therefore it is to be believed that the judgement of even the most prudent men will never reach such a perfection that it will not often be enchanted by the passions. ${ }^{49}$

The passions, in short, are necessary yet also deeply fraudulent aspects of human life: their positive role in helping us relate to the external world is counterbalanced by their ability to undermine rationality and virtue. At the same time, the fact that every one's judgment is dependent on the passions means that the arousal of these passions can steer human judgment. A rhetoric that plays upon the passions thus opens the way to successful persuasion.

The De la Courts based this account on an extensive but also rather amorphous analysis of the physical causes of passionate human behaviour, loosely following the latest physiological insights from Descartes's Les passions de l'âme, first published by Elzevier in $1649 .{ }^{50}$ As Kossmann has shown, the De la Courts at times echoed directly the Cartesian physiological vocabulary, and Kossmann's ensuing classification of the De la Courts as followers of Descartes has become a commonplace characterization of the brothers' thought. ${ }^{11}$ Recently, the De la Courts, together with Spinoza, have even been heralded as the leading lights of a "Cartesian republicanism", of a "radical Cartesian politics" that dominated the Dutch

${ }^{48}$ Cf. e.g. Ibidem II.VI.13, p. 212: “... alle de passien die aan de natuur gegeeven schijnen, om door hare driften de ziel in het ontvlugten van 't quaad, en 't najagen van 't goed, behulpig te zijn"; with Charron, Of Wisdome I.XVIII, p. 71: "Passion is a violent motion of the Soule in the sensitive part thereof, which is made either to follow that which the Soule thinketh to be good for it, or to flie that which it takes to be evill." On Charron, see Anthony Levi, French Moralists. The Theory of the Passions 1585-1649 (Oxford: Clarendon Press, 1964), 95-111.

49 Politike Discoursen II.IV.1, p. 1-2: "Sulks de passien eerst in possessie zijn, en die er op let, sal bevinden, dat sy ook den mensche tot het einde sijns leevens byblyven, en ooversulks is te gelooven, dat het oordeel, selfs der verstandigste menschen, nooit tot soo een volmaaktheid komt, dat het niet dikwils door de passien werde verrukt."

$5^{\circ}$ See esp. the elaborate discussions of the passions in Ibidem I.II.24, II.IV.1,11, II. VI.11,14,27; and in Sinryke Fabulen, 313-314, 407-408, 561-563, 568-570, 612-613. The library of Pieter de la Court van der Voort contained a copy of the first edition of Les passions de l'âme, and also a number of other works by Descartes, most notably his Opera Philosophica (Amsterdam, 1677): Library, fols. 20, 26.

${ }^{51}$ Kossmann, Political Thought in the Dutch Republic, 62-63. Cf. e.g. Haitsma Mulier, Myth of Venice, 131; Blom, Morality and Causality, 160; Malcolm, "Hobbes and Spinoza," 43; Velema, "That a Republic", 14. 
intellectual scene in the second half of the seventeenth century. ${ }^{52}$ The basic assumption behind this interpretation is that the De la Courts' attention for the passions must have been directly inspired by Cartesian philosophy, which made them initiate a new, radical phase in political theory.

Yet this alleged Cartesian influence should not be overemphasized. Although the De la Courts adopted some of Descartes's physiological explanations of passionate behaviour, their view on the passions can hardly be characterized as typically Cartesian. Central to Descartes's Les passions de l'âme is an elaborate mechanical analysis of the soul's passive perceptions of our bodily motions. This analysis departs from the traditional Aristotelian and Scholastic accounts in its integrated account of the human mind, which unifies all different passions under the umbrella of the single passion of desire. However, Descartes's rupture with tradition is not total. As Susan James has shown, for Descartes the passions are attributes of the soul, but dependent on the body, and therefore our passionate condition is both mental and physical, bridging Descartes's own division between soul and body. ${ }^{53}$ In his ensuing analysis of how the passions register and communicate the bodily interests to the soul, Descartes highlights the functionality of the passions, thus following directly in the footsteps of Aristotelianism. This Cartesian view that the passions are all good in nature and that only their misuse and excess should be avoided, entails a fairly standard criticism of the position, often identified with neostocism, that the passions ought to be curtailed instead of motivated. ${ }^{54}$ A comparable criticism can be found in, for example, Burgersdijk's Idea philosophiae moralis, the Leiden textbook in moral philosophy, ${ }^{55}$ or in

\footnotetext{
${ }^{52}$ Van Bunge, From Stevin to Spinoza, 85-88; Harold J. Cook, "Body and Passions: Materialism and the Early Modern State," Osiris 17 (2002), 25-48, elaborated further in Idem, Matters of Exchange. Commerce, Medicine and Science in the Dutch Golden Age (New Haven: Yale University Press, 2007), 262-264; Tammy Nyden-Bullock, "Radical Cartesian Politics: Velthuysen, De la Court, and Spinoza," in Wiep van Bunge (ed.), Spinoza and Dutch Cartesianism. Studia Spinozana 15 (1999/2006), 35-65; and Idem, Spinoza's Radical Cartesian Mind (London and New York: Continuum, 2007).

${ }_{53}$ James, Passion and Action, esp. 106-107. See also Deborah J. Brown, Descartes and the Passionate Mind (Cambridge etc.: Cambridge University Press, 2006).

${ }^{54}$ René Descartes, Les passions de l'âme, ed. Benoît Timmermans (Paris: Librairie Générale Française, 1990), art. 211, p. 176: "Car nous voyons qu'elles sont toutes bonnes de leur nature, et que nous n'avons rien à éviter que leurs mauvais usages ou leurs excès. Ibidem, art. 137, p. 127-128: “... leur usage naturel est d'inciter l'âme à consentir et contribuer aux actions qui peuvent servir à conserver le corps ou à le rendre en quelque façon plus parfait."

${ }_{55}$ Burgersdijk, Idea philosophiae moralis, 71-95. Cf. the analysis in Blom, Morality and Causality, 80-88.
} 
Jean-François Senault's influential De l'usage des passions, published by Elzevier in Leiden in 1643. Senault's position can be called typical for the age: his "apology for the passions against the Stoics" claims that the passions have both utility and merit, but at the same time it insists on the necessity to change the vicious passions to virtue through reason and grace..$^{6}$ Deeply Augustinian but also infused with quotes from Seneca, Senault's treatise embodies the ambivalent attitude of the seventeenth century to the uses and dangers of the passions.

The brothers De la Court share this attitude, and their position is overall much closer to Senault than to Descartes. Following both, they assert that "all passions are good in themselves" because the passions assist us in searching for good and fleeing from evil and thus they further our selfpreservation. Yet it is still "necessary that these urges of the blood are moderated and bridled through good education, reasoning, and experience". In short, the passions are not inherently detrimental, but they should still be mastered and rationally channelled towards positive goals. The De la Courts do not only insist on the need to control the passions, but they also prove to be deeply pessimistic about the feasibility of such control, well aware that "with all triumphs this first Old Man, Flesh and Blood, over the second, New Man, Mind and Reason". ${ }^{77}$ This suspicion of human weakness involves an approach that is much more akin to Senault's Augustinian moralism than to the Cartesian naturalistic approach. Descartes insisted explicitly that he did not aim to analyze the passions as a rhetorician or a moral philosopher, but only as a natural philosopher..$^{5}$ As a result, the public role that human passions play in the body politic is not the main concern of Les passions de l'âme. If anything, it can be argued that Descartes internalized politics within the individual body. ${ }^{59}$ For the De la Courts, however, as for Senault, the public role of the passions was absolutely central. The failure to master the passions would imply that vice

\footnotetext{
${ }^{56}$ Jean-François Senault, De l'usage des passions ([Leiden], 1643) I.I.1, p. 1-9: "Apologie pour les Passions contre les Stoïques." On Senault, see Levi, French Moralists, 213-224.

${ }^{57}$ Politike Weeg-schaal I.I.2, p. 19-20: "En hoewel alle passien in zig zelven goed zijn, vermits zy alle kinderen en dieren drijven, om haar eigen zelven te bewaaren ... hoe noodzakelik het is, dat deese driften des bloeds werden gematigd, en in den toom gehouden, door goede onderrigtinge, redenkavelinge, en ervarentheid ... en bij allen triumpheerd deeze eerste Oude Mensch, Vleesch en Bloed, zoodanig oover den tweeden, Nieuwen Mensch, de Geest en Reeden."

${ }^{8}$ See Descartes's letter from 14 August 1649 in Descartes, Passions.

59 Cf. Victoria Kahn, "Happy Tears. Baroque Politics in Descartes's Passions de l'âme," in Kahn et al. (eds.), Politics and the Passions, 1500-1850 (Princeton and Oxford: Princeton University Press, 2006), 93-110.
} 
triumphs publicly over virtue. Therefore, the public realm is the arena where passionate behaviour ought to be regulated. Pace Descartes, rhetoric and moral philosophy were for the De la Courts the prime objectives in their analysis of the passions.

Instead of stressing the link with Descartes, it is therefore more useful to highlight the De la Courts' connection to Senault's Augustinianism and to the Aristotelian awareness of the rhetorical power of the passions. These two issues come together in the claim that human judgment is often frail and easily seduced into error. Senault, following Augustine, asserted that the overarching passion that dominates all conduct is love. If moderated correctly, such love reveals itself in positive friendship, compassion, and the love of God. Yet if neglected and disordered, it turns out to be amour-propre, self-love, which leads our understanding astray into destructive irrationality. ${ }^{60}$ According to the influential Port Royal Logic that comes from the same Augustinian background as Senault, human opinions are mostly not established by "the penetration of truth and the force of reasons; but [by] some chain of self-love, interest, or passion". ${ }^{6}$

This anxiety with the susceptibility of human judgment to the passions and false appearances also dominates the thought of the brothers De la Court. True judgment is rare, they realized, and our passions all too often lure us into false beliefs. Therefore, speech plays a crucial role for its potential corruption of human judgment by enticing the passions. In other words, false rhetoric, speech that tries to manipulate the opinions of the audience through deception, can be immensely dangerous in the public realm. Since all humans judge according to appearances and to their passions,

lies, cheating, eloquence, and any present good or evil are strong enough to cause a contrary appearance and passions among the majority of humans, and to change their judgment and impulses. And hence comes the fickleness of the Community, being governed by appearance and passions. ${ }^{6}$

\footnotetext{
6o Senault, De l'usage des passions II.I.2, p. 228-239: “Du mauvais usage de l'Amour."

${ }_{61}$ Antoine Arnauld and Pierre Nicole, La logique ou l'art de penser, eds. Pierre Clair and François Girbal (Paris: Presses Universitaires de France, 1965) III.3o, p. 261: “Si l'on examine avec soin ce qui attache ordinairement les hommes plutôt à une opinion qu'a une autre, on trouve que ce n'est pas la penetration de la verité \& la force des raisons; mais quelque lien d'amour propre, d'interêt, ou de passion. C'est le poids qui emporte la balance, \& qui nous détermine dans la plûpart de nos doutes; c'est ce qui donne le plus grand braule a nos jugemens, \& qui nous y arrête de plus fortement."

${ }_{62}$ Politike Discoursen II.IV.1, p. 3: "Voorwaar nietwes, als dat sy geduurig naar schijn, en passien, oordeelen, soo zijn loogens, bedriegery, welspreekendheid, ende eenig teegenwoordig goed ofte quaad kragtig genoeg, om by 't meestendeel der menschen, een contrarie
} 
Eloquence thus proves to be potentially highly treacherous in politics, because eloquence can easily turn into dissimulative demagogy by manipulating the capriciousness of human nature.

Nevertheless, this corrupting power of public speech which plays upon the imagination is offset by the rhetorical usefulness of the passions if correctly mobilized to reach truth and understanding. As Vossius taught, proper rhetoric can turn passions such as fear or shame into positive features of the human condition when they are used as incentives to honest deeds. Similarly, the De la Courts argued that the passions of the soul can be balanced by causing contrary passions. ${ }^{63}$ Indeed, "people would follow their self-love and passions, also to the detriment and ruin of others ... if they did not moderate their own passions through the fear of any future evil". ${ }^{64}$ Such fear can be installed by laws and strong punishment, but also, as Vossius showed, by speech - fear being one of the main four passions within deliberative rhetoric. A rhetorician who incites the fear of the audience by making a coming evil appear imminent, thus moderates the possible detriments of the other passions. Through good rhetoric, passion curtails passion.

Overall, then, speech is a highly ambivalent element of public life, an ambivalence that is rooted in the double-edged power of the human passions. On the one hand, speech can corrupt sound judgment by luring the passions into deception. On the other, it can establish sound judgment by playing upon the imagination to reach attentiveness, understanding, and agreement. The fundamental question therefore is how to cope with this ambivalence of speech, how to find out the proper place for the passions in rhetoric and in the political realm. Consequently, for the De la Courts, as for their contemporaries Milton and Hobbes, the crucial issue was how to distinguish good rhetoric from bad rhetoric. ${ }^{6}$ They acknowledged that both forms of rhetoric are by necessity passionate. Yet while bad rhetoric abuses the passions in order to deceive, good rhetoric uses the passions, it

schijn, en passien, te verwekken, en haar te doen veranderen van oordeel, en driften; en hier van daan komt de wispeltuurigheid der Gemeente, sig laatende bestieren van schijn, en passien."

${ }^{63}$ Ibidem I.II.24, p. 162-163. Cf. Spinoza, Tractatus Politicus X.10, p. 436.

${ }^{64}$ Politike Weeg-schaal I.I.3, p. 22: "Het is eevenwel en blijft waaragtig dat de menschen haare eige liefde en passien, zouden volgen, ook tot naadeel en ondergang van anderen ... ten ware zy door vreeze van eenig toekomend quaad, te zullen lyden oover die begaane daad, haare eigen passien intoomden."

${ }^{65}$ Cf. Skinner, Reason and Rhetoric, and John Staines, "Compassion in the Public Sphere of Milton and King Charles," in Kern Paster et al. (eds.), Reading the Early Modern Passions, 89-109. 
appeals to human ambition, hope and fear in order to convey the truth. In the following sections of this chapter I will clarify what such 'good rhetoric' entailed exactly for the De la Courts. By revealing in detail the various elements of the brothers' own rhetorical endeavour in the public arena, it will become clear that the rhetoric practiced by the brothers is the same as that which they postulated as the best form of speech for a proper persuasion of the passions.

\section{In the Public Arena: Rhetoric in Action}

\section{A First Test: The Confrontation with Heereboord}

The brothers De la Court first entered the public arena in a direct conflict with one of their own teachers at Leiden University, Adriaan Heereboord. This highly rhetorical and passionate conflict aptly reveals the form and the extent of the Dutch seventeenth-century public debate: the conflict began in the lecture-room of the academy but soon extended over the urban realm and briefly stirred up the whole of Leiden society. The controversy with Heereboord thus shows how the De la Courts put their rhetorical education into practice. The first time that the brothers' rhetorical skills were publicly put to the test turned out to be a confrontation with the man who had introduced them to the art of rhetoric.

The conflict with Heereboord started in the context of the public debate over Cartesianism, yet its immediate cause lay in the private sphere of the De la Court household. Heereboord's eclectic defence of Descartes, expounded in particular at the start of 1648 in his public speech De recte philosophice disputandi ratione, caused much debate within the academic community in Leiden. A month after the speech, this debate even led to a fight in the lecture-room between the advocates and opponents of Heereboord, including Pieter de la Court. ${ }^{66}$ After a reprimand by the board the following day, all those involved were admonished to refrain from further dispute, and the board reconfirmed an earlier ban on Cartesian teachings. De la Court's aggressive participation in this debate, however, had little to do with the rising tide of Cartesianism. Instead, it was a consequence of the close but increasingly hostile relationship between him and his teacher, who had by then also become his

\footnotetext{
${ }^{66}$ See Van Tijn, "Pieter de la Court," 311-312. On the Heereboord affair, see also Ed van der Vlist, "Een verstrooide brief van een verloren professor. Het eerewoord van Heereboord," Nieuw Letterkundig Magazijn 21 (2003), 40-48.
} 
brother-in-law. Two years earlier, Heereboord had married Johanna de la Court, the only daughter of the family, born in 1620. As a successful academic, Heereboord offered the social recognition that the De la Courts, as immigrants from humble origins, still lacked. Yet the marriage turned out to be anything but a success. Heereboord had huge debts, he used to drink excessively, and in April 1648 he seriously injured his young pregnant wife. When she gave birth to a son some months later, the child died shortly after being baptized. Soon thereafter, the marital conflict erupted in public.

During the funeral of the child and in the days that followed, numerous short pamphlets were distributed in Leiden, supposedly at the instigation of Heereboord himself, which harshly reproached his family-in-law. ${ }^{67}$ The vivid and very outspoken language typical to this kind of pasquilles mocked the De la Courts for their alien descent and accused them of unchristian behaviour and unjustly attained riches. A particularly fervent pamphlet, suggestively entitled Piere la Cour, gruwel der verwoestinge ["Piere la Cour, Horror of Devastation"] insinuated that Johanna, driven by a typically Walloon lust that could not be satisfied by a scholar like Heereboord, approached her own father instead to alleviate her desires. "O horror! O devastating deed!", the pamphlet exclaimed, "What even a Turk leaves to a Tartar, dares Pieter de la Court to do with his rabble in his own house" ${ }^{68}$ Another pamphlet, meant to be sung on the tune of a popular melody, denounced De la Court sr. as "an alien rogue" who had only become rich "Through lying and deceiving, And haggling on a penny, By virtue's pretence, and being false". Such behaviour would earn De la Court his place in hell, "there where his La court stands", so the song ended with a pun. ${ }^{69}$ Another pasquille, written by a range of self-declared "sworn proponents of the sincere truth and the free verse-right", directly addressed

${ }^{6}$ Op de onrijpe dood van Isak Heereboord (1648), Graf-dicht op den ongesiene Isaak Hereboord [1648], Af-comst ofte reken-tael, van Pieter Lacoer (1648), Het triumpherende Leyden over het beroemde huys-gesin van den vermaerde scietspoelder alias De La Court [1648].

${ }_{68}$ Piere la Cour, gruwel der verwoestinge [1648]: “O grouwel! O verwoeste daet!/'t Geen selfs een Turck een Tartar laet,/Derft Pier la Cour met syn gespuys,/Bedryven in sijn eygen huys."

${ }_{69}$ 'Claes Krynen van Oossanen, met zijn vlammende swaert', Nieuw liedeken van een hoere-waerts soon buyten Yperen, hoe hy van zijn ouders wegh gheloopen, ende to Leyden door dwangh van zijn oom aen 't weven gestelt is, ende daer near door zijn vroome en ontrouwe handel en wandel, tot groote en onrechtveerdighe rijckdom is gheraeckt [1648]: "Door lieghen ende bedrieghen,/En knibbelen op een deuyt,/Door deuchdens schijn, en vals te zijn/Wiert rijck, een vreemde guyt ... Hy wiert so stracks ghevoert/Na d'Hemel heen, of nae beneen/Daer staet doch zyn La court." 
the sons of the family, who where warned that "This is on the paper, the next will be on your skin". ${ }^{\circ}$

In spite of this menace, the stream of pamphlets directed against his family prompted Pieter de la Court to take up his pen in reply. In a pamphlet titled Factum ofte gherechticheyt, van de huysvrouwe van Adriaen Heereboord ["Fact or Justice, from the Wife of Adriaen Heereboord"], supposedly written by Johanna herself but in reality of Pieter's hand, De la Court aimed to refute Heereboord and his adherents in public. ${ }^{71}$ For this purpose, Heereboord's classes in rhetoric proved to be of much value. The various rhetorical strategies used in this open rhetorical clash with Heereboord would remain central in all later publications of the brothers De la Court: the careful establishment of authorial ethos and rebuttal of the adversary, the arousal of the passions, and, in particular, the criticism of duplicitous speech.

In the opening lines of the pamphlet against Heereboord, De la Court tried first of all to win over the audience by establishing his own ethos. As Vossius had instructed, he addressed his readers directly to gain their support and stated that his reaction was not meant as an answer to "the lies and slanders" of the various pasquilles published against him and his family. De la Court thus presented himself as a trustful witness who did not demean himself to the base level of deceit and insult. Insisting that his own testimony was based on evidence, he rebuked Heereboord for having used nothing but "slandering eloquence". Accordingly, the establishment of ethos turned immediately into reproach of the adversary, for which De la Court invoked the authority of the Greek statesman Aristides, mentioned by Vossius as the commonplace embodiment of the virtue of justice $^{7^{2}}$ The ensuing refutation portrayed Heereboord in vivid terms as a highly aggressive and utterly unreliable drunkard. Already on the day of the wedding, De la Court wrote, Heereboord "revealed at once his shameless affection to drunkenness". His wife begged him to stop drinking, but in vain, for even in his study she caught him "filled up with Wine which

${ }^{70}$ Gedwongen waarschouwing van S.v.M. e.a., altemaal gezwooren voorstanders van de oprechte waarheid, en het vrye dicht-recht aen La Courten. Den verkeerden s'Jaak, verrotten Pier, en schurftens Jan [1648]: "Dit is op 't pampier, daar na op je huyt."

${ }^{71}$ [Pieter de la Court], Factum ofte gherechticheyt, van de huysvrouwe van Adriaen Heereboord, voor ende door deselve (The Hague, 1648) [Wildenberg, Bibliografie, nr. 1011] For Pieter's authorship, see Driessen (ed.), Het Welvaren van Leiden, "Bibliographie" nr. 50, a facsimile of a letter concerning the dispute that Pieter wrote to the Leiden court of justice.

${ }^{72}$ Factum, sig. B: "lasterende wel-spreeckentheydt". Cf. Vossius, Rhetorices contractae I.IV.38, p. 45 . 
was hidden near his Books in Bottles". ${ }^{73}$ Apart from being a drunkard, so De la Court's defamation went on, Heereboord also mistreated his wife. By making public all sorts of private details and thus playing upon the shame of the audience, ranked by Vossius as one of the main passions in rhetoric, De la Court tried to damage Heereboord's reputation as much as possible. At the same time, he sought to defend his own credentials as a writer and to defend the honour of his sister, restating at the end of the pamphlet that all said was based on clear evidence.

Not surprisingly, Heereboord reacted with the publication of a defence, in which he made two basic claims. First, immediately unmasking the author of the Factum as Pieter de la Court, he reproached him for having indulged in "a register of slanders, lies, and unchristian acridities" because of his inability to control his passions. "The more impotent as he has been in insulting, the more potent will I be in controlling myself", Heereboord stated. Secondly, he accused De la Court of "playing very curiously the Sophist" and invoking unreliable witnesses and false testimony. Aptly employing rhetorical redescription, Heereboord tried to convince his audience that instead of being drunk, he was merely "sad" because of the distrust of his wife, instigated by her family. He then juxtaposed his own "honest poverty" with the "Political axiom" of the De la Courts "to honour only money and those who have money". In a clear move to arouse his readers' passions, Heereboord finally turned directly to his family-in-law to propose a settlement of the conflict, under the stoic motto that "it is better that we triumph over ourselves than another over us, for the greatest victory we gain over ourselves". ${ }^{74}$ In this way, Heereboord skilfully flung the accusation at De la Court, whom he portrayed as a passionate, greedy man unable to control himself.

De la Court replied again with a new pamphlet, almost twice as long as the first one. No longer hiding his identity, he followed the rhetorical strategies of his earlier work. Again he blamed Heereboord for using mere

${ }^{73}$ Factum, sig. Bv.-B2v.: “... hy openbaerde terstondt sijne dulle ende onbeschaemde ghenegentheyt tot dronckenschap ... wel vondt sy hem altemets, meenende dat hy in sijne Boecken besig was, in sijn Boeck-kamer droncken gekleet te Bedde leggen als hy sigh met Wijn, die by sijn Boecken in Flessen verborgen was, opgevold had."

${ }_{74}$ Adriaen Heereboord, Naackte ende nodige verdedigingh, vande eer ende het leven, van Adrianus Heereboord (Leiden, 1648), sig. A2, B3, Cv., D2v.: “... een register van lasteringen, leugenen, ende onchristelikke bitterheden ... Soo veel te onmachtiger als hy is geweest in het schelden, soo veel te machtiger sal ik wesen in my te bedwingen ... Hier mede speelt hy zeer wonderlick den Sophist ... Eerlicke armoede can niemand verweten werden ... Soo hebbense noch een nieu Polijtyk axioma, men moet niet achten als gelt of die gene die gelt heeft ... Beter is het, dat wy over onsselven, als dat een ander over ons triumphere: de grootste victorie bevechten wy over ons selven." 
eloquence instead of clear argumentation, "because many, whenever it can be advantageous in the defence of their case, without any shame, try to adorn false slanders and lies nicely with many decorated details". The reader, he insisted, should be warned that "many imprudent and simple people are, with the manner of writing that he uses, easily seduced". In other words, De la Court contended that Heereboord rhetorically abused the passions of his audience because he "proclaimed the purest truths for lies, and the virtues for vices". ${ }^{75}$ The controversy with Heereboord, then, had turned from a conflict over the honour of the De la Court family into a conflict over the best form of rhetoric. Both Heereboord and De la Court claimed that they knew best how to moderate the passions; both argued that they played upon the passions in an ethical way by telling the truth, while they repudiated their adversary for employing deceiving eloquence instead of true argument. The conflict reveals how both parties shared the same rhetorical culture, dominated by the ambivalent assessment of the passions in speech.

The dispute continued for some months and caused widespread commotion in Leiden, where the municipal authorities tried in vain to halt the quarrel by prohibiting the publication and circulation of more slanderous writings. Once unleashed, public argument thus proved to be untameable - a phenomenon that the De la Courts would experience again later. Moreover, the Heereboord affair offered De la Court a first opportunity to apply his rhetorical skills outside the lecture-room. As this chapter will continue to show, key elements of the confrontation with Heereboord, from the establishment of authorial ethos, the warning against "slandering eloquence", to the rhetorical power of the passions, were to play a prominent role across the entire œuvre of the brothers De la Court.

\section{Impressing the Reader: The Frontispiece}

How did the De la Courts enter the marketplace of public debate in the 166os? Their rhetorical and commercial involvement in politics started

75 [Pieter de la Court], Antwoordt op de verdediginghe van Adriaen Heereboord, hem ghegheven door zijnen swagher (The Hague, 1648) [Wildenberg, Bibliografie, nr. 1021], sig. B-B2v.: “... sulcks veelen als 't hun maer in de verdediginghe hunner saecke voordeeligh kan zijn, sonder eenighe schaemte, valsche lasteringhen ende leughenen, met veele versierde omstandigheden aerdigh trachten op te proncken ... dat veele onvoorsichtighe ende eenvoudige menschen, met soo eene maniere van schryven die hy ghebruyckt, lichtelik verleydt worden ... moet de Leeser oordeelen, of hy de suyverste waerheden niet voor leugenen, ende de deughden voor ondeughden uytgheroepen heeft." 
with the material aspect of their works. As Kevin Sharpe has argued convincingly, many of the physical features of early-modern texts, from size and frontispiece to typography, entailed important authorial and editorial choices which merged the aesthetic with the political..$^{6}$ The specific language of a text also had profound political consequences. The brothers De la Court did not present their works as scholarly Latin treatises on politics, rather they chose deliberately to write in the vernacular. This linguistic choice had immediate political implications, for it meant that their works could be read and discussed on a much broader level than texts written in Latin. As long pamphlets, often handily published in duodecimo format and as such easily to carry and to distribute, the works of the De la Courts became part of the fervent pamphleteering business in the Dutch Republic. Their decision to write in Dutch therefore reflected a deliberate attempt to be read and commented upon by many. At the same time, their works were published in the elevated Roman typeface rather than the more popular Gothic normally used in pamphlets. ${ }^{77}$ In other words, the brothers' use of the vernacular in Roman typeface expressed a preference for a particular kind of public debate, broad, urban, but also of a certain standing. This notion implied that political issues require widespread, but not too widespread, discussion and engagement - a claim with manifest political implications.

Apart from language and typography, the exterior presentation of the work of the De la Courts also involved obvious political and commercial choices. The first 1660 edition of the Consideratien van Staat and all editions of the Interest van Holland were published with only a simple frontispiece which mentioned the title, De la Court's pseudonym, and the publisher. Yet in his reworking of the Consideratien to the Politike Weegschaal and in the publication of the Politike Discoursen, the Historie der Gravelike Regering and the Aanwysing, Pieter de la Court chose differently. To raise the standing of these works and their capacity to seduce and impress, these new editions were presented to the public with a neatly engraved frontispiece which exploited not only language but also the power of the image, entering the battlefield of public debate in full armour.

${ }^{76}$ Sharpe, Reading Revolutions, esp. 26-27, 44.

77 Marika Keblusek, "Nieuwsvoorziening in de Republiek. De Engelse burgeroorlog in Haagse drukken," in Henk Kleijer et al. (eds.), Tekens en teksten. Cultuur, communicatie en maatschappelijke veranderingen vanaf de late middeleeuwen (Amsterdam: Amsterdam University Press, 1992), 6o-77: 72. 
The case of the Politike Weeg-schaal offers a good example of how De la Court used visual imagery to illustrate and strengthen his argumentation. The frontispiece of the 1661 edition (see fig. 1), copied in all ensuing editions, shows a highly suggestive scene in which the scales of the title, managed by a divine hand emerging from a sunlit cloud, balance the two weights of politics: at the left, the ius belli, adorned with a ribbon mentioning, in rather crude Latin, servitus bellium, and at the right, the ius civille (sic), garlanded with libertas et iusticia. While a king and his courtiers watch at one side and two wise jurists at the other, the ius civille clearly tilts the scales, and from the enlightened sky descends the Ciceronian maxim cedant arma togae..$^{7}$ Below, a scene in which a royal family idly wastes its time in corporal pleasures while armies clash at the background, is juxtaposed with an image of flourishing maritime commerce, at the forefront of which stands a diligent farmer cultivating his land, the archetype of republican virtue. Thus the book immediately directs the reader toward a depiction of divinely inspired good versus bad government, epitomizing the contents of the work. ${ }^{79}$

This frontispiece also contained a distinct intertextual and interpictorial reference that would not have escaped the eye of the attentive reader. In 1618, the famous Dutch poet and playwright Joost van den Vondel had published anonymously a satirical poem on the Arminian controversy that tore apart Dutch society and politics (see chapter 5 below). This poem, entitled $O p$ de jonghste Hollantsche transformatie ["On Holland's Latest Transformation"], entailed an implicit but highly critical account of the way in which the controversy had been settled, accompanied by an elaborate engraving that elucidated Vondel's intentions (see fig. 2). The engraving shows the two opposing camps of the conflict placing their strongest arguments in the scales of a large balance, until the Stadholder, Maurice of Orange, forcefully interferes and makes the scales tilt to his side. ${ }^{80}$ Vondel's poem and its imagery, printed several times throughout

\footnotetext{
${ }^{78}$ Cicero, De officiis I.XXII.77. The same motto embellishes the frontispiece of Lieuwe van Aitzema, Herstelde Leeuw, of discours, over 't gepasseerde in de Vereenighde Nederlanden, in 't iaer 1650, ende 1651 (The Hague, 1652) a historical treatise on the attempted coup d'état by William II.

79 For the rhetorical importance of the frontispiece see Sharpe, Reading Revolutions, 49. The frontispieces of the Politike Weeg-schaal, Politike Discoursen and Historie der Gravelike Regering are all signed by P[ieter] Philippe, an engraver active in The Hague in the early 166os.

${ }^{80}$ [Joost van den Vondel], Op de Jonghste Hollantsche Transformatie [1618]. For an analysis of the political contents of the poem, see B.H. Molkenboer, De jonge Vondel (Amsterdam: Parnassus, 1950), 489-503; and N. Wijngaards, "Vondels Hollantsche Transformatie," De nieuwe taalgids 59 (1966), 302-312.
} 


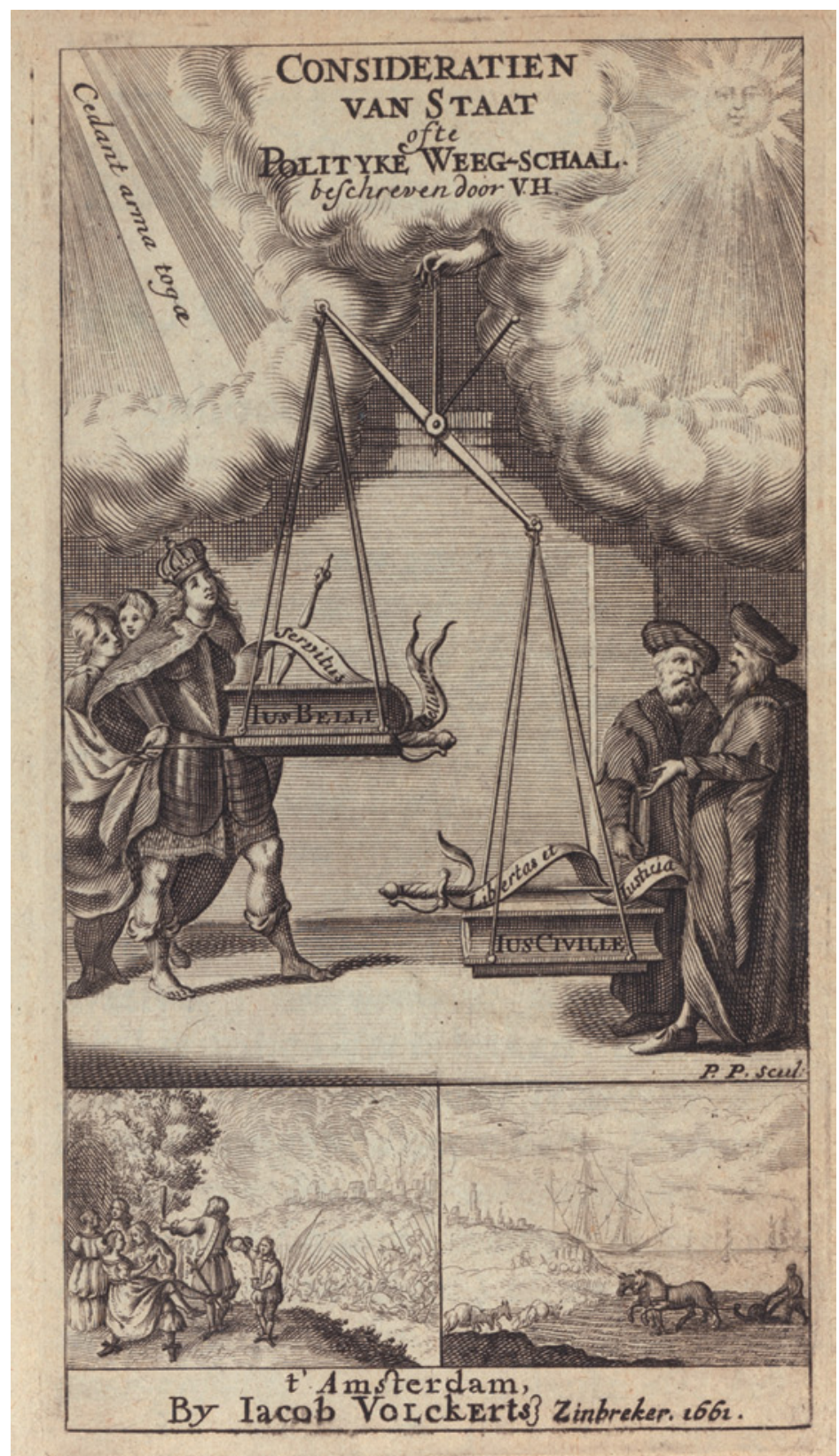

Fig. 1. Frontispiece to Johan and Pieter de la Court, Consideratien van Staat, ofte Polityke Weeg-schaal, 1661. Amsterdam University Library, OTM: OG 63-822 


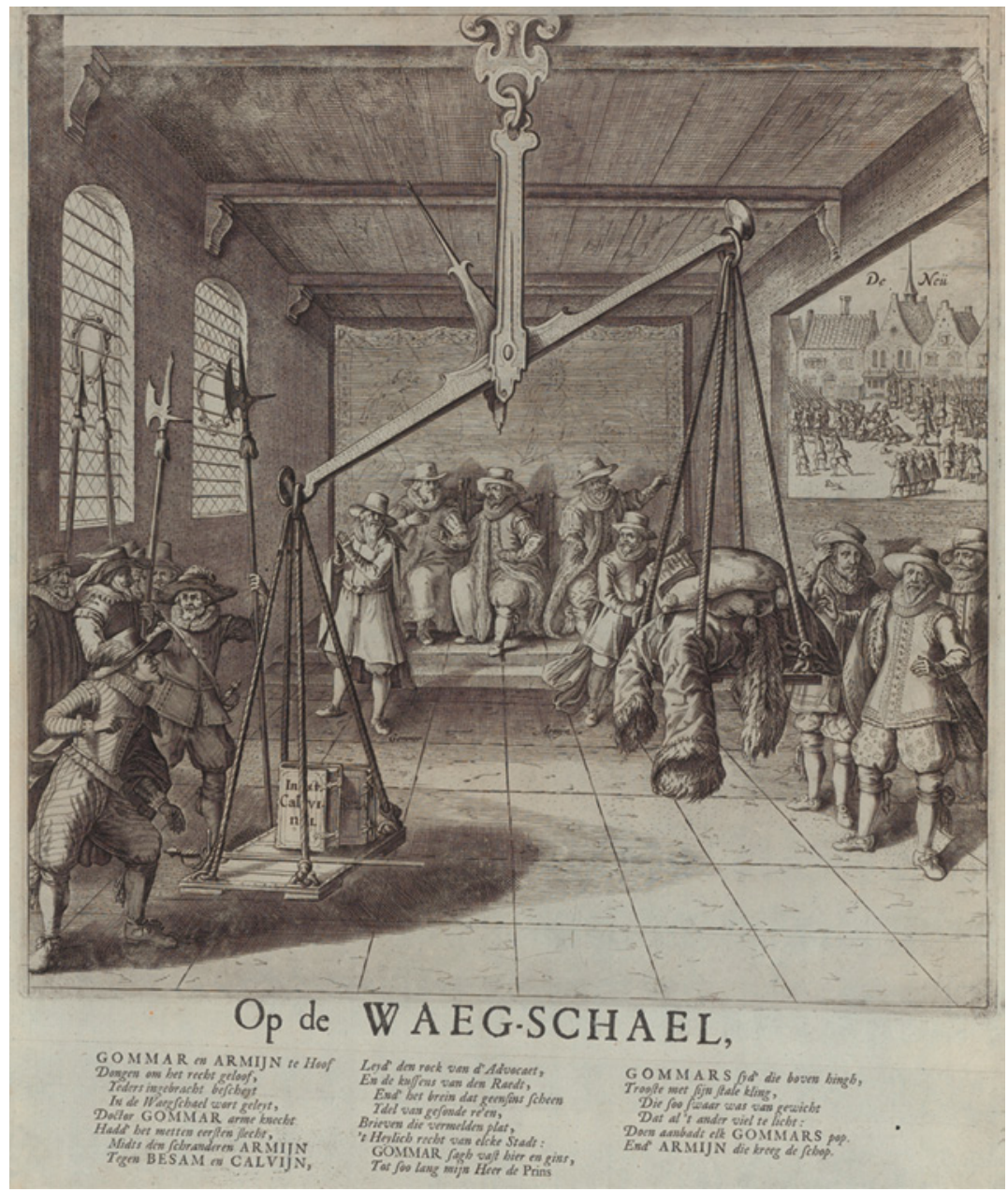

Fig. 2. Joost van den Vondel, Op de Waeg-schaal, 1618. Amsterdam University Library, OTM: Pr. G16a

the century, had in time become known simply as Op de waeg-schaalvan Hollandt ["On the Balance of Holland"]. Even in 1682, it was said that this print was still "in everyone's hands". ${ }^{81}$ Accordingly, the publication of the Politike Weeg-schaal in 1661 might very well have entailed an implicit reference to Vondel's popular depiction of the Arminian controversy,

\footnotetext{
${ }^{81}$ Molkenboer, Jonge Vondel, 501.
} 
with the scales of the Politike Weeg-schaal being exactly asymmetrical to those of Vondel's poem. De la Court's message was obvious: by now, at the height of the era of 'True Liberty', the balance in the Dutch Republic had changed.

De la Court prepared a still more elaborate imagery for the editions of the Politike Discoursen. The frontispiece of this work (fig. 3) is dominated by eight emblematic representations of justice and war, religion and diligence, clarified by telling sententiae that contrast the diligence of the maritime merchant (impiger extremos currit mercator ad Indos) ${ }^{82}$ with the untrustworthiness of soldiers (nulla fides pietasque viris qui castra sequuntur). ${ }^{83}$ Similarly, the reader of the Historie der gravelike regering (fig. 4) is confronted with six symbolic depictions of liberty and slavery: from a bird kept in a cage who watches another bird fly happily away, to the biblical donkey Issaschar beaten by his master, with the maxim Tenere Libertatem aut mori ante Servitium. In both cases, the external appearance of the work introduces the reader to the themes of mercantile politics and republican liberty.

This function of the frontispiece as an introduction to the text is most evident in the case of the Aanwysing, the 1669 revised edition of the Interest van Holland. Whereas the latter was printed with a simple page mentioning just title and publisher, often in cheap and practical duodecimo format, as a work of standing and authority the Aanwysing was instead published in quarto with a highly elaborated frontispiece in the form of a large arch (see fig. 5). This image literally performs the function of an entrance into the text with the powerful connotations of triumph and monumentality. ${ }^{84}$ De la Court's arch is adorned with authoritative weaponry and blazons which depict the fishing industry and trade, Holland's main sources of income and splendour. A scene of cheerful and talkative burghers shows how peace and happiness are only to be found in republics, while another scene of a governmental assembly embodies the republic's rule of law. Entering the text through this arch, the reader is visually confronted with what is to be encountered there in words. As in the case of the other works of the De la Courts, the frontispiece is thus an integral element of the brothers' rhetoric.

\footnotetext{
${ }^{82}$ Horace, Epistles I.1, v. 45. This phrase is also quoted in Hugo Grotius, The Free Sea, ed. David Armitage (Indianapolis: Liberty Fund, 2004), 14.

${ }^{83}$ Lucan, Pharsalia X.407.

${ }^{84}$ See Sharpe, Reading Revolutions, 49.
} 


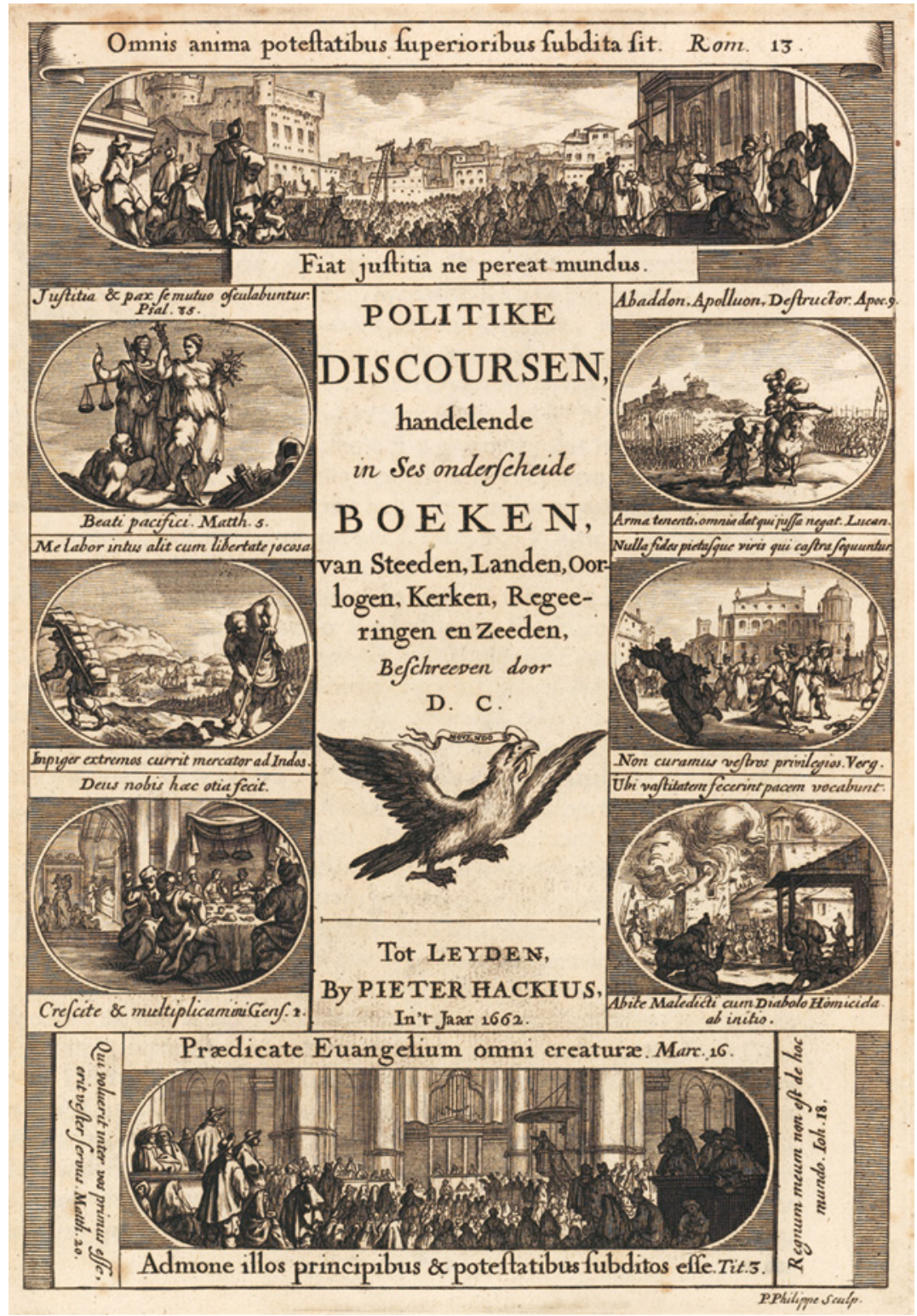

Fig. 3. Frontispiece to Johan and Pieter de la Court, Politike Discoursen, 1662. Amsterdam University Library, OTM: OG 63-7504 


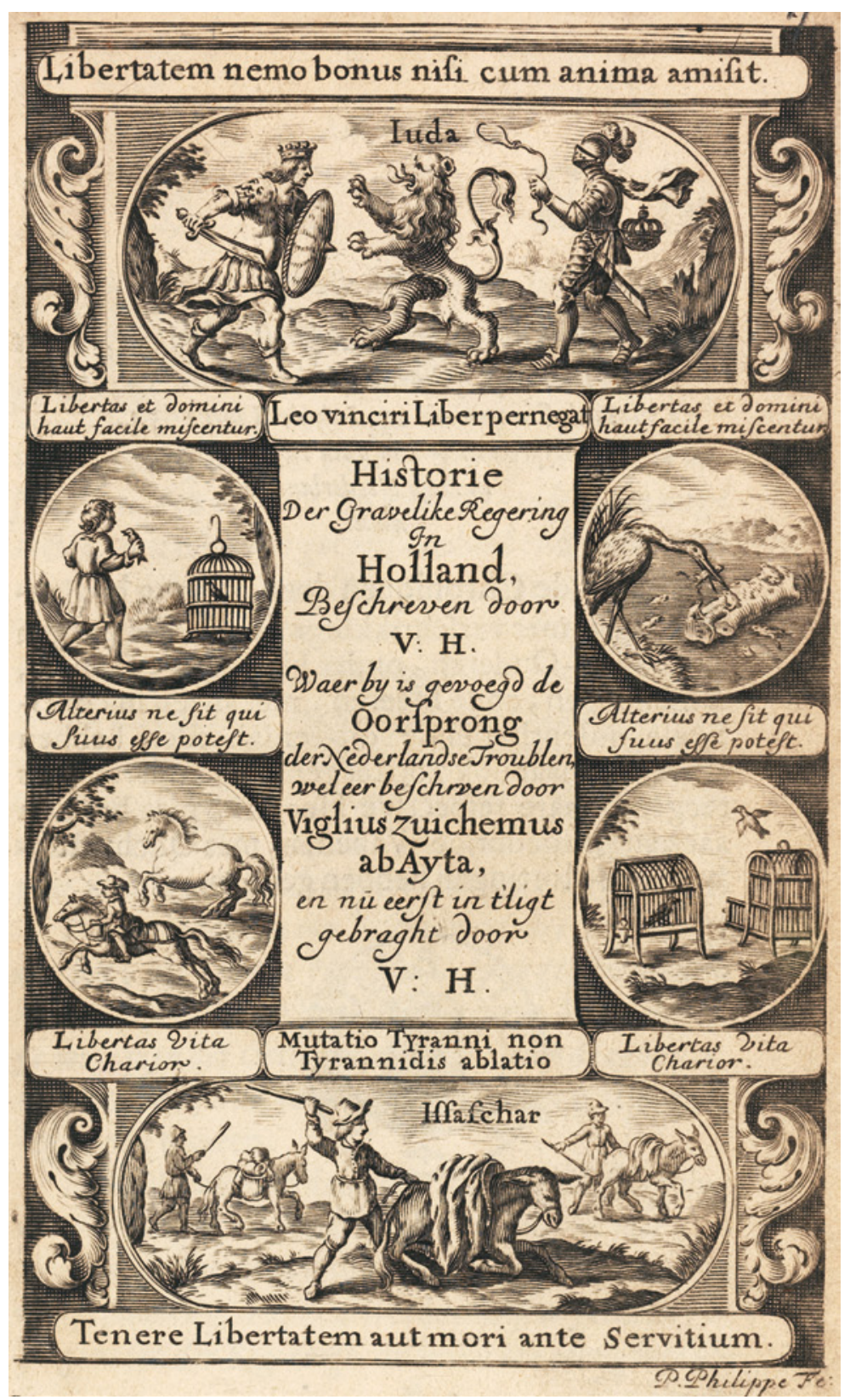

Fig. 4. Frontispiece to Pieter de la Court, Historie der Gravelike Regering in Holland, 1662. Amsterdam University Library, OTM: OK 61-565 


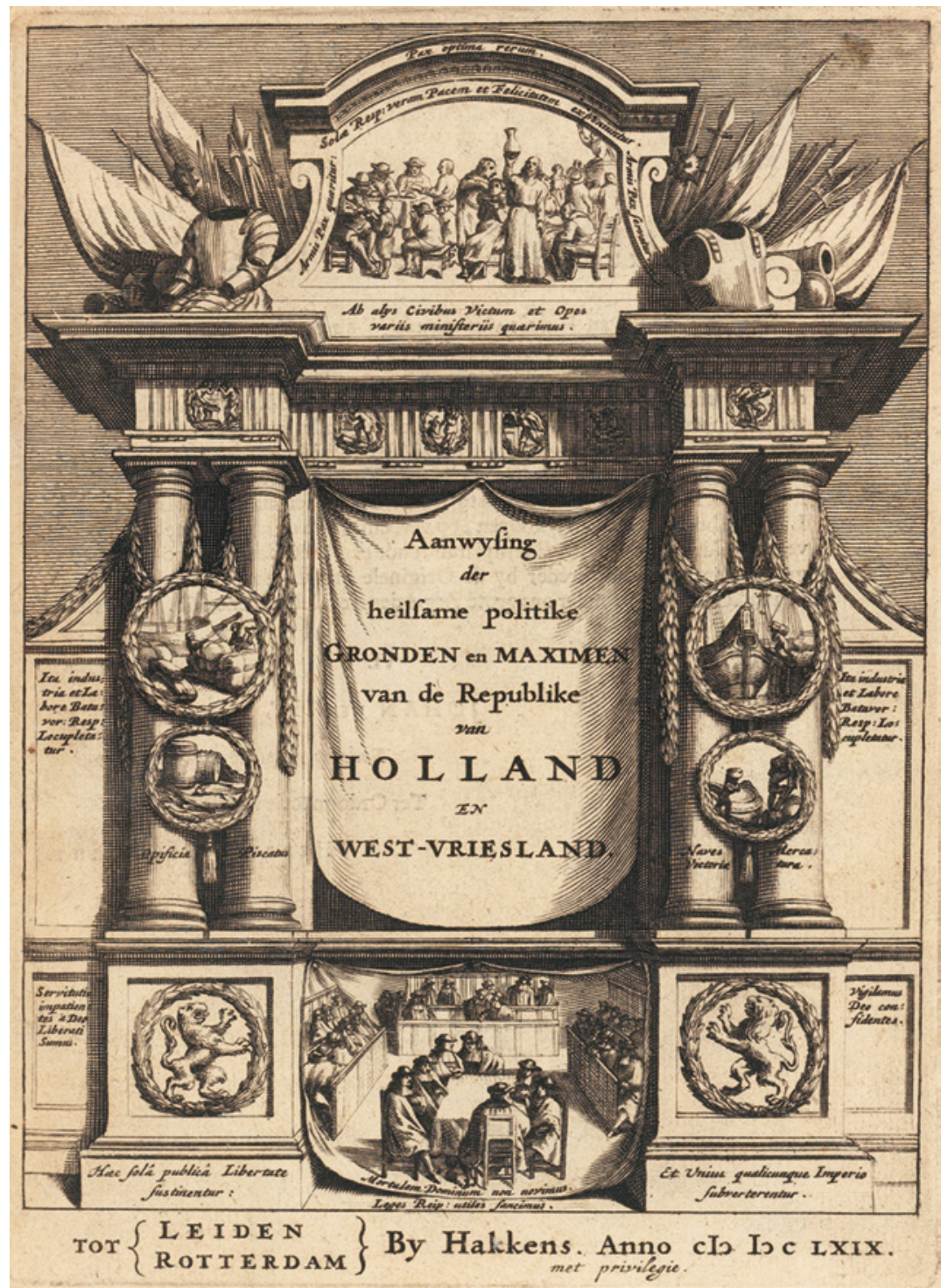

Fig. 5. Frontispiece to Pieter de la Court, Aanwysing der heylsame politike gronden en maximen, 1669. Amsterdam University Library, OTM: O 63-3745 


\section{The Power of the Image: Presentation \& Justification}

Apart from the illustration of a work, this power of imagery is also connected to a second meaning of the term image: the way the author presents himself to the audience, the authorial ethos as emphasized in rhetorical theory. Pieter de la Court demonstrated careful attention to this issue in his editing and revisions of the texts left by his brother Johan, adding large prefaces in which he clarified the intention of these works. These prefaces, each in line with Vossius's remarks about the importance of addressing the reader directly, clearly aimed to justify the writing and to win the support of the audience, thus establishing a positive image of their author. ${ }^{85}$ De la Court constructed an image of himself and his brother as truth-tellers, as liable, trustworthy rhetoricians who know how to play upon the passions of their audience in an ethical way, instead of the "slandering eloquence" of men such as Heereboord. This way of establishing ethos can be compared to the Classical notion of parrhèsia, the rhetorical device of outspokenness.

The establishment of authorial ethos in De la Court's preface to the Politike Weeg-schaal starts with a description of the task of the orator, clarified by a telling metaphor - as Vossius had taught, a useful means of engaging the reader's attention. From the beginning De la Court identifies himself with "all laudable good Orators and Writers" who, like sailors navigating through difficult waters, must employ all their skills in order to reach the shore safely. ${ }^{86}$ This common naval metaphor is employed to justify the brothers' involvement in politics: like the sailor, the orator is forced to devote himself completely to his cause, even if this devotion will lead to what some might judge as exaggerated conclusions. The reader, and especially the political establishment, should therefore take no offence at the work and the style in which it is written, since its writer is truly well-intentioned and keen to avoid causing offence. Indeed, De la Court boldly continues his metaphor,

this Writing should be to the highest degree pleasing to all Regents and Children of Princes [read: the young William of Orange, future William III], since putting them the evil ways of Courtiers and the corruptions, or errors of Governments, clearer before the eyes than possibly has been done by any other Writing so far, it can also serve them as a brightly shining beacon to

\footnotetext{
${ }^{8}$ Ibidem, 54-57.

${ }^{86}$ Politike Weeg-schaal, "Voor-reeden, Inhoudende het oog-wit des autheurs," sig. * $3:$ “... alle loffelike goede Orateurs en Schrijvers."
} 
avoid in this sea of Government all the revealed sandbanks, rocks, and beaches. $^{87}$

Like in the pamphlets of the Heereboord affair, De la Court presents the work as a reliable account that offers the reader a trustworthy and rewarding guide through the panorama of political debate.

This image is reinforced by the presentation of the author (the deceased Johan) as a virtuous man who, "while alive, in general did not consider any Quarrelsome writings worth reading, because those are on both sides always more driven by passion than by reason". Again as in the Heereboord affair, De la Court thus claims the high moral standard of the author who refuses to demean himself to the base level of passionate argument. Anyone is allowed to enter freely the "cantankerous path" of refutation, De la Court writes, yet he continues to insist that "such slanderous scum of Men ... cannot be more forcefully answered than with contempt and silence" ${ }^{88}$ This powerful statement, which mirrors Vossius's remarks on the utility of undermining possible critique from the start, is ultimately repeated to increase its impact in the very last phrases of the work. Here De la Court asserts that by publishing the Politike Weeg-schaal he has merely fulfilled his duty as "a Lover of my free Fatherland" and shall now refrain from further debate. ${ }^{89}$ All throughout the work, this image of the upright and objective author who rationally searches for truth instead of passionate quarrel is upheld eloquently. For example, prior to a long and radical criticism of monarchical rule, De la Court starts with the claim that he will discuss all (dis)advantages of all different kinds of government, "without passing over any of these because of hate or favour, trusting that all impartial Readers will praise my zeal in this". Later, he sides with the advocates of republics, yet supposedly only for the sake of convenience "to avoid difficulty". And juxtaposing aristocracy and democracy

\footnotetext{
${ }^{87}$ Ibidem, sig. * 4 : "Maar is ter contrarie waaragtig dat dit Schrift ten hoogsten aangenaam behoorde te wezen, aan alle Regenten en Kinderen der Princen, alzoo het zelven hun de quaade gangen der Hoovelingen en corruptien, of dwaalingen der Regeeringen, klaarder voor de oogen stellende, als mischien voor deesen, ooit door eenig ander Schrift is geschiet, hun ook kan strekken een helschijnend baaken, om in deeze zee der Regeeringe, alle de aangeweese sanden, klippen en stranden te vermyden."

${ }_{88}$ Ibidem, sig. * 4v.: “... hy, by leeven zijnde, in het generaal geen Twist-schriften leesenswaardig agtede, om dat de selve ten weederzijden altijds meer door passie, als reeden, werden gedreeven." Ibidem, sig. *6v.- ${ }^{* *} 1$ : "Indien nogtans iemant dien anderen twistgierigen weg wil inslaan, hy doe dat vryelik, en zy verseekert ... dat men dienvolgende, dit lasterent schuim van Menschen (Spreta exolescunt; si irascare adgnita videntur. C. Tacit.) niet kragtiger kan beantwoorden, dan met veragten, en stil zwijgen." The quote is from Tacitus, Annals IV.34.

${ }^{89}$ Ibidem III.III.6, p. 670: “... een Liefhebber mijns vry Vaderlands.”
} 
with some room for doubt about which of the two should be considered best, De la Court presents himself as the unbiased and all-knowing guide who has decided "to assist the Reader in resolving these doubts"..$^{\circ}$

A comparable image of a benevolent, prudent, and honourable author, yet now fused with a degree of unease about the reader's independence, is presented in the preface to the Politike Discoursen, also added by Pieter de la Court. In this preface, De la Court again employs the power of metaphor to prove his point. Aware that "malignant, villainous, and hypocrite" readers might loathe the work "out of self-interest", he imaginatively compares the book to a "well-planted Vegetable, herb, and Flower garden consisting of many nutritious, beautiful, curative, and poisonous Herbs"..$^{1}$ Like a pharmacy, such a garden might contain many plants that are potentially very harmful and toxic, but these can nonetheless be useful when applied in the right manner. De la Court thus warns possible adversaries that they are themselves responsible for any misreading when they want to "suck like a malignant Spider in a Herb Garden, or like an evilminded reckless Man in a Medicinal Pharmacy, to chose only the worst, and to taste and apply it either imprudently or malignantly"..$^{92}$ In other words, the author himself is not to blame for any possible mishandling of the work: aware that his playing upon the imagination of the audience is a risky affair, De la Court attempts from the start to elude possible criticism. This is an important feature of his authorial ethos, for it shows that De la Court was acutely aware of the limits to successful persuasion. After all, every reader judges independently.

A skilful rhetorician should therefore know how to steer the reader's judgment in the right direction. As Vossius instructed, it is essential for this purpose that authorial pretensions are not exaggerated and do not necessitate studiousness. De la Court eloquently follows this advice. In

$9^{\circ}$ Ibidem I.I.8, p. 40: “... zonder eenige der zelven, uit haat ofte gonst voorby te slaan. Vertrouwende dat alle onpartijdige Lezers mijnen yver in dezen zullen pryzen." Ibidem I.I.11, p. 52: “... onder de persoon van gemelde liefhebbers der Republiken, en zal om de moejelikheid te schuwen, voortaan dus haar gevoelen, als of het mijn eigen waar, voorstellen.” Ibidem III.I.6, p. 557-558: “... zoo heeft het my goed gedagt, om den Leeser in deese twijffelinge te helpen resolveeren."

${ }_{91}$ Politike Discoursen, "Voor-Reeden, Aen den Leeser," sig. * ${ }_{5}$ : “... van veele andere boosaardige, door-trapte en schynheilige menschen, sullen om eigen interest, ten hoogsten verfoeid werden ... Warelik, dit geheele Werk, werd door my vergeleeken by een welbeplante-Moes- kruyd- en Bloem-hof bestaande uit veelderley voedsame, schoone, heilsaame, en vergiftige Kruiden ... Iaa dat meer is, gelijk een Apotheekers-Winkel."

${ }_{92}^{2}$ Ibidem, sig. (6): “... sulks indien de Leeser als een boosaardige Spin in een Kruid-Hof, uit-suigen, of als een quaadwillig roekeloos mensch in een Medicinale Apotheeke, het argsten alleen uitkiesen, ende 't sy onvoorsigtig, 't sy boosaardiglik smaaken, en appliceren wil." 
the preface to the Politike Weeg-schaal, he reacts fiercely against the "pedantic scholastic humbug of Scholars", ${ }^{93}$ presenting the work as a much more realistic and accurate account of politics than the fruits of academic pens could possibly provide. This dismissal of scholarly politica is even more explicit in the Politike Discoursen, overtly claimed to be written out of disgust with conventional political studies in the Swiss, German and Dutch republics, so meagre when compared to their Italian counterparts. In this way, De la Court evidently tries to capture the reader's attention by emphasizing the autodidactic and anti-establishment character of his and his brother's works. His blatant message is that these works provide something novel and unusual, that they are "more worth reading than any others that have come to light so far about such Matters in any language". ${ }^{94}$ Yet for all this haughtiness, De la Court also realizes that he should not fall into overt arrogance and swollen language. Therefore he also employs the device of modesty. Stating that some passages are "hastily written" and far from comprehensive, while others can hardly hide their "inaccuracy", $95 \mathrm{De}$ la Court asserts that the author "has surely believed to have erred much in such extensive matters, because of far too poor knowledge, weakness of human judgment, and slowness" ${ }^{96}$ As Vossius taught, such a blend of haughtiness and modesty ought to make the reader truly benevolent and attentive.

All these elements of the establishment of authorial ethos finally reappear in the Aanwysing, De la Court's most self-assured treatise. Following the rhetorical strategy of his earlier work, De la Court proclaims his prudence and probity in publishing the work as well as the novelty of its contents yet feebleness of judgment. Most importantly, he again asserts that none should take offence at his writing since he is a truly trustworthy and impartial author, not biased in favour of either side of the political spectrum in the Dutch Republic. De la Court insists that he has never been

93 Politike Weeg-schaal, "Voor-reeden,” sig. *5: “... pedantise school-sieke beuselingen, der Geleerden."

${ }_{94}$ Politike Discoursen, “Voor-Reeden,” sig. * $5:$ “... in 't geheel geconsidereerd weesende, leesens waardiger dunken; als eenige andere, die tot heeden oover diergelijke Materien, in eenigerley taalen, sijn in het ligt gekoomen."

${ }_{95}$ Ibidem, sig. * 4: “... een Naawkeurig Leeser sal konnen merken, dat de Aeutheur veele saaken in sijne gedagten heeft gehad, die hy onder het haastig schryven, of niet gekonnen, of niet gewild, of ook vergeeten heefd, uit te drukken ... Iaa dat meer is, de Leeser sal buiten twijfel omtrent de bygebragte exempelen bespeuren, een veel groter slordigheid."

${ }_{96}^{6}$ Politike Weeg-schaal, "Voor-reeden," sig. * 5: “... seekerlik heeft hy gelooft, in soo wijdluftige materien, door al te geringe kennisse, swakheit van een menschelik oordeel, als ook door traagheit, veelsints te sullen hebben gedwaalt." 
offended by the House of Orange, that "someone would evidently stray from truth if he would slanderously criticize me to have written this Work with a design to flatter the free Rulers of this Serene and Powerful Republic or to the dishonour and disadvantage of the Princes of Orange" ${ }^{97}$ De la Court thus claims his own disinterestedness and rational objectivity, in direct opposition to the "reason- and country-depraving flatteries of Writers". While such flatterers distort the truth out of the fear for repercussions, De la Court stresses his own patriotic desire to proclaim the truth, however unwelcome that may be, inviting the reader "to read the Book as impartially as it has been written by me with a calm Fatherlandand truth-loving mood". ${ }^{8}$ In short, De la Court presents himself as rhetorician who knows how to entice the readers' imagination in the service of the truth and the commonwealth.

This prominent claim of being an outspoken truth-teller involves the specific rhetorical figure of parrhèsia. This device, a prime element of the mechanisms of democracy and the definition of citizenship in Ancient Athens, was a distinct figure of speech in Classical and humanist rhetorical theory: it entailed the act of bluntly telling the truth while at the same time vindicating such straightforwardness. ${ }^{99}$ The Roman treatise Ad Herennium in particular recognized the usefulness of this figure "in presenting us, the speakers, as friendly both to the hearers and to the truth". ${ }^{100}$ Accordingly, parrhèsia was an essential element of the establishment of authorial ethos. By claiming to tell the truth in a straightforward way, without fear or dissimulation, a rhetorician could win the support of the audience while expounding his opinions openly, however unwelcome they might be.

Similarly, for De la Court, the employment of parrhèsia offered the rhetorical means to win over the reader, justify his and his brother's work and proudly expound the radical potential of their political ideas. Besides,

97 Aanwysing, "Voor-Reeden," sig. *4: "soo soudemen kennelik vander waarheid afdwalen, indienmen my lasterlik wilde nageven, dit Werk met voordagt om de Vrye Regeerderen deser Doorlugtige en Grootmogende Republike te vleyen, of wel ter oneere ende ten nadeele der Princen van Oranjen."

$9^{8}$ Ibidem, sig. ${ }^{* *} 1 \mathrm{v} .:$ “... die seer lang gepleegde verstand ende land-verdervende vleyerien der Schrijveren." Ibidem, sig. *****2v.: “... soo gelieve de Leeser, procul ira procul studio, het volgende Bouk alsoo onpartydig te leesen, als het selven door my met een bedaard ende Vaderland- en waarheid-lievend gemoed is beschreven."

99 See David Colclough, Freedom of Speech in Early Stuart England (Cambridge: Cambridge University Press, 2005), esp. 12-6o.

${ }^{100}$ Rhetorica ad C. Herennium, trans. Harry Caplan (Cambridge, Mass.: Harvard University Press, 1954) IV.XXXVII.49, p. 353. 
parrhèsia could entice the imagination of the audience by playing upon the passion of impudence, one of the four main passions in Vossius's account of deliberative rhetoric. Through the act of outspoken parrhèsia, disregarding all forms of decorum, a rhetorician like De la Court made clear to his audience that audacity and impertinence are a virtue, thus motivating the readers' impudence for the sake of persuasion. Finally, as an essential element of the establishment of ethos, De la Court's parrhèsia also gives us a first hint of the sort of speech that he and his brother considered to be effective rhetoric. In being outspoken and singing the praise of such outspokenness, the De la Courts aimed to show that candour offers the key to a constructive public debate.

\section{Tapping the Sources of Eloquence: Ornatus \& Ridicule}

The establishment of authorial ethos is one aspect of the rhetorical design of Vossius's helepolis, the fortified rhetorical battering-tower harnessed for the peaceful invasion of the reader's soul. Another aspect of this design, as shown above, is ornatus. Vossius, in line with Classical rhetorical theory, extensively discussed a range of particular elocutionary devices that can be employed to play upon the imagination of the audience. Many of these tropes and figures of speech are also prominent in the writings of the brothers De la Court.

The most central figure in their work is the explanatory use of sententiae and exempla, which Vossius suggested as means to instruct and delight the audience. All works of the De la Courts are packed with proverbs, expressions, and apophthegms in different languages, most probably taken from the commonplace books that were widely used in the early-modern period. ${ }^{101}$ In line with their rhetorical praise of candour and straightforwardness, the De la Courts are especially fond of witty proverbs that remove the façade of hypocrisy, such as the saying, also mentioned by Vossius, "a monkey is a monkey, even if he wears a golden suit". ${ }^{102}$ More

${ }^{101}$ See Skinner, Reason and Rhetoric, 118-119, and Ann Moss, Printed CommonplaceBooks and the Structuring of Renaissance Thought (Oxford: Clarendon Press, 1996). Many of the sayings in the works of the De la Courts are also present in the widely read work by Jacob Cats, Spiegel van den Ouden ende Nieuwen Tijdt (1632, facsimile ed. Amsterdam 1968), a collection of moralistic poems illustrated with emblems and popular expressions in various languages.

${ }^{102}$ Politike Weeg-schaal I.I.13, p. 78: “... een aap is een aap al heeft hy een gouden rok an, en aapery is aapery." Cf. Vossius, Rhetorices contractae, IV.XII.5, p. 432: "Simia est simia, etiam si aurea gestat insignia." For sententiae as a rhetorical device, cf. E.J. Hundert, "Bernard Mandeville and the Enlightenment's Maxims of Modernity," Journal of the History of Ideas 56 (1995), 577-593: 578-579. 
importantly, the brothers often quote short sententiae of two Classical authors in particular: Tacitus, the prime authority for seventeenthcentury political writing who is invoked by the De la Courts as a critical insider's account of the abject life at a monarchical court; and Lucan, whose Pharsalia offered a telling historical account of what happens when one man tries to attain all power. Clearly, the De la Courts read their Tacitus and Lucan as republican authors, as commentators on the moral and political ruin caused by monarchical rule. This reading of Lucan is particularly significant. As David Norbrook has shown, a similar antimonarchical interpretation of Lucan, following Grotius's influential edition of the Pharsalia from 1614, informed the republican imagination in England at the opening of the Civil War. ${ }^{103}$

While sententiae thus add time-honoured authority to topical political claims, the rhetorical employment of exempla serves a similar purpose. ${ }^{104}$ Numerous historical episodes, travel stories and literary anecdotes pervade the work of the De la Courts as rhetorical display of their wide knowledge and literary taste. Moreover, the recurring exempla taken from authors like Francesco Guicciardini and Philippe de Commines involve a distinctly republican reading of history. As De la Court explains, whoever will "read with attention the Histories by Francesco Guicciardini and Philippe de Commines" must become convinced of De la Court's own claims about the vicious behaviour of kings. ${ }^{105}$ Also significant in this context is the use of less conventional work such as the Gulistan, written by the thirteenth-century Persian author Saadi. This work, translated from a German edition into Dutch as Perssiaansche Roosengaard ["Persian Rose Garden"] was published in 1654 by the controversial Amsterdam editor Jan Rieuwertsz, later the publisher of Spinoza. The De la Courts read this

${ }^{103}$ Lucan, Pharsalia, sive de bello civili Caesaris et Pompeii, ed. Hugo Grotius ([Leiden], 1614), reprinted numerous times throughout the century. Pieter de la Court van der Voort had a copy of the 1643 edition: Library, fol. 33. For Lucan's impact in England, see Norbrook, Writing the English Republic, 23-62. Cf. on the politics of reading in early-modern England the seminal article by Lisa Jardine and Anthony Grafton, “'Studied for Action': How Gabriel Harvey Read His Livy," Past \& Present 129 (1990), 30-78; and Sharpe, Reading Revolutions. On the De la Courts' republican reading of Tacitus, see Jan Hartman, "Tacitism and Trade. Johan (1622-166o) and Pieter (1618-1685) de la Court's Maxims and Algernon Sidney's 'Court Maxims' ", unpublished paper.

${ }^{104}$ On the use of exempla and the auctoritas of quotes, see Wansink, Politieke wetenschappen, $5^{6-59 .}$

${ }^{105}$ Aanwysing II.10, p. 308: “... die gelieve met aandagt te leesen de Historien van Francisco Guicciardini en Philips van Comines." For a republican reading of De Commines, cf. Joël Blanchard, Commynes l'Européen. L'invention du politique (Geneva: Droz, 1996), esp. $205^{-227 .}$ 
work too as a republican assessment of the gruesome fate of those who live under monarchical domination. ${ }^{106}$ Besides, Saadi's anecdotes and parables revealed the rhetorical usefulness of making a point by telling a funny story, another important element of the rhetoric of the De la Courts.

Whereas sententiae and exempla principally play upon the reader's imagination through delightful instruction and illustration of the argument, other figures of speech mobilize the intrinsic power of language itself to entice the passions. One of these figures is the device of interrogatio. A significant passage in the work of the De la Courts on the advantages of democratic rule explicitly acknowledges the use of this device for the sake of persuasion. This passage maintains that

it is evident that this Popular Government is not founded upon any violence but that it is natural, rational, and in itself fair. Which cannot be proven clearer than with questions: What can be more natural than to live according to one's own judgment, order, and laws? What can be more rational than to obey the one of one's own choice? What can be more fair than to endure mistakes and men that one can improve and punish oneself? ${ }^{107}$

Through this device, the De la Courts lure the reader into agreement by making their statements seem obvious and irrefutable. A comparable stylistic figure that entices the audience is ekphonesis, a forceful exclamation, as in another passage that imaginatively warns the audience never more to appoint a Stadholder: "O foolish children of men! Do you think it is enough to make a Lord a Head of State, which then could do much good to a country? O no, that is truly the blind rock where you will be shipwrecked and which you will groan about for all eternity." ${ }^{108}$ Clearly, such an exclamatory

${ }^{106}$ Saadi, Perssiaansche Roosengaard: Beplant met vermaaklijke Historiën, scharpzinnige Redenen, nutte regelen, en leerrijke Sin-spreuken (Amsterdam, 1654), translated from the German edition by Adam Olearius. On this edition, see Faramarz Behzad, Adam Olearius' "Persanischer Rosenthal". Untersuchungen von Saadis "Golestan" im 17. Jahrhundert (Göttingen: Vandenhoeck \& Ruprecht, 1970). On Rieuwertsz, see Pieter Visser, Godtslasterlijck ende pernicieus. De rol van boekdrukkers en boekverkopers in de verspreiding van dissidente religieuze en filosofische denkbeelden in Nederland in de tweede helft van de zeventiende eeuw (Amsterdam: AD\&L, 1996).

${ }^{107}$ Politike Weeg-schaal III.I.4, p. 530: “... dat deese Populare Regeering op geen gewelt gefondeert, maar naturelik, redelik, en in zig zelven billik is. 't Welk niet klaarder beweesen kan werden, als met vragen; Wat kan natureliker zijn, als te leven naar zijn eigen oordeel, ordre, en wetten? Wat kan reedeliker zijn als te gehoorsamen die men zelfs gekooren heeft? Wat kan billiker zijn, als te dulden, mislagen, en menschen die men zelfs beeteren, en straffen kan?"

${ }^{108}$ Ibidem I.III.8, p. 258: "O dwaze menschen kinderen! Meent gy dat het genoeg is, een Heer, een Hooft te maken, dat veel goets aan een land zoude kunnen doen? O neen, dat is waarelik de blinde klip daar gy schipbreuk lyden, en in der eeuwigheid over zugten zult." 
warning plays upon two central passions of deliberative rhetoric: shame, stimulated by the insistence on the stupidity of desiring a Stadholder, and fear, aroused by the description of its disastrous consequences.

Accordingly, these elements of ornatus sustain the De la Courts' republican argumentation by engaging the passions of their audience. The same goes for the important device of paradiastole, the rhetorical redescription of men and actions by changing their conventional characteristics. Vossius had instructed that this figure is particularly powerful when used for reprehension, and this is exactly the way in which it is employed by the De la Courts. An important example is a passage in the Politike Weegschaal that lists, under the guise of objectivity, all advantages commonly ascribed to monarchies, and then continues to re-evaluate and disclaim every one of these arguments. Reprehending the duplicitous rhetoric of flatterers, the passage argues that these "imagined advantages of Monarchical Government are founded on a fundamental error, namely, that people and Monarchs follow rather Reason than their wrong passions and lusts, since, to the contrary, ... there is no shame nor virtue to be found amongst Kings when they follow the common course of human nature" ${ }^{109}$ In short, monarchs cannot escape the human condition. While courtly flattery does not acknowledge this passionate baseness and therefore fails the test of good rhetoric, the paradiastole of the De la Courts implies that republican outspokenness knows how to deal with the passions. This message is especially prominent in the preface to the Aanwysing, which offers an elaborate example of rhetorical redescription, now directly aimed at the Dutch Stadholders. Turning the established reputation of all members of the House of Orange upside down, De la Court insists that "these Princes of Orange are not Angels but Men". ${ }^{10}$ Being human, they are by necessity slaves to their passions, and instead of embodying all princely virtues they are driven by lust and the dangerous ambition to dominate. The good rhetorician, so De la Court suggests, tells the truth

${ }^{109}$ Ibidem I.I.10, p. 47: "Maar hier tegen zeggen de Liefhebbers der Republiken dat alle deeze gemelde en ingebeelde voordeelen der Monarchale Regeringe, zijn gefondeert op een deze groote dwalinge, namentlik, dat de menschen en Monarchen meer de Reeden als haare verkeerde passien en wellusten volgen, daar ter contrarie ... by Koningen nog schaamt nog deugt te vinden is, indien zy de gemeene loop der menscheliker nature involgen." The entire passage, comprising chapters 8-11 (pp. 40-56) from the first part of the work, offers a clear example of how Pieter de la Court revised the writings of Johan: the first edition mentions only the advantages of monarchy, while their rhetorical redescriptions appear in the later editions.

${ }^{10}$ Aanwysing, "Voor-Reeden,” sig. *** 4: “... dat dese Princen van Oranjen geene Engelen, maar Menschen zijnde." 
about this behaviour. The good rhetorician is a straightforward republican who unmasks monarchical dissimulation.

Yet while employing paradiastole to undermine the reputation of their adversaries, the brothers De la Court also emphasize the dangers intrinsic to this device. In late humanist culture, rhetorical redescription was often repudiated for creating moral arbitrariness and the confusion of virtue and vice."11 The De la Courts share this concern, and while they present themselves as impartial seekers of truth, they arraign others who jeopardize an objective assessment of good and evil. Such dishonest speech is especially characteristic to a monarchical court, where deceitful "Courtesans" indulge "impudently in their sycophancies" to please their king. As a result, these courtly flatterers

change his vices into virtues ... as when one calls squandering generosity, excess royalty, drunkenness cheerfulness, whoring love, haughtiness respectability, cruelness justice, thievery swiftness, cursing openheartedness, blabbing eloquence, dissimulation political, or worldly-wisdom, and the poltroonery or pusillanimity common to Grandees, prudence. ${ }^{112}$

In other words, the speech typical of a monarchical court consists of lies and hypocrisy and thus exploits human weakness with false appearances. When rhetorical redescription is abused, truth disappears from sight.

This climactic attack on the duplicitous abuse of rhetoric targets not only the speech of courtiers, but also that of the clergy. Out of fanatical bigotry, the De la Courts argue, clerics tend to slander all who disagree with their opinions, in particular men of learning. The consequence is that the common people have always believed their claim "that the Jurists were evil Christians, the Physicians Libertines, the Philosophers Atheists, the Politicians feigning Machiavellians, the Mathematicians and Astronomers, Wizards and Fortune-tellers" ${ }^{113}$ Such paradiastole not only

${ }^{11}$ See Skinner, Reason and Rhetoric, 172-180, 279-284.

${ }^{112}$ Politike Discoursen II.VI.18, p. 236: “... soo pleegen de Courtisans ombeschaamdelik haare pluim-strijkereijen; daar in meest bestaande, wie omtrent den Souverain aardigst sal konnen liegen, en bedriegen: en vermits yder der Hoovelingen, tragt daar in sijn makkers te booven te gaan, op hoope van meer als sy te verkrijgen; soo roemen sy niet alleen de Vorsten waaragtige macht, maar verkeeren selfs sijn ondeugden tot deugden, en noemense die deugd, daar sy naast by gelijkt. Gelijk wanneermen de quistigheid milddaadigheid, de ooverdaad royaliteit, de dronkenschap vroylikheid, de hoerery liefde, de hoogmoed agtbaarheid, de wreedheid justitite, de dievery gaawigheid, het vloeken openhartigheid, de klap-achtigheid welspreekendheid, de geveinstheid politie, ofte wereld-wijsheid, ende der Grooten gewoonelike poltronerie, ofte kleinmoedigheid, voorsigtigheid noemd."

${ }^{{ }^{13}}$ Ibidem II.IV.5, p. 37: “... dat de Iuristen quade Christen, de Medicyns Libertyns, de Philosophen Atheisten, de Politiken geveinsde Machiavillisten, de Mathematici en Astronomi, Tovenaars en Waarseggers waren." 
perverts the truth, it may also morph easily into a dangerous demagogy that undermines the common good. The De la Courts put forward their own republican redescription of monarchical and clerical behaviour as an alternative to such demagogy, as a form of rhetoric that is persuasive in an ethical way. Against conventional mirrors of princes or clerical preaching, the parrhèsia of the De la Courts aspires to entice the audience by telling the truth straightforwardly.

All the different rhetorical devices employed by the brothers De la Court share one common feature of ornatus: the element of ridicule, used to provoke laughter and delight among the readers, to strengthen the author's popularity and to scorn all opponents. From the use of vivid expressions and colourful metaphors to the biting contempt for academic scholars, Stadholders, courtiers, and clergymen, the writings of the De la Courts are peppered with subtle and often not-so-subtle jokes and derisions. Needless to say, this wittiness serves a clear purpose. As Classical rhetorical theory had already emphasized, joking can be a very useful means to repudiate an adversary, for as Cicero maintained, "humour can be used to break up his case, to obstruct his arguments, to make light of his cause, to deter him from speaking and to turn aside what he has said".14 Winning an argument by provoking the laughter of the audience, laughter directed at the adversary: this is exactly what the brothers De la Court tried to achieve in their writings.

Following Vossius's subdivision of ridicule into six different types, it is arguably the device of diasyrmus, an "inimical mockery" slightly softer than deadly sarcasm, which the De la Courts employ most frequently. ${ }^{15}$ This form of ridicule, obtained through a comparison with something utterly ridiculous, is used for example to scorn the orthodox clerics who pretend to be "God's Ambassadors". For the De la Courts, this pretence is clearly not the consequence of any divine inspiration. Rather, "because of their weak brains and the imprudent reading of Holy Scripture and of the Histories of Godly Heroes", these clerics "started musing" just as Don Quixote who indulged in romances of chivalry. ${ }^{116}$ With these words the

\footnotetext{
${ }^{114}$ Cicero, De oratore II.LVII.236, quoted in Skinner, Reason and Rhetoric, 205.

${ }^{115}$ Vossius, Rhetorices contractae IV.X.3, p. 423: "Diasyrmus est inimica irrisio, sed extra caedem." Cf. Skinner, Reason and Rhetoric, 406.

${ }^{116}$ Politike Discoursen II.IV.4, p. 31-32: “... sy by hun Toe-hoorders sig veeltijds uitgeeven, voor Gods Ambassadeurs ... door haare swakke herssenen, ende het onvoorsigtig leesen der Heilige Schrifture, ende Historien der Goddelike Helden. Gelijkmen exempelen heeft, dat door het leesen der Romans, Historien van Amadis de Gaule, Astrea, en Arcadia, \&cc. de Leesers daar door aan het mymeren zijn geraakt."
} 
brothers effectively mock the ecclesiastical establishment through a comparison with the timeless archetype of the deluded daydreamer.

Vossius had mentioned the fable of Asinus ad lyram, the donkey at the lyre, as a good example of such diasyrmus. Significantly, this same phrase is also used as the epigram of a fable that plays a prominent role in the writings of the De la Courts (see fig. 6). ${ }^{117}$ This tale entails a variation on the classical allegory of two travellers, one an honest man, the other a hypocrite, who together visit the Kingdom of Apes, ${ }^{118}$ an exotic realm that was to become a standard element of many allegorical imaginary travel stories in the eighteenth century. ${ }^{119}$ De la Court's version adds a revealing national element to the tale: a Dutchman plays the honest man while the hypocrite is personified by a Frenchman. Having discovered the Kingdom of Apes, the two travellers are there invited to a lavish dinner and an exquisite ball, they are shown the luxurious Royal bedrooms and they join the court in a huge hunting party. After some days, the Frenchman is asked by the King of the Apes for his opinion about this government, to which the flattering Frenchman answers that he feels to be "in an earthly paradise". The King of the Apes, satisfied and impressed by the Frenchman's eloquence, appoints him his new counsellor, and then turns to the Dutchman with the same question. Yet this "blunt and most unapelike man' answers that he has 'seen nothing here that in any way tends to good government, but only pomp and circumstance, stuffing and boozing, whoring, hunting, dancing, and gambling". Having said this, the Dutchman is instantly executed, with the approval of the Frenchman, "and all the Apes said Amen". ${ }^{120}$

\footnotetext{
${ }^{117}$ Vossius, Rhetorices contractae IV.X.3, p. 423, and Sinryke Fabulen, 7.

${ }^{118}$ See H.W. Janson, Apes and Ape Lore in the Middle Ages and the Renaissance (London: Warburg Institute, 1952), esp. 40-41.

${ }_{119}$ Two Dutch examples from the eighteenth century are Jan Jacob d'Orille, 'T Onbekende nieuwe Apenland (Amsterdam, 1714), and 'J.A. Schasz M.D.' [Gerrit Paape], Reize door het Aapenland [1788], ed. Peter Altena (Nijmegen: Vantilt, 2007). Cf. P.J. Buijnsters, "Imaginaire reisverhalen in Nederland gedurende de $18^{\mathrm{e}}$ eeuw," in Idem, Nederlandse literatuur van de achttiende eeuw. Veertien verkenningen (Utrecht: HES, 1984), 7-35; and A.J. Hanou, "Verlichte vrijheid. Iets over een denkbeeld in imaginaire reizen," in Haitsma Mulier and Velema (eds.), Vrijheid, 187-211. For other imaginary voyages, see Percy G. Adams, Travelers and Travel Liars, 1660-180o (Berkeley etc.: University of California Press, 1962), and the list of eighteenth-century titles in Philip Babcock Gove, The Imaginary Voyage in Prose Fiction (London: Holland Press, 1961), 198-402.

${ }^{120}$ Politike Weeg-schaal I.I.13, p.77-79: “... in een aardsch paradijs ... deeze botte, en van der Apen-natuur zeer veel verscheelende mensch ... rond uit zeide: hier gansch niet te hebben gezien, dat eenigzins naar een goede regeering zweem: Maar wel pragt en praal, vreeten en zuipen, hoereeren, jaagen, danssen en speelen ... en alle de Apen seiden Amen."
} 


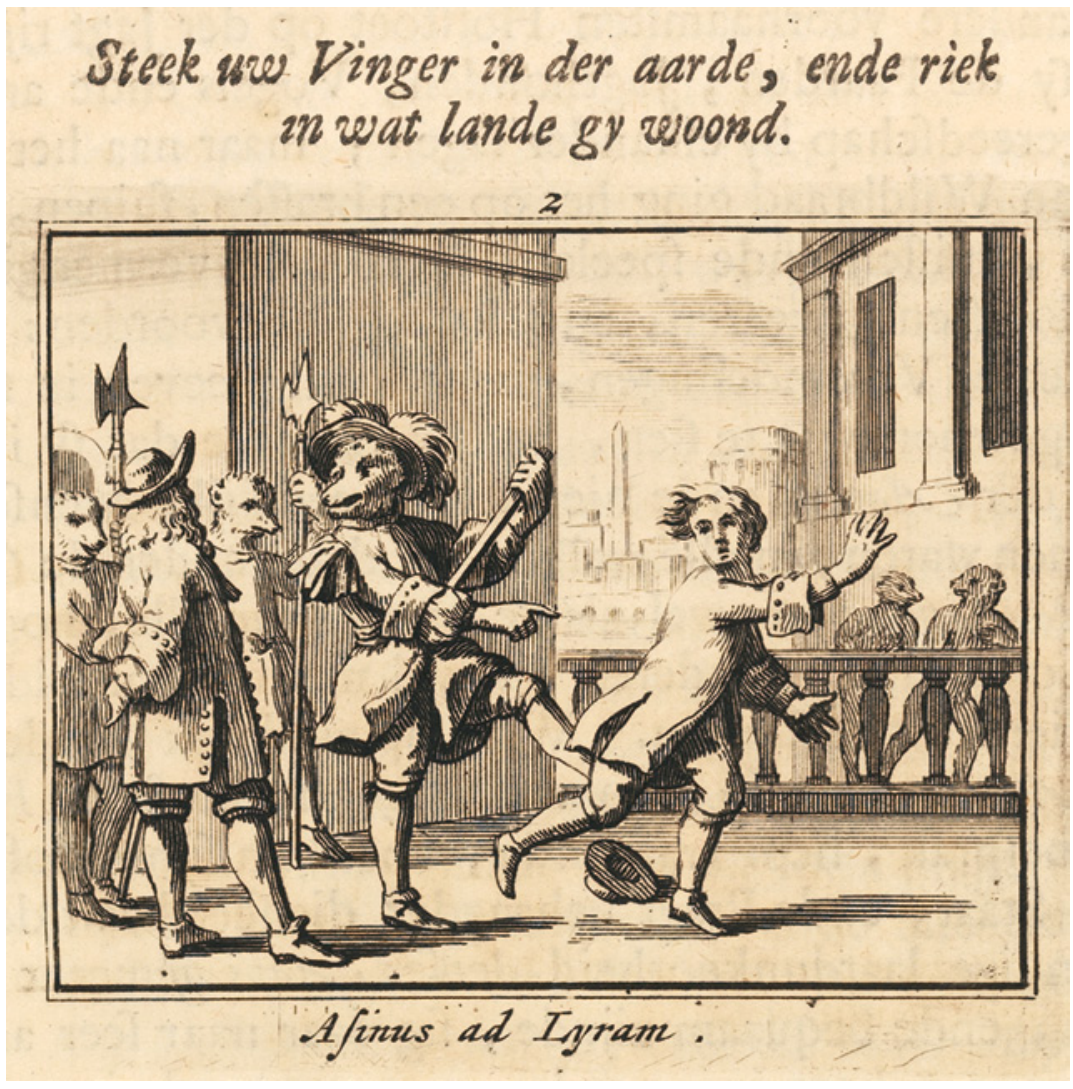

Fig. 6. "A Frenchman and a Dutchman in the Kingdom of Apes," from Pieter de la Court, Sinryke Fabulen, 1685. Amsterdam University Library, OTM: OK 63-2796

With this biting ridicule, De la Court evidently derides monarchical rule through comparing it with the overtly ridiculous kingdom of apes. He contends that monarchs and courtiers, exemplified by the Frenchman, are themselves merely apes, whose slavish nature is diametrically opposed to the outspoken parrhèsia of the free republican Dutchman. More specifically, the fable entails further mockery of the supporters of the monarchical principle in the Dutch Republic, and thus an explicit warning not

The same fable is told again with some amendments in the Sinryke Fabulen, 7-12. Cf. as well the comparable fable in Ibidem, 261-266, also told in Welvaren 43, p. 98-99. 
"to establish in one's own Free Fatherland a Kingdom of Apes" ${ }^{121}$ Such rhetorical scorn involves a double move. First of all, it serves to provoke laughter and please the audience on a scale as wide as possible. In the seventeenth century, this kind of burlesque satire was appreciated by large groups in Dutch society, from the general urban population to the refined tastes of the intellectual establishment. ${ }^{122}$ The employment of such ridicule therefore aimed to address both the higher echelons of society and a more popular audience, entering all social strata of public debate - obviously a deliberate political choice. As the De la Courts experienced in the Heereboord affair and later after the publication of the Interest van Holland, Dutch public debate was characterized by biting satire and offensive ridicule. In order to challenge their opponents, what could be more effective than using the same rhetorical weaponry?

Resorting to satire also served a second purpose: the comical, entertaining guise of a deeply moralistic message. This function of satire went back to the Classical recognition of the power of humour, immortalized by Horace when asking "ridentem dicere verum quid vetat?" ${ }^{23}$ The De la Courts, who quoted these words and often referred to Juvenal's Satires, were deeply aware of this expedient of ex nugis seria, and they clearly employed it in order to convey their political and moral messages in an appealing manner. As in the case of the fable of the Kingdom of Apes, they did so by telling colourful, illustrative parables that could at once delight and instruct their audience. ${ }^{124}$ This use of emblematic fables, itself a genre

${ }^{121}$ Sinryke Fabulen, 12: “... die als een Vry ende regtschaapen Mensch wil spreeken, sig seer sorgvuldiglik wagten moet, van in den lande der Aapen te reisen, ende nog veel meer, van in sijnen eigen Vryen Vaaderlande een Koningrijke der Aapen te stiften."

${ }^{122}$ For humorous conventions in the seventeenth-century Dutch Republic, see the collection of contemporary jokes and anecdotes compiled by the Leiden jurist Aernout van Overbeke, Anecdota sive historiae jocosae, ed. Rudolf Dekker and Herman Roodenburg (Amsterdam: P.J. Meertens-Instituut, 1991), analyzed further in Rudolf Dekker, Lachen in de Gouden Eeuw. Een geschiedenis van de Nederlandse humor (Amsterdam: Wereldbibliotheek, 1997). Dekker shows how Overbeke's jokes arose in a milieu between high and low culture. See also the comparable collection Nugae venales, sive thesaurus ridendi \& jocandi (s.l., 1681).

${ }^{123}$ Horace, Satires I.1, v. 24-25. See Ingrid A.R. de Smet, Mennipean Satire and the Republic of Letters 1581-1655 (Geneva: Droz, 1996), 41-53, for a discussion of the views of Lipsius, Heinsius, and Vossius on satire.

${ }^{124}$ On the close relatedness between emblems and jokes, see Barbara C. Bowen, "Two literary genres: the emblem and the joke," Journal of Medieval and Renaissance Studies 15 (1985), 29-35; elaborated further regarding some Dutch examples in Karel Porteman, "Het embleem als 'genus iocosum'. Theorie en praktijk bij Cats en Roemer Visscher," De zeventiende eeuw 11 (1995), 184-197. 
at the crossroads of popular and elite culture, is arguably the most striking characteristic of the De la Courts' rhetorical ornatus.

\section{FABLES AND FRANKNESS}

\section{The Emblematic Fable between Pedagogy \& Politics}

Ever since Antiquity, when authors like Aesop and Phaedrus had created a distinct genre of allegorical tales, the use of such fables had been as much reproved as their particular rhetorical force had been recognized. ${ }^{125}$ Quintilian maintained that fables should not be a part of the linguistic armoury of the truly decent orator, for fables "are specially attractive to rude and uneducated minds, which are less suspicious than others in their receptions of fictions and, when pleased, readily agree with the arguments from which their pleasure is derived". ${ }^{126}$ The other prime authority of Roman rhetoric, Cicero, was slightly more willing to appreciate the employment of fables. As Cicero stated, an orator can use verisimilar or plausible exempla to obtain the trust from the audience, but "sometimes even a fable, though incredible, will impress people" ${ }^{127}$ In spite of being overtly fictitious, fables were thus said to have a distinctive illustrative power. By creating a lively and easily understandable mental picture of the issue at stake, fables put a case ante oculos, before the audience's eyes by virtue of their imaginative appeal. In Classical and humanist rhetoric, such evocative language was considered to be one of the most significant tools that an orator could employ to make his audience not only hear but actually see things and thus become truly impressed. ${ }^{128}$

This hesitant view on the employment of fables, wavering between distaste and approval, was echoed in late humanist rhetorical and pedagogical theory. Like his Classical predecessors, Vossius frequently emphasized the persuasive power of figures and language 'that put the case before the eyes'. Yet he spoke with reluctance about using fables for this purpose, since fables were only appropriate for, as Vossius insisted, "vulgar souls"

${ }^{125}$ This section builds upon my "The Power of 'Pliant Stuff: Fables and Frankness in Seventeenth-Century Dutch Republicanism," Journal of the History of Ideas 72 (2011), 1-27.

${ }^{126}$ Quintilian, Institutio oratoria, trans. H.E. Butler, 4 vols. (Cambridge, Mass.: Harvard University Press, 1920-1922) V.XI.19, vol. 2, p. 283.

${ }^{127}$ Cicero, Partitiones oratoriae II.40, quoted in James Hankins, "Rhetoric, History, and Ideology: The Civic Panegyrics of Leonardo Bruni,” in Idem (ed.), Renaissance Civic Humanism, 143-178: 168.

${ }^{128}$ Cf. Vickers, In Defence, 320-321; and Skinner, Reason and Rhetoric, 182-188. 
and "coarse characters". ${ }^{129}$ Francis Bacon similarly lamented the "levity and looseness with which people indulge their fancy in the matter of allegories" in the preface to his 1609 collection of Classical fables De sapientia veterum ["On the Wisdom of the Ancients"]. Yet Bacon then vindicated his work claiming "the employment of parables as a method of teaching, whereby inventions that are new and abstruse and remote from vulgar opinions may find an easier passage to the understanding"..$^{130}$ In later years, Bacon's follower Comenius, with whom Pieter de la Court had enjoyed lengthy conversations at the start of his Grand Tour, equally commended the pedagogical use of fables following the commonplace adage "nothing in the mind is not first in the senses" ${ }^{131}$ Finally, towards the end of the century, John Locke argued that fables, "being stories apt to delight and entertain a child, may yet afford useful reflection to a grown man". Accordingly, Locke did not hesitate to include the genre in his political writings. ${ }^{132}$

The insistence on the combination between the pedagogical and the pictorial found its clearest expression within early modern culture in the subgenre of the emblematic fable, which combined the imaginative appeal of two literary traditions: the Aesopian tradition, and the more elitist, iconographical tradition of emblemata. ${ }^{133}$ The latter went back to the early sixteenth-century Emblematum liber by Andrea Alciato, which inspired a rising production of emblem books of an often very abstract and symbolical, even mystical nature, in particular popular among courtly circles. In the course of the following century, the tradition took a decisively bourgeois turn, involving far more realistic, moralized depictions of civic life with a clearly humorous element. In the Dutch Republic this

${ }^{129}$ Vossius, De artis poeticae natura, ac constitutione liber (Amsterdam, 1647) 9.6, 54: "Nec pueros modo, sed omnes vulgares animas, rudiaque ingenia, fabulae juvant."

${ }^{130}$ Francis Bacon, De sapientia veterum, in The Works of Francis Bacon, ed. James Spedding et al., 14 vols. (London, 1857-1874), vol. VI: 617-686. Quotes are from the English translation of the preface in Ibidem, 695-699.

${ }^{131}$ Jayne Elizabeth Lewis, The English Fable. Aesop and Literary Culture, 1651-1740 (Cambridge: Cambridge University Press, 1996), 41.

${ }^{132}$ See Kirstie M. McClure, "Cato's Retreat: Fabula, Historia and the Question of Constitutionalism in Mr Locke's Anonymous Essay on Government," in Kevin Sharpe and Steven N. Zwicker (eds.), Reading, Society and Politics in Early Modern England (Cambridge: Cambridge University Press, 2003), 317-350, quote on 329.

${ }_{133}$ On the relation between fables and emblems, see in particular Barbara Tiemann, Fabel und Emblem. Gilles Corrozet und die französische Renaissance-Fabel (Munich: Wilhem Fink, 1974), and, more generally, Peter M. Daly, Literature in the Light of the Emblem. Structural Parallels between the Emblem and Literature in the Sixteenth and Seventeenth Centuries (Toronto etc.: University of Toronto Press, 1979). 
change was especially reflected by the very popular love emblems of Daniel Heinsius and the moralistic emblem books by Jacob Cats, such as his 1632 Spiegel van den ouden ende nieuwen tijdt ["Mirror of Old and New Ages"]. ${ }^{134}$ Such emblem books were often particularly deployed for their pedagogical use. They played a central role in the education in rhetoric in seventeenth-century Europe at large, including the Latin schools in the Dutch Republic. ${ }^{35}$ Emblems thus served a purpose similar to fables, and as the French Jesuit theorist Claude François Menestrier stressed in the 1684 edition of his treatise L'art des emblemes, Aesopian fables should be seen as essentially emblems. ${ }^{136}$

Many seventeenth-century collections of fables indeed employed emblematic engravings as illustrations to the age-old Aesopian allegories, thus enhancing the latter's illustrative force. A prominent Dutch representative of this subgenre was Joost van den Vondel's Vorsteliicke warande der dieren ["Royal Reserve of Animals"], published in 1617 and arguably the playwright's first intervention in the political debate in the Republic. ${ }^{137}$ Across the North Sea, an important example of such a political use of the emblematic fable was the royalist Fables of Aesop, Paraphras'd in Verse by John Ogilby (1651). ${ }^{138}$ These two collections, both written in times of domestic turmoil (in Vondel's case the Arminian controversy, in Ogilby's the establishment of the Cromwellian regime) reveal that the emblematic fable was increasingly used for the purpose of political argument. These fables share the rhetorical design of another emblematic subgenre, the so-called emblemata politica. One particularly popular example of these collections is the Idea de un príncipe político christiano representada en cien empresas (1642) by the Spanish diplomat Diego Saavedra Fajardo. Written in a dense prose directed to the governing establishment,

${ }^{134}$ See P.J. Meertens (ed.), Nederlandse emblemata. Bloemlezing uit de Noord- en Zuidnederlandse emblemata-literatuur van de 16 e en 17e eeuw (Leiden: Martinus Nijhoff, 1983); and cf. the useful remarks in Frijhoff et al. (ed.), 1650, 464-471.

${ }^{135}$ See Frank-Van Westrienen, Schoolschrift, 196-240.

${ }^{136}$ Claude François Menestrier, L'Art des emblems ou s'enseigne la morale par les figures de la fable, de l'histoire, \& de la nature, ed. Karl Mösenender (Mittenwald: Mäander, 1981), 27: “Les Apologues d'Esope sont aussi d'eux-mêmes des Emblemes, parce que ces Apologues ... ont toujours leur instruction morale jointe aux discours \& aux actions de ces animaux."

${ }^{137}$ On emblematic fables in the Netherlands in general, see Paul J. Smith, Het schouwtoneel der dieren. Embleemfabels in de Nederlanden (1567-ca. 1670) (Hilversum: Verloren, 2006), and the extensive overview in J. Landwehr, Emblem and Fable Books Printed in the Low Countries 1542-1813. A Bibliography, 3d. ed. (Utrecht: HES, 1988).

${ }^{138}$ For this and other English examples, see Lewis, English Fable, esp. 14-25, and Mark Loveridge, A History of Augustan Fable (Cambridge: Cambridge University Press, 1998). 
Saavedra's Idea offers both Tacitean and esoteric guidelines for political and moral behaviour as an alternative mirror of princes. ${ }^{139}$ Another example is the compilation Emblematum ethico-politicorum centuria, published in 1619 in Heidelberg by Julius Wilhelm Zinkgref, which, on the basis of its focus on the common welfare of the republic, might be called a mirror of citizens. ${ }^{140}$ In the wake of these emblemata politica, fable collections too became increasingly politicized. As both Vondel and Ogilby realized, the Aesopian world populated by animals enabled allegorical representations of good government and the colourful parody of opponents. ${ }^{141}$

\section{The Fable's Two Handles}

This short survey reveals that the De la Courts' employment of fables clearly followed an established and successful literary practice that countered the repudiation of the genre by classical and late humanist rhetorical theory. In all the brothers' treatises, parabolic fables play a prominent role, culminating in the Sinryke Fabulen which consists of a hundred different fables with the extra explanatory force of emblematic engravings. ${ }^{142}$ In line with conventional emblemata, every one of this work's fables consists of, first, a motto in Dutch, followed by an emblem which is clarified by a Latin epigram, then the corresponding parable itself and finally some explanatory remarks. Yet in this last part of the emblematic fable, De la Court clearly departed from tradition: to every fable he added a short explanation in the terms of 'who is who?' which he then further elucidated in a long interpretive discussion, starting with general remarks

${ }^{139}$ For Fajardo's reception in the Dutch Republic, see Frijhoff et al., 1650, 468, and Frank-Van Westrienen, Schoolschrift, 221-230. For Fajardo's Tacitist political thought, see André Joucla-Ruan, Le Tacitisme de Saavedra Fajardo (Paris: Éditions Hispaniques, 1977), and especially Christian Romanoski, Tacitus Emblematicus. Diego de Saavedra Fajardo und seine "Empresas Políticas" (Berlin: Weidler, 2006).

${ }^{140}$ See Alain Boureau, "État moderne et attribution symbolique: emblèmes et devises dans l'Europe des XVIe et XVIIe siècles," in Culture et idéologie dans la genèse de l'état moderne (École Française de Rome, 1985), 155-178; and Idem, "Books of Emblems on the Public Stage: Côté jardin and côté cour," in Roger Chartier (ed.), The Culture of Print. Power and the Use of Print in Early Modern Europe (Princeton: Princeton University Press, 1989), 261-289.

${ }^{141}$ Cf. Smith, Schouwtoneel der dieren, 99, and see for Ogilby's royalist critique on the English Revolution in particular Annabel Patterson, Aesopian Writing and Political History (Durham and London: Duke University Press, 1991), 53-54, 85-87.

${ }_{142}$ These emblems were made by the young engraver Jacob Gole (166o-1737), who signed his creations, often much simplified copies of the sixteenth-century emblems by Marcus Gheeraerts the Elder, with his initials 'I.G.' or 'I.G.F[acit]'. Cf. Smith, Schouwtoneel, 97-98. 
on human nature and then focusing on the current political situation in the Dutch Republic. Hence, throughout the Sinryke Fabulen, the reader is persuaded to connect its contents with contemporary events and debates in agreement with De la Court's own conclusions.

This explicit politicization of the fable, as well as the long comments in prose whilst more traditional collections were in general written in verse ${ }^{143}$ reveal the influence of the emblemata politica. The De la Courts proved to be ardent readers of Fajardo and they frequently referred to the Latin edition of his Idea. ${ }^{144}$ Their Leiden teacher Boxhorn had also compiled a comparable emblem collection of emblems in 1635 , which offered its readers guidelines on how to behave in governmental and civic affairs. ${ }^{145}$ In the work of the De la Courts, this political endeavour goes hand in hand with the subject matter, the moralizing message, and satirical features of the Aesopian fable. Written in the vernacular and clearly addressing a much more popular audience than Boxhorn's Latin prose could aspire to, the De la Courts' fables move on the borderline between two closely related subgenres.

In the preface to the Sinryke Fabulen, De la Court offers the reader an extensive discussion of his motives for this employment of emblematic fables. ${ }^{166}$ The preface begins with an analysis of the way in which abstract ideae (De la Court translates this term to the Dutch "Denkbeelden", which has the significant connotation of 'images') are imprinted on the human mind. This analysis is the first direct sign in the brothers' entire œuvre of the influence of Cartesian epistemology: praising "that wonderfully clever Philosopher Renatus Descartes ... who has not had his equal in all previous centuries", ${ }^{147}$ De la Court attempts to present his considerations as being in vogue with the newest philosophy. Yet his reading of Descartes remains fairly superficial. Referring to Descartes's Meditations, De la 164.

${ }^{143}$ Cf. Smith, Schouwtoneel der dieren, 97-98; and Meertens, Nederlandse emblemata,

${ }^{144}$ Fajardo, Idea principis christiano-politici centum symbolis expressa (Brussels, 1649). The library of Pieter de la Court van der Voort contained a copy of this edition: Library, fol. 16 .

${ }^{145}$ Boxhorn, Emblemata politica, et orationes (Amsterdam, 1635).

${ }^{146}$ Cf. Bettina Noak, "De Sinryke Fabulen (1685) van Pieter de la Court: verhulling en onthulling in een 'verlicht' genre," De Zeventiende Eeuw 18 (2002), 65-78; and H. Wansink, "De "Sinryke Fabulen" van Pieter de la Court," in Blom and Wildenberg (eds.), Pieter de la Court, 185-193.

${ }_{147}$ Sinryke Fabulen, "Voorreeden Tot den Leesere," sig. * 3 ; Ibidem, 520: “... die wonderlik klouke Philosooph Renatus des Cartes." Ibidem, 561: "Descartes, die ... sijns gelijken in geene voorgaande Eewen heeft gehad." For the role of fables in Cartesian philosophy, cf. Jean-Pierre Cavaillé, Descartes. La fable du monde (Paris: Vrin, 1991). 
Court discusses how intelligible ideas can be made accessible to the mind, and he then claims that the expedient of the fable is a particularly appropriate means to convey ideas and reveal hidden knowledge, since "every Reader can very easily make the Comparisons with those Images, and also apply them easily, and willingly". ${ }^{148}$ In other words, the use of illustrative images of, for example, speaking animals and plants, offers a rhetorical means to impress people and to make them perceive the issue at stake, arousing the passions of pleasure and delight. As Horace and Juvenal revealed, fables make it possible "to speak the Truth while jesting and laughing, and move the People through their pleasantness, in such a way that the bodily Figures of the FABLES ... can be very easily imprinted in our Memory or Remembrance and be recalled for a very long time". ${ }^{49}$ The emblematic fable combines satire with instruction and is therefore a particularly forceful rhetorical device for playing upon the imagination and expounding the author's truth.

The genre of the fable also entails another highly significant characteristic: its openness to a variety of different readings, whereby it actively engages readers to construct their own interpretation independently. ${ }^{150}$ Bacon, in his preface to De sapientia veterum, had expressed his discomfort with this feature of the fable, assuring that "I know very well what pliant stuff fable is made of, how freely it will follow any way you please to draw it, and how easily with a little dexterity and discourse of wit meanings which it was never meant to bear may be plausibly put upon it"..$^{51}$ Bacon did not feel at ease with this intrinsic ambivalence of the fable, yet not all seventeenth-century writers of fables shared his concerns. Instead, for many the very nature of the fable as 'pliant stuff, as a genre which conveys meanings in an ambiguous, suggestive and indirect manner, involved a deliberate rhetorical move through which the authority of the

\footnotetext{
${ }^{148}$ Sinryke Fabulen, "Voorreeden," sig. **2v.: “... dat yder Leeser die Vergelijkenissen met opgemelde Beelden, seer ligtelik maken, als ook ligtelik toepassen kan, ende gaarne wil." Cf. also Politike Discoursen II.IV.13.

149 Ibidem, sig. **3: “... al schertsende ende al laggende, de Waarheid seggen, ende de Menschen door haare aangenaamheid beweegen, soodanig, dat der FABULEN lighaamelike Figuren, waar van sy spreeken, seer ligtelik in onse Memorie ofte Geheugenisse geprent, ende seer lange onthouden konnen werden."

${ }^{150}$ See Patterson, Aesopian Writing, esp. 4-5. Cf. as well Lewis, English Fable, 35-36, who quotes from the 1703 English translation of the Sinryke Fabulen, yet unaware that its author was De la Court. Lewis states on p. 44 that the author's "name, once thought to be Johan de Wit, has been lost", which reveals the obscurity of the De la Courts within Anglophone historical scholarship, as well as the apparent obstinacy to investigate possible continental influences on English culture more thoroughly.

${ }^{151}$ Bacon, Works, vol. VI: 695.
} 
text was ultimately bestowed by the author upon his readers. De la Court was acutely aware of this feature of the fable. In the preface to the Sinryke Fabulen, he states:

It is said with Truth of all human matters that they have two Handles, one right and one left; and one can say of all Old FABLES more rightly that they have countless levers: Therefore, no one should suspect that a FABLE is made by us and should be explained referring to him only: instead, because the Lessons or Explanations of it are endless, so can any one make for himself the best application and explanation..$^{12^{2}}$

As this significant passage reveals, the use of fables to encode one's convictions serves the additional purpose of renouncing any responsibility for how the text is being interpreted.

Such a rejection of authorial responsibility has a clear political dimension. Ever since Antiquity, when the allegedly black slave Aesop created the genre, fables had been a favourite medium of communication used by or in behalf of those without power to denounce the political establishment: on the one hand, because fables evidently address unequal power relations, on the other because they perform, with their openness to multiple readings, an intrinsic function of self-protection. ${ }^{153}$ As De la Court puts it,

the Peoples who have lived of old mostly under Tyrants and Bullies in the East ... have become compelled ... to teach Men in general of Truth and to recommend Virtues and to deter them from their failings, through adorned Histories, Apologues, Comparisons, Parables, and Fables; to by this means instruct and delight Men at the same time without being subject to the aversion of the People, and to the bitterness or hate of the great Lords. ${ }^{154}$

${ }^{152}$ Sinryke Fabulen, sig. ${ }^{* *} 3:$ “... alsoo men van alle menschelijke saaken met der Waarheid segt, dat sy twee Hand-vatten, eene regte eene linkse hebben; ende men van alle Oude FABULEN met meerdere reedenen kan seggen, dat sy ontallike veele aangreepen hebben: Sulks nieman behoorde te vermoeden, dat alhier door ons eenige FABUL op hem alleen gemaakt zy, ende uitgelegt behoorde te werden: nemaar alsoo de Leeringen ofte Uitleggingen van dien oneindig zijn, soo kan een yder voor sig selven de beste toepassing ende uitlegging maaken." Cf. a similar passage in Ibidem, 464.

153 A point stressed by Patterson, Aesopian Writing, esp. 1-12, 55 .

${ }_{154}$ Sinryke Fabulen, 'Voorreeden', sig. ${ }^{* *} 2$ : “... de Volkeren die van ouds meest onder Tyrannen ende Dwingelanden in het Oosten geleefd, ende dien volgende gevreesd hebben, met de waarheid ende nuttigheid der menschelike Saaken te beschrijven ende te leeren, deselve Tyrannen te vertoornen; genoodsaakt, ende de vrye Grieken ook daar na vrywillig ten raade zijn geworden, de Menschen in het gemeen van der Waarheid te onderrigten, ten Deugden te raaden, ende van haare gebreeken af te schrikken door versierde Historien, Apologen, Vergelijkenissen, Parabolen ende Fabulen; om door dat middel de Menschen te gelijk te leeren ende te vermaaken, sonder opgemelde afkeerigheid der 
In other words, the use of fables liberates a writer from the restrictions imposed by censorship and the wrath of those in power - a particularly important expedient for unconventional authors such as the De la Courts, especially in the case of the Sinryke Fabulen, written under the Stadholdership of William III. While the references in this work to the government in power are always rather obvious, De la Court refrains from making them utterly explicit, and he often resorts to mere rhetorical litotes or abruptly finishes his speech when it comes to the crunch. His method, as he explains, entails that "we do not reveal our own judgment, but leave the Reader judge for himself". ${ }^{55}$ Fables thus entice the reader's imagination, they engage the audience to participate in the establishment of literary meaning and authority. They make not only the author but also the reader an active part of the public debate.

Yet this involvement of the audience is not free of risks. As argued above, the De la Courts were deeply suspicious of the frailty of human judgment if left unattended. The rhetorical strategy of the Sinryke Fabulen therefore also entails an attempt to take the reader by the hand and guide him or her, under the guise of fables, towards agreement with De la Court's republican stance. The fable's veil is thin, the connotations of all its Aesopian characters are often more than obvious, and unlike the traditional, more neutral enactment of animals as mere representation of the human world, De la Court clearly mobilized all the elements of the emblematic genre to expound his overtly partisan republican message.

A good example of this strategy is De la Court's rendering of the Classical story of the frogs who desire a king. Unhappy with their useful but uninspiring leader, a log, the frogs ask Jupiter for an new lord and eventually end up with a hungry stork. De la Court's version of this fable offers first, above the emblem itself, a Dutch motto saying "Happy is he, who does not desire to be anyone's Slave or Tyrant", followed by the Latin epigram ut servitus contra naturam, ita natura in tyrannidem proclivis (see fig. 7). The fable then describes the initial state of the frogs as one of "full freedom" where every frog served in turns as "Head or the First of the Assembly". Yet because of their ignorance and longing for splendour, the frogs aspired to be honoured by a military leader, the stork. As De la Court

Menschen, ende de verbitteringe, ofte haat der groote Heeren onderworpen te zijn." Cf. a similar passage in Politike Weeg-schaal, "Inleyding," p. 1-2.

${ }_{155}$ Sinryke Fabulen, 162: “... dat wy ons eigen oordeel daar van niet oopenbaaren, maar den Leesere selfs laaten oordeelen sullen." Cf. the comparable passages in e.g. Ibidem, 76, 388,644 . 


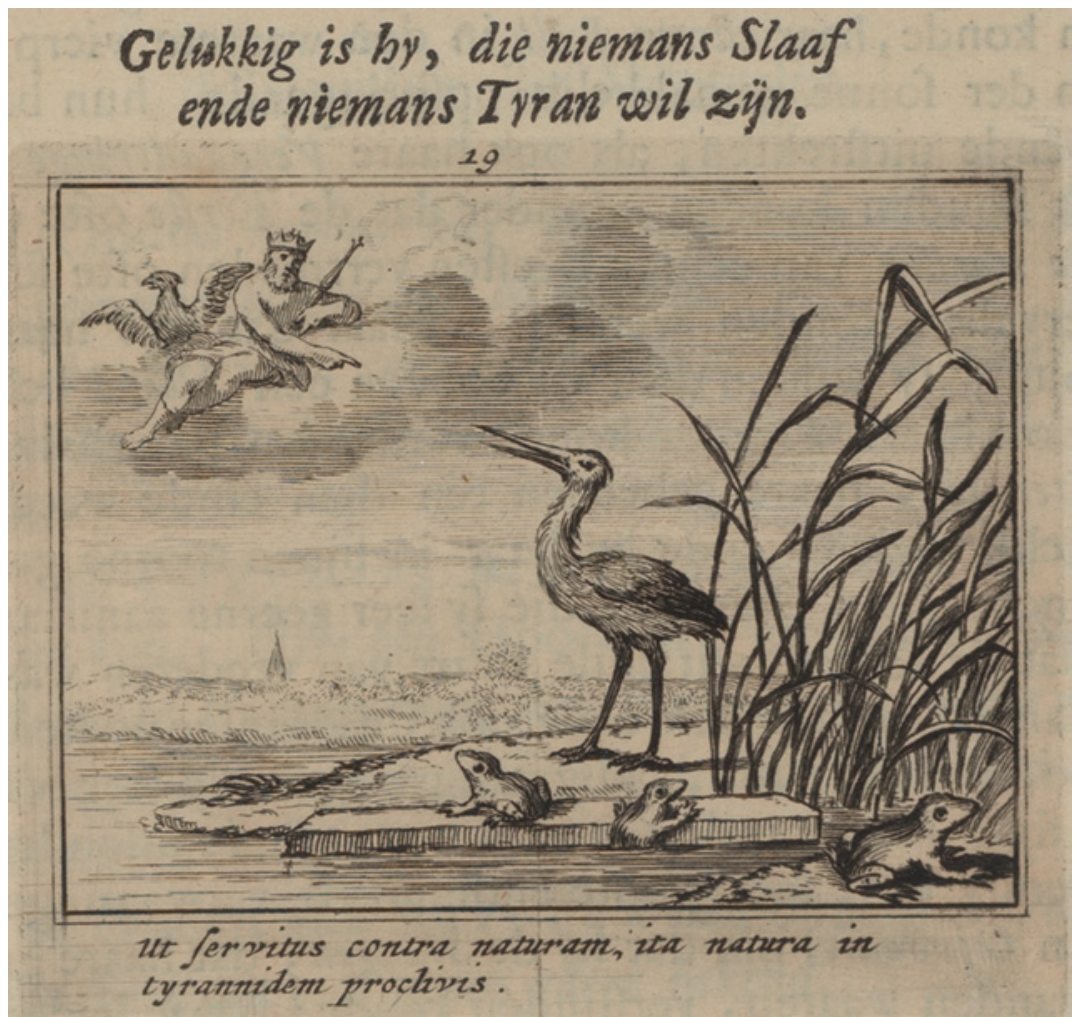

Fig. 7. "The frogs and a log," from Pieter de la Court, Sinryke Fabulen, 1685. Amsterdam University Library, OTM: OK 63-2796

clarifies in the terms of fabula docet, this stork proved to be a "Head of the Republic who cannot only fight its Enemies, but also tyrannize its Lawful Regents and Inhabitants". 'Frogs' was a popular derogative term for Dutchmen, and De la Court asserts that "as we have seen in our times", free republics perish when they bestow the military power in the hands of one man, who as a stork will eat up the country's riches and liberties..$^{15}$

${ }^{156}$ Ibidem, 89-94: "De Kikvorssen seekeren tijd in voller vryheid geleefd hebbende, soodaanig, dat yder van haar op sijne beurt Hoofd ofte de Eerste der Vergaaderinge wierd ... den OJEVAAR ... een Hoofd der Republike, dat niet alleen de Vyanden van dien beoorloogen, maar ook de Wettige Regenten ende de Ingeseetenen van dien, tyranniseeren kan ... Gelijk wy ook in onse tijden gesien hebben." The same fable is told in Politike Weeg-schaal II.II.4. For the mockery of Dutchmen being 'frogs', cf. the fable "Of the Frogs Fearing the Sun Would Marry" in the 1668 edition of John Ogilby's Fables of Aesop, discussed in Loveridge, Augustan Fable, 124-126. 
This obvious - though never explicit - identification of the fable's tyrannical figure as Stadholder William III, who obtained power when he was appointed to captain-general in 1672 , is repeated in many other fables. There is the story of the lumberjack who asks the "Free Republic" of the trees for one branch to repair his axe, with which he eventually chops down the entire forest. This lumberjack, De la Court warns, is like a "General who obtains the power to convoke the soldiers at all times ... and who can use them at all times, and does use them often, to suppress the Republic". Eventually he "makes himself Tyrant over that Free State and all its Inhabitants his Slaves" ${ }^{157}$ Similar is the fable that tells of the dispute between a horse and a dear. To fight his opponent, the horse asks for the assistance of a knight. Together they kill the deer, but when the horse thanks his rider and asks to be free again, the horseman maintains his yoke. Again, De la Court characterizes the horseman as a "General who is employed for one campaign or for one Battle", while being ridden by such a knight equals to "living in slavery". ${ }^{8}{ }^{8}$ With this powerful republican rhetoric designed to play upon the passions of shame and fear, De la Court evocatively suggests that under the regime of William III, the Dutch Republic lost its true liberty and was again enslaved by the tyrannical element of the Stadholder. Conveyed in the characteristic language of republican liberty as opposed to the slavery of arbitrary domination, De la Court's fables prove to be an integral element of his and his brother's antimonarchical enterprise.

The overt politicization of these fables is not restricted to versions of Aesopian allegories. The works of the De la Courts also feature a number of parables that are clearly inspired by their own context and the commercial, urban society of the Dutch Republic. For example, one emblem in the Sinryke Fabulen depicts the members of different guilds disputing over the defence of their town, a scene which reveals that the work was directed at the debating practices of the civic population of the Dutch cities. The same discursive dimension comes to the fore in another fable, which is a variation on the age-old theme of the body politic that aspires

\footnotetext{
${ }_{157}$ Sinryke Fabulen, 99-102: “... het Bos, eene Vrye Republik ... de magt die soo een Overste krijgt om de Krijgs-Knegten ten allen tijden by een te roepen, ende naar sijnen sin te gebieden ter beetere bescherminge der Republike, ende die de selve altijds gebruiken kan, ende ook veeltijds gebruikt, ter onderdrukkinge van dien ... die Krijgs-Ooversten haare onderhoorige Krijgs-luiden gebruikt hebben, om sig Tyrannen oover dien Vryen Staat, ende alle de Ingeseetenen van dien tot haare Slaaven te maaken."

${ }_{15}^{8}$ Ibidem, 43-46: "... de MAN ende die RUITER, een in magt-uitsteekend mensch, die tot Veld-Oversten voor eene reise ofte voor eene Veldtogt aangenoomen werd. Met een RUITER op sig te hebben ... in slaavernie te leeven."
} 
to maintain concord and political health. ${ }^{159}$ This fable introduces a sailor who tells his expectant audience a tale of three islands he has encountered on a long journey through the seas of the East Indies. The first island, he says, was ruled by "one supreme Doctor of Medicine", the second by "many Lords Doctors of Medicine", while the third "was inhabited by people, who with very small knowledge, dared to be their own Medical doctors" ${ }^{160}$ The sailor explains that he saw many people in very bad health on the first two islands, yet on the third, the population was large and people were hale and hearty. The message of this fable has a strong democratic connotation, which is dramatized by an exotic story of travel and discovery. Commercial expansion overseas, as the fable seems to suggest, provides a fresh answer to the question how the metropolis should be organized politically.

This fable of the three islands highlights again the discursive practices of the civic population of the Dutch towns. Its emblem in the Sinryke Fabulen (see fig. 8) captures the sailor's speech-act when addressing his attentive audience. So too does the engraving to another fable which stages a conversation between a charcoal burner and a textile entrepreneur (fig. 9). ${ }^{161}$ Accordingly, these emblematic fables reveal how the genre gradually changed over the course of the seventeenth century. From being disclaimed by Vossius as only apt for a coarse and vulgar audience, with the brothers De la Court the fable had become a literary means for the mobilization of this popular public. Deliberately involving the audience in the establishment of meaning and authority, the fable, from a symbol of an imaginative animal realm outside of human life, had become a representation of the emergent reality of a popular public debate.

\section{Unmasking the Fox: Boccalini vs. Machiavelli}

To summarize, the De la Courts' employment of fables entailed a rhetorical strategy to encode their political message suggestively and in an entertaining way, directly appealing to the imagination of their readers. Apart

${ }^{159}$ Cf. on the same theme Ibidem, 287-294 and 517-530. See for some general comments on the metaphor of the body politic Patterson, Aesopian Writing, 111-137.

${ }^{160}$ Politike Weeg-schaal III.III.2, p. 647-648: “... het eerste van een opperste Doctor in de Medicinen ... het twede Eiland zeide hy bewoond te zijn van veele Heeren Doctoren in de Medicinen ... Maar dat het derde Eiland, ter contrarie geen Medicijn-meesters in hebbende, was bewoond van menschen, die met zeer geringe kennisse, haar eige Medicijn-meesters derfden te weezen." Cf. the slightly different and still more overtly politicized version in the Sinryke Fabulen, 71-76.

${ }^{161}$ Sinryke Fabulen, 501-508: "De Kool-brander ende de Laaken-bereider." 


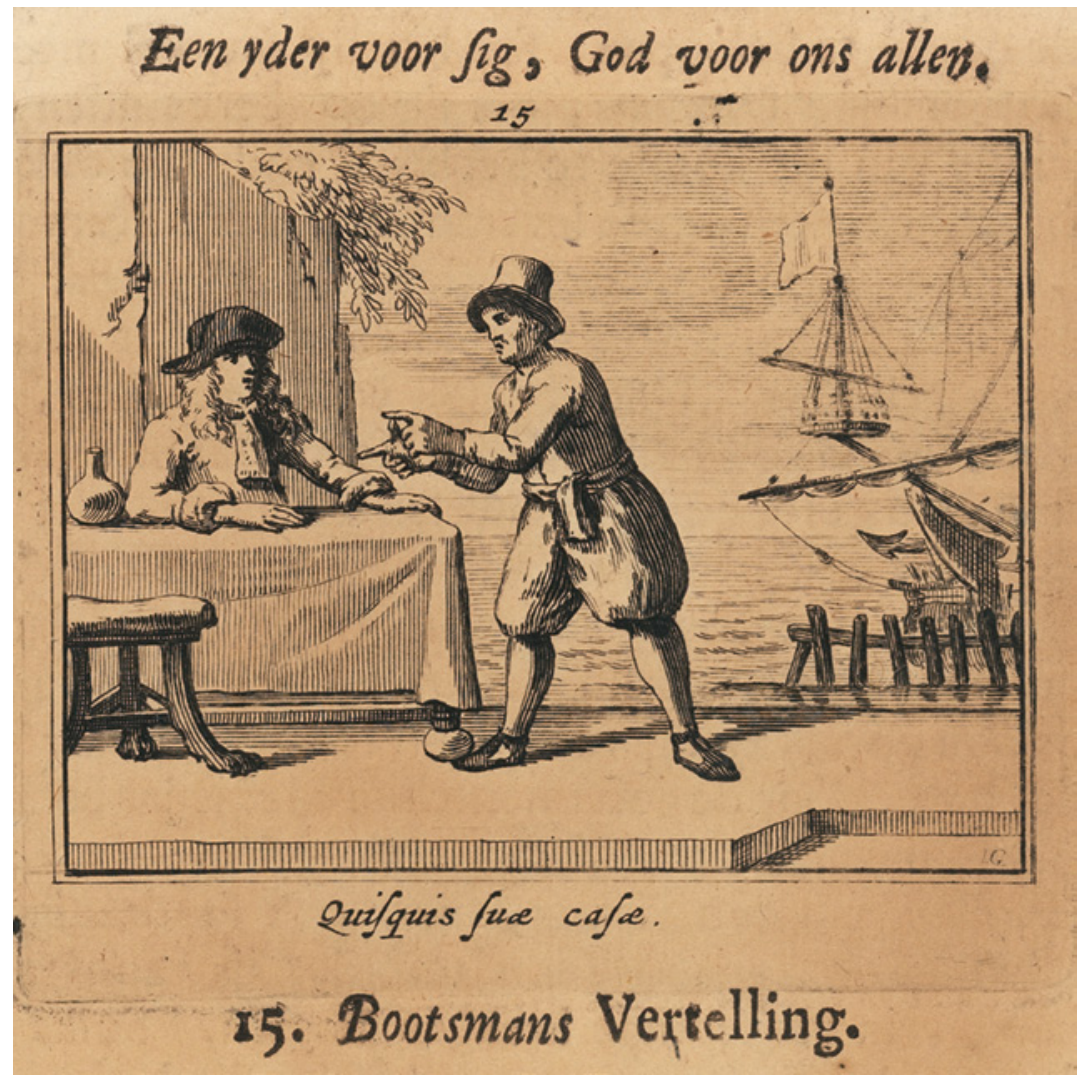

Fig. 8. "A boatman's tale," from Pieter de la Court, Sinryke Fabulen, 1685. Amsterdam University Library, OTM: OK 63-2796

from such instruction and delight, there is also a further dimension to the fable, which brings us back to the issue of parrhèsia. This aspect, aptly revealed in the parable of the Kingdom of the Apes, involves the placing of a mirror in front of two-faced behaviour. The fable confronts the reader with a world where corruption cannot be shrouded and where frankness proves its value..$^{62}$

A telling illustration of this aspect is an emblematic fable that rebukes monarchical and clerical hypocrisy. The emblem of this fable (see fig. 10),

${ }^{162}$ Cf. Sharpe, "Commonwealth of Meanings," 101. On the relation between fables and parrhèsia, see also Jennifer London, "How To Do Things With Fables: Ibn Al-Muqaffa"s Frank Speech in Stories from Kalïla Wa Dimna," History of Political Thought 29 (2008): 189-212. 


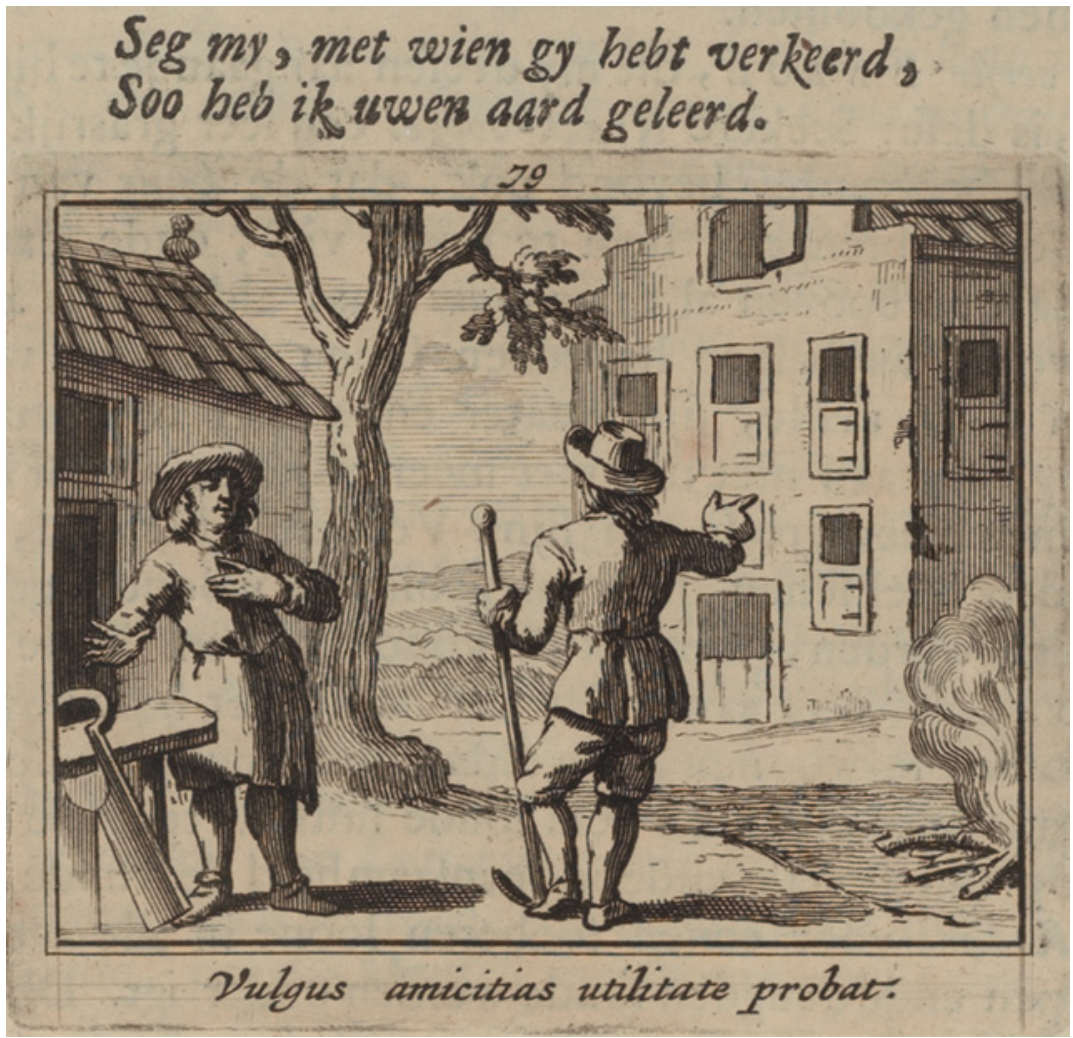

Fig. 9. "The charcoal burner and the textile entrepreneur," from Pieter de la Court, Sinryke Fabulen, 1685. Amsterdam University Library, OTM: OK 63-2796

again a variation on a Classical theme, shows, under a biblical warning for pharisaic dissimulation, a fox in a sculptor's atelier, intrigued by the lifelike statue of a woman. The fox, who represents shrewdness, has taken off his mask, the timeless symbol of duplicity. As the fable then explains, the fox has eventually realized that the woman is only stone, and thus he embodies "wise and experienced people who penetrate appearances and expose underhand Hypocrites". The elements of the fox's mask and the sculpture serve as emblematic representations of the way in which reality can be shaped and manipulated, playfully unmasking the disguised intentions underlying human behaviour. More significantly, in his explanatory words De la Court reproaches "that famous Instructor of Kings and Monarchs", Machiavelli, for encouraging foxy behaviour. As De la Court 


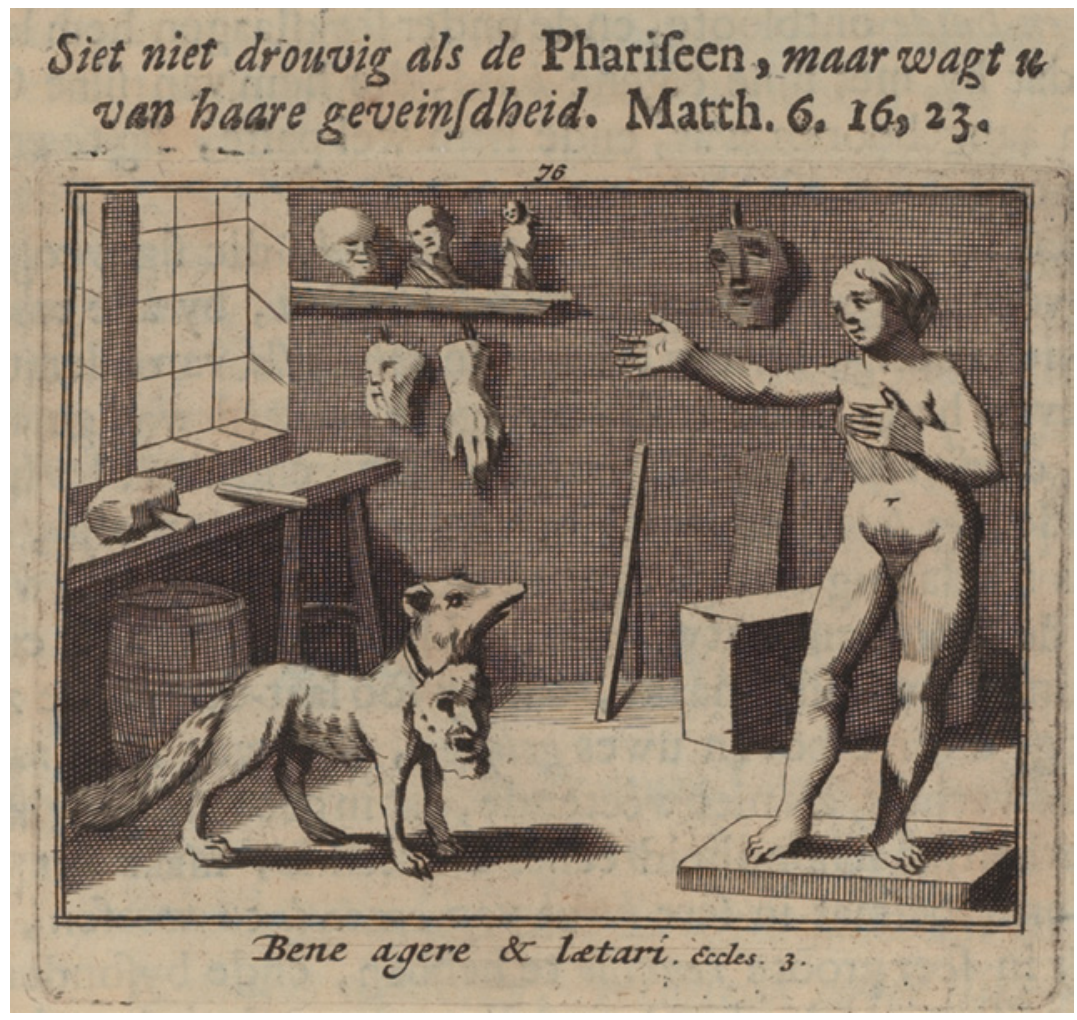

Fig. 10. "The fox and the mask," from Pieter de la Court, Sinryke Fabulen, 1685. Amsterdam University Library, OTM: OK 63-2796

maintains, "in well-ordered Free Republics such dissimulation is not necessary for the Governors" and it will be only detrimental. Here De la Court explicitly aligns with another Italian political writer, stressing that his 'opinion corresponds very well to the in Politics, knowledge of human Matters, and manly stout-heartedness incomparable Traiano Boccalini' ${ }^{163}$

${ }^{163}$ Sinryke Fabulen, 473-480: “... den VossE, wijse ende ervaarene menschen, die den schijn ontdekken, ende de geveinsde Hypocriten ten toone stellen ... Met welke onse meeninge seer wel oover een komt die in Staatkonde, kennisse der menschelike Saaken; ende manhaftige kloukmoedigheid, onvergelijkelike Trajano Boccalini ... die bekende Leermeester der Koningen ende Vorsten ... dat in wel-gestelde Vrye Republiken, opgemelde geveinsdheid den Regenten niet noodsaakelik is, jaa aldaar gebruikt werdende, den selven Geveinsden veeltijds meerdere schaade aanbrengd, dan of sy den regten weg des Deugds waaren ingegaan." Cf. Machiavelli, Principe XVIII. 
This remark reveals an important aspect of the way in which the De la Court brothers appropriated the legacy of Italian Renaissance republicanism. Thus far, historians have emphasized the De la Courts' debt to Machiavelli as a major source of their republican endeavour. Haitsma Mulier, in particular, has highlighted that many passages in the brothers' work directly echo Machiavelli's political and historical treatises. ${ }^{164}$ Surely, Machiavelli's influence on their thought is beyond doubt. Yet his influence is more ambivalent than hitherto assumed. According to Haitsma Mulier, the De la Courts were the first in the Dutch Republic to openly read Machiavelli in a positive way as a republican theorist and an intellectual guide for their own anti-monarchical agenda. Yet if we follow Victoria Kahn's characterization of the Machiavellian Moment as primarily a rhetorical moment, then another issue comes to the fore which has escaped Haistma Mulier's acute insight: the appropriation of Machiavelli not only as a republican theorist, but also as a dangerous rhetorician, a hypocrite Machiavel. As Kahn has shown, the combination of these two different readings dominated the early-modern reception of Machiavelli. In the work of Milton, for example, "the Machiavel and the republican far from being decorously distinguished - are conspicuously linked" ${ }^{165}$

A similar reading of Machiavelli as both a crafty rhetorician and a republican theorist can be detected in the works of the brothers De la Court and their Dutch contemporaries. Their characterization of Machiavelli as "that famous Instructor of Kings and Monarchs" makes clear that the De la Courts did not read Machiavelli only as a republican, but also as a notorious teacher of dissimulation and fraud in speech and politics. Van den Enden similarly portrayed Machiavelli, referring to the Discorsi, as "an unfeigned and open advocate of all foul superstition and deceit". ${ }^{66}$ Machiavelli embodied reason of state politics at its worst, and it

${ }^{164}$ Haitsma Mulier, Myth of Venice, esp. 126-130, and Idem, "Controversial Republican," 254-257. For a meticulous survey of all borrowings from Machiavelli in the Politike Discoursen, see Paul van Heck, "In het spoor van Machiavelli: de Politike Discoursen, 1662, van Johan en Pieter de la Court," LIAS. Sources and Documents Relating to the Early Modern History of Ideas 27 (2000), 277-318. As Van Heck shows, the De la Courts read Machiavelli in Italian and referred to the so-called Testina-edition that was published repeatedly in Geneva between ca. 1610 and ca. 1670 under the false date of publication 'M.D.L.' The library of Pieter de la Court van der Voort contained such a copy of "Tutte l'opere di Nic. Machiavelli" with the year of publication indicated as 1550: see Library, fol. 19.

${ }_{165}$ Kahn, Machiavellian Rhetoric, 169.

${ }^{166}$ Franciscus van den Enden, Vrije politieke stellingen, ed. Wim Klever (Amsterdam: Wereldbibliotheek, 1992), 161: "N. Machiavel, een ongeveinsden, en openbare voorstander van alle vuile superstitie, en bedriegerye." See also Ibidem, 191, 195, 229. 
is this particular aspect of Machiavellianism which may explain why Machiavelli became such a popular source for republicans in England and the Dutch Republic in the course of the 1650 s - in both countries, a period of sudden changes that revealed the highly contingent character of politics. Machiavelli offered a framework to deal with such contingency rhetorically. Out of their anxiety about the role of language in politics, thinkers like the De la Courts turned to Machiavelli for insight in the realm of de facto power, but not necessarily because they saw in him a champion of republicanism. Instead, for the De la Courts Machiavelli continued to be the advisor of princes, the archetypical shrewd counsellor who abuses rhetoric and blurs the distinction between virtue and vice. This was the traditional depiction popularized in Gentillet's AntiMachiavel (1576) and, in the seventeenth-century Dutch Republic, in an oration by the humanist scholar Caspar Barlaeus. ${ }^{167}$ In their rebuttal of dissimulative speech, the De la Courts followed this traditional portrayal of Machiavelli. As this book shows throughout, they heartily differed from Machiavellian republicanism on various significant issues, from their refutation of Roman expansionism to their embrace of commercial wealth and social concord.

It is therefore more instructive to highlight the De la Courts' appropriation of another Italian thinker, and one the brothers openly mention as their real hero: Traiano Boccalini. Boccalini was the author of two works that would become the seventeenth-century locus classicus of Tacitean, republican satire of princely and clerical hypocrisy: the Ragguagli di Parnaso and the Pietra del paragone politico (1612-1614). This series of 'announcements' from mount Parnassus consists of a total of almost three hundred fantastical, allegorical tales in which many famous men, above all sixteenth-century Italian writers, historians and politicians, figure as the characters in a timeless realm of emblematic irony and ridicule governed by Apollo. In every one of these allegories, Boccalini effectively satirized the world of letters and politics through vivid descriptions of how its representatives experience all kinds of bizarre encounters. Boccalini's tales are populated by men and not by animals, yet their fictional and comical character performs the same function of metaphor and parody as

${ }^{167}$ Caspar Barlaeus, "Een Redening of Dissertatie ... Tegens de stockredenen van Nicolaes Machiavel," in Idem, Oratien, en Blijde inkomst van Maria de Medicis (Amsterdam, 1662), 48-89, a Dutch translation of the original Latin oration held in 1633. Gentillet's AntiMachiavel was translated into Dutch in 1637 as Discours van State ... tegens Nicolaes Machiavel, an edition also in the library of Pieter de la Court van der Voort: Library, fol. 19. 
in Aesopian fables. As Boccalini explained his intentions in a letter to - of all people - James I:

In order that the open truth, to which I have paid particular attention, will not harm me through provoking the rage of those great princes, interests and opinions of which I have spoken, I have covered the truth with the cloaks of jokes, masked by the shades of metaphors. ${ }^{168}$

Accordingly, below the surface of satire, Boccalini's allegories reveal committed political convictions. They herald the aristocratic constitution of Venice as the most perfect republican government and eloquently condemn the imperious, lazy, and uncultured behaviour of monarchs and courtiers, disclosed by the ingenious "occhiali politici" of Tacitus's writings. ${ }^{169}$

After Boccalini's death in 1613, his writings enjoyed much appeal across the continent among such diverse groups as German Rosicrucians, Venetian libertines, and English republicans, including Harrington. ${ }^{170}$ Arguably, Boccalini found the largest following in the Dutch Republic, both in terms of publications (after Italy, most seventeenth-century editions of the Ragguagli were published in the Netherlands), and in terms of direct literary and republican impact, enhanced by Boccalini's strong anti-Spanish sentiments which met with substantial Dutch approval. This Dutch interest in Boccalini peaked after 166o. A series of publications of his works in 'Cosmopoli' (i.e. Amsterdam) culminated with the widely circulated 1669 edition of the Ragguagli by the editorial house of Blaeu. Numerous Dutch imitations of the events on Parnassus followed until the end of the century. ${ }^{171}$

Many of these publications had a distinct political connotation, as exemplified by the collection of poems titled Den herstelden Apollos Harp,

${ }^{168}$ Quoted in Harald Hendrix, Traiano Boccalinifra erudizione e polemica. Ricerche sulla fortuna e bibliografia critica (Florence: Olschki, 1995), 5 .

${ }_{169}$ Traiano Boccalini, Ragguagli di Parnasso e scritti minori, ed. Luigi Firpo, 3 vols. (Bari: Laterza, 1948). See for the praise of Venice esp. I.5 and I.39; for the critique of monarchs and princes I.35 and I.77; and for Tacitus I.29 and II.71. For some general remarks on Boccalini's political thought, see Maurizio Viroli, From Politics to Reason of State. The Acquisition and Transformation of the Language of Politics 1250-16oo (Cambridge: Cambridge University Press, 1992), 257-266; and cf. for a more republican reading Vittor Ivo Comparato, "From the Crisis of Civil Culture to the Neapolitan Republic of 1647: Republicanism in Italy between the Sixteenth and Seventeenth Centuries," in Van Gelderen and Skinner (eds.), Republicanism, vol. I: 177-179.

${ }^{170}$ See Harrington, Oceana, 240-241. For a general survey of the reception of Boccalini, see Hendrix, Traiano Boccalini, esp. 109-137.

${ }^{171}$ Ibidem, 25-26, 33-34, 54-56, 146-149, and the overview of Dutch imitations on $35^{2-} 35^{6}$. 
versien met vesrcheyde nieuwe snaren ["The Recovered Harp of Apollo, Provided with Several New Strings"], published in 1663. This partisan anthology is introduced to the public by an "Ordinance", signed by "Traiano Boccalini" on behalf of "Apollo and the broad council of famous poets and sharp-witted minds harmoniously gathered at the mount Helicon". The ordinance states that these men "have as of old been enemies of monarchical and tyrannical governments", who, after their first dwellings in the free republics of Ancient Greece and Renaissance Italy, have now settled in Holland. With their verse, they reveal the baseness of "the chiefdom of one man, both in worldly and ecclesiastical matters". Thus they aim "to support the laudable intention of our lawful Government [read: the regime of 'True Liberty'] as much as possible, and to open the eyes of the blindfolded inhabitants further through the writing of the truth" ${ }^{12}$ In short, this anthology mobilized Boccalini's Parnassus as a poetical realm of Dutch anti-Orangism.

The De la Courts' explicit praise of Boccalini was evidently part of this tendency to read and interpret the Ragguagli in a Dutch republican context. ${ }^{17}$ Their work contains numerous passages directly taken from Boccalini as fable-like illustrations and explanations of the brothers' own republican enterprise. In referring to these allegories explicitly as "Political Fables", ${ }^{174}$ the De la Courts' employment of Boccalini transcends a mere correspondence in political stance and pessimism about human nature. ${ }^{175}$ It serves in particular a distinctly rhetorical function: just as the other fables within their writings, the passages taken from Boccalini combine

${ }^{172}$ Den herstelden Apollos Harp, versien met verscheyde nieuwe snaren [1663], a modified re-edition of Apollos harp, bestaande in Nederduytsche Mengelrymen (Amsterdam, 1658), "Ordonnantie," sig. *2: "Apollo ende den breeden raadt der vermaerde dichteren en scherp-sinnighe verstanden eendrachtelijck vergadert op den berg Helicon ... van ouden tyden vyanden sijn gheweest van monarchale ende tyrannische regeringhe ... dat sy volkomentlijck de opperhoofdigheyt van een mensch soo in wereltlijck als in 't kerckelijck souden verworpen hebben”; sig. * 7 : “... om de loffelijcke intentie van onse wettige Overheyt soo veel in ons was te seconderen, en de geblindthoekte ingesetenen nader door 't schrijven van de waerheyt de oogen te openen." The collection also contains Vondel's poem $O p$ de Weegschael van Hollandt.

${ }_{173}$ The De la Courts most probably read Boccalini in Italian. Hendrix, Boccalini, 135, suggests otherwise, but he does not discuss all the brothers' references to Boccalini so his argument is not conclusive. In any case, the library of Pieter de la Court van der Voort contained only an Italian edition of the Raggguagli, published in Venice in 1617 , as well as a copy of La Bilancia Politica di tutte l'opere di Trajano Boccalini ('Castellana' [= Geneva], 1678): Library, fol. 19 .

${ }^{174}$ Politike Weeg-schaal III.I.6, p. 565: “... heeft Trajano Boccalini wel aardig konnen bespotten in zijne Politike Fabulen."

${ }^{175}$ Cf. Haitsma Mulier, Myth of Venice, 133-134. 
the satirical expedients of delight and instruction, the political feature of indirectness and variability of meaning, and the anti-Machiavellian morality of unmasking hypocrisy and pleading for candour.

This threefold rhetorical function is exemplified by De la Court's employment of one of Boccalini's Ragguagli to conclude his brother's reproof of monarchical rule in the Politike Weeg-schaal. Having disclaimed all possible advantages of a monarchy, De la Court finishes with a powerful prolepsis. He writes: "Finally, if someone asks why men can see so many outstanding virtues in Monarchs, when these are not there?; then he can find his answer in the $59^{\text {th }}$ Ragguaglio of Trajano Boccalini." This ragguaglio tells the story of a pretentious nephew of the Prince of Sparta who, when unexpectedly not appointed as his successor, turns out to be as stupid as any other human being. After a free translation of a part of the tale, De la Court then approvingly rephrases Boccalini's conclusion that "only the fortune of being in absolute authority and highness makes us often believe that those men are wise Salomons, while if they were common Citizens, they would be considered truly brainless Boors". ${ }^{176}$ For contemporary readers, it must have been clear that De la Court was not making a general remark here but that he had a particular pretentious young man in mind: the Prince of Orange, and future king, William III. The employment of Boccalini's parables thus entails all three rhetorical expedients of the fable. First, it serves to illustrate and clarify the argument in a witty and attractive manner. Secondly, it makes any attentive reader aware of the obvious similarity between the unsuccessful Spartan Prince and the young William III, a comparison that therefore does not need to be made dangerously explicit. And thirdly, it shows the necessity of unveiling monarchical dissimulation and the force of humour to convey such a truth. Whilst Machiavelli revealed the political power of dissimulation, Boccalini offered the De la Courts the rhetorical means to challenge this power through the device of the fable.

In sum, the De la Courts' employment of Boccalinian and Aesopian fables can be characterized as a rhetorical endeavour that dramatizes the paradox between a very clear political message and its openness to

${ }^{176}$ Politike Weeg-schaal I.I.35, p. 170-171 (absent from the first edition): "Eindelik indien iemant vraagt, waarom de menschen zoo veele uitsteekende deugden konnen zien in Monarchen; indien de zelven daar niet zijn; die kan zijn antwoort vinden in 't 59 Ragg. van Trajano Boccalini ... En besluit, Boccalini deese Fabul met deeze woorden: Alle welke actien dezes loshoofdigen Prince een yder dede oordeelen, dat het geluk alleen, van in een absolute authoriteit en hoogheyt te zijn, ons zeer dikwils doet gelooven, wijze Salomons te zijn, zoodanige menschen, welke gemeene Borgers weezende, zouden bevonden werden, waarelik te zijn harssenlooze Flegels." 
multiple readings, between the covering of meaning and the necessity and duty to reveal the truth. At the start of the seventeenth century, Bacon, reflecting the verdict of Classical rhetoric that fables were only apt for a vulgar public, had expressed his preoccupation with the genre's capacity to undermine authorial intentions and to enable the reader to make up his own interpretation. However, in the work of the brothers De la Court, these elements of the fable are not any longer seen as detrimental but instead as conducive to the author's aims of political critique. Because of its openness to different readings, the fable offers a façade behind which the author can escape from the censorship and loathing of his inconvenient truths. Yet the meaning and message of the fable can always be understood as they are meant. Indeed, as Hegel has observed, the essential skill of the fabulist is that "since he is not allowed to articulate his message openly, he can only make it intelligible furtively, as in a riddle which is at the same time always being solved". ${ }^{177}$

Thus as a consequence of, rather than despite, its intrinsic opaqueness, the fable entails a distinct rhetorical move that results in an indirect convulsion of traditional authority. ${ }^{178}$ In an age in which the power of monarchs was represented through clear and direct signs of hierarchy and dependence, this convulsion involved a distinctively republican endeavour to construct a system of signs and meanings that are constituted horizontally and autonomously. In other words, by giving fables such a prominent place within their theory, the brothers De la Court pleaded for a kind of debate that is relatively open, free, and independent from received opinion. The almost transparent veil of fables offered the brothers the rhetorical armory to convey this critical message and to present themselves as the embodiment of exactly this ideal of frankness - the ideal embodied by the Dutchman in the parable of the Kingdom of the Apes who, though fearing for his life, did not waver and "called a spade a spade'. ${ }^{179}$

\section{CONCLUSION: The RHETORIC OF THE MARKeT}

This plea for frankness as a distinct form of public speech reveals the extent to which the rhetoric of the De la Courts eventually departed from

177 G.W.F. Hegel, Aesthetik, ed. Friedrich Bassenge, 2 vols. (Frankfurt: Europäische Verlagsanstalt, [1955]), vol. I: 376: “... weil er seine Lehren nicht offen sagen darf, sondern sie nur versteckt, in einem Rätsel gleichsam, zu verstehen geben kann, das zugleich immer gelöst ist."

${ }_{178}$ Cf. Lewis, English Fable, 3, 20.

${ }^{179}$ Sinryke Fabulen, 9: “... deesen Neederlander, die een hark een hark noemde.” 
tradition. In many respects the narrative strategies employed by the brothers followed conventional late humanist rhetorical theory as exemplified by Vossius. Playing upon the passions of their audience through the establishment of authorial ethos and tapping the sources of eloquence by using all kinds of tropes, figures, and forms of ridicule, the De la Courts were evidently embedded within the rhetorical culture of their day. Nevertheless, their criticism of this culture is at least as evident, and ultimately this criticism led the brothers into a direction that opened up new rhetorical ground.

The brothers' departure from the rhetorical conventions is first discernible in their repudiation of the humanist orators par excellence: the courtly advisors and counsellors of princes, and the clergymen who preach from the pulpit. These two groups are the primary target of the brothers' attack on hypocritical and demagogical speech that blurs the essential distinction between virtue and vice, in short, their attack at bad rhetoric. According to the De la Courts, courtiers and clergymen are merely dissimulative flatterers and obsessive agitators, "as averse to all openheartedness and proper reason as they are instead willing to stun through dark and embellished words or signs the good judgment or understanding of Men". ${ }^{180}$ This insincere, irrational speech is disastrous for the maintenance of social peace and political order, for "with vehement eloquence ... the common Citizens can be carried away to the largest excesses of the World".$^{{ }^{81}}$ The humanist rhetoric practiced by courtiers and clergy thus abuses the passions of the audience in an immoral way, and so it leads kings, worshippers and citizens astray into false judgment and immoderate impulsiveness.

Such a dismissal of demagogy and dissimulation was of course a commonplace argument in early-modern political theory, and in essence went as far back as Socrates's dismissal of the sophistry of Callicles in Plato's Gorgias. However, the De la Courts evidently try to surpass the borders of convention in a way that bears much resemblance to the comparable rhetorica contra rhetoricam of Hobbes. ${ }^{182}$ The De la Courts share

${ }^{180}$ Ibidem, 367: “... alsoo afkeerig zijn van alle oopenhertigheid, ende goede reedenkaavelinge, als sy wel in teegendeel geneegen zijn, om door duistere ende opgepronkte woorden ofte teekenen, het goed oordeel ofte verstand der Menschen te bedwelmen." Cf. a comparable passage in Ibidem, 234.

${ }^{181}$ Politike Weeg-schaal III.I.5, p. 544-545: “... met heftige welspreekentheit ... zoo konnen de gemeene Burgers tot de grootste excessen van de Wereld werden vervoerd."

${ }^{182}$ On Hobbes's rhetoric, see the extensive analysis in Skinner, Reason and Rhetoric, and cf. the reaction of Lodi Nauta, "Hobbes the Pessimistic? Continuity of Hobbes's Views on 
Hobbes's suspicion of meaningless, deceptive language. Like Hobbes they specifically target the darkly embellished speech of ecclesiastics who, "from their study, little Cell, or Pulpit, use to write, counsel, or teach other people loosely, or often moreover wrongly, for the enlargement of their own hypocrisy, honour, and profit" ${ }^{183}$ This audacious mockery of clerical counsel involves a refutation of two essential elements of humanist rhetoric. In the first place, the brothers De la Court argue that such detrimental speech is a consequence of awe for tradition and authority, which kills creative innovation and makes its practitioners "think that eloquence exists in repeating some little flowers that other outstanding Teachers have sown in their writings or sermons" ${ }^{184}$ Dismissing imitatio and the standing of auctoritas, this significant remark entails an obvious rejection of conventional humanist practice.

Secondly, and more importantly, the De la Courts criticize the assumption that one of the main tasks of the orator is to be able to argue in utramque partem, on both sides of a case. According to the De la Courts, this traditional humanist claim that any issue can and should be defended on either side, lies at the origin of the duplicitous, cheating rhetoric of courtiers and clerics who play upon the passions of their audience in a wrong, immoral way and thus undermine an objective assessment of the common good. ${ }^{185}$ Such speech is utterly meaningless, for "to speak words that have or express no meaning, or to join words that have contradictory meanings, such as saying that a square is round, or that a part is as big as its whole, is one and the same thing as not speaking at all". ${ }^{186}$ With this Hobbesian move, the De la Courts demonstrate that the humanist

Reason and Eloquence between The Elements of Law and Leviathan," British Journal for the History of Philosophy 10 (2002), 31-54.

${ }^{183}$ Politike Discoursen II.IV.10, p. 72: “... sy uit haar studeer-kamer, Celletjen, ofte Predikstoel, anderen menschen losselik; of veeltijds daar-en-booven looselik, tot grootmaking van haare eige schynheiligheid, eere ende profyt pleegen te schryven, te raaden, ofte te leeren."

${ }^{184}$ Ibidem II. IV.13, p. 87-88: “... de wel-spreekendheid meenen sy te bestaan, in eenige bloemetjens, die uit-steekende Leeraars in haare schriften, ofte predicatien gesaaid hebben, naar te seggen."

${ }^{185}$ Cf. Skinner, Reason and Rhetoric, 298-299, for the comparable stance taken by Hobbes.

${ }^{186}$ Sinryke Fabulen, 687: "Want woorden te spreeken die geenen $\sin$ hebben, ende uitdrukken; ofte woorden by een te vougend die teegen een strijdende sinnen hebben; als dat een vierkant, rond; of een deel soo groot aks sijn geheel is; ende gants niet te spreeken, eene ende de selve saak is." Cf. Hobbes on insignificant speech in Leviathan I.5, p. 113: "And therefore if a man should talk to me of a round Quadrangle ... I should not say he were in an Errour; but that his words were without meaning; that is to say, Absurd." 
ideal of arguing both sides of a case eventually amounts to nothing but silence.

As an alternative to such meaningless discourse, the brothers propose "no doubtful and suggestive, but rather indeed a Rational, conclusive, and insisting way of speech". It is such blunt, persuasive rhetoric that the De la Courts consider necessary to hold court in the public debate and to convince the audience of an unpopular truth:

All matters which do not only consist in knowing something, but also and primarily in Desiring or not Wanting something, and which furthermore oppose the prejudgments and advantages of many people, cannot and should not be treated otherwise. ${ }^{187}$

Essentially, the De la Courts thus repudiate the humanist emphasis on the variability of meaning. This humanist creed is perhaps best represented by Erasmus, for whom the inconsistency of language and the limits drawn by decorum and mutual respect rendered bluntness both impossible and counterproductive. Thus Erasmus praised Thomas More's ability "to play the man of all hours with all men", ${ }^{188}$ and in his famous dispute with Luther on the topic of free will, he argued strongly that "the truth may be spoken but it does not serve everyone at all times and under all circumstances". ${ }^{189}$

The De la Courts occupy a diametrically opposed stance, which bears a certain resemblance to the assertio of Luther, Erasmus's opponent. As the brothers' praise for the Dutchman in the Kingdom of Apes reveals, they declare the need for straightforward speech, even in the face of danger. They present themselves as the embodiment of precisely this ideal of frankness, pretending time and again "to speak very openly the round truth" ${ }^{190}$ Their "manner of writing", so they assert, "is always outspoken,

\footnotetext{
${ }^{187}$ Aanwysing III.8, p. 520-521: “... geene twijfelagtige ende voorstellende, maar wel deegelik eene Reeden-kavelende, Besluitende, ende dringende wijse van spreeken gebruike; ik antwoord, dat alle saaken die niet alleen in ietwes te weeten; maar ook ende voorneementlik in ietwes te Begeeren ofte niet te Willen bestaan; ende die daar en boven teegen veeler menschen vooroor- en voordeelen strijden; niet anders konnen ofte behoorden verhandeld te werden."

${ }_{188}$ Quoted in Stephen Greenblatt, Renaissance Self-Fashioning From More to Shakespeare (Chicago and London: The University of Chicago Press, 1984), 231.

${ }^{189}$ Erasmus, A Diatribe or Sermon Concerning Free Will, in Ernst F. Winter (ed. and trans.), Discourse on Free Will. Erasmus-Luther (London and New York: Continuum, 199o), 8. For a perceptive analysis of the dispute, see Brian Cummings, The Literary Culture of the Reformation. Grammar and Grace (Oxford: Oxford University Press, 2005), 144-183.

${ }^{190}$ Politike Weeg-schaal, "Inleyding," p. 3: “... met de ronde waarheid zeer opentlik te spreeken."
} 
yes at times very Bold and sharp, but it never strays from earnestness and truth". ${ }^{191}$ In short, pace Erasmus, the De la Courts insist that the truth must be spoken at all times. Whilst the courtly Frenchman of the fable might engage in slavish flattery and merely ape the opinions of others, the fable's free republican Dutchman speaks the truth bluntly, even when confronted with death. This ideal of frankness, of parrhèsia, is the core of the De la Courts' rhetorical assault on conventional rhetoric.

Significantly, parrhèsia was not always perceived to be a positive practice in late humanist culture. For example, the very first fable of Bacon's De sapientia veterum, entitled "Cassandra, sive parrhesia", comprised a critical account of such "unreasonable and unprofitable liberty in giving advice and admonition". The fable tells of the fate of Cassandra, who, having openly rejected Apollo's love, encountered his revenge in the punishment "that though she should always foretell true, yet nobody should believe her". For Bacon, her doom offered a clear warning for those who

will not submit to learn of Apollo, the god of harmony, how to observe time and measure in affairs, flats and sharps (so to speak) in discourse, the differences between the learned and the vulgar ear, and the times when to speak and when to be silent.

Bacon, like Erasmus, thus revealed his concern about the maintenance of decorum, respect, and moderation in speech. ${ }^{192}$

This chapter has shown that the emphasis in the work of the De la Courts is strikingly different. This different attitude towards free speech and decorum is perhaps clearest in the brothers' rendering of another Classical fable that can be called their favourite self-fashioning image: the classical myth of the hunter Actaeon who discovered the nudity of Diana. According to Classical mythology, Actaeon was punished by the goddess for his impertinence and transformed into a stag, whereupon his own dogs devoured him. In seventeenth-century Dutch culture, this fable had a clear moralistic message, for example in the widely diffused writings of Jacob Cats. For Cats, Actaeon was the archetype of a lecherous, immoderate and unrestrained man, "a beast full of horny lust" who was justly punished for not containing his passions and curiosity. ${ }^{193}$ Yet the De la Courts

${ }^{191}$ Welvaren, p. 2: “... de maniere van schrijven, die altijds vrijmoedich, jae somtijds langh Stout ende scherp is, maer noijt, mijns wetens, van ernst ende waerheid afdwaeld.”

${ }_{192}$ Bacon, Works, vol. VI: 701-702, and cf. Colclough, Freedom of Speech, 61-62, 73-74.

${ }_{193}$ Jacob Cats, Houwelyck (1625), quoted in Eric Jan Sluijter, De 'Heydensche Fabulen' in de Noordnederlandse schilderkunst circa 1590-1670 (PhD dissertation University of Leiden, 1986), 172. 
give a daringly new interpretation to this Ovidian fable: Actaeon in fact represents the brothers' own intellectual endeavour. As Actaeon, so the De la Courts claim, they have revealed the baseness of the bathing Diana and her nymphs who are normally splendidly dressed. They maintain that the goddess and her attendants are anything but divine. Instead, they represent "Kings or Queens and their retinue, as well as ... the Dissimulative Clerics, or the Governors of Ecclesiastical Matters", whose nudity symbolizes "Ignorance and Stupidity, Vice and Failings" ${ }^{194}$ The revelation of all these monarchical and clerical vices is a duty which should not be neglected out of fear for Diana's wrath. "Thoughts are toll-free", the De la Courts contend, and liberty requires that they actively expose the naked truth. ${ }^{195}$

The brothers De la Court thus stress that speaking the truth is at all times a duty, even in the face of death when confronted with monarchical oppression. Where Erasmus and Bacon emphasized the limits to free speech drawn by decorum, the De la Courts instead insist on the moral obligation to speak straightforwardly, also, if not especially, when decorum and respect for the authorities call for the opposite. True rhetoric means such parrhèsia, the telling of a truth that one is not forced to tell, even if it involves the risk of capital punishment - as in the case of the Dutchman in the Kingdom of Apes. Given his gruesome fate, the essential point for the De la Courts is that speaking the truth without having to fear for one's life is ultimately only possible in free republics. Free speech, for Bacon a sign of hazardous licentiousness, is for the brothers De la Court a quintessentially republican virtue: the ability to raise one's voice freely in public distinguishes the citizens of a true republic, like the Dutchman, from the slavish and ape-like subjects of a monarchy such as Frenchmen. Where the rhetoric of a flattering courtier is necessarily slavish by nature, the candid speech of the republican citizen is free.

This opposition between slavery and liberty is frequently put into a distinctly national vocabulary that reveals the antagonism between the Dutch Republic and the France of Louis XIV. In the words of the Sinryke Fabulen, "Frenchmen are in general capable of pleasing entire companies, and in particular young Women, Kings, or Lords, with humbug or with

194 Sinryke Fabulen, 175-180: "DiANA ende haare NYMPHEN, zijn by de Ouden alle seer aansienelijke Menschen, ende insonderheid Koningen ofte Koninginnen, ende haar gevolg: als ook daar meede verstaan konnen werden de Beveinsde Geestelijken, ofte de Bestierders der Kerkelijke Saaken ... NAAKTHEID ende ONSUIVERHEID, is Onweetendheid ende Dwaasheid, Ondeugd ende Gebreeken." See also Politike Weeg-schaal III.III.1, p. 637-638.

195 Politike Weeg-schaal, "Inleyding," p. 11: “... gedagten zijn tolvry.” 
matters that have no utility in the whole world". ${ }^{196}$ In contrast, Dutchmen are incapable of such flattery because they are far too serious and outspoken. As De la Court presents himself in the preface to the Aanwysing:

I am no foreign and slavish Courtier who does not care for the Country's welfare and who is used to be silent or to speak whenever the Monarch or Prince pleases so ... [I am] a born, rounded Hollander who is used to calling Scapham Scapham, a boat a boat, and who straightforwardly steadies its helm. ${ }^{197}$

As a Dutch republican, De la Court contends to be the archetypical truthteller who openly expresses his opinions to the public regardless of established authorities, decorum, or the impulsiveness of the audience. The fact that the brothers De la Court claim to practice such frankness is highly significant, for it shows that they propose this rhetoric as the most appropriate form of speech to play upon the passionate impulses of the audience in a moral and constructive way.

This plea for republican parrhèsia therefore forms the foundation of the De la Courts' rhetorica contra rhetoricam. ${ }^{198}$ Departing from the conventions of humanism, their rhetoric, dominated by jokes, fables, and ridicule, unmistakably addresses a popular audience, Vossius's "vulgar souls" and "coarse characters". As such it deliberately challenges Bacon's stress on the "differences between the learned and the vulgar ear". Crossing the fault lines between abstract political issues and the popular discussion culture of the Dutch urban centres, the De la Courts postulate an image of the public debate as a 'marketplace of ideas', where the highest, most outspoken bid wins the intellectual contest. ${ }^{199}$ The kind of speech that the De la Courts propagate might therefore be described as the one of

${ }^{196}$ Sinryke Fabulen, 54: "Dus zien wy, dat de Françoisen in het gemeen bequaam zijn; om geheele geselschappen, ende insonderheid jonge Vrowluiden, Koningen ofte Vorsten, te vermaaken, met beuselingen ofte met saaken daar geene nuttigheid ter weereld inne steekt."

197 Aanwysing, "Voor-Reeden," sig. *4v.: “... ik niet ben een uitheems ende slaafs-gesind Hoveling, dien aan 's Lands welvaaren niets gelegen, ende die gewoon is, te swijgen ofte te spreken naar het eenen Monarche ofte Prince lust ... een gebooren rond Hollander, die Scapham Scapham, een schuit een schuit te noemen, en daar mede regt door zee te vaaren, pleeg."

${ }_{198}$ Cf. Dietmar Till, Transformationen der Rhetorik. Untersuchungen zum Wandel der Rhetoriktheorie im 17. und 18. Jahrhundert (Tübingen: Max Niemeyer Verlag, 2004), esp. 26-32.

${ }^{199}$ For the rhetoric of a 'marketplace of ideas', see Gary Remer, Humanism and the Rhetoric of Toleration (University Park: Pennsylvania State University Press, 1996), esp. 248-249. 
the stallholder who extols the virtues of his goods in a loud voice, trying to catch the attention of passers-by: it is the rhetoric of the market.

The rhetorical education of the brothers De la Court, as of all educated seventeenth-century Dutchmen, centred on the prominence of the passions. Following Vossius's elaborate analysis of the ambivalent role of the passions in persuasion, the De la Courts sought to play upon the imagination of their readers in an ethical way by employing powerful imagery and a range of rhetorical devices, in particular fables, that present them as truth-tellers, as outspoken and free authors who do not waver when revealing the naked truth. This characteristic parrhèsia, though following classical example, rejects conventional humanist rhetoric which stressed the changeability of meaning and the need for decorum in speech. Moreover, as Michel Foucault has argued suggestively, such parrhèsia involves a crucial social and political dimension since only those citizens of a certain standing and trustworthiness can be expected to master the "parrhesiastic game". ${ }^{200}$ The rhetoric of candour of the brothers De la Court is therefore of fundamental significance for their account of citizenship. Rhetoric, as the interpretative framework of public speech, informs the way in which we constitute ourselves as citizens by participating in the public debate. The rhetoric of the De la Courts involves the claim that those capable of their mercantile frankness personify true republican citizens.

${ }^{200}$ Michel Foucault, Fearless Speech, ed. Joseph Pearson (Los Angeles: Semiotext(e), 2001), esp. 17-18. 


\section{WISE MERCHANTS}

On 20 November 1657, Pieter de la Court married Elisabeth Tollenaar, the daughter of a family of the ruling class of Leiden. Elisabeth's father and grandfather had been members of the veertigraad, the city council of forty local patricians of whom the four burgomasters of the town were elected annually through cooptation. Elisabeth's brother would join this municipal assembly a decade later, and the husband of her sister, Johannes Eleman, became a burgomaster of Leiden in 1659. ${ }^{1}$ To celebrate his entrance into this influential family, De la Court organized a lavish dinner for the guests at the wedding. A huge baked and gilded game pie stood at the centre of the table, surrounded by poultry and a pyramid of larks, hams, and a large sucking pig. This copious meal was accompanied by over sixty litres of hippocras, a typical wedding drink made of wine and spices. ${ }^{2}$ De la Court clearly took great pains to please his guests and behave as his new position required. Yet the marriage would not last long: before the year was out, Elisabeth had died in childbirth. De la Court remarried in 1661 with the daughter of a rich merchant family from Amsterdam. Meanwhile, he had become close friends with Eleman, whose connection to the governing establishment of the Dutch Republic eventually led to the publication of the bestselling Interest van Holland.

The marriage therefore proved to be of paramount importance for De la Court. It evidently improved the social status of his family, which continued to be conditioned by his father's foreign origins and nouveau riche characteristics - for many in Leiden a source of aversion. Here social tensions blended with xenophobia: the large group of Flemish immigrants who successfully made their way in the Leiden textile business often operated as independent entrepreneurs, bypassing the traditional

\footnotetext{
${ }^{1}$ For an analysis of the social, political, and cultural dimensions of the Leiden veertigraad in the seventeenth century, see Dirk Jaap Noordam, Geringde buffels en heren van stand. Het patriciaat van Leiden, 1574-170o (Hilversum: Verloren, 1996). For a general survey of early-modern Leiden politics, cf. S. Groenveld and Jan A.F. de Jongste, "Bestuur en beleid," in Simon Groenveld (ed.), Leiden. De Geschiedenis van een Hollandse stad, vol. 2: 1574-1795 (Leiden: Stichting Geschiedschrijving Leiden, 2003), 55-83.

${ }^{2}$ See the documents published in C. Willemijn Fock, "Het eerste huwelijk van Pieter de la Court in 1657," Leids Jaarboekje 74 (1982), 72-85.
} 
intermediaries and settled drapers. ${ }^{3}$ As a result, few of them were considered to be truly full members of society, even though they had, like De la Court sr., obtained the citizenship rights of the city. De la Court's marriage into the powerful Tollenaar family reveals that the second generation of wealthy immigrants could eventually enter the ranks of the civic establishment. Nonetheless, this gradual acceptance did not mean that burghers of alien descent were granted any significant political role in the Leiden council, which was ever more reserved to the closed regent oligarchy of a few well-established families. ${ }^{4}$

These issues of immigration, social acceptance, and civic participation in politics, of marriage and household, as well as the indulgence of lavish dinners, pivot on the key political concept of citizenship. This third chapter focuses on the social, political, and ethical aspects of this concept in the thought of the brothers De la Court. It shows that De la Courts constructed an account of commercial citizenship, whereby the merchant who honourably pursues his self-interest within the borders of civil discipline personifies the true republican citizen. I will analyze how this account of commercial citizenship develops from, first, the De la Courts' quasi-Hobbesian theory of the contractual foundation of civil society; second, from their criticism of the exclusivist corporate politics in Leiden; and third, from their mercantile interpretation of the Ciceronian ethics of honour and ambition. The resulting image of the wise merchant, revealed in the brothers' pictorial self-representation, is specifically significant for our understanding of seventeenth-century Dutch civic culture and the relation between commerce and citizenship in early-modern republicanism at large.

\section{Hobbes \& The Foundation of The Commonwealth}

\section{From the State of Nature to a Democratic Polity}

The De la Courts' account of the origins and structure of civil society starts and ends with their assessment of the passionate condition of human

\footnotetext{
3 Van Tijn, "Pieter de la Court," 306-309. See also Dirk Jaap Noordam, "Textielondernemers en het Leidse patriciaat, 1574-1795," Textielhistorische bijdragen 36 (1996): 20-36, esp. 21-23.

${ }^{4}$ Noordam, Geringde Buffels, 36-41; and Idem, "De Leidse veertigraden in de lange zeventiende eeuw, 1574-1700," in Jaap Moes and Dirk Jaap Noordam (eds.), Macht, aanzien en welzijn. Nieuwelingen in het Leids stadsbestuur, 1200-1795 (Leiden: Primavera, 2003), 48-59.
} 
nature. As argued above, human nature is for the brothers De la Court shaped by the unsettling but also functional power of the passions. From the very first edition of the Politike Weeg-schaal, which starts with a discussion of the state of nature to explain the contractual foundation of the commonwealth, this characterization of human nature forms the basis of the analysis.

The initial version of the argument runs as follows. In a hypothetical state of nature, when political organization is still absent, life is totally dominated by the most elementary of all passions: self-love, the furthering of one's own "body, life, and honour". ${ }^{5}$ Such self-love has, on the one hand, positive consequences, since it drives all human beings to the fulfilment of their most basic instinct, their self-preservation. But on the other hand, it causes such competition, mistrust and hate that ultimately the preservation of every individual is jeopardized. This view echoes the French Augustinian emphasis on self-love as the essence, but therefore also the possible corruption, of humanity. ${ }^{6}$ Yet the De la Courts do not share the Augustinian answer to the disruptive consequences of self-love in terms of divine grace. Instead, their solution to overcome the detriments of natural self-love is entirely secular: the solution lies in politics as such. The relentless pursuit of self-love can only be restrained by fear, yet in the absence of any hierarchical power to inflict punishment, such fear for the other necessarily leads to mutual destruction. The result is endless warfare, and

(Homo homini Lupus in statu naturali) such a war of all men against all men is the most disastrous state of men which one could think of here on earth. And therefore it is in all ways necessary that some means are searched to get out of this dreadful natural state. For, although the ignorance and evil of men are so great that in this life no perfect human state or society will or can be found, it is nonetheless true that the most imperfect Government of the World, compared to this disastrous state of war of all men against all, could be called (Homo homini Deus in statu politico) a Paradise. ${ }^{7}$

5 Politike Weeg-schaal, "Inleyding," p. 13: "Vermits de naturelike Menschen boven alles haar eige lighaam, leeven en eere beminnen."

${ }^{6}$ Cf. Senault, De l'usage des passions, I.I.4, p. 41: “... nous ne reconnoissons qu'une passion qui est l'amour, \& que toutes les autres ne sont que des effects qu'il produit ... C'est un premier Mobile qui emporte tous les autres Cieux par son impétuosité."

7 Politike Weeg-schaal I.I.3, p. 22-23: “... (Homo homini Lupus in statu naturali) welke oorlog van alle menschen teegen alle menschen, de rampsaligste staat der menschen is die men hier op aarde zoude konnen bedenken. En dienvolgende zoo is in allen maniere noodzakelik, dat eenige middelen werden gezogt om uit deese ellendige naturelike staat te geraken: want howel de onweetendheid en boosheit der menschen, zoo groot is, dat in dit 
With these common lines about wolf-like versus god-like man, popularized in particular by Thomas Hobbes, ${ }^{8}$ the De la Courts confront the unruly state of nature with civil society, which channels human behaviour and enables people to preserve themselves without harming others. ${ }^{9}$ This concept of a state of nature clearly serves as a hypothetical construct to explain the inevitability of society, for "experience teaches that the natural state of men would necessarily breed Government and politics". ${ }^{10}$ The instinctive desire for self-preservation makes human beings realize that they should commit themselves to a political organization in which their self-love can be directed. Moreover, since all people in the state of nature are equally weak and needy, the use of force cannot lie at the basis of such a political society. The only option is to search for a peaceful pact with other individuals, a pact that ultimately establishes a government based on the consent of the majority of all contractors:

There is nothing more dreadful than the natural state (status naturalis) of men, because then they are all mutual enemies and in continuous anxiety. As a result, man should try to get out of this state of war against all men and obtain some help on this occasion. And because no men are by nature so mighty that they could compel others to help them, therefore they should necessarily try to obtain the same of others through pact. And since no-one would pact with them but on fair and equal conditions, so it follows that according to this fairness, they must necessarily devolve the right and power to rule to the majority.

leeven geen volmaakte menschelike staat, ofte societeit, sal, nog kan werden gevonden: zoo is nogtans waaragtig, dat de onvolmaakste Regeering des Weerelds, vergeleeken zijnde, by deezen rampsaligen oorlogs-stand, aller menschen onder malkanderen, (Homo homini Deus in statu politico) een Heemel zoude konnen werden genaamt." The first Latin phrase is also used in Welvaren 6, p. 14, the second in Aanwysing I.9, p. 44.

8 Thomas Hobbes, On the Citizen, ed. and trans. Richard Tuck and Michael Silverthorne (Cambridge: Cambridge Univerity Press, 1998), 3. Cf. Erasmus, Adages I.I.69-70, and John Owen, Epigrammata (London, 16o6), III.23: 'Homo homini lupus, Homo homini Deus'. See also François Tricaud, “'Homo homini Deus', 'Homo homini Lupus': Recherche des Sources des deux Formules de Hobbes", in Reinhart Koselleck and Roman Schnur (eds.), Hobbes-Forschungen (Berlin: Duncker \& Humblot, 1969), 63-71.

${ }^{9}$ Cf. the classical depictions of the state of nature and the origin of society in Cicero, De inventione I.2, and Niccolò Machiavelli, Discorsi sopra la prima deca di Tito Livio, ed. Corrado Vivanti (Turin: Einaudi, 2000) I.1-2.

${ }^{10}$ Politike Discoursen II.IV.2, p. 11-12: "De ervarendheid leerd dat de natuurlike stand der menschen, noodsaakelik de Regering, en politie soude uitbroejen." Cf. on the hypothetical state of nature in Hobbes, François Tricaud, "Hobbes's Conception of the State of Nature", in G.A.J. Rogers and Alan Ryan, Perspectives on Thomas Hobbes (Oxford: Clarendon Press, 1988), 107-123.

${ }^{11}$ Politike Discoursen II.V.7, p. 123-124: "Daar is niets ellendiger als de natuurrelikke stand (status naturalis) der menschen, dewyl zy als dan alle onderling vyanden, en in 
In short, the state of nature necessarily leads to the establishment of a civil society through contract, and the human condition implies that the terms of this contract necessarily involve a democratic sovereign power.

This fundamental argument that democracy is the elemental form of all political association forms the straightforward argumentation in the first edition of the Politike Weeg-schaal and in the Politike Discoursen - as explained above, probably largely written by Johan de la Court. While rewriting the Politike Weeg-schaal, his brother Pieter added two passages that broaden the line of reasoning. A first addition, clearly meant to ground the argument in the authority of natural law theory, states that self-preservation is not only a passion, but also a right, a right that "surpasses all other natural Laws; and all following civil Laws are founded on the same, or at least presuppose it". One of these natural laws, only to be broken when it conflicts with this primary natural right, is the golden rule "do as you would be done by". This passage ends with a brief yet telling remark: "See all this more broadly and clearly proven by Th. Hobb. Elem. Phil. De Civ." ${ }^{\text {12 }}$ De la Court's second addition clarifies the conditions under which a civil society is formed, and then continues to claim the necessary indivisibility of the thus established sovereignty. A separation of powers would mean a contradictio in adjecto, De la Court asserts, and in obvious reference to the debate on provincial sovereignty in the Dutch Republic, he insists that "the sovereign right to command and to make laws cannot be separated from the sovereign right to execute everything and to be obeyed."13 Again, this passage ends with a significant remark: "He who desires to see all this more broadly should read Thom. Hobbes Elem. Phil. de Cive, Power of a Commonwealth and le Corps politique." ${ }^{14}$

gedurige ongerustheid zijn: en dienvolgende soo moet de mensch tragten uit deesen oorlogsstand teegen alle menschen te geraaken, ende eenige hulp in deese geleegentheid te bekomen. En dewijl geen menschen van nature soo magtig zijn, dat zy andere souden konnen dwingen om haar te helpen; soo moeten zy noodsaakelik van anderen, door verdrag 't selven tragten te bekomen. En vermits niemand met haar, als op billike en gelijke conditien soude willen verdragen, soo volgd hier uit, dat zy volgens deese billikheid, noodsakelik het regt, ende magt van gebieden, aan de meeste stemmen moeten ooverdragen."

${ }^{12}$ Politike Weeg-schaal I.I.1, p. 16: “... het naturelik regt tot onze eige conservatie, alle andere naturelike Wetten te boven gaat: en alle volgende civile Wetten op het selven regt zijn geboud, ofte ten minsten het zelven presupponeren ... Sie dit alles breeder en klaarder beweezen by Th. Hobb. Elem. Phil. de Civ." Cf. Hobbes, On the Citizen I.8-9, III.26.

${ }_{13}$ Politike Weeg-schaal I.I.4, p. 28: “... dat het souverain recht, om te gebieden, en wetten te maken, niet kan werden gescheiden van het souverain recht, om alles te executeeren, en zig te doen gehoorzamen." This statement is explicitly connected to the situation in the Dutch Republic on p. 31-32.

${ }_{14}$ Ibidem, 31: "Die dit alles breeder begeert te sien, leeze Thom: Hobbes Elem: Phil: de Cive. Power of a Commonwealth. en le Corps politique." 
De la Court thus revealed the obvious source of his statements, the recent works of Thomas Hobbes - respectively, De Cive, first published by Elzevier in 1647 , the Leviathan (1651, with as subtitle The Matter, Forme \& Power of a Commonwealth), and the French translation of De corpore politico, published in 1652. ${ }^{15}$ These short references have been the subject of substantial attention in the historiography to date, which has resultes in a widespread interpretation of the De la Courts' account of the state of nature and the contractual foundation of the commonwealth as the essential link between the political thought of Hobbes and Spinoza. As Kossmann put it bluntly in 1960, De la Court "was a pupil and disciple of Hobbes", and "it was of course Hobbes who persuaded De la Court to reject the traditional idea that men first entered the state fully equipped with morality and religion". ${ }^{16}$ This supposedly essential Hobbesian influence on the thought of the brothers De la Court has since been restated by other historians without question - with the sole exception of Hans Blom in his later work. ${ }^{17}$ Moreover, it has been argued repeatedly that this Hobbesian influence turned the De la Courts into the "mediators between Hobbes and Spinoza", ${ }^{18}$ or indeed the "medium" between the two. ${ }^{19}$ As Noel Malcolm maintains, the brothers De la Court constructed a theory in which "the Hobbesian overtones are obvious", a "theory built on thoroughly Hobbesian foundations". Thus, Malcolm argues, they contributed to a "Dutch Hobbesian-republican tradition" which formed the background to Spinoza's political philosophy. ${ }^{20}$

The question arises as to whether these statements offer a fruitful interpretation of De la Court's short references to Hobbes. First of all, the brothers De la Court obviously did not intend to form a 'medium' between Hobbes and Spinoza - a characterization that involves a teleological approach in which historical actors are primarily interpreted ex post facto,

${ }_{15}$ Hobbes, Le corps politique ou les elements de la loy morale et civile ([Rouen], 1652).

${ }^{16}$ Kossmann, Political Thought in the Dutch Republic, 61, 63, 78.

${ }^{17}$ See e.g. Van Tijn, "Pieter de la Court," 331-333; Haitsma Mulier, "Pocock and Seventeenth-Century Dutch Republicanism," 26-27; Visentin, "Assolutismo e libertà," 78; Van Bunge, From Stevin to Spinoza, 86-87. Cf. Blom, Morality and Causality, 159-160, and Israel, Enlightenment Contested, 231-236.

${ }_{18}$ Wolfgang Röd, "Van den Hoves 'Politische Waage' und die Modifikation der Hobbesschen Staatsphilosophie bei Spinoza," Journal of the History of Philosophy 8 (1970), 29-48: 29 .

${ }_{19}$ M.J. Petry, "Hobbes and the Early Dutch Spinozists," in C. de Deugd (ed.), Spinoza's Political and Theological Thought (Amsterdam, 1984), 150-170: 154.

${ }^{20}$ Malcolm, Aspects of Hobbes, 44-47,515. Cf. also Alexandre Matheron, "The Theoretical Function of Democracy in Spinoza and Hobbes," in Genevieve Lloyd (ed.), Spinoza. Critical Assessments, 3 vols. (London and New York: Routledge, 2001), vol. III: 112-121. 
with hindsight of later developments. Secondly, the inclination to position these historical actors between the canonized grand old men of the history of political thought reveals a clear preference for those authors and texts which have passed the tests of time and can therefore be seen as constitutive of modernity. Again, such an inclination likely does not do justice to the past relevance and meaning of texts and statements. The interesting question to ask is not how the De la Courts connected Hobbes and Spinoza, but why and how exactly they appropriated Hobbes in their theory. What do the references to Hobbes's works actually reveal about the brothers' intentions in reading Hobbes?

\section{Reading Hobbes as a Republican}

Hobbes's political philosophy enjoyed a broad and early reception in the Dutch Republic after the first publication of De Cive. ${ }^{21}$ Samuel Sorbière, a French contact of Hobbes who enrolled as a student in 1646 at Leiden University where he attended Heereboord's classes, had brought a copy of De Cive to the Netherlands which was published in 1647 by Elzevier. The work, which was sold out and reprinted within a year, had a large impact, and the discussions about the work reflected clear political positions in the Dutch debate. On the one hand, the Calvinist clergy reproached Hobbes for his moral relativism and allegedly 'Machiavellian' concept of absolute sovereignty, as well as for his subjection of ecclesiastical affairs to the civil magistrate, one of the main controversies in seventeenth-century Dutch politics. ${ }^{22}$ On the other hand, an important critic of Calvinist orthodoxy, the Utrecht regent Lambert van Velthuysen, openly declared himself a disciple of $D e$ Cive, although he did so by fundamentally altering Hobbes's subjectivism into a Grotian theory of natural human sociability. ${ }^{23}$ Thus Hobbes was soon mobilized by different sides in the Dutch debate as either immoral scapegoat or anti-clerical inspiration.

${ }^{21}$ See Cornelis W. Schoneveld, Intertraffic of the Mind. Studies in Seventeenth-Century Anglo-Dutch Translation (Leiden: Brill, 1983), 29-46; Catherine Secretan, "La reception de Hobbes aux Pays-Bas au XVIIe siècle," Studia Spinozana 3 (1987), 27-45; and the large overview by Noel Malcolm, "Hobbes and the European Republic of Letters," in Idem, Aspects of Hobbes, 457-545.

${ }^{22}$ See Gisbert Cock, Exercitationis philosophica-theologicae, de lege in communi (Utrecht, 1653), and Idem, Vindiciae pro lege \& imperio: sive dissertationes duae ... contra tractatum Hobbii De Cive (Utrecht, 1661), esp. 82-88. Cf. Secretan, "La reception de Hobbes," 28-31; and Malcolm, "Hobbes and the European Republic of Letters," 475-477.

${ }_{23}$ [Lambert van Velthuysen], Epistolica dissertatio de principiis iusti, et decori, continens apologiam pro tractatu clarissimi Hobbaei, De Cive (Amsterdam, 1651). See on Van Velthuysen's reading of Hobbes in particular Blom, Morality and Causality, 101-128; 
Given this initial politicized reception of Hobbes in the Dutch Republic, it is likely that the brothers De la Court were introduced to Hobbes's writings in the course of the 165 os. Nonetheless, there is an important caveat here, for textual evidence suggests that this introduction to Hobbes might have arrived fairly late in the development of their thought, perhaps only after Johan's death in 166o. First of all, the references to Hobbes in the Politike Weeg-schaal were, as noted above, only included by Pieter in the later re-editions to clarify passages that had not been present in the first edition. Secondly, the earliest manuscript of Het welvaren van Leiden, which probably dates from the autumn of 1659 , does not mention Hobbes at all, while the later versions of the text, from after 1660 , contain a passage on absolute sovereignty that approvingly refers to Hobbes. ${ }^{24}$ In sum, the few parts of the brothers' works that directly rest on Hobbes were most probably written by De la Court after his brother's death. There are some phrases in the first edition of the Politike Weeg-schaal that hint at least to a superficial reading of De Cive, such as the characterization of the state of nature as a war of all against all, or the predominance of fear and distrust among humans. ${ }^{25}$ Yet overall, the confrontation with Hobbes, pace Kossmann and others, does not seem to have been a fundamental theoretical starting-point for the development of the thought of the De la Courts.

Instead, their reading of Hobbes implies primarily a partisan (and highly partial) appropriation of his political philosophy in the context of Dutch republican politics. This appropriation is exemplified by the 1667 Dutch translation of the Leviathan by Abraham van Berkel, a former student at Leiden in theology and medicine. ${ }^{26}$ In his introduction to the work, Van Berkel compared the execution of Charles I in 1649 with the attempted coup d'état by the Dutch Stadholder a year later: both were

Malcolm, "Hobbes and the European Republic of Letters," 517-518; and Jon Parkin, "Taming the Leviathan: Reading Hobbes in Seventeenth-Century Europe," in T.J. Hochstrasser and P. Schröder (eds.), Early Modern Natural Law Theories. Contexts and Strategies in the Early Enlightenment (Dordrecht etc.: Kluwer, 2003), 31-52: 36.

${ }^{24}$ Cf. Groningen University Library, Ms 233: "t Welvaren der Stad Leyden," fol. 127, with Welvaren 71, p. 154-155. On the dating of this manuscript, see Lucassen, "Het Welvaren van Leiden."

${ }^{25}$ Cf. Politike Weeg-schaal I.I.1, p. 17-18, with Hobbes, On the Citizen, 10, 25.

${ }^{26}$ See Schoneveld, Intertraffic of the Mind, 46-63, and Arie-Jan Gelderblom, "The Publisher of Hobbes's Dutch Leviathan," in Susan Roach (ed.), Across the Narrow Seas. Studies in the History and Bibliography of Britain and the Low Countries (London: The British Library, 1991), 162-166. The library of Pieter de la Court van der Voort contained a copy of Van Berkel's translation and the 1668 edition of Hobbes's Opera Philosophica Omnia, published by Blaeu, but no earlier copies of Hobbes's works: Library, fols. 20, 24. 
illegitimate deeds, he argued, which resulted from a fundamental misunderstanding of the absolute nature of sovereignty in England and the United Provinces. For Van Berkel, Hobbes's argument against the English tyrannicides was therefore also an argument against the Dutch Orangists a highly telling volte-face that mobilized Hobbes for the cause of the provincial sovereignty of the States of Holland. Moreover, Van Berkel insisted that the Leviathan exemplarily revealed the extent of civil liberty and the subordination of ecclesiastical power to the civic magistrate. ${ }^{27}$ In short, he turned Hobbes into a Dutch anti-Orangist republican.

Van Berkel was the central figure of a small circle of Leiden intellectuals which included Pieter de la Court, to whom Van Berkel referred in his 1665 translation of Thomas Browne's Religio Medici as a "trustworthy Friend, that well-trained Mind, the Author of Holland's Interest" ${ }^{28}$ Among the other friends of Van Berkel were Janus Rampius, a teacher related to the governing circles of Leiden by marriage, the Englishman Joseph Hill, who a decade later published a political pamphlet on the relations between England and the United Provinces which directly echoed the De la Courts, ${ }^{29}$ and Adriaen Koerbagh, a radical freethinker whose first publication involved a strong defence of the provincial sovereignty of the States of Holland. In the wake of the political crisis of 1650, Hobbes's political philosophy offered these critical intellectuals an innovative theoretical framework to cope with the fundamental yet undecided question of political obligation. As Jon Parkin has argued convincingly regarding the reception of Hobbes in England, "Hobbes's works made sense of a world of political and religious conflict in a way that more traditional political theory did not". ${ }^{30}$ The same can be said of his reception in the Dutch Republic: for many of his readers in an age defined by political contingency, Hobbes's compelling characterization of civil disorder and the foundation of absolute sovereignty implied a new, potent means to come to terms with de facto politics.

${ }^{27}$ Hobbes, Leviathan: of van de stoffe, gedaente, ende magt van de kerckelycke ende wereltlycke regeeringe, trans. Abraham van Berkel (Amsterdam, 1667), "Voor-reeden," sigs. ${ }^{*} 4-{ }^{*} 5$.

${ }_{28}^{28}$ Religio Medici. Dat is: Noodwendige beschryvinge van Mr Thomas Browne, trans. Abraham van Berkel ('Laege-duynen' [=Leiden], 1665), 238, note 2: "Mijn vertrouden Vrient, dat wel-geoeffende Verstant, den genoemden Autheur van 't Hollands-Interest."

${ }^{29}$ [Joseph Hill], The Interest of These United Provinces, Being a Defence of the Zealander's Choice (Middelburg, 1673), which refers to the Politike Weeg-schaal. See Schoneveld, Intertraffic, 4-6, 38-39, 142, note 21.

${ }^{30}$ Jon Parkin, Taming the Leviathan. The Reception of the Political and Religious Ideas of Thomas Hobbes in England, 1640-1700 (Cambridge: Cambridge University Press, 2007), 205. 
The way in which Hobbes was appropriated by the brothers De la Court equally stems from this novel potential of his ideas. The De la Courts found in Hobbes an authoritative source for three important elements of their theory: the depiction of natural equality and mutual fear as the foundations of political organization, the ensuing argument that all government originates as democracy, and the eventual classification of sovereignty as necessarily absolute and undivided. None of these three issues are exclusively Hobbesian, and therefore it does not make much sense to speak of the De la Courts as Dutch disciples of Hobbes. Instead, the brothers turned to Hobbes to further substantiate their views on the basis of his evocative, though ambiguous, language. Hobbes's rhetorical strategies defied a straightforward reading, as Jon Parkin has shown, and one of the main reasons for his influence in the seventeenth century was his ability to entrap the reader and thus address different political agendas - even the radical republican agenda of the brothers De la Court..$^{31}$

The writings of Hobbes offered the De la Courts compelling new evidence of what they had been taught when studying at Leiden. The politica of their professor Boxhorn gradually moved away from the Aristotelian notion of man as a political animal to a depiction of human nature as essentially self-interested. For Boxhorn civil society originated in necessity and fear, a view shared by other important seventeenth-century scholars on politica such as Henning Arnisaeus, who equally acknowledged fear as an important factor in the establishment of politics, ${ }^{32}$ or the Helmstedt professor Johann Werdenhagen, for whom "fear and indigence" lay at the basis of every commonwealth. ${ }^{33}$ Hobbes, in particular in De Cive, developed this view into a suggestive image of the state of nature that amounted to a full-blown repudiation of Aristotle. In far more compelling detail and expressive language than his academic predecessors, Hobbes emphasized the fundamental equality of power among all natural human beings. It is this equal "power to kill" that makes mutual fear, and

${ }^{31}$ Ibidem, 86, and Parkin, "Taming the Leviathan," esp. 37.

${ }^{32}$ Henning Arnisaeus, De republica, seu reflectionis politicae libri II (Strasbourg, 1636) I.I.2.8, p. 9. On Arnisaeus, see Horst Dreitzel, Protestantischer Aristotelismus und absoluter Staat. Die "Politica" des Henning Arnisaeus (ca. 1575-1636) (Wiesbaden: Franz Steiner Verlag, 1970).

${ }^{33}$ Johannes Angelius Werdenhagen, Universalis introductio in omnes respublicas sive politica generalis (Amsterdam, 1632) II.II.9-13, p. 219-221. Cf. Alfred Voigt, Über die Politica generalis des Johann Angelius v. Werdenhagen (Amsterdam 1632) (Erlangen, 1965), and Rolando Crahay, "Dalla République di Jean Bodin alla Synopsis di Johann Angelius Werdenhagen (1635). Un rinnovamento dei concetti religiosi e politici," Rivista Storica Italiana 104 (1992), 629-677. 
not benevolence, the origin of society. ${ }^{34}$ This emphasis on natural equality was readily adopted by the brothers De la Court. All men are by nature equal in their strengths and passions, and

out of this natural equality arise commonly mutual fear, modesty, and morality, for one feels ashamed and does not dare to desire that others endure from us what we would not want to suffer from others. And since human privation is meanwhile large, and the order to get out from that misery and privation necessary, therefore one very easily, in all diversity of judgment, concedes this fairness: that reasonably, few should comply with the judgment of many. And this natural fairness and rationality is the foundation of all Democratic, or Popular, Governments. ${ }^{35}$

This revealing passage makes clear that the De la Courts eagerly connected Hobbes's evocative depiction of the state of nature with his secondary argument that democracy is the original form of all government. In De corpore politico, the second part of the treatise titled The Elements of Law in the English version, Hobbes argued that democracy must be necessarily "first in order of time", because both aristocracy and monarchy can only be instituted by the consent of the majority. ${ }^{36}$ This idea that democratic consensus must lie at the basis of every commonwealth was, again, not particularly original. Although, for example, Boxhorn maintained that monarchy and aristocracy precede democracy, Johannes Althusius had insisted at the start of the seventeenth century that all commonwealths originate in consent, never in coercion. ${ }^{37}$ Hobbes merely restated this conventional view, but he did so rather ambiguously (and perhaps hastily). ${ }^{38}$ The argument that democracy is the original form of government plays a minor, even anomalous role in his political philosophy, and it gradually

34 Hobbes, On the Citizen I.2-3, p. 21-26.

35 Politike Weeg-schaal III.I.2-3, p. 521, 524-525: "Naademaal volwasse Mannen moeten werden geconsidereert gelijk te zijn in naturelike kragten ... zoo ontstaat gemeenelik uit die naturelike gelijkheid en onderlinge vreese, modestie, en zeedigheyd; zulks men zich schaamt, en niet derfd begeeren dat anderen van ons verdragen, 't gunt wy van anderen niet zouden willen lijden. En vermits onderwijlen de menschelike behoeftigheid groot, en de ordre om uit die ellende en behoeftigheid te geraken noodsaakelik is, zoo staat men zeer ligtelik, in alle verscheidentheit van oordeel, dese billikheit toe, dat reedeliker-wijse, weinigen zig behooren te voegen naa het oordeel van veelen. Welke naturelike billik- en reedelikheit de gront-slag is van alle Demokratike, ofte Populare Regeeringe."

${ }^{6}$ Hobbes, The Elements of Law Natural and Politic, ed. Ferdinand Tönnies, 2d. ed. (London: Frank Cass, 1969) II.II.1, p. 118; Idem, Les corps politiques, 73.

37 Cf. Boxhorn, Institutiones politicae II.I Exp., p. 26o, with Johannes Althusius, Politica methodice digesta, 3d. ed. (Herborn, 1614) IV.1.

$3^{8}$ See Deborah Baumgold, "The Composition of the Hobbes's Elements of Law," History of Political Thought 25 (2004), 16-43. 
disappears almost entirely in the development from The Elements of Law to De Cive and eventually to Leviathan. ${ }^{39}$ Yet the De la Courts appropriated this ambiguous argument from Hobbes for their own ensuing claim that all sovereignty is by necessity popular. As the Politike Weeg-schaal insists (in a passage added to the first edition, so perhaps written by De la Court after having read Hobbes): "Democracy or Popular Government is the oldest and most legitimate one. For no Assembly can charge a sovereign power to someone else, when it does not possess this itself." ${ }^{\circ 0}$ Thus, what was for Hobbes a secondary claim became in the work of the De la Courts a central element of their republican theory.

The brothers De la Court could adapt Hobbes in this way because they looked at his work through Grotian lenses with a fairly radical focus. ${ }^{41}$ Hobbes's subjectivism, coined in a language of rights, is turned by the De la Courts into a language of 'fairness', in which rights do not play any significant role. For the De la Courts, the natural equality among human beings leads not only to mutual fear but also involves natural justice and morality. It is such morality which enables the contractual foundation of the commonwealth along rational and democratic lines. This argument merges the Hobbesian prominence of fear with a Grotian emphasis on mutual human recognition, primarily based on the Stoic notion of oikeiosis, the natural inclination to self-protection and common support. ${ }^{42}$

39 Cf. Hobbes, On the Citizen VII.5, with Leviathan XVIII.1. On democracy in Hobbes, see the debate between Richard Tuck, "Hobbes and Democracy," and Kinch Hoekstra, "A Lion in the House: Hobbes and Democracy," in Annabel Brett et al. (eds.), Rethinking the Foundations of Modern Political Thought (Cambridge: Cambridge University Press, 2006), 171-218.

$4^{4}$ Politike Weeg-schaal I.I.7, p. 36: “... dat de Democratie ofte Populare regeering de oudste en wettelikste is. Want geen Vergaadering, aan een ander een souveraine magt kan opdraagen, indien zy die zelfs niet heeft."

${ }^{41}$ The library of Pieter de la Court van der Voort contained the four volumes of Grotius's Opera omnia (1679), and also editions of Van de oudheijd van de Batavische republyk (The Hague, 1610), Van de wettige regeering van Holland (Paris, s.d.), De jure belli ac pacis (Amsterdam, 1631), De mare libero (Leiden, 1633), and Annales et historiae Belgicae (Amsterdam, 1647): Library, fols. 10, 15, 19, 22, 31.

${ }^{42}$ Cf. Grotius, Commentary on the Law of Prize and Booty, ed. Martine Julia van Ittersum (Indianapolis: Liberty Fund, 2006), esp. 26-28, and The Rights of War and Peace, trans. William Evats (London, 1682), iii-v. For the notion of oikeiosis, see Reinhard Brandt, "SelfConsciousness and Self-Care. On the Tradition of Oikeiosis in the Modern Age," Grotiana (New Series) 22/23 (2001-2002), 73-92; and Benjamin Straumann, "Oikeiosis and appetitus societatis. Hugo Grotius's Ciceronian Argument for Natural Law and Just War," Grotiana (New Series) 24/25 (2003-2004), 41-66. For a more general comparison between Grotius and Hobbes, see Tuck, Philosophy and Government, 303-306, 347-348; and Knud Haakonssen, Natural Law and Moral Philosophy from Grotius to the Scottish Enlightenment (Cambridge: Cambridge University Press, 1996), 26-35. Cf. as well the criticism by Johann 
The De la Courts also adapt Hobbes in a Grotian manner by insisting on the fundamental preservation of sovereignty among the democratic assembly that forms the basis of all government. For Hobbes, the contractual institution of sovereignty turns a multitude of individuals into a unified body of people, and therefore the people cannot set limits to the exercise of that sovereignty. ${ }^{43}$ Yet for the De la Courts, the initial consent that lies at the basis of government implies that all legitimate sovereign power remains in principle with the people - a claim evocatively epitomized in a number of fables that recount how sheep and foxes meet in their animal assembly to discuss the affairs of their community. ${ }^{44}$

This view, rooted in Monarchomach thought and the traditional justification of the Dutch Revolt, clearly involves a crucial departure from Hobbes. Yet more importantly, it also entails a significant reinterpretation of conventional contract theory, including that of Grotius. The work of the De la Courts argues that the hypothetical passage from the state of nature to a political society can proceed along two diametrically opposed lines: either all "would make a mutual civil society, or pacts and laws, and choose Magistrates to let them provide for the benefit of the community, and so create a free Republic"; or the strongest man would prevail by force or deceit and "would thus establish a Monarchy". ${ }^{45}$ In other words, all government by consent is necessarily republican, while monarchy necessarily originates from forceful coercion and is hence no true civil society. This differentiation between democratic government by institution and monarchical government by acquisition is also central to Hobbes, but the essential difference from Hobbes (and most other contract theorists) here is the consequent claim that monarchy can never derive from consent and is therefore essentially illegitimate. ${ }^{46}$ The central passion of self-love, so the argument of the brothers De la Court goes, makes it impossible that any human being would think that another is more competent to rule,

P. Sommerville, "Selden, Grotius, and the Seventeenth-Century Intellectual Revolution in Moral and Political Theory," in Victoria Kahn and Lorna Hutson (eds.), Rhetoric and Law in Early Modern Europe (New Haven: Yale University Press, 2001), 318-344.

${ }_{43}$ See Quentin Skinner, "Hobbes and the Purely Artificial Person of the State," in Idem, Visions of Politics, 3 vols. (Cambridge: Cambridge University Press, 2002), vol. III: 177-208.

44 E.g. Sinryke Fabulen, 301-308, 355-362.

45 Politike Discoursen I.I.1, p. 1-2: “... een onderlinge civile societeit, ofte verbonden en wetten maken, ende Magistraten kiesen, om die tot nut van 't gemeen te doen onderhouden, ende alzoo een vrye Republijck te formeeren. Of de sterkste en looste sig van veelen, d'een voor d'ander naa, 't zy door kragt, 't zy door bedrog, meester gemaakt hebbende, soude een Monarchie opregten." Cf. also Ibidem II.V.9.

${ }^{46}$ Cf. esp. Hobbes, Elements of Law II.II.9; On the Citizen VII.11-17. 
since "men have naturally such a large presumption of their own capability that they will never have willingly and knowingly charged the power to promote their own advantage to some others, however those may be". ${ }^{47}$ Therefore, it is "unthinkable ... that a popular Government has ever authorised one man and his descendants for all eternity" to be sovereign, since "it cannot be presumed at all that there has ever been the least intention from any popular Assembly to take away the own power of choosing, in case of incapability or malevolence of a Ruler and his Successors, a much more capable or better one".$^{8}$ In short, because of human nature, the democratic assembly that forms the basis of all government always retains sovereignty. A hereditary monarchy can only originate in the illegitimate usurping of this original popular government by force or deceit.

For Samuel Pufendorf, who read the Politike Weeg-schaal in the years he spent in the Dutch Republic during the early 166os, this view of the inconceivability of a chosen hereditary monarchy was merely a "pestilens dogma", clearly refuted by the philosophy of Hobbes. ${ }^{49}$ Yet it is more significant that the brothers De la Court not only departed from Hobbes, but essentially employed the Hobbesian characterization of the human condition to reinterpret the contract theory that Hobbes himself argued against. This contract theory is exemplified by the English supporters of Parliament in the 1640s, particularly by Henry Parker's Observations of 1642 - published a few months before Pieter de la Court was in London for his Grand Tour. Parker's main argument in favour of parliamentary sovereignty was "that power is but secondary and derivative in Princes, the fountaine and efficient cause is the people". ${ }^{50}$ Hobbes's reply was intended

${ }^{47}$ Politike Weeg-schaal III.I.2, p. 523: “... waaragtig, de menschen naturelik soo groote presumptie van hare eige bequaamheit te hebben, dat sy nooit willens en wetents, de magt van haar eigen voordeel te betragten, aan eenige anderen, hoedanig die zijn, sullen hebben opgedragen."

${ }^{48}$ Ibidem I.I.7, p. 37: “... onbedenkelik te zijn, dat ooit een populare Vergaadering daar toe hebbe geauthoriseerd een mensch, en zijn afkomelingen inder eeuwigheid ... zoo kan gantsch niet werden gepresumeerd ooit de minste intentie eeniger populare Vergaderinge te zijn geweest zig zelven te beneemen de magt van by onbequaam-of quaadwilligheid eens Regeerders en zijner Successeurs, te kiezen een veel bequamer of beeter." Cf. also Ibidem III.I.2-3, III.III.3.

49 Samuel Pufendorf, De jure naturae et gentium libri octo (1688, facs. ed. Oxford: Clarendon Press, 1934) VII.V.9, p. 706-707, quoting Politike Weeg-schaal I.I.7, p. 37-38. Cf. as well Ibidem VII.V.22, p. 721: "Ex adverso nihil, quod in monarchas maligne aut invidiose dici queat, videtur omisisse scriptor Belgicus Bilancis politicae. Quorum tamen non pauca retundi possunt per cap. X Hobbesii de Cive, \& Leviath.c.19."

$5^{\circ}$ [Henry Parker], Observations upon Some of His Majesties Late Answers and Expresses [London, 1642], 2. See Michael Mendle, Henry Parker and the English Civil War. The Political Thought of the Public's 'Privado' (Cambridge: Cambridge University Press, 1995), 85-88. 
to make clear that this view was both absurd and dangerous, since a division of sovereign power would necessarily entail the dissolution of the commonwealth, and thus a return to the state of nature where every single individual exercises the right of self-preservation..$^{5}$ The De la Courts adopt this argument, but they do so to argue that human selfishness in the state of nature makes it a priori absurd to conceive of a monarchy instituted by consent. They thus use Hobbes's own weapons against Hobbes, while their repudiation of the primacy of monarchy equally undermines the space allocated to kings in the work of Grotius and Parker..$^{52}$ In the political universe of the De la Courts, monarchies might be successful polities, but they cannot be true civil societies based on popular consent.

Finally, the brothers De la Court also appropriate the Hobbesian argument that "the Sovereign is always One, or indivisible" - yet they do so again in a quasi Grotian way. ${ }^{53}$ In reaction to Bodin, Grotius had argued that sovereignty in Holland originated from the people but was administered by the provincial States. In this way Grotius attempted to reconcile Bodin's absolutism with the time-honoured ideal of the mixed regime. This view went back to the period of the Dutch Revolt, when François Vranck, pensionary of the town of Gouda, had written a defence of the sovereignty of the States of Holland, the "Magna Carta of the Dutch Republic", in reply to claims for princely authority. ${ }^{54}$ Hobbes's notion of absolute sovereignty offered the De la Courts a new, powerful source to radicalize this established justification of provincial sovereignty. The result is a sort of republican absolutism, which emphasizes the indivisibility of sovereignty to counter any claims on behalf of a political or military role for the Stadholder, while ardently defending the supreme authority of the States of Holland in all religious and political matters. Thus, like

${ }^{51}$ See esp. Hobbes, Leviathan XVIII, p. 236-238.

$5^{2}$ Cf. Grotius, Rights of War and Peace I.III.9, p. 37-41. For the recent republican reinterpretation of Grotius, see esp. Tuck, Philosophy and Government, 154-201; Annabel Brett, "Natural Right and Civil Community: The Civil Philosophy of Hugo Grotius," The Historical Journal 45 (2002), 31-51; and Martin van Gelderen, "The State and its Rivals in EarlyModern Europe," in Quentin Skinner and Bo Stråth, eds., States and Citizens. History, Theory, Prospects (Cambridge: Cambridge University Press, 2003), 79-96.

53 Politike Weeg-schaal I.I.4, p. 23: “... dat de Souverain altijds Een, ofte onsplitsbaar is." Cf. Hobbes, On the Citizen VI.5-18, XII.5.

${ }_{54}$ François Vranck, Short Exposition (1587), in Martin van Gelderen (ed.), The Dutch Revolt (Cambridge: Cambridge University Press, 1993), 227-238. Vranck's text was republished several times throughout the seventeenth century as an appendix to the re-editions of Boxhorn's Commentariolus. See also the analysis in Van Gelderen, Political Thought, 204-205. 
Van Berkel, the brothers De la Court employ Hobbes's absolutism to reach a conclusion that would probably have horrified Hobbes himself. For the De la Courts, the popular origin and preservation of sovereignty means that a division in sovereignty would entail a violation of the contract that lies at the basis of political society. When the legislature is separated from the executive, individuals gain the opportunity to assume all military command, whereby the power of arms prevails over legitimate rule and all people are again entrenched in mutual warfare:

For it is clear that in all cases of a separation of the sovereign authority, these independent, divided people would have to guard against each other, and that the weakest would be devoured by the strongest, so that the natural state of war would in fact be introduced again..$^{55}$

Civil society, which originates from the human need to escape the war of all against all, would fail in its purpose when sovereignty is divided between different bodies. The eventual result can only be conflict and the abuse of powers, a gruesome fate exemplified by a fable that tells how a lion illegitimately gets hold of all authority in a badly ordered animal republic..$^{5}$ To overcome this monarchical state of affairs, sovereignty must remain absolute and located with its original possessors, the people. The brothers De la Court thus give a decisive republican twist to Hobbes's political philosophy.

This republican appropriation of Hobbes was not unique. Contemporary English republicans, notably Marchamont Nedham and James Harrington, equally adopted elements from Hobbes to sustain their defence of the English Commonwealth. Arguably, the lasting influence of Hobbes is due to precisely this capacity to speak to many different political agendas. ${ }^{57}$ Yet the rather arbitrary and highly partisan way in which the De la Courts adapted Hobbesian arguments means that their thought should not too hastily be labelled as belonging to a certain school of thought, be it 'Hobbesian', 'Grotian', or 'Cartesian'. Instead, like most early-modern political thinkers and pamphleteers, the brothers seem to have chosen whatever suited their argument eclectically from a range of sources, with

55 Politike Weeg-schaal I.I.4, p. 26: "Want het is klaar, dat in alle gevallen van verdeeldheid der souveraine magt, deeze independente verdeelde menschen, gedurig tegen malkanderen zouden moeten waaken; en dat de swakste door de sterkste zoude werden verslonden, zulks metter daad de naturelike oorlogs-stand weederom zoude weezen ingevoert."

${ }^{6}$ Ibidem, 29-30, more extensively in Sinryke Fabulen, 27-32.

57 See Parkin, Taming the Leviathan, 78-79, 178-185; Sullivan, Machiavelli, Hobbes, 165173; and Rahe, Against Throne and Altar, 321-346. 
more concern for rhetorical force than for scholastic consistency. Their diverse reading brought them in due course to the en vogue writings of Hobbes, which offered a temptingly novel outlook on de facto politics and the question of political obligation, the crucial issue in the 1650 os on either side of the North Sea. In constructing their account of the foundation of the commonwealth, they extracted a few of Hobbes's ambiguous views, discarded all the rest, and distilled the residue into an explosive brew that radicalized conventional contract theory with the claim that any legitimate form of political society must necessarily be non-monarchical.

\section{Citizenship in Theory and Practice}

\section{The Acquisition \& Limits of Urban Citizenship}

This account of the contractual origins of politics, based on the hypothetical passage from the state of nature to civil society, plays an important normative role in the political thought of the brothers De la Court. In contrast, their approach to the ensuing question of who actually counts as a citizen in this civil society is far less systematic and does not follow from any rigorous theoretical framework. ${ }^{5^{8}}$ This section therefore turns primarily to the practice of citizenship in the seventeenth-century Dutch Republic and considers how the De la Courts conceived of the extent and limits of citizenship in relation to, and criticism of, the urban corporate politics of the Dutch Golden Age.

In the communal tradition of the early-modern Netherlands, as in Renaissance Italy, the embodiment of the commonwealth was the city. This centrality of the city implied that politics was by definition considered to be civic, i.e. taking place in an urban framework, as is reflected in the contemporary Dutch usage of the term politicus as 'burgherlick', for example in the influential late sixteenth-century treatise on citizenship by the Dutch engineer Simon Stevin. ${ }^{99}$ This urban emphasis equally dominates in the thought of the brothers De la Court. The starting-point of

\footnotetext{
${ }^{5}$ Hans W. Blom, "Burger en belang: Pieter de la Court over de politieke betekenis van burgers," in Kloek and Tilmans (eds.), Burger, 99-112.

59 Simon Stevin, Het burgherlick leven, ed. Pim den Boer (Utrecht: Bijleveld, 2001), esp. 34-37. See also Manfred Riedel, "Bürger, Staatsbürger, Bürgertum," in O. Brunner, W. Conze and R. Koselleck (eds.), Geschichtliche Grundbegriffe. Historisches Lexikon zur politischen-sozialen Sprache in Deutschland, 8 vols. (Stuttgart: Klett-Cotta, 1974-1997) vol. II: 672-725; and cf. Nicolai Rubinstein, "The History of the Word Politicus in EarlyModern Europe," in Pagden (ed.), Languages of Political Theory, 41-56.
} 
their politics is not the single family but rather a large gathering of many households into one civic unit. In line with Burgersdijk's textbook on politica, the De la Courts insist that one household, "consisting of a man, woman, children, servants and maids ... cannot be said to be a Political State", since a single household will never be able to fulfil the principal purpose of civil society, the establishment of order to avoid internal violence and the defence against any external aggression. ${ }^{60}$ For the De la Courts, quantity is an essential criterion for the establishment of a commonwealth. Only an assembly of at least thirty or forty thousand males who convene to establish mutual peace and defence deserves the name of a political state that can be expected to last. This number of thirty or forty thousand men roughly corresponds to the brothers' primary empirical source of inspiration, the larger seventeenth-century Holland cities, like Leiden, which contained a comparable male adult population. ${ }^{61}$ These Dutch urban polities form the central frame of reference for the analysis of citizenship in the work of the De la Courts. "All Inhabitants of a City constitute together truly a Political or Civic body", ${ }^{2}$ and this focus on the city as the essence of politics means that the countryside, and thereby agriculture and ownership of land, play no particular role in the brothers' political thought. This entails a significant difference from the Aristotelian embrace of rural property, especially in the work of Harrington who asserted that "agriculture is the bread of the nation". ${ }^{63}$ In clear contrast, for the De la Courts republican politics are all about being a member of an urban community.

Citizenship in the early modern cities in the Netherlands was a formal, juridical category that separated the poorters, the burghers of a town who enjoyed citizenship rights, from those inhabitants without such rights and from foreigners. ${ }^{64}$ The privileges connected to citizenship included

${ }^{60}$ Politike Weeg-schaal I.I.4, p. 24-25: "Een huisgezin sterk hondert menschen, en bestaande uit man, vrouw, kinderen, dienstknechten en maagden ... kan niet werden gezegt te weezen een Politiken Staat." Cf. Burgersdijk, Idea oeconomicae et politicae II.I.2-3, p. $3^{2-33}$.

${ }^{61}$ On seventeenth-century Dutch urban demographics, see Israel, Dutch Republic, 621, and cf. the more cautious estimate of Leiden's population in Dirk Jaap Noordam, "Demografische ontwikkelingen," in Groenveld (ed.), Leiden, 43-53.

${ }^{62}$ Sinryke Fabulen, 351: "Ende oovermits alle de Ingeseetenen eener Stad te saamen, waarelik een Politik ofte Borgerlik lighaam uit maaken."

${ }_{3}$ Harrington, Oceana, 197.

${ }^{64}$ See Maarten Prak, "Burghers, Citizens and Popular Politics in the Dutch Republic," Eighteenth-Century Studies 30, 4 (1997), 443-448; and Erika Kuijpers and Maarten Prak, "Burger, ingezetene, vreemdeling: burgerschap in Amsterdam in de $17^{\mathrm{e}}$ en $18^{\mathrm{e}}$ eeuw," in Kloek and Tilmans (eds.), Burger, 113-132. Cf. for the case of Leiden: Annie Versprille, "Het 
jurisdictional protection outside the city gates, the possibility to engage in certain occupations organized in guilds or to profit from the local social institutions, and, theoretically at least, the participation in urban government. One became poorter by birth or through marriage, or, as in the case of Pieter de la Court sr., by buying the poorterrecht. In addition to a juridical category citizenship also pertained to a social and economic category, which distinguished relatively rich from poor immigrants who could not afford to become a citizen. In Leiden, citizenship was relatively easy to obtain because it was cheap: during the 1650 and 1660 , the Leiden poorterrecht sold at only a tenth of the price asked in Holland's main metropolis, Amsterdam. ${ }^{6}$ However, Leiden maintained a formal distinction between such paid citizenship and the 'complete right' obtained by birth. An immigrant who had bought his rights had to wait for seven years to become accepted as a full citizen with the same status as the native population. ${ }^{66}$ In theory, by then he was formally entitled to partake in local government, but in practice immigrants and their offspring were excluded from the higher echelons of the Leiden magistracy for generations.

The brothers De la Court, facing this practice, repeatedly criticized these obstructions to the acquisition of full citizenship. The partial poorterrecht purchased by newcomers, their argument goes, "would change into an idle, powerless term if over time all the advantages ... would be separated from it". ${ }^{67}$ To counter this deflation of the value of citizenship, "one should grant all foreigners who want to come to live in the Cities as much freedom as the other old inhabitants" ${ }^{68}$ In other words, the De la Courts proposed the abolition of any formal juridical distinction between new and old poorters by "granting the Citizens uniform Freedom and Right" ${ }^{69}$ This argument for a policy of open citizenship is substantiated by a number of moves. First of all, the brothers insist that biblical morality calls for hospitality towards immigrants, confirmed as well by

\footnotetext{
Leidse poorterschap," Leids Jaarboekje 36 (1944), 76-100. On the practice and theory of citizenship in England, see Phil Withington, The Politics of Commonwealth. Citizens and Freemen in Early Modern England (Cambridge: Cambridge University Press, 2005).

${ }_{6}$ Versprille, "Leidse poorterschap," 80; Kuijpers and Prak, "Burger," 121.

66 Versprille, "Leidse poorterschap," 81-82.

${ }_{7}$ Welvaren 48, p. 111: "Maer wie siet niet, dat het poorter-reght in een ijdele kraghteloosen name soude veranderen, als men aldus met der tijd alle voordeelen, die ijder poorter daer aen pleegh te mogen koppelen, daer van soude scheiden."

${ }_{68}$ Politike Discoursen I.I.1, p. 3: “... zoo behoordemen alle vremdelingen die in de Steeden willen komen woonen, zoo veel vryheids als den anderen oude ingezeetenen te geeven."

${ }_{9}$ Welvaren 2, p. 7: “... den Borgeren eenparige Vrijdom en Reght van alles toestonden."
} 
the classical examples of inclusive citizenship in Athens and Rome. ${ }^{70}$ Following Machiavelli, who repudiated the policy of Sparta of excluding foreigners from civil military service, these references to classical examples of immigration had been a commonplace element of many reason of state treatises that championed the admittance of foreigners as a means to further the greatness of the polity. ${ }^{71}$ The De la Courts adopted this claim for the Dutch context, in particular in connection with their plea for comprehensive religious toleration (see chapter 5 below).

Apart from this assertion that a policy of inclusive citizenship enhances the general interest of society, the brothers De la Court also proposed a second argument in favour of free immigration in terms of natural right. This argument follows partly Grotius's justification of "the right of perpetual cohabitation" for persecuted foreigners who "submit to the Government" of their new home..$^{72}$ The De la Courts develop this Grotian notion in a fable that tells of a group of water birds who seek refuge on an island. After an initial welcome, the native bird population imposes discriminatory regulations upon the water birds, who complain in reply that "against the right of nature and of birth, you call our Children and Grandchildren Foreigners in their own Patria", a verdict that amounts to a "civil death" ${ }^{73}$ The fable serves as an evocative illustration to the claim that the willingness to immigrate reveals that newcomers have tacitly consented with the social contract of the civil society in which they settle. Therefore these newcomers should be granted the same means for their self-preservation as the native population:

It is and remains true that all Inhabitants who have or desire to obtain a permanent residence in this Country are to that extent no foreigners, but Compatriots, and that they should be permitted to the necessary common provisions as much as the old Citizens, since they do not need those less but more. ${ }^{74}$

$7^{70}$ Politike Discoursen I.I.7, p. 63-65, with exempla taken from Thucydides, Xenophon, Plutarch, Cicero, and Lucretius.

${ }^{71}$ Cf. Machiavelli, Discorsi I.6, II.3.

${ }^{2}$ Grotius, Rights of War and Peace II.II.16, p. 85.

${ }_{73}$ Politike Weeg-schaal III.II.4, p. 631-632: “... teegen het regt der nature en geboorte, heet gy onse Kinderen en Kindskinderen in haar eige Patria, Vaderland ofte Geboorteplaats, Vremdelingen ... deese civile dood." The same fable is included in Sinryke Fabulen, 121-126.

${ }^{74}$ Aanwysing I.15, p. 69-70: "Soo is en blijft waarhaftig, dat alle Ingesetenen die hier te Lande een vaste woonplaatse hebben, of begeren te nemen, voor soo veel gene vreemdelingen, maar Landsaaten zijn, ende tot de noodsaaklijke gemeene leevensmiddelen soo wel als de oude Borgers behooren toegelaaten te werden; naademaal sy die niet min maar meer behoeven." 
The De la Courts thus take up Grotius' justification of the right of cohabitation, but turn it into a more fundamental defence of not only the right to settle, but also the right to partake in all social and economic exchanges. This plea for equal economic opportunities involves in particular a strong denunciation of the policy of the Dutch guilds, which excluded non-citizens from the exercise of certain professions (see further chapter 4 below).

The brothers' plea for the abolition of the jurisdictional barriers between natives and newcomers entails a relatively broad conception of citizenship, clearly critical of the restrictive reality in Leiden and elsewhere. Nevertheless, this appeal for hospitality and equal opportunity does not entail the claim that any individual should be considered a full citizen. In particular, one fundamental condition distinguishes those who are capable of actually performing the rights and duties connected to citizenship: the condition of independence in a profoundly hierarchical society.

Seventeenth-century Dutch characterizations of the societas civilis presupposed the active role of its members in a range of ordered communities that together constituted the urban political space. ${ }^{75}$ The fundamental unit of this communal life was the household. As the physician Johan van Beverwijck noted it in Ciceronian vein in his 1639 treatise Van de wtnementheyt des vrouwelicken geslachts ["On the Excellence of the Female Sex"], the family is "the fountain and source" of all authority in which "the first principle of a town and thus the seed of a common state" rests. ${ }^{76} \mathrm{~A}$ similar view was popularized in the widely read manual for a prosperous family life, Jacob Cats's Houwelick ["Marriage"]. Cats's influential work offered its readers a range of moralistic instructions in verse about the four seasons of a female life, from the spring of the bride to the winter of the widow. All culminated in wedlock, described by Cats as "a smithy of men, a foundation of cities, and a nursery of high government". ${ }^{77}$ Women were supposed to perform an exemplary role in taking care of their homes and families. Such 'paragons of virtue' were epitomized in a range of artistic representations of the private life of the household versus the public

\footnotetext{
75 Cf. Marijke Meijer Drees, “'Burgerlijke' zeventiende eeuwse literatuur,” in Kloek and Tilmans (eds.), Burger, 133-153, esp. 144.

${ }^{76}$ Quoted in Simon Schama, The Embarrassment of Riches. An Interpretation of Dutch Culture in the Golden Age (London: Collins, 1987), 386. Cf. Cicero, De officiis I.XVII.54.

77 Jacob Cats, Houwelick, dat is: het gansche beleyt des echten-staets (1625), in Alle de werken van Jacob Cats, ed. W.N. Wolterink, 2 vols. (Dordrecht: J.P. Revers, 1880), vol. I: 253: “... de staet des huwelicx is een smisse van menschen, een grontsteen van steden, en een queeckerye van hooge regeeringe."
} 
life outdoors. ${ }^{7}$ Yet outside the private sphere, male superiority remained largely unquestioned. As 'Father Cats' stated: "The man practices the country's law, the wife the man's will". ${ }^{79}$

This characterization of paternal authority in politics reflected the patriarchal character of seventeenth-century Dutch society. Public life was handled by the male representatives of large elite families, who, linked together through lineage and strategic alliances, constituted the urban councils and the boards of the chartered companies for overseas trade. As Julia Adams has argued, this patrimonial governance was an important factor in the gradual formation of the Dutch Republic as a world power, contributing to the establishment of what she calls a 'Familial State' ${ }^{80}$ This concept clearly entails more than a historical abstraction, for the familial dimensions of politics were echoed in the prevalent political discourse of the time. The writings of the brothers De la Court aptly reveal this language in claims such as "political Rulers are very well called Fathers and the Subjects their Children", or "the Country is an Orphan and the Rulers are the Guardians of that Orphan". ${ }^{81}$

A significant result of this patriarchal emphasis was the idea that women are by nature dependent on their male representatives. As the argument of the De la Courts goes, "all submission originates through lack of power and knowledge, and such lack of power manifests itself fully with Women, since the passions of fear, fright, and sadness seem to be larger, and judgment smaller, in them than in men". Women are for the De la Courts neither able to master their passionate condition, nor to take care of themselves and their offspring without male assistance, and "thus the Domination by Men over Women and Children seems to follow clearly". ${ }^{82}$ The De la Courts conclude that women cannot participate independently in the public life of the community, they cannot speak for

${ }^{78}$ See Wayne E. Franits, Paragons of Virtue. Women and Domesticity in SeventeenthCentury Dutch Art (Cambridge etc.: Cambridge University Press, 1993).

${ }_{79}$ Cats, Houwelick, 283: "De man betracht de wet des lants, Het wijf den wille van de mans."

${ }^{80}$ Julia Adams, The Familial State. Ruling Families and Merchant Capitalism in Early Modern Europe (Ithaca and London: Cornell University Press, 2005).

${ }^{81}$ Aanwysing I.24, p. 118: “... politike Regeerders seer wel Vaders, ende de Onderdaanen haare Kinderen genaamd werden.” Ibidem III.6, p. 495: “... dat het Land een Wees-kind is, en dat de Regeerders zijnde de Voogden van dat Wees-kind.”

${ }^{82}$ Politike Weeg-schaal III.I.1, p. 520: “... alle onderdaanigheit ontstaat door gebrek van magt, en kennisse. Welk gebrek van magt zig allesins openbaart in de Vrouwluiden, om dat de passien van vreese, schrik en droefheit, grooter in haar, en het oordeel minder, als in de mannen schijnt te wesen ... Zulks de Opperhoofdigheit der Mannen, boven de Vrouwen, en Kinderen hier uit klaarlik schijnt te volgen." 
themselves and must be represented by their male superiors. This was a fairly standard view: in theory seventeenth-century Dutch poorterrecht did not make any differentiation on gender grounds, but in practice women were excluded from most civic offices because of their condition of dependence. ${ }^{83}$ For the De la Courts, as for most of their contemporaries, full citizenship was in all aspects implicitly confined to independent men. $^{84}$

\section{The Might \& Right of the Independent Householder}

The brothers' conception of citizenship, then, centres on the male householder who represents his family outside the private realm in the higher strata of the urban society. Dutch cities such as Leiden comprised various gebuyrten or self-installed small neighbourhoods meant to advance the "good peace and civic unity" within the city through the informal settlement of conflict and the organization of communal festivities. ${ }^{85}$ On a more general level, the cities in the Dutch Republic were subdivided into a number of districts that organized the civic militias, or schutterijen. These militias, according to a Leiden statute, ought to protect the "good citizens and inhabitants of this city against all attack, both wanton and otherwise" ${ }^{86}$ The members of Leiden's militias were recruited from poorters and regular inhabitants alike, yet only those men who were settled as independent householders, who practised a certified profession and who were wealthy enough to pay for their own armour, roughly one in every eight male adults, qualified. To serve in the militia was therefore considered a highly honourable task, an essential fulfilment of one's civic duties in the service of the city. ${ }^{87}$

\footnotetext{
${ }^{8}$ See Kuijpers and Prak, "Burger," 123. Cf. for the juridical status of women Donald Haks, Huwelijk en gezin in Holland in de $17^{e}$ en $18^{e}$ eeuw (Utrecht: HES, 1985), 153-154.

${ }^{84} \mathrm{Cf}$. for an exceptional defence of gender equality in this period Siep Stuurman, François Poulain de la Barre and the Invention of Modern Equality (Cambridge, Mass.: Harvard University Press, 2004).

${ }_{55}^{8}$ Quoted in Herman Roodenburg, "Naar een etnografie van de vroegmoderne stad: De 'gebuyrten' in Leiden en Den Haag," in Peter te Boekhorst, Peter Burke and Willem Frijhoff, Cultuur en maatschappij in Nederland 1500-1850: Een historisch-antropologisch perspectief (Meppel etc: Boom, 1992), 219-243, 239: "goede vrede ende burgerlijcke eenigheyt". See also Ronald Sluijter and Ariadne Schmidt, "Sociale verhoudingen en maatschappelijke zorg," in Groenveld (ed.), Leiden, 109-125.

${ }_{86}$ Quoted in Paul Knevel, Burgers in het geweer. De schutterijen in Holland, 1550-1700 (Hilversum: Verloren, 1994), 216: "goede burgeren ende innewoonderen deser stede jegens alle overval, moetwille ende andersints."

${ }^{87}$ Ibidem, 189-190, 200-201. Cf. also the oath for new Leiden poorters quoted in Versprille, "Leidse poorterschap," 96.
} 
In the thought of the brothers De la Court, this urban reality of civic military service attains a distinctive Machiavellian dimension. Directly echoing Machiavelli's dismissal of mercenary armies, the De la Courts argue that "it is better to use in War one's own Subjects than foreign Soldiers". Foreign mercenaries "only serve for money and without love" and hence they do not fight to defend their own liberty, but only to indulge in licentiousness. ${ }^{88}$ With a reference to the same historical episodes as in Machiavelli, the De la Courts insist that "it is most advisable to instruct one's own people in arms, for they are loyal and willing to protect their own goods, wife, and children". ${ }^{89}$ Civic militias that fight in self-defence are therefore a crucial element of a successful commonwealth, for "truly, one becomes very strong when one dares to be his own Master and when the Inhabitants start to know the powers of a People that wants to fight for its Liberty"..$^{\circ 0}$ This assumption is modelled on the experience of a range of republican city-states that preserved their independence for centuries thanks to their arme proprie, from the German free imperial cities and the Swiss cantons to Dalmatian Ragusa and the town of Lucca. De la Court insists that the Dutch Republic also owed its independence from Spain to the patriotic struggle of its people, "especially many prudent Inhabitants, being in trade for years", who fought to safeguard their liberty and commercially attained riches. ${ }^{91}$

With this remark, De la Court establishes a direct connection between mercantile wealth and military civic duty. In line with contemporary practice, he argues that only the rich should be trained in the defence of the state, for they have something to loose and therefore will "serve loyally without payment to protect a lawful Government, as well as their beloved Freedom and all other private Goods, firmly against internal and external violence". The poor, in contrast, should only be allowed to enter

${ }^{88}$ Politike Discoursen I.III.18, p. 297: "Het is beeter sijn eige Onderdaanen, als vremde Krijgs-luiden, in den Oorlog te gebruiken ... vermits sy alleen om geld, en sonder liefde dienen." Cf. Niccoló Machiavelli, Il Principe, ed. Giorgio Inglese (Turin: Einaudi, 1995) XII.5-6, p. 79-8o: "Le mercenarie e ausiliarie sono utile e pericolose ... La cagione di questo è che le non hanno altro amore né altra cagione che le tenga in campo che un poco di stipendio." See also Idem, Discorsi I.43.

${ }_{89}$ Politike Discoursen I.II.31, p. 196: “... sijn eigen volk in waapenen te oeffenen is geraadsaamst: want die sijn getrou, en gewillig om haar eigen goed, bloed, wijf, en kinderen, te beschermen."

90 Aanwysing II.15, p. 370: "Voorwaar dus sterk werd men, als men sijn eigen Meester derfd weesen; ende wanneer de Inwoonders beginnen te kennen de kragten eens Volks dat voor sijne Vryheid vegten wil."

${ }^{91}$ Ibidem II.12, p. 333-334: “... als meede insonderheid veele voorsigtige van ouds koophandel drijvende Ingeseetenen.” 
the armed forces in times of war, at a small reward and under the command of "trustful rich Citizens as Officers" so as to prevent them from rebellion..$^{22}$ De la Court thus makes a crucial distinction on the basis of wealth between those who can be expected to defend the government in power, and the poor who should be kept under close control given their unreliability and seditiousness. This is an important move because it involves a direct repudiation of Pocock's interpretation of the early-modern republican tradition. For Pocock, militant virtù was intrinsically linked to landed property. He therefore suggested that it should not be surprising that, in his reading, "Pieter de la Court ... does not seem to have thought his description of a republic of trade called for any account of how the ownership of arms was related to the ownership of property". ${ }^{93}$ Yet as the material discussed here clearly indicates, De la Court did argue that because of their commercial riches, the wealthy in a republic of trade are competent to bear arms and to defend the country's liberty. However, this mercantile military service is fundamentally different from the Machiavellian expansionist virtù that Pocock assumed to be the paradigmatic republican case. For De la Court, merchants will only take up their arms in defence, never for the sake of territorial expansion. "We are by nature Merchants who cannot be turned into Military servants", so he proclaims: ${ }^{4}$ a citizen of a commercial republic will protect his liberty and wealth if necessary, but he always prefers profitable peace over costly war.

De la Court's claim that only the wealthy can be considered capable to serve in the civic militia and thus fulfil the prime civic duty of the defence of the commonwealth entails a significant restriction of the concept of citizenship in line with economic criteria. This restriction, by which not only women but also all dependent males are excluded from full citizenship, becomes particularly evident in the context of the ultimate characteristic of the true citizen, the right to partake in the political decision -making of the community. In a key passage of the Politike Weeg-schaal, revised after his brother's death, De la Court asserts that the governing

\footnotetext{
${ }^{92}$ Ibidem II.15, p. 377-378: “... souden de rijke Inwoonders sonder soldye getrouwelik dienen om eene wettige Regeeringe, neevens haare dierbaare Vryheid, en alle andere particuliere Goederen, standvastelik teegen in- en uitheems geweld te beschermen: de arme Ingesetenen soude men by Oorlogstijden in geringe soldye neemen, ende die dus de genegentheid, alsmeede de kragt om oproer te maaken beneemen konnen, als men haar geene dan vertrouwde rijke Borgers tot Officieren gaf."

93 Pocock, "Patriotism and Politeness," 8.

${ }_{94}$ Aanwysing II.4, p. 255: “... soo sijn wy van naatuuren Koopluiden, die in geene Krijgsknegten veranderd konnen werden."
} 
assembly in the ideal republican polity should consist of "all the Inhabitants of the Country who can be presumed to have sufficient power and knowledge to take care of their own welfare". This assertion implies that all those members of society who live in a condition of dependence cannot be considered capable to master and know themselves and therefore they should not participate in public politics. Women, children, and servants in a household who depend on the pater familias "should for lack of power be excluded ... since they have to pay obedience to their Parents, Husbands, Masters or Lords, and therefore they cannot vote freely". Moreover, newcomers who do not master the local language should equally be prevented from partaking in political debate since they lack "sufficient knowledge of the interest of the Republic" - an important limitation to the De la Courts' appeal for open citizenship..$^{95} \mathrm{~A}$ final category of persons who do not qualify as full citizens are those inhabitants who work for wages and rely on their masters for their income and reputation. Following the example of Venice, where the economically dependent were not included among the citizenry, ${ }^{96}$ De la Court emphasizes that

all dumb, deaf, infamous, and poor people who live of alms or in relief houses, should be excluded, as well as all others who have practised in a certain amount of time any craft or who have worked as day labourers in someone's service ... Since it must be presumed that this happened due to destitution, it must also be presumed that they lacked sufficient knowledge for government. ${ }^{97}$

In other words, De la Court viewed dependency as a sign of incapacity to govern oneself, and hence incapacity to govern the community. Public

${ }_{95}$ Politike Weeg-schaal III.III.5, p. 662: “... een Vergaaderinge, bestaande uit alle de Ingeseetenen des Lands, die gepresumeerd konnen werden magts en kennisse genoeg te hebben, om hun eigen welvaaren te versorgen ... Ten eersten, weegens gebrek van magt, moesten werden buiten geslooten, alle Onmondigen, Vrouwluiden, en Dieners, als aan haare Ouders, Eegade, en Meesters ofte Heeren gehoorsaamheid schuldig zijnde. En dienvolgende niet vryelik moogende stemmen. Ten tweeden, moesten werden buiten geslooten alle vreemdelingen die niet seekeren bepaalden tijd, noodig om genoegsaame kennise van het interest deeser Republike te verkrijgen, onder die regeering hadden gewoont."

${ }_{96}$ Ibidem II.IV.11, p. 417-418, with an overview of the population of Venice taken from Francesco Sansovino, Le cose meravigliose dell'inclita città di Venezia. Riformate, accomodate, e grandemente ampliate da Leonico Goldioni (1603, facs. ed. Napoli: Liguori, 2003).

${ }_{97}$ Ibidem III.III.5, p. 662-663: "Ten derden, moesten werden buiten geslooten, alle stommen, dooven, infamen, en arme luiden van aalmissen ofte in Godshuisen leevende als meede alle anderen, die binnen seekeren tijd van jaaren, eenig ambagt hadden gedaan, ofte om een dagloon gewrogt in iemands dienst, hoedanig die zoude mogen weesen; vermits het selven moet werden gepresumeert te geschieden, uit behoeftigheid; moet ook werden gepresumeert, de noodige kennisse tot de Regeeringe te ontbreeken." 
performance and active participation in political decision-making require the ability to speak freely and knowingly without any constraint, and this quality is unattainable for those in a condition of dependence. A central asset that distinguishes active citizens from their passive fellow residents is therefore the issue of proper speech, the rhetorical capacity to speak truthfully in public by mastering free republican parrhèsia. The implicit message that underlies the De la Courts' conception of citizenship is the suggestion that only those capable of performing the same rhetoric as they can be expected to speak frankly in public and thus pass the test of being a true citizen..$^{8}$ Those unable to speak the truth should be considered incapable of any political say. The assumption is that their voices are heard through their husbands and masters who represent their interests in public.

Autonomy, being one's own master and sui iuris, is for the De la Courts the key principle that enables men to enjoy their civic rights and perform their civic duties. All those who live in a condition of dependence women, children, servants, the poor, the destitute and the ignorant - cannot enjoy these rights, nor perform these duties, and therefore they are not considered full citizens. The brothers' conception of citizenship is relatively comprehensive for its criticism of Dutch exclusivist practice and its subsequent plea to abolish the existing juridical discrimination between full poorters and newly arrived citizens. Nonetheless, their idea of what constitutes a citizen remains within the narrow Aristotelian boundaries that dominated seventeenth-century theory and practice, even among 'radical' contemporary circles like the Levellers in England or the spinozists in the Dutch Republic. ${ }^{99}$ For instance, Van den Enden, Spinoza's Latin teacher, unequivocally equated citizens with independent males, ${ }^{100}$ while Spinoza employed the very same categories of exclusion as De la Court. ${ }^{101}$ For some historians this might be a reason to criticize

$9^{8}$ See for a more extensive discussion my "Mercury's Two Faces. Commercial Candour as the Key to Capability in the Dutch Golden Age," in Hartman et al. (eds.), Public Offices, Personal Demands, 150-173.

99 See the discussion of the Levellers in David Wootton, "Leveller Democracy and the Puritan Revolution," in Burns and Goldie (eds.), Cambridge History of Political Thought, 412-442: 429-434. On the practice of being an independent citizen, cf. Steven Shapin, $A$ Social History of Truth. Civility and Science in Seventeenth-Century England (Chicago and London: The University of Chicago Press, 1994), 355-407.

${ }_{100}$ Van den Enden, Kort Verhael, 50; and Idem, Vrije politijke stellingen, 179-180.

${ }^{101}$ Spinoza, Tractatus Politicus VI.11, VIII.14, and esp. XI.3-4, p. 442: “... peregrinos secludam, qui sub alterius imperio esse censentur ... mulieres et servos secluderem, qui in potestate virorum et dominorum, ac etiam liberos et pupillos, quamdiu sub potestate 
Spinoza for such a "moment of theoretical inconsistency" that would have impeded him from "putting democracy into practice", but this, needless to say, is a highly anachronistic (and thereby in itself inconsistent) criticism. ${ }^{102}$ Instead, it makes more sense to stress that seventeenth-century republicanism, unlike the modern idea of democracy, was not based on any concept of the intrinsic equality of all people, but only of the equality of all citizens. This fundamental difference should not be underestimated. It shows that it can be problematic to link Spinoza and the De la Courts directly to the "egalitarian tendency" that was to characterize later ages. ${ }^{103}$ Moreover, it reveals an important aspect of early-modern republican ideology that is often overlooked by its current advocates: for its emphasis on the active dominating citizen over the passive dominated individual might be particularly difficult to reconcile with the challenges of modern society. ${ }^{104}$

\section{The Ethics of SELF-INTEREST}

\section{The Two Guises of Self-Love: Eerzucht vs. Heerszucht}

To summarize, civil society originates through a contract between natural men, who thereby turn themselves into citizens and, as independent householders, serve in the defence of the commonwealth and participate in its government. Yet these citizens remain human, enslaved by the fundamental passion of self-love. Is there room for civic morality if citizens will always pursue their deepest instinct of self-preservation, even at the cost of others? This section analyzes the way in which the brothers De la Court tackle this fundamental question. Their moral thought, which involves a significant reinterpretation of Ciceronian ethics, embraces well-understood self-interest as the essence of civil behaviour.

parentum et tutorum sunt ... secluderentur qui ob crimen aut aliquod turpe vitae genus infames sunt." Cf. Jaap Kerkhoven, Spinoza's clausules aangaande uitsluiting van politieke rechten in hun maatschappelijke context. Mededelingen vanwege het Spinozahuis 63 (Delft: Eburon, 1991), esp. 4-5.

${ }^{102}$ Hans Bödeker, "Debating the respublica mixta: German and Dutch Political Discourses around 1700," in Van Gelderen and Skinner (eds.), Republicanism I, 219-246: 228.

${ }^{103}$ Cf. Israel, Radical Enlightenment, 22; and Idem, "Intellectual Origins," 8-9.

${ }^{104}$ On the aristocratic tendencies of early-modern republicanism, see John P. McCormick, Machiavellian Democracy (Cambridge: Cambridge University Press, 2011), 8-11. 
This account forms one of the main pillars of their anti-monarchical and largely secular appeal for the rule of law. ${ }^{105}$

As I have argued in the previous chapter, the brothers De la Court highlight the passionate nature of mankind, a position that merges the rhetorical emphasis on the role of the passions in human speech with Cartesian and Augustinian notions of the way in which our conduct is motivated by the passions. The approach of the De la Courts is particularly close to the contemporary emphasis in French Augustinianism on self-love as the prime human characteristic. Like Jean-François Senault's De l'usage des passions, they begin with the premise that self-love is "the largest and lengthiest Passion by which all People are to a small or large extent captured", ${ }^{106}$ it is "the true origin of all human actions, either good or evil". ${ }^{107}$ This assertion involves the further claim that this central passion of self-love appears in two different ways, either as a moderate virtue or as an excessive vice. Whereas an excess of self-love reveals itself in lust for power and licentiousness, "well-founded Self-love is the root of all laudable outward deeds", ${ }^{108}$ for such true self-love urges humans to preserve themselves and to take care for their nearest family and friends. Loving oneself in a sincere way opens the way to loving "lesser miserable People, out of consideration of common Humanity". Positive self-love thus leads to the love of one's neighbour and of the community of common citizens, the fatherland, and the entire human race:

Since it is necessary that Humans must love above all firstly themselves, and then the ones of their Home, and all the Inhabitants of the Fatherland because they are a part of it, yes that they also must love sincerely the strangest People like they love themselves and those of their Home ... therefore those People, who are in such a way their own Friends that they are at the same time Friends of all the world, are the ones whom God almighty will crown here or hereafter with his Blessing. For this is God's Will, the order of Nature. ${ }^{109}$

${ }^{105}$ This section builds upon my "From the Passion of Self-Love to the Virtue of SelfInterest: The Republican Morals of the Brothers De la Court,"European Review of History 17 , 1 (2010), 75-92.

${ }^{106}$ Sinryke Fabulen, 642: “... de Passien van al te groote Liefde die wy ons selven toe draagen, de aller-grootste ende de allerlangst duurende Passie is, waar meede alle Menschen meer ofte min bevangen zijn."

${ }^{107}$ Politike Weeg-schaal I.I.1, p. 13: " eigen liefde is de waaragtige oorsprong van alle menschelike, 't zy goede, 't zy quade actien."

${ }^{108}$ Welvaren 6, p. 13: “... welgegronde Eige liefde is de wortel van alle lofwaerdige uijterlijcke daden."

${ }^{109}$ Sinryke Fabulen, 130-131: "Ende eindelik aan mindere ellendige Menschen, uit ooverdenkinge der gemeene Menschelikheid ... Derhalven noodsaakelijk zijnde, dat de 
True self-love, in short, fulfils the divine ordainment of the human condition: a claim that distantly echoes Augustine's "brief and true definition of virtue" as "an order of love", by which "someone who loves God does not err in loving himself". ${ }^{10}$

This characterization of self-love as the basis of sociability and charity entails a fairly conventional Christian reading of stoic ethics, in particular of Cicero - a reading exemplified by Augustine, Senault and, in the seventeenth-century Dutch Republic, by Grotius." ${ }^{\text {II }}$ However, the brothers De la Court clearly depart from both the Grotian analysis of self-love and selfpreservation in terms of natural right and the Augustinian emphasis on divine grace to overcome amour-propre. Their differentiation between true and false self-love involves a distinctive rereading of Cicero that eventually amounts to a largely secular, republican interpretation of the diverse guises of passionate human behaviour.

The contours of this interpretation stem from the stoic repudiation of personal ambition in Cicero's De officiis, probably the most influential classical treatise in the early-modern period. ${ }^{112}$ For Cicero, ambition, defined as the desire for glory, was the human passion that most endangered the virtue of justice, for "the higher a man's ambition, the more easily he is tempted to acts of injustice by his desire for fame". Cicero maintained that such a desire for fame generally reveals itself in the desire to rule over others, the desire "for making oneself king even in the midst of a free people; and anything more atrocious or repulsive than such a passion cannot be conceived" ${ }^{113}$ In the Augustinian tradition, this categorical rejection of ambition was not primarily interpreted as a criticism of the lust for political power, but rather as an exposure of human sinfulness

Menschen voor allen eerst sig selfs, ende daar na die van haaren Huise, ende alle de Ingeseetenen haares Vaaderlands, om dat sy daar van een deel zijn, lief moeten hebben, jaa dat sy ook de allervreemdste Menschen ongeveinsdelik, gelijk sy sig selfs, ende die van haaren Huise beminnen, moeten lief hebben, naar geraade, dat yder van dien haar bestaat; Soo zijn die Menschen, welke soodanig haare eigene Vrienden zijn, dat sy met eenen Vrienden van alle de weereld blijven, die geene, welke God almagtig hier ofte hier naa, met sijnen Seegen kroonen sal. Want dit is Goodes Wil, ende by gevolge, de ordre der Natuure."

${ }^{110}$ Augustine, Van de stadt Godts, trans. Johannes Fenacolius, 5 vols. (Amsterdam, 1646) $\mathrm{XV.22}$, vol. IV, fol. 18: "... een korte en waerachtige beschrijvinghe des deuchts zy, namelijcke dat deselfde zy een ordre der liefde." Ibidem XIX.14, vol. V, fol. 18: “... die gene niet en doolt in het lief hebben van sich selven, die Godt lief heeft." Pieter de la Court van der Voort owned a copy of this Dutch translation of Augustine's De civitate Dei: Library, fol. 10.

${ }^{111}$ Cf. esp. Grotius, Commentary, Prolegomena, p. 21, 41.

${ }^{112}$ On the impact of Cicero's De officiis in seventeenth-century Europe, see Peter N. Miller, Defining the Common Good. Empire, Religion and Philosophy in Eighteenth-Century Britain (Cambridge: Cambridge University Press, 1994), 21-87.

${ }^{113}$ Cicero, De officiis, trans. Miller, I.XIX.65, p. 67; III.VIII.36, p. 303. 
when devoid of divine grace. As Senault argued evocatively, the "disordered affection" of amour-propre involves "the death of families, the ruin of States, and the loss of Religion ... For from this disordered Love originate three other loves that poison all souls and that banish all virtues from the earth: the first is the Love of Beauty, which is called Immoderation, the second is Love of Riches, which is called Avarice, and the third is Love of Glory, which is called Ambition". ${ }^{114}$ For Senault, immoderate love of oneself leads to the worship of false appearances instead of true adoration of God.

The brothers De la Court read Cicero's criticism of personal ambition in a different way by establishing a fundamental distinction between eerzucht, the desire for honour, and heerszucht, the desire to rule. This distinction comes down to the claim that sincere self-love causes people to want to be praised and admired. Although such desire for praise might seem nothing but vanity, "in fact it is a large incentive to speed diligently during the short and fragile life of Humanity to perform something laudable". ${ }^{115}$ The desire for honour drives people to fulfil their human potential in a way that does not harm others, thereby gaining esteem through which their self-love is gratified. True self-love as expressed in eerzucht therefore enables people to understand that they have to perform deeds by which they themselves and the rest of society have something to gain.

The De la Courts are acutely aware that such personal ambition can also corrupt, "for many People, driven by a wrong Desire for honour, otherwise called Imperiousness, desire to rise above those who are truly equal to them". ${ }^{16}$ Here the excess of self-love reveals itself, "the false self-love, and bad Desire for honour", which changes eerzucht, the incentive to be praised, into heerszucht, the ambition to rule. ${ }^{117}$ This Tacitean cupido

\footnotetext{
${ }^{114}$ Senault, De l'usage des passions, 235: "Je concluds donc, que cette affection desordonnée est la mort des familles, la ruine des Estats, \& la perte de la Religion ... Car de cet Amour desreglé, naissent trois autres amours, qui empoisonnent toutes les ames, \& qui bannissent toutes les vertus de la terre; Le premier est l'Amour de la Beauté, qu'on appelle Incontinence; Le second est l'Amour des Richesses, qu'on appele Avarice; Le troisiesme est l'Amour de la Gloire, qu'on appele Ambition."

${ }^{115}$ Sinryke Fabulen, 86-87: “... in der daad eene groote aanprikkeling, om geduurende het kort ende broos leeven der selven Menschen, sig met allen yver te spoeden, ietwes loofwaardigs te verrigten."

${ }^{116}$ Ibidem: “... om dat seer veele Menschen door eene verkeerde Eergierigheid, anders gesegt Heerssugt, gedreeven werdende, sig booven de geenen, die haar waarelik gelijk zijn, willen verheffen."

${ }^{117}$ Ibidem, 124: “... eene verkeerde eigen-selfs liefde, ende quaade Eergierigheid.”
} 
dominandi is not only "the most ardent of all our Passions", 18 it is also the most dangerous, since unlike true self-love, the lust for power necessarily jeopardizes others. Heerszucht is a characteristic of those who have become so powerful that they are exclusively lauded and never admonished and thus indulge in all the bodily lusts and other passionate excesses of human nature. Such people are in fact "so Bestial that they think that they are not connected to the common human society and esteem no one but themselves ... and also love no one else" ${ }^{119}$ This false form of self-love is especially characteristic to monarchs, whose relentless pursuit of power remains unchecked by any fear or discipline. Living "like wild men in statu naturali", virtually outside of the ordered civil society, they "do everything that they desire without minding praise or punishment" ${ }^{120}$ Accordingly, "the desire for honour, which is for all common men a very sharp incentive to all virtues, stimulates [these monarchs] to all the villainies concessa pudet ire via civemque videri, Lucan - that are forbidden for the Citizens". ${ }^{121}$ This revealing quote from Lucan's Pharsalia shows that for the De la Courts the figure of Caesar, the commonplace incarnation of tyranny, also embodies false self-love, the ruthless desire to rule. They consider false self-love to be essentially a monarchical passion, contrasted by the sincere republican ambition to be honoured by one's fellow citizens.

\section{Appropriating the Language of Interest}

The focus of this account of the political consequences of the passions is sharpened by the distinctly modern vocabulary that the De la Courts

${ }^{118}$ Ibidem, 385: “... dat de Heerssugt ofte Begeerte, om oover andere Menschen te heerssen, de vierigste van alle onse Herts togten is." The saying is a literal translation from Tacitus, Annals XV.53, p. 300: "cupido dominandi cunctis adfectibus flagrantior est", also quoted in slightly different versions in Politike Weeg-schaal, I.I.18, p. 98; I.III.1, p. 234; and Aanwysing, "Voor-reeden," sig. ${ }^{* * *} 2$.

${ }^{119}$ Ibidem, 131: “... Menschen, die soo Beestagtig zijn, dat sy meenende aan de gemeene menschelijke maatschappie niet verbonden te zijn, niemand dan sig selfs agten, ende by gevolge sig daar van af scheidende, oopenbaarelik voor niemand als voor haar eigen selfs sorgen, ende ook niemand anders lief hebben."

${ }_{120}$ Politike Discoursen II.VI.5, p. 184: "Ten is dan niet vreemd indien de Vorsten, en andere Overheeden, of seer Magtigen, deese vreese ontwassen zijnde, ende gelijk als wilde menschen in statu naturali, of puris naturalibus, alles doen wat hun lust, sonder op lof, of straf, te passen."

${ }^{121}$ Ibidem II.V.11, p. 146: "Jaa dat meer is, den Souveraine Heeren ontbreekt niet alleen dese toom, om haar van de ondeugd te wederhouden; maar de eergierigheid, die den gemeene menschen een seer scherp prikkel tot alle deugden is, prikkel haar tot alle schelm-stukken, concessa pudet ire via, civemque videri, Lucan., die den Borgers verbooden zijn." The quote is from Lucan, Pharsalia II, v. 446. 
employ to characterize human self-love, either true or false: the vocabulary of 'interest'. The use of 'interest' as a political and moral concept originated in the Ricordi of the Florentine republican Francesco Guicciardini, written around 1530 and first published in 1576. Guicciardini argued that human nature is essentially selfish, yet as long as this egotism encourages people to maintain their honour and perform laudable deeds, it can be justifiable. Confronted with the question of how individual gains can be reconciled with the common good, Guicciardini asserted that searching for one's self-interest is positive as long as it pursues aristocratic honour instead of pecuniary advantage as a means to further the public interest. ${ }^{122}$ Guicciardini mainatined that such an interesse dello stato or general interest of the state exists, in particular in international affairs. The relations between different polities, like the intersubjective behaviour of self-interested individuals, can be explained trough a rational calculation of every state's needs and priorities. ${ }^{123}$

This language of interesse, or as it soon was to be called, ragion di stato became widely diffused in late sixteenth-century Italy and subsequently spread over the rest of Europe. ${ }^{124}$ Yet from the outset, it was a highly ambiguous language. As in Montaigne, it contained a strong tension between the notion of "l'interest commun", or the common good, and the notion of "l'interest et passion privée", the disruptive passion of selflove. ${ }^{125}$ This tension, overlooked by Albert Hirschmann in his classic The Passions and the Interests, would characterize the use of the term

${ }^{122}$ Cf. Francesco Guicciardini, Ricordi, ed. Emilio Pasquini (Milan: Garzanti, 1999), 218, p. 254: "Quegli uomini conducono bene le cose loro in questo mondo, che hanno sempre innanzi agli occhi lo interesse proprio, e tutte le azione sue misurano con questo fine. Ma la fallacia è in quegli che non conoscono bene quale sia lo interesse sua, cioè che reputano che sempre consista in qualche comodo pecuniario più che nell'onore, nel sapere mantenersi la riputazione e il buono nome."

${ }^{123}$ For an analysis of the language of 'interest' in Guicciardini and in subsequent natural law theory, see the highly informative article by Lionel A. McKenzie, "Natural Right and the Emergence of the Idea of Interest in Early Modern Political Thought: Francesco Guicciardini and Jean de Silhon," History of European Ideas 2, 4 (1981), 277-298. For Guicciardini's political thought in general, see Viroli, From Politics to Reason of State, 178-200.

${ }^{124}$ For lucid overviews of the emergence and spread of the language of 'interest' and reason of state, see Tuck, Philosophy and Government, 38-119; Viroli, From Politics to Reason of State, 238-280; and for the later seventeenth and eighteenth century, Pierre Force, SelfInterest Before Adam Smith. A Genealogy of Economic Science (Cambridge: Cambridge University Press, 2003).

${ }^{125}$ Michel de Montaigne, Les Essais, ed. Jean Balsamo et al. ([Paris]: Gallimard, 2007) III.1, p. 833, 843 . 
throughout the seventeenth century. ${ }^{126}$ In some writings of the reason of state tradition, 'interest' was equated with the indisputably main concern of a polity, independent of personal opinion or the character of the sovereign. This most roaring and resounding phrasing of this view came in the motto of the Duke of Rohan's De l'interest des princes et des etats de la chrestienté (1639), which exclaimed that "Les Princes commandent aux peuples, et l'interest commande aux Princes", for "Le Prince se peut tromper, son Conseil peut estre corrompu; mais l'interest seul ne peut jamais manquer" ${ }^{127}$ However, not all seventeenth-century authors were so emphatic about the positively unfailing character of interest. For a sceptical Tacitist like Virgilio Malvezzi, who wrote in the same years as Rohan, it should rather "be noted that men will always be more moved by private interest then by public utility" and thus, to their own disadvantage, even prefer to be "a slave and rich then to be poor and free". ${ }^{28}$

By employing the language of 'interest', the brothers De la Court position their writings in this many-sided approach to the connections between self-interested personal behaviour and the needs and concerns of statecraft. Their use of the concept entails a double move that aptly reveals the ambiguities that characterized the term. First of all, the De la Courts appropriate the abovementioned phrase of the Duke of Rohan to claim that there exists a normative common interest such as the interest of Holland', a general political standard that can be scrutinized empirically. Given that "all Peoples of Europe, like the Spanish, the Italians and

${ }^{126}$ Albert O. Hirschmann, The Passions and the Interests. Political Arguments for Capitalism before its Triumph (Princeton: Princeton University Press, 1977). Hirschmann maintains that 'interest' as a concept arose in opposition to the predominant view on the passions, as a countervailing tamer of man's unruly passionate behaviour. However, this interpretation is too narrow, for it overlooks the seventeenth-century notion of 'interest' as a fashionable designation of human self-love, the major human passion. Cf. Force, SelfInterest, 142-144; and Ernst Wolfgang Orth "Interesse," in Geschichtliche Grundbegriffe, vol. III, 305-365: 319-320, with evidence of 'interest' used as a synonym for either proprio amor (Ignatius de Loyola), l'amour naturel de soi-même (Fénelon), or l'âme de l'amour propre (La Rochefoucauld).

${ }^{127}$ Henri de Rohan, De l'interest des princes et Estats de la Chrestienté, in [Rohan], Le parfait Capitane ... augmenté d'un traicté: de l'interest des princes et Estats de la Chrestienté ([Leiden], 1648), 100-101. See also J.H.M. Salmon, "Rohan and Interest of State," in Roman Schnur (ed.), Staatsräson. Studien zur Geschichte eines politischen Begriffs (Berlin: Duncker \& Humblot, 1975), 121-140.

${ }_{128}$ Virgilio Malvezzi, Discorsi sopra Cornelio Tacito (Venice, 1635), 91: "E quì è da notare, che gli huomini si muoveranno sempre più per privato interesse, che per publica utilità: $\mathrm{e}$ che ogn'uno ha più caro d'esser servo, e ricco, che povero, e libero." Pieter de la Court van der Voort owned this edition: Library, fol. 19. For Malvezzi's life and works, see Rodolfo Brändli, Virgilio Malvezzi. Politico e moralista (PhD thesis Basel, 1964). 
the French, express this thing with the word Interest", De la Court assumes that this remarkable linguistic agreement proves the universal validity of the concept. ${ }^{129}$ Such an analysis of politics in terms of interest, originally a commercial term, implies that political behaviour is somehow comparable to commercial exchanges that follow the laws of predictability. ${ }^{130}$ Perhaps the most insistent example of this attitude came from the sharp, chameleonic pen of the English pamphleteer Marchamont Nedham, whose short 1659 treatise Interest will not Lie opens with the claim:

That if you can apprehend wherein a man's Interest to any particular Game on foot doth consist, you may surely know, if the man be prudent, whereabout to have him, that is, how to judge of his designe: For, which way soever you foresee his Interest doth in prudence dispose him, that way (provided he be so wise as to understand his own Concernment) he will be sure to go, and so his Interest (provided also, that in your calculation thereof you be not mistaken) will not lie to you, it will not deceive you in your judgement concerning the mans Intents and Proceedings. ${ }^{1{ }^{11}}$

Accordingly, this first use of the vocabulary of interest involves the pretension that it is possible to achieve certain, calculable knowledge of politics and morals.

On the other hand, the De la Courts also adopt the second meaning of the term, the assertion that the unsettling passion of self-love expresses itself primarily in the desire to further one's self-interest at the cost of the common good. They frequently employ typical proverbs from Italian scepticist reason of state, like Il proprio interesse è una grande bestia, che comanda a tutti and Piú pesa una oncia d'util proprio, che cento libre di stato, to confirm this point: ${ }^{12}$ for "who would bring water to his

${ }^{129}$ Aanwysing I.1, p. 1: "En dewijl meest alle Volkeren van Europa, als Spanjaarden, Italianen en Francoisen, deese saak uitdrukken met den woorde Interest."

${ }^{130}$ See McKenzie, "Natural Right," 279, 294, note 1. For 'interest' as a commercial term, see e.g. Politike Weeg-schaal I.IV.2, p. 297; II.IV.10-11; III.II.4, p. 621; III.III.2, p. 651.

${ }_{131}$ Marchamont Nedham, Interest will not Lie. Or, A View of England's True Interest (London, 1659), 3. On Nedham, see esp. Blair Worden, "Marchamont Nedham and the Beginnings of English Republicanism, 1649-1656," in Wootton (ed.), Republicanism; 45-81; Idem, Literature and Politics in Cromwellian England. John Milton, Andrew Marvell, Marchamont Nedham (Oxford: Oxford University Press, 2007); and Rahe, Against Throne and Altar, 179-244. More on the language of 'interest' in seventeenth-century England in J.A.W. Gunn, “'Interest Will Not Lie': A Seventeenth-Century Political Maxim,” Journal of the History of Ideas 29, 4 (1968), 551-564.

${ }^{132}$ E.g. in Welvaren, p. 119, 138. Cf. on this language of interest in early-modern republican Lucca, Peter N. Miller, "Stoics Who Sing: Lessons in Citizenship from Early Modern Lucca," The Historical Journal 44 (2001), 313-339. For the appropriation of this language in the Dutch political debate, see Tieranny van eigenbaat (1679). Toneel als wapen tegen Oranje, ed. Tanja Holzhey and Kornee van der Haven (Zoeterwoude: Astraea, 2008). 
neighbour's house when his own is on fire", when it is also possible "to set another's house to fire to warm oneself by its coals"? ${ }^{133}$ In the development of the brothers' œuvre, this second usage of 'interest' increasingly replaces the term 'self-love'. Eventually this development results in the claim that "Self-Interest is the most prominent, if not the only, objective of all human deeds", and that "the inclination to hunt for one's own Interest ... is typical of Humanity, and therefore it can and will last for eternity" ${ }^{134}$ The work of the brothers De la Court is thus characterized by the same tension that pervaded the general use of the language of 'interest' throughout the seventeenth century: human behaviour is dominated by the unruly passion of self-interest, often without regard for the common good, yet at the same time society at large has one general interest that is independent of the whims of personal human conduct.

The core of the moral thought of the brothers De la Court involves an attempt to alleviate this very tension. ${ }^{135}$ At the basis of this attempt lies their reappraisal of Ciceronian ambition as the true, sincere form of selflove, the desire to be praised by one's fellow citizens for the performance of laudable deeds. This characterization leads to the acknowledgment that self-interest does not necessarily run counter to the common good: as Guicciardini had argued before, the desire for honour is justifiable if it brings about behaviour that serves society at large. This form of self-interest involves the ability to connect "private advantage wisely with the common welfare", the ability to understand how individual gains can be linked to the public good. ${ }^{136}$ As such it is the direct opposite of "self-interest wrongly understood", ${ }^{137}$ the pursuit of self-love without attention to the

${ }_{133}$ Politike Weeg-schaal I.I.1, p. 15: "Een ander mans huis aan brand steeken om sig by te koolen te warmen." II.I.4, p. 325: “(piu pesa un oncia d'util proprio, che cento libre di stato) wie brengd water aan zijn buyrmans huis als eigen in brand staat?" III.III.1, p. 639: "Niemand hinkt van het seer eens ander mans, in wiens oore is te snijden als in een vilthoed, en wiens huis men ligtelik aan brande steekt, als men sig by de koolen sal konnen warmen."

${ }^{134}$ Sinryke Fabulen, 192: “... Eigen-Interest is het voornaamste, indien niet eenigste oogwit aller menschelike uitwerkingen.” Ibidem, 441: “... de geneegenheid om sijn eigen Interest te bejaagen ... aan den Menschen eigen is, ende dienvolgende in der eewigheid duuren kan, ofte sal." Cf. the similar usage of the term in Aitzema, Historie of verhael, vol. III, 841: “... zijnde natuerlick dat een yeder jaeght en janckt na 't geen hy bemindt, ende een yeder bemindt zijn interest."

${ }^{135}$ Cf. for a more extensive analysis with some different accents: Blom, Morality and Causality, esp. 174-180; and Idem, "Burger en Belang."

${ }^{136}$ Politike Discoursen II.IV.7, p. 50: "Ende dat eigen voordeel, dus wyselik met het gemeen welvaaren verknogt zijnde.”

${ }_{137}$ Sinryke fabulen, 126: “... een verkeerd begreepen eigen Inter-esse.” Cf. Harvey C. Mansfield, "Self-Interest Rightly Understood," Political Theory 23, 1 (1995), 48-66. 
general interest. A proper acknowledgment of the connection between personal advantage and the common good implies that self-interest as the defining characteristic of human behaviour can be reconciled with the indisputable interest of society at large.

This doctrine of well-understood self-interest entails a crucial departure from the classical view that the quest for personal advantage should be subordinated to the common good. As, for example, Senault insisted, "Justice requires that a good Citizen prefers the public interest over the one of his house ... When Self-love only induces a man to work for his pleasure or for his glory, it constitutes the end of all his actions". ${ }^{138}$ Yet for the brothers De la Court, the pursuit of glory does not necessarily entail the demise of civic virtue. Given the predominance of the passion of selflove, this is in fact the only way to achieve any form of virtuous behaviour. According to their logic, an individual who subordinates his personal interest unconditionally to the common good is a mere chimera. For "who can be his guarantee that he will remain steady in his virtue and not fall into vice?"139 Someone who pretends to search for the public interest without regard for his personal advantage should not be trusted, for such a pretension merely reveals that he has misunderstood his self-interest - and thus is enslaved by the worst of all passions, the desire to rule. By contrast, "the virtue of an Honest man and of a Good Politician entails that he prudently connects his own advantage to the Common one. And this is quite doable, for the path of Virtue is not so unfruitful for the Politicians as has been wailed sometimes". ${ }^{140}$ The brothers De la Court see no reason to be overly sceptical about the political consequences of the human condition, as long as the key passion of self-love manifests itself as the virtue of selfinterest well-understood.

\section{The Politics of the Passions}

The crucial means to overcome the corruptive potential of the passion of self-love lies in the disciplinary framework that is established with the creation of civil society. As the argument of the De la Courts goes:

\footnotetext{
${ }^{138}$ Senault, De l'usage des passions, 232-233: “La Justice veut qu'un bon Citoyen prefere l'interest public à celuy de sa maison ... Cependant l'Amour propre ne fait travailler un homme, que pur son plaisir ou pour sa gloire, il le constitüe la fin de toutes ses actions."

${ }^{139}$ Politike Discoursen I.II.5, p. 105-106: "Wie kan sijn borge zijn, dat hy daar in bestendig sal blijven, ende niet tot ondeugd sal vervallen?"

${ }_{140}$ Welvaren 61, p. 141: "En voorwaer hier in bestaet de deughd van een Eerlijck man en van een Goed Politijck, dat hij voorsightighlijck sijn eigen voordeel aen 't Gemeen koppelt. En het is wel doenelijck, want de wegh des Deughds soo onvrughtbaer niet en is voor de Politijcquen, als sij wel werd uijtgekreten."
} 
If all Citizenship and Assembly would not be generated and caused by mutual fear, then Man would, like Children, desire to obtain anything that he likes or that pleases him. So he refrains from doing that, not paying for his lusts, through the fear that Discipline and Reason install in him. ${ }^{141}$

The bridle of discipline, the fear for punishment that regulates a wellordered civil society, thus ensures that the passions intrinsic to human nature are harnessed towards a useful civic purpose. This reformation of manners relies in particular on two central disciplinary factors, education and the rule of law. One of the primary aims of the brothers De la Courts is to demonstrate that in the absence of such a disciplinary framework, that is, in a monarchy, the consequences are disastrous. Meanwhile, their embrace of disciplined civic behaviour involves a distinctive secular appeal for mercantile moderation as the key characteristic of the true citizen.

First of all, the brothers De la Court insist that the passions that define human nature should be disciplined by good civic instruction. This means that parents teach their children "not only to improve through their own experience their passions and judgment, but also to increase that experience wonderfully through studies and knowledge of various Languages and old Histories, and to let them live with all the earlier centuries and far-away Countries". ${ }^{142}$ This typically humanist educational precept, combining historical knowledge with practical experience, leads to knowledge of oneself and the world at large, and thus it teaches people how to take care for themselves without harming others. Yet such civic teaching is not alone sufficient to create true, sincere self-love. Human nature is capricious, and even those who have been raised in virtue may become haughty, pretentious and imperious when praised by others. A further disciplinary means is therefore necessary to counter excessive self-love. This is the corrective framework of the rule of law. In the De la Courts' secular Augustinianism with Hobbesian undertones, human nature always tends to evil unless it is moderated by the rule of law. Hence, "all the laws of a State should be made thus, as if all men were evil, since they will

\footnotetext{
${ }^{141}$ Politike Discoursen II.VI.5, p. 182: "Indien niet alle Burgerschap, en Vergadering, door onderlinge vreese veroorsaakt, en by een gebragt wierd; soo soude de Mensch gelijk de Kinderen, alles wat hem aanstond, of lusten mogte, begeeren te verkrygen; sulks hy sijn lusten niet boetende, het selven naa-laat door de vreese die de Tugt, en de Reeden in hem heeft gebragt."

${ }^{142}$ Politike Weeg-schaal III.I.5, p. 537-538: "Jaa niet alleen door eige ervarentheit haare passien en oordeel te beteren, maar ook door de studien, en kennisse van verscheide Talen, en oude Historien, die ervarentheit wonderlik te vergrooten, en haar te doen leeven met alle de voorgaande eeuwen, en verre-afgelege Landen."
} 


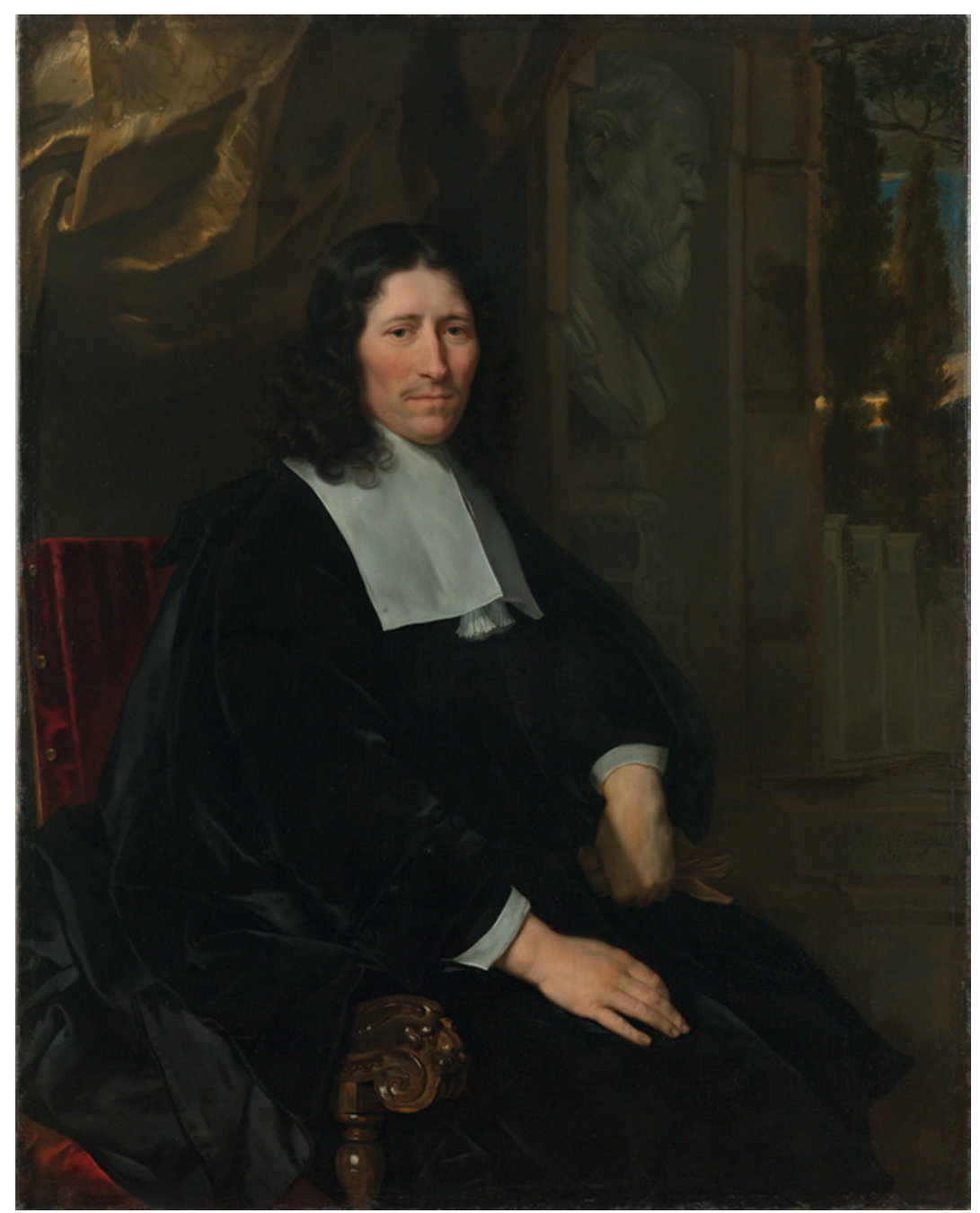

Plate A. Abraham van den Tempel, Pieter de la Court, 1667. Collection Rijksmuseum, Amsterdam. Acquisition with support of the Vereniging Rembrandt. 


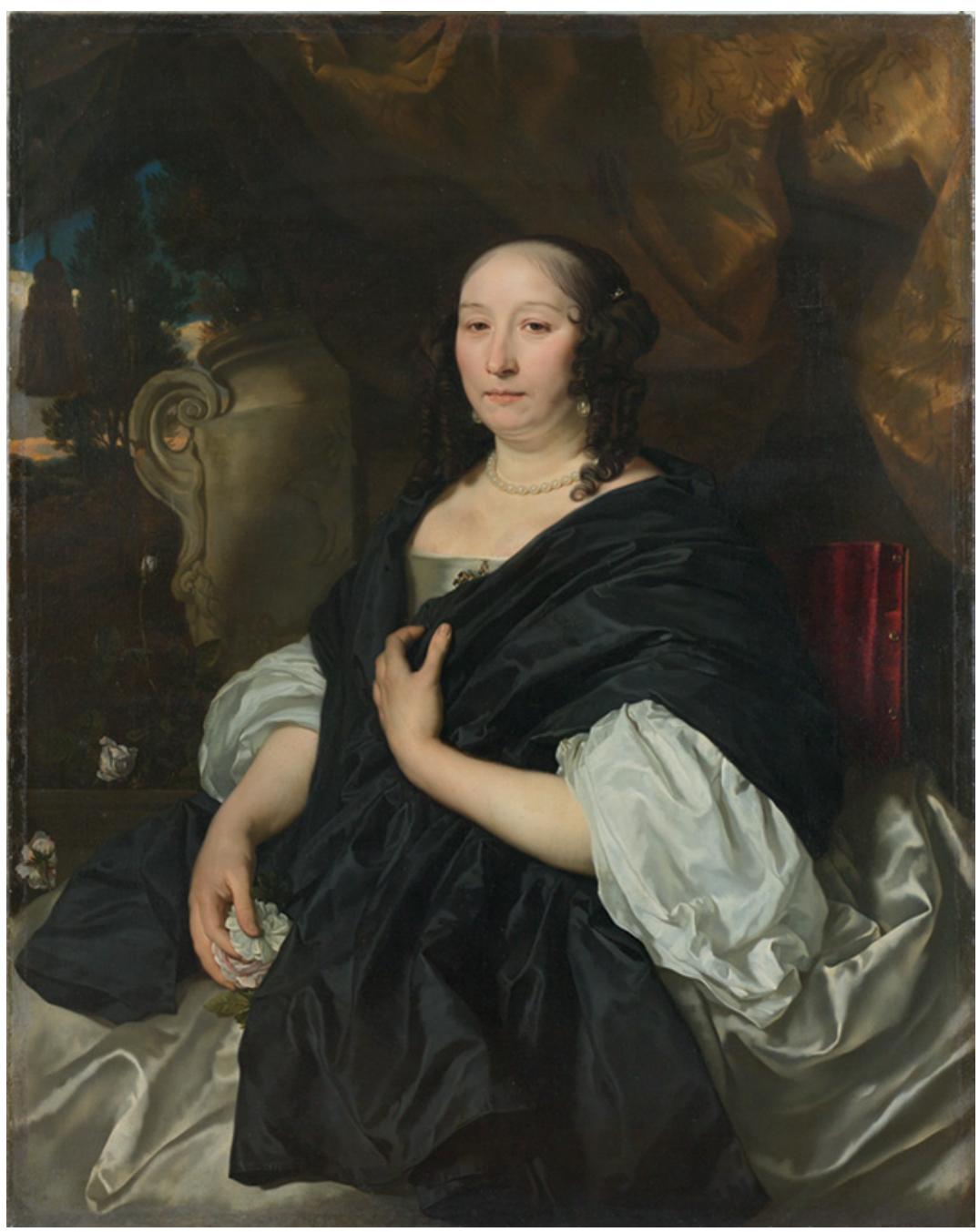

Plate B. Abraham van den Tempel, Catharina van der Voort, 1667. Collection Rijksmuseum, Amsterdam. Acquisition with support of the Vereniging Rembrandt. 


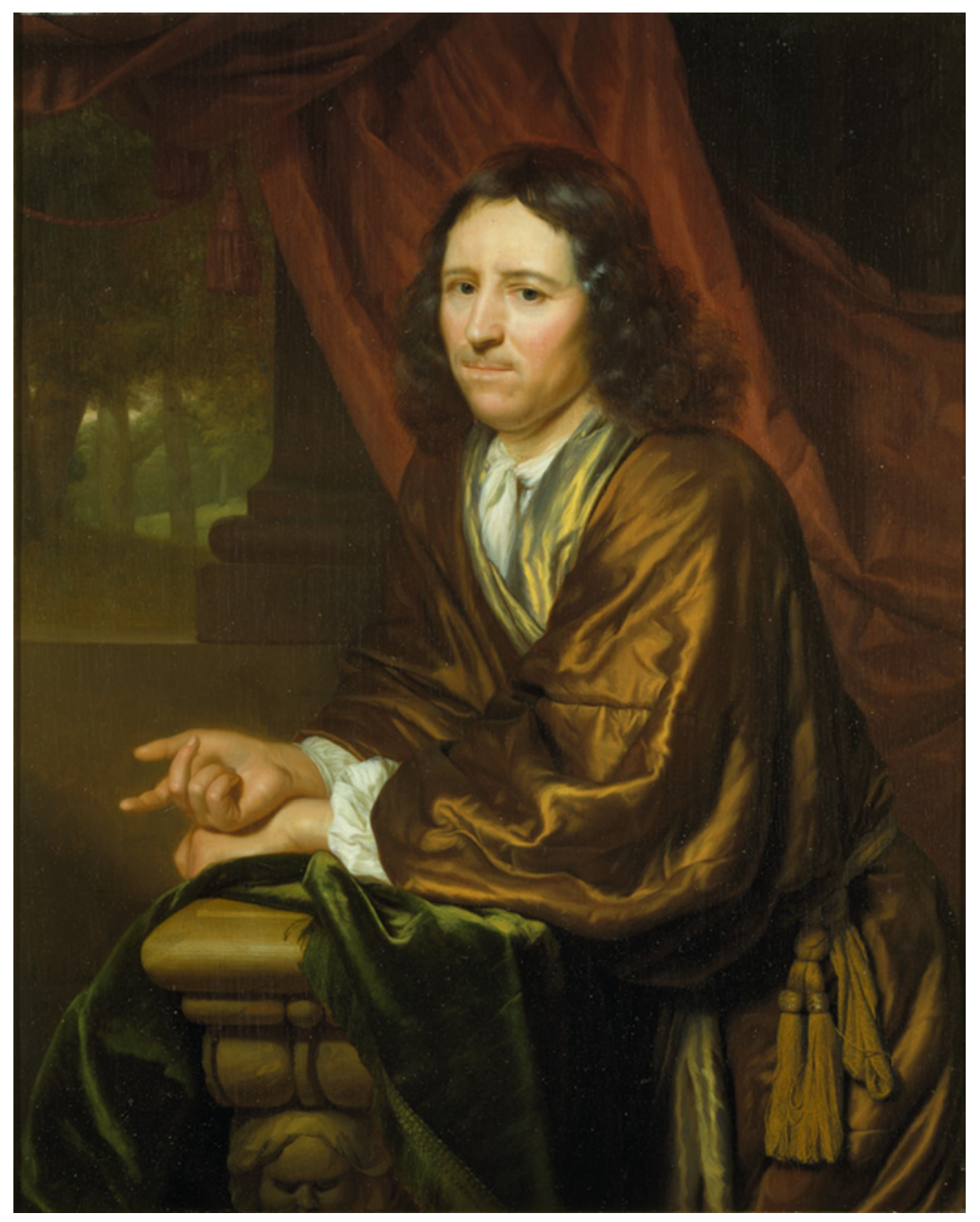

Plate C. Godfried Schalcken, Pieter de la Court, 1679. Museum de Lakenhal, Leiden. 


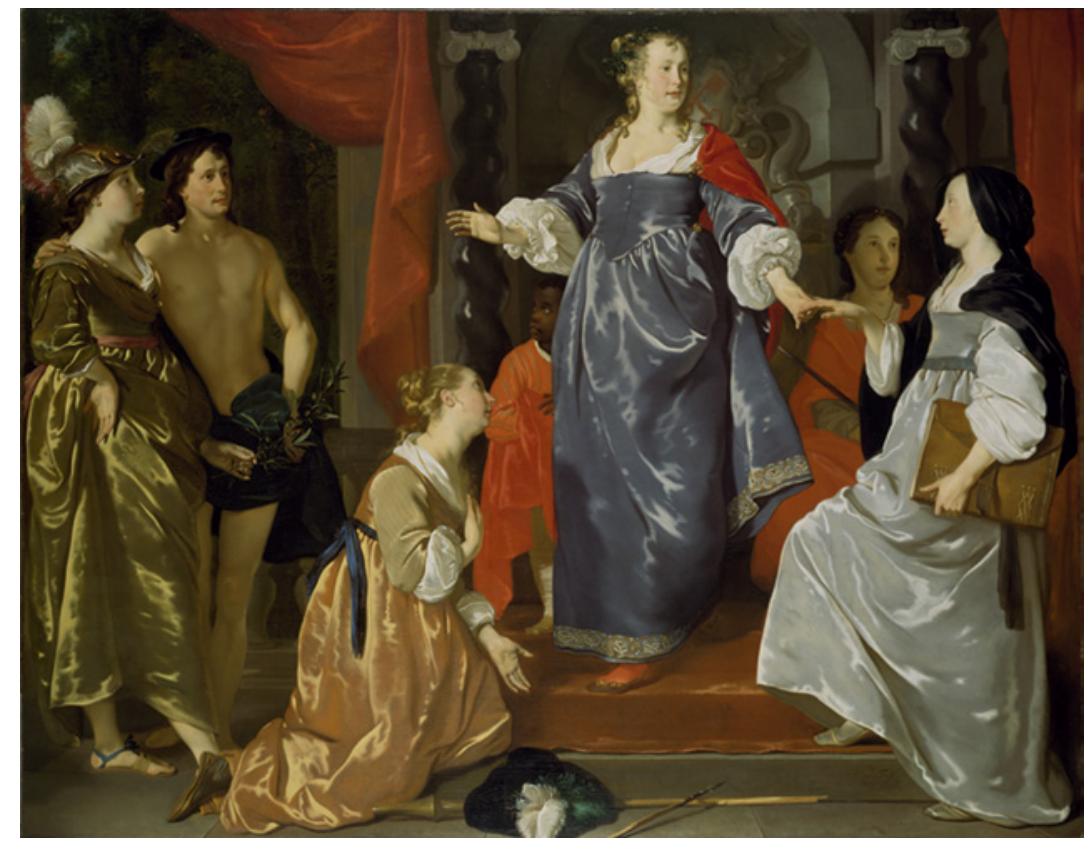

Plate D. Abraham van den Tempel, The City of Leiden Receives the Textile Industry, 1651. Museum de Lakenhal, Leiden. 
indeed become evil, at least for the largest part, unless they are restrained by the fear for punishment. And therefore the saying goes: La fame \& la povertà fa gli homini [sic] industriosi \& le leggi gli fanno boni". ${ }^{43}$ This Machiavellian phrase makes clear that without the rule of law, the passions that define human nature can never be harnessed towards a virtuous purpose. In the absence of education and disciplinary laws, the human condition reveals its most ardent and most dangerous characteristic: the desire for domination.

The republican logic of the brothers De la Court presents the pernicious life at a monarchical court as the exemplary locus where such undisciplined conduct thrives. Princes and courtiers, who have not grown up amongst equals, have never experienced the temperance of "knowledge with knowledge, or passion with passion". Therefore they have never learned "that they are human". Instead, being the victim of the envy and distrust of their parents and competitors, princes and courtiers have been educated in such a way "that all good knowledge and virtues are extinguished in them, and at the contrary all ignorance and vice as much as possible cultivated". This is the reason that the "children of Monarchs" who are about to ascend to supremacy (the allusion to the young Prince of Orange is clear) indulge in "childish ostentation" and all kinds of bodily lusts. ${ }^{144}$ The De la Courts appropriate numerous sources to prove this assumption, from a range of disenchanted sententiae taken from Tacitus's description of Tiberius and his adopted son Germanicus, to a critical version of Philippe de Commines's judgment on Louis XI, and finally, an adaptation of the anti-monarchical satire of the prime contemporary Tacitist, Boccalini. ${ }^{145}$ In revising the Politike Weeg-schaal, De la Court

${ }^{143}$ Politike Discoursen II.VI.20, p. 252: "Ende dien volgende soo is ook klaar dat alle wetten van een Staat soodanig behoorden gemaakt te zijn, als of alle menschen boos-aardig waaren, dewijl sy inder daad boosaardig staan te werden, ten minsten voor het meeste gedeelte, ten zy sy door de vreese van straf, werden weederhouden. En daarom segt het spreek-woord: La fame \& la povertà, fa gli homini industriosi, \& le leggi gli fanno boni." The phrase is from Machiavelli, Discorsi I.3, p. 16.

${ }^{144}$ Politike Weeg-schaal I.I.12, p. 57: “... in hare kindsheid nooit omgaan met kinderen haars gelijk, die zonder geveinstheid, kennisse met kennisse, ofte passie, met passie, opscharpende ofte tegengaande haar zouden leeren dat zy menschen zijn ... dat alle goede kennisse en deugden in haar werden uitgebluscht, en ter contrarie alle onweetenheid en ondeugt, zoo veel mogelik aangequeeckt ... En waar om de kinderen der Monarchen, voorneementlik dien de Hoogheid booven 't hoofd hangt, zig dus vermaaken met kinderlike pronkery."

${ }^{145}$ Ibidem, 57-64, quoting e.g. Tacitus, Annals II.42 an II.82; a passage in translation from Philippe de Commines, Mémoires (1524-28, published in Leiden by Elzevier in 1648), and a fable from Boccalini's Ragguagli, vol. I., ragg. 56, p. 203-204. 
included yet another, less obvious source to substantiate his claims: the Histoire du Roy Henry le Grand by Hardouin de Péréfixe, the former tutor of Louis XIV, published by Elzevier in 1661 when the king took over governmental powers after the death of Mazarin. This work was essentially a mirror of princes in the form of a historical tract that praised the rule of Henry IV, but De la Court deployed it as an insider's account that revealed the baseness of monarchical education. ${ }^{146}$

The second means to harness true self-love, discipline by the rule of law, is equally absent at a royal court. The brothers De la Court insist that the fundamental mistake of the adherents of monarchy is their assumption that kings will be more virtuous than other mortals, though they are merely all too human. This claim is again illustrated by the sententiae of Tacitus and Lucan. ${ }^{147}$ "Living above all Laws and political orders", kings will always follow their passions instead of reason, not bridled by any disciplining. ${ }^{148}$ They do instil fear among their subjects, but of the wrong kind, since it makes people afraid of uttering the truth and instead conduces them to indulge in sycophancy. Subjected to the dissimulative speech of courtiers who change their vices into virtues, kings will in fact lead the unhappiest life, destitute of true Ciceronian amicitia and "living without hearing truth or seeing Friends". ${ }^{49}$ Again, in his revision of the Politike Weeg-schaal De la Court employed a typical mirror of princes as incontestable evidence for this statement: the Idea de un príncipe politico christiano by the Spanish diplomat Fajardo. Fajardo warned his royal audience for the ministers who keep the king "diverted with songs and entertainments, intending to occupy his ears while the murmurings and the voices of truth and exposure cannot enter". ${ }^{\circ}$ All such

${ }^{146}$ Ibidem, 59-62, 66-69, with a translation and a long quote in French from Hardouin de Péréfixe, Histoire du Roy Henry le Grand (Amsterdam: Elzevier, 1661), 458-461, 513-517. The library of Pieter de la Court van der Voort had a copy of this edition: Library, fol. $3^{2}$.

${ }^{147}$ Ibidem I.I.10, p. 47, quoting from Lucan, Pharsalia VIII, v. 452: "Nil pudet adsuetos sceptris" and Tacitus, Annals II.42: "Regibus aequa, nedum infima insolita sunt."

${ }^{148}$ Ibidem I.II.1, p. 172: “... dat de Monarchen boven alle Wetten en politike ordren zijnde, moeten werden geconsidereerd altijds hare passien en driften des bloeds, schoon genoomen die klaarelik ten verderve hunner Onderdaanen strekken, te zullen involgen."

${ }^{149}$ Ibidem I.I.21, p. 105: "De beste geboore Heeren zijn ongelukkige menschen, en Regeerders; levende zonder waarheid te hooren, ofte Vrienden te zien."

${ }^{150}$ Ibidem, 108-110, quoting from Fajardo, Idea principis christiano-politici, symb. XIII. I have used the contemporary Spanish edition: Idea de un príncipe politico christiano representada en cien empresas (Amsterdam, 1661), 116: “... le traen divertido con músicas, y entretenimientos, procurando tener ocupadas sus orejas, sin que puedan entrar por ellas los susurros de la murmuración y las vozes de la verdad, y del desengaño." For an analysis of this passage see Romanoski, Tacitus Emblematicus, 409-412. 
dissimulation necessarily results in the corruption that is intrinsic to life at court where the worst of human passions thrive - a claim based on yet another insider's account of courtly behaviour, the Traicté de la Cour, ou instructions des courtesans by the French diplomat Eustache du Refuge, first published in 1616 and again by Elzevier in several editions in the 1640s and 1650 s. $^{15^{1}}$ This manual for courtiers was meant to instruct its readers how to comply with the conventions at court, paying ample attention to the importance of speech, the uses of flattery and how to moderate the passions. ${ }^{15^{2}}$ Yet the De la Courts merely employ it for its statement "que la Cour est une grande Putain, laquelle corompt [sic] le plus entiers et le plus chastes" - a phrase quoted repeatedly (and with noticeable gusto) throughout the brothers' works. ${ }^{153}$ They thus turn a warning to courtiers into a fundamental critique of courtiers, which entails an obvious rhetorical move: if even the insiders of monarchical life such as Péréfixe, Fajardo, and Du Refuge maintain that the court corrupts, then no adherent of the monarchical principle can possibly refute this claim.

In this way, the brothers De la Court employ numerous sources from the inner circles of the European royal courts to argue that under monarchical rule the passions intrinsic to the human condition will necessarily corrupt true human self-love. They stress empathically that all the passionate defects of a monarch "as far as he is Human" will not only spread among those at his court, but also among all his subjects. ${ }^{154}$ The result is that especially "in old absolutist Monarchies, public shame is not at all bothered about, and self-interest is absolutely shamelessly pursued ...

${ }^{151}$ Elzevier published three Latin editions of the second part of the work in 1642, 1644 and 1649, and a French version in 1656: Eustache du Refuge, Traicté de la Cour, ou instruction des courtisans (Amsterdam, 1656). For the influence of this treatise on English views on courtly conduct and civility, see Markku Peltonen, The Duel in Early Modern England. Civility, Politeness and Honour (Cambridge: Cambridge University Press, 2003), 28-31.

${ }^{152}$ See Du Refuge, Traicté I.II-V, p. 15-17 (on courtly 'civilité' and 'affabilité'), I.XXXIV, p. 149-156, II.VI-VII, p. 193-201, II.XII, p. 224-228 (on dissimulation and flattery), I.XIIIXXVI, p. 44-117 (on how the passions "aveuglent du tout nostre entendement" and on the "Usage de la cognoissance des passions, \& les moyens de les moderer, en nous, \& en autruy").

${ }^{153}$ Ibidem II.V p. 189, quoted in Politike Weeg-schaal I.I.21, p. 110; I.I.27, p. 132 ("te Hoof, in dat Groot Bordeel"); Politike Discoursen II.V.12, p. 150 ("het Hof, sijnde een groote hoer"); and Sinryke Fabulen, 194.

${ }_{154}$ Politike Weeg-schaal I.I.14, p. 82: "Eindelik is onder Monarchale regeeringen een zeer groot quaat, dat de gebreeken des Souverains, voor zo veel hy een Mensch is, terstont werden naargevolgt van zijn Hovelingen, en van daar zig over het geheele Land verspreiden." Cf. Machiavelli, Discorsi III.29. 
without taking any notice of shame or decency". ${ }^{55}$ A society ruled by a monarch is no true civil society where the passionate excesses of the human condition are bridled, but rather "a country that will be filled with Fops, Dancers, Players, Cursers, Fornicators, Hunters, Gluttons, and Boozers $\& c .{ }^{\prime 156}$

These moral concerns about the corruptive potential of immoderate self-love might not seem particularly exceptional, given that the basic conventions of Christian humanism shared the same emphasis on education and discipline vis-à-vis human sinfulness. However, it is important to note that the thought of the brothers De la Court relies neither on a providential divine framework nor on the cultivation of inner virtue to overcome the excesses of human nature. Instead, their approach to the role of the passions in politics centres on a largely secular notion of the rule of law, indebted to, in particular, Machiavelli. Echoing the Discorsi, the De la Courts insist that

in this evil world nothing more detrimental to human society can be thought of than to envisage, when establishing a government and making Laws, how prudent, virtuous and impassionate Rulers and Subjects ought to be inclined ... On the contrary, nothing more beneficial can be thought of than to consider well how cunning, evil, lecherous and fully passionate people will be inclined, so that politics and laws are established in such a way that the evil Rulers and Subjects will always be obliged to behave well. ${ }^{157}$

This key passage asserts that politics is not about the elusive concept of virtue but about the harsh reality of the passions, the self-loving nature of rulers and ruled alike. As a result, the conventional emphasis on a range of Ciceronian and Christian virtues, from fortitude to magnanimity, largely disappears from sight in the work of the De la Courts. Their account

155 Ibidem I.I.27, p. 133: “... in oude absolute Monarchien, wert die publike schande, gantsch niet geagt, en eigen intrest, allesins onbeschaamdelik voortgezet, ... zonder eenigzins op eenige schanden, ofte welvoegentheit, te passen."

${ }^{156}$ Ibidem I.I.14, p. 82-83: “... en niet vreemt is dat een land wert vervult, met Pronkerts, Dansers, Speelers, Vloekers, Hoereerders, Jaagers, Vreeters, en Zuipers, \&c. alles naar dat de Heer zelfs sig geneegen toont te weesen."

${ }^{157}$ Ibidem I.II.1, p. 173: “... in deeze booze werelt, voor de societeit der menschen niet schaadeliker kann werden bedagt, dan dat men, in het formeeren der regeeringe en maaken van wetten, voor oogen hebbe, hoe voorzigtige, duegtzame en ongepassioneerde Regeerders en Onderdaanen behoorden gezint te weezen; en dat in zoo een geval, ter contrarie niet heilsaamer kan werden bedagt, dan wel te considereeren, hoe doortrapte, boosaardige, wellustige, en allezins gepassioneerde menschen gezint zijn, op dat de politie en wetten zoodanig werden geformeert, dat de boosaardige Regeerders, en Onderdaanen, altijt genootsaakt werden, zig wel te draagen." Cf. Machiavelli, Discorsi I.3, p. 15: “... è necessario a chi dispone una repubblica ed ordina leggi in quella presupporre tutti gli uomini rei." 
replaces the devotional love of one's neighbour with calculated self-interest, it subordinates the fear for God and the afterlife to the fear for worldly punishment. Significantly, this passage is followed by the remark that such a secular disciplinary framework corresponds among all religions best with Reformed Calvinism. This embrace of a particular creed is thus not the foundation of the analysis, but only a secondary consequence. Moreover, the De la Courts assert "that the external Profession of Religion, whether Jewish or Christian, does not make any change in human nature, and that all People, whether Jewish, Christians or Heathens, are or become very ignorant and evil if they are born in or ascend to such Supremacy that they are not subjected to any laws or punishments". ${ }^{15}$ The universal human condition reveals its darkest side if it remains unrestrained by the rule of law, regardless of confessional particularities.

The secular emphasis of this politics of the passions is particularly important because it points to a significant difference between the thought of the brothers De la Court and contemporary republican ideology in England. As Jonathan Scott has argued convincingly, seventeenthcentury English republicanism primarily involved a religiously inspired reformation of manners. ${ }^{159}$ In particular John Milton and Algernon Sidney continuously connected their criticism of the corrupted Stuart court with the threat of looming religious corruption. For example, Sidney unequivocally equated monarchical tyranny with impiety, "idolatry" and "the destruction of the godly" ${ }^{160}$ while Milton insisted that the execution of Charles I "delivered the Commonwealth from a grievous domination, and religion from a most debasing thraldom". ${ }^{161}$ This emphasis on political theology also explains the remarkable popularity of the model of the Hebrew Republic among seventeenth-century English republicans. ${ }^{162}$ Yet even

${ }^{158}$ Politike Weeg-schaal I.I.33, p. 167-168: “... dat de uiterlike Proffessie van Religie, 't zy Joodse, 't zy Christelike, geen veranderinge brengt in den menscheliken aart, en dat alle Menschen, 't zy Jooden, Christenen of Heydenen, seer onwetende en boosaardig zijn of werden, wanneer sy tot sodanige Hoogheid geboren zijn, ofte stigen; dat sy gansch geen wetten ofte straffen onderworpen zijn."

159 Scott, Commonwealth Principles, esp. 41-62.

${ }^{160}$ Algernon Sidney, Court Maxims, ed. Hans W. Blom et al. (Cambridge: Cambridge University Press, 1996), 190, 194.

${ }^{161}$ John Milton, Second Defence of the People of England, in Idem, Areopagitica and Other Political Writings (Indianapolis: Liberty Fund, 1999), 315.

${ }^{162}$ See Eric Nelson, The Hebrew Republic. Jewish Sources and the Transformation of European Political Thought (Cambridge, Mass.: Harvard University Press, 2010). For the Dutch context, see also Lea Campos-Boralevi, "Classical Foundational Myths of European Republicanism: The Jewish Commonwealth," in Van Gelderen and Skinner (eds.), Republicanism, vol. I: 247-261. 
though this model was largely developed by Dutch authors, most importantly Petrus Cunaeus, Grotius, and Spinoza, such religious engagement is largely absent from the republican endeavour of the brothers De la Court. Their emphasis on self-interest largely eclipses any notion of Christian virtuousness, and their anti-monarchical criticism consequently lacks the religious connotation of English republicanism. Yet, as the next chapters will continue to argue, this does not mean that the De la Courts are less radical, or 'exclusivist', than their English republican contemporaries. On the contrary: the brothers' anti-monarchism proves to be exceptionally far-reaching and consistent in comparison with other seventeenth-century republicans, while the brothers' religious relativism has equally important consequences for their plea for comprehensive religious toleration.

Overall, the brothers' repudiation of monarchical mores centres on their reappraisal of Ciceronian ambition as the sincere quest for personal honour within the bounds of civic discipline. This particular reading of Cicero, meant to adapt the ethics of honour for an urban society based on commerce, reveals a striking parallel with the archetypical figure in the Dutch Golden Age of the 'wise merchant': the successful entrepreneur who engages in self-interested trade yet, reaping the seeds of a humanist education, proceeds rationally and honestly in public affairs.

\section{Representing the Wise Merchant}

\section{Barlaeus on the Mercator Sapiens}

The concept of the 'wise merchant' was coined in a famous speech by the Dutch humanist scholar Caspar Barlaeus. On January 9, 1632, Barlaeus gave a lecture at the opening of the Amsterdam 'Athenaeum Illustre', a college that, in the absence of a local university, offered higher schooling to the city's youth. ${ }^{163}$ The first chairs of the Athenaeum were taken by Barlaeus and his close friend and colleague Gerard Vossius. Addressing the fathers of the young men he was about to teach, the prosperous elite of a city that had become famous for its trade, Barlaeus chose an appropriate topic for his speech: the connection between commerce and the study of philosophy, or, as he called it, the ideal of a mercator

${ }^{163}$ See Dirk van Miert, Illuster onderwijs. Het Amsterdamse Athenaeum in de Gouden Eeuw, 1632-1704 (Amsterdam: Bert Bakker, 2005). 
sapiens. ${ }^{164}$ Barlaeus' main aim was to reveal the value of the time-honoured studia humanitatis for a modern commercial society. His speech clearly manifests a Ciceronian attempt to reconcile the right and the expedient in a world dominated by the pursuit of private gains.

From the start, the lecture reflected the communal concerns of the speaker and his audience, gathered in "this new sanctuary for the Muses". In an opening oration, Barlaeus asked God for wisdom and guidance in civic and commercial affairs, stressing in particular the need to maintain religious concord in the city of Amsterdam. He then continued to request "that those, who have so far followed Mercury, will by now be called candidates for Wisdom; plain but with elegance; striving for money but without detriment for a better motivation, which is science and virtue". ${ }^{165}$ From the opening lines of his speech, Barlaeus thus made an explicit connection between mercantile virtuousness and the challenges of a society characterized by religious diversity. His professed intention "not to condemn but to control the strivings for possessions through the reins of right reason", ${ }^{166}$ indicates that he considered the rational and balanced pursuit of riches essential for the welfare and stability of the commonwealth. Indeed, Barlaeus stressed that the elements of Aristotelian "civil prudence", from experience and ingenuity to judgment and consultation, were also "the very same elements and tasks of commerce". ${ }^{167}$ The merchant who took up these tasks wisely embodied the ideal citizen engaged in the public life of the polity.

At the same time, Barlaeus also revealed his preoccupation that riches and luxury might corrupt Amsterdam's merchants. His aim was thus to

${ }_{164}$ The lecture was published the next year: Caspar Barlaeus, Mercator sapiens, sive oratio de conjungendis mercaturae \& philosophiae studiis (Amsterdam, 1633). For a modern edition with a Dutch translation see Caspar Barlaeus, Mercator sapiens. Oratie gehouden bij de inwijding van de Illustere School te Amsterdam op 9 januari 1632, ed. S. van der Woude (Amsterdam: Universiteitsbibliotheek, 1967). See also the French edition with an extensive introduction by Catherine Secretan (ed.), Le "Marchand philosophe" de Caspar Barlaeus. Un éloge du commerce dans la Hollande du Siècle d'Or (Paris: Honoré Champion, 2002), and the analysis of Barlaeus's speech, with some different accents, in Cook, Matters of Exchange, 68-73.

${ }_{165}$ Barlaeus, Mercator sapiens, 3-4: "Stat supplex civium ordo ... in novo hoc Musarum sacrario ... Da, ut Mercuriales hactenus, jam Sapientiae candidati audiant; parci, sed cum elegantia; pecuniae studiosi, sed sine detrimento melioris studii, hoc est, artium \& virtutis."

${ }^{166}$ Ibidem, 8: “... non ut opum studia damnem, sed rectae rationis sufflamine coërceam.”

${ }^{167}$ Ibidem, 24: "Aristoteles ... Prudentiae civilis administras comitesque facit, Experientiam, Memoriam, Solertiam, Ingenium, Sententiam \& Consolium. At hae ipsissimae sunt mercaturae partes \& oficia." 
"demonstrate with the weighty precepts derived from Philosophy that Wisdom can cure their vices". First of all, he insisted that merchants should not to be avaricious but rather practice moderation and always acquiesce to their position. "Those who strive for immoderate riches", Barlaeus taught his mercantile audience, "will often lose immoderately ... and thus while luxury overthrows some, ambition brings down others if the lust for profit is destitute of and unadvised by the warnings of Prudence". Hence, "not he who owns more, but he who desires less, is rich ... The philosopher calls the soul of man rich and not the moneyboxes, however full those are, for as long as the soul suffers from the lust for money, she is poor. ${ }^{{ }^{66}}$ To overcome the threat of such commercial corruption, Barlaeus put forward his central claim:

Wisdom does not contemn the wealthy but embraces them, under one condition: that they are rich without harm to others, magnificent without luxury, liberal without ostentation, weighty without pedantry, religious without superstition. ${ }^{169}$

Thus Barlaeus sought to justify mercantile enterprise with an account that, explicitly based on Ancient stoicism and in particular on Cicero's De officiis, highlighted the virtuousness of a rational and moderate pursuit of riches in the service of the common good.

As Barlaeus repeatedly stressed in a distinctly Ciceronian vein, honestum, the morally right, cannot be separated from utile, the expedient. ${ }^{170} \mathrm{He}$ continued to stress the practical merits of the wise merchant, his firmness in times of misfortune, the duty to be honest in commercial exchanges, and, in particular, to take care for the "public welfare" as "a man among men, and a citizen among fellow citizens". ${ }^{171}$ This practice of charity and

${ }^{168}$ Ibidem, 13-14: "Sed proprium libet mercantium virtutes expendere, \& depromptis è Philosophia gravibus praeceptis ostendere, quam \& illorum vitiis mederi possit Sapientia ... Qui immodicas opes sectantur, immodicis saepe excidunt ... atque ita dum alios sua luxuria, alios ambitio praecipitat, hos inconsulta ac Prudentiae monitis destituta lucri cupiditas ... Non enim qui plus habet, sed qui minus cupit, dives est ... Philosophus animum hominis divitem appellat, non loculos. Qui quantumvis pleni sint, dummodo pecuniae cupiditate laboret animus, pauper es."

${ }^{169}$ Ibidem, 16: "Sapientia opulentos non fastidit, sed exosculatur unice. Illos nempe, qui locupletes sunt sine ullius injuria, magnifici sini luxu, liberales sine ostentatione, graves sine morositate, religiosi sine superstitione."

${ }^{170}$ Ibidem, 18-19. Cf. the classic discussion of utile and honestum in Cicero, De officiis, esp. II.III.9, III.III.11, III.VIII.35, p. 303: "quod autem bonum, id certe utile; ita, quicquid honestum, id utile."

${ }^{171}$ Barlaeus, Mercator sapiens, 20: “... cum ea lege natus sis, ne publicae saluti officias, \& ut homo de hominibus, civis de concivi bene merearis." 
sociability would be enhanced by the study of both moral and 'speculative' philosophy (i.e. the sciences of geography, biology, astronomy, and meteorology), and by learning the languages and customs of different peoples. Barlaeus thus suggested that commercial wisdom consists to a large extent of the practical application of theoretical knowledge, and that this practical insight is essential for the fulfilment of civic duties. ${ }^{172}$ His panegyric emphasized that with the establishment of the 'Athenaeum Illustre', Amsterdam would obtain the same status as other outstanding centres of trade, learning and civility such as Ancient Athens and Venice: in educating young merchants to become wise, the entire city would flourish. ${ }^{173}$

This carefully constructed plea for the public cultivation of mercantile virtue and insight involved the claim that one specific commercial quality makes the wise merchant in particular apt for performing in public. As Barlaeus argued, this quality stems from the double divinity of "the most ingenuous of the Gods, Mercury", who apart from being the god of commerce was also "the author of wisdom and eloquence". Through incorporating these two faces of both commerce and wise rhetoric, Mercury revealed that "merchants need both wisdom and fluency; the one so that they can discern honest from disgraceful gains, the other in order to commend with the allure of words the goods which they are satisfied to sell". ${ }^{174}$ This suggestion that the ability to discern honesty from dishonesty is related to appealing speech entails a significant parallel between commercial practice and truthful, persuasive rhetoric. As Barlaeus insisted: "A merchant with a sincere and good mind ... distinguishes decent from vicious merchandise, like he distinguishes virtues from vices." ${ }^{\prime 75}$ The theoretical and practical upbringing of the wise merchant makes it possible to approach human behaviour as if it were merchandise, to differentiate between virtue and vice on the account of commercial insight into what is good and bad, irrespective of any in utramque partem reasoning. With this argument against both unfair trade and dissimulative

${ }^{172}$ Cf. Jacob Soll, "Accounting for Government: Holland and the Rise of Political Economy in Seventeenth-Century Europe," Journal of Interdisciplinary History 40, 2 (2009), $215^{-238 .}$

${ }^{173}$ Barlaeus, Mercator sapiens, $30-31$.

${ }^{174}$ Ibidem, 9-10: “... ingeniosissimum Deorum Mercurium, illum sapientiae ac eloquentiae autorem. Nempe ut doceant, \& sapientia \& facundia opus esse mercantibus; illa, ut quaestum honestum à turpi discernere possint, hac; ut verborum lenocinio commendent eas merces, quas extrudere satagunt."

175 Ibidem, 16: "Erectae \& bonae mentis mercator ... sicut vitiosas merces à probis, ita virtutes a vitiis distinguit." 
speech, Barlaeus asserted that honesty and outspokenness are essentially commercial virtues. It is the wise merchant who masters as no other the proper parrhèsia for entering the marketplace of public political debate, and thus he fulfils the prime prerequisite of a truly civic life.

Barlaeus' inaugural lecture was an important public event, and his portrayal of the mercator sapiens resonated far beyond the walls of the Amsterdam Athenaeum when it was published and translated into Dutch in the following decades. ${ }^{176}$ In general, his attempt to reconcile the vicissitudes of commercial society with the precepts of classical humanism arose from the long-standing mercantile culture of the cities in the Low Countries, which, from the medieval period onwards, resulted in a characteristically urban and commercial approach to civic ethics in which 'the citizen' was at times identified with 'the merchant'. ${ }^{177}$ The speech of Barlaeus evidently stood in this tradition. In particular, his reading of the Ciceronian connection between honestum and utile was part of a more widespread endeavour in the Dutch Golden Age to legitimize the pursuit of commercial gains in light of classical and Christian mistrust of mercantile activity. Aristotle's Politics argued that trade for the sake of the accumulation of wealth is unnatural, a verdict echoed by Cicero in his disapproval of the "vulgarity" of trade..$^{178}$ The Biblical condemnation of usury and worldly riches reinforced this anti-commercial ethics. Accordingly, humanist scholars and clergymen in the Dutch Golden Age struggled with the challenge of how to reconcile this classical and Christian legacy with the commercial realities that defined their society.

An early example of this struggle was the dialogue De Coopman ["The Merchant"], in which the sixteenth-century moralist Dirck Coornhert

${ }^{176}$ The lecture opened the widely circulated collection of Barlaeus's speeches, the Orationum liber (Amsterdam, 1643), which went into three editions and was translated as Oratien, en Blijde inkomst van Maria de Medicis (Amsterdam, 1662). A Dutch translation of the lecture was published separately in 1641: Verstandighe coopman, of Oratie, handelende van de t'samen-voeginghe des koop-handels, ende der philosophie (Enkhuizen, 1641).

${ }^{177}$ See Herman Pleij, "Poorters en burgers in laat-middeleeuwse literaire bronnen," in Kloek and Tilmans (eds.), Burger, 55-79, esp. 56-59. Cf. also Karin Tilmans, "Republican Citizenship and Civic Humanism in the Burgundian-Habsburg Netherlands (1477-1566)," in Van Gelderen and Skinner (eds.), Republicanism, vol. I: 107-125; and Clé Lesger, "Merchants in Charge. The Self-Perception of Amsterdam Merchants, ca. 1550-1700," in Margaret C. Jacob and Catherine Secretan (eds.), The Self-Perception of Early Modern Capitalists (New York: Palgrave MacMillan, 2008), 75-97.

${ }^{178}$ Aristotle, Politica I.9-10 (1257a-1258b); Cicero, De officiis I.XLII.151. 
debated with his interlocutor the need for a range of virtues, most importantly Christian charity, to counter the corruptive effects of trade. ${ }^{179}$ The Calvinist cleric Godefridus Udemans tackled the issue in his widely read treatise 't Geestelyck roervan 't coopmans schip ["The Spiritual Helm of the Merchant's Ship"], which aimed to show "that Commerce is an honest activity, as long as it is pursued in the justice and fear of the Lord". ${ }^{80}$ Udemans reproved Cicero's portrayal of petty trade in De officiis, and in reply argued that commerce is a necessary means to foster the welfare of society and to spread God's word overseas. Yet Udemans then continued with an extensive account of all the devout virtues that the merchant should cultivate - an account that, as Simon Schama has shown in his classic on the subject, The Embarrassment of Riches, left little room for any truly mercantile enterprise. ${ }^{181}$ Meanwhile, at Leiden University, Burgersdijk transmitted the Aristotelian doctrine with the claim that commerce is justifiable, but only if it aims to relieve scarcity, for the mere accumulation of wealth goes against nature. ${ }^{182}$ Other academics such as Boxhorn and Salmasius equally participated in the public debate on the role of commerce, in particular with regard to the pressing issue of usury and the establishment of municipal loan offices. This issue continued to dominate theological and political debate throughout the $1650 \mathrm{~s}$, when one Leiden pamphlet asserted on the basis of a range of classical and Christian sources that usury "is useful for the mutual society and conduct with each other" if compatible with "Christian love", and therefore "founded and based on natural fairness". ${ }^{183}$ Such apologies for mercantile practice were obviously not restricted to the narrow confines of the Dutch Republic. For example, the German academic Johannes Marquardus published a large juridical treatise in 1662 that sought to make commerce salonfähig in the

${ }^{179}$ Dirck Volckertsz Coornhert, De Coopman. Aenwijsende d'oprechte conste om Christelijck ende met eenen gelijcken moede in 't winnen ende verliesen Coophandel te drijven (Norden, 1620).

${ }^{180}$ Godefridus Udemans, 't Geestelyck roer van 't coopmans schip, 3d. ed. (Dordrecht, 1655), sig. *4: "dat de Koopmanschap, is eene eerlijcke handelinge, als die maer gedreven wordt in de gerechtigheyt, ende vreese des Heeren."

${ }^{181}$ Ibidem, 14-61. See Schama, Embarrassment of Riches, 330-331.

${ }^{182}$ Burgersdijk, Idea oeconomicae et politicae I.VIII.16, p. 26: "Mercatura ergo est legitimus acquirendi modus, si adhibeatur ad supplendis nature defectus. At si referatur ad augendam pecuniam, sine aloquo ulteriore fine, jam naturae contraria erit, quia progredietur in infinitum."

${ }^{183}$ Consideratien raeckende 't stuck van leeninge op interest ende panden (Leiden, 1657), sig. A: “... dienstich is tot de onderlinge gemeynschap en hanteringe met malkanderen, welckers handelingen en contracten niet strydigh syn, met de plichten van de Christelycke liefde, en welkce gefundeert en gegrondvest is in de naturele billickheydt." 
Empire. Frequently referring to the Dutch example, including Barlaeus's speech, Marquardus emphasized the public utility of trade, following the adage that "Commerce is not the name of a Vice but of an Office". ${ }^{184}$

Barlaeus's contribution to this debate on the social role of commerce and mercantile wealth stands out for its distinctive humanist use of classical sources, which eclipse the religious emphasis that dominated from Coornhert onwards. Barlaeus did not aim to come to terms with commercial society from a Christian point of view, but rather to turn the icons of humanism, in particular Cicero, into advocates of honourable trade. He took the pursuit of mercantile riches and the accumulation of wealth for granted as unavoidable elements of modern life, not to be curtailed by piety but rather to be mobilized in the service of the common good and the study of the classics. The brothers De la Court continued on this path set out by Barlaeus. On the one hand, they shared a similar emphasis on mercantile moderation and wisdom as essential features of a civic life. On the other, the way in which the De la Courts presented themselves, both in image and in word, reveals that their embrace of riches gradually departed from the classical preoccupation with the corrupting potential of commercial wealth.

\section{Un-courtiers: A Mercantile Reformation of Manners}

It should be stressed that the œuvre of the brothers De la Court does not engage explicitly either with the Aristotelian claim that trade for the sake of the accumulation of riches is unnatural, or with the contemporary debate on the legitimacy of commercial practices such as usury. Instead, their portrayal of what makes a merchant wise involves a clear political move which suggestively contrasts mercantile civic ethics with the base morality of a courtly society. The distinctive reformation of manners that the De la Courts propagate is therefore not directed against the possible excrescences of commerce, but rather against the continuous threat of courtly decadence and dissimulation that corrupt all honour and honesty in commercial affairs. They turn Barlaeus's humanist account of mercantile virtues and honourable trade into a decisively politicized interpretation of true republican citizenship.

${ }^{184}$ Johannes Marquardus, Tractatus politico-juridicus de iure mercatorum et commerciorum singulari (Frankfurt, 1662) I.2, p. 18: "Mercatura non est nomen Vitii sed Officii." Pieter de la Court van der Voort owned a copy of this treatise: see Library, fol. 10. 
One of Barlaeus' main messages was the claim that the pursuit of profit is honourable if it does not give rise to uncivil greed and ostentation. The brothers De la Court adopt this plea for mercantile modesty to their account of the political consequences of self-love. This account reproves "squandering" as "truly a passion that generally belongs to Princes", whose constant exposure to courtly flattery and unbridled power deprives them of self-knowledge and leaves them enslaved by their lusts. In a true civil society, citizens should not try to follow such royal example. Instead, "it is especially for the common Citizens very laudable to lead their live according to the following saying ... A wise man is content with little." ${ }^{185}$ Moderation thus fulfils the civil desire to be praised, while the unrestrained yearning for possessions reveals a greed similar to the desire for domination, as in the imperial devices of plus oultre and semper augustus. ${ }^{186}$ With this juxtaposition of the covetousness of the monarch versus the modesty of the true citizen, the De la Courts give an explicit republican content to Barlaeus's assessment of the poverty of the insatiable soul.

An essential element of such civil moderation is the placid acquiescence with one's social status, a popular theme in seventeenth-century Dutch literature which clearly reflected a widely shared discomfort with the realities of social climbing. ${ }^{187}$ The De la Courts insist that citizens who have successfully obtained an honest way of living should not try to leave this "industrious or careful Civil State" and "commit the stupidity of wanting to rise even higher and imagine to be able to live like Nobles" ${ }^{188}$ Such parvenus merely prove to be driven by false self-love, and "by a too large desire of Honour they dress themselves more splendidly, live in bigger homes and set richer tables than their position or means permit". ${ }^{189}$ This

${ }^{185}$ Politike Discoursen II.VI.15, p. 222, 224-225: “... quist-gierigheid, waarlik een passie die doorgaans in Vorsten is ... Ende ter contrarie is het booven alle, voor den gemeene Borgeren een seer loofwaardige saak sijn leeven naar deese volgende spreek-woorden aen te stellen ... Een wijs mensch, is met weinig te vreeden."

186 Ibidem II.VI.4, p. 178.

${ }^{187}$ See e.g. Cats, Spiegel III, emblem II, p. 5-6 (on a monkey climbing to the top of a post, thereby revealing his bottom), and emblem VIII, p. 21-23, which concludes saying "Die hooger klimt als hem betaemt/Valt laeger als hy heeft geraemt". Cf. also Vondel, Vorsteliicke warande, fables XXVI, LXIX and XCVIII.

${ }^{188}$ Sinryke Fabulen, 65: “... binnen den arbeidsaamen ofte sorgvuldigen Borgerlijken Stand blijvende ... sy des niet te min alsdan die dwaasheid begaan van nog veel hooger te willen stijgen, ende waanen als Eedelluiden te konnen leeven."

${ }^{189}$ Politike Discoursen II.VI.19, p. 242: “... door te groote begeerte van Eere, sig selven pragtiger kleeden, grooter huis bewoonen, en rijker tafel houden als haar staat of middelen toelaaten." Cf. a similar passage in Sinryke Fabulen, 235-236. 
uncivil pretentiousness is imaginatively ridiculed in a fable that tells of a frog who does not understand the fundamental equality of his species and vaingloriously thinks he is able to grow as large as a cow: blowing himself up to the extreme, the frog finally bursts apart. ${ }^{190}$ The obvious message is that such swollenness strips people of all civil dignity and reduces them to the base level of those who personify monarchical manners: nobles and courtiers.

Another fable evocatively explains this difference between the civility of the modest citizen and the incivility of the courtier. The fable tells of a fly who, while eating "at the most sumptuous tables ... sleeping on purple beds, and kissing there the cheeks of the most beautiful Women", ridicules the hard labour of an ant. The ant then replies with saying that he has carefully amassed enough goods to survive, while the fly will certainly not make it through the winter. In a further clarification, De la Court defines the fly as "a Man who lives splendidly and lecherously, or a Courtier", while the ant personifies "a Man who is humble, diligent and thrifty". ${ }^{191}$ This praise of a modest accumulation of goods as opposed to courtly display makes clear that riches as such are not to be condemned if achieved by honest means. De la Court eulogizes how "most of the Riches of Civil Families in Holland" stem from "thrift and frugality" and the utter renunciation of any luxury. Such praiseworthy conduct stands in direct opposition to the idleness of those who refuse to practise a useful occupation, like commerce, and instead indulge in opulence "in the French way". ${ }^{192}$ As in the fable of the Kingdom of Apes, De la Court thus contrasts Dutch diligence and modesty, the example of mercantile morality, with the ostentation and laziness of the Frenchman, the prototype of courtly corruption.

This preoccupation with the corruptive consequences of luxury was fairly conventional. ${ }^{193}$ However, it is important to stress that the brothers De la Court never rebuke the pursuit of riches. On the contrary: in their commercial logic, wealth generally proves to be the result of sincere selflove and civil ambition. It is therefore not riches that corrupt, but power.

${ }^{190}$ Sinryke Fabulen, 61-66. Cf. Vondel, Vorsteliicke warande, fable XXXIII.

${ }^{191}$ Ibidem, 47-50: “... aan de alderkostelikste tafelen, eet aldaar de lekkerste spijse ... slaap op purperen bedden, ende kus aldaar de wangen der allerschoonste Vrouwen ... een Mensch die pragtig ende wellustig leefd; ofte een Hooveling. Met een MiER, een Mensch, die neederig, arbeid-ende spaarsaam is." Cf. Vondel, Vorsteliicke warande, fables XII and LVII.

${ }^{192}$ Ibidem, 272-273: “... de meeste Rijkdommen van Borgerlijke Familien in Holland, sijnen oorsprong heeft van ... naarstig- en suinigheid ... volgens der Francoisen wijse."

193 Cf. Christopher J. Berry, The Idea of Luxury. A Conceptual and Historical Investigation (Cambridge: Cambridge University Press, 1994), which emphasizes the importance of the 'Dutch example' in the seventeenth century, yet without any discussion of Dutch sources. 
As the brothers argue, "people whose wealth is devoid of power are by most reasons incited to knowledge and virtues and deterred from all evil ... Thus actually not wealth but power and licence are the cause of many evils". ${ }^{194}$ The De la Courts thus adopt Barlaeus's claim that mercantile riches should be appraised if employed for the sake of wisdom and virtue. At the same time, they make an implicit move away from the classical concern that the accumulation of goods will lead to corruption. This concern still haunted Barlaeus's portrayal of the wise merchant. For the De la Courts, in contrast, mercantile wealth gives no reason for anxiety, since the real source of evil is the unrestrained lust for power.

The brothers' gradual departure from the traditional mistrust of the accumulation of riches is revealed by the language in which they portray honourable civil conduct. Barlaeus's humanist vocabulary of the classical virtues of the wise merchant, from piety to prudence, virtually disappears from their writings, while his Ciceronian argument for the overlap between utile and honestum becomes couched in the consciously modern language of 'interest'. This gradual move from virtue to self-interest eventually results in a corresponding shift from the common good to private advantage as the standard of mercantile morality. Like his predecessor Coornhert or his Calvinist contemporary Udemans, Barlaeus primarily emphasized the value of individual commercial activity for society at large, in particular through the practice of charity. Yet in the thought of the De la Courts charity attains a strikingly different connotation. A crucial passage in the Sinryke Fabulen describes charity not primarily as a virtue, but as a passion, a passion that can easily turn into "wrong charity" when directed towards people who indulge in laziness and only hope to profit from the riches of their industrious fellow human beings. ${ }^{195}$ This remarkable change in emphasis shows how the brothers De la Court depart from the late humanist view on riches and poverty as expressed by Barlaeus. In the development of their œuvre, and most strikingly in De la Court's last work, the Sinryke Fabulen, wealth is increasingly identified as a moral value that characterizes the thrifty, the diligent, and the wise. Barlaeus's assertion that "wisdom does not contemn the wealthy but embraces them" thus turns into an account that maligns poverty as a

\footnotetext{
${ }_{194}$ Politike Discoursen II.VI.5, p. 183: "Maar men moet seer wel op-merken dat menschen wiens rijkdom ontbloot is van magt, door de meeste reedenen tot kennissen, en deugden geprikkeld, en van alle boosheeden afgeschrikt werden ... sulks niet eigentlik de rijkdom, maar de magt en licencie, oorsaak veeler boosheeden is."

195 Sinryke Fabulen, 512-514: “... eene verkeerde barmhertigheid.”
} 
result of human weakness and vice. The concerns of late humanism make place for the concerns of commercial enterprise.

A significant result of this line of reasoning is the ensuing claim that commercially attained riches and mercantile rationality and moderation are the essential tokens that distinguish true citizens from their counterparts, the poor and the plush. With conventional scorn for the unruly rabble, the De la Courts insist that poor people, who "have to spend their time in working for their subsistence", lack the education and resources necessary to harness their passions into "the appropriate desire for honour", and hence they lose themselves in wastefulness. The other social pole, the nobility, is equally prone to false self-love:

having banned all discipline, these Lords follow their desires so immoderately that they have run into debt before they realize that their goods are diminishing. And therefore luxury brings about the same among them as need tends to cause among the poor People. ${ }^{196}$

The civic middle group in between these two extremes practices diligence and thrift to preserve and accumulate wealth without lavishness and luxury. These citizens, "who are used to being rich, realize that their treasure ... can be easily lost due to the accidents and evil of the world". To weapon themselves and their offspring against the whims of fortune, they "frugally and diligently take care for their household" and they "raise their children ... in all sciences, arts and virtues" ${ }^{197}$ In short, it is these wise merchants who fulfil the prime criteria of honourable citizenship.

Finally, the De la Courts' adaptation of Barlaeus's portrayal of the wise merchant has important implications for their position in the classical debate on how to reconcile the vita activa in the service of the public good with the vita contemplativa of isolated philosophical inquiry. Barlaeus's

${ }^{196}$ Politike Discoursen II.VI.16, p. 227-229: “En dewijl de arme Luiden haar tijd in 't werken tot haar onderhoud, moeten besteeden, soo gebreekt hun de selve om haar ziele te leeren tugtigen ... de behoorlike eersugt ... alle tugt uit-gebannen hebbende, deese Heeren soo onmatig haare lusten volgen, dat sy vol schulden steeken, eer sy weeten dat hun goed verminderd. En hier door brengt de weelde by haer te weege het selfden, dat de behoeftigheid by de arme Luiden te veroorsaaken pleeg." Cf. the similar argument in Milton, Defence of the People of England, in Idem, Areopagitica and Other Political Writings, 250: "... the middle sort, amongst whom the wisest men and most skilful in affairs are generally found; the rest are most commonly diverted, on the one hand by luxury and wealth, on the other by want and poverty, from achieving excellence, and from the study of laws and government."

197 Welvaren 51, p. 115: "Maer die gewoon sijn rijck te weesen, beseffen, dat hare schat ... door de ongevallen ende boosheid des werelds lichtelijck kan werden verlooren ... waar door sij suinigh ende naerstigh op de huishoudingh lettende geneegen sijn hun kinderen ... in alle wetenschappen, konsten ende deughden op te brengen." 
speech addressed this question in a clearly Ciceronian vein by stressing the value of mercantile wisdom and private wealth for the commonwealth at large.$^{198}$ The De la Courts' shifting focus from the community to the individual results in a different, more ambiguous account of the good life. On the one hand, the brothers repeatedly stress the importance of public service and the civic duty to take up arms in defence of the commonwealth. On the other, they suggest that true wisdom consists of the acquiescent acceptance of one's fate, taking care of oneself while maintaining a stoic distance from "the slippery ice" of politics: "For in such a state one needs few things, and using properly the small means that one owns, one becomes with little rich and somehow God's equal, and one can live as a quiet, forgotten Citizen in his own home on his own way." ${ }^{199}$ It is such a life of modesty and utter self-reliance that characterizes those who personify the opposite of base courtly morals. Like hares in a world populated by lions, apes, foxes and parrots, these are the

People who are accustomed to live in peace from their own income without harming others, and who have nonetheless travelled many Countries, as well as learned, heard, and seen a lot. These are people who, having firm and virtuous Maxims of life, do not want to bend to pass through life more easily, and one might very well call them un-Courtiers. ${ }^{200}$

The mercantile reformation of manners of the brothers De la Court thus entails a highly politicized plea for erudition, moderation and self-sufficient perseverance vis-à-vis the threat of courtly corruption. In many ways, this plea follows Barlaeus's endeavour to appropriate the Ciceronian ethics of honour to a commercial society. Honesty and trust are necessary to maintain profitable trade, and the cultivation of personal honour is a crucial means to foster such honesty. ${ }^{201}$ Eerzucht, the civil desire to be praised, is therefore in essence a mercantile virtue. This view was shared

${ }^{198}$ Cf. the classical account in Cicero, De officiis I.XX.69-70 and I.XXVII.92.

199 Sinryke Fabulen, 222, 224: "Want men in soo eenen stande weinige saaken nodig hebbende, ende het weinige dat men heeft, wel gebruikende, met weinig rijk ende eenigsins Goode gelijk werd, ende, als een stil vergeeten Borger, op sijn eigen haard, ende naar sijnen sinne leeven kan ... Ende op hoe gladden yse de hoogste Dienaars van Staat in Republiken, daar een Vorst groot gesag heeft, ofte insonderheid onder Koningen staan."

${ }_{200}$ Ibidem, 39: "Door HAASEN, Menschen die van haar eigen inkoomen, sonder andere te beschaadigen, gewoon zijn te leven in der stilte, ende nogtans veele Landen bereisd, als meede veel geleerd, gehoord, ende gesien hebben. Dit zijn menschen die vaste ende deugdsaame Maximen van leven hebbende, niet willen krommen, om gemakkelijker door de weerelt te koomen, ende mogt men die wel on-Hoovelingen noemen."

${ }^{201}$ Cf. the ranting chapter against fraudulent bankruptcy in Aanwysing I.25. On the importance of honour and trust in seventeenth-century Dutch commercial society, see 
by, for example, the merchant Johan van Nyenborgh, an acquaintance of De la Court who wrote a long poem in praise of modest profits and honourable trade, referring to both Barlaeus and Cicero. ${ }^{202}$ As for Van Nyenborgh, the honest pursuit of riches is for the De la Courts an intrinsic element of such mercantile ambition, and therefore a token of true citizenship.

\section{The Wise Merchant on Canvas}

This self-confident portrayal of honourable wealth not only entails a theoretical model of mercantile manners. It is also a chief component of the way in which the brothers De la Court presented themselves in public. The De la Courts, as commercial entrepreneurs and political pamphleteers outstanding examples of the mercator sapiens, pretended to embody the ideal of wealthy and wise traders capable of honest and truthful speech. They established this image through the power of rhetoric, but also through another powerful source of self-presentation in the Dutch Golden Age: painting.

In 1657, when De la Court married Elisabeth Tollenaar, the newlywed couple was portrayed on canvas in a typical setting of domestic virtue and diligence (see fig. 11). The painting shows De la Court and his wife at a large table in the middle of their home, with a reserved yet not uninviting look to the observer who intrudes their privacy. At the right, Elisabeth is sewing, performing the duty of the obedient and caring housewife; at the left, Pieter is engaged in the bookkeeping of his firm, diligently making notes and calculations in two large volumes. The background of the panel reveals a bed that symbolizes the marital happiness behind the long green curtains. The entire rear wall of the room is occupied by a large bookcase, at the front of which stands a globe. Thus, the painting tells the viewer that this is an exemplary household of carefulness and love, virtue and learning, worldly knowledge and industry; the household, in short, of a wise merchant. ${ }^{203}$

Anne Goldgar, Tulipmania. Money, Honor, and Knowledge in the Dutch Golden Age (Chicago and London: University of Chicago Press, 2007), esp. 253-304.

${ }^{202}$ Johan van Nyenborgh, Bericht van den koophandel, in Idem, Toneel der ambachten (Groningen, 1659), esp. 166, 175, 184. Van Nyenborgh attributed one of his works to De la Court.

${ }^{203}$ The portrait of De la Court and Tollenaar, attributed to Godaert Kamper, was until recently part of the collection of the 'Diaconessenhuis' in Utrecht. See for the entire collection of paintings of the De la Court family J.H. Kernkamp, "De familie-portretten uit de collectie De la Court," in Dancwerc. Opstellen aangeboden aan prof. Dr. D. Th. Enklaar 


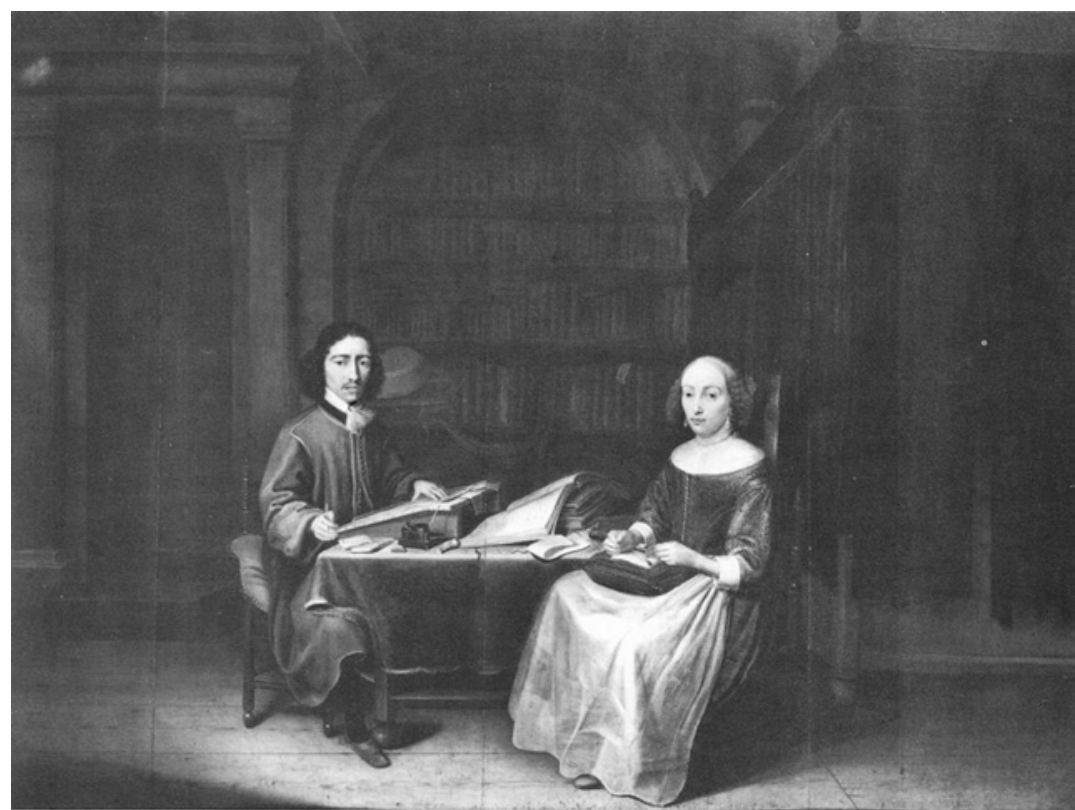

Fig. 11. Godaert Kamper, Pieter de la Court and Elisabeth Tollenaar, 1657/58. Formerly Utrecht, Diaconessenhuis. Present location unknown.

A few years after Elisabeth died in childbirth, De la Court remarried in 1661. His new bride, Catharina van der Voort, came from a very different background. She was the daughter of a rich Italian-Dutch merchant family that, after an initial period in Naples, had settled in Amsterdam, where Catharina's brothers, Giovanni and Guglielmo, continued the thriving commercial firm established by their late father. The difference between the southern Van der Voorts and the Leiden Tollenaar family is aptly revealed in a painting of Giovanni and Catharina by Ferdinand Bol, a pupil of Rembrandt who lived opposite the Van der Voorts in Amsterdam. In 1661, shortly before Catharina's wedding to De la Court, Bol portrayed the two Van der Voorts in an Italianized setting that nostalgically refers to

(Groningen: Wolters, 1959), 290-304; Idem, "De portrettering van Pieter de la Court opnieuw bekeken," in Ondernemende geschiedenis. 22 opstellen geschreven bij het afscheid van mr. H. Van Riel (The Hague: Martinus Nijhoff, 1977), 66-74; and especially C. Willemijn Fock and R.E.O. Ekkart, "De portretgalerij van de familie De la Court," Jaarboek van het Centraal Bureau voor genealogie 35 (1981), 177-230. 
their Mediterranean roots. The painting shows how brother and sister, both sumptuously dressed in the midst of a lavish garden, admire each other in a richly decorated mirror. An opened jewel case reveals the family's wealth, and in the background a copy of the Hercules Farnese completes the opulent scenery. Clearly, De la Court was about to become part of a family whose views on public appearances differed strikingly to those of his previous in-laws. ${ }^{204}$ That said, De la Court's second marriage implied that he could finally settle as a pater familias and establish his own independent household. Over the next years, Catharina gave birth to two children, Magdalena and Pieter de la Court van der Voort. In the letters that he wrote to his brothers-in-law, De la Court aptly cultivated his new status as a loving father and husband. ${ }^{205}$

To celebrate this marital happiness and increased prestige, De la Court commissioned two large separate portraits of himself and his wife from the painter Abraham van den Tempel in 1667 (colour plates A-B). The couple had moved to Amsterdam in 1665 to join Catharina's brothers, and Van den Tempel, who had worked as a textile entrepreneur in Leiden, was perhaps an old acquaintance from the De la Courts. ${ }^{206}$ With his trained eye for cloths and colours, he portrayed Catharina on a red chair in a sumptuous white satin dress with a black cloak, glistening earrings and a pearl necklace; an unfolded curtain reveals in the background a large flower vase and an extensive garden. The portrait of De la Court symmetrically mirrors that of his wife. He too is seated on a red armchair, wearing an eminent black toga with a white jabot. At the left wall, above the entrance to an arcade that leads outside, stands the quintessential symbol of wisdom and modesty: a bust of Socrates.

With such evocative imagery, De la Court aptly represented himself as a learned man who deals in rich textiles, touched by a hint of Italian splendour yet aware of the higher goal of wisdom. The addition of a

${ }^{204}$ See Albert Blankert, Ferdinand Bol (1616-1680). Rembrandt's Pupil (Doornspijk: Davaco, 1982), 153, cat. 173, plate 185. The painting is now in the Royal Museum of Arts in Antwerp.

${ }^{205}$ These letters are published in Kernkamp (ed.), "Brieven (1661-1666)" and Idem (ed.), "Brieven (1667-1685)." Cf. for the upbringing of De la Court's children Benjamin Roberts, Through the Keyhole. Dutch Child-Rearing Practices in the 17th and 18th Century. Three Urban Elite Families (Hilversum: Verloren, 1998), esp. 66-67, 79, 89-9o.

${ }^{206}$ See H.F. Wijnman, "De schilder Abraham van den Tempel," in Idem, Uit de kring van Rembrandt en Vondel. Verzamelde studies over hun leven en omgeving (Amsterdam: NoordHollandsche Uitgevers Maatschappij, 1959), 39-93. The two portraits are now part of the collection of the Amsterdam Rijksmuseum. 
bust of a classical figure was a common feature in seventeenth-century portraiture, and De la Court's choice of Socrates is revealing. In Rubens's famous painting of 'the four philosophers', Lipsius and his friends are accompanied by a bust of Seneca, as is, for example, Jacob Cats in a portrait by Arnoldus van Ravesteyn. ${ }^{207}$ Yet De la Court did not chose for the embodiment of stoic constancy but for the archetype of the engaged philosopher condemned for telling the truth - the very same theme as in the fables of the Dutchman in the Kingdom of Apes and of Actaeon who discovers Diana's nudity. The difference in emphasis and pretension with respect to De la Court's portrait with his first wife is notable (and not surprisingly, the difference in price was almost a hundredfold). ${ }^{208}$ Compared to the portraits that the parents of the brothers De la Court had commissioned in 1635, sober depictions of a respectable and devout couple, the change is still more striking: the bible on which mother De la Court laid her hand has become the extravagant dress of Catharina van der Voort; the sandglass as a symbol of human vanity which attended De la Court sr., has become the bust of a pagan philosopher as the icon of his son. ${ }^{209}$

Accordingly, there was Pieter de la Court the diligent husband, and there was Pieter de la Court the merchant-philosopher. Eventually, there was also Pieter de la Court the orator. At the end of the 1670s, De la Court commissioned a series of portraits of his entire family from the painter Godfried Schalcken, a pupil of the art theorist Samuel van Hoogstraten. Schalcken portrayed De la Court in a brown dressing gown, nonchalantly leaning on a balustrade (see colour plate $\mathrm{C}$ ). With his right hand performing a typical rhetorical gesture, De la Court seems to pause as during a speech. ${ }^{210}$ The wise merchant, who posed with his drapery and his books and who emulated Socrates, here addresses the spectator with the portrayal of words: he characterizes the alluring rhetoric of the market.

${ }^{207}$ Cf. on this type of portraiture Julius S. Held, "Rembrandt's Aristotle," in Idem, Rembrandt Studies (Princeton: Princeton University Press, 1991), 17-59.

${ }^{208}$ See the inventory drafted by Allard de la Court in 1749, published in Kernkamp, "Familie-portretten," 298-304, which mentions the prices paid for these paintings, respectively $f_{4,-}$ and f30o,-.

${ }^{209}$ The portraits of De la Court sr. and his wife are by Pierre Dubourdieu, also a Flemish immigrant in Leiden and a friend of Van den Tempel. Both paintings are now in the Philadelphia Museum of Art. See Fock and Ekkart, "Portretgalerij," 188-190.

${ }^{210}$ See Thierry Beherman, Godfried Schalcken (Paris: Maeght Editeur, 1988), 164-165, 180-181, cat. $65^{-66}, 82$. De la Court's portrait is part of the collection of Museum De Lakenhal in Leiden. 


\section{Conclusion: Commercial Citizenship in Perspective}

The opulence and composure with which the De la Courts presented themselves in word and in image betrays no explicit sign of any embarrassment of riches. Contrary to that which Simon Schama has typified as the main characteristic of the culture of the Dutch Golden Age, the brothers apparently saw no reason to be preoccupied with a self-assured display of their commercial wealth. ${ }^{21}$ They repeatedly argued that a modest accumulation of riches is an indication of the honourable ambition of the educated mercantile citizen who practises diligence, thrift and perseverance to counter the capriciousness of fortune. Indeed, commerce and industry share the same features as Lady Fortune, as the De la Courts suggest with a metaphor that is markedly more chivalrous than bourgeois:

Truly, industry is not an estate but a Lady (tout par amour, rien par force) who turns her back on all those who treat her forcefully, and who gives all, soul, body and goods, to the one that serves her best and takes care of her. ${ }^{212}$

For the De la Courts private wealth is the result of the mercantile virtue of knowing how to please the demanding yet voluptuous Lady Fortune. Wealth is no sign of corruption but of competence, of virtù, and therefore it is to the rich to rule the republic.

At first sight, this identification of wealth with civic virtue, couched in the language of honour and self-interest, as well as the embrace of an uncourtly life in private, seem to place the republican thought of the brothers De la Court squarely outside of the early-modern republican tradition as it has been defined by Pocock. A convinced Pocockian should conclude that the De la Courts, just like Spinoza, ultimately define "the political good as living quietly, obeying the laws and exercising liberty of mind which is a long way from the vivere civile of the Florentines". ${ }^{213}$ There is certainly a fundamental difference between the representation of the true citizen as a peaceful wise merchant and the figure of the militant landowner who serves in the enlargement of the republic as propagated by

${ }^{211}$ Schama discusses two of the De la Court' fables in his work, yet without any analysis of the general characteristics of their thought: see Schama, Embarrassment of Riches, 211, 287-288.

${ }^{212}$ Welvaren 39, p. 90: "Voorwaer neeringh is geen erf, maer een jonkvrouw (tout par amour, rien par force) die den rugge keert aen alle die haer hard handelen, en alles, siel lichaem en goed overgeeft, aen die haer best diend, en oppast." Cf. Machiavelli, Principe $\mathrm{XXV}$, p. 167: "perché la fortuna è donna ed è necessario, volendola tenere sotto, batterla e urtarla."

${ }^{213}$ Pocock, "Spinoza and Harrington," 440. 
Machiavelli and Harrington, Pocock's role models. Yet this difference does not necessarily mean that the commercial republican thought of the De la Courts was of a unique and distinctly 'modern' nature, entirely at odds with the legacy of Renaissance republicanism. ${ }^{214}$ On the contrary, a similar account of the importance of mercantile riches and a comparably hesitative evaluation of the elements of the good life of the merchant can be traced back to exactly the fifteenth-century Florentine tradition of vivere civile - albeit to a number of representatives of that tradition who are largely overlooked in Pocock's work.

Following in the footsteps of the thirteenth-century rhetorician Brunetto Latini, these civic humanists championed the importance of private fortune and commercial activity as an essential part of the life of the virtuous citizen. ${ }^{215}$ They included noteworthy humanists like Poggio Bracciolini, Matteo Palmieri, and, in particular, the famous Renaissance uomo universale Leon Battista Alberti. ${ }^{26}$ In the third book of his wellknown I libri della famiglia, composed in the 1430s, Alberti conveyed a fictional discussion between two members of his family, the aging merchant Giannozzo and the young man of letters Lionardo. The discussion can be read as a dialogue intérieur of Alberti, split apart by two conflicting views on the relation between commerce and public service. Giannozzo first propagates the quiet life of the wealthy merchant who "lives happily of his own goods". He eloquently ridicules the behaviour of the statuali, the men of state "who esteem so much to go with trumpets in front and a twig in the hand that they abstain from proper domestic repose and the true peace of mind". ${ }^{217}$ Then Lionardo stresses in reply

\footnotetext{
${ }^{214}$ Cf. Israel, "Intellectual Origins," esp. 8-17.

${ }^{215}$ See Cary J. Nederman, "Commercial Society and Republican Government in the Latin Middle Ages: The Economic Dimensions of Brunetto Latini's Republicanism," Political Theory 31 (2003), 644-663; Hans Baron, "Civic Wealth and the New Values of the Renaissance: The Spirit of the Quattrocento," in Idem, In Search of Florentine Civic Humanism. Essays on the Transition from Medieval to Modern Thought, 2 vols. (Princeton: Princeton University Press, 1988), vol. I: 226-257; Mark Jurdjevic, "Virtue, Commerce, and the Enduring Florentine Republican Moment: Reintegrating Italy into the Atlantic Republican Debate," Journal of the History of Ideas 62, 4 (2001), 721-743; and the more critical reading by Maria Luisa Pesante, "Il commercio nella repubblica," Quaderni storici 105 (2000), 655-695. See also the classical portrayal in Eugenio Garin, L'umanesimo italiano. Filosofia e vita civile nel Rinascimento (Bari: Laterza, 1993), 54-58, 74-83.

${ }^{216}$ See the biography by Anthony Grafton, Leon Battista Alberti. Master Builder of the Italian Renaissance (London etc.: Penguin, 2001), esp. 152-180.

${ }^{217}$ Leon Battista Alberti, I libri della famiglia, in Opere volgari, ed. Cecil Grayson, 2 vols. (Bari: Laterza, 196o), vol. I: 180-181: “O pazzia degli uomini! I quali tanto stimano l'andare colle trombe inanzi e col fuscello in mano, che a loro non piace più il proprio riposo
} 
that the good citizen will love tranquillity, but not so much his own as the one of other good men, he will enjoy his private leisure but also love the one of his other fellow citizens, he will desire the unity, peace and tranquillity of his own household, but much more the one of his fatherland and of the republic.

Gianozzo agrees, yet eventually, he has the last word. "For reigning others", he says, "never forget to reign yourselves; for guiding public affairs never forget your private ones ... [since] the public affairs never meet private needs." $^{218}$

Through the voices of Gianozzo and Lionardo, Alberti wavered between the civic ideal of public service and the commercial ideal of private gains. Ultimately he made clear that the pursuit of mercantile riches and the maintenance of self-rule are essential preconditions for the enhancement of the common good. ${ }^{219}$ It has been remarked that Alberti's dialogue thus instigated a critical reflection on the ethics of commercial activity, even though his treatise remained unpublished. ${ }^{220}$ Yet in many ways, the interplay between Gianozzo and Lionardo seems to have been restaged in the work of the brothers De la Court. Like Alberti captured in between the needs of the oikos and the demands of the polis, ${ }^{221}$ the De la Courts similarly claim the value of a peaceful and self-sufficient life in private as the best foundation of public service. They echo almost literally Alberti's emphasis on the duties of the merchant-householder, the need for thrift and frugality and the public usefulness of "the riches of private citizens", and they faithfully follow his assertion that "if gains follow from labour, diligence and our industry, then poverty, the contrary of gain, will stem from contrary things, from negligence, laziness and slowness, vices which

domestico e la vera quiete dell'animo ... A me non pare buono colui il quale non vive contento del suo proprio."

${ }^{218}$ Ibidem, 183, 185: "E affermovi che il buono cittadino amerà la tranquillità, ma non tanto la sua propria, quanto ancora quella degli altri buoni, goderà negli ozii privati, ma non manco amerà quello degli altri cittadini suoi, desiderà l'unione, quiete, pace e tranquillità della casa sua propria, ma molto più quella della patria sua e della repubblica ... per reggere altri, mai lasciate di reggere voi stessi; per guidare le cose publiche non lasciate però le vostre private ... e le cose publiche non sovvengono alle necessità private."

${ }^{219}$ See the analysis of the dialogue in Hans Baron, "Leon Battista Alberti as an Heir and Critic of Florentine Civic Humanism," in Idem, In Search of Florentine Civic Humanism, vol. I: 258-288; and cf. the slightly different reading by Viroli, From Politics to Reason of State, 96-98.

${ }^{220}$ Pesante, "Il commercio nella repubblica," 672-675.

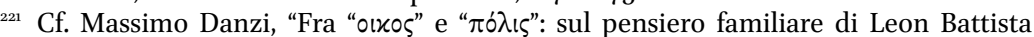
Alberti," in Claudia Bastia and Maria Bolognini (eds.), La memoria e la città. Scritture storiche tra Medioevo ed Età Moderna (Bologna: Il Nove, 1995), 47-62. 
do not lie in fortune or in external causes but in yourself". ${ }^{222}$ In short, both Alberti and the brothers De la Court characterize private mercantile wealth as the expression of civic virtue and hence the foundation of the common good of the republic.

This convergence between the republican ethics of a mercantile aristocrat from fifteenth-century Florence and two schooled entrepreneurs from seventeenth-century Holland reveals that it is doubtful whether Pieter de la Court, allegedly "ganz im geist des alten Calvinismus denkend", would have characterized Alberti's preference for a peaceful family life as "sündhafte Kreaturvergötterung" or as "aristocratische Pathetik", in line with Max Weber's famous thesis on the Protestant ethic. ${ }^{23}$ Instead, the 'capitalist spirit' of the De la Courts, like Alberti's, champions the honest pursuit of profit as a laudable civil ambition that connects the private advantage of the household with the public utility of society at large. This chapter has shown that the brothers' appeal for the disciplinary framework of civil society to overcome the possible corruption of such personal ambition follows from an essentially secular notion of the rule of law. This notion, as the brothers insist, corresponds only secondarily to the dogmas of Reformed Calvinism. Moreover, the cultivation of personal honour that underlies the mercantile ethics of the De la Courts can hardly be defined as a bourgeois ethic of asceticism. As a language of hierarchy and prestige, it entails above all a civic ethics that defines the individual citizen in relation to his fellow citizens and the commonwealth at large. ${ }^{224}$ In the De la Courts' reappraisal of Ciceronian ambition, the pursuit of profit is never for the sake of profit itself, but always for the sake of civil honour. As De la Court summarized in a private letter from 1664: "It is better to be somewhat less searching for profit and more desirous for honour ... although it conflicts with the maxims of a merchant who should, qualitate qua, search for nothing but profits." ${ }^{225}$

${ }^{222}$ Alberti, I libri della famiglia, 141-142, 144: "E sono negli ultimi casi e bisogni alla patria le ricchezze de' privati cittadini, come tutto el dì si truova, molta utilissime ... Se adunque nel guadagnare s'adempie le ricchezze, e se i guadagni seguono la fatica, diligenza e industria nostra, adunque l'impoverire contrario al guadagno diverrà dalle cose contrarie, dalla negligenza, ignavia e tardità, li quali vizii non sono in la fortuna, né in le cose estrinsece, ma in te stessi."

${ }^{223}$ Max Weber, Die protestantische Ethik. Eine Aufsatzsammlung, ed. Johannes Winckelmann, 2d. ed. (München and Hamburg: Siebenstern, 1969), 51, 86.

${ }^{224}$ Cf. Schama, Embarrassment of Riches, 568-569.

${ }_{225}$ Pieter de la Court to the brothers Van der Voort, 7 July 1664, in J.C. Overvoorde (ed.), "De Noord-Oostelijke doorvaart naar China," Bijdragen en mededelingen van het historisch genootschap 47 (1926), 249-331, 270: “... beeter is 't wat min baatsoekende en meer 
On the basis of several different strands of thought concerning human nature, the origin of society, the rights and duties of citizens and the morals of the market, the brothers De la Court constructed an account of commercial citizenship that merged a principled anti-monarchism with an appeal for honourable trade and mercantile wealth. First, the De la Courts appropriated the fashionable writing of Hobbes to argue that all legitimate government originates in democratic consent. Reading Hobbes through Grotian lenses, they radicalized mainstream contract theory with the claim that a true civil society can never be a monarchy. Instead, sovereignty remains indivisibly with the community of contractors, the householders who constitute the ruling citizenry. While critical of the exclusivist practice of seventeenth-century Dutch citizenship, the De la Courts maintained a mainstream definition of this citizenry as the collective of free, independent males who represent their household in the hierarchies of urban society. These merchant citizens, who actively participate in the defence and the decision-making of the polity, harness the defining human passion of self-love towards honourable ambition. Contrary to the corrupting mores of a monarchical court, the disciplinary framework of a true civil society enables such a sincere pursuit of self-interest in connection to the common good - the virtue that reveals itself in the wealth and erudition of those who embody non-monarchical manners: the wise merchants. This intrinsic connection between republicanism and trade applies not only to the individual level of citizenship, but also to the general level of the commercial commonwealth at large.

eergierig te zijn ... hoewel 't strijd teegen maximen van een koopman, die qualitate qua niet dan profijt soeken moet." 


\section{THE COMMERCIAL COMMONWEALTH}

The brothers De la Court were still in their mid-twenties when they sought permission from the Leiden court to start an independent textile business. ${ }^{1}$ With the establishment of their joint firm in March 1645, the brothers aimed at a vertical concentration of the various stages of textile manufacturing and trade: they provided the capital for the purchase of pure woollen materials, they set up a central atelier at their own house and a dyeworks where a group of employees processed the wool, and they were themselves responsible for putting the finished product on the market. The De la Courts thus bypassed intermediary producers and traders, and as so-called reders they became the patrons of an entirely selfsufficient business that went well beyond the system of 'small commodity production' characteristic to the earlier stages of Leiden's economic development. $^{2}$ Thanks to their father's wealth and experience, the brothers were able to make the large investments needed for this new, earlycapitalist type of entrepreneurship, which was soon to dominate the textile industry in Leiden. ${ }^{3}$

The firm 'Pieter and Johan de la Court' would prove to be very successful. By the end of the 1650 s, it had become a thriving firm that manufactured and exported cloth and camlet from Leiden all over Europe, from the Baltic to the Mediterranean. The brothers' joint capital amounted to the substantial sum of 76000 guilders, mainly invested in readymade cloth and loans. ${ }^{4}$ The De la Courts were active at the apogee of the Leiden textile

\footnotetext{
1 The petition is printed in N.W. Posthumus (ed.), Bronnen tot de geschiedenis van de Leidse textielnijverheid, 6 vols. (The Hague: Nijhoff, 1910-1922), vol. IV: 429.

${ }^{2}$ Cf. Robert S. DuPlessis and Martha C. Howell, "Reconsidering the Early Modern Economy: The Cases of Leiden and Lille," Past and Present 94 (1982), 49-84.

3 See Van Tijn, "Pieter de la Court," 306-307, 312-315; and N.W. Posthumus, De geschiedenis van de Leidsche lakenindustrie II: De nieuwe tijd, 2 vols. (The Hague: Martinus Nijhoff, 1939), 548. Posthumus' standard work is critically surveyed in J.G. van Dillen, "Leiden als industriestad tijdens de Republiek," Tijdschrift voor Geschiedenis 59 (1946), $25^{-51}$. For a more recent and more lucid introduction to the early-modern economic history of Leiden, see Boudien de Vries et al., "Het economische leven: spectaculair succes en diep verval," in Groenveld (ed.), Leiden, 85-107.

4 See the inventory of De la Court's possessions in Kernkamp (ed.), "Brieven (16671685)," 148-161. For the De la Courts' relative prosperity, cf. Israel, Dutch Republic, 633.
} 
business, which was by then the largest in Europe and employed more than half of the city's population. Leiden, the city where they were born, where they had studied and where they made their fortune, would be the prime empirical foundation of the brothers' analysis of the challenges and perspectives of a commercial commonwealth.

This chapter shows how the De la Courts' critical analysis of the economic policies of their hometown engendered a radical critique of the principle of monarchy and a related plea for a broad aristocratic government close to democracy. My central argument is that these two crucial characteristics of the brothers' republicanism follow from their distinctive portrayal of a commercial society where liberty reigns. The De la Court modelled their ideal republic on the experience of Leiden, whose fate as a mercantile, self-contained and pacifist city reflected the example of ancient Athens. On the basis of their critical assessment of Leiden's policies, they constructed a commercial reason of state theory that centres on an inclusive notion of republican liberty, merging freedom from economic interference with freedom from arbitrary domination. This comprehensive idea of liberty results in the claim that all forms of monarchy are necessarily tyrannical, a claim with clear implications for the Dutch debate on the position of the Stadholder. The commercial emphasis of their thought leads to the brothers' argument for a broad republican assembly consisting of wise merchants. This radically anti-monarchical and tentatively democratic move is particularly significant in comparison with the De la Courts' republican contemporaries in England.

\section{The Batavian Athens}

\section{Urban Reason of State: Debating Leiden's Welfare}

At the start of their first treatise, Het welvaren van Leiden, the De la Courts stated explicitly that the politics of their hometown should be conceived "sopra la raggion di Stato". From the outset, they thus positioned themselves in the tradition of reason of state. This intellectual current comprised a heterogeneous array of political treatises that, from the end of the sixteenth century onwards, flooded the European markets with intricate accounts how to preserve and enlarge a dominion according to the notorious adage 'necessity has no law'. ${ }^{5}$ One of the first and foremost

${ }^{5}$ See for useful overviews esp. Burke, "Tacitism, Scepticism, and Reason of State"; Stolleis, Staat und Staatsräson; and Viroli, From Politics to Reason of State, 238-280. 
contributions to this tradition was Giovanni Botero's Della ragion di stato, first published in 1589. Botero's definition of reason of state as "the knowledge of the means of establishing, preserving and enlarging a Dominion" became the leading premise of most subsequent reason of state literature, for example of the Duke of Rohan's influential tract De l'interest des princes. ${ }^{6}$ Following this definition, the De la Courts similarly asserted that Leiden's welfare was to be found in "the Conservation and the increase of the Republic of Leiden and its human society consisting of Rulers and Subjects". ${ }^{7}$ Yet this phrasing reveals a significant difference from the conventional reason of state literature, including Botero and Rohan, for whom the term 'state' meant the personal dominion and status of a prince. ${ }^{8}$ For the De la Courts, the state involved the collective body of both rulers and ruled, i.e. the city or commonwealth at large - the traditional idiom of the Italian Renaissance republics. ${ }^{9}$ Botero, in another treatise titled Delle cause della grandezza delle città, often appended to Della ragion di stato, also spoke about the reason of state of cities, yet still with a focus on the central role of a prince and his residence. ${ }^{10}$ The brothers De la Court adopted Botero's guidelines for a self-governing city like Leiden, merging the republican legacy with the language of reason of state.

According to the conventional reason of state logic, Leiden posed a difficult case. Botero had argued that the grandezza of cities consists in the quantity of the people and their belongings, for which, apart from the splendour of a princely court, a favourable geographical position and fecund surroundings are essential. ${ }^{11}$ Yet Leiden, as the De la Courts insisted, lacked all these assets. Therefore, the city should resort to two highly unpredictable means of attaining civic grandezza: the world of learning, embodied by Leiden's famous university, and the world

${ }^{6}$ Giovanni Botero, Della ragion di stato e delle cause della grandezza delle città (Venice, 1598) I, p. 1: "Ragione di Stato è notitia di mezi atti a fondare, conservare, e ampliare un Dominio cosí fatto." Cf. the similar terminology in Rohan, De l'interest des princes, 101.

7 Welvaren 1, p. 3: "Sullende mine gedaghten laten gaen, sopra la raggio di Stato, over't Welvaren der Stad Leiden, soo moet in 't begin werden geseid, dat ick daer mede verstae de Conservatie ende vermeerderingh der Leidsche Republieke, en menschelicke societeit bestaande uijt Regeerders ende Onderdanen."

8 Cf. Botero, Della ragion di stato I, p. 1: "Stato è un dominio fermo sopra popoli ... la Ragione di Stato suppone il principe."

9 Cf. e.g. Aanwsying I.24, p. 118: “... de politike Regeerders, over alle Onderdaanen gesaamentlik een Politik lighaam uitmaakende, welke wy den Staat noemen." On the shifting vocabulary of the state in early-modern Europe, see Quentin Skinner, "From the State of Princes to the Person of the State," in Idem, Visions of Politics, vol. II: 368-413.

${ }^{10}$ Botero, Cause della grandezza delle città, esp. 351-366.

" Ibidem, 309, 318-330. 
of industry and trade. ${ }^{12}$ Leiden's population and riches pivoted on the mutual enhancement of commerce and learning, for "inside the walls of the City the inhabitants have no other means to subsist than those provided by the powers of the soul and the human body, that is, sciences, arts, and manufacturing ... and to trade [these] with strangers for good profits". ${ }^{13}$ The main aim of the De la Courts' treatise on Leiden was to convince the city's establishment to uphold the two central pillars with which they themselves were so well-acquainted: the academy and the market.

This notion that Leiden's welfare depended on the correlation between learning and trade was a standard element of the city's self-representation in the seventeenth century, both in word and in image. For example, the former Burgomaster Jan Orlers praised Leiden in his eulogizing chronicle of the city as a "Dutch Helicon" where industry thrived thanks to divine providence and good government. ${ }^{14}$ The painter Van den Tempel (who later portrayed De la Court and his second wife) celebrated this shared fate of Leiden and its textile industry in three large panels commissioned in the immediate aftermath of the Peace of Westphalia. The first of these panels shows how the personification of the city's industry, escorted by Minerva and Mercury, flees from the destruction brought by Mars, who tramples the figures of Freedom and Justice. In the central piece, the Maid of Leiden is crowned by Minerva under the city's motto "Haec libertatis ergo", while Justice kneels and Mercury reveals his full purse. Finally, in the third panel (see colour plate D), the splendidly dressed Maid of Leiden invites the personification of industry to her stage. At the front, Freedom offers her emblematic attributes to the city; at the left, Minerva and Mercury witness the scene. Mercury's hand rests on Minerva's shoulder: commerce embraces wisdom. ${ }^{15}$

\footnotetext{
${ }_{12}$ Welvaren 1, p. 3-5. Cf. Botero, Cause della grandezza delle città, 339-348.

${ }^{13}$ Welvaren 4, p. 11: “... dat de ingeseetenen binnen de mueren der Stad geene middelen van subsistentie besitten, als die der kraghten der zielen ender menschelijke lichamen verschaffen konnen, Namentlijck wetenschappen, konsten ende handwerken ... hier konnen veijlen en verkopen met geode profijten aen vreemden."

${ }^{14}$ Jan Orlers, Beschrïvinge der Stadt Leyden, 2d. ed. (Leiden, 1641), sig. " $3:$ "Duytschen Helicon.” See also Leonore Stapel, "'Tuyn van heel Holland, Moeder der Wijsheyt en bequam tot de drapery.' Reputatie en zelfbeeld van Leiden in beeld en tekst (circa 15901660)," De zeventiende eeuw 22 (2006), 149-169.

${ }^{15}$ See Linda A. Stone-Ferrier, Images of Textiles. The Weave of Seventeenth-Century Dutch Art and Society (Ann Arbor: UMI Research Press, 1985), 32-34; and Christiaan Vogelaar, "Abraham van den Tempel," in Hollands Classicisme in de Nederlandse schilderkunst (Rotterdam: Museum Boijmans van Beuningen, 2000), 254-263.
} 
In their discussion of Leiden's reason of state, the brothers De la Court borrowed many elements of this iconographical representation of a city in which peace and liberty reign and commerce and learning go hand in hand. Yet their approach was fundamentally more critical of Leiden's status quo than mainstream eulogies such as that of Orlers. They engaged in a fervent criticism of the corporate politics of Leiden's society, based on the primacy of guilds and municipal economic regulation. As independent entrepreneurs and relative newcomers to the Leiden textile industry, they looked at Leiden's economy from within yet with the critical eye of the outsider. This approach resulted in a passionate and remarkable plea for an 'open' city where entrepreneurial liberty fosters prosperity, in opposition to the traditional closed urban system of comprehensive corporate regulation. ${ }^{16}$

The textile industry of early-modern Leiden was organized in various communal institutions, usually installed by the municipal government, which administered and controlled the production and trade of all commodities. Every single branch of the industry was represented by its own corporative association, the so-called nering, presided over by members of the government and wealthy delegates of the industry. Like guilds, the various neringen regulated the production and imposed obligatory inspections of the textiles in a centrally located hall. Through the establishment of such halls, the municipal government sought to support the small producers, the drapers. In exchange for a levy on every article, the hall provided independent producers with opportunities to hire equipment and to purchase raw materials, as well as a marketplace to sell their products. In this way, the system of neringen and halls minimised entrepreneurial risks and maintained industrial stability, which attested to the ideological commitment of both the authorities and the drapers to sustain the order and prosperity of the community. ${ }^{17}$

In 1642 , the Leiden government installed a hall for the commerce of laken, a relatively new form of cloth that had become very fashionable and highly lucrative. The firm of the brothers De la Courts traded primarily in

\footnotetext{
${ }^{16}$ Jan de Vries and Ad van der Woude, The First Modern Economy. Success, Failure, and Perseverance of the Dutch Economy, 1500-1815 (Cambridge: Cambridge University Press, 1997), 175-176.

${ }_{17}$ See DuPlessis and Howell, "Reconsidering," esp. 59-62, and the reworking of their argument in Karel Davids, "Neringen, hallen en gilden. Kapitalisten, kleine ondernemers en de stedelijke overheid in de tijd van de Republiek," in C.A. Davids et al. (eds.), Kapitaal, ondernemerschap en beleid. Studies over de economie en politiek in Nederland, Europa en Azië van 1500 tot heden (Amsterdam: NEHA, 1996), 95-119.
} 
laken, and from the start, independent reders like the De la Courts opposed the establishment of the hall and its legislation, levies, and control. Together with a large group of other producers and traders, the De la Courts addressed their complaints to the Leiden court in 1653. They argued that "there is no better way conceivable to ruin the entire cloth industry of this city" than the hall's regulation of the production, which they denounced as "incompatible with the freedom and nature of trade". ${ }^{18}$ A few years later, the brothers De la Court further elaborated this argument against economic regulation in their treatise on Leiden, following their initial claim "that Leiden has never increased but by Liberty": ${ }^{19}$ the preservation and enlargement of the commonwealth, they asserted, the prime principles of reason of state, could only be furthered if all its citizens were allowed to do business as they please.

The De la Courts primarily insist that the success of Leiden's trade and industry is based on the consumption of its goods outside of the city walls, and is therefore entirely dependent on the mercantile reders. Small producers and petty artisans can only be employed thanks to the investments and success of these large entrepreneurs, especially of those who export Leiden textile across the borders. ${ }^{20}$ Since the largest profits are made in international trade, "these international Merchants are the most profitable inhabitants and they enrich the country the most". ${ }^{21}$ Yet they can only make such high revenues if they are left unhindered in their decisions, for "he who has to eat the porridge cooks and cools it best":

Everyone ought to be totally free and unrestrained in producing and dealing with his own commodity ... Where everyone takes care of himself, everyone is fine, and no one gets lost. This is the natural liberty that the Rulers should never take away from their subjects. ${ }^{22}$

${ }^{18}$ Posthumus (ed.), Bronnen, vol. IV: 498-501: “... strijdich tegen de vrijheyt ende natuyr van coopmanschap ... alsoo daer geen souverainder middel te bedencken is om de gantsche lakenneeringe deses stadts te ruyneeren." For other examples of the resistance of the reders against the system of halls, see Van Tijn, "Pieter de la Court," 315-321.

${ }_{19}$ Welvaren 11, p. 30: " dat Leiden noijt is toegenoomen, als door Vrijheid."

${ }^{20}$ Ibidem 16. Cf. the similar argument in Henry Parker, Of a Free Trade (London, 1647), 31: "If the question then be, whether the Merchants interest, or the Clothiers do more conduce to this publick reason of State; sense it self will presently distinguish, that the Merchants advantage is more compliant with the publick then the Clothiers."

${ }^{21}$ Politike Discoursen I.I.1, p. 9: "... sulks deese buitenlandse Handelers, de aller profitelikste ingeseetenen, ende die het land allermeest verryken, zijn."

${ }_{22}$ Welvaren 16, p. 44: "En die de pap selvs eeten moet, kookt en koelt se best ... een ijder in 't maken van sijn eigen goed, ende besteden desselvs gansch vrij en onbedwongen behoorde te weesen ... daer een ijder sich selven soekt, vind men sich best, en gaet niemand verlooren. Dit is de naturelijcke vrijheid, die de Regeerders noit hunne onderdanen behoorden te beneemen." 
The core assertion of De la Courts is that the system of halls and guilds fundamentally obstructs such natural liberty - and hence, Leiden's reason of state. The halls are governed by oligarchic boards of inexperienced people "who never fail to advise to their own advantage, even if it is obviously to the disadvantage of the community". Driven by such wrongly understood self-interest, the governors of the halls will simply try to fill their own purses under the pretext that they care for the common good, "using that nice cover of wanting to make the Industries eternal". ${ }^{23}$ Yet the hall's rigid system of regulation cannot obtain that goal of eternity given the vicissitudes of international trade. As the De la Courts insist, "none of our industries is fixed to the ground, and therefore they do not resemble the trees, from which one may cut some branches that bear little fruit". ${ }^{24}$ In the realm of commercial Lady Fortune, characterized by cross-border competition and the capriciousness of fashion, a pragmatist mercantile virtù is necessary to maintain Leiden's industry and to improve its competitiveness. As De la Court put it in 1657 when discussing the regulations concerning the production of camlet with his entrepreneurial colleagues: "Persist with liberty. Otherwise, the industries will divert." 25

The De la Courts therefore contend that all sorts of commodities, of whatever quality or price, should be put on the market, irrespective of the hall's obligatory controls. The resulting increase in production would do justice to "the right reputation of the Industries, [which] consists in the ability to provide honest work for the largest number of people". ${ }^{26}$ Opening up the market fosters general employment and the common welfare, whereas corporate regulation would result in the direct opposite. As the De la Courts conclude emphatically: "The poison of the Halls is deadlier to the draperies than the bloody swords of looting soldiers." ${ }^{27}$ With equally vehement language, they continue to reproach the economic policies of the guilds, the central institution of early-modern Dutch corporate

${ }^{23}$ Ibidem 23, p. 56-57: “... die missen noit tot hun eigen voordeel te raden, al is het kennelijck tot nadeel van 't gemeen ... soo gebruijcken sij evenwel die schone dekmantels van de Neeringe eeuwighdurende te willen maecken." See also Ibidem 28.

${ }^{24}$ Ibidem 26, p. 61 “... dat geen onser neeringen aen onse grond vast sijn, en dat sij dienvolgende de boomen niet gelijcken, daer men eenige weinigh vrughtdragende tacken mach afsnijden."

${ }^{25}$ Posthumus (ed.), Bronnen, vol. V: 282: "Persisteert bij de liberteyt. De neringe (anders) te sullen diverteren."

${ }^{26}$ Welvaren 31, p. 68: “... de reghte reputatie der Neeringen bestaet in de bequaemheid, om aen het grootste getal menschen hier eerlijck den kost te geven."

${ }_{27}$ Ibidem 34, p. 74: “... het vergift der Hallen doodelijcker is voor draperien, als de bloedige swaerden der plonderende soldaeten." 
politics. ${ }^{28}$ Like the halls, the exclusivist policies and unifying regulations of the various guilds are "a special pest for Leiden" which obstruct economic freedom and overall prosperity. Guildsmen, who "live lazily and wastefully at the expense of the other inhabitants" embody the prime characteristic of incivility - the desire for domination. To counter this "filthy tyranny and the monopoly of the guildsmen and the Governors of the Halls over their fellow inhabitants", all production should be deregulated, wages should be set free, levies and cartels abolished and every one should be able to choose with whom to trade. ${ }^{29}$ Such economic freedom will increase manufacturing, attract foreigners, and thus enhance Leiden's overall grandezza, for "Liberty is Leiden's welfare". ${ }^{30}$

The second pillar of Leiden's reason of state, next to trade and industry, is its university, which according to the De la Courts requires an equal degree of liberty. The brothers maintain that commerce and science are strikingly similar endeavours that require a similar approach, for "it is impossible to have such uncertain inhabitants who will leave so easily as Students or merchants in a country town" ${ }^{31}$ Just like its merchants, Leiden's students should therefore be cherished and granted freedom of choice. Yet Leiden's policies are very unfavourable to the student body, so the De la Courts claim. As in the textile industry, regulations and monopolist exploitation undermine the advancement of science and they chase students away. Tuition fees have become too high, the Professors, who operate like a guild, "have openly founded a Government within a Government", while the university's senate, like the boards of the halls, "has degenerated from a laudable aristocratic government into an altogether detrimental Stato da Pochi [sic] Government", an oligarchy based on cooptation and characterised by incompetence.$^{32}$ In short, commerce and learning prove to be intrinsically related. For the De la Courts, the status quo of Leiden's academy and market are a clear demonstration of

${ }^{28}$ See Maarten Prak et al. (eds.), Craft Guilds in the Early Modern Low Countries. Work, Power, and Representation (Aldershot: Ashgate, 2006).

${ }^{29}$ Welvaren 46-52, p. 104, 110, 118: “... een bijsondere pest voor Leiden ... om leuij en quistich ten laste der andere ingesetenen te leeven ... de vuijle tijrannie ende monopolie der gildebroederen, ende gouverneuren der Loijhallen over hunne mede ingesetenen." Cf. the similar passages in Politike Discoursen I.I.1, p. 5-7, I.I.6, p. 57-59.

$3^{\circ}$ Groningen University Library, Ms 233, addendum: "Vrijheid is Leidens welvaren."

${ }^{31}$ Welvaren 8, p. 19: “... onmogelijk is het, soo onseeckre inwoonders te hebben, en die soo licht vertrekken sullen, als Studenten, of wel koopluiden van een Landstad."

$3^{2}$ Ibidem 14, p. 33-35: “... met die loffelijcke aristocraticke regeeringe te doen degenereeren in een altoos schadelijcke Stato da Pochi, Regeeringh ... ende opentlijck opgereght eene Regeeringh in Regeeringe." 
what happens when freedom is restrained and when office-holding is not based on merit but on favouritism. The distinctive idiom in which they criticize this status quo reveals the political implications of their plea for economic deregulation.

The urban reason of state of the brothers De la Court principally aims to defend the position of Leiden's independent entrepreneurs against the regulative and exclusivist policies of the city's corporate establishment. Leiden is a diverse society, the brothers insist, it is characterized by the "endless natural division" of its inhabitants which is "that large, that no larger can be imagined when seeing so many Nations, Languages, Religions and occupations as are here assembled". ${ }^{33}$ This diversity should be cherished and enhanced instead of curtailed, for diversity breeds competition and competition breeds prosperity, in the economic as well as in the academic realm. If the Senate of Leiden University could change from an oligarchy into a broad assembly of diverse professors and lecturers, the resulting mutual envy would cause widespread ambition to "teach the Students in the most diligent way". ${ }^{34}$ Diversity thus channels human selflove towards a useful purpose. At the level of society at large, a polity that includes a variety of immigrants, creeds, and professions will engender the welfare and happiness of all, for its inhabitants will then be able to choose from all kinds of produce, employers and preachers, and from "a variety of people with whom to make friendship and to converse". In such an open and diverse city, abundance is assured and hunger rare thanks to "the multiplicity of merchants and artisans", whose presence assures a constant import and production of food and goods. Science and knowledge, arts and music are bound to flourish in all freedom and variety. ${ }^{35}$ The brothers De la Court do not hesitate to claim that their model of an open city amounts to a true commercial arcadia.

\section{Paragons of Republican Splendour \& Demise}

A standard element of many reason of state treatises was the comparison with other polities from the past and the present as noteworthy examples

\footnotetext{
${ }^{33}$ Ibidem 73, p. 160: “... een oneindelijcke naturelijcke verdeeldheid ... jae soo groote, dat geen grooter kan werden bedaght, als te sien, soo veelderleij Natien, Talen, Religien en occupatien, als hier bij een sijn."

${ }^{34}$ Ibidem 68, p. 148: “... den Studenten, door die jalousie, ambitie, ende nijd op het vlijtighste te onderwijsen."

${ }_{35}$ Politike Discoursen I.I.2, p. 40-41: “... keur van menschen, met wien men vriendschappen maken ende converseeren wil ... door de meenigvuldigheid der negotianten ende konstenaars."
} 
of statecraft. In their depiction of Leiden's arcadia amidst which industry and learning thrive in liberty and diversity, the brothers De la Court too referred to such paragons of republican splendour. Haitsma Mulier has shown in detail how the De la Courts appropriated in particular the commercial republics of the early-modern Mediterranean, which by the end of the 1650 s were a common point of reference for both sides of the Dutch debate on 'True Liberty'. The brothers paid ample attention to Venice and Genoa, outstanding examples of prosperous and powerful, yet conservative aristocracies, ${ }^{36}$ and, less extensively, to the small cities of Lucca and Ragusa (modern-day Dubrovnik), which shared Leiden's perspective and geographical hardship. Adopting the typical reason of state description of various countries by the sixteenth-century Venetian polygraph Francesco Sansovino, ${ }^{37}$ the De la Courts praised these commercial citystates for preserving their independence and wealth in a hostile world: the inland town of Lucca "has by good government and Fortification maintained its liberty and abounds in men, arts, and Industries", while Ragusa, though surrounded by infertile land and mighty neighbours, has thrived "in freedom and wealth".$^{8}$ This praise for Ragusa is especially significant, for it reveals a striking parallel with the way in which the contemporary English republican John Streater propagated Ragusa's republican government as the "true Embleme of a Free-State". 39

Yet the primary source of inspiration for the De la Courts' ideal of industry and learning continued to be Antiquity. In particular, they

${ }^{36}$ Politike Weeg-schaal II.III.2-II.IV.12 and II.V.1-11. See the elaborate analysis in Haitsma Mulier, Myth of Venice, 147-157.

${ }^{37}$ Francesco Sansovino, Del governo et amministratione di diversi regni et repubbliche, cosi antiche come moderne (Venice, 1568), esp. 111-115, 146-149. Pieter de la Court van der Voort owned a copy of this work: Library, fol. 19. On Sansovino, see Viroli, From Politics to Reason of State, 243-244, and Paolo Carta, "Magistrature repubblicane e comparazione giuridica nell'opera di Francesco Sansovino," Il pensiero politico 40 (2007), 283-300.

${ }_{38}^{8}$ Politike Weeg-schaal II.IV.13, p. 427: “...in vryheid, en weelde." Ibidem III.I.IV, p. 535: “... kleine Lucca, een Lant-stad, door een goede regeering, en Fortificatie sijn vryheit, hebbende behouden, overvloeit in menschen, konsten, en Manufacturen." See also Welvaren 58, p. 134-135. Cf. the comparison between the mercantile republics of Ragusa, Lucca, and seventeenth-century Boston in Sergio Bertelli, Trittico. Lucca, Ragusa, Boston. Tre città mercantili tra Cinque e Seicento (Rome: Donzelli, 2004). On the development of a republican rhetoric in Ragusa, see Lovro Kuncevic, "On Ragusan Libertas in the Middle Ages," Dubrovnik Annals 14 (2010), 25-69.

39 [John Streater], Government Described ... Together With a Brief Model of the Government of the Common-Wealth, or, Free-State of Ragouse (London, 1659), 8. The phrasing of Streater's description of Ragusa is comparable to the Politike Weeg-schaal, and equally stems from Sansovino. On Streater, see Nigel Smith, "Popular Republicanism in the 165os: John Streater's 'Heroick Mechanicks'," in David Armitage et al. (eds.), Milton and Republicanism (Cambridge: Cambridge University Press, 1995). 
followed the prevalent comparison between Leiden and classical Athens, the foremost historical example of a republic that accommodated both the agora and the academy. In 1625, Joannes Meursius, professor of Greek history at Leiden University, had published a remarkable eulogy of the first decades of his alma mater under the title Athenae Batavae..$^{40}$ Similarly, the poet Jacob Lescaille praised Leiden as a "Batavian Athens", the site of both Apollo's temple and Pallas' court, ${ }^{41}$ while Vondel too heralded Leiden as "The new Athens". ${ }^{42}$ This scholarly and literary identification with Athens was elaborated further by the De la Courts. Their fascination was shared by English political pamphleteers such as Marchamont Nedham, who described Athens as "the onely Patern of a Free-state fit for all the world to follow". ${ }^{43}$ While Harrington, like Machiavelli, focused primarily on militant Sparta and Rome, his more commercially-minded contemporaries on either side of the North Sea turned to other republican role models in the classical and contemporary Mediterranean. ${ }^{44}$

Not unlike Nedham, the brothers De la Court presented Athens as a paradigmatic popular government, a truly commercial city-state that could serve as a model for Leiden. Apart from obvious sources such as Herodotus and Thucydides, this interpretation of Athens owed a particular debt to the overview of the history of Greek city-states by the Frisian historian Ubbo Emmius, a work included in the 'Republics' series of Elzevier. Emmius had characterized all Greek republics as status popolares, which principally implied that the citizenry enjoyed the right to elect the republic's magistrates. ${ }^{45}$ This usage of the term 'popular government' is adopted

\footnotetext{
$4^{40}$ See Anthony Grafton, Athenae Batavae: The Research Imperative at Leiden, 1575-1650. Scaliger Lectures 1 (Leiden: Primavera, 2003).

${ }^{41}$ Jacob Lescaille, "Lof van Leiden," in Toonneel der steden van de Vereenighde Nederlanden, met hare beschrijvingen (Amsterdam, 1652), vol. I, fol. ii D4 d: "O moedig Leiden! ... O voedster van de deugd/En alle wetenschap! Toneel der wijste lieden,/Apollo's tempel, hof van Pallas, wier gebieden/Gij loffelijk bestuurt! Sieraad van 't vrije land,/Der muzen woonplaats en voortteelster van verstand,/Voorspreekster van het recht, geneesvrouw der gebreken,/Die alle volken doet van uwe wijsheid spreken./Bataafs Athene! Leef door voorzicht, trouw en raad/En vreê en voorspoed, als de zuilen van uw staat."

${ }^{42}$ Joost van den Vondel, "Op de geluckige regeeringe van Leiden" (1664), in De werken van Vondel, ed. J.F.M Sterck et al., 11 vols. (Amsterdam: Maatschappij voor goede en goedkope lectuur, 1927-1940), vol. X, 176: "Het nieuwe Athene groeit, nu 't oude in d'assche leit."

${ }^{43}$ [Marchamont Nedham], The Excellencie of a Free-State: or, The Right Constitution of a Common-wealth (London, 1656), 8. On Nedham's description of Athens, see Jennifer Tolbert Roberts, Athens on Trial. The Antidemocratic Tradition in Western Thought (Princeton: Princeton University Press, 1994), 145-147.

44 Cf. Pincus, "Neither Machiavellian Moment nor Possessive Individualism," 724.

45 Ubbo Emmius, Vetus Graecia illustrata (Leiden, 1626), and Idem, Graecorum respublicae (Leiden, 1632). See the analysis in Conti, Consociatio civitatum, 86-104.
} 
in the extensive description of Ancient Greek history in the Politike Weeg-schaal. Following Emmius, this crucial passage, most certainly written by Johan de la Court with small revisions by Pieter, implicitly compares the republican fate of Athens with Leiden and Holland at large. ${ }^{46}$ To begin with, the brothers De la Court highlight the geographical situation of Athens, a maritime city amidst barren lands and therefore forced to make a living by fishing and trade. The similarity with Leiden and Holland is obvious, and the De la Courts argue that Athens' commerce on the Black Sea, like the Dutch trade in the Baltic, had made it into the staple market of Europe. They stress that such commerce could thrive in Athens because of the city's prime characteristic, its "uniform Liberty": citizens as well as foreigners were allowed to trade and participate in all industries without the obstruction of "Patents, Privileges, or Guilds and Halls". Moreover, in Athens "all Citizens had the right to appear in its great Assembly", while mostly "rich and therefore well-educated Citizens were used in the Magistracy" - a practice of which the De la Courts clearly approve. ${ }^{47}$

However, Athens also had flaws. First, the De la Courts criticize its restrictions on the acquisition of citizenship, and insist that these restrictions created "a very large discontent among so many thousands foreign Inhabitants" and hence "a very large disposition to upheaval" ${ }^{8}$ In short, a policy of restrictive citizenship threatens the stability of the commonwealth, again a clear allusion to the situation in Leiden. Secondly, the De la Courts criticize the belligerent politics of Athens, "for nothing more detrimental to a State built on artisanship, trade and sciences can be thought of than all-destroying and commerce-impeding War". In contrast, amongst the "principal causes of Athenian greatness" was its defensive alliance with other Greek states against the Persians, the Attic league so often upheld in the Dutch debate as a noteworthy example for the United

${ }^{46}$ Politike Weeg-schaal III.II.1-III.II.4. The entire passage is already included in the first edition, with small revisions added to the later editions of the work. Cf. also the analysis in Haitsma Mulier, Myth of Venice, 143-144.

47 Ibidem III.II.1, p. 591: “... eenparige Vryheid.” III.II.2, p. 604, 614: “Alle Burgers hadden regt te verschijnen in haare groote Vergaderinge ... zeer weinig andere, als rijke, en dienvolgende wel-opgevoede Burgers in Magistrature wierden gebruikt." III.II.4, p. 620: "Van Octroyen, Privilegien, off Gildens en Hallen werd naar my voorstaat, in geen Historien van Atheenen gewag gemaakt."

${ }^{48}$ Ibidem III.II.2, p. 603: "Een yder stond vry te Athenen te komen woonen, en daar alle Vryheid en Regten nevens de Burgers te genieten.” III.II.4, p. 627: “... een zeer groot misnoegen onder zoo veele duisenden vremde Inwoonders ... een zeer groote dispositie ten oproer." 
Provinces. ${ }^{49}$ Finally, this suggestive comparison between Athens and Holland becomes all but outspoken when the De la Courts insist that Athens flourished in "Sciences and Arts" and "increased exceedingly in all luxury, art, knowledge, and wealth" when it was "under an entirely Popular Government without any Head, or permanent Councillors and Magistrates".$^{\circ}$ The history of Ancient Athens thus serves as a critical mirror to seventeenth-century Leiden and Holland at large. It reveals that a policy of open citizenship, entrepreneurial liberty and peaceful and defensive alliances under a government of the rich who rotate offices without any single ruler such as a Stadholder, fosters commerce, learning and social stability, and hence the preservation and increase of the commonwealth.

This praise of Athens engenders a critique of the other classical polity most frequently heralded as a time-honoured source of inspiration and emulation: Ancient Rome. For the brothers De la Court, the Roman Republic, "utterly founded on the violence of arms to the ruin of all learning and commerce", is the ultimate antithesis of good republican rule. With its belligerent spirit and its distaste for trade, Rome, "that all murdering, plundering and the world destroying Republic, had to be an enemy of commerce" - as proved the case when Rome conquered the great trading republics of Athens and Carthage. ${ }^{{ }^{1}}$ Eventually, the absence of merchants and the excess of empire made Rome relapse into the tyranny of its own military commanders..$^{2}$

This disapproval of the example of Rome was a common theme in the early-modern Netherlands, going back as far as Erasmus's criticism of Roman expansionism. ${ }^{53}$ Boxhorn, for instance, paid considerable attention

49 Ibidem III.II.1, p. 590-591: “... een onderling verbond tot gemeene bescherminge ... een van de voorneemste oorsaaken der Atheniensen grootheid.” III.II.4, p. 624: “... want nietwes schadeliker voor een Staat, die op konst, koopman-en weetenschappen geboud is, bedagt kan werden, als de alles vernielende en commercie belettende Oorlog."

${ }^{50}$ Ibidem III.II.2, p. 615: “... boven maaten in alle weelde, konst, kennisse, en rijkdom is toegenoomen." III.II.4, p. 619, 621: “Onder een volkome Populaare Regeering zonder eenig Hoofd, of blijvende Raads- en Magistraats-persoonen ... Alle Weetenschappen en Konsten wierden hier zoodanig aangequeekt."

${ }^{51}$ Welvaren 9, p. 20: "Want die Roomsche Republijk t'eenemael op geweld van wapenen gefondeerd sijnde geweest tot ruine van alle geleerdheid, ende koopmanschappen ... die alles moordende, plonderende, en wereld verwoestende Republijck viandin der koopmanschappen moste sijn."

$5^{2}$ See the extensive discussion of Roman history in Politike Weeg-schaal II.VI.2-4, and cf. Haitsma Mulier, Myth of Venice, 137-138.

53 See Martin van Gelderen, "The Low Countries," in Howel A. Lloyd et al. (eds.), European Political Thought 1450-1700. Religion, Law and Philosophy (New Haven and London: Yale University Press, 2007), 376-415, esp. 381. 
to the demise of the Roman Republic in his classes from the $1640 s,{ }^{54}$ while another Leiden academic, Antonius Thysius, similarly refuted belligerent Rome in an expansive overview of the history of various republics published in $1646 .{ }^{55}$ Yet the explicit way in which the De la Courts rebuke the Roman Republic is beyond compare. The aristocratic Roman Senate, so the brothers insist with numerous quotes from Lucan, Livy and Tacitus, was enslaved by "the passion and lust to wage war", which condemned the common citizenry to drudge under unbearable imposts and turned the city into "a deadly Pest for the earth". ${ }^{6}$ Indeed, the territorial expansionism of Rome destroyed all the other classical republics and thereby eradicated the ancient European legacy of liberty:

For not only Greece and all the Islands in the Mediterranean, but also all of Italy, France, and Spain and all of Germany was divided among incredibly many Republics, until that ... war-loving and all-destroying Roman Republic had subdued and destroyed them with her weapons, one by one..$^{57}$

By way of conclusion to this flamboyant condemnation of Rome, the brothers De la Court express their wonder "that this murderers' den, this wolfs nest, this most detestable and horrible Republic that has ever been on this earth, is praised so much by many"..$^{8}$ The implicit reference to Machiavelli's Discorsi must have been obvious to most contemporary readers, and it serves as a warning to modern historians not to overemphasize Machiavelli's influence on the De la Courts. ${ }^{59}$ Moreover, their

${ }^{54}$ Boxhorn, Emblemata politica. Accedunt dissertationes politicae de Romanorum Imperio (Amsterdam, 1651), esp. dissertation XIV: "De mutatione Reip. \& initiis Monarchiae Caesarum sive C. Julius Caesar," p. 310-327.

55 Antonius Thysius, Memorabilia celebriorum veterum rerumpublicarum (Leiden, 1646). Pieter de la Court van der Voort owned a copy of this treatise: Library, fol. 31. See also Haitsma Mulier, Myth of Venice, 59-6o.

${ }^{5}$ Politike Weeg-schaal II.VI.4, p. 507, 511: “... passie en geneegentheid tot oorlogen ... een doodelike Pest voor den aardbodem."

57 Ibidem I.III.1, p. 231: "Want niet alleen Griekenland en alle de Eylanden der Middelandse Zee, maar ook geheel Italien, Vrankrijk en Spanjen, jaa ook geheel Duitsland, in ongeloovelik veel Republiken verdeelt was; tot dat die (Non erat is populus quem pax tranquilla juvaret, quem sua libertas immotis pasceret armis. Lucanus) krijgs-lievende, en alles vernielende Roomse Republik alle de zelven, d'eene voor d'ander na, door hare wapenen hebbende doen bukken, en verwoest." The quote is from Lucan, Pharsalia I, vs. 171-172.

${ }^{5}$ Ibidem II.VI.4, p. 513: “... dat deeze moort-kuil, dit Wolve-nest, deeze verfoeyelikste en grouwelikste Republik, die ooit op den aardbodem is geweest, by veelen zeer werd gepreezen."

${ }_{59}$ Cf. Machiavelli, Discorsi, esp. I.6, II.3-4, II.19, II.30, III.24. See the analysis in David Armitage, The Ideological Origins of the British Empire (Cambridge: Cambridge University Press, 2000), 125-132; and Idem, "Empire and Liberty: A Republican Dilemma," in Van Gelderen and Skinner (eds.), Republicanism, vol. II: 29-46. 
harsh criticism of Rome's territorial expansion entails a crucial difference from many English republicans, including Streater, Nedham, and most importantly Harrington and Sidney, who praised the Roman Republic precisely for its glorious conquests. ${ }^{60}$ Where Machiavelli's beleaguered Florence or Cromwell's expanding England looked back to the military greatness of Rome, the commercial commonwealth of the brothers De la Court followed another model of republican splendour.

\section{A Commonwealth of Cats}

Unlike Rome, the republic of the De la Courts is not a commonwealth for the increase of territory, but for the increase of trade. The brothers' argument for such commercial expansionism relies on a seeming paradox: on the one hand, it proposes a non-offensive foreign policy, because commerce thrives in peace, on the other it propagates the establishment of a colonial empire of trading posts to foster global trade. Yet for the brothers De la Court peace and imperialism do not entail a contradiction in terms. Appropriating the experience of ancient Athens and the contemporary city-states of the Mediterranean, they maintain that a republic of trade should refrain from all territorial conquests and remain utterly self-reliant in order that overseas trade can expand without impediment.

This argument follows from several claims. First, the enduring independence of small cities like Lucca and Ragusa reveals that a good defence is the key for maintaining republican liberty. The De la Courts therefore insist repeatedly that the main duty of the magistrate of Leiden and the other towns of Holland is to arm the rich citizens and uphold strong protective fortifications against any external threat. ${ }^{6}$ Moreover, the demise of Rome and the commercial lustre of the contrary republican paradigm, Venice, show that mercantile republics should opt for defensive peace instead of offensive war. A similar claim had been brought forward before by the Venetian author Paolo Paruta, one of the main propagators of the Myth of Venice in the sixteenth century. In a clear repudiation of Machiavelli's celebration of Rome's military expansionism, Paruta argued that the Venetians "employed other means to defend

\footnotetext{
6o See Sidney, Court Maxims, 16-17; and Harrington, Oceana, 223-229. Cf. the discussion in Scott, Commonwealth Principles, 210-229; and Armitage, Ideological Origins, 134-141. See also Fergus Millar, The Roman Republic in Political Thought (Hanover: University Press of New England, 2002), 80-99.

${ }^{61}$ Welvaren 58-6o, elaborated further in Aanwysing I.1, II.15.
} 
liberty and to increase their riches, using for the former the navy, and for the latter traffic and merchandizing". Such commercial growth, Paruta continued, followed from the maxims of "preserving peace and keeping open and free commerce with all". ${ }^{62}$ The De la Courts adopt this Venetian example to the case of Holland in general and with regard to Leiden in particular, for Leiden, "living of the Academy and the Industries, is not founded on arms, but on peace". ${ }^{6}$

Leiden's reason of state must necessarily be pacifist since warfare obstructs international trade and requires large financial resources. Hence, "in Republics that live of commerce ... a Guerre offensive is always a Guerre consumtive" ${ }^{64}$ Offensive warfare is simply too costly for a precarious city like Leiden. With a metaphor that again implicitly refutes Machiavelli, De la Court concludes that a truly commercial commonwealth should not wrap itself up in a lion's skin or a fox's pelt, but rather follow the commendable example of another species:

a $\mathrm{Cat}$, who pays diligent attention to provide for food and takes great care to preserve its own young ones, and never barks or snarls at someone who provokes or abuses it ... When assaulted and pursued, it immediately flees into some hole or natural stronghold, where it remains silent until the emergency is over ... So that by these praiseworthy arts, the cats enjoy more quiet everywhere, live longer, are more pleasant and in much greater number than the devouring Beasts, Lions ... or cheating Foxes. ${ }^{65}$

In short, the best strategy to survive in the aggressive animal realm of international politics is to adopt the self-satisfied stoicism of cats.

${ }_{62}$ Paolo Paruta, Discorsi politici (Venice, 1599) II.1, p. 367, 385: “... si'impiegarono in altri studii, per difendere la libertà, \& accrescere le ricchezze loro, usando in quella cosa la militia del mare, \& in questa i trafichi, \& le mercantie ... il conservare la pace, \& tenere il commercio aperto, \& libero con tutti." Pieter de la Court van der Voort owned a copy of this work: Library, fol. 19. On Paruta, see Haitsma Mulier, Myth of Venice, 29-31; Viroli, From Politics to Reason of State, 231-237; and Comparato, "Republicanism in Italy," 170-172, $183-184$.

${ }^{63}$ Welvaren 58, p. 135: “... van het Akademij ende Manufacturen levende, is niet op de wapenen, maer op de vrede gefondeerd." This argument is extensively elaborated in Aanwysing II.2-4.

${ }^{64}$ Aanwysing II.4, p. 253: “... in Republiken die van de koopmanschap leeven ... is alle aangrijpende oorlog schaadelik, en Guerre offensive altijds Guerre consumtive."

${ }_{5}$ Ibidem, 254-255: "Voorwaar een Kat past vlytig op om sijnen kost te soeken, ende draagd groote sorg om sijne eigene jongen te bewaaren: bast nog smaald noit teegen iemand die hem tergd ofte lasterd ... Sulks hy aangeransd en vervolgd zijnde, terstond vlugt naar eenig gat ofte natuurelike sterkte, alwaar hy sig stille houd tot dat die nood over gaa ... sulks door deese roemwaardige kosnten, de katten overal veel meer rust genieten, langer leeven, alsmeede aangenaamer en in veel grooter getaale zijn, als de verslindende Dieren, Leewen ... ofte de bedriegende Vossen." Cf. Machiavelli, Principe XVIII. 
This imaginative plea for a peaceful, defensive and autarchic foreign policy involved a clear move in the debate on Dutch foreign policy in the wake of the Peace of Westphalia. In line with the claim of the Duke of Rohan that the interest of the United Provinces was to make war, ${ }^{66}$ many Dutch pamphleteers during the 1650 os and 1660 os favoured the resumption of the glorious earlier conquests of the Stadholder's troops against Spain. "War is an exercise of the highest justice", as one pamphleteer argued against the Peace treaty with England in $1654 .{ }^{67}$ Another pamphlet insisted in 1661 that the Dutch should follow the example of the Roman Republic and again take up arms against Spain to safeguard their commercial interests overseas: “if it isn't done for the reputation of our Country, let it then be done for the sake of profit." ${ }^{68}$ To counter such claims, the brothers De la Court asserted emphatically that the interest of Leiden and Holland as a whole could not possibly consist in war and conquests precisely because the general interest was based on international trade. Employing the language of a commercial reason of state, they thus substantiated the position of the Holland mercantile elite, which generally favoured peace and a strong navy over a costly land war and a standing army that was chiefly to be paid for by the province of Holland..$^{69}$

Yet there is a clear limit to the pacifism of the brothers De la Court, for their rejection of territorial conquests does not entail a rejection of colonial expansion..$^{70}$ In the reason of state tradition, the establishment of colonies was often characterized as a peaceful alternative to military conquests for achieving republican grandezza. Botero, in particular, stressed the utility of colonization as a profitable way to pursuit expansion without

${ }^{66}$ Rohan, De l'interest des princes, 124-125.

${ }_{7}$ Bedenckingen op de Deductie, 73: "Oorlogh is een exercitie van de hoogste justitie."

${ }^{68}$ Verthooninge, ghedaen aen die van de Vereenichde Nederlanden (s.l., 1661), sig. B: "so het niet geschiet uyt reputatie van ons Lant, laet het om profyts wille gedaen werden."

${ }_{69}$ On the foreign policy of the States of Holland vis-à-vis the other Dutch provinces, see J.C. Boogman, "Die holländische Tradition in der niederländischen Geschichte," in Boogman, Van spel en spelers (The Hague: Martinus Nijhoff, 1982), 147-161, and the more extensive discussion in J.L. Price, Holland and the Dutch Republic in the Seventeenth Century. The Politics of Particularism (Oxford: Clarendon Press, 1994). Cf. for the debates across the North Sea, Steven Pincus, Protestantism and Patriotism. Ideologies and the Making of English Foreign Policy, 1650-1668 (Cambridge: Cambridge University Press, 1996).

$7^{7}$ On the development of Dutch colonial ideology in the seventeenth century, see Martine van Ittersum, Profit and Principle. Hugo Grotius, Natural Rights Theories and the Rise of Dutch Power in the East Indies (1595-1615) (Leiden and Boston: Brill, 2006); and my "Republican Empire. Colonialism, Commerce and Corruption in the Dutch Golden Age," Renaissance Studies 26 (2012). 
resorting to violence. ${ }^{71}$ The brothers De la Court readily adopted this commercial ideology of colonization. While "the Conquests of other Cities" might lead to "the demise of nearly all Free-States", they argued that there is also a positive form of expansion, namely "Conquests that improve Commerce ... like the Europeans obtained from the Indians" ${ }^{72}$ Elaborating on this claim, De la Court insisted that the settlement of overseas colonies should be a central policy of a commercial commonwealth like Holland. One of the characteristics of a republic based on immigration and trade, so De la Court argued, is a large number of unhappy and restless inhabitants. The capriciousness of commerce causes a continuous threat of instant poverty, and hence there will always be discontented people who prefer to try their luck elsewhere. Moreover, the constant rotation in government and the meritocracy typical of a true republic result in similar dissatisfaction among the sons of the establishment who are not elected to the ranks of the administration. They too will therefore long for another territory where they can give full rein to their ambition and where they will be honoured for their deeds. The powers in being should try to get rid of these young men who, driven by self-love, might easily endeavour to rebel against the government. With these arguments, De la Court tried to convince the Dutch political establishment of the necessity of erecting satellite states overseas, in which Dutch expatriates would enjoy new opportunities whilst remaining subject to the political supervision of the metropolis. To alleviate internal pressure and to pursue external greatness, a commercial commonwealth should follow the example of classical commercial republics like Athens and establish such a network of colonial trading posts that enhance commercial increase. ${ }^{73}$

At first sight, this mercantile colonialist ideology, which clearly intended to legitimize the seventeenth-century practice of Dutch overseas expansionism, might be characterized as a distinctly modern justification of colonization, typical to the rise of the imperialist state in the West. Nonetheless, it is important to stress that the logic behind the De la Courts' commercial imperialism remains largely within the classical

${ }^{71}$ Botero, Cause della grandezza delle città, 333-334. For the impact of Botero's argument for commercial colonization, see Andrew Fitzmaurice, "The Ideology of Early Modern Colonisation," History Compass 2 (2004), 1-14.

${ }^{72}$ Politike Discoursen II.V.6, p. 121: “... de Conquesten van andere Steeden, buiten haare Republijk te doen, dat is kennelijk de ondergang van meest alle Vrye-Staaten ... Maar aangaande Conquesten die de Koopmanschap verbeteren, en doen bloejen, gelijk die van Europa op de Indiaanen gedaan hebben, die zijn goed."

${ }^{73}$ Aanwysing I.26. 
framework of the single metropolis and its dependent colonies. Their model of a colonizing republic is not the territorial state of the Dutch Republic at large, but the independent, self-contained city of Leiden and by extrapolation the amalgam of cities that constituted the States of Holland. De la Court categorically stressed that each city in Holland could easily subsist independently, and that Holland at large, "observing its own Interest, could establish here in Europe $a$ State without depending on any other". ${ }^{74}$ While arguing for overseas colonization, De la Court fervently spurned a closer union of the United Provinces beyond a mere alliance for mutual defence. This rejection of federalisation even entailed the radical proposal of digging a large trench to separate Holland once and for all from the other provinces and hence turn it into an isle of splendid isolation. ${ }^{75}$

Like their assessment of the Roman expansionist model, this particularist core of the republican politics of the brothers De la Court involves a crucial distinction of contemporary English republicanism. In spite of their widespread admiration of Dutch prosperity, English republicans generally maintained that the Dutch Republic suffered from one fundamental shortcoming: its lack of a strong centralized government. Milton, for example, asserted with characteristic bravura that the English Commonwealth would "far exceed the United Provinces by having, not as they ... many Sovranties united in one Commonwealth, but many Commonwealths under one united and entrusted Sovrantie"..$^{7} \mathrm{~A}$ few years later Sidney similarly rejected the Dutch model by arguing that "their constitutions seem to have a more particular regard to the preservation of the liberties and privileges of each town and province than to the welfare of the whole ... Their commonwealth seems to be a vast building of loose stones, which not well cemented, threatens ruin".77 In clear contrast, the fragmentation of the Dutch Republic was no issue at all for the De la Courts, whose republican model, unlike Milton's or Sidney's, continued to focus on the self-contained city instead of the centralized national state.

\footnotetext{
${ }^{74}$ Ibidem II.11, p. 311: “... dat Holland sijn eigen Interest wel waarneemende, hier in Europen een Staat op sig selven soude konnen maaken, sonder van eenig ander te dependeeren."

${ }_{75}$ Ibidem II.14. Following the judgment of Pieter de Groot, who called it a "dubious" argument, this proposal had not been included in the Interest van Holland. See Pieter de Groot to Johan de Witt, 2 June 1662, in Brieven aan Johan de Witt, ed. Japikse, vol. II: 108.

${ }^{76}$ Milton, The Readie and Easie Way to Establish a Free Commonwealth, in Idem, Areopagitica and Other Political Writings, 443.

77 Sidney, Court Maxims, 172-173.
} 
A revealing passage in the Politike Weeg-schaal stresses the advantage of such an urban republic which, precisely because it is confined to the limits of a single city, must practice a peaceful foreign policy that promotes trade. When rewriting this passage De la Court added a short side note to the effect that republics can very well consist of a federation of different cities, hastily referring the reader to the source of this claim: "All of which has been very well demonstrated in detail by J. Harrington in his Commonwealth of Oceana. So it is unnecessary to talk about it further." ${ }^{78}$

This manuscript reference to Harrington - the sole mention of any English republican in the entire œuvre of the brothers De la Court - is particularly significant because it shows how De la Court appropriated an argument wholly secondary to Harrington's thought for his own Dutch republican agenda. ${ }^{79}$ Ironically, this appropriation thus reveals how little the English republican experience of the 1650 s could offer to the fragmented federation of cities and provinces across the North Sea. Clearly, the role model for the De la Courts, as for all their republican compatriots, was not the centralized, expansionist monarchical republic of England but the self-contained city-states of the classical and the contemporary Mediterranean, the colonizing, commercial cities of Athens and Venice. Just like these shining examples of haughty and stoic self-rule, the republic of the brothers De la Court proudly maintained its distance from the hectic pursuits of the centralized state: it was, after all, a commonwealth of cats.

\section{The Politics of Free Trade}

\section{Liberty as the Highest Law}

Leiden's prospects, modelled on Ancient Athens, form the inductive foundation of a general theory of commercial reason of state that the brothers De la Court apply to the case of Holland at large. The core of this

${ }^{78}$ Amsterdam University Library, Ms. XXV C41, addition to Politike Weeg-schaal III.I.6, p. 577: “... twelk alle in 't bysonder seer wel is aangeweesen door J. Harrington in syn Commonwealth of Oceana. Sulks onnodig is hiervan breeder te spreeken." De la Court probably refers to the passage in Harrington, Oceana, 163 . The date of this addition remains unknown, but it must have been made after 1662. The first and only evidence that De la Court knew Harrington is his letter of New Year's Eve 1672.

${ }^{79}$ For two lucid analyses of the main characteristics of Harrington's republicanism, see Jonathan Scott, "The Rapture of Motion: James Harrington's Republicanism," in Nicholas Phillipson and Quentin Skinner (eds.), Political Discourse in Early Modern Britain (Cambridge: Cambridge University Press, 1993), 139-163; and Blair Worden, "James Harrington and 'The Commonwealth of Oceana,' 1656," in Wootton (ed.), Republicanism, $82-110$. 
theory lies in the Ciceronian maxim salus populi suprema lex, a powerful and widespread early-modern commonplace that, like the connected adage 'necessity has no law', could be mobilized for various political purposes, both monarchical and republican. ${ }^{80}$ The De la Courts comment on this diverse usage of the axiom by contending that the phrase is like "a nice doll praised by all outwardly, but by only a few valued and cared for inwardly". ${ }^{81}$ For the brothers, the true significance of the maxim is revealed by the case of Leiden, which shows that the health of the people in a mercantile republic consists of two intrinsically connected elements: the greatness of the commonwealth and the advancement of liberty. Since a republic of trade should forsake territorial conquests, commerce itself must be the means to achieve the preservation and increase of the polity, and commerce, as the example of Athens demonstrates, thrives in liberty. Hence, freedom of trade, which includes freedom of immigration, occupation and enterprise, is the supreme law that leads to commercial greatness.

This fundamental claim that free trade forms the essence of commercial reason of state is based on several premises. The argument of the De la Courts starts with the assertion that human natural liberty should be maintained as much as possible within the boundaries of the law in order to promote common prosperity and the growth of society. As the brothers boldly assert, "all Political thinkers generally admit that the highest perfection of Politics and human society consists in this single point, namely, that the Subjects are left as much natural liberty as is in any way doable". ${ }^{82}$ A commonwealth where all inhabitants enjoy such liberty will improve its competitiveness with the surrounding polities and therefore fulfil its chief goal, the increase of its population. Indeed, a city like Leiden "will only be able to subsist by giving its inhabitants much more freedom than they can find in any nearby or better situated Cities or places". ${ }^{83}$ The De la

${ }^{80}$ Cf. Miller, Defining the Common Good, 39-40.

${ }^{81}$ Welvaren 61, p. 141: "Salus populi Suprema Lex ... waerelijck het is een schoone pop bij allen uijterlijck gepreesen, bij weinigen innerlijck besorght ofte geaght."

${ }_{82}$ Ibidem 3, p. 10: "Want alle Politijcken bekennen in het generael, dat de hooghste volmaecktheid der Politie ende menschelijcke societeijt bestaet in dit eenige point, namentlijk Dat den Onderdanen werde gelaten soo groote naturelijcke vrijheid als eenighsins doenlijck is." See the similar passage in Politike Discoursen I.I.1, p. 21. Cf. Hobbes, Elements of Law II.9, p. 178: "That to leave man as much liberty as may be, without hurt of the public, and to ordain means for trade and labour, and to forbid superfluous expenses, is a duty of a sovereign by the law of nature."

${ }_{3}$ Welvaren 80, p. 171: “... gansch niet subsisteeren kan, dan met den inwoonderen veel meer vrijheid te geeven, als sij in eenige nabij, of beeter geleegene Steden, ofte plaetsen konnen beleeven." 
Courts therefore stress the need to grant all immigrants citizenship rights and the same opportunities to make a living as the indigenous population, for "absolute uniform freedom for all inhabitants, bearing uniform burdens" is apart from a natural right a "powerful means to attract foreigners" ${ }^{84}$

Such freedom of immigration and occupation is all the more important since immigrants will also bring "knowledge and goods" from outside. Newcomers do not own any fixed property and therefore they will have to invest their foreign experience and capital "to invent and create new fisheries, manufactures, trade, and navigations". Hence, a constant influx of immigrants will guarantee the constant renewal and improvement of trade and industry. ${ }^{85}$ Commercial increase and liberty are thus mutually dependent:

Trade is a very powerful means to employ and feed many people. ... Yet Trade is not fixed to one place only. Where Merchants are burdened least and where they are given more freedom to make and keep profits, there they will remain. But where, on the contrary, the freedom to make profits is restricted, or where the rich Merchants are harshly charged, there they are chased away or extinguished. ${ }^{86}$

In short, in an emerging era of international commercial competition, a commercial commonwealth like Leiden or Holland at large can only endure by conceding all inhabitants a range of liberties: "freedom in Religion, Study, trade, manufactures, arts, citizenship and Government" ${ }^{87}$

In the course of the later seventeenth century, at the threshold of modernity, this idea that commercial success is the key to compete with other polities became an important element of political thinking all over Europe. Istvan Hont has analyzed this intellectual development in considerable detail, convincingly arguing that such 'jealousy of trade' "was an

${ }^{84}$ Ibidem 2, p. 8: “... hoe kraghtigen middel om vremde inwoonders aentelokken ... de absolute eenparige vrijheid voor alle inwoonders, eenparige lasten dragende, intevoeren."

${ }^{85}$ Aanwysing I.15, p. 69: “... alle haare kennise en goederen te besteeden, om nieuwe visserien, handwerken, koopmanschap, ende navigatien te bedenken, en te formeeren.”

${ }^{86}$ Politike Discoursen I.I.1, p. 4: “... dat de koopmanschap een zeer kragtig middel is, om zeer veele menschen besig te houden ende te voeden ... Maar de Koopmanschap is aan geen plaats vast, daarmen den Koopluiden minst beswaard, en meer vryheids geeft om haare profiten te mogen doen, ende te conserveeren, daar heeftmense: ende daarmen ter contrarie de vryheid om winsten te doen besnoeit, ofte de rijke Koopluiden hard taxeert, daar verjaagd of blustmense uit."

${ }^{87}$ Welvaren 80, p. 171: “... door vrijheid in Religien, Studien, koopmanschappen, manufacturen, konsten, borgerschap en Regeeringh.” 
extrapolation of Machiavellianism to the modern trading economy", and "the application of reason of state to international trade". ${ }^{88}$ Yet surprisingly, Hont has paid very little attention to Dutch theorizing about such commercial reason of state, although the Netherlands were the principal object of much of the jealousy in question. ${ }^{89}$ To mention just one example, Josiah Child stressed in 1668 that the "prodigious increase of the Netherlands in their domestick and foreign Trade, Riches, and multitude of Shipping, is the envy of the present, and may be the wonder of all future Generations". ${ }^{\circ}$ This assumption was shared by the Dutch themselves, such as a pamphleteer who argued in 1661 that Dutch primacy in world trade had caused that "several Nations have become jealous, especially the English, who cannot bear the prosperity of the Dutch"..$^{11}$

The brothers De la Court similarly realized that Holland's commercial success lead to the envy of other polities: even though "all Republics that are founded on peace and commerce share the same Interest with Holland", they would still try to obstruct "our main design, namely the increase of commerce"..$^{2}$ Therefore, all competitors, and in particular England, should be outplayed by a policy of insuperable freedom of trade. Drawing such a connection between liberty and commerce was, of course, hardly exceptional in the mercantile world on either side of the North Sea. Already in 1568, at the start of the Dutch Revolt, a pamphlet explicitly stressed that "Marchandise, Manufacture et Negotiations" should be seen as the sisters of "Liberté". ${ }^{33}$ The issue of free trade continued to dominate much of the political and economic debate - and warfare - between England and the Dutch Republic throughout the seventeenth century,

\footnotetext{
${ }^{88}$ Istvan Hont, Jealousy of Trade. International Competition and the Nation-State in Historical Perspective (Cambridge, Mass.: Harvard University Press, 2005), 9, 13.

${ }^{89}$ Hont only discusses the famous views of William Temple, the English ambassador to The Hague in the 166os: Ibidem, 194-201. More on the Dutch context can be found in Gijs Rommelse, The Second Anglo-Dutch War (1665-1667). International Raison d'État, Mercantilism, and Maritime Strife (Hilversum: Verloren, 2006).

${ }^{90}$ Josiah Child, Brief Observations Concerning Trade, and Interest of Money (London, 1668), 3, reprinted in Idem, A New Discourse of Trade (London, 1693).

${ }^{91}$ Verthooninge, ghedaen aen die van de Vereenichde Nederlanden, sig. A2: “... dat verscheyde Natien daer over jaloers sijn geworden en boven alle de Engelse, dewelcke niet kan verdragen de prosperiteyt van de Nederlanders."

${ }^{92}$ Aanwysing II.6, p. $275^{-276: ~ “ . . . ~ d a t ~ a l l e ~ R e p u b l i k e n, ~ o p ~ v r e e d e ~ e n ~ k o o p m a n s c h a p ~}$ gefondeerd zijnde, het selve Interest met Holland hebben ... ons in ons voornaemste dessein, namentlik het vermeerderen der koopmanschap, altijds naar haar vermoogen sullen dwersdrijven."

${ }_{93}$ Quoted in Martin van Gelderen, "De Nederlandse Opstand (1555-1610): van 'vrijheden' naar 'oude vrijheid' en de 'vrijheid der conscientien'," in Haitsma Mulier and Velema (eds.), Vrijheid, 27-52: 31.
} 
from Grotius's famous treatise Mare liberum and its repudiation by John Selden ${ }^{94}$ to the writings of Dutch-English merchants like Gerard de Malynes and Edward Misselden..$^{95}$ In particular from the 1640 s and 1650 s onwards, many English pamphleteers expressed their envious admiration of the mercantile model of the Dutch, who, as the merchant Henry Robinson proclaimed, "may be thought one of the happiest [peoples] throughout the knowne world" since they "finde the advancing of Trade to be the onely true State Interest and Policy". ${ }^{96}$ By the early 166os, the claim that "a happy continuation of Commerce requires freedom" had become all but commonplace among the propagators of Dutch commerce vis-à-vis such English jealousy of trade. ${ }^{97}$

The argument for free trade of the brothers De la Court is clearly rooted in this Anglo-Dutch commercial and intellectual exchange ${ }^{98}$ Their contribution to the debate on Dutch commerce is particularly significant because of the comprehensiveness of their claim what exactly commercial liberty entails. Merging a Grotian notion of free property with mercantile reason of state, the thought of the De la Courts amounts to an extensive discussion of several concrete policy measures to promote free trade and thus enhance Holland's commercial greatness..$^{99}$

${ }_{94}$ On the debate between Grotius and Selden, see Mónica Brito Viera, "Mare Liberum vs. Mare Clausum: Grotius, Freitas, and Selden's Debate on Dominion Over the Seas," Journal of the History of Ideas 64 (2003), 361-377. Cf. also the different interpretations of Richard Tuck, "Grotius and Selden," in Burns and Goldie (eds.), Cambridge History of Political Thought, 499-529; and Sommerville, "Selden, Grotius, and the SeventeenthCentury Intellectual Revolution."

${ }^{95}$ See Andrea Finkelstein, Harmony and the Balance. An Intellectual History of Seventeenth-Century English Economic Thought (Ann Arbor: University of Michigan Press, 2000), esp. $26-73$.

${ }^{96}$ Henry Robinson, Certain Proposals in Order To the Peoples Freedome and Accommodation (London, 1652), 10. For other examples, see e.g. Parker, Of a Free Trade, 14; and Samuel Lambe, Seasonable Observations (s.l., [1658]), 7-8. Cf. Pincus, "Neither Machiavellian Moment nor Possessive Individualism," 719-720, and the extensive analysis in Joyce Appleby, Economic Thought and Ideology in Seventeenth-Century England (Princeton: Princeton University Press, 1978), 73-98.

${ }_{97}$ Speculatien over den innerlijcken toestant van regeringe in de Vereenigde Provintien (Heusden, 1660), 7: “... een geluckige voortganck van den Koophandel vereyschet vryheyt."

${ }_{98}^{8}$ Cf. the references in Aanwysing I.6 and I.9 to Gerard de Malynes, Consuetudo vel Lex Mercatoria, or the Ancient Law-Merchant (Londen, 1622). On the importance of merchant manuals such as the Lex Mercatoria, see Jochen Hoock, "Professional Ethics and Commercial Rationality at the Beginning of the Modern Era," in Jacob and Secretan (eds.), Self-Perception of Early Modern Capitalists, 147-159.

${ }_{99}$ For a lucid analysis of seventeenth-century Dutch views on free trade, see HansJürgen Wagener, "Free Seas, Free Trade, Free People: Early Dutch Institutionalism," History of Political Economy 26, 3 (1994), 395-422. For the period following the De la Courts, see Ida 
This discussion forms the core of De la Court's reworking of the manuscript on Leiden's welfare to the Interest van Holland and the Aanwysing. De la Court maintains that like Leiden, Holland is plagued by numerous natural burdens, not only the "for people unhealthy weather" but especially the small size and scarcity of the country's soil. As a result, Holland's population "should by all means search its food abroad and continuously attract new Inhabitants from foreign Countries" ${ }^{100}$ Commerce and immigration are necessary for survival, and here Holland has an obvious advantage, for it is "very well situated to procure its food from the Sea, which is common to all" - the allusion to Grotius is implicit but clear. ${ }^{101}$ This favourable maritime position has led to the growth of Dutch fishery, soon followed by trade, industry, and seafaring, all essential sources of welfare. De la Court asserts self-assuredly that "in Europe no Country is more capable for Trade than Holland". In spite of war, international competition and jealousy of trade, "the Hollanders have navigated almost all Nations out of the great Ocean, the Mediterranean, the Indian Ocean, and the Baltic". ${ }^{102}$

For De la Court, the continuation of this commercial success depended on a range of liberties that would lure foreigners to Holland and promote the growth of trade. Apart from the freedom of immigration and occupation, these liberties include the freedom of enterprise and the freedom from taxation. Following the plea for entrepreneurial liberty against the control and levies of the halls in Leiden, De la Court contended that commercial enterprise in Holland at large should not be obstructed by the imposition of too heavy a tax burden. ${ }^{103}$ In his treatise on the grandezza of cities, Botero already argued that the towns of the Netherlands were "the most mercantile" because of "the frankness of taxes", which made that "the merchandise that entered there and left (and entered and left infi-

Nijenhuis, "De ontwikkeling van het politiek-economische vrijheidsbegrip in de Republiek," in Haitsma Mulier and Velema (eds.), Vrijheid, 233-252; and Karel Davids, "From De la Court to Vreede. Regulation and Self-Regulation in Dutch Economic Discourse from c. 1660 to the Napoleonic Era," The Journal of European Economic History 30, 2 (2001), $245^{-289 .}$

${ }_{100}$ Aanwysing I.3-5, p. 21, 27: “... voor den menschen ongesond weeder ... dat het in allen manieren sijn voedsel buiten 's Lands moet soeken, ende geduurig niewe Ingesetenen uit vreemde Landen tot zig trekken moet."

${ }^{101}$ Ibidem I.6, p. 27: "En om sijn voedsel uit der Zee, die een ieder gemeen is, te haalen; legd Holland seer wel."

${ }_{102}$ Ibidem I.7, p. 31: "In Europa is geen Land tot de Negotie bequaamer als Holland." Ibidem I.13, p. 58: “... dat de Hollanders by naast alle Natien, soo uit den grooten Oceaan, Middelandse, Indise, als Belt-Zee, gevaaren hebbende."

${ }^{103}$ Cf. Welvaren 44 with Aanwysing I.17, 20-21. 
nitely) paid almost nothing". ${ }^{104}$ De la Court adopted this assertion, claiming that by the 1660 s Holland had deviated from this admirable policy. Although the "Freedom of Fishery and Trade is still greater than elsewhere", he argued, the tax burden was far too heavy. De la Court forcefully maintained that taxes "have risen now that high, that the like has never been seen or heard of in any Republic in the World, much less in a Country only subsisting of commerce". ${ }^{105}$ This assertion involved only a little hyperbole, for per capita taxation in seventeenth-century Holland was indeed considerably higher than in other countries. ${ }^{106}$ Facing this reality, De la Court insisted that such "heavy and numerous imposts" threatened to divert Holland's commerce and would thus "eventually chase away the Country's welfare". ${ }^{107}$

This argument for free enterprise and moderate taxation is loosely based on a conventional defence of undiluted property rights. Echoing Grotius' discussion of the creation of individual property, the De la Courts stress "that man is by nature the master and appreciator of his own goods and labour ... for nature gives him privately the judgement over his property". ${ }^{108}$ In other words, private ownership is a natural right that predates the establishment of the commonwealth. This claim involves an explicit repudiation of the classical arguments in Plato and Thomas More's Utopia for the collectivisation of property, which De la Court classifies as "so alien to human nature". ${ }^{109}$ In his mercantile logic, collective property can only

${ }^{104}$ Botero, Cause della grandezza delle città, 343-4: "Le Città di Fiandra sono state le più mercantili, e le più frequentate Città d'Europa: Se tu ne ricercherai la cagione, troverai essere stata tra l'altra, la franchezza dalle gabelle: perché la mercantia, che vi entrava, e n' usciva, (e ve ne' entrava, e n' usciva infinita) non pagava quasi nulla."

${ }^{105}$ Aanwysing I.19-21, p. 84, 91: "De Vryheid van Visseryen en Negotie aangaande is nog grooter als ergens'; ‘... soo hoog gereesen, dat nooit diergelijke in eenige Republijke ter Weereld, veel min in eenen Lande op koopmanschap, en nergens anders op bestaande, is gehoord of gesien geweest."

${ }^{106}$ See the comparison in Jan Luiten van Zanden and Maarten Prak, "Towards an Economic Interpretation of Citizenship: The Dutch Republic Between Medieval Communes and Modern Nation-States," European Review of Economic History 10 (2006), 111-145: 130.

${ }^{107}$ Aanwysing I.21, p. 90: "Dat de swaare ende eenigvuldige imposten, 's Lands welvaaren endelik sullen verjaagen."

${ }_{108}$ Politike Discoursen I.I.5, p. 54: “... dat de mensch van nature meester en waardeerder van sijn eigen goed en arbeid zijnde, dien-volgende vermag daar meede te leeven, en 't selven soo hoog te agten, als hy wil, sulks de natuur hem privativelik het oordeel over het sijnen geeft." Cf. Grotius, Rights of War and Peace II.II.2, p. 78-80, and see the analysis in Stephen Buckle, Natural Law and the Theory of Property. Grotius to Hume (Oxford: Clarendon Press, 1991), 10-14, 35-44.

${ }^{109}$ Sinryke Fabulen, 534: “... soo vremd van der menscheliker aard.” See Plato, Republic, 416d-417b, 462b-c, and Thomas More, Utopia, trans. Clarence H. Miller (New Haven and 
be established by civil law, but it is utterly unthinkable that a law that collectivises property could arise out of general consent:

We are humans by nature, and only by coincidence are we members of a Society or Republic, so we should have property before the law could make it collective. It is therefore not easily understood how the diligent and thrifty could have been moved to share their own riches voluntarily with the poverty of the lazy and the wasteful People. ${ }^{10}$

It is claims like these that put the De la Courts squarely outside of the 'Greek republican tradition', which according to Eric Nelson championed the redistribution of wealth and collective property from Plato to the American Revolution. ${ }^{111}$ The republican model of the De la Courts is clearly a Greek model, but instead of the philospher's republic of Plato, their model is the merchant's republic of Ancient Athens.

In such a commercial commonwealth, the taxation of private property can only be justified if it enhances the general interest of the state, for "without taxes, a State cannot be protected". ${ }^{112}$ De la Court concludes that Holland's commercial reason of state requires a protectionist policy of taxation that "burdens least the means of subsistence which matters us most, which we lose the soonest and which, once lost, we cannot easily recover". ${ }^{13}$ The pillars of Holland's economy, the fishermen, artisans, and especially the international merchants, should therefore be exempted from taxation. "Bringing profit from abroad into the Country, they are very necessary for the State, yet they can, because of their commerce and correspondence, divert themselves, their goods, and their arts very easily into other Countries."114 Facing international competition, Holland should

London: Yale University Press, 2001), 46-48. Pieter de la Court van der Voort owned two editions of Plato's Opera omnia (one with the commentary of Marsilio Ficino), a French edition of La République (Paris, 160o), and the Amsterdam 1631 edition of Respublica Th. Mori Eutopiae. See Library, fols. 10, 11, 31.

${ }^{110}$ Sinryke Fabulen, 535: “... dat wy uit der aard menschen, ende niet dan by toevalle leeden eener Maatschappie ofte Republike zijn; sulks wy ook eer goederen souden hebben, eer de wet soude konnen de selve gemeen maken; soo is niet wel te begrijpen, dat de naarstige en spaarsaame souden konnen werden bewoogen haaren eigen rijkdom, met de arremoede der leuje ende quistige Menschen vrywillig gemeen te maken.”

${ }^{11}$ See Nelson, Greek Tradition.

${ }_{112}$ Politike Discoursen I.I.1, p. 18: "Sonder lasten, is een Staat niet te beschermen."

${ }^{113}$ Aanwysing I.24, p. 115: “... dat men nogtans minst beswaren mag dat middel van subsistentie waar an ons meest gelegen is, en welk wy allerligst verliesen, en verloren zijnde niet ligtelik wederom bekomen."

${ }^{114}$ Politike Discoursen I.I.1, p. 19: “ ... want alle deesen van buiten winst in 't Land brengende, zeer noodsaakelik voor den Staat zijnde, nogtans zeer gemakkelik door haare correspondentie ende koopmanschap, haare personen, goederen en konsten in andere Landen konnen brengen." 
favour those who make profits abroad: the entire community depends on their wealth, and if they would be taxed excessively they would leave the country. Accordingly, the manufacturing of goods should not be taxed, nor should any tariffs be raised on the export of these goods or on the import of raw materials needed for the industry. Yet taxation of consumption and landed property is an easy and necessary means to secure the state's revenue, and foreign goods that compete with Holland's trade and industry are to be levied as much as possible. International trade is a zerosum game, and Holland must take it all. ${ }^{15}$

\section{Circumventing Monopoly}

This combined argument for free enterprise within the commonwealth and a protectionist policy vis-à-vis foreign competitors amounts to the further claim that chartered monopolies in international trade, such as the Dutch East India Company (VOC), go against true commercial reason of state. This claim is still absent from the De la Courts' discussion of Leiden's welfare, but it takes centre stage in the Interest van Holland and the Aanwysing, reflecting a significant development in the brothers' economic thought. While their treatise on Leiden focused on unrestricted entrepreneurial freedom in the domestic sphere of an urban economy, from the start of the 166os De la Court's concerns gradually moved from domestic industry towards global trade. This results in a more regulative approach that emphasizes protectionist economic legislation "e mercaturae bono, more to the Interest of Merchants" in order to promote Holland's trade in the expanding arena of international competition overseas. ${ }^{116}$

Arguably, this change of emphasis from a domestic to a global economy is related to De la Court's growing involvement in international commerce and state policy in the wake of his marriage to Catharina Van der Voort in 1661. The relationship with the Van der Voorts significantly expanded De la Court's mercantile horizons, particularly after he left his native Leiden to settle with his family-in-law in Amsterdam in 1665. There, at the centre of global commerce, De la Court developed his business further in close collaboration with the successful firm of his family-in-law. Towards the end of the decade, he travelled as an agent for the Van der

\footnotetext{
${ }^{115}$ See Ibidem I.II.29-30, and the more regulative elaboration in Aanwysing I.21-24. Cf. also the mercantilist 'speculations' by De la Court's brother-in-law Van der Voort, published as appendix I in Kernkamp (ed.), "Brieven (1667-1685)," 90-95.

${ }^{116}$ Aanwysing II.15, p. 382: “... e mercaturae bono, meer naar het Interest der Koopluiden.”
} 
Voorts to London and Italy. ${ }^{117}$ Eventually his trading network reached as far as the Caribbean, where his cousin Nicolaas, based in the Dutch settlement on Curaçao, worked on behalf of his family. ${ }^{118}$ The bond with the Van der Voorts also brought De la Court closer to Holland's political establishment. In the course of the Second Anglo-Dutch war, the firm of the Van der Voorts became directly involved in governmental policy by delivering over 900.000 guilders worth of artillery and provisions for the States of Holland and the Dutch fleet. ${ }^{119}$ This lucrative deal was mediated by Johan de Wit, a namesake and cousin of Holland's Grand Pensionary, who was also related to the Van derVoorts. As a representative of the States-General, De Wit kept the Amsterdam merchants informed of the latest news from The Hague and the operations of the fleet. ${ }^{120}$ This growing connection to the establishment in The Hague was ultimately sealed in 1670 when De la Court and his brother-in-law Guglielmo obtained a doctorate in law at the University of Orléans, a formality required to become a lawyer of the Court of Holland for which both took the oath in February $1671 .^{121}$

De la Court's increasing experience in international trade and government affairs is reflected in his forceful repudiation of the widely shared conviction that colonial trade in the East and West Indies should be regulated by chartered companies like the VOC. Both in the Dutch Republic and beyond, for example in Henry Parker's 1647 treatise Of a Free Trade, numerous mercantile theorists argued that the commercial interests of a state could best be served by establishing such companies to administer overseas trade. ${ }^{122}$ This was the dominant view, yet there were also a few dissonant voices. In the 1630 s and 1640 , a couple of Dutch pamphleteers and private merchants strongly advocated free trade in Dutch Brazil. ${ }^{123}$

${ }^{117}$ See RAL, FA De la Court, inv. nr. 8: The "Libro de Belanci" (1657-1670) of the brothers Van der Voort, which refers on fols. 20-22 to De la Court's stay in Messina, Naples and London in December 1669 .

${ }^{118}$ See the letters of Nicolaas de la Court to Pieter de la Court from 1672-1673 in Kernkamp (ed.), "Brieven (1667-1685)," 51-63. On De la Court's commercial activities later in his life, see also the documents concerning his inheritance, dated 19 May 1691, in RAL, FA De la Court, inv. nr. 17 .

${ }^{19}$ The relevant documents are published as appendices IIa and IIb in Kernkamp (ed.), "Brieven (1667-1685)," 95-136.

${ }^{120}$ See Stadsarchief Amsterdam, Family Archive Backer, inv. nr. 465: letters from Johan de Wit to the brothers Van der Voort (1667-1671), and inv. nr. 466: undated documents on international affairs addressed to Giovanni Van der Voort.

${ }^{121}$ Kernkamp (ed.), "Brieven (1667-1683)," 43, note 2; and Frijhoff, "Reisjournaal," 17-18, note 19 .

${ }_{122}$ Parker, Of a Free Trade.

${ }^{123}$ See e.g. Vertoogh by een lief-hebber des vaderlants vertoont. Teghen het ongefondeerde ende schadelijck sluyten der vryen handel in Brazil (s.l., 1637); Deductie, waer by 
In England, the Leveller and merchant William Walwyn denounced in his $165^{2}$ Conceptions for a Free Trade "the restriction and Government of Forraine Trade by Companyes", arguing that chartered monopolies conflict with the "Native Right" of merchants and the "publique good" of society. ${ }^{124}$ The Portuguese ambassador to Paris, Manuel Fernandez de Villareal, had a similar view. In his Le politique tres-chrestien ou discours politiques, a eulogy of Cardinal Richelieu published in 1645 by Elzevier in Leiden, he maintained that trading companies will only search for their own interest without regard for the common good. Fernandez de Villareal insisted that the establishment of such companies would therefore "oblige everyone to live in the disorders of avarice and not in the freedom of abundance". Tellingly, he mentioned the Dutch chartered companies as the prime example of this gruesome fate. ${ }^{125}$

As one of the most outspoken critics in the Dutch Republic itself, De la Court developped this condemnation of chartered companies further with the claim that freedom of trade should also entail free competition on the colonial market, and hence the abolition of the monopoly of trading companies like the VOC. The roots of this claim lie in the strong condemnation of the economic monopolisation by Leiden's guilds. Like guilds, De la Court insists, the Dutch trading companies curtail the "free trade of the common inhabitants" and "their natural liberty of seeking a livelihood in their fatherland" ${ }^{126}$ Moreover, facing a globalizing economy and growing international rivalry, it is necessary that all Holland's merchants are able to trade with the vast territories outside of Europe so that commerce and foreign consumption can continue to increase. In line with Walwyn and Fernandez de Villareal, De la Court insists that these opportunities for worldwide commerce are discarded because the private interests of the trading companies necessarily conflict with the public

onpartijdelijck over-wogen ende bewesen wort, wat het beste voor de Compagnie van WestIndien zy: de handel te sluyten of open te laten (The Hague, 1638); Consideratien als dat de negotie op Brasil behoort open gestalt te worden (s.l., 1638); Consideratie over de tegenwoordige ghelegentheydt van Brasil (Amsterdam, 1644).

${ }^{124}$ "W Walwins Conceptions; For a Free Trade," in The Writings of William Walwyn, ed. Jack R. McMichael and Barbara Taft (Athens and London: University of Georgia Press, 1989), 446-452.

${ }_{125}$ [Manuel Fernandez de Villareal], Le politique tres-chrestien ou discours politiques ('Paris' [Leiden], 1645), 146: "C'est obliger tout le monde à vivre dans les desordres de l'avarice, \& non dans la liberté de l'abondance." Pieter de la Court van der Voort owned a copy of this treatise: see Library, fol. 19 .

${ }_{126}$ Aanwysing I.7, p. 32: “... vrijen handel der gemeene Ingeseetenen.” Ibidem I.16, p. 71: "... haare naturelike vryheid van 's leevens middelen in haar vaderland soekende, te besnoejen met geoctroyeerde ofte geslootene Compagnien en Gildens." 
interest of society at large. Whereas the general welfare lies in the increase of industry and trade, the "true Interest of such companies consists in seeking the most benefit for its common Participants ... and, in short, in making the most profits with the least trade and navigation". ${ }^{127}$ Their monopolistic position means that trading companies are not encouraged to open up new markets. "Certain profits make them stupid and slow", as De la Court asserts repeatedly. Trade will only prosper when there is competition, "for necessity makes an old wife trot, hunger makes raw beans sweet, and poverty begets ingenuity". ${ }^{28}$ De la Court imaginatively summarizes his criticism with the claim that the establishment of chartered monopolies attests to the same stupidity as Aesop's cat who, while licking the oil of a file, does not realize that he drills through his tongue and ends up sucking his own blood. ${ }^{129}$

This criticism of the Dutch trading companies was not confined to pure theory. In the summer of 1664, De la Court and his brothers-in-law asked the States-General for permission to search for a northern passage towards China along the shores of Siberia, thus circumventing the monopoly on Asian trade enjoyed by the VOC. Assisted in The Hague by their relative and informant Johan de Wit and by the jurist and anti-Stadholder publicist Johan Uytenhage de Mist, De la Court and the Van der Voorts thus endeavoured to challenge the vested colonial interests. ${ }^{130}$ A first request was turned down by the States-General after it heard the objections of the directors of the VOC. Yet De la Court cum suis did not give in and they sent a subsequent request to the States of Holland. Following De la Court's argumentation in the Interest van Holland, their petition insisted that the general interest would be greatly enhanced if all Dutch merchants were allowed to trade in Asia, while "the particular interest of the Chartered

${ }^{127}$ Ibidem I.19, p. 85-86: “... het waarhaftige Interest soodaniger Compagnien bestaat, in het meesten voordeel der gemeene Participanten te souken ... ende in het kort gesegt met de allerminste negotie ende navigatie, de meeste winsten te doen." Cf. the diametrically opposed view in Parker, Free Trade, 21-23.

${ }_{128}$ Aanwysing I.16, p. 72: “... soo maaken haar de seekere profijten dom en traag. Daar aan de andere zijde waarhaftig is, dat de nood een oud wijf doed draaven; ende de honger raawe boonen soet maakt; alsmede dat de armoede list soekt." See the similar passages in e.g. Welvaren 50, p. 113 and Politike Discoursen I.I.1, p. 7-8. Cf. also Walwyn, "Conceptions," 5: "The numerousness of Merchants will occasion a strife \& emulation among them, who shall produce the best ordered goods ... whereas Merchants in Companyes have noe need of such diligence."

${ }^{129}$ Aanwysing I.16, p. 76. The same fable is told in Sinryke Fabulen, 169-174. Cf. as well the comparable fables in Ibidem, 261-266, 347-354.

${ }^{130}$ All the documents concerning the project are published in Overvoorde (ed.), "Noord-Oostelijke doorvaart." 
East Indian Company is, on the contrary ... to alienate and exclude for eternity the common inhabitants of all knowledge, navigation and commerce of those Asian countries" ${ }^{131}$ In spite of these arguments, the second request was also rejected and the VOC maintained its monopoly. For the petitioners this clearly proved "the perniciousness of the company, which prefers that other nations come into the possession of such a considerable passage (if it could be found) instead of our own nation". ${ }^{132}$

De la Court's enterprise against the VOC is not only significant because it amounts to the most comprehensive criticism of the Dutch trading companies in the seventeenth century, but also because it differs in an important way from the dominant Grotian approach to freedom of trade. For Grotius and his followers, the crucial issue was the jurisdictional question of the dominion over the seas and hence the extent of the rights of navigation, fishery and trade. ${ }^{133}$ Yet De la Court's approach implies that free trade is not primarily a matter of right but of interest. This different emphasis is particularly clear in the largest chapter of the Aanwysing, which extensively discusses the need to rid the seas of pirates so as to safeguard "free Navigation", yet without a word on universal ownership or the law of nations. ${ }^{134}$ In the thought of the brothers De la Court, freedom of trade means not the collective freedom of the seas, but the freedom of individual merchants in a realm dominated by international rivalry and the premises of reason of state.

\section{From Natural to True Liberty}

De la Court's critical assessment of Holland's interest pivots on the claim that liberty, which should lead the way to commercial greatness, is in practice too much restrained in its many different facets - from the freedom of immigration to the freedom of enterprise. But what then does liberty' mean exactly? To answer this question I will show how the concept of liberty in the thought of the De la Courts merges a notion of individual

${ }^{131}$ Ibidem, 285: “... het particulier interest der Geoctroyeerde Oostindische Compagnie ter contrarie is ... Gemeene ingeseetenen van alle kennisse, navigatie en negotie der opgemelde Asiatische landen te vervremden en te secluderen in der eewigheid."

${ }^{132}$ Ibidem, 299: “... blijckt hieruuijt de quaedaerdigheijt van de compagnie, die liever heft dat andere natien de possessie van soo consideraebelen passage (bijaldien het te vinden waere) soude becomen dan onse eijgene natie."

${ }^{133}$ See Grotius, Free Sea, and cf. Den vryen handel ter zee, voor de Vereenighde Nederlanden (The Hague, 1666).

${ }^{134}$ Aanwysing II.1, p. 161: "Dat de vrye Zeevaart teegen alle Roovers en Vyanden sorgvuldiglik beschermd behoorde te werden." 
freedom as non-interference with a strong plea for republican 'True Liberty' in the sense of independence from any arbitrary domination. ${ }^{135}$

The different facets of freedom that the brothers De la Court propagate in their description of Leiden and Holland's commercial interest are based on the fundamental assertion that individuals do not relinquish their natural liberty when they agree to leave the state of nature for civil society. The establishment of sovereignty limits the freedom of all citizens through the rule of law, but the exercise of such freedom within the boundaries of civil law still involves a natural right that cannot be entirely alienated. ${ }^{136}$ In a vocabulary that echoes the Digests of Roman law, the De la Courts define this natural right as "the full freedom to do everything that is not conflicting with Politics and human society, either the freedom to serve God or to gain a living here [in Leiden] without the impediment by anyone and with whatever art, trade, or labour it may be". ${ }^{137}$ In other words, the natural liberty that is preserved in civil society entails the freedom from any obstruction of personal choices as long as these do not undermine society's raison d'être by bringing back the state of nature.

At first sight, this conceptualisation of liberty appears to be strictly negative: it emphasizes freedom from interference in religious and economic affairs, for example through persecution or the establishment of exclusivist monopolies. Yet this is not the whole picture, for the brothers De la Court maintain that human freedom involves more than merely the absence of interference. Following a long discussion of monarchical rule, a key section in the Politike Weeg-schaal under the general heading "On LIBERTY" draws a sharp distinction between, on the one hand, "the necessity to obey one man, called Servitude", and, on the other,

${ }^{135}$ For general notions of liberty in early-modern Europe, see esp. Werner Conze, "Freiheit," in Geschichtliche Grundbegriffe vol. II: 425-542. For the Dutch background, see E.H. Kossmann, "Het probleem van de vrijheid in de zeventiende-eeuwse Nederlandse Republiek," in Idem, Vergankelijkheid en continü̈teit. Opstellen over geschiedenis (Amsterdam: Bert Bakker, 1995), 63-86; and the various contributions to Haitsma Mulier and Velema (eds.), Vrijheid.

${ }^{136}$ See e.g. Aanwysing III.8, p. 518-519; Sinryke Fabulen, 97.

${ }^{137}$ Welvaren 17 , p. 45: “... een volkoomen vrijheid, om alles te doen, 't geene tegen de Policie, en menschelijcke societeit niet strijdich is, 't sij om God te dienen, 't sij om sonder bekroon van ijmand, hier den kost te mogen winnen, met hoedanige konst, koopmanschap, of arbeid het soude mogen wesen." Cf. Digestae I.5.4 pr: "Libertas est naturalis facultas eius quod cuique facere libet, nisi si quid vi aut iure prohibetur." On seventeenth-century Dutch conceptualisations of natural liberty, see the useful article by Hans Blom, "Vrijheid in de natuurrechtelijke politieke theorie in de zeventiende-eeuw," in Haitsma Mulier and Velema (eds.), Vrijheid, 133-155. 
a State where no Man can dictate, but where the utmost is to appear in a certain assembly to cast one's vote so that a conclusion is reached with the majority of votes ... This State the Greeks and Romans have called liberty: because no one there is bound to live according to the will and desire of one man ... but to the spirit of order and Law, to which all Inhabitants of that State are uniformly subjected, as they are to Reason ... Therefore, no one in such a State is a Lord, and no one a Slave. Indeed, one can hardly call one of the residents in such a country a subject, since they are subjected to no one at all. ${ }^{138}$

Liberty, then, entails not only the absence of interference, but also the condition of self-government under the rule of law without being dominated by the arbitrary will of any other - a status diametrically opposed to that of a slave.

The brothers De la Court state explicitly that the vocabulary that underlies this passage stems from "the Rules of Roman Law"'139 the classical language of libertas codified in the Digests, which stress the dichotomy between those who are free and independent and those who are, as slaves, "within the power of someone else". ${ }^{140}$ The De la Courts imaginatively explain this glaring contrast between liberty and servitude in a number of fables. One fable tells of a hungry wolf who prefers his precarious but "precious liberty" in the forest above the opulent life of a dog who "is used to make himself a Slave to Humans and thus, by wagging his tail and sitting up, to beg them for a piece of bread". ${ }^{141}$ Another fable praises

${ }_{138}$ Politike Weeg-schaal II.I.1, p. 309-313: “Van de VRYHEID ... die noodzaakelikheid, om aan een mensch te gehoorsaamen hebben genoemd Slavernye ... zoodanigen Staat daar geen Mensch gebieden mag, maar daar het oppersten is te mogen verschijnen in zeekere vergaderinge, om aldaar zijn stemme te geeven, op dat, naar meerderheid der zelven werde gemaakt een conclusie ... Welke Staat de Grieken en Latinen hebben genoemd vryheid: alsoo niemand aldaarverbonden is, te leeven naar den wil en zin van een mensch, (daar zeer wel op te letten staat,) maar naar de zin van de ordre en Wet, aan welke alle Ingezeetenen van dien Staat, gelijk als aan de Reeden, eenpariglik onderworpen zijn ... en dienvolgende, is niemand in zoodanige Staat een Heer, ook niemand een Slaaf; ja naweliks mag men in zodanige landen, iemant der ingezeetenen een onderdaan noemen, dewijl zy aan geen mensch onderworpen zijn."

139 Ibidem, 313: “... de Regulen der Roomse Regten."

${ }^{140}$ Quoted in Skinner, Liberty before Liberalism, 41. Simon van Leeuwen, a prolific Leiden jurist and acquaintance of De la Court, edited the Corpus juris civilis for the publishers Blaeu and Elzevier in 1663. On Van Leeuwen's political views and his relation to De la Court, see Robert Fruin, "Over Simon van Leeuwen en zijn bedenckingen over de stadhouderlijcke magt," in Idem, Verspreide geschriften, ed. P.J. Blok, P.L. Muller and S. Müller (The Hague: Martinus Nijhoff, 1903), vol. VIII: 95-113.

${ }^{141}$ Politike Weeg-schaal II.I.2, 318: "dierbare vryheid." Sinryke Fabulen, 84: "De Hond daar en teegen is gewoon, sig een Slaaf der Menschen te maaken, ende dienvolgende soo met quispelstaarten als met opsitten, een stukjen broods van de selven te beedelen." 
the determination of a goldfinch who happily escapes his birdcage, confronting his former owner with the statement "that I could not live according to my own will, and that all my happiness or unhappiness depended continuously on your care or carelessness". ${ }^{142}$ Illustrated with these fables, the account of the De la Courts advances the fundamental argument that such liberty from arbitrary domination is only attainable in a free state where the citizens govern themselves. As the brothers insist, those countries where no one is a lord and no one a slave "are called Republics". ${ }^{43}$

This phrase obviously raises the question what this term 'republic' then exactly refers to - a question that I address in more detail below. A first glimpse of what the brothers De la Court meant by 'republic' becomes clear by their appropriation of the Roman language of libertas and its resurgence in Renaissance Italy. Boccalini was a first important source. In his revision of the Politike Weeg-schaal, De la Court included a ragguaglio on monarchical rule in which he translated Boccalini's libertà into the Dutch vryheid. He also turned Boccalini's distinction between patrie libere and altra spezie di governi into an explicit opposition of "Republics" versus "Monarchical Government" ${ }^{144}$ A second important source was the work of the infamous Florentine priest Girolamo Savonarola. In another revised passage, De la Court praised Savonarola for having revealed the hardships of servitude under the rule of the De Medici, translating one of Savonarola's powerful predications with vryheid for libertà. Revealingly, De la Court added that Savonarola's "Tyrant and Violator of liberty", Piero de Medici, "did not have such a great power in the Republic of Florence as a Stadholder does in the United Provinces". ${ }^{145}$ Finally, a passage on the demise of the Roman Republic, interspersed with quotes from Tacitus, puts vryheid explicitly in opposition to Augustus who "has violated the liberty of the

${ }^{142}$ Politike Weeg-schaal II.I.2, p. 318: “... dat ik naar mijn eige zin niet mogte leeven, en dat alle mijn geluk, ofte ongeluk geduurig van uwe zorg, ofte zorgloosheid dependeerde." The fable is also told in Sinryke Fabulen, 95-98.

${ }^{143}$ Politike Weeg-schaal II.I.1, p. 312: "Deeze Staaten en Landen werden nu genaamd Republiken."

${ }^{144}$ Cf. Ibidem I.III.11, p. 268-273 (not yet in the first edition), with Boccalini, Ragguagli I.21, p. $63^{-65}$.

${ }^{145}$ Ibidem II.I.1, p. 310-311 (not yet in the first edition): “... dat Piero de Medici, (in de Republike van Florencen soo grooten magt niet hebbende, al seen Stad-houder in de Vereenigde Neederlanden) als een Tiran en Verkragter der vryheid." The predication partly translated by De la Court is of December 13, 1496, printed in Savonarola, Prediche sopra Ezechiele, ed. Roberto Ridolfi, 2 vols. (Rome: Angelo Berlardetti, 1955), vol. I: 69-102: 79 . 
Republic". Augustus is then suggestively described as "the Captain General or Stadholder of the Roman Republic". ${ }^{146}$

In this way, the work of the De la Courts unequivocally connects the language of libertas to the political situation in the Dutch Republic: liberty in the sense of non-domination cannot subsist under a monarchical figure such as a Stadholder. In the early 166os, this comparison between Piero de Medici and Augustus to the Dutch Stadholders was clearly invoked to warn the contemporary audience to refrain from ever appointing a Stadholder. At the same time, the fact that Savonarola had been burnt at the stake, that the De Medici dynasty eventually suppressed the Florentine Republic, and that Roman liberty gave way to Augustus' imperial domination, suggested something else too: that Holland, no longer subdued by a Stadholder, had surpassed the role models of Classical and Renaissance republicanism. While Machiavelli fashioned his ideal republic after victorious Rome, the De la Courts eschewed emulation and implicitly pretended that the libertas of Rome and the libertà of Florence were outshone by the beacon of Holland's 'True Liberty'.

To summarize, the concept of liberty in the work of the brothers De la Court moves from a negative notion of freedom from interference to a republican notion of freedom from monarchical domination. These two notions are not systematically distinguished in the brothers' work, and they prove to be far from mutually exclusive. The core of the De la Courts' thought, the common ground where the notions of non-interference and non-domination come together, is the contention that only true republics where the citizens govern themselves will safeguard freedom of movement and occupation and protect property rights and free trade. This blessed correlation "is the reason why usually, quippe ubi libertas ibi \& populus \& divitiae, all Republics are seen to flourish remarkably more in arts, commerce, population, and strength than Monarchical countries and Cities". ${ }^{147}$ In short, only republican liberty as opposed to monarchical domination can ensure the prosperity of a commercial commonwealth:

${ }^{146}$ Politike Weeg-schaal II.VI.3, p. 501-503: “... voor de Vryheid ofte teegen Augustus ... dat hy de vryheid der Republiek had verkragt ... de Kapitain Generaal, of Stadhouder der Roomse Republike, Augustus."

${ }^{147}$ Aanwysing I.1, p. 7: “... de reeden waarom men gemeenelik, quippe ubi libertas ibi \& populus \& divitiae, alle Republijken in konst-, koop-, volkrijkheid, ende sterkte, merkelik meer als de Monarchale Landen en Steden, sie bloejen." The quote is from Nicolas de Bourgogne, Historia Belgica (Antwerp, 1629), 5 . 
For the Inhabitants under this free Government, when they legitimately gain some treasures and riches, will possess these peacefully and they will be able to use them fully in line with their own perception, without fearing that a very needy and wasteful Lord or his Courtiers and Nobles, who are usually all just as wasteful, needy, and avaricious, will seize under any picked up cloak these treasures of the Subjects. Therefore, all Inhabitants here are much inclined to subsist through [various] means, and to win, save, and gather riches for their dear children. ${ }^{148}$

And thus the freedom from interference coincides with the freedom from domination as the foundation of the mercantile ethics of industrious frugality.

The thought of the De la Courts offers a clear example of the concept of republican liberty that Quentin Skinner has highlighted in his influential work on seventeenth-century English republicanism. ${ }^{149}$ The brothers' use of the concept, explicitly based on the Roman legal language of liberty as opposed to servitude that was revived in Renaissance Italy, reveals that they consciously positioned themselves in a long-standing tradition of republican liberty which originated in antiquity. Yet their fierce criticism of the Roman example and their emphasis on individual economic freedom also suggest that the De la Courts moved in a more 'liberal' direction which supposed a break with the classical past. Their case therefore shows that it can be difficult to draw a sharp opposition between republican and liberal notions of liberty: in the work of the De la Courts these two notions simply reinforce each other, for freedom from interference is only attainable when freedom from arbitrary domination is ensured..$^{50}$ Overall, the De la Courts' 'liberal' argument for free enterprise and free trade neatly fits into a 'republican' criticism of monarchical rule in all its guises.

${ }^{148}$ Aanwysing I.8, p. 37: "Ende vermits de Ingeseetenen, onder deese vrije Regeeringe eenige schatten ende rijkdommen wettelik komende te winnen; de selve aldaar gerustelik besitten, ende naar hunne eigene sinnelikheid allesins gebruiken mogen; sonder te vresen dat eenig veel behouftig en quistend Opper-heer ofte sijne Hovelingen ende Edellieden, die gemeenelik alle ook eeven quistig, behouftig, en gierig zijn, gemelde schatten der Onderdanen onder den eenen ofte den anderen op geraapten dekmantel naar sig trekken sullen: soo zijn alle Inwoonders hier ook seer geneegen, om door gemelde ende andere leevensmiddelen te subsisteren, ende voor hare lieve kinderen rijkdommen te winnen, te sparen, ende te vergaderen."

149 See Skinner, Liberty before Liberalism, and Idem, Hobbes and Republican Liberty, esp. ix-xiii, 64-72, 144-148. For critical discussion, see esp. Sullivan, Machiavelli, Hobbes, 23-27, and Sommerville, "English and Roman Liberty."

${ }^{150}$ Cf. the comparable claim as regards English republicanism in Pincus, "Neither Machiavellian Moment nor Possessive Individualism” and Sullivan, Machiavelli, Hobbes. 


\section{MONARCHY DETHRONED}

\section{Good Government: The Harmony between Private \& Public Interests}

How should the government of a commercial commonwealth be organized? The answer of the De la Courts to this question largely derives from their commercial reasoning. Contrary to the institutional focus that dominates the few existing studies of their thought, I contend that the brothers' central argument against monarchy is based on their embrace of commerce as the mainstay of republican politics. For the De la Courts, commerce needs liberty, and such liberty can only be furthered by a broad representative assembly that establishes a harmony between private and public interests. In contrast, all forms of monarchical rule, including the Dutch Stadholderate, essentially amount to tyranny.

At the basis of the De la Courts' assessment of good government lies their implicit claim that the essence of politics is not the issue of sovereignty, but of interest. At odds with the dominant view of Bodin, Grotius, and Hobbes, ${ }^{151}$ the brothers De la Court suggest that the citizens and cities of Holland are not primarily connected through the institution of a unifying sovereign, but rather (if at all) by sharing a similar general interest. While Holland is characterized by a "variety of Rulers, Subjects, Lands, and situation" which "necessarily causes variety of interests", still "all its Cities and Lands concur in one thing or interest" ${ }^{\prime \prime}{ }^{22}$ Through a meticulous calculation of Holland's entire population and the rates of employment in all its different economic sectors, De la Court concludes that "all Inhabitants of Holland, living in freedom, are by a common well- and illbeing wonderfully linked together". This common ground is the all-embracing interest of commerce. ${ }^{53}$

In the preceding chapter I have discussed the tension between this notion of a general interest and the self-loving human condition that is central to the thought of the De la Courts. Following their claim that this tension can only be solved by the cultivation of well-understood

${ }^{15^{1}}$ See Skinner, "State of Princes to the Person of the State," 398-399.

${ }^{152}$ Aanwysing I.2, p. 20: “... dat verscheidentheid van Regeerders, Onderdaanen, Landen, en situatie, ook noodsaakelik verscheidentheid van interesten veroorsaakende ... soo veele alle sijne Steeden ofte Landen in eene saake, ofte interest overeenkomen." Cf. the less reassuring phrasing of the opening chapter of Interest I, p. 1: "Holland is geen een Land, en heeft niet allesins een interest."

${ }_{153}$ Ibidem I.9, p. 38: "Dat alle Ingesetenen van Holland, in vryheid zijnde, door een gemeen wel en qualik-vaaren, wonderlik aan een zijn gekoppeld." 
self-interest, civic virtue in the sense of subordinating personal advantage to the common good looses its classical prominence as the basis of politics. Consequently, the brothers De la Court insist repeatedly that good government can only be established upon the self-interested nature of rulers and rule alike. The common good will only be furthered if the rulers have something to gain personally from promoting the interests of all:

And therefore it is clear that A good government is not that where the well- or ill-being of the subjects depends on the virtue or vice of the Rulers, but, which is worthy of observation, that where the well-and ill-being of the Rulers necessarily depends on and follows from the well-and ill-being of the Subjects. For since one should assume that self is always preferred, so in the first case one's own advantage will be sought after even to the detriment of the common inhabitants. Yet because in the second case one's own advantage can only be obtained through the Common good, therefore the latter will always be aimed at by the Rulers. ${ }^{154}$

To put it more succinctly, the "true Interest of all Countries consists in the joint welfare of Rulers and Subjects." And given that "the Common good is not aimed at but for the sake of personal welfare, therefore the best Government is that where the Supreme Rulers can obtain their own welfare best and mostly by the Common good". ${ }^{155}$

At first sight, this correspondence between private and public interests does not appear to be particularly unconventional. In De officiis, Cicero similarly stressed that "the chief end of all men [ought to be] to make the interest [utilitas] of each individual and of the whole body politic identical." This influential phrase reverberated through early-modern political thought. ${ }^{156}$ Machiavelli insisted empathically that such a coincidence between private advantage and the common good is only possible

\footnotetext{
${ }^{154}$ Politike Weeg-schaal I.I.5, p. 34-35: "En dienvolgende zoo is klaar, dat Een goede regeering is, niet daar het wel ofte qualik varen der onderdanen, hangt van de deugd of ondeugd der Regeerders, maar, dat zeer aanmerkens-waardig is, daar het wel en qualik varen der Regeerders, noodwendig hangt van, en volgt op het wle en qualik varen der Onderdanen. Want vermits men geloven moet, dat eygen altijts voorgaat, zal in het eersten geval, eigen voordeel ook tot naadeel der gemeene ingezetenen werden gesogt. Maar vermits in het tweeden geval, eigen voordeel niet dan door het Gemeen kan werden verkreegen, zal het zelven door de Regeerders altijts werden betragt."

${ }^{155}$ Aanwysing I.1, p. 2, 6: "Namentlik, vermits aller Landen waarhaftig Interest, bestaat in het welvaaren der Regeerderen en Onderdaanen gesaamentlik ... dat het Gemeen niet dan om eigen welvaren betragt werd: ende dat het dienvolgende de beste Reegering is, alwaar de Opper-Regeerders haar eigen welvaren best en meest door het Gemeen verkrijgen konnen." See the similar passage in Ibidem III.1, p. 387-388.

${ }^{156}$ Cicero, De officiis III.VI.26, trans. Miller, p. 293.
} 
in republics. ${ }^{57}$ Hobbes argued "that where the publique and private interest are most closely united, there is the publique most advanced", which brought him to the diametrically opposite assertion that only "in Monarchy the private interest is the same with the publique". ${ }^{15}$ The brothers De la Court adopt this time-honoured concern of how to reconcile personal advantage with the common good, yet their approach entails a crucially different emphasis: the foundation of their analysis is not the public, but the private interest, the self-love that characterizes every human being. The common good can only be based on the pursuit of personal advantage, never vice versa. Accordingly, the De la Courts employ a Hobbesian view of mankind to reach a Machiavellian conclusion that only in republics the essential harmony between public and private interests will be sustained.

This claim follows from two connected assumptions. First, the education of princes and the sheer absence of discipline at a monarchical court determine that "Single Rulers rarely have that much judgment and knowledge that they can understand their own Interest well". ${ }^{159}$ Since a monarch is not able to identify his own interest correctly, he will be equally unable to make it coincide with the general interest of society at large. A monarchy that intentionally furthers the common good is therefore a mere chimera. Secondly, monarchs are not only unable to establish a harmonious connection between their self-interest and the welfare of the community, they deliberately oppose the general interest because of their characteristic lust for domination. Enslaved to their passions, they desire to enslave others and have their arbitrary power rule over the precepts of reason, thus proving the truth of the Italian saying La forza caca sopra la raggione. ${ }^{160}$ The eventual results are disastrous, in particular in a commercial commonwealth where the public interest consists of the increase of population and trade. As De la Court emphatically warns his Dutch readers, Holland's "laudable harmony and concurrence could be broken to the ruin of all Inhabitants ... by one single mistake: namely, by choosing a Supreme head over all these Inhabitants and their arms". Should this

${ }_{157}$ See Machiavelli, Discorsi II.2, p. 138: "E sanza dubbio questo bene comune non è osservato se non nelle repubbliche ... Al contrario interviene quando vi è uno principe: dove il più delle volte quello che fa per lui offende la città, e quello che fa per la città offende lui."

${ }^{158}$ Hobbes, Leviathan XIX, p. 241.

159 Aanwysing II.10, p. 305: “... de Een-hoofdige Regeerders selden soo veel verstands ende kennisse hebben, dat haar eigen Interest wel begrijpen konnen."

${ }^{160}$ Quoted e.g. in Politike Weeg-schaal III.II.4, p. 633, and Sinryke Fabulen, 285. 
occur, the existing harmony of interests would collapse under the domination of this monarchical figure and his followers:

And since the Lords, Courtiers, and Soldiers, who are devoted to him and depend on him, necessarily prey upon the industrious Inhabitants, therefore it appears that they would use all their power to their own advantage and at the expense of the common good ... and make all cities small and the Inhabitants poor, so that they can be obeyed without any opposition. If this is true, then it is clear that we should truly always pray to God a furore Monarcharum libera nos Domine: Oh God, please save Holland from a Monarch, Prince, and Head. ${ }^{161}$

\section{Turning Monarchy into Tyranny}

The principal intention that underlies the entire œuvre of the brothers De la Court is to reveal, like a modern Actaeon or the Dutchman in the Kingdom of Apes, the dangers and detriments of such monarchical furore. Their mercantile frankness aims to dethrone monarchy in general and the monarchical principle in the Dutch Republic in particular with the general assertion that all modes of single rule are incompatible with the liberty that represents the highest law of a commercial commonwealth. Essentially, this endeavour collapses the Aristotelian distinction between monarchy and tyranny: as the De la Courts contend, "Monarchy, where one man may command, is the Government that the Greeks and Romans of old have called Tyranny". ${ }^{162}$

This crucial statement arises from a general rhetorical strategy of extensive prolepsis and paradiastole, directed against the conventional Aristotelian wisdom that monarchical government as opposed to tyranny

\footnotetext{
${ }^{161}$ Aanwysing I.9, p. 45: “... deese loffelike harmonie en overeenstemming soude konnen werden gebrooken, tot ruine van alle Ingesetenen ... met eene eenige misslag; naamentlijk, met te kiesen een Opper-hooft over alle de selve Ingeseetenen ofte der selver wapenen ... ende dat de Heeren, Hoovelingen, en Soldaaten, alle hem toe gedaan zijnde, ende van hem dependerende, noodwendig op de arbeidende Ingeseetenen aasen, soo schijnd, dat sy alle haare magt souden gebruiken tot eigen voordeel, en tot nadeel van 't gemeen ... dat zy kennelik alle Steeden klein, ende de Ingeseten arm maaken souden, om zig sonder teegenspreeken te konnen doen gehoorsaamen. 't Welk indien waarhaftig is, soo is kennelik, dat men hier te regt altijds God behoorde te bidden, a furore Monarcharum libera nos Domine. O God: bewaard dog Holland voor een Monarch, Prins, en Hoofd." See Welvaren, 143, and Politike Weeg-schaal I.III.11, p. 273, for the same prayer, following a fable taken from Boccalini.

${ }_{162}$ Politike Weeg-schaal II.I.1, p. 309: “... Monarchie, daar een enkeld mensch gebieden mag, welke Regeering de Grieken en Latinen van ouds hebben genoemd Tirannie." For the Aristotelian distinction between monarchy and tyranny, see Aristotle, Politics V.10 (1310b). Cf. also Boxhorn, Institutiones I.IV.3-4.
} 
is conducive to the common good. ${ }^{16_{3}}$ According to the brothers De la Court, the duplicitous speech that proliferates under monarchical rule is responsible for this widespread mistake. The flattery of courtiers and political writers who live under a monarchical yoke implies that in such a regime, "the truth is more concealed, so that the deeds of Monarchs are always elevated above the truth" ${ }^{164}$ Such dissimulation means that the vices of kings are commonly heralded as virtues and that their "ambition and desire to rule" are lauded. ${ }^{1{ }_{5}}$ The consequence is that rulers like Caesar and Augustus, "those horrible Monsters, are still praised by most Historians as if they had been very pious Heroes" ${ }^{166}$ Even in the Dutch Republic such admiration of kings remains influential, with the result that many think that the monarchical incivility embodied by the House of Orange deserves the same esteem as the exemplary civic behaviour of the wise merchant:

And therefore one will say that the Prince of Orange should be praised for his expansion and growing authority and power in serving or Governing the United Netherlands as much ... as a diligent and honest Merchant, who knows how to accumulate his goods by Industry and Trade, is commonly esteemed and lauded. For apparently, all Prince's business and Commerce consist in that accumulation of Power. ${ }^{167}$

In short, courtly hypocrisy obscures the vital distinction between honourable mercantile ambition and the disastrous monarchical desire to dominate.

The brothers De la Court contend that thus far in history there has been only one author who dared to speak his mind to a monarch: George Buchanan, whose work "can serve as a brightly shining beacon to all

${ }_{163}$ This strategy dominates the entire first book of Politike Weeg-schaal, esp. I.I.8-11, and is repeated throughout the entire œuvre of the De la Courts, esp. in the third part of the Aanwysing.

${ }^{164}$ Politike Discoursen II.V.4, p. 109: “... de waarheid bedekter is: sulks de daaden der Monarchen altijd booven de waarheid werden verheft." Cf. Machiavelli, Discorsi I.58, p. 128: “... de' principi si parla sempre con mille paure e mille rispetti."

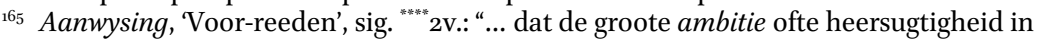
Koningen ende Princen seer pleeg gepreesen te werden."

${ }^{166}$ Sinryke Fabulen, 463: “... die schrikkelijke Gedrogten als nog by de meeste Historieschrijvers gepreesen, als of het seer vroome Helden waaren geweest." Cf. Politike Weegschaal I.I.12, p. 65, for a similar passage.

${ }^{167}$ Aanwyisng, "Voor-reeden," sig. ${ }^{* * * * *} 2$ v.: "Ende dienvolgende, soo schijnd iemand te sullen seggen, datmen de Princen van Oranjen over haare vermeerderinge ofte aanwassende authoriteit ende kragt in het bedienen ofte Regeeren der Vereenigde Neederlanden ende der veroverde Steeden, alsoo seer behoorde te prijsen, alsmen te agten ende te looven pleeg een vlytig eerlik Koopman, die sijne goederen door Neeringe ende Negotie weet te vermeerderen; want in die vermeerderinge van Magt kennelik alle der Princen hanteering ende Negotiatie bestaat." 
contemporary Historians who would like to write scandalous truths about Monarchs". ${ }^{168}$ With this praise of Buchanan's repudiation of "flattery, which is the nurse of Tyranny, and a most grievous plague of a Kingdome", the De la Courts clearly position themselves in the Monarchomach tradition. ${ }^{169}$ Yet unlike Buchanan, they do not maintain that kings are bound to uphold the social contract and that resistance is lawful if they forsake this duty. Instead, the brothers make a decisively more radical move by insisting that monarchy is by its very nature unconducive to the salus populi. Even when checked by the rule of law or balanced in a mixed regime, monarchy is and remains tyrannical.

The De la Courts insist that monarchs consider the population over which they rule as enemies and therefore "try to decrease the power, honour, and goods of their subjects as much as possible". ${ }^{170}$ A monarch aims to subdue the people as "tame and powerless" horses, "so that they cannot refuse the bit and bridle or imposts and obedience"; he restrains their cities through garrisons and citadels instead of protecting them with defensive fortifications, and he imposes all kinds of taxes to finance his wasteful pleasures and his expensive royal household. ${ }^{171}$ Moreover,

Monarchs hate studies and knowledge, since they consider it dangerous when many people tower above Them in intellect. And because they realize that an intelligent Community is not tyrannized or ruled as peacefully as one that is less intelligent, therefore these Monarchs extinguish all knowledge as much as they can. ${ }^{172}$

${ }^{168}$ Politike Weeg-schaal I.I.33, p. 161: "En dienvolgende soo kan gemelde Buchananus, tot een hel-schijnent baken strekken, voor alle hedendaagse Historie-schrijvers, die geneegen souden mogen wesen van Monarchen aanstotelike waarheeden te schrijven."

${ }^{169}$ George Buchanan, De jure regni apud Scotos. Or a Dialogue, Concerning the Due Priviledge of Government in the Kingdom of Scotland (s.l., 1680), sig. A5. Pieter de la Court van der Voort owned the 1643 Edinburgh edition of Buchanan's Rerum Scoticarum historia, published together with De jure regni apud Scotos: Library, fol. 28. On Buchanan, see Skinner, Foundations, vol. II: 339-348, and J.H. Burns, "George Buchanan and the AntiMonarchomachs," in Phillipson and Skinner (eds.), Political Discourse, 3-22.

${ }^{170}$ Politike Weeg-schaal I.I.11, p. 52: “... de magt, eere, en goederen hunner onderdanen zoo zeer tragten te verminderen als doenelik is."

${ }^{171}$ Aanwysing I.1, p. 3-4: “... soo mak ende magteloos blijven, dat sy niet souden konnen breidel ende toom ofte schatting ende gehoorsaamheid weigeren." The passage on the erection of citadels refers to Aristotle, Politics V.11, VII.11, and also evidently follows Machiavelli, especially Discorsi II.24. Cf. also Aanwsying III.2, which refers directly to the Politike Weeg-schaal, esp. I.I.13 and I.I.28.

${ }^{172}$ Politike Discoursen II.V.9, p. 133: "Ende om de selfde reden haten de Vorsten de studien, en geleerdheid; want Sy gevaarlik agten, dat veele booven Haar in verstand uitsteeken; ende siende dat een verstandige Gemeente, sig soo vreedsaam niet laat tiranniseren, of regeren als een onverstandiger, soo blussen deese Vorsten alle geleertheid soo veel uit, als sy konnen." 
The overall result is that a commonwealth under monarchical rule will never be able to prosper in liberty. Instead, monarchies only promote licentiousness. Kings spend their days among their concubines, and thus often leave daily administration to their favourites or, at best, they sell state offices to the highest bidder. Indecisiveness, nepotism, and corruption are the inevitable consequences. ${ }^{173}$ The rule of law is all but absent in a monarchy, for "all orders and laws will conduce privatively to the advantage of the King and his Courtiers". ${ }^{174}$ In sum, the private interest of the sovereign is not harmoniously connected to the general interest, but pursued at the expense of the common good.

This gruesome fate is especially catastrophic for a society based on commerce. Since monarchs and courtiers can enrich themselves effortlessly by imposing taxes and selling offices, it is unthinkable that they would "seek their maintenance by an uncertain gain with the danger of losing all in that ever laborious and anxious Commerce". ${ }^{175}$ The dominant ethics of a courtly society, based on laziness, easy gains and squandering, are fundamentally incompatible with the mercantile ethics of a commercial commonwealth. Kings and courtiers will therefore do their best to frustrate all trading activity. "Under a Single-headed Government", De la Court warns, "the Lords and their Courtiers envy and deadly hate the most fortunate Owners of Freight-ships, as well as the Merchants and Traders, because with their legally obtained Riches and the use thereof they obscure the lustre and pomp of the Court and Gentry" ${ }^{176}$ This monarchical jealousy of trade in turn leads to even more excessive taxes and the establishment of monopolies to line the courtiers' purses, which constrain economic freedom. Accordingly, the rule by a king and his corrupting court fundamentally thwarts the preservation and increase of the polity, the prime principle of reason of state. Monarchs forsake the necessary defence of the country, and instead of establishing

${ }^{173}$ See Politike Weeg-schaal, esp. I.I.11-27, and cf. the similar passages in Aanwysing I.1 and III.2, and e.g. in Sinryke Fabulen, 277-278.

${ }^{174}$ Politike Weeg-schaal I.I.27, p. 126: “...dat alle ordre en wetten zullen strekken privativelik, ten voordeele des Konings en zijner Hovelingen.”

${ }^{175}$ Aanwysing III.2, p. 423: “... sijne onderhoud door een onseeker gewin, met perikel van alles te verliesen, in de altijds arbeidsame ende bekommerlike Koopmanschap te soeken."

${ }^{176}$ Ibidem, 434: "Sulks dan waarhaftig zijnde, dat onder de Een-hoofdige Regeeringe, de Heeren en haare Hovelingen ... de gelukkigste Reeders in Vragt-scheepen, als ook Koopluiden en Negotianten benijden, ende doodelik haaten, om dat sy door hunne wettelik verkregene Rijkdommen, ende het gebruik van dien, den Hoofsen ende Adeliken praal ende glans verduisteren." 
profitable colonies overseas, they wage offensive wars to conquer new territories. ${ }^{177}$

All of which brings about that the people, sighing under the burdens of their Monarch, under the injustice and pillaging of their Governors, and living in continuous insecurity about their lives and goods, do not employ diligence to accumulate goods, nor do they have desire to marry and to breed children, who will be led to the slaughters of war as slaves of the Monarch..$^{17}$

Thus a commonwealth based on commerce and learning will necessarily disintegrate when it is enslaved to such domination, for merchants "shun and should flee from such a government like from a deadly Plague". ${ }^{179} \mathrm{De}$ la Court stresses that worldwide historical experience shows that this has been exactly the case, from the imperial Pre-Columbian courts of Cuzco, Quito, and Mexico to the large cities of Japan, China, Persia and India, and from Fez and Cairo to Nineveh and Jerusalem. ${ }^{180}$ All these instances reveal that if a people lives under domination by the arbitrary will of one man, commerce will collapse: because "in general, commerce always disappears from those countries and cities where one single man can rob a Merchant at his pleasure of his goods; that is, in short, from all monarchical government" ${ }^{181}$

\section{Paradigms of Tyranny}

An important part of the Politike Weeg-schaal discusses at length various instances of such monarchical rule and its ruinous consequences. The first and most prominent of these paradigms of tyranny is the Ottoman Empire - a commonplace element of comparison in early-modern European political thought from Bodin to Harrington. In line with the prevailing 'orientalist' depiction of Eastern despotism which can be traced

177 Ibidem, 437-439, and Politike Weeg-schaal I.I.28-29.

${ }_{178}$ Politike Discoursen V.II.9, p. 134-135: "Alle het welk te weege brengd, dat het volk onder de lasten van haar Vorst, onder de onregtvaradigheid, en plondering van haare Gouverneurs sugtende, en leevende in geduurige onseekerheid van haar leeven, en goederen; geen naarstigheid gebruikt, om goederen te vergaaderen, nog lust heeft om te trouwen, en kinderen aan te queeken, die als slaaven van den Vorst in de oorlogen ten slagtbanken werden gevoerd."

${ }^{179}$ Politike Weeg-schaal I.I.13, p. 72: “... de Koopluiden, van zoodanige regeeringe niet min schuw zijn, en vlieden moeten, als van een doodelike Pest."

${ }^{180}$ Aanwysing III.3, p. 443-444. De la Court refers to Blaeu's Atlas and to a Dutch translation of José de Acosta, Historia natural y moral de las Indias (1590).

${ }^{181}$ Welvaren 37, p. 82: “... in 't generael verloopt de negotie altijds uijt ende van die landen en steden, daer een eenigh mens een Negotiant na sijn gelieven, van sijn goederen kan berooven, dat is met eenen woorde geseght van alle monarchale regeringe." 
back to Aristotle ${ }^{182}$ the De la Courts' overview abhors the ignorance and devastation among the Turkish lands and the decadence and cruelty of the Sultan. ${ }^{18_{3}}$ In particular, the De la Courts insist that "those of Asia have always been fainthearted, feminine, and childish, those of Africa dumb and slavish ... but those of Europe have always been more courageous, manly, diligent and rational". ${ }^{84}$ Yet in spite of this conventional defence of European superiority, the De la Courts do not consider the Ottoman case as an example of fundamental otherness, typical to the particular culture and mores of the Orient or to Islam. Instead, the brothers list approvingly the Islamic rules of life and they insist that "under a Christian Religion those Lands would have been still much more destroyed" ${ }^{185}$ The Ottoman Empire offers therefore a universally valid warning that monarchy degrades humanity.

The only reason that Western Europe has for the most part not yet become prey to this fate, and that "under the Christian European Monarchs science, commerce, wealth, arts and virtues are not yet extinguished", is because of the republican legacy of Antiquity and the resulting decentralization and fragmentation of power. But the De la Courts feared this tide was changing. Just fairly recently in history, they argued, the European kings had started to reveal their truly tyrannical face. "The evil effects of Monarchical government are therefore, essentially, to be expected in due time." ${ }^{186}$ In 1685 , the year when Louis XIV crowned his absolutist rule with the revocation of the Edict of Nantes, De la Court saw these earlier fears justified. In the preface to the Sinryke Fabulen, he wrote:

Especially in our Century, Single-headed Rule, both in Church and State and suppressing so many Free Republics, has come to the fore to such an extent, that if it would continue among the Tyrants with the same pace for

${ }^{182}$ See Patricia Springborg, Western Republicanism and the Oriental Prince (Cambridge: Polity, 1992), and Joan-Pau Rubiés, "Oriental Despotism and European Orientalism: Botero to Montesquieu," Journal of Early Modern History 9, 1-2 (2005), 109-180.

${ }^{183}$ See Politike Weeg-schaal I.II.2-22. This overview is largely based on the massive work of Francesco Sansovino, Historia universale dell'origine et imperio de' Turchi (Venice, 1561) and on the Voyage du Levant by the French envoy Louis Deshayes, baron of Courmenin, a travel account first published in 1624 .

${ }^{184}$ Politike Weeg-schaal I.III.1, p. 230: “... die van Asien zijn altijt kleynhertig, verwijft, en kinderlijk, die van Afriken dom, en slaafs geweest ... Maar die van Europen zijn t'allen tijden stouter, manneliker, arbeydzaamer en vernuftiger geweest."

${ }^{185}$ Ibidem I.II.22, p. 227-228: “... dat die Landen, onder een Christelike Religie, nog veel meer verwoest zouden weesen."

${ }^{186}$ Ibidem I.I.34, p. 168-169: “... onder de Christelike Europise Monarchen, de geleerdheydt, koopmanschap, rijkdom, konsten en deugden niet uitgebluscht ... Sulks die quade effecten der Monarchale regeeringe, nu voorneementlik, met der tijdt te verwagten staan." 
yet another Century, then also in the whole of Europe all salutary Knowledge, Sciences, good Arts, Virtues and Riches of the People, indeed the People itself in number, will be diminished, just like we see it now in Muscovy, Greece, Turkey, Persia, India, \&c., unless God Almighty would forbid it miraculously. ${ }^{187}$

De la Court's pessimism stems from the crucial claim that there is in due course no fundamental difference between an overtly despotic monarchy such as the Ottoman Sultanate and a monarchy that is checked by laws and constitutional contract. This assertion involves a significant departure from the conventional republican credo that a king who respects the law is not the same as a tyrant. For Machiavelli, the Roman emperors who lived sotto le leggi deserved at least a bit of praise, ${ }^{188}$ while Milton made sure to deny "that all kings are tyrants". "As much as a good man differs from a bad", Milton insisted, "so much, do I maintain, that a king differs from a tyrant". ${ }^{189}$ Yet for the brothers De la Court, this distinction between monarchy and tyranny fails because it does not take into account the baseness of human nature. They acknowledge that monarchical government under the law may be slightly better than a state "where a Monarch rules absolutely and without fear", but it is still a government based on the principle of a single ruler, who is human and who will therefore necessarily try to free himself from the reins of the law. ${ }^{190}$ The recent history of France, Spain, and England - the standard examples of pure monarchy in the academic politica - was for the De la Courts a case in point of this predictable fate. ${ }^{191}$

${ }_{187}$ Sinryke Fabulen, "Voorreeden," "** 4v.: “... dat bysonderlik in deese onse Eewe de Eenhoofdige Regeering, soo in Kerke als in Staat, ter onderdrukkinge veeler Vrye Republiken, soodaanig is doorgedrongen, dat indien geduurende nog eene volgende Eewe, met dieselfde treeden by den Dwingelanden werd voortgevaaren, ook door geheel Europa alle heilsaame Kennissen, Weetenschappen, goede Konsten, Deugden ende Rijkdommen der Menschen, jaa de Mensche selfs in getaale, verminderd staan te werden; Eeven gelijk wy dat nu in Moscovien, Griekenland, Turkien, Persien, Indien, \&c. zien; ten zy God Almagtig sulks wonderlik verhoede."

188 See Machiavelli, Discorsi I.10, p. 34-35.

${ }_{189}$ Milton, Defence of the People of England and Second Defence, in Idem, Areopagitica and Other Political Writings, 148, 324. Cf. on absolutist theories that equally emphasized the difference between monarchy and tyranny Wolfgang Weber, "'What a Good Ruler Should Not Do': Theoretical Limits of Royal Power in European Theories of Absolutism, 1500-1700," The Sixteenth Century Journal 26, 4 (1995), 897-915.

${ }^{190}$ Politike Discoursen II.V.10, p.145: “... dat sy nog beeter zijn, als daar een Monarch absolutelik, en sonder eenige vreese, regeerd."

${ }^{191}$ Politike Weeg-schaal I.III.2-7, based on De Perefixe and Fajardo, and on the survey in Jean Pinson de La Martinière, Estat et gouvernement de France, of which numerous editions were published throughout the 1650 . 
England is thus unequivocally classified as a monarchy, which may seem surprising given the English republican experiment of the 1650 . Revealingly, the brothers De la Court remained largely silent about the fate of the English Commonwealth. Apart from De la Court's letter to Harrington of New Year's Eve 1672 and the manuscript reference to Harrington's Oceana, there is no direct evidence that the brothers were familiar with English republican thought. This can be explained by the fact that few English publications were available on the Dutch market, while Dutch enthusiasm for the English republican experiment was from the outset rather meagre. ${ }^{192}$ Of all contemporary English republican writings, only Milton's Defensio pro populo Anglicano, published in $165^{1}$ in reply to the Leiden academic Claudius Salmasius, was disseminated widely in the Dutch Republic, both in its Latin version and in French and Dutch translations. ${ }^{193}$ Milton indeed wrote this treatise with an international audience in mind, and he frequently addressed the Dutch directly. ${ }^{194}$ Nevertheless, his Dutch audience remained rather reserved about Milton's endeavour to justify the establishment of the English Commonwealth. While Isaac Vossius, the son of the rhetorical theorist, stressed that he "had expected nothing of such quality from an Englishman", another scholar, Nicolaas Heinsius (the former schoolmate of De la Court) aptly summarized the general Dutch sentiment by arguing "not so much that a bad cause has been well pleaded by Milton as that Scribonius [i.e. Salmasius] has pleaded most abominably the cause of the unfortunate King" ${ }^{195}$ The execution of Charles I had met with widespread condemnation in the Dutch Republic - the Dutch, after all, had abjured but never decapitated their king in the days of the Revolt - and for all his zeal, Milton could not significantly change that attitude. ${ }^{196}$ Other important

${ }^{192}$ See P.G. Hoftijzer, "The English Book in the Seventeenth-Century Dutch Republic," in Hellinga et al. (eds.), Bookshop of the World, 89-107, and cf. Marika Keblusek, "The Exile Experience: Royalist and Anglican Book Culture in the Low Countries (1640-166o)," in Ibidem, 151-158.

193 Joannis Miltons Engelsmans verdedigingh des gemeene volcks van Engelandt, tegens Claudius sonder naem alias Salmasius Konicklijke Verdedigingh [1651]. The library of Pieter de la Court van der Voort held this edition: Library, fol. $3^{2 .}$

${ }^{194}$ See Milton, Defence of the People of England, esp. 105. For Milton's intentions to convince the Dutch, cf. Worden, Literature and Politics, 202-203.

195 Quoted in H. Scherpbier, Milton in Holland. A Study in the Literary Relations of England and Holland before 1730 (PhD dissertation University of Amsterdam, 1933), 6, 13.

${ }^{196}$ See e.g. Vondel's poem “Op den Vader-moort in Groot-Britanie," in Werken, vol. V: 476. On Dutch public opinion about Cromwell, see Daniël Grosheide, Cromwell naar het oordeel van zijn Nederlandse tijdgenoten (Amsterdam: Noord-Hollandsche Uitgevers Maatschappij, 1951). 
writings in defence of the republican regime in England, from the newsbooks and treatises of Nedham to Harrington's Oceana, were never published in the Netherlands, let alone translated into Dutch. ${ }^{197}$

This absence of English sources partly explains why the De la Courts had so little to say about the English Commonwealth. Yet perhaps a more important reason for their relative silence is that the English revolution and Cromwell's eventual supremacy offered the brothers an example of "mutatio tyranni, non tyrannidis ablatio". As they insisted when discussing monarchical rule: "We must not take away the name King, but the thing King." ${ }^{198}$ This phrase, which vaguely echoes a comparable saying of Nedham, ${ }^{199}$ reveals that the supremacy of Cromwell and the eventual Restoration were for the De la Courts a sign that the English commonwealth was no true republic, but rather the same monarchy in different guise. The brothers maintained that England's violent past proves that even when a monarch is balanced by a powerful parliament, political upheaval is all too common. Therefore, "this blessed, fertile country", even though it never experienced similar warfare as continental Europe, "has still remained so lowly only because of the Monarchical government" ${ }^{200}$ It was clear to the De la Courts that the English, though doing their best to compete with the Dutch, would never be able to accomplish the same mercantile success as a truly free commercial commonwealth. ${ }^{201}$

Having thus disposed of England as yet another paradigm of tyranny, the brothers De la Court continue to discuss the distinct type of polity that is not subjected by a hereditary monarchy but by a ruler who is chosen advitam. The subjects in such a state probably fare better than those living under the yoke of absolutism, yet they are still dependent on the passionate whims of one man. Following a commonplace in Florentine political thought from Machiavelli to Guicciardini, the De la Courts discuss two examples of such "Monarchs in fieri": the Papal States, which

197 Revealingly, the only work of Nedham translated into Dutch was his anti-French pamphlet Christianissimus christianandus (Amsterdam, 1678).

${ }_{198}$ Politike Weeg-schaal I.I.32, p. 157-158.

199 Nedham, Excellencie, 155: “... onely the name King was expelled, but not the thing” (referring to the Tarquins).

${ }^{200}$ Politike Weeg-schaal I.II.7, p. 256: "Zulks dit gezeegende, vrugtbare landt, ook met hondert jaaren vreede, en zoo veel oorlogs onder alle de nabuuren, moet werden gelooft, zoo laag gebleeven te zijn, alleen door de Monarchaale regeering." See also the remarks on England in Politike Discoursen I.II.9, I.II.26, and Sinryke Fabulen, 725, which refers to Thomas Smith, De republica anglorum, published in the 'Republics' series of Elzevier.

${ }^{201}$ Aanwysing I.22, p. 99, and see De la Court's letter to Harrington discussed in the Introduction above. 
"should be loathed and eradicated", and the Mamluk Sultanate in medieval Egypt and Syria, in their words "the Saracen Republic that was so monstrous that it should be smothered". ${ }^{202}$ The De la Courts' version of the history of the Mamluks, based in particular on the fifteenth-century travel account of the Flemish nobleman Joos van Ghistele, discusses in detail the procedures of the election of the sultan, and it stresses that the regime was exceptionally beneficial for Mediterranean trade. ${ }^{203}$ But in spite of these positive qualities, the Mamluks remained under the domination of one ruler. Therefore they merely exemplified "lesser Slavery", for "Republics provided with a Head ad vitam who has any Military power, are truly Monarchies, or become so". ${ }^{204}$ Overall, then, the extended discussion of all various guises of monarchical rule, from the Ottoman Empire to the Mamluk Sultanate, involves a clear rhetorical strategy: to assert that any form of monarchy, no matter how moderate or balanced, necessarily involves servitude. The purpose of this strategy is of course obvious, and indeed, the Politike Weeg-schaal explicitly classifies Holland under the Stadholders as one of the monarchies in fieri. ${ }^{205}$

\section{The Dutch Republic: Lion or Ass?}

The precise intention of this move becomes clear in the context of the Dutch political debate on the position of the Stadholder in the years following the failed coup d'état by William II and the subsequent establishment of the regime of 'True Liberty'. Towards the end of the 165os the debate between the supporters of the House of Orange and those who defended the status quo remained fundamentally undecided. On one side, the miscellaneous front of Orangists propagated the mixed republican regime balanced by a Stadholder, while De Witt and his allies maintained in reply that the principle of non-hereditary offices prolonged the time-honoured Batavian model. The brothers De la Court attempted to move beyond this stalemate by arguing that any form of single rule within

${ }^{202}$ Politike Weeg-schaal I.IV.4-6, p. 307-308: “... minder Slavernye en Monarchen in Fieri ... in allen manieren behoorde te verfoejen en te verdelgen ... die Sarrasinise Republik, sy was soo monstrueus, dat men die behoorde te smooren." Cf. Machiavelli, Principe XIX, p. 136-137, and the description of the demise of the Mamluk Sultanate in Francesco Guicciardini, La historia d'Italia (Venice, 1567) XIII, p. 647-648.

${ }^{203}$ For a modern edition of Joos van Ghistele's travel account, see Ambrosius Zeebout, Tvoyage van Mher Joos van Ghsitele, ed. R.J.G.A.A. Gaspar (Hilversum: Verloren, 1998).

${ }_{204}$ Politike Weeg-schaal I.IV.6, p. 308: “... dat de Republiken voorsien met een Hooft, ad vitam, eenige magt in den Oorlog hebbende, waarlik Monarchien zijn, ofte werden."

${ }^{205}$ Ibidem I.IV.1-2. 
a republican constitution, hereditary or not, undermines the harmony within the body politic and ultimately brings about its demise. Thus emerges their radical assertion that, no matter how moderate or balanced, any monarchical figure is essentially a tyrant. In order to vindicate this claim, the brothers departed from both the conventional Aristotelian emphasis on the tripartite mixed regime and from the Batavian model of Grotius and instead turned to the binary opposition of liberty versus servitude. Heavily equipped with this republican language of liberty, the De la Courts entered the Dutch rhetorical battlefield to assail the Orangist positions and thus win over the middle ground in the debate. ${ }^{206}$

This verbose attack starts in the first edition of the Politike Weeg-schaal with a decided yet still relatively cautious attempt to persuade those who doubt the risks involved in appointing a Stadholder. Following the detailed survey of all the examples of monarchical tyranny, this attempt centres on the message that if one man is appointed as a Stadholder, Holland sets foot on a stairway to servitude. As the De la Courts insist: "Damned for eternity be the name of the Man who knowingly gives in his free Fatherland the first step to the Monarchical government, for all other steps will follow necessarily" ${ }^{207}$ In his later revision, De la Court then adds more force to this statement with a warning to those "Lovers of Liberty" who think "that the road to Servitude and Monarchical government is steep enough to give away some steps". Directly addressing these middle groups who had not been convinced by the anti-Orangist argument of De Witt, De la Court stresses that "someone who is on the first step to make himself Lord of the Republic" will easily obtain the favour of the military and the "ignorant Rabble", and thus eventually command an indomitable alliance of anti-establishment sentiments. "And therefore", De la Court concludes, "it is the truth that the liberty of a Republic can only remain intact by cautiously taking care not to put anyone, under whatever lovely name or cover, on the lowest first step of exceptional power". ${ }^{208}$

${ }^{206}$ For a comprehensive overview of the Orangist ideology that the De la Courts argued against, see Stern, Orangism.

${ }^{207}$ Politike Weeg-schaal I.III.9, p. 261-263: "Vervloekt zy des Menschen naam in der eeuwigheit die willens en weetens in zijn vry Vaderlant, na de Monarchaale regeering de eerste treede geeft, want alle anderen moeten noodzakelik volgen; (primas dominandi spes in arduo, ubi sis ingressus adesse studia \& ministros. C. Tacitus.)" The suggestive quote is from Tacitus' description of Sejanus, confidant of Tiberius, in Annals IV.7.

${ }^{208}$ Ibidem, 261-263 (not yet in the first edition): "Dog indien eenige Liefhebber der Vryheit, van meeninge zijn ... dat de weg ter Slavernie en Monarchale regeeringe zo steil niet is, of dat men in de selve wel eenige treeden geven, en dan nog blijven staan kan; zo gelieven de selven te gedenken, dat iemant die op den eersten trap is om sig Heer der 
One of these 'lovely names' that De la Court had in mind was the title of Captain-General, the office of commander-in-chief over the Republic's armed forces which traditionally belonged to the Stadholder. The military command was one of the crucial issues in the Dutch political debate since many, and not only the committed Orangists, claimed the necessity to appoint a single supreme military leader to protect the country. The De la Courts suggestively undermine this claim. Again and again, they subtly hint to the implications of appointing a Captain-General by calling respectively Caesar, Augustus and Tiberius "the Captain-General of the Roman Republic". ${ }^{209}$ Other passages and fables, drawing largely on Machiavelli and Boccalini, insist with similar meaningful obliqueness that the reputation and authority granted to a military leader open up the gates to tyranny. ${ }^{210}$

These passionate but still implicit references to the dangers of appointing a Stadholder or a Captain-General become much more overt in the Interest van Holland and especially in the revised version of the work, the Aanwysing, published two years after the signing of the Perpetual Edict that formally abolished the office of the Stadholder. In this new context, De la Court markedly increases the bluntness of his anti-Orangist assault, extensively quoting from the text of the Edict to substantiate his views. ${ }^{211}$ First, he maintains with much hyperbole "that never any Country has been in such great servitude as Holland during or under the Service and Rule of the Princes of Orange". This assertion is further elaborated throughout the work. Until 1650, De la Court repeatedly insists, Holland suffered under the monarchical yoke of the Stadholders, and only God's intervention prevented a life in eternal slavery with the sudden death of William II. ${ }^{212}$

Republike te konnen maken ... het onwetende Graaw ... En dienvolgende zo is waaragtig, dat de vryheid eener Republike niet kan werden staande gehouden, dan met sig sorgvuldiglik te wagten, iemand onder wat lieffelike naam en dekmantel het zy, te setten op de minste eerste trede van uitsteekende magt."

${ }^{209}$ Ibidem, "Inleyding,” p. 2: “ ... die wreede Capitain Generaal der Roomse republike Tiberius." Similar references to Caesar, Augustus and Tiberius e.g. in Ibidem I.IV.1, p. 280; I.IV.2, p. 293; II.VI.3, p. 503; and Sinryke Fabulen, 655. Aanwsying II.1, p. 211, compares Stadholder Frederik Hendrik to Augustus through a telling quote from the opening lines of Tacitus, Annals I.2.

${ }^{210}$ See esp. Politike Weeg-schaal I.III.10-11, and Politike Discoursen I.III.11. Cf. Machiavelli, Discorsi I.40, III. 28.

${ }^{211}$ Aanwysing II.12, p. 338-341.

${ }^{212}$ Ibidem, "Voor-reeden," sig. .* 2v.: “... dat noit eenig Land in soo groote slavernye, als Holland gedurende, ofte onder de Dienst ende de regeeringe der welgemelde Princen van Oranjen, geweest zy." References to the salvation of liberty by the premature death of William II e.g. in Ibidem, sig. ${ }^{* * * * *}$ v.; I.25, p. 130; III.1, p. 417; III.4, p. 474. 
Thus began the period of True Liberty, which De la Court, unlike De Witt, does not characterize as the absence of hereditary power but as the inexistence of any arbitrary domination - the possibility to lead a peaceful life in accordance with the law "without being forced, like before, to speak, sing, and dance to the piping and will of one Man". ${ }^{213}$

A number of rhetorical moves substantiate this assertion that Holland under the rule of the Stadholders was not a true republic but merely a monarchy in disguise. A first move intends to show that the Princes of Orange inherited a long tradition of monarchical imperiousness of the Counts of Holland - a direct confutation of the Orangist claim that the Stadholders upheld a time-honoured Batavian heritage of well-balanced government. ${ }^{214} \mathrm{~A}$ second move then involves a refutation of another standard element of the Orangist republican credo: the view that the Dutch Republic had gained its independence thanks to the prudence and guidance of the various Stadholders in the war against Spain. ${ }^{215}$ The De la Courts daringly turn this conventional image upside down through a rhetorical redescription of the role of William the Silent, the pater patriae. First, they hint with a quote from the Spanish diplomat Fajardo (that is, from the side of the former enemy), that William the Silent only pretended to fight for liberty but in fact deliberately caused upheaval and thus established a "much more unbearable Servitude" than before. ${ }^{216}$ Then, in the Aanwysing, De la Court intensifies this move with the rhetorical question whether "these Countries have been in harsher slavery under the Service of the Princes of Nassau, or under the Domination of the Habsburgs?" Of course, no answer follows, yet the suggestion that there is no fundamental difference speaks for itself. ${ }^{217}$

${ }^{213}$ Aanwysing II.12, p. 342: “... sonder sig als voordeesen genoodsaakt te vinden, naar eenes Mans sin en voorpijpen, te moeten spreeken, singen, en dansen.”

${ }^{214}$ See Politike Weeg-schaal I.IV.2, Aanwsying I.25, and the entirety of Historie der gravelike reeegering.

${ }^{215}$ See e.g. Onwederleggelycke bewys-redenen daer door betoont wort, dat de Vereenighde Nederlanden, alleen door Godts voorsieninge ende der Princen van Orangien beleyt, van Spaensche jock, ende slavernije vrij gemaeckt zijn (Willemstad, 1663).

${ }^{216}$ Politike Weeg-schaal I.IV.2, p. 289-290: “... een veel onverdraageliker Slavernie,” following a quote from Fajardo, Idea, symb. 78 .

${ }^{217}$ Aanwysing II.11, p. 323: “... of deese Landen onder den Dienst der Nassowsen, ofte onder de Heerschappye der Oostenrijkers, in hardere slavernye waren geweest?" The question is based on a verse in Latin, borrowed from Aitzema, Saken van Staet en Oorlogh, vol. VII, 8og: "Servivi Auriacis famulis, dominisque Philippis: dic mihi conditio durior utra fuit?" - to which Aitzema tellingly adds that the difference between 'Auriacis' (i.e. the Princes of Orange) and 'Austriacis' (the Habsburgs) consists merely of the letters 'st'. 
In this way, De la Court boldly depicts the Dutch Stadholderate as merely a rippling reflection of the Habsburg monarchy. In a next move, he then openly argues that the appointment of a Captain-General is no lesser evil than to empower a Stadholder. With a telling quote from Lucan's Pharsalia, De la Court asserts that a man who commands the military has all the means and reputation to overrule any opposition. This military commander should therefore be considered noting but a "Sovereign, a Monarch of that State ... and accordingly, such a Government should no longer to be called a Republic, but a Monarchy in practice and in fact". The fate of the Roman Republic, again illustrated by a quote from Lucan, proves that only the shadow of liberty remains when men bow to such military might. ${ }^{218}$ Under a Stadholder or a Captain-General Holland would equally "lose the name and the appearance of a Free Republic in a very short time, and change into an evident Monarchical or Single-headed Government". Merchants and commerce would then inevitably flee the country, and the deplorable result would be "truly a Country without Inhabitants, a Body without a Soul, and a lamentable fountain of unspeakable misery". ${ }^{219}$

All the different threads of the argumentation of the De la Courts come together in the final and most important rhetorical move against the Orangists: the overarching claim that the particular interest of the Stadholder cannot possibly coincide with the general interest of Holland at large. Holland, based on trade, needs liberty, yet a Stadholder will only enhance servitude. Like any monarch, he will enforce large taxes to weaken his subjects and to finance his decadent court. This is what the Princes of Orange have done in the past, as a result of which the Dutch "more than any people in the world seem to be sentenced to labour like Asses and to eat thistles in order to subsist". ${ }^{220}$ Such hyperbole serves the obvious purpose of contradicting the Orangist argument that Dutch commerce

${ }^{218}$ Ibidem III.1, p. 391-392: “... Souverain, Monarch van dien Staat ... ende dat men dienvolgende soodanige Regeringe niet meer eene Republike, maar eene Monarchye te weesen in practik ende inder daad, behoorde te seggen." The quotes from Lucan that illustrate this passage are from Pharsalia III.145-147, and X.407.

${ }^{219}$ Ibidem III.7, p. 517-518: “... door het maaken van een Stadhouder ofte een Capitein Generaal, ad vitam ... de naam ende de schijn eener Vrye Republike in seer korte Jaaren soude verliesen, ende veranderen in eene baarblijkelijke Monarchale ofte Eenhoofdige Regeeringe ... waarelik een Land sonder Inwoonders, een Lighaam sonder Ziele, ende eene beklaaglijke waaterpoel van onuitspreekelike ellenden, soude weesen."

${ }^{220}$ Politike Weeg-schaal I.IV.2, p. 294: “... dat zy meer als eenige volkeren des werelds schijnen verweezen te zijn, gelijk als Eezels te arbeiden, en distelen te eeten, om te mogen leeven." 
had prospered under the rule of the Stadholders. De la Court develops this argument further with a meticulous overview of the economic policies of all Stadholders from William the Silent to William II, concluding that had the last Prince of Orange not died so suddenly, "commerce and navigation would have been subjected here to the same demise as in all other Monarchical Countries". ${ }^{221}$ In short,

for all free States, and especially for those founded on Knowledge and Commerce, no greater disaster can be thought of than to fall from a free City or Republic to a Monarchical Government, where commonly all knowledge, arts, virtues, Wealth and commerce are destroyed, and the Inhabitants devoured like bread. ${ }^{222}$

To substantiate this assertion that a commercial commonwealth cannot persist under monarchical domination, De la Court enumerates a range of illustrious trading cities of the past that lost their prosperity along with their liberty, such as the Phoenician cities of Sidon and Tyre. Ancient Sidon, "whose Inhabitants lived in complete peace and certainty under a Free Republic without having a Supreme Head or King over them", is now deprived of its former wealth under Ottoman domination, "since the Inhabitants cannot peacefully possess their riches and sciences under this Monarchical or Princely Government". Tyre was struck by a similar fate, and thus "these two Republics lost their navigation and commerce not by Wars or Earthquakes ... but by the loss of their Free Government" ${ }^{223}$ Further examples of this essential link between liberty and commerce abound: Carthage, Athens, Rhodes, exemplary republics which all lost their trade and liberty to the Romans; the republics of the Italian Renaissance, like Pisa, Florence and Milan, which "when they obtained

${ }^{221}$ Aanwysing III.IV, p. 476: “...dat de koopmanschap en schipvaart, \&c. hier deselve ondergang, als in alle andere Monarchale Landen, onderworpen zijn geweest." The chapter builds heavily on passages from De Witt's Deductie. Cf. as well Ibidem, "Voor-reeden," sig. ${ }^{* * * * *}$, and II.1, p. $236-237$.

${ }^{222}$ Welvaren 64, p. 143-144: “... van alle vrije Staeten, insonderheid die op Geleerdheid en Koopmanschap sijn gefondeerd, dat voor deselve grooter rampsalicheid niet kan werden bedaght, als van eene vrije Stad ofte Republijck te vervallen tot een Monarchale Regeeringh, daer gemeenelick alle geleerdheid, konsten, deughden, Rijkdom ende koopmanschap vernietight, ja de ingesetenen verslonden werden als brood."

${ }^{223}$ Aanwsying III.3, p. 444-449: “... wiens Inwooners leefden in volkome rust en seekerheid, onder eene Vrye Republike, sonder Opper-hoofd ofte Koning over sig te hebben ... alsoo de Ingeseetenen onder deese Monarchale ofte Princelike Regeeringe haare rijkdommen en wetenschappen niet souden konnen gerustelik besitten ... En dus siet men, dat deese twee Republiken haare schipvaart ende koopmanschap, door geene Oorlogen ofte Aard-beevingen ... hebben verlooren; maar dat sy deselve alleen door het verlies van haare Vrye Regeeringe zijn quijt geworden." 
the Court of a Monarch or his Stadholder much decreased in commerce during the Monarchical Government"; and finally, at the end of the list, the Dutch Republic itself, which had a narrow escape yet faces an insecure future. ${ }^{24}$

All these examples issue an unmistakable warning to those who argue in favour of a Stadholder. Their crime, De la Court stresses daringly, is "similar to Adam's first sin", with the same everlasting catastrophic consequences for posterity. ${ }^{225}$ The Orangists who boast that they are the true patriots are in fact traitors to their country, because "it is a ridiculous stupidity and a damned folly, or detestable treason against the state, to install in one's free Fatherland any Head, however it be, over Politics, Justice, or the Military". ${ }^{226}$ In a final rhetorical move, De la Court addresses the supporters of the Stadholder directly in a potent exclamation that merges biblical imagery with biting wit:

You bastards from the Tribe of Judah! You who have dared to carry for so long a Lion in your escutcheon, erase, erase that old blood-coloured Lion, whom you are unworthy in every way. And as true children of Issachar, carry instead in your decorous escutcheon a strongly boned Ass oppressed under a double burden. ${ }^{227}$

In 1672, the Dutch lion was indeed to show its true nature. Some thirteen years later, in his swansong the Sinryke Fabulen, De la Court lamented its fate in the implicit yet well-understood terms of the proverb "wherever an ass falls, there will he never fall again": in spite of the fact that God's intervention in 1650 had freed Holland from a tyrant, the Dutch appointed a new one in $1672 .{ }^{228}$ Once more, De la Court repeated his anti-Stadholder mantra, stressing "how great Servitude or miserable condition it is to live in a Country where the well or ill-being, yes the Life or Death of all

${ }^{224}$ Ibidem, 458: “... de Hof-houding des Monarchs ofte sijns Stadhouders bekoomen hebbende, seer in koopmanschap afgenoomen zijn, geduurende de Monarchale Regeeringe."

${ }_{225}$ Ibidem III.7, p. 517: “... gelijk als Adams eerste sonde.”

${ }^{226}$ Politike Weeg-schaal I.III.8, p. 258: “... is het een bespottelike dwaas- en een vervloekte dolligheyd, ofte een verfoeijelijke landverraderij, in zijn vry Vaderland eenig Hooft, hoedanig het zy, over de Politie, Justitie, ofte Militie in te voeren." Cf. Ibidem I.IV.1, p. 282, for the same charge of high treason against the Orangists.

${ }^{227}$ Ibidem I.IV.2, p. 298 (not yet in the first edition): "Gy bastaart-kinderen uit den Stamme Juda! die zoo langen tijd een Leew in uwen schild hebd derven voeren, wisch uit, wisch uit, dien ouden bloedverwigen Leew, wiens gy in aller manieren onwaardig zijt. En als waaragtige kinderen van Issaschar, soo voer in teegendeel tot u welvoegend wapen, een sterk gebeende Eezel neder-gedrukt onder eenen dubbelden last."

${ }^{228}$ Sinryke Fabulen, 160: “... dat een Eezel sig niet meer dan eens stoot aan den selfden steene." For a similar rhetorical move, see Ibidem, 98. 
Inhabitants of the Country, depends on the favours or disfavours of one single Man". ${ }^{229} \mathrm{He}$ could not say more, he insisted, for under the new regime of William III, "a solemnly proclaimed Oblivion" forbade the remembrance of the near past, "since those wounds are too fresh to be scratched open". ${ }^{230}$ Now was no time for parrhèsia, De la Court realized, yet his message remained obvious. The Dutch commercial commonwealth had stood at crossroads, one way leading to prosperity-in-liberty, the other to decadence-in-servitude. It had chosen the latter.

\section{TOWARDS A MERCHANT DEMOCRACY}

\section{Republic: A Sovereign Assembly in Name \& in Fact}

To summarize, the fundamental principle that underlies the political thought of the brothers De la Court is the statement that "it is truly the best Government where the Rulers and most of the Inhabitants cannot find their Self-Interest and Welfare but with furthering the welfare of the Community". ${ }^{231}$ This harmony between private and public interests can never be sustained under monarchical domination, for any form of single rule necessarily undermines the common good. The De la Courts' alternative is a republican government that fosters liberty instead of servitude, but the question remains what kind of republic exactly meets this criterion. In short: what is a true republic according to the De la Courts?

In early-modern political thought, the term 'republic' was characterized by an elementary ambiguity. Originally, following Cicero, the words res publica stood for any kind of legitimate government, monarchical or not, as opposed to tyranny. ${ }^{232}$ This use of the term remained widespread throughout the seventeenth century, when 'republic' was often employed in the same neutral terms as its literal translation 'commonwealth', devoid of any non-monarchical connotation. In the academic politics as taught

${ }^{229}$ Ibidem, 361: “... hoe groote Slaavernie ofte ellendige stand het is, te woonen in eenen Lande, daar het wel- ofte quaalik-vaaren, jaa Leeven ofte Dood aller Ingeseetenen eenes Lands, hangd van de gonsten ofte afgonsten eenes eenigen Mensche." Cf. also Ibidem, 46, 143-144.

${ }^{23^{\circ}}$ Ibidem, 315, 585: “... eene plegtiglik afgekondigde Vergeetelheid"; "Want die wonden te vers zijn om oopen gekrabt te mogen werden."

${ }^{231}$ Ibidem, 185: “... dat het waarelik de beste Regeeringe is, daar de Regenten ende de meeste Ingeseetenen, haar Eigen-Interest ende Welvaaren niet vinden konnen, dan met het Welvaaren van het Gemeen, te besorgen."

${ }^{232}$ Cicero, De re publica, ed. and trans. Clinton Walker Keyes (Cambridge, Mass.: Harvard University Press, 1928) I.XXV-XXVI.39-42, p. 64-66. 
at Leiden, a res publica stood for the political order in which a body of individuals obtains the status of subjects under a single overarching central authority. Boxhorn, for example, defined a 'republic' very generically as "a body of many established for the advantage of all and every individual to acknowledge the authority of the government over that body by certain laws". ${ }^{233}$ Other representatives of academic politica, from Arnisaeus to Werdenhagen, defined 'republic' in largely comparable terms. ${ }^{234}$

Yet significantly, Boxhorn added an explanation to his definition of 'republic' indicating that the term had obtained a further gradation of meaning. Boxhorn stressed that his definition applied to every sort of government, including that of a single ruler, but because such a ruler "often puts public after private, or is ensnared by the temptations of lust, or when inclining to tyranny inflicts the more damage the more powerful he is, therefore it occurs that res publica is contrasted with Monarchy". ${ }^{235}$ With these words, Boxhorn neatly captured a second meaning of the term 'republic' that had crept slowly but steadily into the political discourse of the various European languages. The roots of this altered meaning lay in Renaissance Italy, particularly in Florence, which, as a free city-state ruled not by one but by many, claimed to embody the true res publica in opposition to a polity governed by a monarch. A crucial text in the establishment of this opposition was Machiavelli's Principe, which in the opening lines famously subdivides all states as either republiche or principati. ${ }^{236}$ In the course of the sixteenth-century, this non-monarchical meaning of the term 'republic' became common in Italian, and throughout the next century it spread over the rest of Europe, challenging the dominance of the established Ciceronian understanding. ${ }^{237}$

This second definition of 'republic' as a polity that is opposed to a monarchy clearly dominates the work of the brothers De la Court. Two crucial

${ }^{233}$ Boxhorn, Institutiones I.II.1, p. 8: "Respublica est corpus multorum ad agnoscendam ejusdem Imperii Majestatem, iisdem legibus, omnium \& singulorum utilitatis causa, imbutum."

${ }^{234}$ Cf. Arnisaeus, De republica II.I.1, and Werdenhagen, Politica generalis II.I.5.

${ }^{235}$ Boxhorn, Institutiones I.II Exp., p. 10: "Respublica quam hic definimus pro quovis imperio usurpatur, etiam pro eo, cui unus praeest, si modo ille saluti obedientum consulat. At quia saepe is aut publica privatis postponit, aut illecebris voluptatum rapitur, aut ad tyrannidem inclinans tanto plus infer damni, quanto potentior est, obtinuit, ut Respubl. Monarchiae fere opponatur."

${ }^{236}$ Machiavelli, Principe I, p. 1: "Tutti li stati, tutti e dominii che hanno avuto et hanno imperio sopra li uomini, sono stati e sono o republiche o principati."

${ }_{237}$ See the painstaking but rather unstructured overview in Wolfgang Mager, "Republik," in Geschichtliche Grundbegriffe, vol. V: 549-651, and cf. the more concise and more useful discussion in Hankins, "Exclusivist Republicanism." 
chapters in the Politike Discoursen unequivocally claim "That a Republic is better than a Monarchy", even that "The best Monarchical Government is not as good to the Subjects as the worst Republican Government" ${ }^{238}$ Thus the brothers move beyond the cautious remark of their teacher Boxhorn, and they explicitly equate monarchy with tyranny and republic with liberty. Using the same Ciceronian language that opposes legitimate to tyrannical government, the De la Courts radically undermine the classical connotations of res publica by insisting that a monarchy is necessarily tyrannical and only a republic is truly legitimate.

A republic, then, is essentially "a State where no Man can dictate" - a state where the sovereignty is vested in an assembly of many, where the law governs all and where arbitrary domination by a single man is impossible. Yet this generic definition does not encompass the De la Courts' concept of a republic in its entirety. As De la Court argues, a definition solely in terms of sovereign right is bound to be insufficient in a realm of de facto politics. He therefore insists that a republic not only entails "such a State, where a certain Sovereign Assembly has all the Right and Power to take, make or break resolutions, orders and laws ... [but] also such as State, where a certain Assembly, even though without any Right, has the Power to have all its resolutions, orders and laws being obeyed". ${ }^{239}$ In short, a true republic means the government by an assembly that is not only sovereign in name, but also in fact. This contention stems from De la Court's assertion that a state where a single man can usurp power without any right is effectively a monarchy. "Right is totally idle without force, and where violence comes it must always cease", De la Court insists. ${ }^{240}$ The theoretical issue of the location and administration of sovereignty does not establish the main distinction between republics and monarchies - an important move away from the conventional Grotian defence of the States of Holland vis-à-vis the Stadholder. All that

${ }_{238}$ Politike Discoursen II.V.4, p. 105: "Dat een Republijk beeter is als een Monarchie." Ibidem II.V.9, p. 131: "De beste Monarchale Regeering, is den Onderdaanen soo goed niet, als de geringste Republikse Regeering."

${ }^{239}$ Aanwysing III.1, p. 388: "Naamentlik, met den woorde Republike en Republikse Regeerders versta ik, niet alleen soodanige Staat, waar in seekere Souveraine Vergadering alle Regt ende Kragt heeft, om alle resolutien, ordren en wetten te nemen, te maaken, ofte te breeken ... maar ik verstaa daar meede ook soodanige Staat, waar in eenige Vergaaderinge, schoongenomen sonder eenig Regt, de Kragt heeft alle haare resolutien, ordren en wetten te doen gehoorsamen."

${ }^{240}$ Ibidem, 389: “... Regt dat sonder kragt gansch ydel is, ende daar geweld komt altijd ophouden moet." 
matters in reason of state politics is the actual ability to enforce one's interest. A republic, consequently, is a polity where the government is in the hands of an assembly that has sufficient coercive power to ensure that the harmony of interests is not jeopardized by the ascendancy of one man; in short, "such an Assembly where, for the large amount and the diversity of Members, self-Interest cannot be pursued and obtained at the expense of the common welfare" ${ }^{241}$

\section{Aristocracy \& the Pitfalls of Paucity}

What sort of assembly is best equipped for this task? In line with the conventions of academic politica, the brothers De la Court discuss two variations of republican government as alternatives to tyrannical monarchy: either aristocracy, basically defined as "an assembly of some people", or democracy, "an assembly of all people capable". ${ }^{242}$ In a clear rhetorical move to uphold the ethos of the objective, impartial guide through the labyrinth of politics, the Politike Weeg-schaal lists all the advantages and disadvantages of both aristocracy and democracy, and then continues to balance the particular merits of each specific form of government. Largely written by Johan and later modified and extended by Pieter de la Court, this overview clearly reveals the intricate and at times conflicting collaboration between the two brothers.

Following a central claim advanced by Machiavelli, the De la Courts insist that in general, the advantage of a republican assembly lies in the plurality of its members. Mastering the art of speech, "many people can always hear, see, and know more than one", while the competition between all members of an assembly will create "diligence and sincerity" as well as cautiousness. In a direct echo of Machiavelli's dictum that "a people is more prudent, more stable and of better judgment than a prince", the De la Courts conclude that

in an assembly of equally powerful Members, there is always a large variety of passions, which keep each other in check without insight of own benefit. Thus, when it comes to political matters, reason finds always more place in

${ }^{241}$ Sinryke Fabulen, 107: “... in soodaanige Vergaaderinge, waarin, om het groot getal, ende de verscheidenheid der Leeden, eigen Interest ten naadeele des gemeenen welvaarens, niet konnende bejaagd ende verkreegen werden."

${ }^{242}$ Politike Weeg-schaal I.I.4, p. 33: “...in een vergaaderinge van eenige menschen in de Aristokratia of in een vergaaderinge allermenschen des bequaam zijnde in een Demokratia." Cf. Boxhorn, Institutiones II.I.1, p. 257: "Inde Monarchia, in qua singuli; Aristocratia, in qua pauci; Democratia, in qua omnes praesunt." 
legitimate assemblies than in one man, whose judgment is frequently stunned by the passions. ${ }^{243}$

In theory, therefore, the larger the assembly is, the better, because the plurality of members enhances competition between their passions, which eventually keeps a check on individual wrongdoing. Yet in practice, such plurality may result in long deliberations and lack of decisiveness. Since the members of an assembly have "not only variety of interest but also of judgment", the sovereign power might fall apart through intrigues and discord. ${ }^{244}$ Therefore, the crucial issue is of the optimum dimensions the governing assembly should assume in order to benefit from the advantages of plurality without suffering under its disadvantages.

The first possibility is aristocracy, described in conventional Aristotelian terms as a government "where an assembly of people, being born or chosen thereto, has to command and all others outside of that assembly are to obey". ${ }^{245}$ The fundamental advantage of this aristocratic ruling body lies in the eminence of its members, who can be expected to have enjoyed a good education and therefore will understand how to connect their selfinterest to "the right Interest and welfare of the Country". ${ }^{46}$ Yet an aristocracy also has numerous flaws, of which the De la Courts stress three in particular. First, if the members of an aristocratic assembly vote openly, they are liable to be manipulated by the strongest among them, who will then get hold of the "power and act of Government". Thus, such aristocracies, though "Republics in name", will become "close to Monarchies

${ }^{243}$ Politike Weeg-schaal II.I.3, p. 320-321: “... dat veele menschen altijd meer hooren, zien en weeten konnen, als een ... naarstigheid en opregtigheid ... dat sig in een vergaderinge van eevenmagtige Leeden, altijd een groote verscheidentheid van passien oopenbaard, die ook, zonder inzigt van eigen baat, malkanderen in den toom houden; zulks de reeden, in wettige vergaaderingen, omtrent politike zaaken, altijds meer plaatse vind als by een mensch, wiens verstand door de passien veeltijds verdoofd werd." Cf. Machiavelli, Discorsi I.58, p. 126: “... un popolo è più prudente, piu stabile e di migliore giudizio che un principe ... molte volte erra ancora un principe nelle sue proprie passoni, le quali sono molte più che quelle de' popoli."

${ }^{244}$ Politike Weeg-schaal II.I.4, p. 327: “... niet alleen verscheidenheid van interest, maar ook van oordeel."

${ }^{245}$ Ibidem I.I.6, p. 35: “... een vergaadering van menschen, daar toe gebooren ofte verkooren, heeft te gebieden, en alle anderen buiten die vergaaderinge weezende te gehoorzaamen." Cf. Burgersdijk, Idea oeconomicae et politicae II.XXII.1, p. 118: “Aristocratia est status in quo excellentioribus aliquot, jus majestatis, \& imperium in caeteris concessum est."

${ }^{246}$ Politike Weeg-schaal II.II.2, p. 335: “... dat het regte Interest en welvaaren des Lands, door gemelde Leeden zeer wel kan worden begrepen, en dat een yder, die in 't gemeen zijn eigen voordeel betragten kan, zoo veel in hem is, niet zal toelaaten, dat het Gemeen, en hy te gelijk schade lijde." 
in fact" ${ }^{247}$ Secondly, aristocratic assemblies are likely to fall into discord and factions. This happens particularly when guild masters are granted membership, for they can mobilize their entire profession to put pressure on the rest of the assembly. Finally, the third flaw of an aristocracy is that, since "the Members of the sovereign assembly are so few", it runs the risk of becoming an "Oligarchy, Dominatio Paucorum, stato da pochi [sic]". The ultimate consequence is that "in such a Government the interest of the Rulers will always precede, also at the detriment of the common good". ${ }^{248}$

With this assertion that an aristocracy is likely to lapse into either monarchy or oligarchy, the brothers De la Court adopt a standard refutation of a closed government of the few, echoing Machiavelli, who argued that a government of ottimati easily becomes a stato di pochi, ${ }^{249}$ and Boxhorn, who equally insisted that an aristocracy often changes into monarchy or into Tacitus's paucorum dominatio. ${ }^{250}$ The De la Courts continue to discuss extensively how the advantages and disadvantages of aristocracy are revealed in the constitutions and republican practices of contemporary and historical examples of aristocratic government, from Venice and Genoa to Sparta and Rome. As Haitsma Mulier has shown in detail, when revising the Politike Weeg-schaal De la Court gave particular praise and attention to the republic of Genoa. In Genoa, according to De la Court, the large ruling councils and the constant rotation of office prevented the demise of true republican government. ${ }^{251}$ Yet Haitsma Mulier does not highlight that the reference to this international model clearly served to criticize the Dutch status quo, the oligarchic governing bodies in Leiden and Holland at large.

This criticism specifically involved a strong repudiation of the size of Leiden's ruling council of forty, the veertigraad. In line with their general discussion of aristocratic government, the De la Courts argued that so small an assembly will not be able to resist the preponderance of one imperious member or the external pressure of guilds. As they insisted, it is

${ }^{247}$ Ibidem II.II.3-5, p. 339, 344: "Maar dat de kragt en daad van Regeering, meest is by dat uitsteekend Lid ... Republiken met naame; bij naast Monarchien in der daad."

${ }^{248}$ Ibidem II.II.6, p. 348: "Het derde grootste gebrek der Arsitokratike Regeeringe, bestaat in Oligarchie, Dominatio Paucorum, stato da pochi ... als de Leeden der souveraine vergaderinge zoo weinig zijn." Ibidem II.VI.5, p. 514: “... zoo zal in zoodanige Regeeringe altijd het interest der Regeerders voortgaan, ook tot nadeel van het gemeen."

${ }^{249}$ Machiavelli, Discorsi I.2, p. 11: “... gli Ottimati con facilità diventano stato di pochi.”

${ }^{250}$ Boxhorn, Institutiones I.3 Exp., p. 21, quotinq Tacitus, Annals VI.42.2. See also Ibidem II.V.11, II.VII.3.

${ }^{251}$ See Politike Weeg-schaal II.V.1-11, and the analysis in Haitsma Mulier, Myth of Venice, 147-157. 
very improbable "that ever a Republic has been able to uphold its Free Government against the world's incidents, both from the inside and from the outside, with as few members as forty". ${ }^{252}$ In other words, a republican assembly that excludes a large part of the citizenry will easily fall prey to nepotism or succumb to one leader, who will then destroy republican liberty. Therefore, the De la Courts concluded, it is "humanly impossible" that Leiden's government would "subsist in such an unequal rule by so few people". ${ }^{253}$ This same risk loomed large in most Dutch cities, for while the urban population had increased drastically in the seventeenth century, the size of the ruling town councils had remained the same. All over Holland the "disproportion between Rulers and Subjects has become much larger" and consequently "that Rule by a few people (Paucorum Dominatio) will not be tolerated for a long time by the idle and uncomfortable Subjects in case the industry and the welfare decline". ${ }^{254}$

The brothers De la Court thus argued that the closed urban aristocracies of Holland ought to open up their ranks to comply with the changing demography and to preserve the lawful government vis-à-vis an insecure future. This contention involved a fundamental criticism of the political status quo in Holland under the De Witt regime. ${ }^{255}$ The De la Courts contended that the Dutch aristocratic republican government in power was on the brink of lapsing into oligarchy and, sooner or later, into the monarchical domination by a Stadholder, because it did not represent the general citizenry at large. This critical deviation from the dominant ideology of the establishment clashed openly with the views of De Witt himself in the months prior to the publication of the Interest van Holland. In the manuscript version of this treatise, De la Court argued that none of Holland's citizens ought to be excluded from the government by laws: citizens from foreign descent should be granted the right to be elected to

\footnotetext{
${ }^{252}$ Welvaren 71, p. 153: “... dat oijt een Republijk hare Vrije Regeeringh heeft konnen staende houden tegen de gevallen des werelds soo van binnen, als van buijten met soo weinich leden als veertich." This chapter refers explicitly to the examples of Sparta, Genoa and Lucca.

${ }^{253}$ Ibidem 79, p. 170: “... dat de Regeeringh in soo een ongelijke heerschingh van soo weinigh menschen niet bestaen kan, menschelijcker wijse gesproocken.”

${ }^{254}$ Politike Weeg-schaal II.II.6, p. 350: “... zoo is die disproportie, tussen Regeerders, en Onderdaanen veel grooter geworden; en is te verzen dat die (Paucorum Dominatio) Heersching van weinig menschen, by verminderinge van neering, en welvaaren, by leedige en ongemakkelike Onderdaanen, niet zal konnen werden lang gedragen."

${ }^{255}$ For a lucid overview of the oligarchic character of Dutch government and the formal and informal limits to civic participation in politics, see Henk van Nierop, "Popular Participation in Politics in the Dutch Republic," in Peter Blickle, Resistance, Representation, and Community (Oxford: Clarendon Press, 1997), 272-29o.
} 
the urban councils. In a cynical mode, he then added that such a right, though beneficial in theory, would in practice only be "an idle wind", since the "few rulers would always agree on excluding the foreigners in fact, and prefer to leave that privilege to their families instead of to strangers". This sarcastic remark, which clearly alluded to the nepotistic practices of the ruling regent families, was smothered by the censorious interference of De Witt himself, who erased it from the text with a fervent stroke of his aristocratic pen. ${ }^{256}$

In another passage, De la Court voiced his criticism of the powers-inbeing still more openly. Discussing the reasons why the Dutch Republic had not profited much more from its recently gained liberty, he argued that the existing government was, although much better than the rule by a Stadholder, still far from perfect, given that many judiciary offices were exercised for life by members of the elite families. As De la Court cried out: "I do not know what an oligarchy is if it cannot be seen here." He then continued with a strong rebuttal of De Witt's foreign policy, too bellicose in his eyes and only conducive to high taxes instead of commercial diligence. ${ }^{257}$ On reading these lines, De Witt deleted the entire passage and replaced it with two large chapters which, on the basis of a concept written by himself, justified in a densely informed prose the "resolute management by the pious Rulers in Holland" ${ }^{25}{ }^{8}$ Clearly, then, a simplistic classification of the brothers De la Court as mere propagandists of the De Witt regime is untenable. Although the Interest van Holland was deployed as propaganda by De Witt cum suis, the De la Courts directed their criticism not only against the Stadholderate but also against the closed ruling circles that maintained power among themselves through nepotism and patronage. What they did approve in the regime of De Witt was its new republican élan, yet their goal was not as much to support this regime as to transform it into a genuine government of True Liberty.

\section{Democracy \& the Pitfalls of Public Speech}

The arguments that the De la Courts put forward against aristocracy spring from their assessment of the specific economic and political

${ }^{256}$ The passage is published in Veegens, "Johan de Witt," 45: “... een ijdele wind ... soo weinig regeerders altijds wel sullen accordeeren om de vreemdelingen metter daad buiten te sluiten, ende dat voordeel aan hare familien liever als aan vreemden te laten."

${ }^{257}$ Ibidem, $54-56$ : “... soo en weet ik niet wat een oligarchie is, indien men die hier niet ziet."

${ }^{25^{8}}$ Aanwysing III.5, p. 494: “... de cordate directie van de vroome Regeerders in Holland.” The chapters based on De Witt's concept are Interest, 29-30; Aanwysing III.5-6. 
situation in Holland at large and Leiden in particular, where the governing boards of the industrial halls, the university's senate, and the city's ruling council revealed the detriments of a closed oligarchy. The republican examples of the classical past and the Italian present, from Rome to Genoa, provided an interpretative framework to grasp the significance of this Dutch reality. The example of Ancient Athens underlies the brothers' discussion of the second alternative of republican rule: democracy, or to use its more common early-modern phrasing, 'popular government'. According to the De la Courts, the contrast between aristocracy and democracy is best epitomized in a phrase from Tacitus that constantly recurs in their works: Dominatio paucorum regiae libidini propior, populi imperium juxta libertatem est, "while the rule of the few approaches closely to a king's wantonness, a popular government stands near to liberty". 259

For the De la Courts, a true civil society that is established when people leave the state of nature must be such an imperium populi, based on the equality of all adult male contractors. They define this democracy, again in largely Aristotelian terms, as the government

where all people who are by nature not under someone else's custody, like Women and Children, have the power to appear in an assembly, and to issue laws there with the majority of votes, and to appoint the executives of those laws to whom every human has to pay obedience. ${ }^{260}$

Or, more succinctly, a democracy is a "Popular State or Government where every Citizen has his share in the Government, so that these citizens, being assembled, together constitute the sovereign Government". As I have argued in detail in the preceding chapter, the rationale of this popular government follows from the brothers' depiction of the human condition. Democracy is the most natural form of government because "all people, loving their own welfare, also believe to be wise enough to know in what it consists", and therefore they will never be satisfied with someone else

${ }^{259}$ Tacitus, Annals VI.42.2, quoted in this form (the original is vice versa) in Politike Weeg-schaal III.I.4, p. 530. The phrase is also quoted in Boxhorn, Institutiones I.3 Exp., p. 21.

${ }_{260}$ Politike Weeg-schaal I.I.6, p. 35-36: “... daar alle menschen, die van nature wegen onder een anders voogdye niet zijn, als Vrouwen en Kinderen, magt hebben, om in een vergaadering te verschijnen, en aldaar met de meeste stemmen, wetten en Executeurs der zelven te maaken, aan de welken yeder mensch gehoorsaamheit schuldig is, by de Ouden Demokratia genaamt." Cf. Burgersdijk, Idea oeconomicae et politicae II.XXIII.1, p. 120-121: "Democratia est status, in quo civium vel omnium, vel magnae partis nomine, quidam ad tempus caeteris omnibus in universum \& singulis imperant, \& jus majestatis, summamque potestatem exercent." 
deciding on their wellbeing. ${ }^{261}$ At the same time, democratic rule is confined to independent citizens only, and only male householders have the power to speak for themselves and thus fulfil the prime criterion of citizenship.

Does such a popular government maintain the advantages of plurality without suffering under its disadvantages? To answer this question, the Politike Weeg-schaal continues, after the extensive review of aristocratic government, to list all democracy's merits and flaws. This analysis starts with the contention that many of the characteristics of popular rule speak clearly in its favour. To begin with, a popular government is the original form of any polity. Unlike both monarchy and aristocracy, it is "not founded upon any violence, but natural, rational, and in itself fair". In his later revision, De la Court even maintained "that only in Democracy the perfect government can be found". ${ }^{262}$ The list of advantages continues with the contention that the Ciceronian maxim salus populi suprema lex will only be truly materialized in a popular government, for the majority of all citizens will by necessity agree on those issues that advance the wellbeing of the largest part of the community. Moreover, a popular government employs all human potential fully "so that nobody's capability or desire for honour ... is made fruitless". Since democratic magistrates are appointed for their quality and not for their ancestry,

all Citizens who excel in knowledge, virtue and wealth will therefore be all the sooner chosen as Magistrates, without being ... because of that excellence, hated and persecuted, as in Aristocratic, or rather killed, as in Monarchical Governments. Thus everyone here applies his utmost diligence to assemble sciences and goods. ${ }^{263}$

In short, a democracy cultivates and profits from the true self-love that defines human behaviour in a well-ordered civil society.

${ }^{261}$ Politike Weeg-schaal III.I.1, p. 518-519: “... de Populare Staat ofte Regeering, daar yder Burger sijn deel sulks aan de Regeering heeft, dat de zelve, vergadert zijnde, met malkanderen de souveraine Regeering uit maken ... dat alle menschen, haar eigen welvaaren beminnende, ook wjs genoeg meenen te zijn, om te weeten waar in het zelven bestaat."

${ }_{262}$ Ibidem III.I.4, p. 530: “... dat deese Populare Regeering op geen gewelt gefondeert, maar naturelik, redelik, en in zig zelven billik is." De la Court's addition is in the annotated edition in Amsterdam University Library, Ms. XXV C41: “... dat alleen in de Democratie de perfecte regeering kan gevonden werden."

${ }^{263}$ Ibidem, 531-534: “... zulks niemants bequaamheit, of eergierigheit in deze Populare Regeering wert vrugteloos gemaakt ... dat alle Burgers, die in kennisse, deugt, en rijkdom uitsteeken, daar door alleen eer tot Magistraats-persoonen zullen werden gekooren, zonder dat zy ... door die uitsteekentheit hier gehaat en vervolgt, gelijk als in de Aristokratike; of wel gedoot werden, gelijk als in Monarchale Regeeringen. Zulks een yder hier zijn uiterste vlijt aanwend, om weetenschappen en goederen by een te vergaaderen." 
This clear praise of popular government is highly remarkable, since the term democracy was used for centuries in an overtly negative way as the pejorative denominator of the disastrous rule by the multitude. ${ }^{264}$ Indeed, the De la Courts' appropriation of the term deviates significantly from the overtly disparaging remarks on democratic government in the traditional politica. Burgersdijk, for example, described democracy as "by its nature the most imperfect state", while Boxhorn similarly disclaimed the anarchic licentiousness when all share in the government. ${ }^{265}$ In the seventeenth-century Dutch Republic, only a few marginal authors proved to be more sympathetic to the idea of democratic government, and their arguments often involved mere carnavelesque casuistry. A good example of this stance is the curious little book Democratia Corporis Humani, published in 1640 by the Dutch medical doctor Petrus Baardt. Adopting the time-honoured metaphor of the body politic, Baardt argued that all parts of the human body are equally important for our physical well-being, including the 'lower' parts that we conceal and prefer not to speak about. Human beings thus have democratic bodies, Baardt concluded, and the same is true for the body politic: all members of society should participate in decision-making to maintain a healthy political structure. For Baardt, our bodies function like "an unspeakable well-ordered Democracy, in which the common People accords by agreement of votes. Who in the world could ordain a better established Republic than the one thus established by our High and Mighty Creator?"266

With similar wit and imagination but also with much more theoretical sophistication, the De la Courts develop this defence of democracy into an elaborate justification of popular rule, clearly departing from the conventions of the established politica. The importance of this move can hardly be overemphasized: it amounts to the first outspoken theoretical defence of democracy in the seventeenth-century Dutch Republic, and as such it forms an important steppingstone for Spinoza's argumentation on

${ }^{264}$ See John Dunn, Setting the People Free. The Story of Democracy (London: Atlantic, 2005), 55-59.

${ }^{265}$ Burgersdijk, Idea oeconomicae et politicae II.XXIII.11, p. 121: "Democratia est status natura sua imperfectissimus.” Cf. Boxhorn, Institutiones I.V Exp., p. 56; II.X.2, p. 356.

${ }^{266}$ Petrus Baardt, Democratia Corporis Humani; dat is, Leden-Stemminghe des Menschelijcken Lichaems; gevoegt op een Democratike Regieringe sommiger Republijken (Leeuwarden, 1640), adapted from [Adriaan Stikke], Leeden strydt (The Hague, 1630), 14: "Immer hebben niet minder onse Lichamen by sich een on-uyt-spreeckelijcke wel-gestelde Democratia, in de welcke het gemeene Volck over een comende in stemminge accordeert; wie doch ter Wereldt soude beter gestelde Republijck connen ordineren als nae welcke dien so Hoogmogenden Schepper alle dusdanige bestellinge heeft geordineert?" 
democracy in the 1670 . $^{267}$ Yet while the brothers' argument for democracy stands out for breaking new terrain, a strong residue of the age-old criticism remains in their claim that democracies suffer from one fundamental drawback: human ignorance. Whereas an aristocracy enjoys the benefit of well-educated rulers, a "Popular State, being ruled by the majority, is also truly ruled by stupid and ignorant people who have neither eyes nor ears". The most likely results are hasty and labile judgments, incomplete and extremist resolutions, while the "fervent eloquence" of a demagogue can easily convince the ruling assembly with populist sophistry. ${ }^{268}$ The main challenge that confronts popular government is therefore the issue of public deliberation. When everyone has a say, liable and truthful speech can easily be undermined by dangerous rhetoric that blurs the distinction between virtue and vice.

This centrality of the role of speech and the passions in democratic decision-making forms the core of the hesitant and somewhat inconclusive embrace of popular government in the work of the De la Courts. This embrace follows from the assertion that the passions of both true and false self-love "produce nowhere less detrimental fruits than in a Popular Government. Eliminating them completely is impossible and would also be entirely useless, since these passions cause endlessly more good than evil within the world". ${ }^{269}$ This crucial contention, close to the Augustinian acknowledgement of the benefit of the passions, is fully taken to heart in the grand finale of the first edition of the Politike Weeg-schaal - a passage most probably written by Johan de la Court. Having carefully balanced the pros and cons of the three Aristotelian forms of government as an impartial seeker for truth, he eventually deploys all his rhetorical skills to elicit the readers' agreement by mobilizing their passions: first through a number of colourful fables that illustrate the argument, and then by turning directly to the audience with a powerful interrogative anaphora that enhances the inevitability of his conclusion. The passage is worth quoting at length since it clearly reveals how the authorial ethos of rationality merges with a passionate rhetoric that directly addresses the reader with the question:

\footnotetext{
${ }^{267}$ See Israel, "Intellectual Origins," and cf. the Conclusion below.

${ }^{268}$ Politike Weeg-schaal III.I.5, p. 542-544: "Dat een Populare Staat, werdende geregeert van het meestendeel, ook waarelik geregeert werd van domme en onweetende menschen, nog oogen, nog ooren hebbende ... met heftige welspreekentheit."

${ }_{269}$ Ibidem III.II.4, p. 627-628: “... die passien brengen nergens min schadeliker vrugten voort, als in een Populare Regeering: in het geheel die weg te neemen, is onmogelik, en soude ook gansch ondienstig zijn, also gemelde passien oneindelik meer goeds als quaads in de wereld veroorsaken."
} 
Whether it isn't true that in Monarchical Governments the Lord ... ruling on his own (which would be the most detrimental of all Governments), in general wants to rule to the disadvantage of his Subjects, according to the Monarchical maxim: Divide, impera. Pour faire un grand Roy, il faut diviser le peuple? Whether it isn't true that in Aristocratic Governments the Rulers ... always can, will, and shall employ their knowledge and power of Government ... to protect and enhance themselves, also with, and through the ruin and decline of the common Subjects? Whether it isn't true that only in Popular Governments the Rulers (namely, not the Magistrates, Servers of the State; but the People, with whom Sovereignty is there) search (Salus Populi suprema Lex) their own welfare, the one of the common Inhabitants? [note the subtle change from 'subjects' to 'inhabitants'] ... And whether therefore the Monarchical Government should not be esteemed very little? Whether the Aristocratic Government should not be placed far above the Monarchical? Whether the Popular Government is not evidently more advantageous to the Inhabitants and therefore better than the Aristocratic? ${ }^{270}$

Thus finishes the first edition of the Politike Weeg-schaal, with a rhetorical move that, in engaging the audience to decide for itself, underscores the work's eventual conclusion: if guided by the trustworthy speech of the wise merchant, the common people should be considered judicious enough to make their own decisions.

Yet when preparing a new edition of the work after Johan died, Pieter de la Court did not seem to be entirely confident about the form as well as the contents of his bother's conclusion. Is the independent judgment of the general public really to be trusted? De la Court doubted it, as he equally doubted whether his brother's open plea for democracy could persuade the powers-in-being as a feasible alternative for the established oligarchy in Holland. Accordingly, De la Court attached a couple of additional chapters that modify Johan's initial conclusion as well as his democratic rhetoric. In a striking change of tone, De la Court takes the reader

${ }^{270}$ Ibidem III.III.1, p. 639-640: “Of niet in Monarchaale Regeeringen de Heer ... (het welk het schaadeliksten van alle Regeeringen soude weesen) selfs regeerende, gemeenelik regeeren wil, tot nadeel zijner Onderdaanen, volgens de Monarchale maxim? Divide, impera. Pour faire un grand Roy, il faut diviser le peuple ... Of niet in Aristokratike Regeeringen de Regeerders ... altijds alle hare kennisse, en magt der Regeeringe konnen, willen, en sullen gebruiken ... om haar zelven te bewaaren en te vergrooten, ook met, en door den ondergang, envermindering der gemeene Onderdaanen. Of niet alleen, in Populare Regeeringe, de Regeerders (namentlik, niet de Magistraats-persoonen, Dienaars van den Staat; maar het Volk, by wien aldaar de Souverainiteit is) soeken (Salus Populi suprema Lex, ) haar eigen, der gemeene Ingesetenen welvaren? ... En of dienvolgende de Monarchaale Regeeringe niet behoorde te wezen zeer weinig geagt? Of niet de Aristokratike Regeering verre boven de Monarchaale behoorde te werden gesteld? Of niet de Populare Regeering, kennelik, den Ingesetenen voordeeliger, en dienvolgende beeter is als de Aristokratike." 
firmly by the hand, adding a paternalist assertio to the text's original reliance on the reader's own judgment. First, De la Court explains the "Reasons why the Popular Government has been depicted so favourably until now, although it is truly not the best one". Then he continues to insist that, although a popular assembly is obviously better than an oligarchy, it does suffer heavily from the ignorance of its members. Therefore, as he concludes resolutely, "an Aristocracy that is closest to the Popular Government is surely the best Government". ${ }^{271}$

At first sight, this modification of the argument seems to entail a blatant contradiction of the initial embrace of democracy. Indeed, Kossmann maintained that in revising the Politike Weeg-schaal, De la Court unjustifiably and wilfully killed his brother's democratic darlings. ${ }^{272}$ However, as both Haitsma Mulier and Blom have argued, such a portrayal of the development of the brothers' thought is not very convincing. In Blom's words, the "change is one of emphasis more than of principle":273 De la Court's additions mainly tried to resolve a tension that characterizes his brother's use of the term popular government from the start. The first edition of the Politike Weeg-schaal overtly embraced democracy as the best form of government, but it also stressed that "one should make a very large distinction between an illegitimate rebellious assembly of the people ... and a lawful assembly of the common Citizenry". This distinction is clarified by a Latin saying, "inter populum \& multitudinem differentia permagna est", which reveals that a popular government (i.e. a government by the citizenry, the populus) should not be equated with a government of the unruly rabble, the multitudo. ${ }^{274}$ Hence, for both brothers De la Court a popular government does not entail a government by all, but rather a government consisting of the select group of men who qualify as citizens. This definition is largely in line with the conventional seventeenth-century denotation of popular rule. Althusius, for example, argued that a democraticus status requires a ratio gubernandi aristocratica, a

${ }^{271}$ Ibidem III.III.3-5, p. 652, 661: "Reedenen waarom de Populare Regeering voor desen zo gunstig is voorgestelt geweest; hoewel die warelik de beste niet zy ... Dat een Aristokratie, die allernaast aan de Populare komt, gewisselik de beste Regeering is."

${ }^{272}$ Kossmann, Political Thought, 70 , note 3.

${ }^{273}$ Blom, Morality and Causality, 179, note 39. See also Haitsma Mulier, Myth of Venice, 141-142, 145 .

${ }^{274}$ Politike Weeg-schaal III.I.6, p. 561-562: “... (inter populum \& multitudinem differentia permagna est) dat men zeer groot onderscheid maaken moet tusschen een onwettige oproerige vergaderinge, des volks ... en tusschen een wettige vergaaderinge der gemeene Burgerschap." Cf. also Aanwysing I.2, p. 19: “... eene multitudo, meenigte buiten civili societeit en regeering leevende." 
government of optimi. ${ }^{275}$ Similarly, across the North Sea, a 'popular' republican like Nedham equally stressed that "when we mention the People, observe all along, that we do not mean the confused promiscuous Body of the People". ${ }^{276}$

Accordingly, De la Court's additions to his brother's initial conclusion did not involve a radical shift, but rather a clarification of the argument. The reason for this clarification stems in particular from his continuous rethinking of the importance of speech in politics - a process that is reflected in the change in rhetoric, from Johan's initial interrogatio to Pieter's eventual assertio. When revising the work, De la Court increasingly stressed that the members of a truly popular assembly will be easily carried along "by eloquent Orations". ${ }^{277} \mathrm{~A}$ republican government should therefore be established thus "that no Citizen is ever allowed to practice his eloquence by debating anything before the people". ${ }^{278}$ This rising concern about the possible abuse of public speech echoes a similar argument in Harrington, who equally warned that "any commonwealth where the people in their political capacity is talkative" will be "carried away by vainglorious men". ${ }^{279}$ De la Court's concern also resulted in the same claim as in Harrington's Oceana that all voting should be secret and based on a system of blind balloting as in Venice, so that rhetorical manipulation and intimidation are impossible and "the common interest of the Republic will always be promoted" ${ }^{280}$ Eventually, De la Court's unease with the role of eloquence led him to a tentative plea for a bicameral solution, again like in Harrington, with a senate that debates and proposes its advice to a general assembly. This assembly has no debating powers but only the ultimate right of decision, "because the people are then not being misled by any eloquence of any eminent Citizen who tries to embellish his own particular advantage as if it were a common one". ${ }^{281}$ Yet this gradual move

${ }^{275}$ Althusius, Politica XXXIX, quoted in Conti, "Modelli repubblicani," 63.

${ }^{276}$ Nedham, Excellencie, 71.

${ }^{277}$ Politike Weeg-schaal III.III.3, p. 656: “... welspreekende Oratien.”

${ }_{278}$ Amsterdam University Library, Ms XXV C41, addition to Politike Weeg-schaal III.I.6, p. 573: “... dat geenen Borgere ooit geoorlofd zy syne welspreekendheid te oeffenen nmet iets voor den voke te debatteren."

${ }^{279}$ Harrington, Oceana, 149.

${ }^{280}$ Ibidem II.IV.12, p. 421: “... dat in de zelven het gemeen interest der Republike altijds zal werden betracht." See also Politike Discoursen I.I.1, II.V.2, II.V.7. Cf. Harrington, Oceana, 114-118, and see Haitsma Mulier, Myth of Venice, 152-153.

${ }^{281}$ Amsterdam University Library, Ms XXV C41, addition to Politike Weeg-schaal III.I.6, p. 566: “... also 't volk alsdan door geen welspreekendheid van eenig aansienelik Borger, die syn eigen particulier voordeel als of het een gemeen waar tragt op te pronken, milseid werdende." 
towards a constitutional arrangement that avoids the pitfalls of public speech remained inconclusive. Unlike Harrington, who extensively discussed the intricacies of the voting procedures in his model of Oceana, ${ }^{282}$ the brothers De la Court did not enter into detail about the practical realization of their ideal republican government.

\section{A Government of Merchants, by Merchants, for Merchants}

The De la Courts' vision of the ideal republican assembly does not so much follow from a well-defined constitutional design as from their general argument that commerce must prosper in liberty. Their main goal is to make clear that the government should be in the hands of and for the sake of those who further the interest of trade. At the basis of this correlation between politics and commerce lies the idea that the concerns of trade correspond to the concerns of the commonwealth as such. De la Court explicitly compares civil society to the establishment of a commercial company, for both are founded on "this Fairness, that to every one of the Participants ... belongs his share in the future Profits and Losses ... and that there is such an equality among the Participants that none of them can disregard this Fairness and these conditions". De la Court then continues to assert that were these criteria of fairness also to be met in politics, "there would not be seen so many unequal Societies of common Inhabitants with Great Lords, of Merchants, Citizens and Farmers with Kings, Monarchs, Noblemen, and Soldiers" ${ }^{283}$ In other words, the organisational principles of a well-ordered commercial company, based on equality, reveal how to overcome a disproportionate distribution of power in the political realm. ${ }^{284}$

${ }^{282}$ See Harrington, Oceana, esp. 78-80. On Harrington's exceptional attention to constitutional arrangements, see Scott, Commonwealth Principles, 141-143; and Idem, "Classical Republicanism," 64-65.

${ }_{283}$ Sinryke Fabulen, 78-79: "Soo maaken sy alsdan Maatschappien, ende bouwen die in het aangaan der selven altijds op deese Billikheid, dat yder der Maats ... ook sijn aandeel der toekoomende Winsten ende Schaaden behoorde ... ende onder de Maats soodaanige gelijkheid zy, dat geen der selven deese Billikheid ende Voorwaarden mooge veragten ende straffeloos breeken ... Het welk, indien wel behertigd werd, soo soude men niet sien soo veele ongelijke Maatschappien, van gemeene Ingeseetenen met Groote Heeren, van Koopluiden, Borgers ende Boeren, met Koningen, Vorsten, eedelen, ende Krijgs-luiden."

${ }^{284} \mathrm{Cf}$. the elaborate statute drafted by De la Court for the establishment of a mercantile company as an alternative to the VOC in Overvoorde (ed.), "De Noord-Oostelijke doorvaart," $305^{-311}$. The statute, which consists of fifty organisational principles, particularly emphasises the equality between the members of the company, the principle of majority rule, rotation of office and the various ways to counter a conflict of interests. 
This parallel between commercial equality and republican politics ultimately implies that a republic of trade where wise merchants govern preserves the fundamental harmony of private and public interests. For the brothers De la Court, the capricious nature of trade makes excessive wealth unattainable and thus guarantees a fairly equal distribution of power and property. In a commercial commonwealth like Holland, individual riches are based on "Movable goods", which means that possessions are so insecure that "in no other country on the whole surface of the Earth there have been as many cases of being Rich and becoming Poor". ${ }^{285}$ The political consequences of this uncertainty are highly positive. Since it is impossible to attain excessive wealth, "there will be no room" in a commercial commonwealth for "everything that makes a Monarch jealous". Moreover, the contingency of commercial property implies that the "citizens of the popular Government, noticing that they only become distinguished in government by their reason, virtue, and Wealth" will educate their children "in all knowledge, sciences, and virtues". ${ }^{286}$ Thus commerce has an effect comparable to the agrarian law proposed by Harrington: it establishes a balance of dominion and enhances continuous competition on the basis of merit instead of covetousness. ${ }^{287} \mathrm{~A}$ large assembly of merchants will therefore not succumb to monarchical greed, but instead enable all people "to search for their advantage in satisfactory freedom, and while they surely own what they have, everyone is diligent to gain still more". The overall result is the increase of commerce and industry and the growth of the population, the true sources of grandezza of a republic of trade. ${ }^{288}$

Accordingly, the governing assembly of a commercial commonwealth should consist of all citizens who can be expected to enhance this general interest of trade - those, that is, who would go against their own interests if they would impose exorbitant taxes or wage costly wars. The larger this assembly is, the better, "for if there are many in the Government and

${ }^{285}$ Sinryke Fabulen, 462: “... in Losse goederen ... Soo heeft men ook in geenen Lande des geheelen Aardboodems soo veele ge- ende vervallen van Rijk te zijn, ende Arm te werden."

${ }^{286}$ Politike Discoursen II.V.9, p. 136-137: “... alle het geene aan een Monarch jaloesie geeft, heeft in haar geen plaats ... Maar dese Burgers der populaire Regeeringe, siende dat sy door haar verstand deugd, en Rijkdom, alleenlik aansienelik in Regeering werden ... voedense in alle kennisse wetenschappen ende deugden op."

${ }^{287}$ Harrington, Oceana, 100-114. Cf. Haitsma Mulier, Myth of Venice, 164-165.

${ }^{288}$ Politike Discoursen II.V.9, p. 138: “... soo mogen sy in genoegsame vryheid haar voordeel soeken: en dewijl sy seekerlik besitten, 't gene sy hebben, soo is een yder vlytig, om nog meer te winnen." 
everyone follows his interest, the Community enjoys the advantage of all those interests, whereas otherwise they only enjoy the interest of the Monarch" ${ }^{289}$ Yet there is a clear limit to the size of the assembly. As the De la Courts maintain, the private interests of the lower social strata and of guild masters in particular do not represent the general interest of society. Government must therefore be in the hands of "many of the eminent Citizens", ${ }^{290}$ the independent male householders who know how to relate their private advantage wisely to the common good. Speaking freely for those who depend on them, these wise merchants will enhance by majority of votes the welfare of all, for

the legislative Power is shared by so many and so diverse Men, who, representing or substituting the entire People not only with words but truly in fact, can only practise their own Welfare by promoting at the same time the Welfare of the entire People. ${ }^{291}$

Thus the harmony between private and public interests is preserved if the entire population is represented by a broad assembly. Such an assembly, as De la Court once more emphasized in the Sinryke Fabulen, is "truly the very best form of Government" the more it approaches democracy and the more it deviates from monarchy. ${ }^{292}$

The De la Courts' plea for a merchant democracy - a government of merhants, by merchants, for merchants - involved a significant move towards opening up the Dutch oligarchy in power. Clearly alluding to the situation in Leiden and Holland at large, the De la Courts asserted that their model implied that the "number of sovereign Councillors ought in a moderate City be no less than two hundred" - at least five times the number of Leiden's existing council. ${ }^{293}$ This criticism of the Dutch status quo, with its emphasis on popular sovereignty and gradual opening towards democracy, inaugurated a 'popular turn' in Dutch republicanism during the 1660 s and 1670 , developed further in the work of Van den Enden and

${ }^{289}$ Ibidem, 139: "Want dewijl er veelen in Regeering zijn, en ene yder sijn interest vervolgd, geniet de Gemeente het voordeel van alle die interesten, daar Sy andersins maar het genot van het interest des Monarchs geniet."

${ }^{290}$ Ibidem: “... veele der voorneeme Borgers."

${ }^{291}$ Sinryke Fabulen, 320: “...de wet-geevende Magt is by soo veele ende soo veelerlei slag van Menschen, dat die niet alleen met woorden, maar waarelik ende in der daad, het geheele Volk representeerende ofte vervangende, niet konnen haar eigen Welvaaren betragten, dan meteenen het Welvaaren des geheelen Volks te besorgen."

${ }^{292}$ Ibidem, 75: "Sulks dit waarelik de allerbeste forme der Regeeringe is."

${ }^{293}$ Ibidem I.I.1, p. 17: "Dit getal der souveraine Raads-Heeren behoord daarom in een matelike Stad, niet min als twee honderd te zijn." 
Spinoza (see the conclusion below). Arguably, the De la Courts thus stood at the roots of an important tradition in Western political thought which continued throughout the Enlightenment.

Yet we should be warned not to equate the brothers' argument for a broad ruling assembly with the late eighteenth-century arguments for a representative democracy. The brothers De la Court still remained firmly within the Athenian paradigm of the city-state where the independent citizenry engages in direct decision-making. Their plea for a large ruling assembly did not depart radically from Aristotle's claim that the ideal politeia entails a perfect fusion of oligarchy and democracy, nor from Boxhorn's claim that Holland should be ruled by an open and broad aristocracy of the rich. ${ }^{294}$ To a large extent, the De la Courts followed this line of reasoning, tentatively moving in a more democratic direction. Their originality lies mainly in the outspokennes with which they tried to free the term 'democracy' from its long-standing negative connotations. With the De la Courts, democracy started its slow but spectacular rise that changed it from a derogatory description of anarchy into the universal denominator of legitimate rule. Yet the brothers' description of what a popular government exactly entails was not particularly innovative. After all, the most fundamental and pioneering aspect of their criticism of the Dutch status quo was their categorical rejection of the Stadholderate, which amounted to perhaps the most radical argument against monarchy in Ancien Régime Europe.

\section{Conclusion: The RAdical Republic}

The republican thought of the brothers De la Court merges the idea that freedom of trade is the essence of commercial reason of state with a comprehensive criticism of monarchy in all its guises. Following the claim that all people are self-interested, good government must be based on a harmony between the private interest of those who rule and the public interest of society at large. Since monarchs are by necessity the enemies of commerce, such a harmony can only be preserved if the sovereignty remains in theory and in practice with a large assembly of eminent citizens, who represent all the individual interests in society without giving in to any individual domination. Only in such a broad aristocratic

${ }^{294}$ Boxhorn, Institutiones II.5, p. 329-330. Cf. Aristotle, Politics IV.8 (1293b-1294a), and see the extensive analysis in Nieuwstraten, "Why the Wealthy Should Rule." 
republic commerce will thrive in liberty and thus increase the greatness of the commonwealth. Hence, the interest of trade lies at the basis of the two fundamental features of the De la Courts' republic: its radical antimonarchism and its gradual opening to democracy.

The significance of the way in which the brothers De la Court connect an argument for commerce with an argument against monarchy is especially apparent in comparison with their contemporary republicans across the North Sea. As shown above, the English republican experiment of the 165 os did not play an important role in the thought of the De la Courts. There is no evidence that they were familiar with English republican treatises apart from, most likely, Milton's Defensio and, in a later stage, Harrington's Oceana. Yet both Milton and Harrington had a strikingly different appreciation of commerce than the Dela Courts. Milton emphasized emphatically that trade could never be a reason "to prostitute religion and libertie"; ${ }^{295}$ Harrington claimed that although "in manufactures and merchandise the Hollander has gotten the start of us", the English Commonwealth had "a far more sure and effectual foundation" because it was based on agriculture. ${ }^{296}$ Other English republican theorists from the 1650 s and 166os, most notably Marchamont Nedham and Algernon Sidney, were much closer in their argumentation to the brothers De la Court. Nedham's 1656 "Commonwealth-Principles" show many similarities to the thought of the De la Courts - from the claim that republican magistrates will "have made the Publick Interest, and their own, all one", to a rhetorical plea for a broad aristocratic government close to Athenian democracy. ${ }^{297}$ In the following decade, Sidney's Court Maxims continued to stress the republican harmony of private and public interests in similar terms, now with explicit attention to the importance of trade. As Jonathan Scott has shown in detail, Sidney's adaptation of this language of commercial interest was deeply informed by his exile in the Dutch Republic at the start of the $1660{ }^{298}$ Sidney frequently praised the republican example of the Dutch, emphasizing that it is "the king's interest to destroy trade"

295 Milton, Readie and Easie Way, 443.

${ }^{296}$ Harrington, Oceana, 198.

297 Nedham, Excellencie, 82, 191-192.

${ }^{298}$ Jonathan Scott, Algernon Sidney and the English Republic, 1623-1677 (Cambridge: Cambridge University Press, 1988), 210-221. See also the comparison between De la Court and Sidney in Charles-Édouard Levillain, "L'Angleterre de la Restauration au miroir de la 'vraie liberté' (1660-1672). La rencontre entre republicanismes anglais et hollandais à travers les écrits de Pieter de la Court," E-rea 1.2 (2003), from http://erea.revues.org/index205. html [retrieved May 13, 2011]. 
while Holland's prosperity and power were due to its "good government and liberty of traffic" - two crucial claims that also dominate the work of the brothers De la Court. ${ }^{299}$

There was therefore a significant congruence between the republican thought on either side of the North Sea, where the languages of liberty, interest and trade merged into a comparable republican interpretation of the gradual commercialization of society. Scott has argued compellingly that this common Anglo-Dutch republican project "emerged from a connected practical, as well as intellectual context", from a shared late humanist culture and related political and economic developments. For Scott, the resulting anti-monarchism in England and the Dutch Republic "was almost identical", but what separated Dutch and English republicans was their different assessment of the role of reason and the passions: while "Dutch republicanism focused on the constitutional management of the passions, for public prosperity and peace, English republicanism entailed a warlike championship of reason". ${ }^{300}$

Yet Scott's lucid comparison covers only a part of the story, because in spite of the similarities, the anti-monarchism of the De la Courts entails a decisively more radical, or 'exclusivist', twist than its contemporary English counterpart..$^{301}$ First of all, it is important to stress that the domestic backgrounds of Dutch and English republican thought, though related, differed significantly. The Dutch political debate between Orangists and anti-Orangists was not, as in England, a debate between monarchists and supporters of the commonwealth, but it was rather a contest between two different visions of republican liberty. The anti-monarchism of the brothers De la Court did not emerge in response to royalist claims, as for example Nedham's, but instead to counter the equally republican argument that the Stadholder fulfilled the balance in the Dutch body politic. As a result, the De la Courts claimed on the basis of their analysis of commercial reason of state that all sorts of single rule, even within a republican constitution, entail the establishment of tyranny and servitude. This is why they insisted that there was no fundamental difference between the Dutch Republic under a Stadholder or Captain-General and the Ottoman

\footnotetext{
299 Sidney, Court Maxims, 73, 161.

${ }^{300}$ Scott, "Classical Republicanism," 62, 69, 71. For the impact of the Dutch republican example in England, see esp. Idem, Commonwealth Principles, 353-357.

${ }^{301}$ On exclusivist republicanism in the Renaissance, see Hankins, "Exclusivist Republicanism." See also Nelson, Hebrew Republic, 23-56, which slightly overstates the anti-monarchism of English republicans like Milton.
} 
Empire under the Sultan, for even the looming threat of the desire to dominate brings about the demise of republican and commercial liberty.

This categorical rejection of any form of personal authority goes far beyond the republican claims of the De la Courts' English contemporaries. Milton took care not to equate monarchy with tyranny, stressing that "both the name and the power of a king are entirely consistent with a greater power in the people and the law". ${ }^{302}$ In comparable vein, Harrington emphasized the pre-eminent role of a "Lord Archon" as "the sole legislator of Oceana". Directly contradicting the anti-Orangism of the De la Courts, he argued that "the Low Countries under a monarch were poor and inconsiderable, but in bearing a prince, could grow unto a miraculous height" ${ }^{303}$ Even Nedham, who was arguably the fiercest (and most opportunistic) anti-monarchical activist in England, justified a form of elective monarchy. In his words, "if any Kingly Form be tolerable, it must be that which is by Election, chosen by the Peoples Representatives" - a government that the De la Courts would have characterized as merely tyranny in disguise.$^{304}$ Finally, also Sidney stressed that he "dare[d] not say all monarchy is absolutely unlawful", since legal kingship is just and virtuous, as opposed to the outright "despotical government that is exercised over slaves". ${ }^{305}$ In short, all the main English republicans of the 1650 s and 1660 s targeted a corrupted monarchy, not monarchy as such. The categorical anti-monarchism of the brothers De la Court, which remained remarkably consistent from 1660 to 1685 , thus proves exceptionally far-reaching and exclusivist in comparison with their contemporaries across the North Sea.

Following their critical analysis of the economic policies of Leiden, the brothers De la Court constructed a commercial theory of reason of state that, modelled on Ancient Athens, pursues a republican empire of trade. The highest law of that empire is a comprehensive notion of liberty, which merges freedom from interference with freedom from arbitrary domination as the main characteristic of a true republic. Such liberty can only be maintained within a governmental framework where the rulers enhance the common good of society by searching for their private advantage. This harmony of interests is by definition unattainable in a state where one single man rules: monarchy in all its guises, including the Dutch

\footnotetext{
${ }^{302}$ Milton, Defence, 233.

${ }^{303}$ Harrington, Oceana, 67, 257.

304 Nedham, Excellencie, 69, 170.

305 Sidney, Court Maxims, 193, 199.
} 
Stadholderate, necessarily amounts to tyranny. In contrast, a true republic entails a government of many, a government for trade that represents all individual interests in society, impervious to the tyranny of one as to the anarchy of all. How then is it possible to preserve such a harmonious model of republican rule in an open society characterized by pluralism and latent conflict? This question is addressed in the next and final chapter, which turns to the central notions of social concord and religious toleration in the political thought of the brothers De la Court. 


\section{CHAPTER FIVE}

\section{CONCORD AND TOLERATION}

In the hot summer of 1672 , when the Dutch Republic fell prey to a climactic combination of foreign assault and internal uproar, Pieter de la Court prepared for escape. The regime of 'True Liberty' had fallen apart, the enemy's armies stood at the borders of Holland - only halted thanks to an improvised realization of De la Court's plan to protect the province with a large trench - and De la Court himself packed his most valuable belongings: jewellery, silver service, pocket-sized Latin books, and a copy of the New Testament with golden clasps, a pious indication of the wise merchant's wealth. ${ }^{.}$Shortly thereafter, De la Court fled to Antwerp, where he would remain for more than a year, killing his time playing trick-track, that favourite pastime of republican exiles, with other refugees like Pieter de Groot. ${ }^{2}$ When De la Court eventually returned home at the end of 1673 , he wisely, if also rather bitterly, decided not to interfere in the political debate again. ${ }^{3}$ Another pastime called for his attention: his garden at his country estate Meerburg, on the banks of a branch of the Rhine near Leiden. Legend has it that Meerburg was the site where the first European pineapple was cultivated; be that as it may, De la Court's son, who never proved to be endowed with his father's sharp political pen, inherited at least some of his enthusiasm, and decades later he would publish a lavishly illustrated treatise on the art of horticulture. ${ }^{4}$

\footnotetext{
${ }^{1}$ See the inventory from 25 June 1672 , published as appendix IIIa in Kernkamp (ed.), "Brieven (1667-1685)," 137-140.

${ }^{2}$ See the letter of Pieter de Groot to Abraham de Wicquefort, 4 July 1673 , in Lettres à Abraham de Wicquefort (1668-1674), ed. F.J.L. Krämer (The Hague, 1894), 134. Cf. Machiavelli's famous letter to Francesco Vettori, 10 December 1513, in Lettere a Francesco Vettori e a Francesco Guicciardini (1513-1537), ed. Giorgio Inglese (Milan: Rizzoli, 2002), $192-196$.

3 Cf. the cynical comments in Sinryke Fabulen, 16, where De la Court covertly apologizes for his escape to Antwerp and blames his compatriots for not having listened to his warnings.

4 [Pieter de la Court van der Voort], Byzondere aanmerkingen over het aenleggen van pragtige en gemeene landhuizen, lusthoven, plantagien en aenklevende cieraden (Leiden, 1737). On the mixed fate of the De la Court family in the eighteenth century, see Maarten Prak, Gezeten burgers. De elite in een Hollandse stad, Leiden 1700-1780 (Amsterdam etc.: De Bataafsche Leeuw, 1985).
} 
Yet for De la Court, the days at Meerburg must have had a more profound significance. As Lipsius proclaimed almost a century before, a "delight in Gardens is Commendable; a Pleasure, to which ... the Best, and most Ingenuous Men are inclin'd by Nature". Writing at the height of the religious warfare that shattered his native Netherlands in the late sixteenth century, Lipsius presented the private world of the secluded garden as a heaven of constancy, a peaceful retreat where one could hide from the turmoil of the public realm and the violent passions of one's soul. "May my time ever pass away amongst your Shades!" Lipsius addressed his stoic garden. "May it be lawful for me, being deliver'd from the Wild, endless Tumults of the People, with a free, satisfy'd Eye, to wander among these Flowers, of the knowne, and unknown World!"5 De la Court, in the wake of his own turbulent experiences, must have found a similarly serene shelter at Meerburg, far away from the concerns of daily life and the turmoil of politics. But such a stoical retreat still involved a clear political stance: as a place for conversation and debate and as a symbol of both order and variety, Lipsius's garden embodied a blooming civil society where the roots of dissension and upheaval are rigorously curtailed to cultivate the fruits of harmonious diversity.

This image of a stoic garden of concord and constancy represents the De la Courts' account of how to establish stability and peace in a society characterised by religious conflict and political unrest. As I will argue in this fifth and final chapter, the brothers De la Court experienced an 'Erasmian moment' which involved a strong rejection of revolutionary change, a parallel attack at clerical interference in politics, and a commercially inspired commitment to religious freedom. Adopting the Grotian claim that the civil sovereign holds supreme authority over all ecclesiastical affairs, the De la Courts pleaded for a broad public church overseen by the magistracy, which tolerates confessional dissent in private. This ideology of toleration, in particular for the sake of commercial prosperity, was fairly far-reaching since it also included Catholics. Yet the brothers' tolerationist stance remained limited by their embrace of a single true faith, based on the purity of Scripture. The inviolability of Scripture also

\footnotetext{
${ }^{5}$ Justus Lipsius, A Discourse of Constancy (London, 1654), 75-77. For a detailed analysis, see Mark Morford, "The Stoic Garden," Journal of Garden History 7, 2 (1987), 151-175. Pieter de la Court van der Voort owned a copy of the Leiden 1589 edition of De constantia, as well as Lipsius's Politica (Leiden, 1634) and Opera Omnia (Antwerp, 1637): Library, fols. 15, 20, 31.
} 
delimited the De la Courts' conception of free speech, which involved a dedicated yet altogether futile attempt to create consensus through outspokenness.

\section{THe ERASMIAN MOMENT}

\section{Curtailing the Roots of Discord}

Since the days of Erasmus, political thought in the Netherlands was dominated by the language of concord. As the official motto of the Dutch Republic, taken from Sallust, self-assuredly declared: concordia res parvae crescunt, discordia maximae dilabuntur, 'in concord small affairs rise; in discord even the largest decline'. ${ }^{6}$ The brothers De la Court clearly adhered to this Erasmian legacy that emphasized the values of consensus, resignation, and constancy over conflict, defiance, and agitation. They emphatically stressed the civic duty of acquiescing to one's political fate and forcefully rejected any attempt to rebel against the powers in being. This sceptical argument against revolutionary change was especially directed against those who, according to the De la Courts, threatened the delicate balance in the Dutch body politic: the supporters of the Stadholderate, organized economic factions such as guilds, and the orthodox clergy. Only if the rebellious designs of these pressure groups were utterly eradicated, concord in society would be maintained so that the republic could endure the whims of fortune.

The spectre of civil disorder that haunted seventeenth-century Europe clearly lies at the basis of the insistence with which the De la Courts argued against open rebellion. In the 1650 s and 1660 s, the memories of the Dutch Revolt were still fresh, while the more recent episodes of civil war and revolt in France and England served as an equally distressing reminder of the dangers of political and religious upheaval. Reflecting on these experiences, the Politike Weeg-schaal ends with a sceptical conclusion that reproves all desire for open rebellion: "For, rebelling against the Government in being (de facto), one immediately establishes the state of nature or War of all Inhabitants against all."7

\footnotetext{
${ }^{6}$ See the comprehensive overview of this language of concord in Van Gelderen, "The Low Countries."

${ }^{7}$ Politike Weeg-schaal III.III.6, p. 666: "Want men, rebelleerende teegen de Regeeringe die in wesen is, (de facto) dadelik invoert de natureliken stand ofte Oorlog aller Ingezeetenen tegens malkander."
} 
This Hobbesian defence of de facto political power might come as a surprise given the inflammatory anti-Orangist rhetoric of the brothers' work. Yet as I have argued above in chapter 3, the De la Courts appropriated Hobbes to legitimize the establishment of the regime of 'True Liberty' after the death of William II. They employed the language of de facto rule and the state of nature to strengthen a fairly conventional argument against illegitimate rebellion. This argument was an essential element of the legacy of Lipsius and his followers. For example, in his 1590 treatise Vita politica, the famous engineer and mathematician Simon Stevin highlighted in a Lipsian vein the disasters that would be brought about by civil disobedience. ${ }^{8}$ The brothers De la Court, who read Stevin, radicalized this argument to justify the new political order of the Stadholderless era. While Stevin argued in line with the conventional justification of the Revolt against Philip II that "honest violence" should be allowed to overcome tyranny, ${ }^{9}$ the De la Courts suggested that in principle every de facto government is to be obeyed.

On the one hand, this stance is an important element of the brothers' establishment of authorial ethos: in order to please and pacify their readers among the regent establishment, the De la Courts insist that they do not intend to overthrow the powers in being but rather instruct their fellow citizens to abide by the status quo. As Het welvaren van Leiden, dedicated to the Leiden patrician Eleman, insists, "I will always curse a subject who tries to bring about change in the Government". Similarly, the Aanwysing concludes with a resounding quote from Erasmus that a good patriot should always defend the existing order. ${ }^{10}$ Yet on the other hand, apart from such rhetorical reassurance, the De la Courts' abhorrence of revolt also involves a more fundamental move in its repudiation of resistance theory and Monarchomach thought. Unlike the resistance republicanism of their English contemporaries such as Milton (and later Locke), the De la Courts have a very sceptical outlook on the utility of

${ }^{8}$ Stevin, Burgherlick leven, esp. 41-47. Stevin is quoted in Sinryke Fabulen, 453.

${ }^{9}$ Ibidem, 126: "Eerlicke ghewelt."

${ }^{10}$ Welvaren 79, p. 170: "... altijds sal ick vervloecken een onderdaen, die veranderinge in der Regeeringe traght te brengen." Aanwysing III.8, p. 523: "Boni Civis est liberum Reipublicae Statum tueri, nec eum mutatum velle." The quote is from the preface to Erasmus's edition of Suetonius in the Historiae Augustae scriptores, published in Erasmus, Opus epistolarum, ed. P.S. Allen et al., 12 vols. (Oxford: Clarendon Press, 1906-1958), vol. II: nr. 586, p. 585. This Erasmian maxim was one of the main slogans of the advocates of 'True Liberty': see e.g. "Een korte verhandelinge van de nootsakelijckheydt ofte den ondienst van een stadthouder in Hollandt ende West-Vrieslant, en dat in dese tijden," in Uytenhage, De Stadhouderlijcke Regeeringe in Hollandt ende West-Vrieslant (Amsterdam, 1662). 
sweeping political change. This attitude is in particular informed by the politique scepticism of Montaigne and exemplified by the verses of the Lord of Pibrac, which are quoted twice in the brothers' work:

Aime l'Estat tel que tu le vois estre,

S'il est Royal, aime la Royauté.

S'il est de Peu, ou bien Communauté,

Aime l'aussi, car Dieu t'y a fait naistre."

These verses, clearly more than just figurative embellishment, reveal above all a deep-rooted conviction that the stability of the commonwealth is always preferable to the incertitude of sudden regime change.

The brothers De la Court employ this argument in their general strategy against the Orangist claim that the Dutch body politic requires an eminent head to maintain its concord and strength. The obvious message of the brothers is that the Dutch have to accept the existing republican government, whether legitimate or not, and that any attempt to reinstall the Stadholderate would imply an unacceptable alteration of the status quo. They repeatedly insist that violent upheaval is inevitable if a republic does not subdue the political pretensions of individuals. Their rebellious aspirations will be easiest in "a badly established Republic" where unequal governmental representation can cause "that one man who commands over the Military for a long time gets enough power and esteem to violate everything". ${ }^{12}$ In short, the Stadholder does not represent the stronghold of the political order, but rather the personification of menacing anarchy: the "Trojan Horse" that will destroy the commonwealth from within. ${ }^{13}$ The endemic civil unrest in all Italian republics with a powerful military leader serves as a proof of this claim, for their history reveals that the monarchical maxim divide \& impera prevails if a single man obtains too much power. In contrast, the example of the German Imperial Cities and the Swiss Cantons shows that republics without such a leader never fall apart through civil war. As before, the De la Courts thus legitimize the situation in the Dutch Republic by referring to time-honoured republican models abroad: in the absence of a Stadholder the Dutch are not less but

${ }^{11}$ Politike Weeg-schaal III.III.6, p. 669, also quoted in Welvaren 79, p. 171. For the original, see Montaigne, Essays III.9, p. 1002. The library of De la Court van der Voort had a sumptuous folio edition of the Essays (Paris, 1635): Library, fol. 17.

${ }_{12}$ Politike Discoursen I.II.27, p. 172: "Maar veel ligter is een oproer in een quaalik gestelde Republijk uit te voeren, daar men de Leeden soo ongelijk laat groejen, dat een die lang over 't Krijgs-volk gebied, magt, en agtbaarheid genoeg krijgd, om alles te verkragten." Cf. the comparable passage in Ibidem II.V.8, p. 128-130.

${ }^{13}$ Aanwysing II.12, p. 333: “... het Trojaanse Paard op het binnen-Hof." 
more likely to maintain political stability. De la Court develops this argument, in line with Boxhorn, to contradict the assertion of Cardinal Bentivoglio that the United Provinces would because of their mutual discord soon turn into an Orangist monarchy. Directly addressing Bentivoglio's claim, De la Court insists that under its newly won liberty without a Stadholder, Holland will easily neutralize internal uproar. ${ }^{14}$

Such stability is further enhanced because "a Republic where many govern in equal dignity cannot be curtly ruined and brought into disorder". ${ }^{15}$ To overcome possible revolt, the powers in being have to open up gradually towards a more representative government where no individual enjoys disproportionate powers, so that the motivation and opportunity to rebel are eradicated. With this rhetorical move, the De la Courts craftily turn a conservative argument against sweeping change into a progressive argument in favour of cautious gradual democratization, in praise of those regents who "know how to bring Republics in a calm mood and without bloodshed into a better order and form of Government". ${ }^{16}$ As I have argued in detail in the preceding chapter, this superior political order entails the establishment of a broad ruling assembly and a policy of inclusive citizenship and economic freedom in order to attract foreigners and to challenge organized vested interests. Clearly alluding to the situation in Leiden, the De la Courts maintain that "in large cities filled with foreigners and stripped from Halls and Guilds, one has surely never seen arise any tumults than those that were ignited and fed by any prominent Minster of State or prominent Head". ${ }^{17}$ An open and free society offsets the rebellious designs of economic pressure groups such as guilds, which, like the Stadholder, do not enhance but rather undermine the concord and strength of the commonwealth. This friction is vividly represented in a fable of various guildsmen who gather to fill a crack in the walls of their city (see fig. 12). In order to fill the gap, the guild of masons suggests using stone, the carpenters argue that it should be nailed up with planks, the glassblowers opt for windows while the blacksmiths insist they should be

${ }^{14}$ Ibidem, 332, 342. Cf. Bentivoglio, Relatione, 128-129.

15 Politike Discoursen I.II.27, p. 172: “... dat een Republijk daar veele, en in gelijke waardigheid regeeren, niet in 't kort bedorven, en in wan-ord'ren kan gebragt werden."

${ }^{16}$ Politike Weeg-schaal III.III.6, p. 669: “... Republiken met bedaarde zinnen, en zonder bloedvergieten weten te brengen tot een beeter ordre en forme van Regeeringe."

${ }_{17}$ Welvaren 66, p. 146: "Maer in groote Steden vervuld met vremdelingen ende ontbloot van Hallen en Gildens heeft men genoeghsaem noijt eenige oproeren sien ontstaen, dan die ontstoocken en gevoed wierden door eenigh aensienelijck Minister van den Staet, ofte aensienelijck Hooft." 


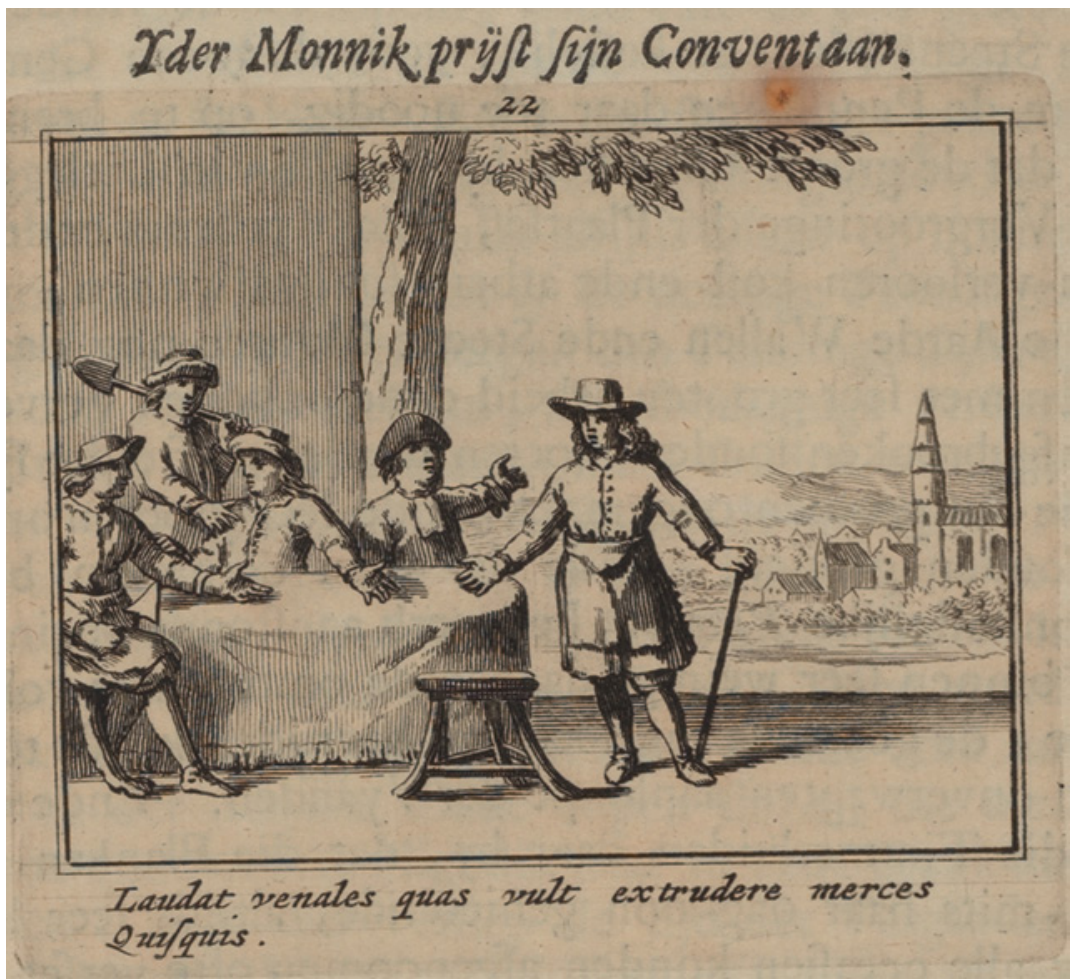

Fig. 12. "The guilds and a city," from Pieter de la Court, Sinryke Fabulen, 1685. Amsterdam University Library, OTM: OK 63-2796.

strengthened with iron bars. Then the merchants suggest using just garbage and mud in order to avoid new taxes, and they find support among the vintners and brewers who thus see an opportunity to get rid of their dregs. "What kind of nice Walls would you provide us with, which would be eaten by the Pigs?", the other ask in reply. Eventually, all guildsmen remain undecided as to how to repair the city's walls. ${ }^{18}$ With this allegory, the De la Courts imaginatively warn that organized interest groups such as guilds will necessarily cause conflict and irresolution, threatening the stability and survival of the commonwealth.

A number of Italian exempla illustrate such a dreadful state of factionalism and discord, from a fable of Boccalini that ridicules the "art of war", to a satirical story about the Guelphs and Ghibellines taken from the

${ }^{18}$ Politike Weeg-schaal II.I.4, p. 326-327: "Wat schoone Wallen zoud gy ons verschaffen, die van de Zwijnen opge-eeten zouden werden?'. See also Sinryke Fabulen, 103-108. 
Facetiae of the Florentine humanist Poggio Bracciolini. ${ }^{19}$ But perhaps the most important reference in this context is to Machiavelli, whose shadow looms large over an extensive part of the Politike Discoursen that discusses the danger of conflicts and conspiracies. ${ }^{20}$ If the brothers De la Court ever experienced a 'Machiavellian Moment', facing the question of how to preserve the republic vis-à-vis capricious fortune, then it is here. Nevertheless, it is striking that the key Machiavellian notion of the utility of discord, the idea that the tumults between the nobili and the plebe strengthened the Roman body politic, is largely absent from the thought of the De la Courts. ${ }^{21}$ Whereas Machiavelli argued that conflict is to be preferred over consensus because it makes a republic dynamic and hence powerful and free, the De la Courts adhered to the more conventional attitude that stability and concord should always prevail. Although political strife is unavoidable, in true republics tumults are never fatal but rather function like a strong medicine that eradicates the disease. However, in a badly ordered government - and here the De la Courts mention the last years of the Roman Republic as an example - conflict will eventually become endemic and lead to the deathblow of republican liberty. ${ }^{22}$ This repudiation of the Roman model makes clear that the brothers De la Court experienced less a Machiavellian than an Erasmian Moment: their republic will persist by peaceful resignation and concord, not by the militant seizure of indomitable fortune.

On one important issue, however, the De la Courts followed both Erasmus and Machiavelli. This issue is their virulent anti-clericalism. Erasmus frequently ridiculed the corruption of the Catholic clergy and the degeneration of Christian doctrine, most famously in The Praise of Folly. Machiavelli in turn argued that the moral teachings of the Church were to blame for the downfall of Italian strength and independence. ${ }^{23}$ The De la Courts' criticism of the Calvinist clergy of their day adopts elements from both Erasmus's ridicule and Machiavelli's outspokenness.

\footnotetext{
19 Politike Discoursen I.II.14, p. 128-130, including a Dutch translation of Boccalini, Ragguagli I.75, and of Poggio Bracciolini, Facetiae 149.

${ }_{20}$ Ibidem I.II.13-28. For all the corresponding passages in Machiavelli, see Van Heck, "In het spoor van Machiavelli," 288-291.

${ }^{21}$ Cf. Machiavelli, Discorsi I.4.

${ }^{22}$ Politike Weeg-schaal III.I.6, p. 573-575.

${ }_{23}$ See Machiavelli, Discorsi I.12, II.2, and cf. Marcia L. Colish, "Republicanism, Religion, and Machiavelli's Savonarolan Moment," Journal of the History of Ideas 60, 4 (1999), 597-616. For Machiavelli's civil religion, see also Maurizio Viroli, Il Dio di Machiavelli e il problema morale dell'Italia (Bari: Laterza, 2005).
} 
The brothers argue in particular that the dissimulative teachings of the clergy undermine social harmony and adulterate the word of God, thus jeopardizing, like Stadholders and guilds, the fundamental preservation of republican concord.

\section{Confronting Clerical Conceit}

Throughout the seventeenth century, the position of the Dutch Calvinist clergy was profoundly linked to the debate on the political order of the Republic. This connection between religion and politics became especially clear during the pamphlet war of $165^{\circ}$, when a couple of orthodox ministers, such as the Zeeland minister Maximiliaen Teelinck, stood up as spokesmen of the Orangist camp. In 1650, at the height of the political storm, Teelinck republished the main work of his late father, who had been one of the key proponents of a 'Further Reformation' in Dutch Calvinism, a puritan movement that sought to strengthen the church's grip on all facets of daily life and public morality. ${ }^{24}$ Teelinck dedicated his father's work, a Christian mirror-for-princes suggestively titled Den politijcken Christen, ofte instructie ... tot destructie vande hedendaegsche Machiavelsche wijsheydt ["The Political Christian, or Instruction to Destroy the Current Machiavellian Wisdom"], to William II. ${ }^{25}$ In unambiguous terms he praised the House of Orange's support for Calvinist orthodoxy. When this dedication was published separately (and probably without authorization) as a pamphlet shortly afterwards, it provoked a furious reaction from those who opposed either the Further Reformation, or the Stadholder, or both. ${ }^{26}$ The poet Vondel did not hide his contempt of Teelinck's "rebellious seed", the "Monsters" which, if not tempered by "Civil Discipline", would surely make the country "swim up to the throat in blood and tears". ${ }^{27}$ This characterization of the clerical provocation

\footnotetext{
${ }^{24}$ On the Further Reformation, see Israel, Dutch Republic, 474-477, 690-699.

${ }^{25}$ Willem Teelinck, Den politycken Christen. Ofte instructie voor alle hooge en leege staets-persoonen ... tot destructie van de hedendaeghsche Machiavelsche wijsheydt (Middelburg, 1650).

${ }^{26}$ Maximiliaen Teelinck, Vrymoedige aenspraeck aen Sijn Hoogheyt, de Heere Prince van Oraengjen (Middelburg, 165o). Cf. also [Jacob Stermont], Lauweren-krans gevlochten voor Syn Hoocheyt Wilhelm, de Heer van Oranjen (s.l., 1650). For a short analysis, see Groenveld, Prins voor Amsterdam, 93-95, and Israel, Dutch Republic, 6o1-602.

${ }^{27}$ Joost van den Vondel, "Op d'oproericheit van den Godtloosen Zeeuw, Maximiliaen Teeling," in Werken, vol. V: 517: "maer dit oproerigh zaet/Noch Vryheit laet in rust, noch Koningklijcken Staet./Kon Burgerlijcke Tucht die Monsters niet betemmen,/Al 't lant zou tot de keel in bloet en tranen zwemmen." Cf. also Het rechte derde deel van 't Hollands Praatje, aangaande de wettige souverayniteyt van de Groot-Mogende Heeren Staten van
} 
of discord and tumult became one of the main commonplaces of anticlerical writing throughout the next decades. Even in 1668, almost two decades later, Teelinck was still rebuked as a prime example of the "swollen arrogance" of the clergy. ${ }^{28}$ The Teelinck affair thus caused the clergy to become increasingly politicized, even though Orangism and Calvinist orthodoxy did not necessarily coincide. ${ }^{29}$

For the brothers De la Court, the designs of the supporters of the House of Orange and of the Calvinist clergy were clearly connected by their shared abuse of rhetoric. Duplicitous speech is fatal for a proper public debate, and the De la Courts insist that clerics, as much as courtiers, avail themselves of exactly this kind of language that blurs the distinction between virtue and vice. Clerics are therefore bad rhetoricians who do not dare to say the truth or even deliberately mislead their congregation. Embodying hypocrisy, "the Pharisaic Ecclesiastics are only because of the Mask of Wisdom and Virtue considered to be wise and virtuous, for in reality they are ignorant, stupid and vicious People". ${ }^{30}$ With their "premeditated, dragging words and artificial gestures", they teach Christian humility only because they "intend nothing else than to be regarded as devout People, and to rule under that guise over the Soul and the Thoughts of other Men, and to live in the meantime on the quiet in all lusts and extravagance". Examples of this behaviour are to be found "among all Religions or Sects, be it Heathens, Jews, Christians or Muslims" and among all those clerics who are "eloquent". ${ }^{11}$ This important remark makes clear that for the De la Courts, the dangers involved in fanatical speech are not limited to the Calvinist world: clerical rhetoric, which is universally

Hollandt (s.l., 1650), esp. 14-15. On Vondel's anti-Stadholder engagement in this period, cf. Duits, Van Bartholomeusnacht to Bataafse opstand, 154-272; and Jill Stern, “A Playwright in His Time: Vondel's Drama Faeton of 1663," Dutch Crossing 23 (1999), 22-57.

${ }_{28}$ Leids schuitpraatje: zijnde een t'zamenspraak tusschen verscheide personen: rakende de vrijheid van ons vaderland, der religie, en de macht der hooge overheid in kerkelijke zaken (s.l., 1668), sig. B v.: “... opgeswollen hoovaardigheid.”

${ }_{29}$ See Jill Stern, "Religion and the Orangists, 1650-1672," Dutch Crossing 30 (2006), $181-196$.

3o Sinryke Fabulen, 179: “... de Phariseeuse Kerkeliken, die alleen door het Mom-aansigt van Wijsheid ende Deugd, voor soodaanigen werden gehouden, daar sy waarelik onweetende, dwaase, ende ondeugende Menschen zijn."

${ }^{31}$ Ibidem, 234-235: “... met haare voorbedagte sleepende woorden, ende gemaakte gebaaren ... niet anders voor hebben, dan voor heilige Menschen geagt te werden, ende onder dien Mantel over de Siele ende Gedagten van andere Menschen te heerssen, ende middeler-wijle stillekens in alle wellusten ende overdaad te leven ... Van den Schijnheiligen vinden wy dageliks ende ooveralle voorbeelden, onder alle Godsdiensten ofte Secten, het zy der Heidenen, Jooden, Christenen, ofte Mohametanen. Ende insonderheid by den Priesteren, Moniken ende Leeraaren der selven, wanneer die welbespraakt zijn." 
artificial and deceitful, abuses the passions of the audience and hence fundamentally corrupts the public debate.

This hypocritical speech is intrinsically related to another clerical characteristic that the brothers De la Court repudiate: the pretension that virtue can possibly surpass self-interest. A fable in the Sinryke Fabulen describes how a diligent craftsman, the personification of civic probity, accuses a couple of mendicant friars, who "under the pretext of loving other People more than themselves ... carelessly plundered the World"..$^{2}$ The craftsman thus reveals that clerical modesty and humility are merely a façade for the relentless pursuit of self-interest at the cost of others. Like guildsmen, kings, and courtiers, clerics are therefore guilty of the cardinal sin in the mercantile logic of the De la Courts: self-interest wrongly understood. "Because of their all too large self-love, which commonly stems from larger ignorance and poor judgment", clerics think that they are superior to their equals, indulging in heerszucht and haughtiness..$^{33}$ This accusation against the political preponderance of the clergy was often raised in the Dutch debate, for example by Vondel. Yet it is important to note that the ranting anti-clericalism of the brothers De la Court stresses the worldwide consequences of this clerical lust for dominion. As the fable of the craftsman and the friars makes clear, hypocritical clerics are equally to be found among all religions, "and the World will never be so happy that it is relieved from this most rogue scum of People". ${ }^{34}$

The De la Courts' dismissal of clerical duplicity does not entail a commonplace Protestant attack on Catholic dissimulation, but rather a crucial feature of their republican criticism of two-faced rhetoric and of the contemptible ambition to rule. Indeed, the "causes of corruption in Politics", namely the domination by one man, by a small oligarchy or by the ignorant masses, are also "the cause of the decay in Religion", and the same evils are to be found on the "Pulpits of all kinds of Sects" as in "Monarchical Palaces or Republican Town halls" ${ }^{35}$ Politics and religion are intrinsically connected. This message is perhaps clearest in a passage

\footnotetext{
${ }^{32}$ Ibidem, 128: “... dat sy onder pretext van andere Menschen meer als haar selven te lieven ... de Weereld ongevoelig plonderden." Cf. also the comparable fable in Ibidem, $115-120$.

${ }_{33}$ Ibidem, 252: “... door hare al te groote eigen-selfs liefde, die gemeenelik uit grooter onkunde ende kleinen oordeele spruit."

${ }^{34}$ Ibidem, 132: “... sal de Weereld nooit soo gelukkig zijn, van dit oolikste gespuis van Menschen ontslaagen te werden."

35 Politike Discoursen II.IV.6, p. 44: “... de meeste oorsaaken van de corruptien in Politie ... oorsaak van het verval in den Gods-dienst zijn ... allerley Secten Preedik-stoelen ... als der Monarchen Palleisen, of der Republiken Raads-huisen."
} 
that refers approvingly to Boccalini's satirical disclosure of deceit. Elaborating on one of Boccalini's Ragguagli, this passage sarcastically accuses the pretensions of both the "Political Zealots" and "the devout Friars who continuously speak of Conscience, God, and his holy Word", although they are in fact no "young Angels, as they commonly claim to be, but old Devils", the personification of "the light turned into darkness of which the Gospel reports". ${ }^{6}$ This evocative imagery of the opposition between biblical light and clerical darkness is often repeated in the work of the De la Courts. Although of course a standard element of much anticlerical satire, it brings to mind the similar rhetorical disclosure of the ecclesiastical "Kingdom of Darkness" in Hobbes. ${ }^{37}$

The argument against clerical rhetoric, hypocrisy and imperiousness leads to the ensuing assertion, also reminiscent of Hobbes, that the main menace of the clergy lies in its demagogy. "Motivated by their Ambition, Haughtiness, and personal advantage", clerics tend to slander the worldly powers in order to increase their own status. ${ }^{8}$ Hence, they encourage political insubordination for the sake of their personal benefit, while they endanger social concord still further by promoting bigotry and the persecution of all who disagree, especially men of learning. The consequences are fatal: as Machiavelli had argued, art and science fall victim to clerical fanaticism,39 while, "under the cloak of devoting themselves to God's Glory", clerics slander all dissenters and eventually "hand them over to Satan", thus fundamentally dishonouring their duties as pastors. ${ }^{40}$ Moreover, those "honest and openhearted" people who endeavour to disclose this deceit are accused by the clergy of being "Libertarians" and "Atheists". ${ }^{41}$ Clerical demagogy obstructs the parrhèsia that is indispensable for a truly republican political debate.

${ }^{36}$ Politike Weeg-schaal III.I.6, p. 565-566: “... de Politike Yveraars ... en de heilige Broeders, die gedurig van de Conscientie, God, en zijn heilig Woord spreken ... geen jonge Engelen, daar zy zig voor pleegen uit te geeven, maar oude Duivelen ... het tot duisternisse veranderd ligt daar het Evangelie van gewaagt."

37 Sinryke Fabulen, 368: “... dat opgemelde ontrouwe Christen Leeraars, op dese duistere gronden hebben gebowd haar Rijk der Duisternissen." Cf. Hobbes, Leviathan part IV ("Of the Kingdome of Darkness"), and see the analysis in Skinner, Reason and Rhetoric, 398-399.

${ }^{8}$ Politike Discoursen II.IV.4, p. 33-34: “... door haare Ambitie, Hovaardie, ende eigen voordeel, bewoogen."

39 See Ibidem II.IV.5, which borrows from Machiavelli, Discorsi II.5.

$4^{40}$ Sinryke Fabulen, 113: “... onder den schijn van te yveren voor Goodes Glorie ... den Satan oover-leeveren."

${ }^{41}$ Ibidem, 178: “... opregt ende oopenhertig ... voor Vry-Geesten, Atheïsten, ende Menschen van een seer schandelik ofte aanstootelik leeven by de gemeene Menschen doorgaan." 
Unsurprisingly, the ecclesiastical authorities in Holland did not condone these remarks, and in 1662 the Leiden consistory duly punished De la Court by excluding him from the Lord's Supper. Yet in spite of this open clash with the church, the passionate anti-clericalism of the brothers De la Courts should not be confused with a criticism of organized religion and the institution of the church as such. ${ }^{42}$ Rather, their thought attests to a distinctive Erasmian critique of clerical degeneration and a related longing for the age of apostolic purity before "God's Church and the true Faith lapsed into exceptional superstition, idolatry and humbug". ${ }^{43}$ In a passage that might as well be taken from The Praise of Folly, this critique entails a vivid denunciation of the teaching of theology at Leiden University, where, as the De la Courts knew from firsthand experience, students were educated that "they occupy the Pulpit with utterly inexperienced brains", having learned how to dissect Holy Scripture "with many meaningless words and senseless disputations". ${ }^{44}$ In short, the schooled clergy adulterates instead of spreads the word of God.

The extent of this anti-clerical argument becomes especially clear from a letter that De la Court wrote to his brothers-in-law on account of the publication of an Orangist pamphlet in 1663 - a pamphlet that reminded De la Court of Teelinck's dedication to William II back in 1650. Following Teelinck and armed with an arsenal of biblical references, the author of this pamphlet argued that the "true internal peace and Concord" in the Dutch Republic had been maintained by the divinely inspired policy of the Princes of Orange. ${ }^{45}$ For De la Court, this assertion was "a sign that among the Reformed Orangists there are such godless people, that they

${ }^{42}$ Significantly, some of the Orangist critics of the De la Courts shared their religious views: see Stern, "Religion and the Orangists," 188-192. Moreover, also the theologian Guiljelmus Saldenus, a prominent propagator of the Further Reformation, referred approvingly to their work in his Neerlands Interest, tot vrede der kercke, en wegh-neminge van alle opkomende misverstanden in de selve (Middelburg, 1664). On this work, see G. van den End, Guiljelmus Saldenus (1627-1694). Een praktisch en irenisch theoloog uit de Nadere Reformatie (Leiden: Groen, 1991), 176-188.

43 Politike Discoursen II.IV.6, p. 42: “... dat Gods Kerk, en 't regte Geloof, vervallen is, tot bysonder oover geloof, afgoderie, en beuselingen." Cf. Heinz Schilling, "Afkeer van domineesheerschappij: ein neuzeitlicher Typus des Antiklerikalismus," in Peter A. Dykema and Heiko A. Oberman (eds.), Anticlericalism in Late Medieval and Early Modern Europe (Leiden: Brill, 1993), 655-668.

${ }_{44}$ Welvaren 47, p. 107: “... met gansch ongeoeffende herssenen den Canzel betreden ... met veel sinnelose woorden. en stighteloose disputatien."

45 Onwederleggelycke bewys-redenen daer door betoont wort, dat de Vereenighde Nederlanden, alleen door Godts voorsieninge ende der Princen van Orangien beleyt, vant Spaensche jock, ende slavernye vry gemaeckt zijn (Willemstad, 1663), 12: “... de ware, inlantsche ruste en Eendrachtigheydt." 
dare to dress God and all the prophets, and Christ and all his apostles, in the cloths of comedians to let them play in their theatre". Utterly enraged, he continued to question the credentials of the Dutch clergy and their dubious exploitation of Calvin's legacy:

Is this the fruit of the Reformation and of Holy Scripture, to have put the light on the candlestick, and is this what our ministers do? Should one follow their example? Woe these godless people, much worse than atheists ... What shall one answer to the papists, who had the light under the bushel, when they point us at this? Which abuse is bigger, theirs or ours? What is better, to be blind, or foolish, or mad? The papists were blind, these Reformed ministers are holy fools, their disciples holy madmen. Quaking was English and now it's played out there; here, the matter is the same but devilish and infinitely blacker. God beware us of such blackcoats. ${ }^{46}$

De la Court reserved such inflammatory language for his private correspondence, but his public criticism of the Calvinist clergy reflected much of this confidential outburst. With a similar dismissal of clerical conceit and a comparable rhetorical play with the opposition between light and darkness, the De la Courts persistently undermined the political pretensions of the clergy. Moreover, deftly returning the accusation of atheism, they argued that the clergy itself was to blame for the violation of true religion.

Clearly then, the anti-clericalism of the brothers De la Court involves primarily a defence rather than a censure of revealed religion. This endeavour to defend religion against the clergy involves a fundamental political move that, echoing Vondel, denounces the clergy for provoking sectarianism and thus undermining social concord. As the Politike Discoursen argues in language that infuriated the Leiden consistory, the "public Ministers or commentators of Scripture" deserve "the name of

\footnotetext{
${ }^{46}$ Pieter de la Court to the brothers Van der Voort, 27 September 1663, in Kernkamp, Brieven, 131-132: “... een teeken dat onder de Gereformeerde Prinsgesinde ook soo goddelose menschen zijn, dat God en alle de propheeten, Christus en alle sijne apostolen derven commediantskleederen aan trekken, ende op haar tonneel soodanige rolle doen speelen als 't haar gelieft ... Is dit de vrugt der Reformatie en van de H. Schrift het ligt op den kandelaar geset te hebben en doen dit onse leeraars? Behoorde men haar daar in naar te volgen? Wee deese goddelose menschen, slimmer veel as atheisten ... Wat sal men de papen, die 't ligt onder de korenmaat hadden, antowwrden, als sij ons dit aanwijsen? Wat misbruik is groter, 't hare of 't onse? Wat is beter blind, of dol of gek te zijn? De papen waren blind, dusdanige gereformeerde leeraars heilige dolle, en hare discipulen heilige gekken. Quaken was engels en is nu aldaar uitgespeeld; hier is de selve saak maar duivels en oneindelik swarter, God beware ons voor dusdanige swartrokken." De la Court probably refers to the Quaker Act of 1662, by which the English Parliament outlawed the meetings of the Quakers.
} 
Ringleaders, Enthusiasts, Fanatics, or Quakers", they are "wicked, hypocritical, or otherwise ignorant, Melancholic, Medicine-needing People". ${ }^{47}$ If these rebellious clerics gain too much power over their followers, the consequences are the same as when other self-interested pressure groups like guilds become too powerful: it sows the seeds for a "government within the government", an imperium in imperio..$^{48}$ This distinctive terminology reveals that the view of the De la Courts on the political role of the clergy stems directly from the Arminian position in the debate that dominated much of seventeenth-century Dutch politics, the debate on the relation between church and state and the sovereignty in ecclesiastical affairs.

\section{The Relation Between Church and State}

\section{The Arminian Legacy}

The so-called Arminian controversy of the 1610s, when rivalling theological theories about divine predestination and the position of the church shook the foundations of the Dutch body politic, had a lasting impact on the religious-political debate in the Republic throughout the entire century. ${ }^{49}$ After a short analysis of the key points in this debate, I will show how the Arminian position informed the argument of the brothers De la Court for a broad public church overseen by the sovereign, an argument that involved a clear political statement in the heated theologicalpolitical debate of the 1660 .

The tone of the controversy was set by a short treatise by the Arminian (or 'Remonstrant') spokesman Johannes Uytenbogaert, the Tractaet van 't ampt ende authoriteyt eener hooger christelijcker overheydt, in kerckelijcke saecken ["Treatise on the Office and Authority of a Superior Christian Government in Ecclesiastical Affairs"], first published in 1610 and reissued several times in later decades. Uytenbogaert explicitly invoked the Defensor Pacis by Marsilius of Padua to highlight his time-honoured

${ }^{47}$ Politike Discoursen II.IV.4, p. 31: “... publike Leeraars, ofte uitleggers der Goddelike Schriften ... de naam van Oproermaakers, Enthusiasten, Gesst-dryvers, of Quakers ... boosaardige, schynheilige, of wel onweetende, Melancholike, Medecyn-behoevende Menschen."

${ }^{48}$ See e.g. Welvaren 69, p. 151; Politike Discoursen II.V.9, p. 140; Overvoorde, "NoordOostelijke doorvaart," 285-286; Aanwysing III.1, p. 411.

49 The best account of the intricate issues at stake is still Douglas Nobbs, Theocracy and Toleration. A Study of the Disputes in Dutch Calvinism from 1600 to 1650 (Cambridge: Cambridge University Press, 1938). For a concise overview of the 'Bestandstwisten', see Israel, Dutch Republic, 421-449. 
battle against the 'papist' political pretensions of the clergy..$^{\circ}$ His main aim was to reinterpret Calvinist theology in such a way that the church became fully subordinated to temporal authority. Opposing the claims by the followers of the theologian Gomarus (thus 'Gomarists', or 'ContraRemonstrants'), the Tractaet argued that the civil magistracy exercises supreme power over all ecclesiastical affairs. For the Gomarists church and state were essentially distinct yet interdependent institutions, and therefore the sovereignty of the church should be distinguished from the sovereignty of the state. ${ }^{51}$ Uytenbogaert insisted that such a view amounts to papist "collaterality", to the establishment of two conflicting supreme authorities. Such an "equally supreme power of the Ecclesiastical and the Secular Government", whereby "the Care of Religion and Worship, with all that is ecclesiastical and attached to it, in fact belongs to the Ecclesiastical persons and assemblies", meant for Uytenbogaert an unjustifiable infringement of Calvin's teachings and of Scriptural Revelation. ${ }^{{ }^{2}}$

Uytenbogaert contended that the divine right of the sovereign extends over civil and ecclesiastical affairs alike. This indivisible sovereignty necessitates the civil control and coordination of the public profession of Christianity. The ministers of the church are to be appointed by the magistracy, which thus "takes care that the Gospel is taught purely and well". Moreover, the magistracy has the right to make ecclesiastical laws and ordinances, and to convoke, administer and preside over synods in order to settle theological disputes. ${ }^{53}$ All matters concerning the external worship of God fall under the responsibility of the secular authorities, who hence oversee the fundamental task of "bringing all erring Subjects through good teachings to the knowledge of the truth and the right

$5^{5}$ Johannes Uytenbogaert, Tractaet van 't ampt ende authoriteyt eener Hooger Christelijcker Overheydt, in kerckelijcke saecken, 3d. ed. (Rotterdam, 1647), 3-4, with an extensive quote of discourse II, chapter I of the Defensor pacis, a passage where Marsilius attacks the dangerous demagogy and despotism of the papacy: see Marsilius of Padua, The Defender of the Peace, ed. and trans. Annabel Brett (Cambridge: Cambridge University Press, 2005), 139-140.

${ }^{51}$ See Nobbs, Theocracy and Toleration, 1-24, for a comprehensive analysis of the Gomarist position.

${ }^{5}$ Uytenbogaert, Tractaet, 19: “... Collateraliteyt, dat is, eene even hooge macht der Geestelijcker ende Wereltlijker Overheydt ... alle Sielen, van wat qualiteydt ofte state sy mogen wesen, de macht der Overheyden moeten onderdanich sijn in 't gene Burgerlijck is, ende het tijdtlijcke aengaet ... dat nochtans de besorginge van de Religie ende Godsdienst, met alles wat daer aen-kleeft ende kerckelijck is, eygentlijck toe komt den Kerckelijcken persoonen ende vergaderingen." Cf. Nobbs, Theocracy and Toleration, 27-49.

${ }^{53}$ Uyttenbogaert, Tractaet, 94-115, quote on 101: “... versorgen, dat het Evangelium suyver en wel geleert." 
Religion, all with the spiritual Sword, which is God's word". Uytenbogaert thus argued that there is one true interpretation of Christian faith, and that it is the responsibility of the civil powers to ensure that this interpretation is universally taught. ${ }^{54}$ However, the sovereign's powers do not go beyond the affairs of external worship. In line with the official sanctioning of freedom of conscience in the constitutional charter of the Dutch Republic, the Union of Utrecht, Uytenbogaert stressed that the internal conscience of every individual owes only obedience to God. All matters of public devotion are subjected to the state, but the private conscience remains free. ${ }^{55}$

In the years following the publication of the Tractaet, Uytenbogaert's close friend Hugo Grotius developed this account of inalienable private conscience and a public church administered by the civil powers into a full-blown Erastian theory. Taking sides with the Arminians, Grotius, then employed by the States of Holland, published in 1613 his Ordinum Pietas on behalf of the sovereign power of the provincial States over the church. He further specified this position in the treatise De imperio summarum potestatum circa sacra, written in the 1610 s in cooperation with Gerard Vossius and published posthumously in 1647. De imperio focuses on a notion of a single, indivisible supreme power (or summa potestas). It aims to prove "that the authority possessed by the supreme power thus defined extends not only to secular, but also to religious matters". ${ }^{6}$ Grotius stresses with a reference to Bodin and the Spanish scholastics that the supreme authority he has in mind is that of the provincial States. In a move that radicalizes Uytenbogaert's position, he then openly denies that church and state are fundamentally distinct institutions. Since sacred and secular cannot be distinguished, the means and the aims of the church are the same as those of the civil society, namely "the outward peace of the community" and "the virtue of individuals". As Grotius insists:

Now if it is true that the objective which the supreme powers must set themselves is to make the people as religious as possible, and if all things which lead to that end are called religious, it follows that the competence

\footnotetext{
54 Ibidem, 127: “... doolende Onderdanen, met goede onderwijsinge, totte kennisse der waerheydt, ende der rechten Godsdienst te bewegen, al met het geestelijcke Swaert, 't welcke is Gods woort."

55 See Nobbs, Theocracy and Toleration, 35. For the debate on freedom of conscience during the Dutch Revolt, see Van Gelderen, Political Thought, 213-259.

$5^{6}$ Hugo Grotius, De imperio summarum potestatum circa sacra, ed. and trans. Harm-Jan van Dam, 2 vols. (Leiden etc.: Brill, 2001), vol. I, I.1, p. 157. On the role of Vossius, see Ibidem, "Introduction," 14-15, 19, and Nobbs, Theocracy and Toleration, 58.
} 
of the supreme power as such, that is its authority, encompasses religion too. ${ }^{57}$

The supreme powers (i.e. the States of Holland) therefore exercise an undiluted authority over all activities of the church, from the building of places of worship to the election of ministers. ${ }^{58}$ Moreover, religion is a necessary means to further the harmony and peace within society: it "makes people quiet, obedient, patriotic and adherents of justice and equity". Apart from such moral instruction, "doctrines or ceremonies are also of great importance to morality and public happiness". The supreme power cannot renounce its authority over matters that prove to be so essential. ${ }^{59}$

Grotius therefore pleads for the establishment of one all-inclusive public church which, supervised by the civil magistracy, teaches the fundamentals of Christian belief, the self-evident articles of faith that are necessary for salvation and on which all denominations agree. ${ }^{60}$ This irenicist solution to contain religious diversity within the church, leaving the adiaphora or 'indifferent matters' of faith to the judgment of each individual, entails a defence of freedom of conscience and state supervision similar to that of Uytenbogaert's Tractaet. In private, people are only accountable to God, yet in public, the secular powers have the authority and the duty to suppress forms of worship that exceed the limits of the public church. ${ }^{61}$ In line with this argument, Grotius suggested that Jews be granted admission to Holland and freedom of religion, yet only under the condition of very restricted rules regarding public worship. In his De veritate religionis christianae, he merely tried to convince Jews and Muslims alike to come together under the one true religious umbrella of Christianity. ${ }^{62}$ Grotius' model, then, is a model of unity and consensus.

57 Grotius, De imperio I.5, p. 165. Cf. Nobbs, Theocracy and Toleration, 62-90, and Tuck, Philosophy and Government, 179-190.

${ }_{58}^{8}$ Grotius, De imperio VII.11, X.15, p. 355, 477.

59 Ibidem I.11-13, p. 173-179.

6o See esp. Grotius, Ordinum Hollandiae ac Westfrisiae Pietas, ed. and trans. E. Rabbie (Leiden: Brill, 1995), 169-171. Cf. as well De imperio VI.9, p. 309-313, and see G.H.M. Posthumus Meyjes, "Hugo Grotius as an irenicist," in The World of Hugo Grotius (1583-1645) (Amsterdam and Maarssen: APA-Holland University Press, 1984), 43-63.

${ }_{61}$ Grotius, De imperio VIII.3, p. 377: "It is the task of the supreme ruler, and of him alone, not only to grant the true religion official force, but also to remove or abolish by punishment false beliefs."

${ }^{62}$ Cf. the qualifications of Grotius' position in Jonathan Israel, "The Intellectual Debate about Toleration in the Dutch Republic," in C. Berkvens-Stevelinck et al. (eds.), The Emergence of Tolerance in the Dutch Republic (Leiden etc.: Brill, 1997), 3-36: 11-13; and John Marshall, John Locke, Toleration and Early Enlightenment Culture. Religious Intolerance and 
De imperio hints that such concord is endangered by the political pretensions and demagogy of the clergy, for "the mass, victims of vain superstition, obeys the soothsayers better than it does its own leaders". To counter such dangerous defiance, the clergy should be kept under close control by the magistracy, for only then can the stability of society and religion be maintained. ${ }^{63}$

With the defeat in 1618 of the political regime that championed this Grotian view on church and state, the Arminian cause collapsed. Following the intervention of Stadholder Maurice of Orange, Grotius was charged of treason and imprisoned, Uytenbogaert fled into exile, and their main political ally, Grand Pensionary Johan van Oldenbarnevelt, was executed on the scaffold. The famous National Synod of Dordrecht officially sanctioned the Contra-Remonstrant theology of grace and clerical independence as the orthodox dogma of the Dutch Reformed Church. ${ }^{64}$ Before long, however, the debate flamed up again. In the course of the 1620 s the political dominance of the Contra-Remonstrants diminished, and after the death of Maurice of Orange, most Arminian leaders again openly engaged in the political and religious life of the Republic. Uytenbogaert returned from France in 1626, and although Grotius remained in exile, he continued to influence the Dutch debate, in particular with the publication of his Verantwoordingh ["Apology"] that reaffirmed his theory of the ecclesiastical sovereignty of the States of Holland. ${ }^{65}$ Yet the most important spokesman of the Arminians turned out to be the theologian Simon Episcopius, who strove for the establishment of an independent Remonstrant Church, which was eventually inaugurated, under Episcopius' own guidance, in Amsterdam in 1630. Radicalising the earlier stance of Uytenbogaert and Grotius, Epsicopius maintained the need for civil control over the public church, but he also insisted that outside of this remit the magistracy has no right to prohibit or punish dissenting congregations. ${ }^{66}$ Emphasizing not only freedom of conscience but also

Arguments for Religious Toleration in Early Modern and 'Early Enlightenment' Europe (Cambridge: Cambridge University Press, 2006), 345-350.

${ }_{63}$ Grotius, De imperio, I.13, p. 179. Cf. Nobbs, Theocracy and Toleration, 71: "The spectre of theocratic tyranny, direct or indirect, was laid only by taking refuge in the charity of the supreme power."

${ }^{64}$ See Israel, Dutch Republic, 460-463.

${ }_{5}$ Grotius, Verantwoordingh van de wettelicke regiering van Hollant ende Westvrieslant (Paris, [1622]), esp. 14-29.

${ }^{66}$ See esp. Epsicopius' public disputation "De jure magistratus circa sacra," in Episcopius, Opera Theologica, 2 vols. (Amsterdam, 1650-1655), vol. II: 409-411, and the analysis in Nobbs, Theocracy and Toleration, 91-107. Epsicopius was also the author of the 
freedom of worship and expression, Episcopius thus gave an essential tolerationist twist to Arminian theology.

None of the three main Arminian spokesmen of the first half of the century - Uytenbogaert, Grotius, and Episcopius - would live to see the establishment of the regime of 'True Liberty' in 1650. However, their Erastian theory of secular sovereignty over church affairs lost none of its relevance in the new political constellation. In 1647, on the threshold of the Stadholdership of William II, Uytenbogaert's Tractaet went into its third edition, and the first edition of Grotius' De imperio was published the same year in Paris. After the Stadholder's death, Dutch editions of De imperio followed in 1652 and in $1661,{ }^{67}$ while Episcopius' Opera Theologica were issued in two imposing folio editions between $165^{\circ}$ and 1655 . Moreover, the Arminian version of the history of the Dutch Reformation, Uytenbogaert's Kerckelicke Historie ["Ecclesiastical History"], refuelled the controversy with the Contra-Remonstrants. First published in 1646, it was reissued several times over the next couple of years. Like the extensive reply by the orthodox theologian Jacob Trigland, it enjoyed wide readership throughout the 1650 s and $1660{ }^{68}{ }^{6}$ The Arminian legacy, in short, did not die with its main representatives.

It should therefore not come as a surprise that, during the years of 'True Liberty', the political debate on the position of the Dutch Reformed Church in society carried on along the path set out during the first decades of the century. One of the protagonists in this revived debate was the Utrecht regent Van Velthuysen, also the first continental European to comment publicly upon the political philosophy of Hobbes (see chapter 3 above). With Hobbes's notoriously anti-clerical views as support, Van Velthuysen invigorated the Erastian theory of the Arminians in a number of manifest interventions in the public debate, most importantly in his 1660 pamphlet Het predick-ampt en 't recht der kercke ... tegen het gevoelen van eenige Gereformeerde leeraers, die der selve macht verder uytbreyden

influential declaration of the Arminian creed, the Confessio, sive declaratio, sententiae pastorum, qui in Foederato Belgio Remonstrantes vocantur (1622), translated into Dutch by Uytenbogaert in 1621 and republished several times throughout the century, also in England.

${ }^{67}$ Grotius, De imperio, "Introduction," 92.

${ }^{68}$ [Johannes Uytenbogaert], De kerckelicke historie (s.l., 1646); Jacob Trigland, Kerckelijcke geschiedenissen (Leiden, 1650). The library of De la Court van der Voort had the authoritative folio editions of both works: Library, fol. 10. On the historical controversy between Uytenbogaert and Trigland, see Charles H. Parker, "To the Attentive, Nonpartisan Reader: The Appeal to History and National Identity in the Religious Disputes of the Seventeenth-Century Netherlands," The Sixteenth Century Journal 28, 1 (1997), 57-78. 
als het behoort ["The Clerical Office and the Right of the Church ... Against the Sentiment of Some Reformed Ministers who Extend its Power more than Appropriate"]. As the title makes abundantly clear, this pamphlet aimed to undermine any notion of separate ecclesiastical sovereignty. In several ways that directly echo the Arminians, Van Velthuysen insisted that the civil authorities have the right and the duty to supervise the public church in order to counter discord and strife. For Van Velthuysen, "the Church is not only part of Politics ... but the Church is also a political Society, like all other Colleges, Guilds, Fraternities, \&c" ${ }^{69}$ Following the Grotian argument that there is no distinction between church and state, Van Velthuysen maintained that the magistracy has the obligation to take care of the true faith, "like it has to ensure that there are capable Doctors and Surgeons, capable Captains and Steersmen, capable Judges and Lawyers". ${ }^{70}$ Clerics, in short, are nothing but civil servants. The alternative is "to lapse into Papacy", a powerful rhetorical argument against Contra-Remonstrant orthodoxy also employed by Uytenbogaert. ${ }^{71}$ In a second treatise published in 166o, Van Velthuysen also stressed in line with the Arminians that its is both impossible and in contradiction of God's law to control man's private conscience. $7^{2}$

At the other side of the debate stood the towering figure of Gijsbert Voetius, professor of theology at the University of Utrecht since 1636 and one of the main protagonists of the Further Reformation. As the eminence grise of Contra-Remonstrant orthodoxy, Voetius played a pivotal role in the political and cultural life of the Dutch Republic around the middle of the century. The three massive parts of his Politica ecclesiastica, published in four volumes between 1663 and 1676 , can be characterized as the ultimate encyclopaedia of seventeenth-century Dutch Reformed theology. ${ }^{73}$ In opposition to the Arminians, Voetius essentially defended the independence and autonomy of the church as a self-sufficient institution

${ }_{9}^{6}$ [Lambert van Velthuysen], Het Predick-Ampt en 't Recht der Kercke ... Tegen het gevoelen van eenige Gereformeerde Leeraers, die de selve macht verder uytbreyden als het behoort (Amsterdam, 1660), 87: “... dat de Kerck niet alleen in de Politie is ... maer dat de Kerck mede een politijcke Societeyt is; ghelijck alle andere Collegien, Gilden, Broederschappen, \&c."

$7^{70}$ Ibidem, 100: "Gelijck hy besorgen moet, datter bequame Doctoors, en Chirurgijns zijn: bequame Schippers en Stier-luyden: bequame Richters en Rechts-geleerden."

${ }^{71}$ Ibidem, 69: "Men kan van dese Leer niet afwijcken, of men vervalt tot het Pausdom."

$7^{2}$ [Lambert van Velthuysen], Ondersoeck of de Chritselijcke Overheydt eenigh quaadt in haar gebiedt mach toe lateen (Middelburg, 1660), esp. 98-141.

73 See Andreas J. Beck, Gisbertus Voetius (1589-1676). Sein Theologieverständnis und seine Gotteslehre, (PhD dissertation Utrecht University, 2007). 
based on the mutual consent of its members. The church is a community of the faithful who have voluntarily entered its ranks, and therefore it is of a fundamentally different nature than the state, pace Grotius and Van Velthuysen. Ecclesiastical power and secular power should be distinguished, for the power of the state only concerns the outward wellbeing and safety of its citizens, while the power of the church concerns the internal, spiritual welfare of its members. That aim is utterly beyond the range of physical force, and hence beyond the might of the state. ${ }^{74}$ The civil authorities are therefore to be excluded from any ecclesiastical office. Voetius explicitly mentioned Hobbes, Grotius and Episcopius for undermining this principle, and thus he unequivocally equated Arminian theology with the Erastianism of Hobbes. ${ }^{75}$

\section{The Public Church \& Private Conscience}

This panorama of theological and political debate forms the background to the thought of the brothers De la Court on the relation between church and state. The De la Courts, keen readers of especially Grotius's Verantwoordingh and Uytenbogaert's Kerckelijcke Historie,${ }^{76}$ prove to be largely indebted to the Arminian tradition, albeit rather on political than theological grounds. In particular, they adopt the Arminian stance to plea for a broad, inclusive public church which, overseen by the magistracy, frees the republic of clerical bondage and demagogy and thus guarantees social concord, the purity of faith, and the freedom of private conscience.

In a number of key chapters of the Politike Discoursen, the brothers De la Court begin by highlighting the fundamental political importance of religion. Following a standard claim brought forward from Lipsius to Boxhorn, they argue that religion is essential for civil society, for it would be unlikely that the social contract could be maintained on the basis of only fear of punishment or sentiments of honour and gratitude. Indeed,

${ }^{74}$ See esp. Voetius, Politicae ecclesiasticae partis primae, 2 vols. (Amsterdam, 16631666), vol. 1: I.I.1, I.II.2, I.II.7, and cf. the analysis in Nobbs, Theocracy and Toleration, $144-176$.

75 Voetius, Politicae ecclesiasticae pars secunda (Amsterdam, 1669) II.I.1, p. 221-222. See also Malcolm, "Hobbes and the European Republic of Letters," 475-476.

${ }^{76}$ See the notes added to the manuscript of Boxhorn's 1643 lecture, Royal Library The Hague Ms $70 \mathrm{G12}$, which include many references to the Verantwoordingh in the hand of Pieter de la Court. These notes, touching especially on the issue of provincial sovereignty, probably stem from the period of the preparation of the Interest van Holland, because the last date mentioned is 1661 (fol. 37 v). References to Uytenbogaert's Kerckelijcke Historie abound, especially in the Politike Discoursen and the Aanwysing. 
these punishments, promises, Honour, and gratitude for enjoyed protection would, without Religion, which as regards disobedience inflicts fear for God's punishment after this life, not be sufficient to maintain people in continuous obligations to their Government and their fellow humans. ${ }^{77}$

Because of its transcending disciplinary power, religion thus has a fundamentally utilitarian value: it makes subjects as well as rulers aware of their duties to each other and of the need for charity, friendship and trust. God has endowed humankind with the means "to find out that there is a God", and to realize "according to our own good reasoning and impulses" that people should behave in accordance with "the laws of nature, which everyone can find by examining himself". ${ }^{78}$ In short, humanity is necessarily endowed with religion, for without religion it is impossible to conceive of natural law and the existence of civil society.

Yet while religious belief as such is necessary, institutionalized Christianity is not, for it remains possible to "presuppose a Government that would grow out of the status naturalis, the natural condition, without public Religion". Indeed, "Indians and Pagans" are a living example that some societies subsist without knowing the true faith. ${ }^{79}$ Religious diversity is therefore a natural fact. Given all the differences between human beings, a proliferation of various religious sects is unavoidable, and so is the ensuing conflict among these sects, for people are by their passionate nature inclined to challenge those who disagree and to try to convert them to their own particular creed. In a situation where there is no higher authority over religion, endless warfare would be the inevitable result, "and because that would be ruinous for humankind, its causes should necessarily be removed by Politics to maintain the people and keep them alive".$^{80}$ In short, the passage from the state of nature to civil

77 Politike Discoursen II.IV.2, p. 12: "Maar deese straffen, beloften, Eer, en dankbaarheid, voor genoote protectie, soude sonder Gods-dienst, die oover ongehoorsaamheid na dit leeven, voor Gods straf doet vreesen, niet genoegsaam zijn om de menschen in gedurige pligten teegen haare Ooverheid, en haar Eeven-naasten, te onderhouden."

${ }^{78}$ Ibidem, 14: “... kan bevinden dat er een God is ... volgens onse eige goede reeden-kavelinge en driften ... de wetten der nature, die een yder met naa-soeken in sig selven kan vinden."

${ }^{79}$ Ibidem II.IV.3, p. 19: "Maar nogtans soudemen een Regeering konnen begrypen, die uit den status naturalis, aangebooren stand, soude groejen, sonder publike Gods-dienst. Sulks de Gods-dienst gemeenelik in een politike Regeering zijnde, nogtans seeker is, dat er seer goede Regeringen onder de Indianen, en Heidenen, geweest zijn, daar seer weinig, of seer verkeerde Gods-dienst was."

8o Ibidem, 21: “... en dewijl die ruineus voor het menschelik geslagt soude zijn, so moet die noodsaakelik, door de Politie, weg-genoomen werden, om de menschen te behouden, en in 't leeven te doen blyven." 
society necessitates that the established sovereign oversees organized religion. Otherwise there would be no civil society, but only the continuation of a war of all against all.

Accordingly, the De la Courts argue that the very essence of sovereignty implies secular control over the church. Religion is conducive to social concord because it teaches the love of one's neighbours, yet it can only do so if supervised by one indivisible sovereign. Noel Malcolm has argued that this claim draws "directly on Hobbes's political theories", in particular because of the resulting "peculiarly Hobbesian twist to this argument" that the public judgment of good and evil belongs to the sovereign. ${ }^{81}$ Yet the influence of Hobbes on the De la Courts' views on the relation between church and state should not be overstated. The brothers do not refer to Hobbes at all in this context, and in so far as they appropriate Hobbes for their argument, they merely, like Voetius, turn Hobbes into an Arminian. Their account of the secular control over the church remains largely within the Arminian framework of a single sovereign in both civil and ecclesiastical affairs. With a vocabulary that distantly echoes Grotius's De imperio, the De la Courts assert "that in a Country there is or should be not more than one supremo [sic] potestas, High Government, and that no Subject possesses any public legitimate power than that which descends from this Sovereign power". ${ }^{82}$ The alternative would be a plethora of "rebellious clerics" who try to spark off tumults and discord "to their own advantage", making their followers believe "that by their querulous writings and disputing predications or Conquests of the unbelievers or dissenters, the true Religion would be propagated". ${ }^{83}$ For the De la Courts, as for Grotius, the opposite is the case. In order to preserve religion and concord in society, it is necessary that all clerics are restrained in their words and deeds by the civil magistrates, who should "Govern the State in such a way that even the most malicious and haughtiest Preachers would not be able to overturn the Republic and to destroy the Country's welfare". ${ }^{84}$

${ }^{81}$ Malcolm, Aspects of Hobbes, 45, referring to Politike Discoursen II.IV.3, p. 24.

${ }_{22}$ Politike Discoursen II.IV.4, p. 32: “... dat in een land niet meer als eene supremo potestas, Hoge Overigheid is, ofte behoord te weesen: ende dat geen Onderdaan eenige publike wettelike magt besit, dan die van deese Souveraine magt afdaald."

${ }^{8}$ Ibidem II.IV.2, p. 18: “... oproerige Geesteliken ... tot haar eigen voordeel ... met den gemeene Ingeseetenen te doen gelooven, dat door hare twist-schriften, en disputerende predicatien, ofte Conquesten op de ongeloovigen ofte dissenterenden, de ware Religie soude werden voortgeplant."

${ }^{84}$ Aanwysing III.1, p. 408: “... dat sy den Staat soo Regeeren, dat selfs de allerboos-aardigste ende hoovaardigste Predikers niet souden konnen de Republike omkeeren, ende 's Lands welvaaren vernietigen." 
This secular government over ecclesiastical affairs to counterbalance the rebellious and demagogical clergy amounts to a public church that is overseen by the sovereign. Inspectors, appointed by the magistracy, administer the external affairs of this public church, while the magistracy (and only the magistracy) also has the authority to convene a synod "to suppress deviations and to maintain the purity of the Doctrine". Such a synod, which settles doctrinal affairs, is made up by delegates of the sovereign, and clerics have "neither a deliberative, nor a sentencing vote" ${ }^{85}$ All discussion and decision-making about doctrine is therefore left to laymen. Clerics are merely like soldiers who have to execute the orders of the sovereign without asking why. For the De la Courts, such a strict secular control over the church entails the only policy that corresponds to a true republic:

Like a Country is happiest when it is governed by a large number of prudent and most eminent Inhabitants, and when it has no discord because of a Government within Government or having the Sovereignty divided amongst different Colleges; so it appears as well in speculation that the rule over the Religion, being a very considerable part of Politics, would in a Republic remain best with a large number of the most eminent Citizens. ${ }^{86}$

The ecclesiastical body of the public church mirrors the body politic of the state: like the commonwealth, the church should be one because it binds the many together into a unity, a communal framework that integrates individual differences. In both civil and ecclesiastical affairs, this representative unity is best safeguarded by a broad government that will not succumb to anarchy or tyranny, be they political or religious.

The correlation between politics and religion means that the causes of as well as the antidotes against such anarchy and tyranny are largely comparable in both spheres. As the De la Courts argue, "the very same passions of people spoil the Religion and install slavery or corruptions in Politics". Hence, as liberty is maintained in a well-ordered republic, "the same remedies should be employed to protect the Religion against decay" and to

\footnotetext{
${ }_{5}$ Politike Discoursen II.IV.6, p. 43: “... om de dwaalingen te weren, en de suiverheid der Leere te behouden ... nog deliberative, nog vonnissende stem."

${ }^{86}$ Ibidem, 45: “... gelijk een Land gelukkigst is dat door een meenigte verstandige, en voorneemste Inwoonders werd geregeerd, en geen twee-spald heeft, door Regeering, in Regeering, ofte de Souverainiteit in verscheide Collegien gedeeld te hebben: soo schynd ook in speculatie, dat het bestier oover den Gods-dienst, een seer considerabel gedeelte der Politie zijnde, in een Republijk, by ene meenigte der voorneemste Borgers, best soude stand houden."
} 
keep divine revelation "unadulterated". ${ }^{87}$ Whereas republican liberty and concord are undermined if the monarchical desire to rule is allowed free rein, religion will likewise disintegrate under the domination of the clergy. This clerical ascendancy can be countered if the teachings of the public church are exclusively informed by Scripture and supervised by the sovereign. As the De la Courts maintain in a move that again merges Erasmus with Machiavelli, this policy boils down to the application of one fundamental principle: the "Political rule to keep the State in its ancient liberty and purity, ad principia redeundum, namely to turn back on all occasions to the first principles and to the pure fountain of God's word". 88

Significantly, the De la Courts then maintain utter silence about what these first religious principles might be. This silence reveals how little importance they attach to the contents of theological dogma, quite unlike for example Grotius. Yet they do clearly follow Grotius with the further claim that a broad public church, which preserves the purity of faith, necessarily leaves room for individual dissent in private. Like the hypothesis of a civil society without institutionalized religion, this assertion is clarified by a reference to the supposedly primordial state of America. Imagine, the De la Courts tell their readers, a sovereign power in America that dictates its own faith to all its subjects. This sovereign may be allowed to punish all dissenters who publicly preach another creed. Yet "according to the laws of nature", the sovereign still has to protect those dissenters who remain politically loyal, because the only alternative is to put them back "in statu naturali, outside of the Civil state", whereby they would cease to be its subjects. Through this thought experiment, the De la Courts argue that "man, coming out of the natural into the Civil state, has not given up his right or power to believe that which appears him to be true". In other words, the social contract does not and cannot imply that people have renounced their freedom of conscience. As a consequence, "the Government is bound, according to the laws of nature, to allow Freedom of conscience to all its Subjects who would be willing to obey him as far as

${ }^{87}$ Ibidem, 47: "En gelijk in een fraai gestelde Republijk, de Vryheid soo lange kan bewaard werden, tot dat sy door uitheems geweld haarer Nabuuren werd verkragt: soo soudemen ook de Religie, ende 't geen men voor Godes woord, of revelatie hield, onvervalst konnen bewaaren: want het zijn alle de selve passien der menschen, die den Godsdienst bederven, en de slavernie, of corruptien, in de Politie invoeren; sulks en ook alle de selve remedien behoorde aan te wenden, om den Gods-dienst voor verval te beschermen."

${ }^{88}$ Ibidem, 48: “...doen volgens den Politiken regul, om den Staat by sijn oude, vryende suiverheid te behouden, ad principia redeundum. Namentlik, in alle geleegentheid tot de eerste beginselen, ende de suivere fonteine, Gods Woord, keeren." Cf. Machiavelli, Discorsi III.1. 
possible and as much as they are bound". ${ }^{89}$ Following the legacy of the Dutch Revolt that was continued by the Arminians, the brothers De la Court thus insist that freedom of conscience is an inalienable natural right to which no sovereign power, let alone any clerical preachers, can lay a claim. The authority of the magistracy extends over all external affairs of the church and even over the contents of preaching and doctrine, yet it can never touch on the private conscience of every individual..$^{\circ}$

\section{The Debate over the Public Prayer}

The extent to which this theory of secular supervision over the church and freedom of conscience entailed a direct intervention in the Dutch public debate, becomes clear in the controversy that arose shortly after the first works of the De la Courts were published. The immediate cause for this controversy was the ruling by the States of Holland, announced in 1663, that all public preaching in the province should forsake prayers for the Prince of Orange. This ruling touched the sore spot of the political status quo, for it concerned the crucial issue of the degree of secular sovereignty over the church, as well as the antagonism between the advocates of 'True Liberty' and the Orangists. ${ }^{91}$ Revealingly, the States' declaration was publicly legitimized by Johan de Wit, the cousin of his namesake the Grand Pensionary and also a relative of the Van der Voorts, and hence De la Court's main intermediary with the The Hague establishment. In a large, three-volume treatise titled Public Gebedt ["Public Prayer"], De Wit followed Grotius in appropriating Bodin's theory of sovereignty for the argument that the supreme authority in the Dutch Republic falls to the provincial States. ${ }^{92}$ The Prince of Orange might

\footnotetext{
${ }^{89}$ Ibidem II.IV.3, p. 21-22: “... volgens de wetten der nature, moeten beschermen, gelijk als vooren, of haar in statu naturali, buiten den Borgerliken stand, stellen ... want de mensch uit den natuurlike stant, tot de Burgerlike komende, heeft niet overgegeeven, sijn regt ofte magt om te geloven 't gunt hem waaragtig schynd te weesen; om dat het hem onmogelik was ... Sulks hier uit soude volgen, dat de Ooverheid, volgens de wetten der nature, gehouden is, Vryheid voor de conscientie, en 't gewissen te laaten, aan alle haare Onderdaanen, die haar, in 't geene haare mogelik is, en daar sy toe gehouden zijn, soude willen gehoorsamen."

${ }^{\circ}$ Ibidem, 23-24.

$9^{1}$ See Israel, Dutch Republic, 760-764.

${ }_{92}$ 'D.H.' [Johan de Wit], Public Gebedt, ofte consideratien tegens het nominatim bidden in de publique kerken voor particulieren persoonen, en specialijken voor den jegenwoordigen Heere Prince van Orangien, 3 vols. (Amsterdam: 'Cyprianus van der Gracht', 1663-4), vol. I: esp. 26-37.
} 
enjoy sovereign authority in his own estates but he has never done so in the Republic at large, where he is but a private individual. ${ }^{93}$ As De Wit insisted, in a "Democratic" state the sovereignty "is with the Community, as formerly in Athens and now in Zurich in Switzerland, and in this State with the States of each Province". ${ }^{94}$ Thus characterizing Holland as a democratic republic, De Witt stressed that the right to decide the contents of public prayers belongs only to the sovereign, i.e. to the States of Holland..$^{95}$ De la Court, who by then had been silenced by the Leiden consistory, was delighted with the Public Gebedt, as he wrote to his brothers-in-law shortly after its publication. The book "pleases me unusually much", he said, "so that I hope that the good inhabitants will more and more appreciate the procedures of their lawful government and loathe the incessant pretended dominance and tyranny of the other provinces over Holland"..$^{6}$

At the other side of the political spectrum, the Public Gebedt encountered much criticism. Moreover, Orangist pamphleteers immediately linked the work to De la Court, who in one particularly vitriolic pamphlet was hailed as "the resurrected Barnevelt", as the incarnation of politicized Arminianism. De la Court, according to this pamphlet, was a "hell-dog" full of lies and slanders, "a degenerated, reeking and rotten Walloon who ... overthrows the foundation of the Government of these Lands with his writings and pernicious maxims against the Union and the Reformed Religion". ${ }^{97}$ Such qualifications had by then become a commonplace element of anti-De la Courtism, and it is more revealing that the pamphlet explicitly equated De la Court's Interest van Holland with Grotius, Episcopius and the Public Gebedt. The pamphlet countered this Arminian tradition by arguing, in line with Voetius, that "the Church considered essentially in itself is not a part of Politics". ${ }^{8}$ Therefore, ecclesiastical

93 De Wit, Public Gebedt, vol. I: $37-48,52$, and the entirety of vol. III.

${ }_{94}$ Ibidem, vol. I, 45: “... in een Democratische by de Gemeente, als eertijts te Athenen, ende nu tot Zurich in Switserlant, ende in dezen Staat by de Staten van elke Provintie."

95 Ibidem, vol. II: esp. ch. 5 .

${ }^{96}$ Pieter de la Court to the brothers Van der Voort, 24 November 1663, in Kernkamp (ed.), "Brieven (1661-1666)," 143: "Het Vervolg van't Publik Gebedd behaagd mij ongemeen seer, sulks ik hoope dat de goede ingeseetenen meer en meer sullen prijsen de proceduren van hare wettige overheid, en verfoeien de gedurige gepretendeerde dominatie en dwinglandie der andere provintien omtrent Holland."

97 Den verresenen Barnevelt, betabbert met alle sijne politycke maximen (Zierikzee, 1663), 13: “... eenen veraerden, ongeurigen en verrotten Waal, die ... 't fundament vande Regeringe deser Landen om verre werpende met sijne schriften, en schadelijcke maximen tegen Unie en Gereformeerde Religie.”

${ }_{98}^{8}$ Ibidem, 37-38: "Nademael de Kercke in haer selven wesentlijck aengemerckt, niet en is een deel van de Politie." 
authority cannot be subordinated to secular authority. Those who serve God have another duty than those who govern the commonwealth, and hence there is no question of a divided sovereignty or imperium in imperio should the clergy remain independent of the magistracy. Rather, church and state each operate in their own distinct spheres. Since "that which is ecclesiastical does not belong to the Government but privately to the Servants of the Church", it is to the clergy to decide whom to pray for. In this way the pamphlet defended the "Freedom of praying" against the Erastian usurpation of the church propagated by De la Court cum suis. ${ }^{99}$

The controversy over the public prayer continued to dominate the public debate throughout the 166os. A subsequent pamphlet openly denounced Voetius as a "Scottish Devil" with "Jesuit maxims", an "arch master of mutiny" who propagated a treacherous blend of Catholicism and Presbyterianism..$^{100}$ In reply, the Voetians returned the accusation of sowing discord and endangering the social harmony. ${ }^{101}$ Both sides of the debate thus claimed to safeguard concord and peace against the rebellious assaults of the adversary. Eventually, the controversy also lured more radical freethinkers into the hazardous sphere of public disputation. Adriaen Koerbagh, a particularly non-conformist author who was close to Spinoza, clearly chose sides by championing the sovereignty of the States of Holland against the "Jesuit maxims" of the "Voetian consistorians". ${ }^{102}$ In 1665 , the dispute was taken at a higher theoretical level with the publication of the treatise Dejure ecclesiasticorum, issued in the fictional "Alethopolis" ("True-State") under the pseudonym of 'Lucius Antistius Constans'. Spinoza, Van Velthuysen and De la Court have all been suspected of hiding under this name, yet the least improbable candidate is Lodewijk Meijer, a graduate in philosophy and medicine

${ }_{99}$ Ibidem, 45-46: "Om dat't geene Kerckelijck is, niet den Overheydt maer de Dienaren van de Kerck privatelick toekomt ... Vryheydt van bidden, zijnde der Kercken machtighste wapenen, en die die Kercken noyt konnen ontnomen werden."

${ }^{100}$ Den Schotsen duyvel, betabbert in den verresenen Barnevelt ... met alle sijne Jesuitsche maximen van 't Presbyterisch convenant, en 't Utrechtsch Presbytery. Uyt de gemeene lessen en legenden van Gisbertus Voetius, aerts-muyt-meester (Utrecht, 1663). See also Herstelden Barneveldt, ofte t'samenspraeck tusschen een Hollander, Seeu ende Vries (Leiden, 1663).

${ }_{101}$ See esp. Der Remonstranten vocale letters (Schiedam, 1664), Consideratien op het publijck gebedt ofte gebede-formulier van Hollandt, tegen D.H. (Leeuwarden, 1663) and Nadere ofte tweede consideratien tegen het publijck gebedt (Leeuwarden, 1663).

${ }^{102}$ 'Vrederyck Waermont' [Adriaen Koerbagh], De souverainiteyt van Holland ende West-Vriesland ... Tot refutatie van den verresen Barnevelt (Middelburg, 1664): "Jesuytsche maximen en sustinuen ... Voetiaensche Consistorianten." On the authorship of this pamphlet, see Gerrit Jongeneelen, "An Unknown Pamphlet of Adriaan Koerbagh," Studia Spinozana 3 (1987), 405-415. 
from Leiden University and also a member of Spinoza's circle. Meijer's Philosophia sacrae scripturae interpres, published anonymously in 1666 in "Eleutheropolis" ("Free-State"), caused a major uproar for its radical subordination of theological dogma to rational inquiry and its rejection of the doctrine of the Trinity. ${ }^{103}$

The De jure ecclesiasticorum does not entail such a radical stance, yet it intervenes directly in the public debate with a comparably provocative attitude and pushes the Arminian legacy to the extreme. Condemning the "impious, inept \& pernicious Ambition of the Ecclesiastics of all ages", the treatise rejects any claim to ecclesiastical independence. ${ }^{104}$ It follows in the footsteps of Grotius and the brothers De la Court but radicalizes their theory of the establishment of the civil society. For the author of De jure, people leave the state of nature through a double pact, whereby all give up their right and power of judging and deciding how to lead their life. Accordingly, every single member of the civitas has agreed to "cease being Gods for themselves". Citizens surrender their natural right and power entirely to the sovereign magistrates, the prodii, those who "take God's place". ${ }^{105}$ No member of society can possibly be exempted from this double pact. As a result, all forms of social hierarchy (such as a public ministry) issue from the prodii alone: "All Inequality of the Ecclesiastics, which is not less or different than the inequality of other Citizens, proceeds only from the Prodii: There is no difference between them [i.e. the Ecclesiastics] and others. ${ }^{{ }^{106}}$ Rebutting every claim that the clergy enjoys distinctive privileges, De jure thus aims to prove that clerics are just ordinary citizens who always remain dependent on the favour of the sovereign, as does any other civil servant. ${ }^{107}$

${ }^{103}$ [Lodewijk Meijer], Philosophia sacrae scripturae interpres ('Eleutheropolis' [=Amsterdam], 1666). The library of De la Court van der Voort had a copy of this work: Library, fol. 17. For Meijer, see Israel, Radical Enlightenment, 197-217, and Van Bunge, From Stevin to Spinoza, 94-96. On the authorship of De jure ecclesiasticorum, cf. Wildenberg, Bibliografie, 30, and Israel, Radical Enlightenment, 201.

104 'Lucius Antistius Constans', De jure ecclesiasticorum ('Alethopolis', 1665), "Praefatio," sig. A4 v.: "ea impia, inepta \& perniciosa omnis aevi Ecclesiastcorum Ambitio." For a short analysis of the work, see Nobbs, Theocracy and Toleration, $245^{-250}$. See also Hans Blom, "Le contexte historique du De jure ecclesiasticorum" and Christian Lazzeri, "L.A. Constans entre Hobbes et Spinoza," in Du droit des ecclésiastiques, trans. V. Butori (Caen : Centre de philosophie politique et juridique, 1991), viii-xli.

105 'Constans', De jure, 22-25.

${ }^{106}$ Ibidem, 52: "Omnem Inaequalitatem Ecclesiasticorum non minus aut aliter, quam caeterorum Civium a solis Prodiis procedere: Nec ullum illorum \& horum discrimen esse."

${ }^{107}$ Ibidem, 64-152. 
This far-reaching Erastian argument relies on two important conceptions of religion as such. First, clearly following the Arminian tradition, the treatise distinguishes between internal and external religion. The former concerns the individual soul and can only be overseen by God, but the latter concerns all the 'corporal' aspects of religion and is fully administered by the clergy on the authority of the sovereign. The author of De jure emphasizes that speech too is a corporal action. Therefore the contents of public prayers are always to be supervised by the secular powers - an obvious reference to the controversy on the Public Gebedt. ${ }^{108}$ Secondly, De jure highlights the value of religion as a political tool. While Grotius and the De la Courts stressed the political importance of religion, the author of Dejure pushes their argument further by maintaining that the utilitas of religion can in fact be of more importance than its veritas. In other words, the prodii do not necessarily take the place of the one and only true God: they might propagate a specific creed only for its utility. ${ }^{109}$ The implications of this view would be developed further by Spinoza, whose Tractatus Theologico-Politicus, published in 1670, entails by far the most radical intervention in the Dutch debate on the relation between state and church and the political pretensions of the clergy. ${ }^{110}$

De jure was also read outside of the Republic, for example by Pufendorf, who referred to the treatise as support for his conception of the causes of inequality in civil society." ${ }^{111}$ Another keen reader of De jure was De la Court. In preparing the Aanwysing, De la Court saw his own ideas on the position of the clergy demonstrated by that "excellent" and "irrefutable book". It made him insist once more that the "potestas coercendi", the power of coercion, belongs only to the sovereign, "and from the same Political Power must descend all power and right of the Ecclesiastics, if they have any". ${ }^{12}$ In the end, perhaps because of his manifestly popular

${ }^{108}$ Ibidem, 2, 56-57.

109 Ibidem, 4.

${ }^{110}$ On Spinoza's “'theological-political' intervention”, see Etienne Balibar, Spinoza and Politics (London and New York: Verso, 2008), esp. 1-24. Pieter de la Court van der Voort owned copies of Spinoza's Tractatus Theologico-Politicus ('Hamburg, 1670') and of the Opera Posthuma by 'B.D.S.', published in 1677 . See Library, fol. 17. For the fascinating story behind the publication and distribution of Spinoza's works, see Israel, Radical Enlightenment, 275-294.

${ }^{11}$ See Pufendorf, De jure naturae et gentium III.II.9, discussed in Blom, "Le contexte historique," xix-xx.

${ }^{112}$ Aanwysing I.14, p. 61: "Want de Potestas coercendi, die dwingende magt niemande dan den Politiken is gegeeven; Ende van de selve Politike magt, ook alle magt ende regt op den Kerkeliken, indien sy eenige hebben, moet neederdalen." See also the qualifications of De jure as a "voortreffelik" and "onweederleggelik Boukjen" in Ibidem III.1-2, p. 407, 425. 
rhetoric, De la Court came to be seen as the principal spokesman of this Arminian theory of church and state. Years later, in 1674, many of the Voetian pamphlets concerning the controversy of the public prayer were republished as a general refutation of "the pernicious Maxims of La Court and others". ${ }^{113}$ And even after De la Court's death, a pro-Stadholder pamphlet of 1690 accused the "Main Article of the Arminian Faith, Build on the Foundations of Barnevelt, confirmed by so many lessons of Hugo Grotius ... and finally completed by Pieter la Court" ${ }^{114}$

Yet although his opponents overtly portrayed him as an Arminian, De la Court should not be characterized too hastily as a dedicated disciple of Remonstrant theology. Theological issues are all but absent from the writings of the De la Courts, and their adherence to the Arminian legacy is principally political: it is an intrinsic element of their republican account of civil society and their criticism of the monarchical desire to rule. This republican emphasis becomes clear in a number of passages that comment on the fate of religion in monarchies. The De la Courts assert that kings, easily misled by flattery and detrimental advice, "do not grasp the affairs of Religion at all" and "err from the truth or fear for God". This lack of devoutness and understanding leads to religious instability, for monarchs "are easily brought that far that they change from Religion ... and also remodel and embellish the entire public Religion according to their own or their Favourites' interest" ${ }^{115}$ The unadorned purity of Christianity, based on Scripture and the simplicity of the apostolic era, degenerates into artificial ornamentation when left to the whims of a monarchical court. Monarchs tend to support rebellious clerics in order to achieve their supremacy (with Henry IV, Cromwell, and William the Silent as revealing examples), and this clerical prominence poses an acute threat to the social concord and the stability of religion as such. ${ }^{16}$

\footnotetext{
${ }^{13}$ Recht-heylsame polityke en kerckelycke maximes, gestelt tegens de schadelijcke maximes van La Court, en andere (Utrecht, 1674).

${ }^{114}$ [Ericus Walten], Spiegel der waarheyd. Ofte t'samensprekinge tusschen een Arminiaan ende vroom patriot (s.l., 169o), 4: "Dit is 't Hoofd-Articul van 't Arminiaanse Geloof, Gebouwt op de Fondamenten van Barnevelt, bekrachtigt door soo veel Lessen van Hugo de Groot, op nieuws vermeerdert door Jan de Wit, ende Pieter de Groot, ende eyndelijk voltoyt door Pieter la Court."

${ }^{115}$ Politike Weeg-schaal I.I.25, p. 117-118: “... dat de Monarchen de zaaken van den Godsdienst gantsch niet doorgronden ... van de waarheit ofte Godvreesendheit afdwalen ... en dienvolgende werden de Monarchen ligtelik gebragt soo verre, dat sy van Religie veranderen ... als meede den geheelen publiken Godsdienst verfatsoeneeren, en verzieren; naar haar eigen ofte Favoriten interest." Cf. also Aanwysing III.7, p. 513-516.

${ }^{116}$ Aanwysing III.1-2, p. 398-400, 426-429.
} 
In sharp contrast, "the Republics, once having thrown off the yoke of the Papacy, have all together remained constant until today". ${ }^{117}$ A republican regime that utterly discards courtly or clerical demagogy is able to uphold a broad, consensus-based public church that keeps religion pure and stable. The sovereign control over the church, necessary to counter the pretensions of the clergy, is only possible in republics where that sovereignty belongs to an assembly of many. ${ }^{118}$ Moreover, the maintenance of a public church is easiest when that church is governed in a republican way, freed from papal and bishopric usurpation, by "a Church council, or Republican Ecclesiastical Office, with which the Liberty of the Republic would be better preserved". ${ }^{19}$ The political organization of the public church is more important than the particularities of its creed, the adiaphora of Christian faith. This fairly relativist attitude towards the contents of religious dogma becomes particularly clear in the remarkable plea of the brothers De la Court for the ultimate characteristic of a true commercial commonwealth: the toleration of dissenters.

\section{Toleration: PluRAlism For the SAKe of Unity}

\section{Dutch Toleration between Practice \& Theory}

What did toleration entail in the seventeenth-century Dutch Republic? This is an important question because the practice of religious co-existence in the Dutch Golden Age has often been heralded as an exceptional phenomenon that, though an anomaly in its own age, somehow prophesied the problems and promises of modern-day societies. At the same time, revisionist historiography has maintained that the relatively tolerant practices of the Dutch urban world entailed merely a pragmatic modus vivendi that lacked any principled theoretical underpinning. ${ }^{120}$ The rather paradoxical consensus on Dutch toleration in the seventeenth

${ }^{117}$ Politike Weeg-schaal I.I.25, p. 119: “... maar de Republiken, eenmaal het zware juk des Pausdoms afgeworpen hebbende, zijn al te saamen volstandig gebleeven tot huiden toe."

${ }_{118}$ Aanwysing III.1, p. 406-407.

${ }^{119}$ Ibidem III.2, p. 427-428: “... een Kerken-Raad, ofte Republikse Kerkelike Bedieninge, waarmede de Vryheid der Republike beeter bewaard soude weesen.”

${ }^{120}$ On the practice of early-modern Dutch toleration, see in particular the various essays in R. Po-Chia Hsia and H.F.K. van Nierop (eds.), Calvinism and Religious Toleration in the Dutch Golden Age (Cambridge: Cambridge University Press, 2002). For a comparative approach that puts Dutch toleration into international perspective, see Benjamin Kaplan, Divided by Faith. Religious Conflict and the Practice of Toleration in Early Modern Europe (Cambridge, Mass.: Harvard University Press, 2007). Cf. as well the revisionist essays on early-modern European toleration in Ole Peter Grell and Bob Scribner (eds.), 
century seems to be that the United Provinces were characterized by a far-reaching practice of toleration as compared to other European polities, while toleration as a theoretical ideal was mainly formulated outside of the Netherlands - or at best by foreigners confronted with the realities of Dutch religious co-existence such as John Locke and Pierre Bayle. As a result, the varying degrees of toleration of seventeenth-century Dutchmen are often judged along a modern standard of what it means to be tolerant, yet what the concept of toleration meant to those Dutchmen themselves has thus far received little detailed analysis. ${ }^{121}$

For early-modern Europeans, the Latin tolerantia had the obvious connotation of a burden that had to be borne for the sake of a lesser evil. In order to overcome the religious conflicts that shattered Europe in the wake of the Reformation, such forbearance of difference and disagreement was considered necessary for the maintenance of social peace. Yet importantly, it was not seen as a goal in itself. Thus, toleration (in Dutch tolerantie or verdraagzaamheid, the literal equivalent to forbearance) did not originally imply the unconditional acceptance of otherness as a virtue, but rather the provisional connivance with diversity as the only means to counter open conflict. Toleration therefore bore the suggestion of Biblical patience, the temporary endurance of evil so that eventually, unity and concord within society could be re-established. In short, the foundation and the ideal of toleration was not the celebration of pluralism but the search for common ground. Because of this communal connotation of the concept, toleration usually implied a collective permission to a dissenting group on the authority of the civil power. Contrary to its modern significance as an individual, moral quality actively pursued by one individual and open for another to claim as an innate right, in the seventeenth century toleration involved a revocable license granted by the magistracy for the sake of order and stability. Toleration therefore meant political interference, paradoxically as it may sound to modern

Tolerance and Intolerance in the European Reformation (Cambridge: Cambridge University Press, 1996), and Ole Peter Grell and Roy Porter (eds.), Toleration in Enlightenment Europe (Cambridge: Cambridge University Press, 2000).

${ }^{121}$ For some notable exceptions, see Israel, "Intellectual Debate"; Marshall, Locke, Toleration; and Joris van Eijnatten, Mutua Christianorum Tolerantia. Irenicism and Toleration in the Netherlands: the Stinstra affair, 1740-1745 (Florence: Olschki, 1998). See also Willem Frijhoff, "The Threshold of Toleration. Interconfessional Conviviality in Holland During the Early Modern Period," in Idem, Embodied Belief. Ten Essays on Religious Culture in Dutch History (Hilversum: Verloren, 2002), 39-65. For the English case, see Alexandra Walsham, Charitable Hatred. Tolerance and Intolerance in England, 1500-1700 (Manchester and New York: Manchester University Press, 2006) 
ears: while its present-day meaning is intrinsically linked to the conception of a separation between church and state, early-modern toleration implied the active intervention of the state in matters of faith. ${ }^{122}$

Thus in the seventeenth-century Dutch Republic the debate on toleration was intrinsically linked to the debate on the sovereignty in ecclesiastical affairs and the political role of the church. The Arminian plea for a public church supervised by the state left the private exercise of freedom of conscience as an inviolable asset beyond the coercive powers of the sovereign. However, this defence of freedom of conscience did not necessarily entail a tolerationist attitude as regards religious dissenters. In its earliest stages, Arminianism in fact proved to be anything but tolerant towards religious diversity. ${ }^{123}$ Both Uytenbogaert and Grotius advocated severe measures against those forms of worship that exceeded the limits of the public church. It was only after 1618 , when the Arminians themselves became the victims of persecution, that they started to plead openly for religious toleration. As Andrew Pettegree has remarked, early-modern toleration was "only ever likely to be the party cry of the disappointed, the dispossessed, or the seriously confused", in short, "it was only ever a loser's creed". ${ }^{24}$

The main Arminian representative of this loser's creed was Episcopius. His 1627 pamphlet Vrye godes-dienst ["Free Worship"], different to his theological work published in the vernacular, entailed perhaps his most manifest intervention in the Dutch public debate. The pamphlet stages a dialogue between a Remonstrant and a Contra-Remonstrant on the issue of religious diversity. With this literary form Episcopius rhetorically emphasizes the importance of open conversation to overcome confessional disagreement. At the start of the dialogue the Contra-Remonstrant character insists on the necessity of force to punish dissenters. He negates the utility of discussion, because "our religion is a pure, sheer gift of God" which therefore transcends any form of debate or doubt. ${ }^{125}$ However, in

${ }^{122}$ See the lucid discussion in Van Eijnatten, Mutua Christianorum Tolerantia, 7-21, and cf. Kaplan, Divided by Faith. Van Eijnatten insists on the conceptual distinction between 'tolerantie', i.e. active non-discrimination, and 'verdraagzaamheid' in the sense of passive forbearance, yet I am not convinced that this distinction holds for the seventeenth century: the brothers De la Court, for example, used both terms interchangeably.

${ }_{123}$ See Israel, "Intellectual Debate," 11, and Marshall, Locke, Toleration, 344-345.

${ }^{124}$ Andrew Pettegree, "The Politics of Toleration in the Free Netherlands, 1572-1620," in Grell and Scribner (eds.), Tolerance and Intolerance, 182-198: 198.

${ }_{125}$ [Simon Episcopius], Vrye godes-dienst, of t'samen-spreeckinghe tusschen Remonstrant en Contra-Remonstrant (s.l., 1627), 7: “... soo is onse gheloof een puere loutere gave Godts, die alleen van Godt komt, sonder eenighe onse toedoen. 'T Disputeeren, 't krackeelen helpt daer niet meer toe." 
the course of the dialogue the Contra-Remonstrant gradually comes to perceive that matters are more complex. Eventually the conversation challenges his earlier certainties and brings him closer to the position of his Remonstrant challenger. Episcopius thus shows that dialogue is an essential means to solve differences of faith peacefully, and that the truth is not given a priori but that it must be found through a collective endeavour. The pamphlet both propagates and performs this Erasmian, irenicist ideal. $^{126}$

To persuade his opponent, the Remonstrant character in Vrye godesdienst stresses the Biblical virtue of loving one's neighbour and continues with an exposition of the main principles of the Arminian theory of a public church. Here Episcopius crucially departs from his Arminian predecessors by admitting room for religious dissent outside of that public church. In this way, he broadens freedom of conscience to freedom of worship and expression. ${ }^{127}$ The pamphlet emphasizes that "everyone is always and anywhere, be it in a Kingdom or in a Republic, free and permitted to declare his feeling about Religion and to let it know to others" ${ }^{128}$ The only condition for such a public affirmation of faith is that it does not go against the civil law, even though there should always be opportunity for private congregations to convene in secret - a clear defence and rationalization of the practical connivance of schuilkerken, clandestine churches, in the Dutch Republic. ${ }^{129}$ In line with this judgment, Episcopius also advocates the toleration of Catholics, at least if they act in accordance with the law, for "where freedom of conscience is advocated, there anyone should enjoy it, or else it would not be true freedom. That which is free must be common, or else it becomes again coercion". ${ }^{130}$

This significant, principled defence of a broad conception of religious freedom obviously entails much more than a deliberate but unconvinced pragmatist attitude, as seventeenth-century Dutch toleration has often been characterized. Episcopius unequivocally stresses the value of a

${ }^{126}$ Cf. Remer, Humanism and the Rhetoric of Toleration, esp. 43-101. For a slightly different interpretation, which stresses the polemical aspects of Epsicopius' dialogue, see Sierhuis, "A Babel Full of Confusion", 322-324.

${ }^{127}$ For Episcopius' theory of toleration, see Israel, "Intellectual Debate," 18-20, Marshall, Locke, Toleration, 351-354, and Nobbs, Theocracy and Toleration, 94-107.

${ }^{128}$ Epsicopius, Vrye godes-dienst, 16: “... dat een yeghelijck altijdt en overal, 't zy in een Coninghrijck, 't zy in een Republijcke, vry en gheoorloft is sijne ghevoelen van de Religie te verklaren en anderen mede te deelen."

${ }_{129}$ Cf. Kaplan, Divided by Faith, 172-197.

${ }^{130}$ Episcopius, Vrye godes-dienst, 44: "Want daer vryheydt van conscientie voorghestaen wordt, daer moet elck een die genieten, of het is geen rechte vryheyt: Dat vry is moet gemeen zijn, of het wort wederom dwangh." 
diversity of religious beliefs, for "the more convictions, the less danger and fear. The one balances the other, and the majority always easily weighs more than one that would desire to take the upper hand. Freedom itself is a remedy against all inequality and disaster" ${ }^{1{ }^{131}}$ With this claim Episcopius also advocates religious freedom as a political tool, as a means to counter instability and social discord by mutually attaching all citizens of different creeds to the commonwealth. As the Remonstrant protagonist in the dialogue tells his opponent, those who undermine the concord of the Republic are in fact the intolerant Contra-Remonstrant ministers. They mislead their congregations with dangerous paradiastole, "calling the virtues sins, the sins virtues, good evil, evil good, light darkness, darkness light". ${ }^{132}$ A tolerationist policy counters such deceitful, demagogical speech, Episcopius suggests. However, it is important to stress that his principled plea for the toleration of dissent does not involve a variety of public churches, but rather, true to Erasmus's irenicist ideal, one broad and inclusive public church that encompasses a variety of mutually accommodating opinions and beliefs. ${ }^{133}$ In short, for Episcopius too, the goal is unity, not plurality per se.

Three years later, in 1630 , Uytenbogaert expressed the very same desire for "variety on the unity of the foundation" in a pamphlet that defended Epsicopius's plea for toleration against its refutation by Henricus Arnoldi, a Contra-Remonstrant preacher and pamphleteer from Delft. ${ }^{134}$ Arnoldi basically argued that, following the spirit of the Dutch Revolt, freedom of conscience should be guaranteed, but that such freedom does not involve freedom of worship. Instead, further toleration of public congregations like the Remonstrants would, according to Arnoldi, endanger social concord and sow chaos and conflict. ${ }^{135}$ In reply, Uytenbogaert recapitulated

${ }^{131}$ Episcopius, Vrye godes-dienst, 37: “... hoe meerder ghesintheden, hoe minder perijckel en vreese. D'een houdt d'ander in ghewichte en balance, en de meeste overweghen altijdt licht eenen, die de Meester soude willen maken. De vryheyt selve is een remedie teghen alle onghelijck en onheyl."

${ }^{132}$ Ibidem, 54-55: "Sy noemen de deughden sonden, de sonden deughden, het goed quaedt, het quaedt goed, licht duysternisse, en duysternisse licht."

${ }_{133}$ Israel, "Intellectual Debate," 19, states that Episcopius advocated "a plurality of churches", but I have only found evidence that Episcopius argued in favour of a plurality of convictions ("ghesintheden"), which is something else. Cf. also Marshall, Locke, Toleration, 354 .

${ }_{134}$ [Johannes Uytenbogaert], Voorstant van de vryheyt der conscientie, teghen den conscientie-dwangh van Henricus Arnoldi vander Linden (s.l., 1630), 34 (marginal): "Men moet de verscheydenheyt op d'eenicheyt van 't fondament verdraghen."

${ }^{135}$ Henricus Arnoldi vander Linde, Vande conscientie-dwangh (Delft, 1629). For a short analysis of this pamphlet, see Israel, "Intellectual Debate," 17-18, and H.A. Enno van Gelder, Getemperde vrijheid. Een verhandeling over de verhouding van Kerk en Staat in de 
the main principles of the Arminian theory of church and state. He insisted that a variety of publicly propagated beliefs would not undermine the social stability, given that "such a variety does not create various Christian Churches, but various parts (though the one purer or scabbier than the other) of one General Christian Church". ${ }^{136}$ This revealing statement makes clear that for Uytenbogaert, toleration did not extend beyond the borders of Christianity, while within those borders as well, one 'pure' (read: Remonstrant) interpretation of Scripture should be preferred.

As Jonathan Israel has convincingly shown, "the great Dutch toleration debate" of the late 1620 s eventually instigated a looser, more flexible political climate in which the Remonstrants and other dissenting religious groups were, at least in some towns in the Republic, able to obtain permission for the public practice of their beliefs. ${ }^{137}$ However, the limits to such toleration remained the object of dispute. Certain cities, most notably Leiden, continued a strong repressive policy of heterodox congregations. It might be argued that the overall result of the debate was a relatively lenient attitude as regards conventional diversity within Protestantism, for example towards Lutherans and Anabaptists, while more radical deviations from the norm fell victim to renewed repression. In the orthodox camp, Voetius insisted on the Christian duty of clemency and moderatio so as to reinstall peace and concord, a notion that opened the way to a certain degree of toleration within the Reformed church. ${ }^{138}$ He stressed that individual conscience is only answerable to God and that compulsion cannot engender true faith, thus acknowledging that people should be allowed to worship as they want in private. ${ }^{139}$ Yet in public, the truth should remain triumphant. Therefore all 'heretics' who deny the fundamentals of faith ought to be banned from the church, and thus, from

Republiek der Verenigde Nederlanden en de vrijheid van meningsuiting in zake godsdienst, drukpers en onderwijs, gedurende de 17 e eeuw (Groningen, 1972), 238-240.

${ }^{136}$ Uytenbogaert, Voorstant van de Vryheyt der Conscientie, 35: “... welcke verscheydenheyt als dan maeckt, niet verscheyden Christelijcke Kercken, maar verscheyden deelen (doch d'een suyverder of schurfter als 't ander) van eene Alghemeyne Christelijcke Kercke."

${ }_{137}$ Israel, "Intellectual Debate," 18, 20-21; and Idem, Dutch Republic, 637-638.

${ }_{138}$ See Van Eijnatten, Mutua Christianorum Tolerantia, 18-19, and esp. Aart de Groot, "Heterodoxie, Häresie und Toleranz in der Sicht von Gisbertus Voetius (1589-1676)," in Henry Méchoulan et al. (eds.), La formazione storica della alterità. Studi di storia della tolleranza nell'età moderna offerti a Antonio Rotondò, 3 vols. (Florence: Olschki, 2001), vol. II: 517-539. See also O.J. de Jong, "Voetius en de tolerantie," in J. van Oort et al. (eds.), De onbekende Voetius (Kampen: J.H. Kok, 1989), 109-116.

${ }_{139}$ Voetius, Politicae ecclesiasticae partis primae, vol. II, esp. IV.I.2 ("De libertate conscientiae \& permissione religionum in Republica"). 
the official religious life. Given Voetius's view on the relation between state and church, he left it to the civil authorities to decide whether these 'sects' should be permitted in the civil sphere, but he also contended that the sovereign could not support the propagation of a false religion..$^{140}$

In line with Voetius's decrees, a gradual Catholic revival and the growing influence of Socinianism prompted a renewed offensive to counter the spread of heterodoxy over the course of the 1640 s and 1650s. In 1653, the States of Holland issued a far-reaching decree against all forms of Socinianism, which set severe limits to toleration for decades to come. ${ }^{141}$ Theologians such as Voetius insisted on the necessity to eradicate hidden anti-Trinitarian beliefs among Remonstrant circles, which thus remained the victim of repression. ${ }^{142}$ As a result, the main propagators of toleration in the second half of the century continued to come from the ranks of Arminianism. Adriaan Paets, a Rotterdam regent who was close to the free-thinking Collegiant movement, reacted against the persecution of Socinianism with a number of pamphlets that highlighted the peacefulness of true faith and condemned the "heerszucht, rebelliousness, rigidity, and greediness" of the "reformed Papists" .143 Some years later, in 166o, Van Velthuysen published a comparable pamphlet in which he defended the right and duty of the state to tolerate religious dissent. He insisted repeatedly that such toleration follows from the maxim "God desires mercy and not offering". ${ }^{144}$ In a direct confutation of Voetius, Van Velthuysen further asserted that political necessity and the unenforceability of conscience demand that certain "sins" be tolerated. The fundamental Christian commandment of loving one's neighbour asks for hospitality towards those

${ }^{140}$ Nobbs, Theocracy and Toleration, 208, and De Groot, "Heterodoxie," 533-536. Cf. on the justification of persecution in England: Mark Goldie, "The Theory of Religious Intolerance in Restoration England," in Ole Peter Grell et al. (eds.), From Persecution to Toleration: The Glorious Revolution and Religion in England (Oxford: Oxford University Press, 1991), 331-368.

${ }^{141}$ Israel, Dutch Republic, 911-912.

${ }^{142}$ Voetius, Politicae ecclesiasticae partis primae, vol. 2, IV.I.9-10, p. 529-58o. Cf. Marshall, Locke, Toleration, 368, and De Groot, "Heterodoxie," 530-532.

${ }^{143}$ [Adriaan Paets], Antwoord, van een Gereformeerdt Hollander, op een klaagbrief van N.N. Over zommige onrustige Rotterdamsche Predicanten, en voornamentlijk Iacobus Borstius (s.l., 1654); Idem, Sedig antwoord van N.N. Gereformeerd Hollander ... Waar in bewesen werd dat de dwalende als soodanige niet strafbaar zijn door uyterlijk geweld (Leiden, [1655]); Idem, Fabula vetus actores novi. Dat is, de oude paep onder een nieuwe kap (s.l., 1656): “... heersucht, oproerigheyt, precijsheyt, geltgierigheyt \&c. ... dese hervormde Papen." On Paets, see Enno van Gelder, Getemperde vrijheid, 245-249.

${ }^{144}$ Van Velthuysen, Ondersoeck of de Christelijcke Overheydt eenigh quaedt in haer gebiedt mach toe laeten, 140: "Laat ons altijdt dencken dat Godt barmherticheydt en geen Offerande begeert." 
who flee from persecution, such as Jews, "if there is no hope that they will be received elsewhere". ${ }^{145}$ Nevertheless, Van Velthuysen also made clear, referring to Catholics, that the magistracy has the authority to ban "the external practice of a false Religion". ${ }^{146}$

Another active Arminian champion of irenicism and secular interference in religion was Gerard Brandt. His aptly titled didactic poem De vreedzame Christen ["The Peaceful Christian"] denounced clerical ambition and pride for creating discord. Brandt argued for apostolic simplicity, mutual forbearance and the agreement on the fundamentals of faith, which, so he hoped, established a broad public church supervised by the civil authorities that would be "a devourer of all sects". ${ }^{147}$ He sent a copy of the poem to Van Velthuysen, and he dedicated the 1665 collection of poetry in which it was published to Pieter de Groot. ${ }^{148}$ In the 1670 , Brandt would gain fame for his historical overview of the Dutch Reformation, the Historie der Reformatie ["History of the Reformation"], a work in the vein of Uytenbogaert that involved a similar Erasmian, anti-clerical and irenicist plea for concord and toleration. ${ }^{149}$ Brandt's colleague at the Remonstrant Seminary of Amsterdam, Philippus van Limborch, proved to be at least as important for the continuation of the Arminian ideal of toleration. Van Limborch was related to Episcopius, whose manuscripts he had inherited, and also by marriage to De Groot. In 1661, he published a tolerationist pamphlet in the form of a dialogue akin to Episcopius's rhetorical strategy of Vrye godes-dienst. ${ }^{150}$ Throughout the next decades, he

145 Ibidem, 296: “... die arme Joden te ontfangen, te herbergen, en verblijf te geven, als er geen hoop is, dat sy elders sullen ontfangen worden."

${ }^{146}$ Ibidem, 128-129: "Soo kanmen dan besluyten, dat een uyterlijck bedrijf van een valschen Gots-dienst, in voege voor-haalt, door de Regenten souden mogen geweert worden."

${ }^{147}$ See Joris van Eijnatten, "Lodestars of Latitude. Gerard Brandt's Peacable Christian, c. 1664, Irenicism and Religious Dissent," LIAS. Sources and Documents Relating to the Early Modern History of Ideas 26 (1999), 57-75: 62 ("een verslindster aller sekten").

${ }^{148}$ Ibidem, 71-72.

${ }_{149}$ Gerard Brandt, Historie der Reformatie, en andre kerkelyke geschiedenissen, 4 vols. (Amsterdam, 1671-1704). See for this work Peter Burke, "The Politics of Reformation History: Burnet and Brandt," in Alistair Duke and C.A. Tamse (eds.), Clio's Mirror. Historiography in Britain and the Netherlands (Zutphen: Walburg Pers, 1985), 73-85. For some remarks on its reception, cf. Christine Berkvens-Stevelinck, "La reception de l'Historie der Reformatie de Gerard Brandt et son influence sur la conception de la tolérance hollandaise," in Idem et al. (eds.), Emergence of Tolerance, 131-140.

${ }^{150}$ Philippus van Limborch, Korte wederlegginge van 't boexken onlangs uytgegeven by Iacopus Sceperus ... by vorme van 't samen-sprekinge tusschen een Remonstrant en Contraremonstrant (Amsterdam, 1661), esp. 160-162, which directly quotes from Epsicopius' Vrye godes-dienst. 
republished Episcopius's theological works. He recommended these works (as well a hiding place) to an English exile in Holland, who in reply honoured Van Limborch as the addressee of his 1689 Epistola de Tolerantia. John Locke's famous intervention in the English debate on toleration was thus to a large extent also a part of the Dutch Arminian legacy. ${ }^{151}$

\section{Cultivating Diversity}

The theory of toleration of the brothers De la Court shares many of the arguments in favour of religious liberty that were raised from Episcopius onwards. Yet their tolerationist stance also involves a more inclusive dimension in its explicit plea for the connivance of the public exercise of a variety of different religions, most importantly Catholicism. Combining a principled defence of the freedom of religion with a pragmatic claim of the utility of confessional diversity, this plea is an essential element of the brothers' commercial republicanism. Moreover, it is one of the main features that set the De la Courts apart from many of their republican contemporaries across the North Sea.

The starting-point of the brothers' conception of toleration is their analysis of the roots of intolerance, an analysis that stems directly from their reproof of clerical pedantry and imperiousness. Religious persecution, so the De la Courts argue, is primarily caused by the desire to rule over others. When left uncontrolled by the magistracy, clerics are particularly cursed with this imperious desire, and hence they slander and persecute those who disagree with them. A main perpetrator of such "odio Theologico" is of course the Catholic Inquisition. Yet "it would be greatly surprising when the Clerics in Holland, if they could, would not want to follow the same human conduct to the detriment of the Country, whenever that should conduce to the increase of their own profit, honour, power, and greatness" ${ }^{15^{2}}$ For the De la Courts, there is ample evidence that every dominant creed starts to persecute others, even if it has itself

${ }^{151}$ For Van Limborch, see P. J. Barnouw, Philippus van Limborch (The Hague: Mouton \& Co., 1963) and cf. for his contacts with Locke: Marshall, Locke, Toleration, esp. 481-482. On the international resonance of Dutch notions of toleration, in particular at the end of the seventeenth and the start of the eighteenth century, see also Antonio Rotondò, Europe et Pays-Bas. Evolution, rééleboration et diffusion de la tolerance aux XVIIe et XVIIIe siècles (Florence: Università degli Studi, 1992).

${ }^{15^{2}}$ Aanwysing I.14, 60, 63-64: “... soo soude grooteliks zijn te verwonderen, indien de Kerkelijken in Holland, den selven menschelijken trant ten verderve des Lands konnende, niet souden willen, involgen; soo wanneer die tot vermeerdinge van haare eigen profijt, eere, magt, ende grootheid zoude strekken." 
been a victim of such persecution in the past. In short, intolerance does not "stem from the wrongness of Religion, but from the wickedness of men". ${ }^{153}$

To counter this intrinsic human evil, the De la Courts firstly insist on the antidote offered by Christian revelation as such, unaffected by clerical abuse. With a biblical message often used by advocates of toleration, they stress that it is both an "Evangelical Lesson and the Law of Nature to do nothing unto another but what you want another to do unto you". ${ }^{54}$ A quote from psalm 73 as well as numerous references to the Old and the New Testament serve as a further proof that "a reasonable Christian Religion is alien to all coercion", for "the right path of true Christianity consists of enduring and not committing violence to other People". ${ }^{155}$ Since the power of coercion is exclusively exercised by the civil authorities, Christian ministers have no right to use any force but only to teach and advise their flock "all the Christian virtues" - narrowly defined as the trust in God, the hope of a blessed afterlife, and the love of God and of one's neighbour. These virtues are purely internal and voluntary and therefore only mouldable by peaceful persuasion, for "it is impossible to make someone by compulsion hope for something he cannot apprehend to be well-founded". Faith exists "internally in Spiritu \& Veritate", and though the "evil imperious maxims of the Clergy" infringe this inner Christian spirit and truth, "the Gospel teaches us that they ought not be Lords over the People, but its Servants, and the Servants of the Word of God". ${ }^{156}$ Accordingly, the particular order of civil society, the teachings of the Bible and the law of nature necessitate that clerics and all other citizens refrain from persecution.

${ }^{153}$ Politike Weeg-schaal III.I.3, p. 526: “... dit niet te spruiten uit de verkeertheit der Religien, maar uit de boosaardigheit der menschen." Cf. also Politike Discoursen II.IV.5, Sinryke Fabulen, 330-331.

${ }_{154}$ Aanwysing I.18, p. 83-84: “... de Evangelisse Lesse en de Wet der Natuure: Doe een andere niets, dan 't gunt gy wild dat een ander u doe." Cf. the title page of William Walwyn, The Compassionate Samaritane (s.l. [London], 1644).

155 Sinryke Fabulen, 329, 367: “... den regten weege des waaren Christendoms, bestaande in geweld te lijden, ende niet te doen van ende aan andere Menschen, maar te ooverreeden die men bekeeren wilde, afgedwaald zijnde ... eenen reedeliken Christeliken Godsdienst, die vremd van alle $d$ wang is." The last passage refers to Matth. 4:13, Rom. 12, and Genesis 10.

${ }^{156}$ Aanwysing I.14, p. 61-62, 64: “... den menschen te Leeren ende te Raaden alle Christelijke Deugden ... bestaande alleen in onse innerlike gedagten der Ziele ... innerlik in Spiritu \& Veritate ... daar ook het Evengelium ons leerd, dat sy geene Heeren over Menschen, maar der selver Dienaars des Goddeliken woords behoorden te zijn ... dese quaade heersugtige maximen der Geesteliken ... hoe onmogelik het is iemand door dwang te doen hoopen, het gunt hy niet kan vatten wel gefondeerd te weesen." 
Apart from contradicting divine, natural, and civil law, religious persecution also proves to be useless and even counterproductive, endangering the concord within society. Since individual conscience cannot possibly be compelled by humans, the only result of intolerance will be that "the persecuted are by compulsion completely made averse of the truth of the public Religion and stubborn in their own errors". ${ }^{157}$ Civil and religious warfare is then the inevitable consequence. Therefore, the sovereign (which does possess the power of coercion, at least as regards the outward exercise of religion) should equally refrain from persecution. "Compulsion in Religion is very detrimental to the Rulers", for persecution of dissenters will only "stiffen" the clerics in their zeal, who will then incite the masses, win over members from the government, and ultimately subvert all stability. ${ }^{158}$ If anything, "persecutio semen Ecclesiae", persecution breeds sects: instead of engendering unity, it creates a plurality of heresies. ${ }^{159}$ Intolerance thus fundamentally undermines its own objective.

This argument that religious persecution is highly unadvisable from the perspective of reason of state makes clear how the brothers De la Court depart from the principles of Lipsius's stoic garden. At the height of the confessional warfare during the Dutch Revolt, Lipsius advised political rulers to rigorously curtail religious fanaticism in order to safeguard social concord. Political stability was essential to protect freedom of conscience in private, Lipsius insisted, but for that purpose public manifestations of confessional diversity had to be punished ruthlessly. "One religion is the author of unity; and from a confused religion there always grows dissension", as a famous passage in his 1589 Politica runs. ${ }^{160}$ For Lipsius the rational management of society required the forceful implementation of one single creed, not for the sake of truth, but for the sake of utility. This view provoked an important controversy when his contemporary, the polemicist Dirck Coornhert, reacted by stating that such a stance implied an unacceptable subordination of the true Word of God to mere political expediency. For Coornhert toleration was a moral, Christian imperative,

${ }^{157}$ Ibidem, 65: “... sulks de gepersecuteerden allesins door dwang vande waerheid des publiken Gods-dienst afkeerig, ende in haare eigene dwaalingen halsterrig gemaakt werden." Cf. Politike Discoursen II.IV.3, p. 25.

${ }^{158}$ Welvaren 65, p. 144: "Dat dwangh in Religie den Regeerderen seer schadelijck is ... dat door de vervolgingen de auctoriteit der publijke leeraeren dapper werd gestijft."

${ }_{59}$ Politike Discoursen II.IV.8, p. 57.

${ }^{160}$ Justus Lipsius, Politicorum sive civilis doctrinae libri sex (Amsterdam, 1632) IV.2, p. 107: "Unionis auctor illa una: \& a confusa ea, semper turbae." See also the short treatise De una religione adversus dialogistam liber, written by Lipsius in 1591 to clarify his views on persecution and added to most later editions of the Politica. 
and because persecution could impossibly compel the inner soul, toleration was also a necessary means to uphold harmony within society. The alternative would be turmoil and strife, and Coornhert maintained that if all worship was overseen by the magistracy, the purity of Scripture alone would guarantee social peace. ${ }^{161}$

Lipsius and Coornhert thus articulated diametrically opposed solutions to what Richard Tuck has called "the central dilemma of the age: if religious strife and persecution were to be avoided, the power of the state in religious matters had to be upheld" ${ }^{162}$ The brothers De la Court, confronted with the same dilemma, occupy a position that lies somewhere in between. They adopt Lipsius's perspective of reason of state, but discard his plea for persecution as unfeasible and counterproductive. Thus they agree to Coornhert's argument for toleration, yet with a decidedly less resounding spiritualist overtone. For the De la Courts the cultivation of concord implies the curtailment of religious fanaticism, and hence the strong supervision by the sovereign of the public religious life. At the same time, it also entails a pragmatic acceptance of confessional diversity.

The principled pragmatism that underscores the brothers' tolerationist theory is most apparent in the reason of state argument that openness towards religious dissenters attracts foreigners and thus increases a state's competitiveness with neighbouring polities. "Freedom or Toleration as regards the various external Religions is the most powerful means to maintain in Holland many Residents, and to attract foreign Inhabitants from the surrounding Countries hither to reside", as the title of one of the key chapters of the Aanwysing announces. Referring to the fate of the cities of Lübeck, Cologne, and Aachen, this chapter emphasizes the detriment of religious persecution for those polities that are dependent on trade. Commerce is highly volatile and therefore easily chased away; because of the importance of religion for every human being, merchants who are persecuted for their beliefs will simply settle in another country where they can enjoy greater liberty. This is proven by the desolateness of the German cities, which have since the Reformation lost all their former splendour and riches due to the "impiety" of their clergy,

${ }^{161}$ On the controversy between Lipsius and Coornhert, see Van Gelderen, Political Thought, 251-256. Cf. for the extent of Coornhert's concept of toleration also Marshall, Locke, Toleration, 340.

${ }^{162}$ Richard Tuck, "Scepticism and Toleration in the Seventeenth Century," in Susan Mendus (ed.), Justifying Toleration. Conceptual and Historical Perspectives (Cambridge etc.: Cambridge University Press, 1988), 21-35: 30. 
who "teach that it is better to have a pure-religious depopulated Town than one that is very populous and religious, but infected with heresy". For De la Court, of course, the opposite is the case. Therefore he insists on the usefulness "of granting all Inhabitants a larger freedom in the exercise of Religion than they enjoy in other countries". ${ }^{163}$ Freedom of religion, in short, is an essential element of the liberty that defines a true commercial commonwealth.

This explicit connection between religious liberty and commercial prosperity did not come out of a void. Coornhert already linked toleration to riches, ${ }^{164}$ and in 1619 the Remonstrant ministers of Leiden similarly defended "freedom of conscience and the connivance of several Christian convictions" as a means of increasing the population and promoting "industry and welfare". ${ }^{165}$ Passchier de Fijne, a Leiden minister and one of the Remonstrant pamphleteers of the 1620 , also argued that persecution undermines prosperity. ${ }^{166}$ And so did Vondel, who unfavourably compared the bleak fate of repressive Leiden to the more tolerant policy of Amsterdam, where "the merchant reaches to the elbow in gold". ${ }^{167}$ In short, the argument that toleration stimulates prosperity was far from new, and importantly, it was raised frequently in Leiden, a city that depended heavily on foreign immigration, yet also practised one of the most strictly orthodox policies as regards religious dissent.

The brothers De la Court adopted this plea for toleration on commercial grounds and turned it into a general rule, into a political principle of

${ }^{163}$ Aanwysing I.14, p. 59, 65-66: "Dat vryheid ofte Tolerantie omtrent de vesrchillende uiterlike Gods-diensten, is het kragtigste middel, om in Holland veele Inwoonders te behouden, ende vremde Ingeseetenen uit de omleggende Landen herwaarts ter woone te trekken ... leeren, dat het beeter is eene suiver-geloovige ontvolkte, als eene seer vol-rijke, geloovige; dog met ketterie besmette Stad te hebben ... allen Ingeseetenen in het stuk van exercitie der Religien toe te laaten eene grootere vryheid, als sy in andere landen genieten."

${ }^{164}$ See Van Gelderen, Political Thought, 255.

${ }^{165}$ Brandt, Historie der Reformatie, vol. III: 756 (quoting the 1619 petition): “... dat door de vrijheit van conscientie en dulding van verscheide Christelijke gesintheden in de Religie, niet alleen dese Landen en insonderheit dese ons stadt Leyden, maer ook verscheide andre Landen en Steden, treffelijk sijn opgesteegen, gebloeit hebben, en als noch bloejen; ende dat de geenen, dier contrarie wegen ingingen, verloop van volken en aftrekking van vertier, neering en welvaeren hebben geleden."

${ }^{166}$ [Passchier de Fijne], Een broederlicke vermaninge: waer in vertoont wort d'ellende onses lieven Vaderlants (s.l., 1624).

${ }_{167}$ Vondel, "Haec libertatis ergo, papieren geld geoffert op het auteaer van de Hollandsche Vryheyd," in Werken, vol. III: 333: "Soo tast de koopman tot den elleboogh in 't goud." For Vondel's views on religious toleration, see Sierhuis, "A Babel Full of Confusion", 324-337. 
potentially universal applicability. As a result, this principle would also resonate outside of Holland, in particular across the North Sea. The English republican Slingsby Bethel, who had been exiled in the Dutch Republic and proved to be a keen reader of the De la Courts, took up the argument in an anti-Cromwell pamphlet of 1668 and subsequently in his ${ }_{1671}$ treatise The Present Interest of England Stated. Referring directly to the Interestvan Holland, Bethel insisted that "Imposition upon Conscience, hinders the resort of Strangers, and so the encrease of people, [and it] drives the soberest, and most industrious sort of Natives into corners, leaving trade into too few hands" ${ }^{168}$ In a short essay of 1674 , Locke too mentioned "freedom of religion" as one of the main "promoters of trade". ${ }^{169}$ Towards the end of century, the argument had become a commonplace element of political and economic thought in England. William Petty and Josiah Child, for example, praised liberty of conscience as one of the main causes of Dutch commercial greatness. ${ }^{170}$ John Toland continued in the same vein by stating that "where there is no Liberty of Conscience there can be no civil Liberty, no Incouragement of Industry, no proper means of rending the contry populous". ${ }^{171}$

Yet there is one particular aspect that sets the De la Courts' plea for toleration apart from many of their English contemporaries who advocated religious freedom, from Milton and Harrington to Bethel and Locke: their unequivocal acceptance of Catholicism. In England, the Catholic minority was mistrusted to such a degree that most Protestant propagators of toleration insisted that Catholics should not be tolerated. For Milton, "Popery" was on a par with "open superstition, which as it extirpats

${ }^{168}$ Slingsby Bethel, The Present Interest of England Stated (London, 1671), 17. See also Idem, The World's Mistake in Oliver Cromwell (London, 1668), 18-19, and Idem, The Interest of Princes and States (London, 1680), 111-113.

${ }^{169}$ Locke, "Trade," in Political Essays, ed. Mark Goldie (Cambridge: Cambridge University Press, 1997), 221-222. Goldie mentions that this particular essay draws upon Carew Reynal, The True English Interest (London, 1674), a treatise that often refers to the Dutch Republic as an example worth imitating, yet without mentioning freedom of religion. In his 1667 "An Essay on Toleration,” in Essays, ed. Goldie, 134-159, Locke already announced "to show what influence toleration is like to have upon the number and industry of your people, on which depends the power and riches of the kingdom."

${ }^{170}$ William Petty, Political Arithmetick (London, 169o), 23-27; Child, A New Discourse of Trade, 7,187 .

${ }^{171}$ Quoted in Simone Zurbuchen, "Republicanism and Toleration," in Van Gelderen and Skinner (eds.), Republicanism, vol. II: 47-71: 58 . For a comparative overview of Dutch and English notions of toleration, see Jonathan Israel, "Toleration in Seventeenth-Century Dutch and English Thought," in Simon Groenveld and Michael Wintle (eds.), The Exchange of Ideas: Religion, Scholarship and Art in Anglo-Dutch Relations in the Seventeenth Century (Zutphen: Walburg Pers, 1994), 13-30. 
all religious and civill supremacies, so it self should be extirpat". ${ }^{172}$ Harrington too insisted that religious freedom was only to be granted to those "being not Popish, Jewish, nor idolatrous". ${ }^{173}$ Bethel even contended that "there is a kind of Natural unaptness in the Popish Religion to business", and hence, Catholicism should be banned for the sake of common prosperity. ${ }^{174}$ Locke's position was more ambiguous, yet his argument that certain citizens cannot possibly remain loyal to the civil government because of their allegiance to an external power, suggested that Catholics, being dependent on the Vatican, ought not to be tolerated by the magistracy. ${ }^{175}$

In sharp contrast, De la Court promotes "the freedom of all Religions differing from the Reformed", explicitly referring to Catholicism. Reflecting on the substantial Catholic presence in Holland, ${ }^{176}$ De la Court acknowledges the risk of Catholic commitment to Rome and to the King of Spain, the Dutch Republic's former archenemy. Yet he refutes this oft-raised argument and continues to say that the war with Spain is over, and that persecution of Catholics would either imply that many wealthy inhabitants are forced to leave the country, or that they become hostile to the government. ${ }^{177}$ It is therefore not toleration, but intolerance that endangers the security and the prosperity of the commonwealth. As De la Court explains with a reference to the French historian Jacques-Auguste de Thou:

Good dissenting Residents who do well or possess any considerable goods, should not be suspected to lapse into such rebellious thoughts that ruin Themselves and our Country, as long as one does not make them leave and embittered through any persecution, but on the contrary commit them by

${ }^{172}$ Milton, Areopagitica, 47. For toleration in Milton in theory and literary practice, see the essays in Sharon Achinstein and Elizabeth Sauer (eds.), Milton \& Toleration (Oxford: Oxford University Press, 2007).

${ }^{173}$ Harrington, Oceana, 81.

${ }^{174}$ Bethel, Present Interest, 24.

${ }^{175}$ Locke, A Letter Concerning Toleration, ed. Shapiro, 245: "That church can have no right to be tolerated by the magistrate, which is constituted upon such a bottom, that all those who enter into it, do thereby, ipso facto, deliver themselves up to the protection and service of another prince." For a discussion of Locke's views on Catholicism, see Marshall, Locke, Toleration, 686-694.

${ }^{176}$ Around 1656 , roughly $15 \%$ of the population of Leiden was Catholic: see Jan Wim Buisman, "Kerk en samenleving," in Groenveld et al. (eds.), Leiden, 127-147: 141. On the presence and persecution of Catholicism in the seventeenth-century Dutch Republic at large, see Charles H. Parker, Faith on the Margins. Catholics and Catholicism in the Dutch Golden Age (Cambridge, Mass.: Harvard University Press, 2008).

${ }^{177}$ Aanwysing I.14, p. 6o, 66: “... de vryheid van allerley Religien vande Gereformeerde verscheelende." 
such Freedom and a soft and moderate Government to show gratitude to so good Rulers and Magistrates. ${ }^{178}$

The reference in this context to De Thou is important, not only because De Thou was a strong critic of religious persecution, but also because he embodied the irenicist settlement between Protestants and Catholics in France - a model that De la Court suggests is worth imitating. ${ }^{179}$

De la Court extends the argument in favour of toleration by insisting that toleration would deprive "imperious, rebellious Residents" of all the followers that they could otherwise mobilize "under the cloak of Religion". ${ }^{180}$ Toleration thus serves to enlarge the authority of the sovereign, for by "the protection of all dissenters against the violence of the ecclesiastics ... all the former will be boldly committed to the Rulers" ${ }^{181}$ As the Leiden professor Burgersdijk had already argued, "diversity of religions among subjects does not avert unity of Politics", ${ }^{182}$ and De la Court even maintains that religious uniformity might undermine political unity, for the more people agree on matters of faith, the larger the power of the clergy. ${ }^{183}$ The cultivation of religious plurality is therefore an essential means of curbing the clerical desire to rule and to safeguard the stability and welfare of society.

In line with these judgments, De la Court deplores that the religious freedom of the days of the Dutch Revolt has, as he sees it, diminished in his age. He characterizes Holland as still much more tolerant than its neighbours, yet the "laudable maxim" of toleration has lost ground since 1618, the year that Calvinist orthodoxy was firmly established. Since then,

${ }^{178}$ Ibidem III.1, p. 398: “... dat goede dissentierende Ingesetenen, die hier te Lande welvaaren, ofte eenige merkelike goederen besitten, niet behoorden te werden vermoed te sullenn vervallen tot soodaanige oproerige, haar Eigen- ende ons Land-verdervende gedagten, soo lange men haar door geene vervolginge gaande maakt ende verbitterd; maar in teegendeel door soodanige Vryheid, sagte en moderate Regeeringe, verpligt, aan soo goede Regeerderen ende Magistraats-persoonen dankbaarheid te bewijsen."

${ }^{179}$ The reference is to the dedication to Henry IV in De Thou, Historia sui temporis,

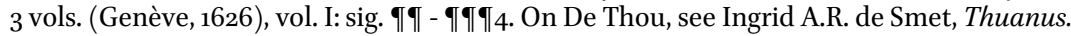
The Making ofJacques-Auguste de Thou (1553-1617) (Genève: Droz, 2006).

${ }^{180}$ Aanwysing III.1, p. 398: “... de Heersugtige, oproerige Ingeseetenen, souden werden ontbloot van allen aanhang, die sy andersins onder den dekmantel van Religie ligteliker souden konnen maaken."

${ }^{181}$ Welvaren 65, p. 145: “... indien sij ale dissentierende tegen 't geweld der kerckelijcken beschermen ... sullen alle deselve dapper aen den Regeerderen werden verplicht."

${ }^{182}$ Burgersdijk, Idea oeconomicae et politicae doctrinae II.20, p. 115: "Et diversitas religionum inter subditos non evertit unitatem Politicae." On Burgersdijk's views on religion, see Blom, Morality and Causality, 92-94.

${ }^{183}$ Aanwysing III.1, p. 406-407. 
Remonstrants and Catholics have been persecuted and chased away, "which is not less unreasonable than it is detrimental to the Country. For if we cannot lack the advantages of their residence and commerce, why should we prohibit that which is not harmful to the State?"184 Like Episcopius and in clear contrast with many of his English contemporaries, De la Court thus unambiguously advocates the toleration of Catholicism on the basis of both reasonableness and expediency. Moreover, his explicit emphasis on "the freedom of all Religions differing from the Reformed" opens up a wider tolerationist horizon beyond the borders of Christianity. The brothers De la Court concentrate on the position of Catholics and Remonstrants in the Dutch Republic, but some passages in their work also comment on the fate of Muslims and Jews in other polities, such as the expulsion of the moriscos from Spain and the inquisitorial persecution of the Jews in Portugal. The overt religious activity of Portuguese Jews in Amsterdam proves that the Inquisition utterly failed in its own objectives and only provoked migration and feigned conversion, "so that this pretence is the surest and true fruit of the cruel persecutions" ${ }^{185}$ Intolerance of any creed forcefully breeds hypocrisy instead of honesty, it creates nothing but a bleak appearance of religious unity at the cost of true faith, concord and prosperity.

\section{The Public Limits to Toleration}

The theory of toleration of the brothers De la Court, then, is fairly extensive, as it opens up an inclusive model of religious plurality. Nonetheless, their idea of toleration also remains strictly limited. These limits are imposed by the notion of a single public church. The brothers' conception of toleration basically encompasses the principled recognition of religious liberty and the pragmatic connivance of various forms of worship. Using tolerantie (toleration), verdraagzaamheid (forbearance), moderatie (moderation), oogluiking (connivance) and vrijheid van religie (freedom of religion) more or less as synonyms, ${ }^{186}$ the De la Courts make

\footnotetext{
${ }^{184}$ Aanwysing I.18, p. 82-83: “... dat men seederd den Jaare 1618 van die loffelike maxime meer en meer heeft beginnen af te wijken ... Het welk niet min onreedelik, als den Lande schaadelik is; Want indien wy de voordeelen van haare inwooning en koopmanschap niet moogen derven, waarom sullen wy verbien 't geen den Staat niet schaadelik is."

${ }^{185}$ Politike Discoursen II.IV.8, p. 60-63, 66: "Sulks dit veinzen de seekerste ende waaragtige vrugt der wreede vervolgingen is."

${ }^{186}$ See Aanwsying I.14, p. 59 ("vryheid ofte Tolerantie omtrent de verschillende uiterlike Gods-diensten"), a passage changed by De la Court into "Verdraagsaamheid omtrent de verschillende uiterlike Godsdiensten" when rewriting this chapter (Royal Library The
} 
clear that toleration entails a political permission to worship that is granted by the sovereign on the basis of the inviolability of conscience. By providing its citizens the freedom "to serve and to pray to God in the way that they think will be most agreeable to His Godly Majesty", a government acknowledges that such freedom is an essential element of the natural liberty that all citizens maintain when the civil society is established..$^{187}$ Freedom of worship is therefore an integral part of republican liberty, and it is "evident that the freedom of Religion or Toleration is not to be expected in Holland under a Monarchical or SingleHeaded Government". ${ }^{188}$ Toleration, in short, is a fundamentally republican principle.

In the De la Courts' republic, such toleration works on two different levels, both within and outside of the public church. First, the theological relativism of the brothers implies a broad, comprehensive public church that peacefully integrates all the different tenets of Reformed Calvinism without splitting hairs over the adiaphora of faith. This Grotian, irenic program means principally that the Orthodox Calvinists and the Remonstrants should be able to find a common ground of shared fundamentals under the banner of a single public church. In a letter that refers to the clandestine position of the Remonstrant congregations in Holland, De la Court stresses that the Remonstrants are basically "pious, honest and in all respects obedient citizens". There is therefore no need for repression; rather the aim should be one of "bending and flexing, drawing in and giving in". In short, all law-abiding Calvinists should come together in one church based on compromise and harmony. ${ }^{189}$

Hague, Ms 393 C22, insertion at p. 59). Cf. also e.g. Ibidem I.18, p. 82 ("Vryheid ofte Tolerantie en oogluiking"); Ibidem III.1, p. 398 ("Vryheid ofte Tolerantie van verschillende Godsdienstige Vergaderinge en Religien"); and Politike Discoursen I.I.1, p. 31 ("moderatie ... tolereeren").

${ }^{187}$ Welvaren 11, p. 30: “... vrijheid om sich te erneeren, te studeeren, te woonen, jae selvs om God te dienen, ende te bidden soo als sij meenen, sijner Goddelijker Majesteit aengenaemst te sullen weesen."

${ }^{188}$ Aanwysing III.2, p. 425: "De Vryheid van Religie ofte Tolerantie aangaande, is kennelik, dat die in Holland onder eene Monarchale ofte Een-hoofdelike Regeeringe niet behoorde verwagt te werden."

${ }^{189}$ Pieter de la Court to the brothers Van der Voort, 20 December 1663, in Kernkamp, 'Brieven (1661-1666)', 148-149: “... vrome eerelike en allesints gehoorsame borgers ... te buigen en te krommen, inhalen en toegeeven, gelijk hier behoorde te geschieden." On the repression of clandestine Remonstrant congregations in Leiden, see Buisman, "Kerk en samenleving," 137-138. Cf. also the pamphlet Leydsche proceduuren, ofte oprecht ende eenvoudigh verhael, van de onverwachte vervolginge, gepleeght tegen der Remonstranten godtsdienstige vergaderingen, binnen de stadt Leyden (s.l., 1664). 
This church, overseen by the magistracy, will enjoy uncontested primacy in the public realm. "It is in all Countries evidently necessary for the common tranquillity", De la Court maintains, "that one Religion prevails above all others, and that it is therefore fully authorized, protected, favoured and propagated by the State, in such a way that nonetheless the practices of other Religions are meanwhile somewhat publicly tolerated, namely not persecuted". ${ }^{190}$ This means that there is also room for toleration at the second level, outside of the limits of the public church, whereby dissenters can practice their faith in private without having to fear for persecution. Yet this second level of toleration does not imply the equality of all churches. Given that church and state are not separated, the single public church always maintains its exceptional status above other private congregations.

This exceptional status requires that all members of the government adhere to the public church. As the De la Courts stress, "disagreement of Religion among Regents must be shunned above all". ${ }^{191}$ Toleration does therefore not extend to the realm of politics - which in the Dutch context means that Catholics, Anabaptists, or Lutherans (let alone Jews) should not be permitted to participate in political decision-making. Moreover, the De la Courts argue that

while a Country is most peaceful and flourishes best when the practice of all Religions is permitted ... the Government should permit these as much, as is undamaging to its Religion. Consequently, the Government should forbid those who err to mislead the true-believer or to come together in such a large number that they could damage Politics, but it should not forbid that they practice their Religion covertly and in small number ${ }^{192}$

In other words, toleration does not imply that every creed can establish its own church in the public realm. Instead, it involves the claim that

\footnotetext{
${ }^{190}$ Aanwysing I.14, p. 63: “... alsoo kennelik in alle Landen voor de gemeene rust noodsaakelik is, dat eene Religie booven alle andere prevaleere, ende dienvolgende door den Staat allezins geautoriseerd, beschermd, begonstigd, en gevorderd werde; soo nogtans dat des niettemin de oeffeningen van andere Religien onder en tussen eenigsins publijkelijk getollereerd, immers niet vervolgd, werden."

${ }^{191}$ Politike Discoursen I.I.1, p. 31-32: "Maar verdeeldheid van Religie onder Regenten, moet boven alle geschout werden." Cf. also Aanwysing II.15, p. 382.

${ }_{192}$ Politike Discoursen II.IV.3, p. 24: "Dog dewijl een Land aller vreedsaamst is, ende best bloeid, daar de oeffeningen van alle Gods-diensten werden toe-gelaten ... soo moet de Ooverheid die voor soo veel toe-laaten, als haar Gods-dienst onschaadelik is. En ooversulks behoord de Ooverheid, den dwaalenden, wel te verbieden, de regt-geloovige te misleiden, of in soo groote meenigte by-een te komen, dat sy de Politie souden konnen schaaden: maar niet, dat sy bedektelik, ende in kleinen getale hun Gods-dienst oeffenen."
} 
there is one true religion, supported by the state, while all who dissent from that religion are allowed to assemble in private under the strict condition that they refrain from infringing the social order. This leads to the paradox that dissenting groups should be concealed, but also observable and controllable by the civil authorities. Accordingly, Catholics in Holland are to be permitted "in none but small assemblies, at the home of known Citizens with Priests agreeable to the Rulers". In this situation the "vexations would end, and among the good Residents, peace and friendship, yes even the true Religion would augment more and more". ${ }^{193}$

The freedom of worship that the De la Courts advocate thus offers theoretical support for the actual practice of confessional connivance in the Dutch Republic, the existence of schuilkerken in which dissenters were allowed to exercise their faith covertly but recognizably. The brothers' plea for toleration can be characterized as a rationalization of this peaceful endurance of religious plurality for the sake of maintaining social concord. The De la Courts argue that through such connivance, the civil authorities "will propagate the Reformed Religion among their good dissenting Residents, not through compulsion, but through moderate, soft means". ${ }^{194}$ Toleration is supportive of the one true faith, and instead of provoking religious pluralism, it eventually facilitates the victory of truth. Locke famously esteemed "toleration to be the chief characteristical mark of the true church"; 195 likewise, the De la Courts insist

that there could be no greater sign of a false Religion than to persecute those who dissent, for then one does not dare to rely on its truth. So it is clear that the freedom of Religion would not only be very beneficial to the Common Land, but especially for the Reformed Religion, which can and should lean on its evident truth. ${ }^{196}$

${ }^{193}$ Aanwysing I.18, p. 83: "Voorwaar indien men in de Steeden niet dan kleine vergaaderingen, ten huise van bekende Borgers, onder Priesters den Regeerders aangenaam, toeliet; soo souden die vexatien ophouden, en onder de goede Ingeseetenen vreede en vriendschap, jaa selfs de waare Religie meer en meer toe neemen."

${ }^{194}$ Ibidem III.1, p. 408-409: “... de Gereformeerde Religien, niet door dwang, maar door moderate sagte middelen, onder haare goede dissentierende Ingesetenen voort planten sullen."

195 Locke, Letter Concerning Toleration, 215.

${ }^{196}$ Aanwysing I.14, p. 66-67: “... datter geen grooter kenteeken van een valsche Religie, immers dat men sig op de waarheid van dien niet derfde verlaaten, konde zijn, dan de dissentierende te vervolgen. Sulks blijkt, dat de vryheid van Religien niet alleen voor het Gemeene Land, maar insonderheid voor de Gereformeerde Religie, die op haar klaare waarheid kan en behoorde te steunen, seer voordeelig soude weesen." Cf. Politike Discoursen I.I.1, p. 31 . 
Overall, then, the theory of toleration of the brothers De la Court stems neither from a sceptical, Pyrrhonist attitude that certainty and agreement in religious matters are beyond human reach (the position later adopted by Pierre Bayle), nor from the universalistic claim, popular among Collegiant circles in the Dutch Republic, that a single true Christian church does not yet exist. ${ }^{197}$ Instead, their theory is based on the fundamental assumption that in due course, the Reformed church will be perceived as true by all on account of its moderation and leniency - that is, by virtue of its true interpretation of God's Word. Unity, not diversity, is therefore the foundation of the brothers' tolerationist zeal, even though they embrace religious pluralism more openly than many of their contemporaries, especially when it comes to the explicit acceptance of Catholicism. In this sense, their plea for religious freedom, though remarkably silent about any theological issues, remains thoroughly religious in inspiration. Israel has rightly observed that the republican toleration of the brothers De la Court is "markedly secular in character", ${ }^{198}$ and indeed, the reason of state arguments that underpin their views on religious dissent involve a largely secular approach towards matters of faith. However, it should be stressed that this secular emphasis stems from a religious agenda. In the words of Mark Goldie: "It is not of course inapt to speak of the emergence of secular political theory: the mistake is to speak disjunctively. For secularization was an evangelical pursuit, it was the working out of a central idea in the thought of the Reformers, the 'priesthood of all believers'." 199 Or, to quote Alexandra Walsham on the debate on toleration in seventeenth-century England: "It is generally impossible to draw a neat line between the 'religious' and 'secular' elements of contemporary discourse on this controversial issue: the prudential, no less than the philosophical points made by its advocates can rarely be abstracted from the Christian framework within which they were enunciated." ${ }^{200}$ The same should be said of the points made by the brothers De la Court: when he revised the Aanwysing for a new edition to clarify his views, De la Court emphatically stressed that toleration "does neither go against Reason, nor against

197 On toleration in Collegiant thought, see Andrew C. Fix, Prophecy and Reason. The Dutch Collegiants in the Early Enlightenment (Princeton: Princeton University Press, 1991), $113^{-132 .}$

${ }^{198}$ Israel, "Toleration in Dutch and English Thought," 25.

199 Mark Goldie, 'The Civil Religion of James Harrington', in Pagden, Languages of Political Theory, 197-222: 200.

${ }^{200}$ Walsham, Charitable Hatred, 238. 
Scripture". ${ }^{201}$ In short, he stressed that his idea of toleration was both secular and evangelical.

\section{EPIlogue: From Freedom of Religion to Freedom of SpeEch?}

The importance of the De la Courts' plea for religious toleration lies in particular in their groundbreaking comprehensive combination of different arguments that had previously been raised separately. Merging a principled defence of religious freedom based on divine revelation and natural law with a pragmatic plea for toleration on behalf of civic harmony and economic prosperity, the brothers set the standard for a range of tolerationist writings that would appear throughout the following decades. ${ }^{202}$ At the same time, their characterization of the dangers of clerical demagogy and their insistence on the triumphant purity of God's Word reveal that their views on religious freedom and social concord cannot be separated from the crucial notion of public communication. To what extent does the De la Courts' conception of freedom of conscience also entail a committed defence of freedom of speech? This closing epilogue argues that the brothers' idea of free speech stems from the rhetoric that they employ in reaction to censorship and repression in the Dutch Republic. Returning to the issue of mercantile parrhèsia, it shows how their rhetoric of free speech entails a paradoxical account of what it means to be tolerant in conversation, aiming for the Erasmian goal of concord through decisively non-Erasmian outspokenness. Overall, this paradox would seal the fate of the De la Courts' participation in the public debate.

During the seventeenth century, there was relatively little preventive censorship in the Dutch Republic, while repressive measures after the publication of a work often proved to be unsuccessful. As a result, the Republic became a hotbed for the international publishing industry, lauded with the epithets of "the bookshop of the world" or, in Voltaire's words, "le magasin de l'univers" ${ }^{203}$ Nevertheless, principled pleas in favour

\footnotetext{
${ }^{201}$ See the insertion at p. 59 of Royal Library The Hague, Ms 393 C22: "Ende dat het selfde nog teegen de Reden, nog teegen de H: Schriften strijd.” De la Court rewrote the entire chapter on toleration, which reveals how much importance he attached to this issue.

${ }^{202}$ Cf. Marshall, Locke, Toleration, 357.

${ }^{203}$ Lotte Hellinga et al. (eds.), The Bookshop of the World. The Role of the Low Countries in the Book-Trade 1473-1941 ('t Goy-Houten: Hes \& De Graaf, 2001); C. Berkvens-Stevelinck et al. (eds.), Le magasin de l'univers. The Dutch Republic as the Centre of the European Book Trade (Leiden etc.: Brill, 1992).
} 
of liberty of speech were, in spite of this flourishing practice of a free press, largely absent from the Dutch debate. There was no Dutch counterpart of Milton's Areopagitica, nor even a sign of any direct influence of this key treatise in the Netherlands. By way of an explanation, it has been argued that the relative absence of censorship in the Dutch Republic rendered any theoretical arguments in favour of free speech redundant. ${ }^{204}$ A more perceptive interpretation highlights that the modern concept of liberty of speech and of the press as an inviolable human right only became common towards the end of the eighteenth century. ${ }^{205}$ Yet for all the insightfulness of such an assertion, little attention has been paid to the way in which seventeenth-century Dutch publicists, by the very act of writing, negotiated the extent of freedom of speech that an author could claim within the pubic debate. Instead of searching in vain for the roots of the modern conception of liberty of speech, it might therefore be more fruitful to look at how early-modern writers, through entering the political debate, defined a domain of what could be expressed in public.

The brothers De la Court, writing in the vernacular and addressing large segments of society, evidently attempted to engage a broad, popular audience in issues of abstract politics. Thus far historians have maintained that the issue of freedom of speech is almost entirely absent from the republican thought of the De la Courts, but this attempt to appeal to a wide audience clearly aimed to extend the political debate beyond the erudite echelons of society. ${ }^{206}$ Indeed, in the prefaces to the Politike Weegschaal and the Politike Discoursen, the brothers justify their literary endeavour by asserting explicitly that in a true republic, all tongues and printing presses should be free. "Those who are used to bow their necks under the yoke of European Kings" might follow the maxim of the popular satirist John Owen "that a tongue is free enough when licensed to be silent". However, "the peoples in Europe who were used to Liberty" teach the direct opposite: as even Tiberius acknowledged in Sallust's account, "in a free Republic, also the tongue should be free". ${ }^{207}$ With the inclusion of

\footnotetext{
${ }^{204}$ Enno van Gelder, Getemperde vrijheid, 236.

${ }^{205}$ Joris van Eijnatten, "Van godsdienstvrijheid naar mensenrecht. Meningsvorming over censuur en persvrijheid in de Republiek, 1579-1795," BMGN 118, 1 (2003), 1-21.

${ }^{206}$ Cf. Enno van Gelder, Getemperde vrijheid, 250-253; Van Eijnatten, "Van godsdienstvrijheid naar mensenrecht," $5^{-6 .}$

${ }^{207}$ Politike Weeg-schaal, "Inleyding," 2: "Jaa die gewoon zijn haaren nek onder het jok der Europise Koningen te buygen, gaan nog verder, als zy leeren (Libera lingua sat est, cui tacuisse licet. Owen) Dat een tong die zwijgen mag, vryheids genoeg heeft. Maar de Volkeren die in Europa de Vryheid gewoon waren, hebben ons ter contrarie geleerd ... (In libera civitate etiam linguam liberam esse oportere,) Dat in een vrye Republik, de tong ook
} 
these quotes at the very start of their works, the De la Courts suggested that freedom of speech is an integral element of republican liberty, and that the establishment of 'True Liberty' had facilitated the unhindered enjoyment of such freedom.

Yet in actual censorship policies, the regime of 'True Liberty' had proven to be anything but lenient. The anti-Socinian edict of 1653 and a comparable decree issued in 1656 to counter the spread of Cartesian philosophy showed that the De la Courts' eulogy of republican freedom of speech was hardly met by reality. The Politike Discoursen was officially banned by the Leiden consistory and the Aanwysing even outlawed by the States of Holland, albeit with limited success. Hence, the brothers' acclamation of free speech should not only be seen as an appeal to increase popular participation in the debate, but also as a rhetorical request to the civil authorities to tolerate their writings under the banner of true republican liberty and in opposition to ecclesiastical interference. This request entailed more than mere rhetoric. When reprimanded by the Leiden consistory for his publications, De la Court turned directly to Johan De Witt to ask for his political backing. In a letter to the Grand Pensionary, he denounced "those procedures of the clerics [that] do not only seem to conduce to extinguish the freedom of the common inhabitants ... but [that] also, apparently, seem to serve to claim their machinated Imperium in imperio". ${ }^{208}$ Yet this request for intervention was in vain. De Witt discussed "the case of monsr. De la Court" with their mediator Pieter de Groot, and his eventual reply was short and clear: "It is, to my opinion, a mistake to make and try to obtain glory from works that are not generally conditioned according to the proclamations of the country." ${ }^{09}$ The official version of True Liberty, in short, did not involve unlimited freedom of speech.

De la Court therefore had to reconcile himself with the Leiden consistory, which admonished him to "uphold the honour of the church in all

behoorde vry te weezen." The quotes are from Owen, Epigrammata III.74, and Sallust, De vita Caesarum, Tiberius 28. Cf. also Politike Discoursen, "Voor-Reeden," sig. *2v.

${ }^{208}$ Pieter de la Court to Johan de Witt, 3 October 1662, in Brieven aan Johan de Witt, ed. Japikse, vol. II: 112: “... soodanige proceduren der kerkeliken niet alleen schynen te strekken, om der gemeene ingeseetenen vryheid uit te blusschen, die nu meer als ooit ten voordeele des Vaderlands ende der vrye regeeringe in alle manieren behoorde te werden opgewekt, maar ook kennelik souden dienen, om te vorderen haar gemachineerd Imperium in imperio."

${ }^{209}$ Johan de Witt to Pieter de Groot, 19 January 1663 , in Brieven van Johan de Witt, ed. N. Japikse, 4 vols. (Amsterdam, 1906-1913), vol. II: 472: "De saecke van monsr. De la Court ... Het is, mijns oordeels, een misslach glorie te scheppen en te willen trecken uut wercken, die niet in allen deele geconditionneert sijn volgens de placcaeten van het landt." 
events". He complied with this reprimand, but his comments in a subsequent letter to his brothers-in-law are revealing:

I do not think that they have meant that the honour of the ministers is the honour of the church, and that the former should be upheld by all means. Truly, this is the attitude of the papists, not mine, nor the one of our church, whose honour, in contrast, does not consist of its foundation on the lives or doctrine of the ministers, but of its foundation on the true Gospel, even when the Devil would preach it. ${ }^{210}$

With this powerful statement, De la Court clarified once more that his anti-clericalism did not concern the Reformed church as an institution but rather the conduct of its ministers. He claimed to defend the purity of Scripture as the only foundation of the true church against clerical contamination. In line with this judgment, De la Court became more and more outspoken and explicit in his rhetorical assault on the clergy after his repeated clashes with the ecclesiastical hierarchy. Whereas the anticlerical language of the Interest van Holland was still relatively reserved, it became much more explicit in the Aanwysing and even more so in the rewritten version of this work, which categorically rebuked the "Coercive ecclesiastical Ministers" as "truly Imperious, Lazy, gourmet, careless, frisky, and only in sheer appearance holy people". ${ }^{211}$ With such fervent criticism of the clergy the brothers De la Court evidently tried to claim a relatively large domain of freedom of speech in the public arena.

Nonetheless, there are also clear boundaries to this domain of free speech. These boundaries are set by the inviolability of Scripture, as becomes clear from De la Court's reaction to a crucial event in 1668. That year, Adriaen Koerbagh became the first real victim of the repression during the 'True Liberty' era. Koerbagh was the author of a number of highly unconventional works, particularly Een bloemhof van allerley lieflijkheyd sonder verdriet ["A Garden of All Kinds of Loveliness without Sorrow"], a rationalist dictionary that intended to purify Dutch language from

${ }^{210}$ Pieter de la Court to the brothers Van der Voort, 18 September 1663, in Kernkamp (ed.), "Brieven (1661-1666)," 128: “... ik meen niet, sij sullen hebben gemeend, dat de eere der predikanten de eerde der kerke zij en dat die in alle manieren moet opgehouden zijn. Warelik dit is wel 't gevoelen der papisten, niet het mijn, nog onser kerke, welkers eer ter contrarie daarin bestaat, dat sij niet op het leeve of leere der predikanten, maar op het ware Evangelium, al waar 't dat de Duivel het predikte, gefondeerd is."

${ }^{211}$ Royal Library The Hague, Ms 393 C22, insertion at p. 59, p. 32: "Soo is voorwaar geen wonder, dat soodanige Dwingende kerkelike Leeraars, in alle Landen van der Wereld, by alle Verstandige ende Wereldwyse Ingeseetenen, werden gehouden warelik Heersugtige, Leuje, lekkere, sorgelose, dertele, en niet dan in enkele schyn, heilige menschen te zyn." 
obscure, dogmatic terminology. ${ }^{212}$ According to the church authorities, this work was full of "blasphemous remarks about God, our Saviour Jesus Christ, the Son of God, and the divine and perfect Word of the Lord". ${ }^{213}$ When Koerbagh tried to publish another work clandestinely, he was betrayed, arrested, and condemned to ten years in prison, where he died within a few months. De la Court must have known Koerbagh, at least indirectly, since both were friends of Van Berkel, the translator of Hobbes' Leviathan. Moreover, a few years earlier, Koerbagh had clearly sided with De la Court in the debate over the public prayer and the sovereignty over church affairs. Yet this time, De la Court did not share Koerbagh's stance, on the contrary. When he heard of Koerbagh's arrest, he insisted that "all wise men should accuse him of large mindlessness and imprudence and also of evilness". De la Court did not agree with the form of punishment, for as he said, a fine would have sufficed for this kind of intellectual offence. However, he unambiguously rejected Koerbagh's public undermining of Christian dogma. ${ }^{214}$

This judgment reveals the distance that separates the De la Courts from two controversial intellectual currents that developed a different conception of free speech in this period. The first is the movement of the Collegiants, a group of "Christians without a church" who advocated an "assembly of believers" in which all were allowed to articulate their interpretation of Scripture. As Laurens Klinkhamer, a prominent Leiden spokesman of the Collegiants, argued, the freedom to publicly express one's opinion about Scripture is "the only means to maintain true Peace and Unity among Christians and to reduce all sects and divisions". ${ }^{215}$ For the Collegiants, such a free debate on theological matters and the abolishment of any ecclesiastical hierarchy would eventually bring all Christians together in the spiritual contemplation of divine revelation.

${ }^{212}$ [Adriaen Koerbagh], Een bloemhof van allerley lieflijkheyd sonder verdriet (Leiden, 1668). Most of the copies of this work were destroyed immediately after publication, yet De la Court's son owned a copy, which therefore probably had belonged to his father: Library, fol. 30. On Koerbagh, see in particular Michiel Wielema, "Adriaan Koerbagh: Biblical Criticism and Enlightenment," in Wiep van Bunge (ed.), The Early Enlightenment in the Dutch Republic, 1650-1750 (Leiden: Brill, 2003), 61-80.

${ }^{213}$ Quoted in Israel, Radical Enlightenment, 190.

${ }^{214}$ Pieter de la Court to the brothers Van der Voort, 21 July 1668, in Kernkamp (ed.), "Brieven (1667-1683)," 29-30: “... alle wijse luiden haar moeten beschuldigen van groot onverstand en onvoorsigtigheid en ook van boosheid."

${ }^{215}$ Laurens Klinkhamer, Vryheydt van spreecken in de gemeynte der geloovigen (Leiden, 1655), 229: “... het eenige middel, om waere Vreede en Eenigheydt onder den Christenen te onderhouden, en alle secten en gedeeltheeden te minderen." On Klinkhamer, see Fix, Prophecy and Reason, 177-180. 
For the De la Courts, instead, social concord and the truth of God's Word can only be maintained if all issues of theological debate are left exclusively to the judgment of the sovereign.

The second intellectual current from which the De la Courts differed was the more radical circle of freethinkers who gathered around Spinoza. Significantly, Koerbagh's gruesome fate was one of the main reasons for Spinoza to include a principled defence of libertas philosopandi, the "liberty to philosophize", in the Tractactus Theologico-Politicus. According to Spinoza, the unenforceability of conscience implies that all individuals have the right to express their opinions in public, as long as they do so rationally and without contradicting the sovereign's authority. Spinoza famously insists, following his teacher Van den Enden, that such freedom of speech does not endanger the peace and stability of society, indeed that a commonwealth cannot maintain concord if citizens are not allowed to say what they think. ${ }^{216}$ This freedom of expression also applies to the contents of Scripture, and Spinoza's Tractatus can be characterized as a radical exercise in such free biblical hermeneutics. In clear contrast, for the brothers De la Court divine revelation is utterly beyond public debate. In order to preserve the purity of Scripture, not only should clerics be thwarted in their political designs, but also writers such as Koerbagh who undermine the Christian articles of faith and thus create confusion, discord, and strife. Freedom of speech thus ends where God's Word begins.

This fundamental difference between Spinoza and the De la Courts is well captured by their distinct use of the same phrase of Tacitus: rara temporum felicitate, ubi sentire quae velis et quae sentias dicere licet, "rare is the happiness of times when it is allowed to think as you want and to say what you think". Spinoza employs this saying prominently as the motto of his last, conclusive argument in the Tractatus that freedom of speech should be safeguarded by the sovereign. ${ }^{217}$ The De la Courts quote these words in a different context, namely in explicit relation to the dangers of speaking the truth at a monarchical court. ${ }^{218}$ Spinoza's universal principle of freedom of thought and expression, in particular as regards biblical criticism, instead involves for the De la Courts an anti-monarchical message: it is kings who should be criticized, not Scripture. In other

\footnotetext{
${ }^{216}$ Spinoza, Tractatus Theologico-Politicus XX, esp. p. 293-294, 299. Cf. Van den Enden, Kort verhael, 68-83. For the importance of the Koerbagh affair for Spinoza, see Steven Nadler, Spinoza. A Life (Cambridge: Cambridge University Press, 1999), 264-270.

${ }^{217}$ Spinoza, Tractatus Theologico-Politicus XX, p. 291. The phrase is from Tacitus, Histories I.I.4.

${ }^{218}$ Politike Weeg-schaal I.I.33, p. 161.
} 
words, for the De la Courts the Tacitean maxim "to think as you want and to say what you think" signifies republican parrhèsia, the ability to tell the truth and to reveal, like Actaeon, the nakedness of the unconcealed desire to rule.

The De la Courts' conception of free speech, then, amounts to the kind of rhetoric that the brothers themselves employ in their work. Freedom of speech does not mean that everything can be expressed in public, since certain statements, specifically those touching on religious dogma, endanger the public peace. Instead, freedom of speech means speaking frankly, independent of monarchical might. In this sense, it forms an integral part of republican liberty and it is in itself conducive to such liberty, for a republic can only prosper if criticism of monarchical pretensions is allowed. In writing and publishing their treatises and performing exactly such criticism, the brothers De la Court aim to vindicate this conception of free speech. By being outspoken and candid in their disapproval of kings, courtiers and clerics, they attempt to prove that the magistracy should tolerate such frankness for the sake of the survival of the commonwealth.

The De la Courts hereby suggest that the connivance of an open debate eventually facilitates the public victory of truth. The underlying, implicit justification of their involvement in the Dutch debate is that outspokenness in conversation, "calling a spade a spade", leads to an environment in which the truth, their truth, can ultimately triumph. The rhetoric of toleration that the De la Courts employ does therefore not adopt the humanist, Erasmian ideal of entering a conversation with decorum and modesty, trying to argue on both sides of a case in order to find common ground between seemingly incompatible arguments. ${ }^{219}$ On the contrary, the brothers De la Court envisage a public arena of debate in which opinions will prevail on account of their competitive value, that is, on account of their truth and outspokenness. Their model is based on the assumption that toleration is enhanced by frank speech, by clearly establishing one's own position and using plain and vivid language to repudiate the adversary. Only when differences are explicitly pronounced is there room to find common ground. Toleration, in short, is a matter of monologue, not of dialogue.

The intrinsic contradiction of this rhetoric of toleration lies behind the ultimate failure of the De la Courts' attempt to win the hearts and minds of the middle ground in the Dutch debate. This contradiction arises out of

${ }^{219}$ Cf. Remer, Humanism and the Rhetoric of Tole ration, 43-101. 
their endeavour to adopt the Erasmian agenda of concord, yet to achieve that agenda by employing a decisively non-Erasmian rhetoric based on confrontation. Directly challenging clerical demagogy, the brothers engage in a similar form of populist speech as that which they deride, a rhetoric that is more akin to a Calvinist sermon than to a polite humanist exchange of ideas. Eventually, this paradox proved fatal for the De la Courts' engagement in the public debate: their works were banned by the church, the political establishment around De Witt soon withdrew its patronage, and among the general public they only met with opposition and contempt. Before long, the brothers De la Court did indeed end up like a modern Actaeon.

It was a fate that the De la Courts were prepared to bear. In the very last fable of the Sinryke Fabulen, written in the last years of his life, De la Court insisted that if one has lived in sincerity and for the sake of truth, regardless the disdain of others, there is no reason to fear death, following the brave example of the "Political Martyrs" of the recent Dutch past who had paid with their lives for defying the House of Orange. ${ }^{220}$ "Let him stand who will, in pride of power, on empire's slippery height; let me be filled with sweet repose", De la Court quoted from Seneca's Thyestes. "On him does death lie heavily, who, but too well known to all, dies to himself unknown". ${ }^{221}$ With this stoic message, De la Court delivered his swansong. Buried in the New Church at the heart of Amsterdam, an anonymous elegy recalled his achievements in teaching "civic duty" and unmasking the "Burden and Oppression of Tyranny" ${ }^{222}$ In similar vein, another sympathetic mind praised how De la Court's sharpened pen had attempted to overthrow "Agamemnon's Mycenae" so that "Liberty would build itself a new home" - even though the groundwork of this republican stronghold still remained to be "polished and paved". ${ }^{223}$

${ }^{220}$ Sinryke Fabulen, 725: "Politiek Martelaars," implicitly referring to Johan van Oldenbarneveldt and the brothers De Witt.

${ }^{221}$ Seneca, Thyestes, vss. 391-403, trans. Frank Justus Miller, quoted in Politike Weegschaal I.III.11, p. 273-274, and in Sinryke Fabulen, 224: "Stet quicunque volet potens/aulæ culmine lubrico,/me dulcis saturet quies/ ... Illi mors gravis incubat/qui notus nimis omnibus/ignotus moritur sibi."

${ }^{222}$ Kernkamp (ed.), "Brieven (1667-1683)," 88-89, note 4: "Hier rust La Court die Hollands Magt, Regt, Intrest heeft verweert/Bedrog van Graaf, Prins, Hoff, ontdekt, en Burgerpligt geleert/Die in des Werelts-Staat, en Nêerlandts-Policy,/Aanwijst Tyrannen Overlast en Dwingelandij."

${ }^{223}$ Joachim Oudaan, Poëzy, 3 vols. (Amsterdam, 1712), vol. I: 339-340: "Daar valt de pen van 't blad, die, met zig op te scherpen,/'t Agamemnonische Mycenen om wouw werpen/ ... Op dat de Vryheid zig een woning vesten zouw/ ... Een ander mag den grond pollysten en plaveijen." 


\section{CONCLUSION}

\section{THE BROTHERS DE LA COURT AND THE COMMERCIAL REPUBLICAN TRADITION}

History has not been generous to the brothers De la Court. In 1702, the London bookseller John Darby published an English translation of their work under the name "John de Witt, and other Great Men in Holland", in which he praised how "many nice and curious Subjects, as well Religious as Civil and Political, are accurately handled". This erroneous attribution certainly made the work of the De la Courts appeal to a wider audience, yet it also caused the brothers themselves to fall into utter oblivion. New English editions of their work appeared in 1743 and 1746, again under the authorship of De Witt, while a 1709 French translation was issued under the resounding title Mémoires de Jean de Wit, Grand Pensionnaire de Hollande. Among the last to remember the name of the true author was the famous German philosopher Gottfried Leibniz. In 1676, Leibniz paid De la Court a visit when he was on his way to meet Spinoza in The Hague, a visit he recalled in his Essais de Théodicée of 1710. Referring to the recent French translation of De la Court's work, Leibniz deplored that it had been attributed to De Witt, "as if the thoughts of an individual who was effectively of De Witt's party, and habile, yet who did not have sufficient knowledge of public affairs, nor sufficient capacity to write like that great Minister of State, could pass for the production of one of the prime men of his age". ${ }^{2}$ With this posthumous blow, the reputation of De la Court was sealed - and before long his name submerged entirely in the scrapheap of history.

This book does not intend to show that Leibniz was wrong (because perhaps, in the end, he was right), but rather that the political thought of the brothers De la Court is of fundamental significance for the history of

${ }^{1}$ Books Sold by John Darby in Bartholomew-Close, London [1717], 10-11.

${ }^{2}$ G.W. Leibniz, Essais de Théodicée III.375, in C.J. Gerhardt (ed.), Die philosophischen Schriften von Gottfried Wilhelm Leibniz, 7 vols. (Berlin, 1875-189o), vol. VI: 339: “... comme si les pensées d'un particulier, qui étoit en effect du parti de de Witt, et habile, mais qui n'avoit pas assés de connoissance des affaires publiques, ny assés de capacité, pour ecrire comme auroit pu faire ce grand Ministre d'État, pouvoient passer pour des productions de l'un des premiers hommes de son temps." 
early-modern republicanism. True republics, so the De la Courts argued, are commercial republics, and truly commercial states must be republican states. This intrinsic parallel between trade and republicanism that forms the core of the brothers' œuvre substantially broadens and sharpens our understanding of what early-modern republican thought was all about. In particular, it shows that the seventeenth-century development of republicanism as an ideology of active civic participation in politics, free of any form of arbitrary domination, was strongly connected to the rise of commercial society. The case of the brothers De la Court, arguably the most radical republican theorists in the most successful early-modern republic, reveals how the embrace of commercial enterprise led to a powerful plea for comprehensive republican liberty and to a categorical rejection of monarchical rule in all its guises.

The commercial republican outlook that pervades the work of the De la Courts comprises three related claims: first, that a true citizen connects his self-interest to the common good by pursuing mercantile honour within the disciplinary limits of civil society. Second, that the increase of trade as the essence of reason of state requires liberty (which includes freedom from interference and freedom from domination), and that such liberty can only be fostered by a broad representative government in which any form of single rule is impossible. And third, that social concord and prosperity in this commercial republic are fostered by secular control over the public church and toleration of private religious dissent. All three claims crucially combine an argument in favour of commerce with an argument against monarchy: the monarchical lust for domination is inherently incompatible with the civic ethics of mercantile moderation, with the liberties that foster commercial prosperity, and with the religious toleration characteristic to a society based on trade. In short, for the brothers De la Court commerce and republicanism go hand in hand.

The rationale behind this theory stems from the application of a range of internationally constituted political languages to the local context of the centre of seventeenth-century global trade, the Dutch Republic. Combining natural law theory from Grotius to Hobbes with reason of state literature from Botero to Rohan, Augustinian and Cartesian theories of the passions with the republicanism of Machiavelli and Boccalini, and classical historical writing with late humanist rhetoric and ethics, the De la Courts endeavoured to construct a novel theoretical framework to substantiate as well as criticize the existing Dutch republican model. The central tenets from their thought all follow from this attempt to give meaning to the Dutch experience within a broad amalgam of various 
international political vocabularies. The brothers adopted and adapted the fashionable ideas of Hobbes on the origin of the commonwealth and Cicero's time-honoured ethics of ambition, to assess the practices of Dutch citizenship and mercantile enterprise, justifying the honourable pursuit of commercial wealth as the prime characteristic of a 'wise merchant'. They employed the principles of reason of state and the republican language of liberty to insist that a commercial commonwealth can never subsist under the single rule of a Stadholder, that peculiar monarchical element of the Dutch republican constitution, nor under a small oligarchic government such as the De Witt regime. In line with the Erasmian model of concord, the Grotian plea for a broad public church and the practice of religious co-existence in Dutch cities, they maintained that dissenters like Catholics ought to be granted freedom of worship in private so that general peace and prosperity are secured. Finally, they employed the precepts of late humanist rhetoric to make their case within the pulsating arena of public debate during the Dutch Golden Age.

This rhetorical engagement forms the thread that weaves together the various parts of this book. The frank speech that characterized the De la Courts' rhetorical practices and self-presentation makes clear how the brothers departed from late humanist rhetorical conventions to arrive at a novel form of public speech: a mercantile rhetoric of outspokenness which, adopting the classical figure of parrhèsia, contended that telling the truth is all that matters, regardless of the reins of decorum or censorship. This rhetoric of the market underlies the argument that true citizens embody the archetype of 'wise merchants' who engage in honourable trade and frankness. Such a form of public speech is essential for assessing the common good, and therefore these wise merchants should form a broad representative assembly that governs the republic. Moreover, this rhetoric of outspokenness entails the best way to address political and confessional differences in the public realm, for social and religious concord can only be maintained if the truth progresses without restraints in the marketplace of ideas. Political debate and decisionmaking, in short, should follow the rules of mercantile frankness - or so the brothers De la Court maintained. Their own passionate practice of such frankness reveals the extent to which their successful stirring of the Dutch debate eventually resulted in the utter failure to win over their readers.

Rhetoric, then, is a crucial key to disclose the De la Courts' ideas on the relationship between language and politics and to assess their fate in 
seventeenth-century Dutch debates. Contrary to the institutional focus central to the few existing studies of the brothers' thought, turning our attention toward rhetoric illuminates how the essence of their republican endeavour is not a passive reflection on governmental structures, but rather an active engagement in public debate, challenging existing notions of what Dutch republican politics were all about. This new approach to the thought of the brothers De la Court has important implications for the study of the political culture of the Dutch Golden Age, which was clearly much more rhetorical and ridden by ideological conflict than is often assumed. Moreover, the case of the De la Courts points to the general importance of the study of rhetoric to assess ideas about public speech, citizenship and deliberative politics within early-modern republican thought at large.

Armed with an extensive rhetorical arsenal, the brothers De la Court positioned the seventeenth-century Dutch experience within this international republican tradition. They strongly maintained that the Dutch Republic was part of a long-standing republican heritage that originated in antiquity, evident from their use of Ancient Athens as a prime model of inspiration for a commercial commonwealth, their references to Roman law and the Italian Renaissance as the main source for their concept of liberty, and their discussions of various examples of republican practice in the classical and contemporary Mediterranean. Yet the brothers gave a distinctive twist to this shared international heritage by championing the cause of commerce. They applied the Ciceronian language of honour to the mercantile society of the seventeenth century, changing the classical focus on virtue to the commercial language of interest, whereby the wise merchant eclipsed the land-owning citizen as the embodiment of civic morality. Similarly, they expanded the Roman language of liberty to an inclusive notion that merged freedom as non-domination with free trade as the essence of commercial reason of state. Finally, in spite of this evident Roman inspiration, they fervently rejected the Roman Republic as a belligerent state that destroyed all trade and was ultimately doomed to lapse into tyranny. The brothers De la Court claimed to be part of a republican tradition, but this was a tradition that originated in trading Athens rather than militant Rome: it was a commercial republican tradition with the Dutch Republic as its vanguard.

This mercantile move of the De la Courts did not come out of a void. Their praise of honourable commercial enterprise as the essence of good citizenship reflects a similar claim already brought forward in fifteenthcentury Florence, in particular by Alberti. Likewise, their emphasis on 
free trade as the essence of republican politics was clearly informed by a general development in reason of state theory from Botero onwards and by Anglo-Dutch commercial competition and debate. On a number of issues, especially their argument for a broad aristocratic government that furthers commercial increase, the De la Courts continued in the footsteps of the academic politica taught at Leiden, while their argument that toleration causes prosperity adopted earlier claims raised in Dutch religious debate throughout the seventeenth century.

The commercial republicanism of the De la Courts also involved a number of significant parallels with contemporary English republican writing. The brothers developed their ideas largely independently of republican theory and practice in England, but this apparent absence of direct intellectual exchange does not confirm a deep Pocockian rift between both sides of the North Sea. On the contrary: the thought of the brothers De la Court entails a powerful elaboration of many claims that are considered to be characteristic of seventeenth-century English republicanism. Above all, the ideal of republican liberty that Skinner maintains dominated republican writing in England can be similarly traced in the thought of the De la Courts. As in England, if we follow Rahe and Pincus, this ideal of liberty merged the combined legacy of Machiavelli and Hobbes into a liberal' ideology of self-interest, freedom of trade and commercial increase. The case of the De la Courts arguably offers the most comprehensive example of these general trends in seventeenth-century republicanism that have thus far only been analyzed from an English perspective.

Nonetheless, certain aspects of the brothers' thought remain peculiar to the Dutch context. In particular, the quintessentially Dutch debate on the position of the Stadholder resulted in the brothers' radical claim that all forms of monarchy are necessarily tyrannical - a claim hardly equalled by any other political thinker before the Revolutionary Era. Thus, while the brothers De la Court were evidently part of an international republican tradition, the extent of their virulent anti-monarchism shows that its is important to stress that unlike most of their European contemporaries, they in fact lived in a real republic.

The international reception of the De la Courts throughout the late seventeenth and eighteenth centuries precisely shows that the commercial dimension of their thought was readily adopted elsewhere, but without its sharp anti-monarchical edge. The first foreign translations of their work already appeared in the 1660 s, in German: first, in 1665 the Interesse von Holland, oder Fondamenten von Hollands-Wohlfahrt, followed by 
translations of the Politike Weeg-schaal in 1669 and the Aanwysing in $1671 .^{3}$ As a result, some important German scholars referred to the De la Courts in their political writings, from Pufendorf, who read them primarily as republican antagonists of Hobbes, ${ }^{4}$ to Leibniz, who adopted their interestbased politics to the situation in the Holy Roman Empire. ${ }^{5}$ This German reception of the De la Courts' work was exemplified by the versatile alchemist and mercantile theorist Johann Joachim Becher. Having visited the Dutch Republic during the 166os on behalf of the elector of Bavaria, Becher explicitly acknowledged his debt to the De la Courts in the second, 1673 edition of his Politischer Discurs, von den eigentlichen Ursachen deß Auf- und Abnehmens der Städt, Länder und Republicken. In particular, Becher sought to adapt their commercial reason of state to a territorial princedom like Bavaria. He extensively discussed a range of mercantile policies, often directly drawing on Dutch experience, and he heralded a commercial colony in the West-Indies as the ultimate "political philosopher's stone". ${ }^{6}$ A successful society is a society for commercial expansion, Becher learned from his Dutch sources, and he directly echoed the De la Courts with the claim that "Republics generally flourish better than countries that are governed by absolute lords" since "a Republic has only one Interest, but a territory has two, namely its own and its lord's". Yet in spite of this tentative republican move, Becher duly remained within the traditional confines of the German territorial states, conventionally claiming that the best form of state is a mixed regime where a prince overlooks commercial enterprise. ${ }^{7}$ This adoption of the De la Courts' language of

\footnotetext{
${ }^{3}$ Interesse von Holland, oder Fondamenten van Hollands-Wohlfahrt (s.l., 1665); Consideratien van Staat, Oder politische Wagschale, trans. Christophorus Kormarten (Leipzig and Halle, 1669); Anweisungen der heilsamen politischen Grunde und Maximen der Republicqen Holland und West-Friesland (Rotterdam, 1671).

${ }_{4}$ Pufendorf owned the Dutch editions of Politike Weeg-schaal, Politike Discoursen and Interest van Holland: see Fiametta Palladini (ed.), La biblioteca di Samuel Pufendorf. Catalogo dell'asta di Berlin del settembre 1697 (Wiesbaden: Harrassowitz, 1999), nrs. 850-852.

5 See esp. Leibniz, Sämtliche Schriften und Briefe. Vierte Reihe: Politische Schriften, ed. Leibniz-Editionsstelle Potsdam (Berlin: Akademie Verlag, 1983-20o8), vol. I: 133-141 (a 1670 manuscript that refers to Interesse von Holland); Ibidem, vol. VI: 14-15 (De eo quod principum interest, referring to "La Courii Consideratien van Staat").

${ }^{6}$ Johann Joachim Becher, Politische Discurs, von den eigentlichen Ursachen deß Auffund Abnehmens der Städt, Länder und Republicken (Frankfurt, 1673), 1271: "Dr Bechers politischer philosophischer Stein in der indischen Colonie beruhend."

7 Ibidem, 15, 256-257: “... die Republiquen ins gemeins besser floriren, als die Länder welche durch absolute Herrn regirt werden ... Dann eine Republick hatt nur ein Interesse, aber ein Landt hat zwey, nemlich ihr eigenes, und ihres Herren." See the analysis in Pamela H. Smith, The Business of Alchemy. Science and Culture in the Holy Roman Empire (Princeton: Princeton University Press, 1994), 123-126.
} 
commercial interest without its anti-monarchical dimension typified the general reception of the brothers' thought throughout the German Enlightenment. $^{8}$

In France, the work of the De la Courts also started to raise interest during the 166os, when Jean-Baptiste Colbert and his fellow ministers heard that a volume titled Interest van Holland contained "the entire secret of commerce". ${ }^{9}$ The work was not translated until 1709, when three French editions of the Aanwysing appeared under the authorship of De Witt, allegedly published in The Hague and in Regensburg. It is revealing that the translator warned her French audience not to be shocked by the strong language of the author, "who was a Republican of the most zealous sort". ${ }^{10}$ Eighteenth-century French readers of the De la Courts, like their German contemporaries, thus rejected the brothers' anti-monarchism but eagerly took up their commercial politics. In particular the circles around Vincent Gournay, intendant of commerce during the 1750s, and his disciple Anne-Robert Jacques Turgot, governmental administrator in the 1760 s and 1770 s, intended to appropriate the De la Courts' commercial model to the absolutist French monarchy." According to Turgot, Gournay closely studied the French translation of the Aanwysing, which he classified together with the work of Josiah Child as "the legislators of commerce". ${ }^{12}$ Following this judgment, French economic theorists throughout the later eighteenth century employed De la Court to promote Montesquieu's esprit de commerce. One of Gournay's disciples extensively quoted from De la Court's argument against trading monopolies to contend that "a monarchy should render its commerce republican", ${ }^{13}$ while another referred approvingly to De la Court to claim that freedom of enterprise entails "the most fecund principle and the most infallible means to extend and augment our exportations". ${ }^{14}$ In this way, the

\footnotetext{
${ }^{8}$ See for some examples Wildenberg, Bibliografie, $55^{-56}$.

9 Quoted in Ibidem, 52: “... un volume appelé l'Interêt de Hollande dans lequel on dit qu'est contenu tout le secret du commerce."

${ }^{10}$ Mémoires de Jean de Wit, Grand Pensionaire de Hollande, trans. M. de *** [Mme. Van Zoutelandt] 3d. ed. (Regensburg, 1709), vii: "C'étoit un Républicain des plus zelez."

"See the analysis in Henry C. Clark, Compass of Society. Commerce and Absolutism in Old-Regime France (Lanham etc.: Lexington, 2007), esp. 62-63, 129-143, 221-228.

${ }^{12}$ Quoted in Ibidem, 241.

${ }_{13}$ Abbé Coyer, Développement et défense du systéme de la noblesse commerçante, 2 vols. (Amsterdam, 1757), vol. I, 72: “... qu'une Monarchie doit rendre son commerce Républicain." Ibidem, vol. II: 16-19.

${ }_{14}$ [Simon Clicquot de Blervâche], Considerations sur le commerce, et en particulier sur les compagnies, societés et maitrises (Amsterdam, 1758), 72-73: "voilà le principe le plus fécond, \& le moyen le plus infaillible d'étendre \& d'augmenter nos exportations."
} 
commercial thought of the brothers De la Court had a significant impact on the development of laissez faire economics.

Especially in Britain the work of the De la Courts enjoyed a lasting readership as an insider's account of the Dutch mercantile model. English republican exiles in Holland during the 166os, most importantly Algernon Sidney and Slingsby Bethel, were the first to appropriate the brothers' thought for an English audience. Sidney's Court Maxims clearly echo the De la Courts' language of republican interest and trade, while Bethel directly reproduced the argumentation of Interest van Holland in his own writings, especially in the 1680 Interest of Princes and States. True interest, so Bethel insisted, is commercial interest, and commerce thrives through liberty, peace, and toleration. Bethel also adopted the De la Courts' claim that the Dutch were better off without a Stadholder, "as Trade is their grand Interest ... and as liberty and freedom are the great increasers of it, and as an uncircumscribed standing head, in both Civil and Military Affairs, is under temptation of obstructing their liberty for publick Interest, if contrary to his private". ${ }^{15}$ This emphasis on commerce, liberty, and the harmony of private and public interests continued to dominate the political thought of another English refugee in the Dutch Republic who also owned a copy of De la Court's Interest van Holland, John Locke. ${ }^{16}$

The first English translation of the De la Courts' work was not long in the making. Samuel Pepys, who probably had purchased a copy of the Aanwysing when he visited the Dutch Republic in the summer of 1669 , owned a manuscript English version of that work, translated by Toby Bonnel, a Dublin merchant with Dutch family connections. ${ }^{17}$ This particular translation would never be published, yet De la Court's arguments, especially concerning Dutch foreign policy vis-à-vis England, were certainly known among English political circles. ${ }^{18}$ Eventually, the Aanwysing

\footnotetext{
${ }_{15}$ Bethel, Interest of Princes and States, 112. On Sidney's and Bethel's reading of the De la Courts, see Scott, Algernon Sidney and the English Republic, 214-216.

${ }^{16}$ See Ibidem, 218-220, and John Harrison and Peter Laslett (eds.), The Library of John Locke (Oxford: Oxford University Press, 1965), 167. On the experiences of Locke, Sidney and other English exiles in the Dutch Republic, see Luisa Simonutti, "English Guests at 'De Lantaarn'. Sidney, Penn, Locke, Toland and Shaftesbury," in Sarah Huto (ed.), Benjamin Furly 1646-1714: A Quaker Merchant and his Milieu (Florence: Olschki, 2007), 31-66.

${ }^{17}$ See Pepys Library, Magdalene College, Cambridge, Ms. 2888: The Political Grounds and Maxims of the Republic of Holland and West Friesland. On Bonnel, see Pincus, Protestantism and Patriotism, 105.

${ }_{18}$ See e.g. Bodleian Library, Oxford, Ms Don. b8 (Od8), papers Sir William Haward, fol. 265-276: "Some considerations concerning Holland's making alliances with England, written by a Hollander in the year 1671 ", a document that directly reproduces De la Court's
} 
was published in English by John Darby in 1702 - not coincidentally, the year that William III died. ${ }^{19}$ One year later, Darby also published an English translation in two volumes of the Sinryke Fabulen under the title Fables, Moral and Political with Large Explications. Darby, who attributed both treatises to Johan de Witt, was acutely aware of their subversive anti-monarchical content. Significantly, he was also the publisher of the radical tolerationist writings of Pierre Bayle, Jean le Clerc, and Philippus van Limborch, and of the main texts of English republican thought, Sidney's Discourses Concerning Government, the collected works of John Milton, and John Toland's seminal edition of the writings of James Harrington. In this way, Darby enabled his English customers to read the De la Courts as the Dutch representatives of a broad seventeenth-century republican legacy.

An important author in this Anglo-Dutch exchange was Bernard Mandeville. Born in Rotterdam in 1670 and a student at Leiden, Mandeville moved to England being strongly influenced by the rhetorical, commercial and political culture of his home country. His intellectual endeavours, which merged the rhetorical figure of Aesopian fables with concerns of how to connect private with public interests, was clearly indebted to the thought of the brothers De la Court. Yet Mandeville decisively departed from his Dutch predecessors: emphasizing the utility of private vice instead of disciplined self-love, Mandeville, in the words of E.G. Hundert, “aimed to demolish the De la Courts' assumption that the passions could only properly be harnessed in a republic and to ridicule the claim that a genuinely civil life could only be led under a republican government". ${ }^{20}$ A comparable claim can be made with regard to the Commonwealthman Thomas Gordon, who was a keen reader of both Mandeville and of the 1702 English translation of De la Court. ${ }^{21}$ Together with John Trenchard, Gordon published the influential Cato's Letters, which insisted that "Trade and Naval Power" are "the Offspring of Civil Liberty only, and cannot subsist without it" - a De la Courtian claim that particularly referred to the Dutch example of commercial success. Gordon defined such liberty as

claims on trade, foreign policy and Dutch republican supremacy over the English monarchy.

19 The True Interest and Political Maxims of the Republick of Holland and West-Friesland. Written by John de Witt, and Other Great Men in Holland (London, 1702).

${ }^{20}$ E.G. Hundert, The Enlightenment's Fable. Bernard Mandeville and the Discovery of Society (Cambridge: Cambridge University Press, 1994), 29.

${ }^{21}$ See Annie Mitchell, "Character of an Independent Whig - 'Cato' and Bernard Mandeville,” History of European Ideas 29 (2003), 291-311: 297, note 21. 
the absence of "arbitrary government", yet he continued to argue that a limited monarchy such as in England was actually less arbitrary than the government of its "neighbouring Republick ... vulgarly mistaken for a commonwealth". ${ }^{22}$ Like the English republicans of the seventeenth century, Gordon thus appropriated Dutch commercial politics yet rejected its republican model.

British readers of the brothers De la Court throughout the eighteenth century continued to employ their work likewise as a noteworthy example of Dutch political economy, largely discarding its radical argument against monarchy. Two short extracts of Darby's 1702 edition of the Aanwysing, one concerning Holland's foreign policy, the other joint-stock companies in overseas trade, were republished separately, ${ }^{23}$ and the entire work was again translated and reissued in two new editions in the 1740 s. $^{24}$ These new editions were particularly influential among political economists of the Scottish Enlightenment, including Adam Smith, who owned a copy of the 1743 translation. ${ }^{25}$

Finally, the work of the De la Courts also crossed the Atlantic. In 1732, the English MP James Oglethorpe published a compendium of Select Tracts Relating to Colonies to promote the establishment of the new colony of Georgia. For this purpose, Oglethorpe had selected a number of texts on the usefulness of colonization, including Machiavelli, Francis Bacon, and a chapter from the De la Courts on Holland's commercial colonies. $^{26}$ Apart from the colonization of North-America, the brothers' shadow also coloured the constitutional debates in the emergent United States. In the summer of 1788 , when the delegates of Virginia met to discuss the ratification of the American Constitution, James Madison tried to convince his audience that a modern commercial republic required a strong federal government. Loose confederacies amount to "anarchy and confusion", he argued, and to validate this claim he referred in particular to the example of the United Provinces, "a further confirmation of the

${ }^{22}$ Thomas Gordon and John Trenchard, Cato's Letters, ed. Ronald Hamowy, 2 vols. (Indianapolis: Liberty Fund, 1995), vol. I, nr. 64: 442-450; vol. II, nr. 85: 613-618.

${ }^{23}$ Extract of Divers Passages Relating to Exclusive Joint-Stock Companies (London, s.d. [1710]); The True Interest of Holland as to Their Alliances with France, Spain, England, \&c. (s.l., s.d.)

${ }^{24}$ Political Maxims of the State of Holland. By John de Witt, Pensionary of Holland (London, 1743); The True Interest and Political Maxims of the Republic of Holland. Written by John de Witt, trans. John Campbell (London, 1746).

${ }^{25}$ See James Bonar, A Catalogue of the Library of Adam Smith (London: Macmillan, 1932), 197; cf. also Wildenberg, Bibliografie, 53-54.

${ }^{26}$ James Oglethorpe (ed.), Select Tracts Relating to Colonies (London, [1632]). 
characteristic imbecility of such governments". His source for this statement was the De la Courts' argument that the province of Holland would be better off as an independent state - for Madison this was clear proof that in the absence of a strong federal government, dismemberment is unavoidable. ${ }^{27}$ In short, the commercial republicanism of the brothers De la Court enjoyed ongoing and widespread readership, yet it was the commercial, instead of the republican dimension of their thought that was mainly adopted abroad.

And what about the reception of the brothers' thought in the Dutch Republic itself? By and large, most Dutch readers also turned their back on the De la Courts' anti-monarchical agenda. Among the first to appropriate their work was the group of radical freethinkers around Spinoza. Spinoza's Latin teacher, Van den Enden, decided to enter the public debate after having read the De la Courts, and his political treatises clearly followed in their footsteps. In particular, Van den Enden engaged in a critical discussion of the inconclusive constitutional design of the brothers De la Court. Referring to the changes in the different editions of the Politike Weeg-schaal, he expressed his agreement with De la Court's eventual definition of an aristocracy close to democracy as the best form of government. As Van den Enden argued, this is "the essential and correct definition of a right Popular government, because it would be irrationality itself if Poor and Indigent people ... together with serving and other impotent Folk, would have a right to government". Thus, Van den Enden agreed with the view that a popular government means a government of the independent citizenry. Yet he then continued to criticize the De la Courts for overlooking the practical unlikelihood of such a government where all concur in one general interest, given the many differences in opinion that will divide such a large body of people. ${ }^{28}$

${ }^{27}$ Jonathan Elliot (ed.), The Debates in the Several State Conventions, on the Adoption of the Federal Constitution, 2d. ed., 4 vols. (Washington, 1836), vol. III: 144-146. Madison refers to the 1743 edition of Political Maxims, 257. See also William H. Riker, "Dutch and American Federalism," Journal of the History of Ideas 18, 4 (1957), 495-521; and J.W. Schulte Noordholt. "The Example of the Dutch Republic for American Federalism," in J.C. Boogman and G.N. van der Plaat, Federalism. History and Current Significance of a Form of Government (The Hague: Martinus Nijhoff, 1980), 65-77.

${ }_{28}$ Van den Enden, Kort verhael, "Voor-Reeden,” p. v-vi: “... de wezentlijke, en eigentlijke definitie, eener rechte Populare regeering: want het de onreedelijkheit zelve zouw zijn, dat Arme, Behoeftige ... mitsgaders dienstbare, en andere impotente Lieden tot regeeren souwen gerechtight zijn.” Cf. Wim Klever, "Conflicting 'Considerations of State'. Van den Enden's Opposition Against De la Court's Aristocratic Republicanism and its Follow-Up in Spinoza's Work," Foglio Spinozi@no. Notiziario periodico difilosofia spinoziana (2001), from http://www.fogliospinoziano.it/artic17b.htm [retrieved May 13, 2011]. 
There is no convincing evidence that Spinoza knew the De la Courts personally, even though he lived just a stone's throw away from Leiden in the small village of Rijnsburg in the years that De la Court gained fame and notoriety. ${ }^{29}$ Nonetheless, as numerous scholars have highlighted, Spinoza was clearly influenced by the De la Courts..$^{30}$ He owned a copy of the Politike Discoursen and of the revised edition of the Politike Weegschaal, and in his unfinished swan-song, the Tractatus Politicus, he approvingly referred to the "prudentissimus Belga V.H." (De la Court's pseudonym) as an important source - besides Hobbes and Descartes the only contemporary author Spinoza deigned to mention. ${ }^{3^{1}}$ Indeed, Spinoza's political thought revisits many of the central claims of the brothers De la Court. He similarly asserts that all government is in selfinterest, that good government must therefore consist of a harmony between private and public interests, and that such a harmony is only feasible if "nothing which concerns the common welfare is wholly entrusted to the good faith of any man". Spinoza also highlights that this form of government will harness individual ambition towards peace and the protection of property, and thus it particularly suits a mercantile republic like Athens, where the "only means of gain will be to engage in trade"..$^{2}$ Yet in spite of these similarities, Spinoza's republicanism deviates from that of the De la Courts in two important ways. First, his argument against single rule does not involve the same radical assault of all things monarchical. Instead, Spinoza asserts that it is conceivable that a people will freely establish a monarchy and transfer to a king "the power to settle disputes and to take rapid discussions", because "a people can maintain a fair amount of freedom under a king" - a direct contradiction of the anti-monarchism of the brothers De la Court. ${ }^{33}$ Secondly, Spinoza moves beyond their hesitant argument for democracy towards a broader conception of the political significance of the masses. By collapsing the conventional distinction between populus and multitudo that is central to the thought of the De la Courts, Spinoza suggests that the most powerful and most stable polity is a commonwealth that enhances the political

\footnotetext{
${ }^{29}$ See J.M. Kerkhoven and H.W. Blom, "De la Court en Spinoza: van correspondenties en correspondenten," in Blom and Wildenberg (eds.), Pieter de la Court, 137-16o.

$3^{30}$ See the extensive analyses in Haitsma Mulier, Myth of Venice, 170-208; Blom, Morality and Causality, 217-239; and Prokhovnik, Spinoza and Republicanism, esp. 237-256.

${ }^{31}$ Spinoza, Tractatus Politicus VIII.31, p. 396.

${ }^{32}$ Ibidem VI.3, VII.7-8, p. 315, 341. See also X.6.

33 Ibidem VII.5, VII.31, p. 339, 365 .
} 
participation of all its inhabitants. ${ }^{34}$ While Spinoza does not follow the radical anti-monarchism of the brothers De la Court, he turns their argument for a broad representative government into a more inclusive notion of popular rule.

After Spinoza only a few Dutchmen openly sided with the De la Courts. ${ }^{35}$ In the eighteenth century they received most attention from the strongly pro-Orangist polygraph Elie Luzac, who praised their commercial thought yet utterly rejected their republicanism..$^{36}$ Ultimately, the brothers De la Court mainly encountered ridicule. In 1690, when a local political conflict erupted in Amsterdam, a number of pamphlets staged a satirical conference at the Parnassus where renowned philosophers commented on the situation. ${ }^{37}$ It was an eminent gathering that included Plato and Aristotle, Cicero and Tacitus, Machiavelli, Lipsius, Hobbes, Descartes, and Spinoza. Yet the most prominent speaker of all was De la Court. Thus, the brothers De la Court were finally admitted to the Parnassus of political thought - even though it was only in the realm of parody.

${ }^{34}$ Ibidem II.17, VIII.3. On the significance of Spinoza's conception of the multitudo, see Balibar, Spinoza and Politics, esp. 116-122. See also Steven B. Smith, "What Kind of Democrat was Spinoza?," Political Theory 33, 6 (2005), 6-27.

35 See Ivo W. Wildenberg, "Appreciaties van de gebroeders De la Court ten tijde van de Republiek," Tijdschrift voor geschiedenis 98 (1985), 540-55.

${ }^{36}$ See Wyger Velema, Enlightenment and Conservatism in the Dutch Republic. The Political Thought of Elie Luzac (1721-1796) (Assen: van Gorcum, 1993), 121-122, 173-174.

37 [Govard Bidloo], Beschryving van eenige portraiten, vertoont op Parnassus [169o]); Idem, Extract uyt de politique conferentien, gehouden op Parnassus [169o]; Idem, Tweede extract uit de politijcque conferentien, gehouden op Parnassus [169o]; [Nicolaes Muys van Holy], Romein de Hooge voor den rechterstoel van Apollo (Haarlem, 169o). On the background of these pamphlets, see C. van de Haar, "Romeyn de Hooghe en de pamflettenstrijd van de jaren 1689 en 169o," Tijdschrift voor geschiedenis 69 (1956), 153-171. 



\section{BIBLIOGRAPHY}

\section{MANUSCRIPT SOURCES}

Amsterdam

Cambridge

Groningen

Leiden

Oxford
Stadsarchief

172: Familiearchief Backer

nr. 465: Correspondence Pieter de la Court and brothers Van der Voort

nr. 466: Undated papers on international affairs, addressed to Giovanni van der Voort

nr. 470: Correspondence Pieter de la Court and brothers Van der Voort

\section{Universiteitsbibliotheek}

Ms XIV E16: Untitled manuscript of loose notes by Pieter de la Court Ms XV B2: Het welvaren der stad Leyden

Ms XV B3: Aenmerkinge op het welvaren en Intrest der Stad Leyden Ms XVI B1: Hollandse Chronijk. Geschreeven door Pieter de la Court Ms XXV C41: Copy of the Politike Weeg-schaal (fourth ed., 1662) with handwritten revisions by Pieter de la Court

Magdalene College, Pepys Library

Ms 2888: The Political Grounds and Maxims of the Republic of Holland and West Friesland, translation by Toby Bonnell of the Aanwysing (1669)

Universiteitsbibliotheek

Ms 233: 't Welvaren der Stad Leyden

Regionaal Archief

23: Familiearchief De la Court

nr. 8: Libro de Belanci (1657-1670) of the brothers Van der Voort nr. 14: Diary of Pieter de la Court's Grand Tour, 1641-1643

nr. 17: Documents concerning the inheritance of Pieter de la Court, 1691

nr. 59: Catalogue of the library of Pieter de la Court van der Voort, 1739

nr. 116: Catalogue of books and drawings, 1749

Universiteitsbibliotheek

Ms LTK 679: Copy of Historie der Gravelike Regeering (1662) with handwritten revisions by Pieter de la Court

Ms LTK 784: Het Welvaaren der Stad Leijden

Ms LTK 785: Het Welvaren der Stad Leiden

Bodleian Library

Ms Don. b8 (Od8), papers Sir William Haward, fol. 265-276: "Some considerations concerning Holland's making alliances with England, written by a Hollander in the year 1671 " 
The Hague

\section{Printed Works of the Brothers De la Court}

\section{Pamphlets}

[Pieter de la Court], Factum ofte gherechticheyt, van de huysvrouwe van Adriaen Heereboord, voor ende door deselve (The Hague: Ludolph Breeckevelt, 1648)

[Pieter de la Court], Antwoordt op de verdediginghe van Adriaen Heereboord, hem ghegheven door zijnen swagher (The Hague: Ludolph Breeckevelt, 1648)

\section{Treatises}

'V.H.' [Johan and Pieter de la Court], Consideratien en exempelen van staat, omtrent de fundamenten van allerley regeringe (Amsterdam: 'Ian Iacobsz Dommekracht', 1660)

Second, revised edition: Consideratien van Staat, ofte Polityke Weeg-schaal (Amsterdam: Iacob Volckertsz Zinbreker, 1661)

Third, revised edition: Consideratien van Staat, ofte Polityke Weeg-schaal (Amsterdam: Dirk Dirksz, 1662)

Pirated third edition: Consideratien van Staat, ofte Polityke Weeg-schaal ('Ysselmonde, voor Quirinus Overal, alias: Dwaal-star', 1662)

Fourth, revised edition: Consideratien van Staat, ofte Politike Weeg-schaal (Amsterdam: Dirk Dirksz, 1662)

Alternative fourth edition: Consideratien van Staat, ofte Politike Weeg-schaal (Amsterdam: Abraham and Jan van Wees, 1662)

Pirated fourth edition: Consideratien van Staat, ofte Politike Weeg-schaal (s.l.: Jacob Vinckel, 1662)

'D.C.' [Johan and Pieter de la Court], Politike Discoursen, handelende in Ses onderscheide Boeken van Steeden, Landen, Oorlogen, Kerken, Regeeringen en Zeeden (Leiden: Pieter Hackius, 1662)

Second, revised edition: Politike Discoursen, handelende in Ses onderscheide Boeken van Steeden, Landen, Oorlogen, Kerken, Regeeringen en Zeeden (Amsterdam: 'Ciprianus vander Gracht', 1662)

Pirated second edition: Politike Discoursen, handelende in Ses onderscheide Boeken van Steeden, Landen, Oorlogen, Kerken, Regeeringen en Zeeden (Amsterdam: Jacob Venkel, 1663)

'V.H.' [Pieter de la Court], Historie der Gravelike Regering in Holland (s.l., [1662]) [two editions dated 1662]

Pirated edition: Historie der Gravelike Regeering in Holland (Amsterdam: Jacob Vinkel, 1662) 
'V.D.H.' [Pieter de la Court], Interest van Holland, ofte gronden van Hollands-welvaren (Amsterdam: 'Cyprianus vander Gracht', 1662) [nine editions dated 1662]

Revised edition: Aanwysing der heilsame politike Gronden en Maximen van de Republike van Holland en West-Vriesland (Leiden and Rotterdam: Hakkens, 1669) [second edition dated 1671]

[Pieter de la Court], Sinryke Fabulen, verklaart en toegepast tot alderley zeede-lessen, dienstig om waargenoomen te werden in het menschelijke en burgerlijke leeven (Amsterdam: Hieronymus Sweerts, 1685)

\section{Contemporary Translations}

Interesse von Holland, oder Fondamenten van Hollands-Wohlfahrt (s.l., 1665)

Consideratien van Staat, Oder politische Wagschale, trans. Christophorus Kormarten (Leipzig and Halle, 1669)

Anweisungen der heilsamen politischen Grunde und Maximen der Republicqen Holland und West-Friesland (Rotterdam, 1671)

The True Interest and Political Maxims of the Republick of Holland and West-Friesland. Written by John de Witt, and Other Great Men in Holland (London, 1702)

Fables, Moral and Political with Large Explications, 2 vols. (London, 1703)

Mémoires de Jean de Wit, Grand Pensionaire de Hollande, trans. M. de *** [Mme. Van Zoutelandt] (The Hague, 1709) [three editions dated 1709]

Political Maxims of the State of Holland. By John de Witt, Pensionary of Holland (London, 1743)

The True Interest and Political Maxims of the Republic of Holland. Written by John de Witt, trans. John Campbell (London, 1746)

\section{Printed Manuscripts}

Pieter de la Court, "Dagboek," in F. Driessen (ed.), De reizen der De la Courts 1641-1700-1710 (Leiden, 1928), 1-30; and in Willem Frijhoff (ed.), "De reisnotities (1641-1643) van Pieter de la Court," in Blom and Wildenberg (eds.), Pieter de la Court, 34-64

Johan and Pieter de la Court, Het welvaren van Leiden. Handschrift uit het jaar 1659, ed. F. Driessen (The Hague: Martinus Nijhoff, 1911)

Pieter de la Court, "Twee 'niet ter drukperse bereide' geschriften van Pieter de la Court," ed. J.H. Kernkamp, Bijdragen en mededelingen van het historisch genootschap 56 (1935), $160-214$

\section{Printed Correspondence and Petitions}

Brieven aan Johan de Witt, ed. N. Japikse, 2 vols. (Amsterdam: Müller,1910-1922)

Brieven van Johan de Witt, ed. N. Japikse, 4 vols. (Amsterdam: Müller, 1906-1913)

Kernkamp, J.H. (ed.), "Brieven uit de correspondentie van Pieter de la Court en zijn verwanten (1661-1666)," Bijdragen en mededelingen van het historisch genootschap 70 (1956), 82-156

Kernkamp, J.H. (ed.), "Brieven uit de correspondentie van Pieter de la Court en zijn verwanten (1667-1685), met bijlagen (1657-1685)," Bijdragen en mededelingen van het historisch genootschap 72 (1958), 3-195

Overvoorde, J.C. (ed.), "De Noord-Oostelijke doorvaart naar China," Bijdragen en mededelingen van het historisch genootschap 47 (1926), 249-331

Posthumus, N.W., Bronnen tot de geschiedenis van de Leidse textielnijverheid, 6 vols. (The Hague: Nijhoff, 1910-1922) 


\section{Other Primary Sources}

All anonymous pamphlets are listed chronologically. The abbreviation Kn. refers to the general catalogue of Dutch pamphlets by W.P.C. Knuttel, Catalogus van de pamflettenverzameling berustende in de Koninlijke Bibliotheek, 1486-1853, 9 vols. (The Hague: Algemeene Landsdrukkerij, 1889-1920).

Aitzema, Lieuwe van, Herstelde Leeuw, of discours, over 't gepasseerde in de Vereenighde Nederlanden, in 't iaer 1650, ende 1651 (The Hague, 1652)

- - Historie of verhael van saken van staet en oorlogh, 14 vols. (The Hague, 1657-1671)

Alberti, Leon Battista, Opere volgari, ed. Cecil Grayson, 2 vols. (Bari: Laterza, 196o)

Anon., Den Arminiaenschen dreck-waghen (Amsterdam, 1618) Kn. 2772

Anon., Vertoogh by een lief-hebber des vaderlants vertoont. Teghen het ongefondeerde ende schadelijck sluyten der vryen handel in Brazil (s.l., 1637) Kn. 4514

Anon., Consideratien als dat de negotie op Brasil behoort open gestalt te worden (s.l., 1638) Kn. 4580

Anon., Deductie, waer by onpartijdelijck over-wogen ende bewesen wort, wat het beste voor de Compagnie van West-Indien zy: de handel te sluyten of open te laten (The Hague, 1638) Kn. 4581

Anon., Consideratie over de tegenwoordige ghelegentheydt van Brasil (Amsterdam, 1644) Kn. 5124

Anon., Op de onrijpe dood van Isak Heereboord (s.l., 1648) Kn. 5808b

Anon., Graf-Dicht op den ongesiene Isaak Heereboord (s.l., [1648]) Kn. $5808 \mathrm{c}$

Anon., Af-comst ofte reken-tael, van Pieter Lacoer (s.l., 1648) Kn. 5808e

Anon., Gedwongen waarschouwing van S.v.M. e.a., altemaal gezwooren voorstanders van de oprechte waarheid, en het vrye dicht-recht aen La Courten. Den verkeerden s'Jaak, verrotten Pier, en schurftens Jan (s.l., [1648]) Kn. $5808 \mathrm{f}$

Anon., Het triumpherende Leyden over het beroemde huys-gesin van den vermaerde scietspoelder alias De La Court (s.l., [1648]) Kn. 5808g

Anon., Piere la Cour, gruwel der verwoestinge (s.l., [1648]) Kn. $5808 \mathrm{~h}$

Anon., ["Claes Krynen van Oossanen, met zijn vlammende Swaert"], Nieuw liedeken van een hoere-waerts soon buyten Yperen (s.l., [1648]) Kn. $5808 \mathrm{i}$

Anon., Het recht der souverainiteyt van Hollandt, ende daer tegens de welgefundeerde redenen ... tot weder-legginge van de Hollantsche souverainiteyt (s.l., 1650) Kn. 6741

Anon., Brief, rakende het vangen der ses leden van de Groot-mogende Heeren Staten van Hollandt en West-vrieslandt (s.l., 1650) Kn. 6772

Anon., Bickerse beroerten, ofte Hollandtschen eclypsis, teghen den Helderen dageraedt der Provintie van Hollandt (s.l., 1650) Kn. 6846

Anon., Hollands praatjen, tusschen vier personen ... aangaande de souverainiteyt van Syn Hoogheyt, en tot justificatie van de Ed. Mog. Heeren Staten van Hollandt (Antwerp, 1650) Kn. 6824

Anon., Het tweede deel van 't Hollands praatjen ... aangaande het bedrijf van Zyn Hoogheidt (Antwerp, 1650) Kn. $683^{1}$

Anon., Het rechte derde deel dan 't Hollands Praatje, aangaande de wettige souverayniteyt van de Groot-Mogende Heeren Staten van Hollandt (s.l., 1650) Kn. 6842

Anon., Nootwendige aenmerkinge op een fameus libel, ghenaemt de Bickerse beroerte (Antwerp, 1650) Kn. 6847

Anon., Extract eens briefs uyt Vlissingen, inhoudende een roef-praatje (The Hague, 1650) Kn. 6855

Anon., Oogen-salve, voor de blinde Hollanders (Rotterdam, 1650) Kn. 6852

Anon. ["Galeacus de Rivo Ursino"], Grondich bericht, nopende den interest van desen staet (Rotterdam, 1651) Kn. 7009

Anon., Ontdeckinghe van den Nederlantschen cancker. Waer mede 't gehele lichaem van onsen staet deerlijck is besmet ('Heyl-Stadt', 1653) Kn. 7441 
Anon., Bedenckingen op de Deductie van de Ed. Gr. Mog. Staten van Hollandt (s.l., 1654) Kn. 7551

Anon., Noodig bericht aan alle oprechte patriotten en beminders van de duer-gekochte vryheyt (Amsterdam, 1654) Kn. 7567

Anon., Korte aenteeckeninge, dienende tot antwoort op seker libel, genoemt Bedenckingen op de Deductie (s.l., 1655) Kn. 766 o

Anon., Consideratien raeckende 't stuck van leeninge op interest ende panden (Leiden, 1657) Kn. 7906

Anon., Speculatien over den innerlijcken toestant van regeringe in de Vereenigde Provintien (Heusden, 1660) Kn. 8384

Anon., Verthooninge, ghedaen aen die van de Vereenichde Nederlanden (s.l., 1661) Kn. 8542

Anon. ['F.J.A.'], Wederleggingh tegens eenige poincten, de welcke soo lasterlijck verhaelt worden in het boeck genaemt de Hollandtsche Intrest (Amsterdam, 1662) Kn. 8653

Anon., Haeghs Hof-Praetje, ofte 't samen-spraeck tusschen een Hagenaer, Amsterdammer, ende Leyenaar. Op ende tegens de valsche calumnien ende versierde leugenen van Pieter la Court (Leiden, 1662) Kn. 8654

Anon., Toetze op het laster-schrift, 't onrecht genaamt Stadhouderlyke Regeeringe van Holland en West-Vriesland (Leiden, 1662) Kn. 8655

Anon., Den rechten Hollander, tegen de twee pasquillen op de heer Pieter la Court, of syn boeck genaemt Hollantsche Intrest [1662] Kn. 8655d

Anon., Helle-vreucht over den herbooren, ende nieu-regeerende Hollantschen Cromwel alias s'Hollandts Intrest ende Stadthouders Regeringh beschrijver [1662] Kn. 8656

Anon., Tafel-praetje ... over de schendige boecken genaemt den Intrest van Hollandt, mitsgaders de Consideratien van Staet, ende Politijcque Discourssen (Dordrecht, [1662]) Kn. 8657

Anon., Den klagenden veen-boer, over de faem-roovende pasquillen tegens sijn Hoogheyt den Heere Prince van Orangie, en de selfs loffelijcke voorvaderen (The Hague, 1662) Kn. 8658

Anon., Aesopus Defensor sig erbarmende over de diepe sugten van den Klagenden Veenboer (The Hague, 1662 ) Kn. 8658b

Anon., Een onverwelckbare kroon, gevlochten op het noyt-genoegh verachte boeck, genaemt de Hollantsche Intrest, door Pieter la Court [1662] Kn. 8659

Anon., Op de op-roerige schriften van Pieter la Court, door hem uyt-gegeven onder de naem van V.D.H. en D.C. [1662] Kn. 8659a

Anon., Nadere ofte tweede consideratien tegen het publijck gebedt (Leeuwarden, 1663) Kn. 8793

Anon., 't Afgeruckte masker van den Haegsen Hofprater (Leiden, 1663) Kn. 8794

Anon. ["Aesopus Stomachatus"], Apologie ofte verantwoordinge van den ondienst der stadthouderlyke regeeringe (Amsterdam, 1663) Kn. 8794a

Anon., Den verresenen Barnevelt, betabbert met alle sijne politycke maximen (Zierikzee, 1663) Kn. 8797

Anon., Herstelden Barneveldt, ofte t'samenspraeck tusschen een Hollander, Seeu ende Vries (Leiden, 1663) Kn. 8799

Anon., Den Schotsen duyvel, betabbert in den verresenen Barnevelt ... met alle sijne Jesuitsche maximen van 't Presbyterisch convenant, en 't Utrechtsch Presbytery. Uyt de gemeene lessen en legenden van Gisbertus Voetius, aerts-muyt-meester (Utrecht, 1663) Kn. 8801

Anon. ['H. van V.'], Hollandse Vrijheid verdedigt tegen de usurpatie der Stadhouders ('Loevestein', 1663) Kn. 8803

Anon., Onwederleggelycke bewys-redenen daer door betoont wort, dat de Vereenighde Nederlanden, alleen door Godts voorsieninge ende der Princen van Orangien beleyt, van Spaensche jock, ende slavernije vrij gemaeckt zijn (Willemstad, 1663) Kn. 8806

Anon., Den herstelden Prins tot Stad-houder ende Capiteyn Generaal ... tegens de boekjens onlangs uyt gegeven met den naem van Interest van Hollandt, ende Stadthouderlijcke Regeringe in Hollandt (Amsterdam, 1663) Kn. 8806a

Anon. ['W.H.'], Den oprechten Stadthouder in Hollant, waer in oock aengewesen wort de ydelheydt van de Interest van Hollant (Amsterdam, 1663) Kn. 8806b 
Anon., De gulde legenden van de Stadthouders in Hollant ende West-Vrieslandt (Amsterdam, 1663) Kn. 8806c

Anon., De gansche distructie van den nieuw-gebooren Hollantschen Cromwel alias Leydtschen Quaker; genaemt t'Intrest van Hollandt, ofte gronden van 's Hollants welvaren (Schiedam, [1663]) Kn. 8806d

Anon., Consideratien op het publijck gebedt ofte gebede-formulier van Hollandt, tegen D.H. (Leeuwarden, 1663) Kn. 8972

Anon., Den herstelden Apollos Harp, versien met verscheyde nieuwe snaren [1663]

Anon., Der Remonstranten vocale letters (Schiedam, 1664) Kn. 8925

Anon., Leydsche proceduuren, ofte oprecht ende eenvoudigh verhael, van de onverwachte vervolginge, gepleeght tegen der Remonstranten godtsdienstige vergaderingen, binnen de stadt Leyden (s.l., 1664) Kn. 8978

Anon., Den vryen handel ter zee, voor de Vereenighde Nederlanden (The Hague, 1666) Kn. 9253

Anon., Leids schuitpraatje: zijnde een t'zamenspraak tusschen verscheide personen: rakende de vrijheid van ons vaderland, der religie, en de macht der hooge overheid in kerkelijke zaken (s.l., 1668) Kn. 9727

Anon,. Recht-heylsame polityke en kerckelycke maximes, gestelt tegens de schadelijcke maximes van La Court, en andere (Utrecht, 1674)

Anon., Consideratien ende redenen, daer by de nootsaeckelijckheyt van de Stadthouderlijcke regeringe in desen staet ende republique wordt aengewesen (The Hague, 1677) Kn. 11514

Anon., Den verresen geest van Pieter de la Court, ontrust door eenige inlandse woel-geesten [1690] Kn. 13473

Anon., Pieter de la Court wederom op nieuws door eenige begerige, staetsieke, en nieusgierige geesten ontrust [169o] Kn. 13474

Aristotle, The "Art" of Rhetoric, ed. and trans. John Henry Freese (Cambridge, Mass.: Harvard University Press, 1926)

— Politica, ed. Daniel Heinsius (Leiden, 1621)

Arnauld, Antoine and Pierre Nicole, La logique ou l'art de penser, ed. Pierre Clair and François Girbal (Paris: Presses Universitaires de France, 1965)

Arnisaeus, Henning, De republica, seu reflectionis politicae libri II (Strasbourg, 1636)

Arnoldi vander Linde, Henricus, Vande conscientie-dwangh (Delft, 1629) Kn. 3969

Augustine, Van de stadt Godts, trans. Johannes Fenacolius, 5 vols. (Amsterdam, 1646)

Baardt, Petrus, Democratia Corporis Humani; dat is, Leden-Stemminghe des menschelijcken lichaems; gevoegt op een democratike regieringe sommiger republijken (Leeuwarden, 1640)

Bacon, Francis, De sapientia veterum, in The Works of Francis Bacon, ed. James Spedding et al., 14 vols. (London, $1857-1874$ ), vol. VI: $617-764$

Barlaeus, Caspar, Mercator sapiens, sive oratio de conjungendis mercaturae \& philosophiae studiis (Amsterdam, 1633)

- Oratien, en Blijde inkomst van Maria de Medicis (Amsterdam, 1662)

Becher, Johann Joachim, Politische Discurs, von den eigentlichen Ursachen deß Auff- und Abnehmens der Städt, Länder und Republicken (Frankfurt, 1673)

Bentivoglio, Guido, Relatione delle Provincie Unite, ed. S. Mastellone and E.O.G. Haitsma Mulier (Florence: Centro Editoriale Toscano, 1983)

Berg, A. van den, Verdediging, of antwoort op het schandaleuze en monstreuze boek, genaamt Hollandts Intrest (Dordrecht, 1663) Kn. 8808

Bethel, Slingsby, The World's Mistake in Oliver Cromwell (London, 1668)

— , The Present Interest of England Stated (London, 1671)

— The Interest of Princes and States (London, 1680)

[Bidloo, Govard], Beschryving van eenige portraiten, vertoont op Parnassus [1690]) Kn. 13493

—, Extract uyt de politique conferentien, gehouden op Parnassus [169o] Kn. 13488

_, , Tweede extract uit de politijcque conferentien, gehouden op Parnassus [169o] Kn. 13491 
Boccalini, Traiano, Ragguagli di Parnasso e scritti minori, ed. Luigi Firpo, 3 vols. (Bari: Laterza, 1948)

Botero, Giovanni, Della ragion di stato e delle cause della grandezza delle città (Venice, 1598)

Boxhorn, Marcus Zuerius, Commentariolus de statu Confoederatorum Provinciarum Belgii (The Hague, 1649)

$\longrightarrow$ - De successione et iure primogenitorum in adeundo principatu dissertatio (Leiden, 1649)

_- Politijck hant-boecxken, van de staet van 't Nederlandt, vertoonende den florissanten staet ende veelvoudighe middelen, tot onderhoudinghe van de wijdt-beroemde republijck (s.l., 1650)

—- Emblemata politica. Accedunt dissertationes politicae de Romanorum Imperio (Amsterdam, 1651)

- Metamorphosis Anglorum, sive mutationes variae regum, regni, rerumque Angliae (s.l., 1653)

-, Institutiones Politicae, ed. and comm. Georgius Hornius (Utrecht, 1702)

Brandt, Gerard, Historie der Reformatie, en andre kerkelyke geschiedenissen, 4 vols. (Amsterdam, 1671-1704)

Browne, Thomas, Religio Medici. Dat is: noodwendige beschryvinge van Mr Thomas Browne, trans. Abraham van Berkel ('Laege-duynen'[=Leiden], 1665)

Buchanan, George, De jure regni apud Scotos. Or a Dialogue, Concerning the Due Priviledge of Government in the Kingdom of Scotland (s.l., 1680)

Burgersdijk, Franco, Idea philosophiae moralis, sive compendiosa institutio (Leiden, 1644)

, Idea oeconomicae et politicae doctrinae (Leiden, 1644)

Cats, Jacob, Houwelick, dat is: het gansche beleyt des echten-staets (1625), in Alle de werken van Jacob Cats, ed. W.N. Wolterink, 2 vols. (Dordrecht: J.P. Revers, 1880), vol. I: 183-391

- Spiegel van den ouden ende nieuwen tijdt (1632, facs. ed. Amsterdam, 1968)

[Cattenbaert, Jasper], Hollands op-komst, oft bedenkingen, op de schaadelijke schriften, genaamt Graafelyke Regeeringe en Interest van Holland, uit-gegeven door V.D.H. (Leiden, 1662) Kn. 8653c

Charron, Pierre, Of Wisdome (1612, facs. ed. Amsterdam and New York: Da Capo Press, 1971)

Child, Josiah, BriefObservations Concerning Trade, and Interest of Money (London, 1668)

- A New Discourse of Trade (London, 1693)

Cicero, De officiis, ed. and trans. Walter Miller (Cambridge, Mass.: Harvard University Press, 1913)

—, Tusculan Disputations, ed. and trans. J.E. King (Cambridge, Mass.: Harvard University Press, 1927)

- De re publica, ed. and trans. Clinton Walker Keyes (Cambridge, Mass.: Harvard University Press, 1928)

[Clicquot de Blervâche, Simon], Considerations sur le commerce, et en particulier sur les compagnies, societés et maitrises (Amsterdam, 1758)

Cock, Gisbert, Vindiciae pro lege \& imperio: sive dissertationes duae ... contra tractatum Hobbii De Cive (Utrecht, 1661)

Comenius, Jan Amos, Via lucis vestigata et vestiganda (Amsterdam, 1668)

—, Pforte der Dinge/Janua rerum, ed. and trans. Erwin Schadel (Hamburg: Felix Meiner Verlag, 1989)

'Constans, Lucius Antistius', De jure ecclesiasticorum ('Alethopolis', 1665)

—_, Du droit des ecclésiastiques, trans. V. Butori (Caen: Centre de philosophie politique et juridique, 1991)

Coornhert, Dirck Volckertsz, De Coopman. Aenwijsende d'oprechte conste om Christelijck ende met eenen gelijcken moede in 't winnen ende verliesen Coophandel te drijven (Norden, 1620) 
[Court van der Voort, Pieter de la], Byzondere aanmerkingen over het aenleggen van pragtige en gemeene landhuizen, lusthoven, plantagien en aenklevende cieraden (Leiden, 1737)

Coyer, Abbé, Développement et défense du systéme de la noblesse commerçante, 2 vols. (Amsterdam, 1757)

De Bourgogne, Nicolas, Historia Belgica (Antwerp, 1629)

[De Brun, Antoine], Pierre de touche, des veritables interests des Provinces-Unies du PaisBas (Dordrecht, 1647) Kn. 5477

De Péréfixe, Hardouin, Histoire du Roy Henry le Grand (Amsterdam, 1661)

Descartes, René, Les passions de l'âme, ed. Benoît Timmermans (Paris: Librairie Générale Française, 1990)

De Thou, Jacques-Auguste, Historia sui temporis, 3 vols. (Genève, 1626)

Du Refuge, Eustache, Traicté de la Cour, ou instruction des courtisans (Amsterdam, 1656)

Elliot, Jonathan (ed.), The Debates in the Several State Conventions, on the Adoption of the Federal Constitution, 2d. ed., 4 vols. (Washington, 1836)

Emmius, Ubbo, Vetus Graecia illustrata (Leiden, 1626)

—_, Graecorum respublicae (Leiden, 1632)

Enden, Franciscus van den, Kort verhael van Nieuw-Nederlants gelegentheit (1662), ed. F. Mertens, from http://users.telenet.be/fvde/WorksP/KortVerhael.pdf [retrieved May 13, 2011]

__ Vrije politieke stellingen, ed. Wim Klever (Amsterdam: Wereldbibliotheek, 1992)

Episcopius, Simon, Confessio, sive declaratio, sententiae pastorum, qui in Foederato Belgio Remonstrantes vocantur (Harderwijk, 1622)

— - Vrye godes-dienst, of t'samen-spreeckinghe tusschen Remonstrant en ContraRemonstrant, over de vrye godts-dienstighe vergaderinghen der Remonstranten (s.l., 1627) Kn. 3753

- Opera Theologica, 2 vols. (Amsterdam, 1650-1655)

Erasmus, Desiderius, A Diatribe or Sermon Concerning Free Will, in Ernst F. Winter (ed.), Discourse on Free Will. Erasmus-Luther (London and New York: Continuum, 1990)

Fajardo, Diego Saavedra, Idea de un príncipe político christiano representada en cien empresas (Amsterdam, 1661)

[Fernandez de Villareal, Manuel], Le politique tres-chrestien ou discours politiques ('Paris' [Leiden], 1645)

[Fijne, Passchier de], Een broederlicke vermaninge: waer in vertoont wort d'ellende onses lieven vaderlants (s.l., 1624) Kn. 3556

Gordon, Thomas and John Trenchard, Cato's Letters, ed. Ronald Hamowy, 2 vols. (Indianapolis: Liberty Fund, 1995)

Grotius, Hugo, Verantwoordingh van de wettelicke regiering van Hollant ende Westvrieslant (Paris, [1622])

—, Annales et historiae de rebus Belgicis (Amsterdam, 1657)

, The Rights of War and Peace, trans. William Evats (London, 1682)

_- Ordinum Hollandiae ac Westfrisiae pietas, ed. and trans. E. Rabbie (Leiden: Brill, 1995)

- The Antiquity of the Batavian Republic, ed. and trans. Jan Waszink (Assen: Van Gorcum, 2000)

— De imperio summarum potestatum circa sacra, ed. and trans. Harm-Jan van Dam, 2 vols. (Leiden etc.: Brill, 2001)

—

_- Commentary on the Law of Prize and Booty, ed. Martine Julia van Ittersum (Indianapolis: Liberty Fund, 2006)

- et al., Dissertationes de studiis instituendis (Amsterdam, 1645)

Guicciardini, Francesco, La historia d'Italia (Venice, 1567)

— Ricordi, ed. Emilio Pasquini (Milan: Garzanti, 1999)

Harrington, James, The Commonwealth of Oceana and A System of Politics, ed.J.G.A. Pocock (Cambridge: Cambridge University Press, 1992) 
Heereboord, Adriaen, Naackte ende nodige verdedigingh, vande eer ende het leven, van Adrianus Heereboord (Leiden, 1648) Kn. 5808a

_- Collegium ethicum, seu philosophia moralis (London, 1658)

[Hill, Joseph], The Interest of These United Provinces, Being a Defence of the Zealander's Choice (Middelburg, 1673) Kn. 10909

Hobbes, Thomas, Le corps politique ou les elements de la loy morale et civile ([Rouen], 1652) - Leviathan: of van de stoffe, gedaente, ende magt van de kerckelycke ende wereltlycke regeeringe, trans. Abraham van Berkel (Amsterdam, 1667)

- Leviathan, ed. C.B. MacPherson (London etc: Penguin, 1968)

- The Elements of Law Natural and Politic, ed. Ferdinand Tönnies, 2d. ed. (London: Frank Cass, 1969)

- On the Citizen, ed. and trans. Richard Tuck and Michael Silverthorne (Cambridge: Cambridge Univerity Press, 1998)

[Huybert, P. de], Apologie, tegens de algemeene, en onbepaelde vryheyd, voor de oude Hollandsche regeeringe (Middelburg, 1669) Kn. 9762

Klinkhamer, Laurens, Vryheydt van spreecken in de Gemeynte der geloovigen (Leiden, 1655)

[Koerbagh, Adriaen], De souverainiteyt van Holland ende West-Vriesland ... tot refutatie van den verresen Barnevelt (Middelburg, 1664) Kn. 8924

—, Een bloemhofvan allerley lieflijkheyd sonder verdriet (Leiden, 1668)

Lambe, Samuel, Seasonable Observations (s.l., [1658])

Leibniz, G.W. Essais de Théodicée, in C.J. Gerhardt (ed.), Die philosophischen Schriften von Gottfried Wilhelm Leibniz, 7 vols. (Berlin: Weidmann, 1875-189o), vol. VI.: 1-471

—, Sämtliche Schriften und Briefe. Vierte Reihe: Politische Schriften, ed. LeibnizEditionsstelle Potsdam (Berlin: Akademie Verlag, 1983-2008)

Lettres à Abraham de Wicquefort (1668-1674), ed. F.J.L. Krämer (The Hague, 1894)

Limborch, Philippus van, Korte wederlegginge van 't boexken onlangs uytgegeven by Iacopus Sceperus ... by vorme van 't samen-sprekinge tusschen een Remonstrant en Contraremonstrant (Amsterdam, 1661)

Lipsius, Justus, Monita et exempla politica (Leiden, 1630)

- Politicorum sive civilis doctrinae libri sex (Amsterdam, 1632)

—, A Discourse of Constancy (London, 1654)

Locke, John, Political Essays, ed. Mark Goldie (Cambridge: Cambridge University Press, 1997)

- , Two Treatises of Government and A Letter Concerning Toleration, ed. Ian Shapiro (New Haven and London: Yale University Press, 2003)

Lucan, Pharsalia, sive de bello civili Caesaris et Pompeii, ed. Hugo Grotius ([Leiden], 1614)

Machiavelli, Niccolò, Il Principe, ed. Giorgio Inglese (Turin: Einaudi, 1995)

_- Discorsi sopra la prima deca di Tito Livio, ed. Corrado Vivanti (Turin: Einaudi, 200o)

_ Lettere a Francesco Vettori e a Francesco Guicciardini (1513-1537), ed. Giorgio Inglese (Milan: Rizzoli, 2002)

Malvezzi, Virgilio, Discorsi sopra Cornelio Tacito (Venice, 1635)

Malynes, Gerard de, Consuetudo vel Lex Mercatoria, or the Ancient Law-Merchant (London, 1622)

Marsilius of Padua, The Defender of the Peace, ed. and trans. Annabel Brett (Cambridge: Cambridge University Press, 2005)

Marquardus, Johannes, Tractatus politico-juridicus de iure mercatorum et commerciorum singulari (Frankfurt, 1662)

Menestrier, Claude François, L'Art des emblems ou s'enseigne la morale par les figures de la fable, de l'histoire, \& de la nature, ed. Karl Mösenender (Mittenwald: Mäander, 1981)

Mey, Johannes de, Al de Nederduistche wercken (Middelburg, 1681)

[Meyer, Lodewijk], Philosophia sacrae scripturae interpres ('Eleutheropolis' [=Amsterdam], 1666)

Milton, John, Joannis Miltons Engelsmans verdedigingh des gemeene volcks van Engelandt, tegens Claudius sonder naem alias Salmasius Konicklijke Verdedigingh [1651]

—, Areopagitica and Other Political Writings (Indianapolis: Liberty Fund, 1999) 
Montaigne, Michel de, Les Essais, ed. Jean Balsamo et al. ([Paris]: Gallimard, 2007)

More, Thomas, Utopia, trans. Clarence H. Miller (New Haven and London: Yale University Press, 2001)

[Muys van Holy, Nicolaes], Romein de Hooge voor den rechterstoel van Apollo (Haarlem, 1690) Kn. 13541

[Nedham, Marchamont], The Excellencie of a Free-State: or, The Right Constitution of a Common-wealth (London, 1656)

- Interest will not Lie. Or, A View of England's True Interest (London, 1659)

'Nil Volentibus Arduum', Tieranny van eigenbaat (1679). Toneel als wapen tegen Oranje, ed. Tanja Holzhey and Kornee van der Haven (Zoeterwoude: Astraea, 2008)

Nyenborgh, Johan van, Bericht van den koophandel, in Idem, Toneel der ambachten (Groningen, 1659)

Oglethorpe, James (ed.), Select Tracts Relating to Colonies (London, [1632])

Orlers, Jan, Beschrijvinge der Stadt Leyden, 2d. ed. (Leiden, 1641)

Oudaan, Joachim, Poëzy, 3 vols. (Amsterdam, 1712)

Overbeke, Aernout van, Anecdota sive historiae jocosae, ed. Rudolf Dekker and Herman Roodenburg (Amsterdam: P.J. Meertens-Instituut, 1991)

Owen, John, Epigrammata (London, 1606)

[Paets, Adriaan], Antwoord, van een Gereformeerdt Hollander, op een klaagbrief van N.N. Over zommige onrustige Rotterdamsche predicanten, en voornamentlijk Iacobus Borstius (s.l., 1654) Kn. 7592

— Sedig antwoord van N.N. Gereformeerd Hollander ... Waar in bewesen werd dat de dwalende als soodanige niet strafbaar zijn door uyterlijk geweld (Leiden, [1655]) Kn. 7692

_- Fabula vetus actores novi. Dat is, de oude Paep onder een nieuwe kap (s.l., 1656) Kn. 7785

[Parival, Jean-Nicolas de], Le vray l'intérêt de la Hollande, elevé sur les ruines de celuy qui voit le jour sous le nom de V.D.H. ([Amsterdam], 1662) Kn. 8653a

[Parker, Henry] Observations upon Some of His Majesties Late Answers and Expresses [London, 1642]

—, Of a Free Trade (London, 1647)

Paruta, Paolo, Discorsi politici (Venice, 1599)

Petty, William, Political Arithmetick (London, 169o)

Plato, Republic, ed. and trans. G.M.A. Grube and C.D.C. Reeve (Indianapolis: Hackett, 1992)

Pufendorf, Samuel, De jure naturae et gentium libri octo (1688, facs. ed. Oxford: Clarendon Press, 1934)

Quintilian, Institutio oratoria, trans. H.E. Butler, 4 vols. (Cambridge, Mass.: Harvard University Press, 1920-1922)

Reynal, Carew, The True English Interest (London, 1674)

Rhetorica ad C. Herennium, ed. and trans. Harry Caplan (Cambridge, Mass.: Harvard University Press, 1954)

Robinson, Henry, Certain Proposals in Order to the Peoples Freedome and Accommodation (London, 1652)

Rohan, Henri de, Le parfait Capitane ... augmenté d'un traicté: de l'interest des princes et Estats de la Chrestienté ([Leiden], 1648)

Saadi, Perssiaansche Roosengaard: Beplant met vermaaklijke historiën, scharp-zinnige redenen, nutte regelen, en leerrijke sin-spreuken (Amsterdam, 1654)

[Saldenus, Guiljelmus,] Neerlands interest, tot vrede der kercke, en wegh-neminge van alle opkomende misverstanden in de selve (Middelburg, 1664) Kn. 8972

Sansovino, Francesco, Del governo et amministratione di diversi regni et repubbliche, cosi antiche come moderne (Venice, 1568)

— L Le cose meravigliose dell'inclita città di Venezia. Riformate, accomodate, e grandemente ampliate da Leonico Goldioni (1603, facs. ed. Napoli: Liguori, 2003)

Savonarola, Girolamo, Prediche sopra Ezechiele, ed. Roberto Ridolfi, 2 vols. (Rome: Angelo Berlardetti, 1955) 
Senault, Jean-François, De l'usage des passions ([Leiden], 1643)

Sidney, Algernon, Discourses Concerning Government (London, 1704)

—, Court Maxims, ed. Hans W. Blom et al. (Cambridge: Cambridge University Press, 1996)

Spinoza, Baruch, Tractatus Theologico-Politicus, ed. and trans. Samuel Shirley (Leiden etc.: Brill, 1991)

—, Tractatus Politicus, in The Political Works, ed. and trans. A.G. Wernham (Oxford: Clarendon, 1958)

[Stermont, Jacob], Lauweren-krans gevlochten voor Syn Hoocheyt Wilhelm, de Heer van Oranjen (s.l., 1650) Kn. $685^{1}$

Stevin, Simon, Het burgherlick leven, ed. Pim den Boer (Utrecht: Bijleveld, 2001)

[Streater, John], Government Described ... Together With a BriefModel of the Government of the Common-Wealth, or, Free-State of Ragouse (London, 1659)

Tacitus, The Annals, ed. and trans. John Jackson, 4 vols. (Cambridge, Mass.: Harvard University Press, 1931-1937)

Teelinck, Willem, Den politycken Christen. Ofte instructie voor alle hooge en leege staetspersoonen ... tot destructie van de hedendaeghsche Machiavelsche wijsheydt (Middelburg, 1650)

Teelinck, Maximiliaen, Vrymoedige aenspraeck aen Sijn Hoogheyt, de Heere Prince van Oraengjen (Middelburg, 1650) Kn. 6859

Thysius, Antonius, Memorabilia celebriorum veterum rerumpublicarum (Leiden, 1646)

Udemans, Godefridus,'t Geestelyck roer van 't coopmans schip, 3d. ed. (Dordrecht, 1655)

[Uytenbogaert, Johannes], Voorstant van de vryheyt der conscientie, teghen den conscientiedwangh van Henricus Arnoldi vander Linden (s.l., 1630) Kn. 4092

-

- Tractaet van 't ampt ende authoriteyt eener Hooger Christelijcker Overheydt, in kerckelijcke saecken, 3 d. ed. (Rotterdam, 1647)

[Uytenhage de Mist, Johan], De Stadthouderlijcke regeeringe in Hollandt ende WestVrieslant (Amsterdam, 1662) Kn. 8655a

Valkenier, Petrus, 't Verwerd Europa (Amsterdam, 1675)

[Velthuysen, Lambertus van], Epistolica dissertatio de principiis iusti, et decori, continens apologiam pro tractatu clarissimi Hobbaei, De Cive (Amsterdam, 1651)

- , Ondersoeck of de Chritselijcke overheydt eenigh quaadt in haar gebiedt mach toe lateen (Middelburg, 166o)

—, Het predick-ampt en 't recht der kercke ... Tegen het gevoelen van eenige Gereformeerde Leeraers, die de selve macht verder uytbreyden als het behoort (Amsterdam, 1660)

Veth, Adriaen, Copia van de resolutie ende motiven der Ed. Moog. Heeren Staten van Zeelandt teghens d'Acte van Seclusie (s.l., 1654) Kn. 7554

— - Propositie door den Heer Raedt Pensionaris, der Heeren Staten van Zeelandt ... aengaende de designatie van den Heere Prince van Orangien, tot Capiteyn, en Admirael, der Vereenighde Nederlanden, mitsgaders Stadhouder (Middelburg, 1660) Kn. 8362

Voetius, Gijsbert, Politica ecclesiastica, 4 vols. (Amsterdam, 1663-1676)

[Vondel, Joost van den], Op de jonghste Hollantsche transformatie [1618] Kn. 2770

—, Vorsteliicke warande der dieren. Waerin de zeden-rijcke philosophie, poëtisch, morael, en historiael, vermakelijck en treffelijck wort voorghestelt (1617, facs. ed. Soest: Davaco, 1974)

- De werken van Vondel, ed. J.F.M Sterck et al., 11 vols. (Amsterdam: Maatschappij voor goede en goedkope lectuur, 1927-1940)

Vossius, Gerard, Elementa rhetorica, oratoriis ejusdem partitionibus accomodata, inque usum scholarum Hollandiae et West-Frisiae edita (Leiden, 1626)

-, De artis poeticae natura, ac constitutione liber (Amsterdam, 1647)

— Elementa rhetorica, Dat is be-ghinselen der reden-riik-konst (Amsterdam, 1648)

-, Rhetorices contractae, sive partitionum oratoriarum libri V(Oxford, 1651) 
Vranck, François, Short Exposition (1587), in Martin van Gelderen (ed.), The Dutch Revolt (Cambridge: Cambridge University Press, 1993), 227-238

[Walten, Ericus], Spiegel der waarheyd. Ofte t'samensprekinge tusschen een Arminiaan ende vroom patriot (s.l., 169o) Kn. 13480

Walwyn, William, The Compassionate Samaritane ([London], 1644)

, "W Walwins Conceptions; For a Free Trade," in The Writings of William Walwyn, ed. Jack R. McMichael and Barbara Taft (Athens and London: University of Georgia Press, 1989), 446-452

Wassenaer, Gerard van, Bedekte konsten in regeringen en heerschappien (1657), reprinted as 'V.D.H.', Nauwkeurige consideratie van staet, wegens de heerschappye van een vrye en geheymen staets-regering over de gantsche aertbodem (Amsterdam, 1662)

Werdenhagen, Johannes Angelius, Universalis introductio in omnes respublicas sive politica generalis (Amsterdam, 1632)

[Wit, Johan de], Public Gebedt, ofte consideratien tegens het nominatim bidden in de publique kerken voor particulieren persoonen, en specialijken voor den jegenwoordigen Heere Prince van Orangien, 3 vols. (Amsterdam, 1663-4) Kn. 8789, 8790, 8913

[Witt, Johan de], Deductie, ofte declaratie van de Staten van Hollandt ende West-Vrieslandt (The Hague, 1654) Kn. 7546

Zeebout, Ambrosius, Tvoyage van Mher Joos van Ghistele, ed. R.J.G.A.A. Gaspar (Hilversum: Verloren, 1998)

\section{SECONDARY LITERATURE}

Achinstein, Sharon and Elizabeth Sauer (eds.), Milton \& Toleration (Oxford: Oxford University Press, 2007)

Adams, Julia, The Familial State. Ruling Families and Merchant Capitalism in Early Modern Europe (Ithaca and London: Cornell University Press, 2005)

Akkerman, F., "Le caractère rhétorique du Traité théologico-politique, " in Idem, Met iets van eeuwigheid, eds. G.C. Huisman et al. (Groningen: Universiteitsbibliotheek, 1995), 67-79

Appleby, Joyce, Economic Thought and Ideology in Seventeenth-Century England (Princeton: Princeton University Press, 1978)

Armitage, David, The Ideological Origins of the British Empire (Cambridge: Cambridge University Press, 2000)

_ _ "Empire and Liberty: A Republican Dilemma," in Van Gelderen and Skinner (eds.), Republicanism, vol. II: $29-46$

Armstrong, Brian G., Calvinism and the Amyraut Heresy. Protestant Scholasticism and Humanism in Seventeenth-Century France (Madison etc.: University of Wisconsin Press, 1969)

Balibar, Etienne, Spinoza and Politics (London and New York: Verso, 2008)

Barner, Wilfried, Barockrhetorik. Untersuchungen zu ihren geschichtlichen Grundlagen (Tübingen: Max Niemeyer Verlag, 1970)

Barnouw, P. J., Philippus van Limborch (The Hague: Mouton \& Co., 1963)

Baron, Hans, In Search of Florentine Civic Humanism. Essays on the Transition from Medieval to Modern Thought, 2 vols. (Princeton: Princeton University Press, 1988)

Baumgold, Deborah, "The Composition of the Hobbes's Elements of Law," History of Political Thought 25 (2004), 16-43

Beck, Andreas J., Gisbertus Voetius (1589-1676). Sein Theologieverständnis und seine Gotteslehre (PhD dissertation Utrecht University, 2007)

Behzad, Faramarz, Adam Olearius' "Persanischer Rosenthal." Untersuchungen von Saadis "Golestan" im 17. Jahrhundert (Göttingen: Vandenhoeck \& Ruprecht, 1970)

Berkvens-Stevelinck, Christine et al. (eds.), The Emergence of Tolerance in the Dutch Republic (Leiden etc.: Brill, 1997) 
Bertelli, Sergio, Trittico. Lucca, Ragusa, Boston. Tre città mercantili tra Cinque e Seicento (Rome: Donzelli, 2004)

Bijl, M. van der, "Pieter de la Court en de politieke werkelijkheid," in Blom and Wildeberg (eds.), Pieter de la Court, 65-91

Blanchard, Joël, Commynes l'Européen. L'invention du politique (Geneva: Droz, 1996)

Blanning, T.C.W., The Culture of Power and the Power of Culture. Old Regime Europe, $1660_{-}$ 1789 (Oxford: Oxford University Press, 2002)

Blom, Hans W., "Political Science in the Golden Age. Criticism, History and Theory in Dutch Seventeenth Century Political Thought," The Netherlands'Journal of Sociology 15 (1979), 47-71

—, Spinoza en De la Court. Politieke wetenschap in de zeventiende eeuw [Mededelingen vanwege het Spinozahuis, nr. 42] (Leiden: Brill, 1981)

- , "Virtue and Republicanism. Spinoza's Political Philosophy in the Context of the Dutch Republic," in Helmut G. Koenisgberger (ed.), Republiken und Republikanismus im Europa der Frühen Neuzeit (München: R. Oldenbourg Verlag, 1988), 195-212

- Morality and Causality in Politics. The Rise of Naturalism in Dutch SeventeenthCentury Political Thought (PhD dissertation Utrecht University, 1995)

— Kloek and Tilmans (eds.), Burger, 99-112

— , "The Republican Mirror: The Dutch Idea of Europe," in: A. Pagden (ed.), The Idea of Europe. The Politics of Identity from Antiquity to the European Union (Cambridge: Cambridge University Press, 2002), 91-115

—, "Spinoza on Res Publica, Republics, and Monarchies," in Idem et al. (eds.), Monarchisms in the Age of Enlightenment. Liberty, Patriotism, and the Common Good (Toronto etc.: University of Toronto Press, 2007), 19-44

- and Ivo W. Wildenberg (eds.), Pieter de la Court in zijn tijd (1618-1685). Aspecten van een veelzijdig publicist (Amsterdam and Maarssen: APA-Holland University Press, 1986)

Bock, Gisela, Quentin Skinner and Maurizio Viroli (eds.), Machiavelli and Republicanism (Cambridge: Cambridge University Press, 1990)

Bödeker, Hans, "Debating the respublica mixta: German and Dutch Political Discourses around 1700," in Van Gelderen and Skinner (eds.), Republicanism, vol. I: 219-246

Boogman, J.C., Van spel en spelers (The Hague: Martinus Nijhoff, 1982)

Bos, E.P., and H.A. Krop (eds.), Franco Burgersdijk (1590-1635) (Amsterdam: Rodopi, 1993)

Boureau, Alain, "État moderne et attribution symbolique: emblèmes et devises dans l'Europe des XVIe et XVIIe siècles, " in Culture et idéologie dans la genèse de l'état moderne (École Française de Rome, 1985), 155-178

_ (ed.), The Culture of Print. Power and the Use of Print in Early Modern Europe (Princeton: Princeton University Press, 1989), 261-289

Bowen, Barbara C., "Two literary genres: the emblem and the joke," Journal of Medieval and Renaissance Studies 15 (1985), 29-35

Brändli, Rodolfo, Virgilio Malvezzi. Politico e moralista (PhD dissertation Basel University, 1964)

Brandt, Reinhard, "Self-Consciousness and Self-Care. On the Tradition of Oikeiosis in the Modern Age," Grotiana (New Series) 22/23 (2001-2002), 73-92

Brett, Annabel, "What is Intellectual History Now?," in David Cannadine (ed.), What is History Now? (Basingstoke etc.: Palgrave Macmillan, 2002), 113-131

- "Natural Right and Civil Community: The Civil Philosophy of Hugo Grotius," The Historical Journal 45 (2002), 31-51

- et al. (eds.), Rethinking the Foundations of Modern Political Thought (Cambridge: Cambridge University Press, 2006)

Briels, J., Zuid-Nederlanders in de Republiek, 1572-163o (Sint-Niklaas: Danthe, 1985)

Brito Viera, Mónica, “Mare Liberum vs. Mare Clausum: Grotius, Freitas, and Selden's Debate on Dominion Over the Seas," Journal of the History of Ideas 64 (2003), 361-377 
Brown, Deborah J., Descartes and the Passionate Mind (Cambridge etc.: Cambridge University Press, 2006)

Bruin, Guido de, "Political Pamphleteering and Public Opinion in the Age of De Witt (1653-1672)," in Deen et al. (eds.), Pamphlets and Politics, 63-95

Brunner, O., W. Conze and R. Koselleck (eds.), Geschichtliche Grundbegriffe. Historisches Lexikon zur politischen-sozialen Sprache in Deutschland, 8 vols. (Stuttgart: Klett-Cotta, 1974-1997)

Buckle, Stephen, Natural Law and the Theory of Property. Grotius to Hume (Oxford: Clarendon Press, 1991)

Buijnsters, P.J., "Imaginaire reisverhalen in Nederland gedurende de $18^{\mathrm{e}}$ eeuw," in Idem, Nederlandse literatuur van de achttiende eeuw. Veertien verkenningen (Utrecht: HES, 1984), 7-35

Bunge, Wiep van, From Stevin to Spinoza. An Essay on Philosophy in the SeventeenthCentury Dutch Republic (Leiden etc: Brill, 2001)

Burke, Peter, "The Politics of Reformation History: Burnet and Brandt," in Alistair Duke and C.A. Tamse (eds.), Clio's Mirror. Historiography in Britain and the Netherlands (Zutphen: Walburg Pers, 1985), 73-85

_ , "Tacitism, Scepticism, and Reason of State," in Burns and Goldie (eds.) Cambridge History of Political Thought, 479-498

Burns, J.H., "George Buchanan and the Anti-Monarchomachs," in Phillipson and Skinner (eds.), Political Discourse, 3-22

and Mark Goldie (eds.), The Cambridge History of Political Thought, 1450-17oo (Cambridge: Cambridge University Press, 1991)

Campos-Boralevi, Lea, "Classical Foundational Myths of European Republicanism: The Jewish Commonwealth," in Van Gelderen and Skinner, Republicanism, vol. I: 247-261

Carta, Paolo, "Magistrature repubblicane e comparazione giuridica nell'opera di Francesco Sansovino," Il pensiero politico 40 (2007), 283-300

Caton, Hiram, The Politics of Progress. The Origins and Development of the Commercial Republic, 1600-1835 (Gainesville: University of California Press, 1988)

Cavaillé, Jean-Pierre, Descartes. La fable du monde (Paris: Vrin, 1991)

Clark, Henry C., Compass of Society. Commerce and Absolutism in Old-Regime France (Lanham etc.: Lexington, 2007)

Colclough, David, Freedom of Speech in Early Stuart England (Cambridge: Cambridge University Press, 2005)

Colish, Marcia L., "Republicanism, Religion, and Machiavelli's Savonarolan Moment," Journal of the History of Ideas 6o, 4 (1999), 597-616

Comparato, Vittor Ivo, "La repubblica napoletana del 1647/48: Partiti, idee, modelli politici," Il pensiero politico 21 (1998), 205-238

_ - "From the Crisis of Civil Culture to the Neapolitan Republic of 1647: Republicanism in Italy between the Sixteenth and Seventeenth Centuries," in Van Gelderen and Skinner (eds.), Republicanism, vol. I: 169-193

Conley, Thomas M., Rhetoric in the European Tradition (Chicago and London: The University of Chicago Press, 1990)

Connell, William J., "The Republican Idea," in Hankins (ed.), Renaissance Civic Humanism, 14-29

Conti, Vittorio, Consociatio Civitatum. Le Repubbliche nei testi elzeviriani (1625-1649) (Florence: Centro Editoriale Toscano, 1997)

, "Modelli repubblicani nel primo Seicento," Filosofia politica 12 (1998), 57-65

Cook, Harold J., "Body and Passions: Materialism and the Early Modern State," Osiris 17 (2002), 25-48

- Matters of Exchange. Commerce, Medicine and Science in the Dutch Golden Age (New Haven: Yale University Press, 2007)

Crahay, Rolando, "Dalla République di Jean Bodin alla Synopsis di Johann Angelius Werdenhagen (1635). Un rinnovamento dei concetti religiosi e politici," Rivista Storica Italiana 104 (1992), 629-677 
Cummings, Brian, The Literary Culture of the Reformation. Grammar and Grace (Oxford: Oxford University Press, 2005)

Daly, Peter M., Literature in the Light of the Emblem. Structural Parallels between the Emblem and Literature in the Sixteenth and Seventeenth Centuries (Toronto etc.: University of Toronto Press, 1979)

Danzi, Massimo, "Fra 'oıxos' e ' $\pi \dot{\lambda} \lambda ı s$ ': sul pensiero familiare di Leon Battista Alberti," in Claudia Bastia and Maria Bolognini (eds.), La memoria e la città. Scritture storiche tra Medioevo ed Età Moderna (Bologna: Il Nove, 1995), 47-62

Davids, Karel, "Neringen, hallen en gilden. Kapitalisten, kleine ondernemers en de stedelijke overheid in de tijd van de Republiek," in Idem et al. (eds.), Kapitaal, ondernemerschap en beleid. Studies over de economie en politiek in Nederland, Europa en Azië van 1500 tot heden (Amsterdam: NEHA, 1996), 95-119

— - "From De la Court to Vreede. Regulation and Self-regulation in Dutch Economic Discourse from c. 1660 to the Napoleonic Era," The Journal of European Economic History 30, 2 (2001), 245-289

Deen, Femke, David Onnekink and Michel Reinders (eds.), Pamphlets and Politics in the Dutch Republic (Leiden and Boston: Brill, 2011)

Dekker, Rudolf, Lachen in de Gouden Eeuw. Een geschiedenis van de Nederlandse humor (Amsterdam: Wereldbibliotheek, 1997)

Del Lucchese, Filippo Tumulti e indignatio. Conflitto, diritto e moltitudine in Machiavelli e Spinoza (Milan: Edizioni Ghibli, 2004)

Dibon, Paul, La philosophie néerlandaise au Siècle d'Or. L'enseignement philosophique dans les universités a l'époque précartésienne (1575-1650) (Paris etc.: Elsevier, 1954)

Dijn, Herman de, "Adriaan Heereboord en het Nederlands Cartesianisme," Algemeen Nederlands Tijdschrift voor Wijsbegeerte 75 (1983), 56-69

Dillen, J.G. van, "Leiden als industriestad tijdens de Republiek," Tijdschrift voor geschiedenis 59 (1946), 25-51

Dingemanse, Clazina, Rap van tong, scherp van pen. Literaire discussiecultuur in Nederlandse praatjespamfletten (circa 16oo-1750) (Hilversum: Verloren, 2008)

Dreitzel, Horst, Protestantischer Aristotelismus und absoluter Staat. Die "Politica" des Henning Arnisaeus (ca.1575-1636) (Wiesbaden: Franz Steiner Verlag, 1970)

—_ "Der Aristotelismus in der politischen Philosophie Deutschlands im 17.Jahrhundert," in Echard Keßler et al. (eds.), Aristotelismus und Renaissance. In memoriam Charles B. Schmitt (Wiesbaden: Otto Harrassowitz, 1988), 163-192

- , "Reason of State and the Crisis of Political Aristotelianism: An Essay on the Development of 17th Century Political Philosophy," History of European Ideas 28 (2002), 163-187

Duits, H., Van Bartholomeusnacht tot Bataafse opstand. Studies over de relatie tussen politiek en toneel in het midden van de zeventiende eeuw (Hilversum: Verloren, 1990)

Dunn, John, Setting the People Free. The Story of Democracy (London: Atlantic, 2005)

DuPlessis, Robert S. and Martha C. Howell, "Reconsidering the Early Modern Economy: The Cases of Leiden and Lille," Past and Present 94 (1982), 49-84

Eijnatten, Joris van, Mutua Christianorum Tolerantia. Irenicism and Toleration in the Netherlands: the Stinstra affair, 1740-1745 (Florence: Olschki, 1998)

_- , "Lodestars of Latitude. Gerard Brandt's Peacable Christian, c. 1664, Irenicism and Religious Dissent," LIAS. Sources and Documents Relating to the Early Modern History of Ideas 26 (1999), 57-75

——, "Van godsdienstvrijheid naar mensenrecht. Meningsvorming over censuur en persvrijheid in de Republiek, 1579-1795," Bijdragen en mededelingen betreffende de geschiedenis der Nederlanden 118, 1 (2003), 1-21

End, G. van den, Guiljelmus Saldenus (1627-1694). Een praktisch en irenisch theoloog uit de Nadere Reformatie (Leiden: Groen, 1991)

Enno van Gelder, H.A., Getemperde vrijheid. Een verhandeling over de verhouding van Kerk en Staat in de Republiek der Verenigde Nederlanden en de vrijheid van meningsuiting in 
zake godsdienst, drukpers en onderwijs, gedurende de $17^{e}$ eeuw (Groningen: WoltersNoordhoff, 1972)

Finkelstein, Andrea, Harmony and the Balance. An Intellectual History of SeventeenthCentury English Economic Thought (Ann Arbor: University of Michigan Press, 2000)

Fitzmaurice, Andrew, "The Ideology of Early Modern Colonisation," History Compass 2 (2004), 1-14

Fix, Andrew C., Prophecy and Reason. The Dutch Collegiants in the Early Enlightenment (Princeton: Princeton University Press, 1991)

Fock, C. Willemijn, "Het eerste huwelijk van Pieter de la Court in 1657," Leids Jaarboekje 74 (1982), $72-85$

— and R.E.O. Ekkart, "De portretgalerij van de familie De la Court," Jaarboek van het Centraal Bureau voor genealogie 35 (1981), 177-230

Foucault, Michel, Fearless Speech, ed. Joseph Pearson (Los Angeles: Semiotext(e), 2001)

Franits, Wayne E., Paragons of Virtue. Women and Domesticity in Seventeenth-Century Dutch Art (Cambridge etc.: Cambridge University Press, 1993)

Frank van Westrienen, A., De Groote Tour. Tekening van de educatiereis der Nederlanders in de zeventiende eeuw (Amsterdam: Noord-Hollandsche Uitgeversmaatschappij, 1983)

- Het schoolschrift van Pieter Teding van Berkhout: vergezicht op het gymnasiaal onderwijs in de zeventiende-eeuwse Nederlanden (Hilversum: Verloren, 2007)

Frankel, Steven, "Politics and Rhetoric: The Intended Audience of Spinoza's Tractatus Theologico-Politicus," The Review of Metaphysics 52 (1999), 897-924

Frijhoff, Willem, "Pieter de la Courts reisjournaal (1641-1643) als ego-document," in Blom and Wildenberg (eds.), Pieter de la Court, 11-34

_ - "Pieter de la Court and Comenius' Third Visit to Holland (1642)," Acta Comeniana. Revue Internationale des Études Coméniologiques 7 (1987), 183-192

— - "The Threshold of Toleration. Interconfessional Conviviality in Holland During the Early Modern Period," in Idem, Embodied Belief. Ten Essays on Religious Culture in Dutch History (Hilversum: Verloren, 2002), 39-65

— et al., 1650. Bevochten eendracht (The Hague: SdU, 1999)

Fruin, Robert, "Over Simon van Leeuwen en zijn bedenckingen over de stadhouderlijcke magt," in Idem, Verspreide geschriften, ed. P.J. Blok, P.L. Muller and S. Müller (The Hague: Martinus Nijhoff, 1903), vol. VIII: 95-113

Gaber, Daniel and Michael Ayers (eds.), The Cambridge History of Seventeenth-Century Philosophy, 2 vols. (Cambridge: Cambridge University Press, 2003)

Garin, Eugenio, L'umanesimo italiano. Filosofia e vita civile nel Rinascimento (Bari: Laterza, 1993)

Gelderblom, Arie-Jan, “The Publisher of Hobbes's Dutch Leviathan," in Susan Roach (ed.), Across the Narrow Seas. Studies in the History and Bibliography of Britain and the Low Countries (London: The British Library, 1991), 162-166

Gelderen, Martin van, "The Machiavellian Moment and the Dutch Revolt," in Bock, Skinner and Viroli (eds.), Machiavelli and Republicanism, 205-223

- The Political Thought of the Dutch Revolt, 1555-1590 (Cambridge: Cambridge University Press, 1992)

_ _ , "Holland und das Preußentum: Justus Lipsius zwischen niederländischem Aufstand und brandenburg-preußischem Absolutismus," Zeitschrift für historische Forschung 23 (1996), 29-56

_- "Aristotelians, Monarchomachs and Republicans: Sovereignty and respublica mixta in Dutch and German Political Thought, 1580-1650," in Van Gelderen and Skinner (eds.), Republicanism, vol. I: $195^{-217}$

_ - "The State and its Rivals in Early-Modern Europe," in Quentin Skinner and Bo Stråth (eds.), States and Citizens. History, Theory, Prospects (Cambridge: Cambridge University Press, 2003), 79-96 
—-, "The Low Countries," in Howell Lloyd, Glen Burgess and Simon Hodson (eds.), European Political Thought. Religion, Law and Philosophy (New Haven: Yale University Press, 2007), 376-415

-and Quentin Skinner (eds.), Republicanism: a Shared European Heritage, 2 vols. (Cambridge: Cambridge University Press, 2002)

Geyl, Pieter, "Het Stadhouderschap in de Partijliteratuur onder De Witt," in Idem, Pennestrijd over Staat en Historie (Groningen: Wolters-Noordhoff, 1971), 3-71

Goldgar, Anne, Tulipmania. Money, Honor, and Knowledge in the Dutch Golden Age (Chicago and London: The University of Chicago Press, 2007)

Goldie, Mark, "The Civil Religion of James Harrington," in Pagden (ed.), Languages of Political Theory, 197-222

- , "The Theory of Religious Intolerance in Restoration England," in Ole Peter Grell et al. (eds.), From Persecution to Toleration: The Glorious Revolution and Religion in England (Oxford: Oxford University Press, 1991), 331-368

Grafton, Anthony, Leon Battista Alberti. Master Builder of the Italian Renaissance (London etc.: Penguin, 2001)

— Bring Out Your Dead. The Past as Revelation (Cambridge, Mass.: Harvard University Press, 2001)

— Athenae Batavae: The Research Imperative at Leiden, 1575-165o. Scaliger Lectures 1 (Leiden: Primavera, 2003)

Green, Lawrence D., “Aristotle's Rhetoric and Renaissance Views of the Emotions,” in Mack (ed.), Renaissance Rhetoric, $1-26$

Greenblatt, Stephen, Renaissance Self-Fashioning from More to Shakespeare (Chicago and London: The University of Chicago Press, 1984)

Groenveld, Simon, De Prins voor Amsterdam. Reacties uit pamfletten op de aanslag van 1650 (Bussum: Fibula-Van Dishoeck, 1967)

- (ed.), Leiden. De geschiedenis van een Hollandse stad, vol. 2: 1574-1795 (Leiden: Stichting Geschiedschrijving Leiden, 2003)

Groot, Aart de, "Heterodoxie, Häresie und Toleranz in der Sicht von Gisbertus Voetius (1589-1676)," in Henry Méchoulan et al. (eds.), La formazione storica della alterità. Studi di storia della tolleranza nell'età moderna offerti a Antonio Rotondò, 3 vols. (Florence: Olschki, 2001), vol. II: 517-539

Grosheide, Daniël, Cromwell naar het oordeelvanzijn Nederlandse tijdgenoten (Amsterdam: Noord-Hollandsche Uitgevers Maatschappij, 1951)

Gruys, J.A., “De reeks 'Republieken' van de Elzeviers en Johannes de Laet," in B.P.M. Dongelmans et al. (eds.), Boekverkopers van Europa. Het $17^{\text {de }}$-eeuwse Nederlandse uitgevershuis Elzevier (Zutphen: Walburg Pers, 2000), 77-114

Gunn, J.A.W., “'Interest Will Not Lie': A Seventeenth-Century Political Maxim,” Journal of the History of Ideas 29, 4 (1968), 551-564

Haakonssen, Knud, Natural Law and Moral Philosophy from Grotius to the Scottish Enlightenment (Cambridge: Cambridge University Press, 1996)

Haar, C. van de, "Romeyn de Hooghe en de pamflettenstrijd van de jaren 1689 en 169o," Tijdschrift voor geschiedenis 69 (1956), 153-171

Habermas, Jürgen, Strukturwandel der Öffentlichkeit. Untersuchungen zu einer Kategorie der bürgerlichen Gesellschaft, 2d. ed. (Frankfurt: Suhrkamp, 199o)

Haitsma Mulier, E.O.G., The Myth of Venice and Dutch Republican Thought in the Seventeenth Century (Assen: van Gorcum, 1980)

_ "J.G.A. Pocock and Seventeenth-century Dutch Republicanism: A Reconsideration," Theoretische geschiedenis 9 (1982), 24-29

— - "De Naeuwkeurige consideratie van staet van de gebroeders De la Court. Een nadere beschouwing," Bijdragen en mededelingen betreffende de geschiedenis der Nederlanden 99 (1984), 396-407

- "The Language of Seventeenth-Century Republicanism in the United Provinces: Dutch or European?," in Pagden (ed.), Languages of Political Theory, 179-195 
"A Controversial Republican: Dutch Views on Machiavelli in the Seventeenth and Eighteenth Centuries," in Bock, Skinner and Viroli (eds.), Machiavelli and Republicanism, $247-263$

— Gerhard Schwinge (eds.), Pieter Valkenier und das Schicksal der Waldenser um 1700 (Heidelberg: Regionalkultur, 2004), 109-122

- and W.R.E. Velema (eds.), Vrijheid: een geschiedenis van de vijftiende tot de twintigste eeuw (Amsterdam: Amsterdam University Press, 1999)

Haks, Donald, Huwelijk en gezin in Holland in de $17^{e}$ en $18^{e}$ eeuw (Utrecht: HES, 1985)

Hankins, James (ed.), Renaissance Civic Humanism. Reappraisals and Reflections (Cambridge: Cambridge University Press, 2000)

- "Rhetoric, History, and Ideology: the Civic Panegyrics of Leonardo Bruni," in Hankins (ed.), Renaissance Civic Humanism, 143-178

- "Exclusivist Republicanism and the Non-Monarchical Republic," Political Theory 38 (2010), 452-482

Hanou, A.J., "Verlichte vrijheid. Iets over een denkbeeld in imaginaire reizen," in Haitsma Mulier and Velema (eds.), Vrijheid, 187-211

Harline, Craig E., Pamphlets, Printing and Political Culture in the Early Dutch Republic (Dordrecht etc.: Martinus Nijhoff, 1987)

Harms, Roeland, "Thievery of Literature. Consequences of the Interaction Between Politics and Commerce for the Form and Contents of Pamphlets," in Deen et al. (eds.), Pamphlets and Politics, 37-62

Harris, Tim, "Propaganda and Public Opinion in Seventeenth-Century England," in Jeremy D. Popkin (ed.), Media and Revolution. Comparative Perspectives (Lexington: University Press of Kentucky, 1995), 48-73

Hartman, Jan, "Tacitism and Trade. Johan (1622-166o) and Pieter (1618-1685) de la Court's Maxims and Algernon Sidney's 'Court Maxims'," unpublished paper

— et al. (eds.), Public Offices, Personal Demands. Capability in Governance in the Seventeenth-Century Dutch Republic (Newcastle: Cambridge Scholars Publishing, 2009)

Heck, Paul van, "In het Spoor van Machiavelli: de Politike Discoursen van Johan en Pieter de la Court," LIAS. Sources and Documents Relating to the Early Modern History of Ideas 27 (2000), 277-318

Heesakkers, Chris L., "An Lipsio licuit et Cunaeo quod mihi non licet? Petrus Francius and Oratorical Delivery in the Amsterdam Athenaeum Illustre," in Gilbert Tournoy and Dirk Sacré (eds.), Ut granum sinapis. Essays on Neo-latin Literature in Honour ofJozef IJsewijn (Leuven: Leuven University Press, 1997), 324-349

Hegel, G.W.F., Aesthetik, ed. Friedrich Bassenge, 2 vols. (Frankfurt: Europäische Verlagsanstalt, [1955])

Held, Julius S., "Rembrandt's Aristotle," in Idem, Rembrandt Studies (Princeton: Princeton University Press, 1991), 17-59

Hellinga, Lotte et al. (eds.), The Bookshop of the World. The Role of the Low Countries in the Book-Trade 1473-1941 ('t Goy-Houten: Hes \& De Graaf, 2001)

Hendrix, Harald, Traiano Boccalini fra erudizione e polemica. Ricerche sulla fortuna e bibliografia critica (Florence: Olschki, 1995)

Hirschmann, Albert O., The Passions and the Interests. Political Arguments for Capitalism before its Triumph (Princeton: Princeton University Press, 1977)

Hoekstra, Kinch, "A Lion in the House: Hobbes and Democracy," in Brett et al. (eds.), Rethinking the Foundations, 191-218

Hoftijzer, Paul G., "Sic Transit Gloria ... The End of the Officina Hackiana," Quaerendo 26, 4 (1996), 258-273

- "The English Book in the Seventeenth-Century Dutch Republic," in Hellinga et al. (eds.), Bookshop of the World, 89-107 
Holenstein, André, Thomas Maissen and Maarten Prak (eds.), The Republican Alternative. The Netherlands and Switzerland Compared (Amsterdam: Amsterdam University Press, 2008)

Hont, Istvan, Jealousy of Trade. International Competition and the Nation-State in Historical Perspective (Cambridge, Mass.: Harvard University Press, 2005)

Hoock, Jochen, "Professional Ethics and Commercial Rationality at the Beginning of the Modern Era," in Jacob and Secretan (eds.), Self-Perception of Early Modern Capitalists, $147-159$

Hundert, E.G., The Enlightenment's Fable. Bernard Mandeville and the Discovery of Society (Cambridge: Cambridge University Press, 1994)

- "Bernard Mandeville and the Enlightenment's Maxims of Modernity," Journal of the History of Ideas 56 (1995), 577-593

Israel, Jonathan, "Toleration in Seventeenth-Century Dutch and English Thought," in Simon Groenveld and Michael Wintle (eds.), The Exchange ofIdeas: Religion, Scholarship and Art in Anglo-Dutch Relations in the Seventeenth Century (Zutphen: Walburg Pers, 1994), 13-30

- The Dutch Republic. Its Rise, Greatness, and Fall 1477-1806 (Oxford: Oxford University Press, 1995)

—, "The Intellectual Debate about Toleration in the Dutch Republic," in BerkvensStevelinck et al. (eds.), Emergence of Tolerance, $3-36$

- Radical Enlightenment. Philosophy and the Making of Modernity 1650-1750 (Oxford: Oxford University Press, 2001)

- "The Intellectual Origins of Modern Democratic Republicanism (1660-1720)," European Journal of Political Theory 3 (2004), 7-36

- Monarchy, Orangism, and Republicanism in the Later Dutch Golden Age, Second Golden Age Lecture (Amsterdam: Amsterdams Centrum voor de Studie van de Gouden Eeuw, 2004)

- Enlightenment Contested. Philosophy, Modernity, and the Emancipation of Man $1670-$ 1752 (Oxford: Oxford University Press, 2006)

Ittersum, Martine van, Profit and Principle. Hugo Grotius, Natural Rights Theories and the Rise of Dutch Power in the East Indies (1595-1615) (Leiden and Boston: Brill, 2006)

Jacob, Margaret C. and Catherine Secretan (eds.), The Self-Perception of Early Modern Capitalists (New York: Palgrave MacMillan, 2008)

James, Susan, Passion and Action. The Emotions in Seventeenth-Century Philosophy (Oxford: Clarendon Press, 1997)

- , "The Passions in Metaphysics and the Theory of Action," in Gaber and Ayers (eds.), The Cambridge History of Seventeenth-Century Philosophy, vol. I: 913-949

— , "Reason, the Passions, and the Good Life," in Gaber and Ayers (eds.), The Cambridge History of Seventeenth-Century Philosophy, vol. II: 1358-1396

Jansen, Jeroen, "De Institutiones oratoriae van G.J. Vossius (1577-1649)", Lampas. Tijdschrift voor Nederlandse classici 34 (2001), 373-390

- , "Het geslaagde spreken: welsprekendheid als beroepsbekwaamheid in de zeventiende eeuw," De zeventiende eeuw 18 (2002): 31-42

Janson, H.W., Apes and Ape Lore in the Middle Ages and the Renaissance (London: Warburg Institute, 1952)

Jardine, Lisa and Anthony Grafton, “'Studied for Action': How Gabriel Harvey Read His Livy," Past \& Present 129 (1990), 30-78

Jong, O.J. de, "Voetius en de tolerantie," in J. van Oort et al. (eds.), De onbekende Voetius (Kampen: J.H. Kok, 1989), 109-116

Jongeneelen, Gerrit, “An Unknown Pamphlet of Adriaan Koerbagh,” Studia Spinozana 3 $(1987), 405^{-415}$

Jorink, Eric, Het Boeck der Nature. Nederlandse geleerden en de wonderen van Gods Schepping, 1575-1715 (Leiden: Primavera Pers, 2007) 
Joucla-Ruan, André, Le Tacitisme de Saavedra Fajardo (Paris: Éditions Hispaniques, 1977) Jurdjevic, Mark, "Virtue, Commerce, and the Enduring Florentine Republican Moment: Reintegrating Italy into the Atlantic Republican Debate," Journal of the History of Ideas 62, 4 (2001), 721-743

Kahn, Victoria, Machiavellian Rhetoric. From the Counter-Reformation to Milton (Princeton: Princeton University Press, 1994)

_ - "Happy Tears. Baroque Politics in Descartes's Passions de l'âme," in Ead. et al. (eds.), Politics and the Passions, 1500-1850 (Princeton and Oxford: Princeton University Press, 2006), 93-110

Kaplan, Benjamin, Divided by Faith. Religious Conflict and the Practice of Toleration in Early Modern Europe (Cambridge, Mass.: Harvard University Press, 2007)

Keblusek, Marika, "Nieuwsvoorziening in de Republiek. De Engelse burgeroorlog in Haagse drukken," in Henk Kleijer et al. (eds.), Tekens en teksten. Cultuur, communicatie en maatschappelijke veranderingen vanaf de late middeleeuwen (Amsterdam: Amsterdam University Press, 1992), 6o-77

- , "The Exile Experience: Royalist and Anglican Book Culture in the Low Countries (1640-1660)," in Hellinga et al. (eds.), Bookshop of the World, 151-158

Kerkhoven, J.M., Spinoza's clausules aangaande uitsluiting van politieke rechten in hun maatschappelijke context [Mededelingen vanwege het Spinozahuis, nr. 63] (Delft: Eburon, 1991)

_ and H.W. Blom, "De la Court en Spinoza: van correspondenties en correspondenten," in Blom and Wildenberg (eds.), Pieter de la Court, 137-16o

Kern Paster, Gail et al. (eds.), Reading the Early Modern Passions. Essays in the Cultural History of Emotions (Philadelphia: University of Pennsylvania Press, 2004)

Kernkamp, J.H., "De 'Aanwysing' op de lijst van verboden boeken," Bijdragen voor geschiedenis en oudheidkunde 7, 6 (1935), 102-110

—, "De familie-portretten uit de collectie De la Court," in Dancwerc. Opstellen aangeboden aan prof. Dr. D. Th. Enklaar (Groningen: Wolters, 1959), 290-304

- , "De portrettering van Pieter de la Court opnieuw bekeken," in Ondernemende geschiedenis. 22 opstellen geschreven bij het afscheid van $\mathrm{mr}$. H. Van Riel (The Hague: Martinus Nijhoff, 1977), 66-74

Klashorst, G.O. van de, "'Metten schijn van monarchie getempert'. De verdediging van het Stadhouderschap in de partijliteratuur, $1650-1686$," in Blom and Wildenberg (eds.), Pieter de la Court, 93-136

—_, "De 'Ware Vrijheid'," in Haitsma Mulier and Velema (eds.), Vrijheid, 157-185

Klein, S.R.E., Patriots republikanisme: politieke cultuur in Nederland (1766-1787) (Amsterdam: Amsterdam University Press, 1995)

Klever, Wim, "Conflicting 'Considerations of State'. Van den Enden's Opposition Against De la Court's Aristocratic Republicanism and its Follow-Up in Spinoza's Work," Foglio Spinozi@no. Notiziario periodico de filosofia spinoziana (2001), from http://www .fogliospinoziano.it/artic17b.htm [retrieved May 13, 2011]

Kloek, J. and K. Tilmans (eds.), Burger. Een geschiedenis van het begrip 'burger' in de Nederlanden van de Middeleeuwen tot de 21ste eeuw (Amsterdam: Amsterdam University Press, 2002)

Knevel, Paul, Burgers in het geweer. De schutterijen in Holland, 1550-1700 (Hilversum: Verloren, 1994)

Knox, Dilwyn, Ironia. Medieval and Renaissance Ideas on Irony (Leiden etc.: Brill, 1989)

Korsten, Frans, "The Elzeviers and England," in Hellinga et al. (eds.), Bookshop of the World, 131-143

Kossmann, E.H., "Het probleem van de vrijheid in de zeventiende-eeuwse Nederlandse Republiek," in Idem, Vergankelijkheid en continuïteit. Opstellen over geschiedenis (Amsterdam: Bert Bakker, 1995), 63-86

- Political Thought in the Dutch Republic. Three Studies (Amsterdam: KNAW, 2000) 
Kraye, Jill, "Conceptions of Moral Philosophy," in Gaber and Ayers (eds.), The Cambridge History of Seventeenth-Century Philosophy, vol. II: 1279-1316

Kuijpers, Erika and Maarten Prak, "Burger, ingezetene, vreemdeling: burgerschap in Amsterdam in de $17^{\mathrm{e}}$ en $18^{\mathrm{e}}$ eeuw," in Kloek and Tilmans (eds.), Burger, 113-132

Kuncevic, Lovro, "On Ragusan Libertas in the Middle Ages," Dubrovnik Annals 14 (2010), $25-69$

Lake, Peter and Steve Pincus, "Rethinking the Public Sphere in Early Modern England," Journal of British Studies 45 (2006), 270-292

Landwehr, J., Emblem and Fable Books Printed in the Low Countries 1542-1813. A Bibliography, 3d. ed. (Utrecht: HES, 1988)

Laplanche, François, L'écriture, le sacré et l'histoire. Érudits et politiques protestants devant la bible en France au XVIIe siécle (Amsterdam and Maarssen: APA-Holland University Press, 1986)

La Vopa, Anthony J., "Doing Fichte. Reflections of a Sobered (But Unrepentant) Contextual Biographer," in Hans Erich Bödeker (ed.), Biographie schreiben (Göttingen: Wallstein Verlag, 2003), 107-171

Lesger, Clé, "Merchants in Charge. The Self-Perception of Amsterdam Merchants, ca. 1550-1700," in Jacob and Secretan (eds.), Self-Perception of Early Modern Capitalists, 75-97

Levi, Anthony, French Moralists. The Theory of the Passions 1585-1649 (Oxford: Clarendon Press, 1964)

Levillain, Charles-Édouard, "L'Angleterre de la Restauration au miroir de la 'vraie liberté' (1660-1672). La rencontre entre republicanismes anglais et hollandais à travers les écrits de Pieter de la Court," E-rea 1.2 (2003), from http://erea.revues.org/index205.html [retrieved May 13, 2011]

—, "William III's Military and Political Career in Neo-Roman Context, 1672-1702," The Historical Journal 48, 2 (2005), 213-350

Lewis, Jayne Elizabeth, The English Fable. Aesop and Literary Culture, 1651-1740 (Cambridge: Cambridge University Press, 1996)

London, Jennifer, "How To Do Things With Fables: Ibn Al-Muqaffa"s Frank Speech in Stories from Kalīla Wa Dimna," History of Political Thought 29 (2008): 189-212

Loveridge, Mark, A History of Augustan Fable (Cambridge: Cambridge University Press, 1998)

Lucassen, Jan, "Het Welvaren van Leiden (1659-1662): de wording van een economische theorie over gilden en ondernemerschap," in B. de Vries et al. (eds.), De kracht der zwakken. Studies over arbeid en arbeidersbeweging in het verleden (Amsterdam: IISG, 1992), $13-48$

Lucassen, Leo and Boudien de Vries, "Leiden als middelpunt van een Westeuropees textiel-migratie-systeem, 1586-1650," Tijdschrift voor sociale geschiedenis 22 (1996), $138-167$

Luiten van Zanden, Jan and Maarten Prak, "Towards an Economic Interpretation of Citizenship: The Dutch Republic Between Medieval Communes and Modern NationStates," European Review of Economic History 10 (2006), 111-145

Mack, Peter (ed.), Renaissance Rhetoric (New York: St. Martin's Press, 1994)

—, Elizabethan Rhetoric. Theory and Practice (Cambridge: Cambridge University Press, 2002)

Maissen, Thomas, "Petrus Valkeniers republikanische Sendung. Die niederländische Prägung des neuzeitlichen schweizerischen Staatsverständnis," Schweizerische Zeitschrift für Geschichte 48 (1998), 149-176

— Die Geburt der Republic. Staatsverständnis und Repräsentation in der frühneutzeitlichen Eidgenossenschaft (Göttingen: Vandenhoeck \& Ruprecht, 2006)

Malcolm, Noel, Aspects of Hobbes (Oxford: Oxford University Press, 2002)

Mansfield, Harvey C., "Self-Interest Rightly Understood," Political Theory 23, 1 (1995), $48-66$ 
Marshall, John, John Locke, Toleration and Early Enlightenment Culture. Religious Intolerance and Arguments for Religious Toleration in Early Modern and 'Early Enlightenment' Europe (Cambridge: Cambridge University Press, 2006)

Mastellone, Salvo, "I repubblicani del Seicento ed il modello politico olandese," Il pensiero politico 28 (1985), 145-163

Matheron, Alexandre, "The Theoretical Function of Democracy in Spinoza and Hobbes," in Genevieve Lloyd (ed.), Spinoza. Critical Assessments, 3 vols. (London and New York: Routledge, 2001), vol. III: 112-121

Mathieu-Castellani, Gisèle, La rhétorique des passions (Paris: Presses Universitaires de France, 2000)

McClure, Kirstie M., "Cato's Retreat: Fabula, Historia and the Question of Constitutionalism in Mr Locke's Anonymous Essay on Government," in Kevin Sharpe and Steven N. Zwicker (eds.), Reading, Society and Politics in Early Modern England (Cambridge: Cambridge University Press, 2003), 317-350

McCormick, John P., Machiavellian Democracy (Cambridge: Cambridge University Press, 2011)

McKenzie, Lionel A., "Natural Right and the Emergence of the Idea of Interest in Early Modern Political Thought: Francesco Guicciardini and Jean de Silhon," History of European Ideas 2, 4 (1981), 277-298

Meerhoff, Kees, "Ramus en tijdgenoten: de humanistische receptie van de retorica," Lampas. Tijdschrift voor Nederlandse classici 34 (2001), 351-372

Meertens, P.J. (ed.), Nederlandse emblemata. Bloemlezing uit de Noord-en Zuidnederlandse Emblemata-literatuurvan de 16e en 17e eeuw (Leiden: Martinus Nijhoff, 1983)

Meijer Drees, Marijke, “'Burgerlijke' zeventiende eeuwse literatuur," in Kloek and Tilmans (eds.), Burger, 133-153

Mendle, Michael, Henry Parker and the English Civil War. The Political Thought of the Public's "Privado" (Cambridge: Cambridge University Press, 1995)

Miert, Dirk van, Illuster onderwijs. Het Amsterdamse Athenaeum in de Gouden Eeuw, 16321704 (Amsterdam: Bert Bakker, 2005)

Mijnhardt, Wijnand W., "The Limits of Present-day Historiography of Republicanism," De Achttiende Eeuw 37 (2005), 75-89

Millar, Fergus, The Roman Republic in Political Thought (Hanover: University Press of New England, 2002)

Miller, Peter N., Defining the Common Good. Empire, Religion and Philosophy in EighteenthCentury Britain (Cambridge: Cambridge University Press, 1994)

_ - "Stoics Who Sing: Lessons in Citizenship from Early Modern Lucca," The Historical Journal 44 (2001), 313-339

Mitchell, Annie, "Character of an Independent Whig - 'Cato' and Bernard Mandeville," History of European Ideas 29 (2003), 291-311

Morfino, Vittorio, Il tempo e l'occasione. L'incontro Spinoza Macchiavelli (Milan: Edizioni Universitarie di Lettere, Economia, Diritto, 2002)

Morford, Mark, "The Stoic Garden," Journal of Garden History 7, 2 (1987), 151-175

Moss, Ann, Printed Commonplace-Books and the Structuring of Renaissance Thought (Oxford: Clarendon Press, 1996)

Nadler, Steven, Spinoza. A Life (Cambridge: Cambridge University Press, 1999)

Nauta, Lodi, "Hobbes the Pessimistic? Continuity of Hobbes's Views on Reason and Eloquence between The Elements of Law and Leviathan," British Journal for the History of Philosophy 10 (2002), 31-54

Nedermann, Cary J., "Commercial Society and Republican Government in the Latin Middle Ages: The Economic Dimensions of Brunetto Latini's Republicanism," Political Theory 31 (2003), 644-663

Nelson, Eric, The Greek Tradition in Republican Thought (Cambridge: Cambridge University Press, 2004) 
The Hebrew Republic. Jewish Sources and the Transformation of European Political Thought (Cambridge, Mass.: Harvard University Press, 2010)

Nierop, Henk van, "Popular Participation in Politics in the Dutch Republic," in Peter Blickle, Resistance, Representation, and Community (Oxford: Clarendon Press, 1997), 272-290

Nieuwstraten, Jaap, "Why the Wealthy Should Rule: Marcus Zuerius Boxhorn's Defence of Holland's Aristocratic Mercantile Regime," in Hartman et al. (eds.), Public Offices, Personal Demands, 126-149

- - History and Politics in Seventeenth-Century Dutch Political Thought. The Case of Marcus Zuerius Boxhorn (1612-1653) (PhD dissertation Erasmus University Rotterdam, forthcoming)

Nijenhuis, Ida, "De ontwikkeling van het politiek-economische vrijheidsbegrip in de Republiek," in Haitsma Mulier and Velema (eds.), Vrijheid, 233-252

Noak, Bettina, "De Sinryke Fabulen (1685) van Pieter de la Court: verhulling en onthulling in een 'verlicht' genre," De Zeventiende Eeuw 18 (2002), 65-78

Nobbs, Douglas, Theocracy and Toleration. A Study of the Disputes in Dutch Calvinism from 1600 to $165^{\circ}$ (Cambridge: Cambridge University Press, 1938)

Noordam, Dirk Jaap, Geringde buffels en heren van stand. Het patriciaat van Leiden, 15741700 (Hilversum: Verloren, 1996)

- "Textielondernemers en het Leidse patriciaat, 1574-1795," Textielhistorische bijdragen 36 (1996)

_, "De Leidse veertigraden in de lange zeventiende eeuw, 1574-1700," in Jaap Moes and Noordam (eds.), Macht, aanzien en welzijn. Nieuwelingen in het Leids stadsbestuur, $1200-$ 1795 (Leiden: Primavera, 2003), 48-59

Norbrook, David, Writing the English Republic. Poetry, Rhetoric and Politics, 1627-166o (Cambridge: Cambridge University Press, 1999)

Nyden-Bullock, Tammy, "Radical Cartesian Politics: Velthuysen, De la Court, and Spinoza," in Wiep van Bunge (ed.), Spinoza and Dutch Cartesianism. Studia Spinozana 15 (1999/2006), 35-65

- Spinoza's Radical Cartesian Mind (London and New York: Continuum, 2007)

Oestreich, Gerhard, Neostoicism and the Early Modern State (Cambridge: Cambridge University Press, 1982)

Otterspeer, Willem, Het bolwerk van de vrijheid: de Leidse universiteit, 1575-1672 (Amsterdam: Bert Bakker, 2000)

Pagden, A. (ed.), The Languages of Political Theory in Early-Modern Europe (Cambridge: Cambridge University Press, 1987)

Panhuysen, Luc, De Ware Vrijheid. De levens van Johan en Cornelis de Witt (Amsterdam: Atlas, 2005)

Parker, Charles H., "To the Attentive, Nonpartisan Reader: The Appeal to History and National Identity in the Religious Disputes of the Seventeenth-Century Netherlands," The Sixteenth Century Journal 28, 1 (1997), 57-78

_ Faith on the Margins. Catholics and Catholicism in the Dutch Golden Age (Cambridge, Mass.: Harvard University Press, 2008)

Parkin, Jon, "Taming the Leviathan: Reading Hobbes in Seventeenth-Century Europe," in T.J. Hochstrasser and P. Schröder (eds.), Early Modern Natural Law Theories. Contexts and Strategies in the Early Enlightenment (Dordrecht etc.: Kluwer, 2003), 31-52

- Taming the Leviathan. The Reception of the Political and Religious Ideas of Thomas Hobbes in England, 1640-1700 (Cambridge: Cambridge University Press, 2007)

Patterson, Annabel, Aesopian Writing and Political History (Durham and London: Duke University Press, 1991)

Peacey, Jason, Politicians and Pamphleteers. Propaganda During the English Civil Wars and Interregnum (Aldershot: Ashgate, 2004)

Peltonen, Markku, Classical Humanism and Republicanism in English Political Thought, 1570-1640 (Cambridge: Cambridge University Press, 1995) 
The Duel in Early Modern England. Civility, Politeness and Honour (Cambridge: Cambridge University Press, 2003)

Pesante, Maria Luisa, "Il commercio nella repubblica," Quaderni storici 105 (2000), $655-695$

Petry, M.J., "Hobbes and the Early Dutch Spinozists," in C. de Deugd (ed.), Spinoza's Political and Theological Thought (Amsterdam, 1984), 150-170

Pettegree, Andrew, "The Politics of Toleration in the Free Netherlands, 1572-1620," in Ole Peter Grell and Bob Scribner (eds.), Tolerance and Intolerance in the European Reformation (Cambridge: Cambridge University Press, 1996), 182-198

Phillipson, Nicholas and Quentin Skinner (eds.), Political Discourse in Early Modern Britain (Cambridge: Cambridge University Press, 1993)

Pincus, Steve, Protestantism and Patriotism. Ideologies and The Making of English Foreign Policy, 1650-1668 (Cambridge: Cambridge University Press, 1996)

_ - "Neither Machiavellian Moment nor Possessive Individualism: Commercial Society and the Defenders of the English Commonwealth," The American Historical Review 103 (1998), 705-736

Pleij, Herman, "Poorters en burgers in laat-middeleeuwse literaire bronnen," in Kloek and Tilmans (eds.), Burger, 55-79

Po-Chia Hsia, R. and H.F.K. van Nierop (eds.), Calvinism and Religious Toleration in the Dutch Golden Age (Cambridge: Cambridge University Press, 2002)

Pocock, J.G.A., "The Problem of Political Thought in the Eighteenth Century: Patriotism and Politeness," Theoretische geschiedenis 9 (1982), 3-24

_ - "Virtues, Rights, and Manners: a Model for Historians of Political Thought," in Pocock, Virtue, Commerce, and History. Essays on Political Thought and History, Chiefly in the Eighteenth Century (Cambridge: Cambridge University Press, 1985), 37-50

— - "Clergy and Commerce. The Conservative Enlightenment in England," in R. Ajello (ed.), L'Età dei Lumi. Studi storici sul Settecento europeo in onore di Franco Venturi, 2 vols. (Naples: Jovene, 1985), vol. I: 525-562

_- "Spinoza and Harrington: An Exercise in Comparison," Bijdragen en mededelingen betreffende de geschiedenis der Nederlanden 102 (1987), 435-449

— , "The Dutch Republican Tradition," in Margaret C. Jacob and Wijnand W. Mijnhardt (eds.), The Dutch Republic in the Eighteenth Century. Decline, Enlightenment, and Revolution (Ithaca and London: Cornell University Press, 1992), 188-193

- The Machiavellian Moment. Florentine Political Thought and the Atlantic Republican Tradition, 2d. ed. (Princeton: Princeton University Press, 2003)

—, The Discovery of Islands. Essays in British History (Cambridge: Cambridge University Press, 2005)

_ - "The Atlantic Republican Tradition: The Republic of the Seven Provinces," Republics of Letters: A Journal for the Study of Knowledge, Politics and the Arts 2, 1 (2010), from http://rofl.stanford.edu/node/72 [retrieved 22 June 2011]

Pollmann, Judith and Andrew Spicer (eds.), Public Opinion and Changing Identities in the Early Modern Netherlands (Leiden: Brill, 2007)

Porteman, Karel, 'Het embleem als 'genus iocosum'. Theorie en praktijk bij Cats en Roemer Visscher," De zeventiende eeuw 11 (1995), 184-197

Posthumus, N.W. De geschiedenis van de Leidsche lakenindustrie II: De nieuwe tijd, 2 vols. (The Hague: Martinus Nijhoff, 1939)

Posthumus Meyjes, G.H.M., "Hugo Grotius as an irenicist," in The World of Hugo Grotius (1583-1645) (Amsterdam and Maarssen: APA-Holland University Press, 1984), $43-63$

Prak, Maarten, Gezeten burgers. De elite in een Hollandse stad, Leiden 1700-1780 (Amsterdam etc.: De Bataafsche Leeuw, 1985)

_ _ "Burghers, Citizens and Popular Politics in the Dutch Republic," Eighteenth-Century Studies 30, 4 (1997), 443-448

— et al. (eds.), Craft Guilds in the Early Modern Low Countries. Work, Power, and Representation (Aldershot: Ashgate, 2006) 
Price, J.L., Holland and the Dutch Republic in the Seventeenth Century. The Politics of Particularism (Oxford: Clarendon Press, 1994)

Prokhovnik, Raia, Spinoza and Republicanism (Basingstoke and New York: Palgrave, 2004)

Rademaker, C.S.M., Life and Work of Gerardus Joannes Vossius (1577-1649) (Assen: Van Gorcum, 1981)

Rahe, Paul A., Republics Ancient and Modern, 3 vols. (Chapel Hill: University of North Carolina Press, 1992)

_- "Situating Machiavelli," in Hankins (ed.), Renaissance Civic Humanism, 270-308

_, Against Throne and Altar. Machiavelli and Political Theory under the English Republic (Cambridge: Cambridge University Press, 2008)

- (ed.), Machiavelli's Liberal Republican Legacy (Cambridge: Cambridge University Press, 2006)

Raymond, Joad, Pamphlets and Pamphleteering in Early Modern Britain (Cambridge: Cambridge University Press, 2003)

Reinders, Michel, Printed Pandemonium. The Power of the Public and the Market for Popular Political Publications in the Early Modern Dutch Republic (PhD dissertation Erasmus University Rotterdam, 2008)

Remer, Gary, Humanism and the Rhetoric of Toleration (University Park: Pennsylvania State University Press, 1996)

Riker, William H., "Dutch and American Federalism," Journal of the History of Ideas 18, 4 (1957), 495-521

Roberts, Benjamin, Through the Keyhole. Dutch Child-Rearing Practices in the $17^{\text {th }}$ and $18^{\text {th }}$ Century. Three Urban Elite Families (Hilversum: Verloren, 1998)

Roberts, Jennifer Tolbert, Athens on Trial. The Antidemocratic Tradition in Western Thought (Princeton: Princeton University Press, 1994)

Röd, Wolfgang, "Van den Hoves 'Politische Waage' und die Modifikation der Hobbesschen Staatsphilosophie bei Spinoza," Journal of the History of Philosophy 8 (1970), 29-48

Rodgers, Daniel T., "Republicanism: the Career of a Concept," The Journal of American History 79 (1992), 11-38

Romanoski, Christian, Tacitus Emblematicus. Diego de Saavedra Fajardo und seine "Empresas Políticas" (Berlin: Weidler, 2006)

Rommelse, Gijs, The Second Anglo-Dutch War (1665-1667). International Raison d'État, Mercantilism, and Maritime Strife (Hilversum: Verloren, 2006)

Rood, Wilhelmus, Comenius and the Low Countries (Amsterdam: Van Gendt \& Co., 1970)

Roodenburg, Herman, "Naar een etnografie van de vroegmoderne stad: De 'gebuyrten' in Leiden en Den Haag," in Peter te Boekhorst, Peter Burke and Willem Frijhoff, Cultuur en maatschappij in Nederland 1500-1850: Een historisch-antropologisch perspectief (Meppel etc: Boom, 1992), 219-243

Rosenthal, Michael A., "Persuasive Passions: Rhetoric and the Interpretation of Spinoza's Theological-Political Treatise," Archiv für die Geschichte der Philosophie 85 (2003), 249-268

Rossum, Leo van, "Het aandeel van Johan de Witt aan het Interest van Holland" (MA-thesis Utrecht University, 1964)

Rotondò, Antonio, Europe et Pays-Bas. Evolution, rééleboration et diffusion de la tolerance aux XVIIe et XVIIIe siècles (Florence: Università degli Studi, 1992)

Rowen, Herbert A., John de Witt, Grand Pensionary of Holland, 1625-1672 (Princeton: Princeton University Press, 1978)

_ - "Neither Fish nor Fowl: The Stadholderate in the Dutch Republic," in Idem and Andrew Lossky (eds.), Political Ideas and Institutions in the Dutch Republic (Los Angeles: Clark Library, 1985), 3-31

_, "The Dutch Republic and the Idea of Freedom," in Wootton (ed.), Republicanism, Liberty, and Commercial Society, 310-340

Rubiés, Joan-Pau, "Oriental Despotism and European Orientalism: Botero to Montesquieu," Journal of Early Modern History 9, 1-2 (2005), 109-180 
Rubinstein, Nicolai, "The History of the Word Politicus in Early-Modern Europe," in Pagden (ed.), Languages of Political Theory, 41-56

Salman, Jeroen, "Het nieuws op straat. Actueel drukwerk in het vroegmoderne distributienetwerk," in: José de Kruif et al. (eds.), Het lange leven van het pamflet. Boekhistorische, iconografische, literaire en politieke aspecten van pamfletten 1600-19oo (Hilversum: Verloren, 2006), 56-67

Salmon, J.H.M., "Rohan and Interest of State," in Roman Schnur (ed.), Staatsräson. Studien zur Geschichte eines politischen Begriffs (Berlin: Duncker \& Humblot, 1975), 121-140

_ , "The Legacy of Jean Bodin: Absolutism, Populism or Constitutionalism?," History of Political Thought 17 (1996), 500-522

Schama, Simon, The Embarrassment of Riches. An Interpretation of Dutch Culture in the Golden Age (London: Collins, 1987)

Scherpbier, H., Milton in Holland. A Study in the Literary Relations of England and Holland before 1730 ( $\mathrm{PhD}$ dissertation University of Amsterdam, 1933)

Schilling, Heinz, "Der libertär-radikale Republikanismus der Holländischen Regenten," Geschichte und Gesellschaft 10 (1984), 498-533

—, "Dutch Republicanism in its Historical Context," in Schilling, Religion, Political Culture and the Emergence of Early Modern Society (Leiden etc.: Brill, 1992), 413-427

__ , "Afkeer van domineesheerschappij: ein neuzeitlicher Typus des Antiklerikalismus," in Peter A. Dykema and Heiko A. Oberman (eds.), Anticlericalism in Late Medieval and Early Modern Europe (Leiden: Brill, 1993), 655-668

Schoneveld, Cornelis W., Intertraffic of the Mind. Studies in Seventeenth-Century AngloDutch Translation (Leiden: Brill, 1983)

Schorn-Schütte, Luise, "Einleitung," in Idem (ed.), Aspekte der politischen Kommunikation im Europa des 16. und 17. Jahrhunderts (Munich: R. Oldenbourg Verlag, 2004), 1-12

Schulte Noordholt, J.W., "The Example of the Dutch Republic for American Federalism," in J.C. Boogman and G.N. van der Plaat, Federalism. History and Current Significance of a Form of Government (The Hague: Martinus Nijhoff, 1980), 65-77

Scott, Jonathan, Algernon Sidney and the English Republic, 1623-1677 (Cambridge: Cambridge University Press, 1988)

—, "The Rapture of Motion: James Harrington's Republicanism," in Phillipson and Skinner (eds.), Political Discourse, 139-163

_ _, "Classical Republicanism in Seventeenth-Century England and the Netherlands," in Van Gelderen and Skinner (eds.), Republicanism, vol. I: 61-81

- Commonwealth Principles. Republican Writing of the English Revolution (Cambridge: Cambridge University Press, 2004)

Secretan, Catherine, "La reception de Hobbes aux Pays-Bas au XVIIe siècle, " Studia Spinozana 3 (1987), 27-45

- (ed.), Le "Marchand philosophe" de Caspar Barlaeus. Un éloge du commerce dans la Hollande du Siècle d'Or (Paris: Honoré Champion, 2002)

Shapin, Steven, A Social History of Truth. Civility and Science in Seventeenth-Century England (Chicago and London: The University of Chicago Press, 1994)

Sharpe, Kevin, "'An Image Doting Rabble': The Failure of Republican Culture in Seventeenth-Century England," in Sharpe and Steven N. Zwicker (eds.), Refiguring Revolutions. Aesthetics and Politics from the English Revolution to the Romantic Revolution (Berkeley etc.: University of California Press, 1998), 25-56

_ . "A Commonwealth of Meanings: Languages, Analogues, Ideas and Politics," in Idem, Remapping Early Modern England. The Culture of Seventeenth-Century Politics (Cambridge: Cambridge University Press, 200o), 38-123

-, , Reading Revolutions. The Politics of Reading in Early Modern England (New Haven and London: Yale University Press, 2000)

Sierhuis, Freya, "A Babel Full of Confusion". Politics, Literature and the Stage During the Arminian Controversy, 1610-1630 (PhD dissertation European University Institute, Florence, 2009) 
Simonutti, Luisa, "English Guests at 'De Lantaarn'. Sidney, Penn, Locke, Toland and Shaftesbury," in Sarah Huto (ed.), Benjamin Furly 1646-1714: A Quaker Merchant and his Milieu (Florence: Olschki, 2007), 31-66

Skinner, Quentin, The Foundations of Modern Political Thought, 2 vols. (Cambridge: Cambridge University Press, 1976)

_, "Machiavelli's Discorsi and the Pre-humanist Origins of Republican Ideas," in Bock, Skinner and Viroli (eds.), Machiavelli and Republicanism, 121-141

—, "The Republican Ideal of Political Liberty," in Bock, Skinner and Viroli (eds.), Machiavelli and Republicanism, 293-309

- Reason and Rhetoric in the Philosophy of Hobbes (Cambridge: Cambridge University Press, 1996)

— , Liberty before Liberalism (Cambridge: Cambridge University Press, 1998) , Visions of Politics, 3 vols. (Cambridge: Cambridge University Press, 2002) , Hobbes and Republican Liberty (Cambridge: Cambridge University Press, 2008)

Sluijter, Eric Jan, De 'Heydensche Fabulen' in de Noordnederlandse schilderkunst circa 15901670 (PhD dissertation University of Leiden, 1986)

Smet, Ingrid A.R. de, Mennipean Satire and the Republic of Letters 1581-1655 (Geneva: Droz, 1996)

- Thuanus. The Making ofJacques-Auguste de Thou (1553-1617) (Geneva: Droz, 2006)

Smith, Nigel, "Popular Republicanism in the 1650s: John Streater's 'Heroick Mechanicks'," in David Armitage et al. (eds.), Milton and Republicanism (Cambridge: Cambridge University Press, 1995)

Smith, Pamela H., The Business of Alchemy. Science and Culture in the Holy Roman Empire (Princeton: Princeton University Press, 1994)

Smith, Paul J., Het schouwtoneel der dieren. Embleemfabels in de Nederlanden (1567-ca. 1670) (Hilversum: Verloren, 2006)

Smith, Steven B., "What Kind of Democrat was Spinoza?," Political Theory 33, 6 (2005), 6-27

Soll, Jacob, "Accounting for Government: Holland and the Rise of Political Economy in Seventeenth-Century Europe," Journal of Interdisciplinary History 40, 2 (2009), 215-238

Sommerville, Johann P., "Selden, Grotius, and the Seventeenth-Century Intellectual Revolution in Moral and Political Theory," in Victoria Kahn and Lorna Hutson (eds.), Rhetoric and Law in Early Modern Europe (New Haven: Yale University Press, 2001), 318-344

- , "English and Roman Liberty in the Monarchical Republic of Early Stuart England," in John F. McDiarmid (ed.), The Monarchical Republic of Early-Modern England. Essays in Response to Patrick Collinson (Aldershot: Ashgate, 2007), 201-216

Springborg, Patricia, Western Republicanism and the Oriental Prince (Cambridge: Polity, 1992)

Staines, John, "Compassion in the Public Sphere of Milton and King Charles," in Kern Paster et al. (eds.), Reading the Early Modern Passions, 89-109

Stam, F.P. van, The Controversy over the Theology of Saumur, 1635-1650. Disrupting Debates among the Huguenots in Complicated Circumstances (Amsterdam and Maarssen: APAHolland University Press, 1988)

Stapel, Leonore, "'Tuyn van heel Holland, Moeder der Wijsheyt en bequam tot de drapery.' Reputatie en zelfbeeld van Leiden in beeld en tekst (circa 1590-1660)," De zeventiende eeuw 22 (2006), 149-169

Stern, Jill, "A Playwright in His Time: Vondel's Drama Faeton of 1663," Dutch Crossing 23 (1999), 22-57

—, "The Rhetoric of Popular Orangism, 1650-72," Historical Research 77 (2004), 202-224

_- "Religion and the Orangists, 1650-1672," Dutch Crossing 30 (2006), 181-196

- Orangism in the Dutch Republic in Word and Image, 1650-1675 (Manchester: Manchester University Press, 2010) 
Stolleis, Michael, Staat und Staatsräson in der frühen Neuzeit. Studien zur Geschichte des öffentlichen Rechts (Frankfurt: Suhrkamp, 1990)

Stone-Ferrier, Linda A., Images of Textiles. The Weave of Seventeenth-Century Dutch Art and Society (Ann Arbor: UMI Research Press, 1985)

Straumann, Benjamin, "Oikeiosis and appetitus societatis. Hugo Grotius's Ciceronian Argument for Natural Law and Just War," Grotiana (New Series) 24/25 (2003-2004), 41-66

Strier, Richard, "Against the Role of Reason: Praise of Passion from Petrarch to Luther to Shakespeare to Herbert," in Kern Paster et al. (eds.), Reading the Early Modern Passions, $23-42$

Stuurman, Siep, François Poulain de la Barre and the Invention of Modern Equality (Cambridge, Mass.: Harvard University Press, 2004)

Sullivan, Vickie B. Machiavelli, Hobbes, and the Formation of a Liberal Republicanism in England (Cambridge: Cambridge University Press, 2004)

Thijssen-Schoute, C.L., Nederlands Cartesianisme (Amsterdam: Noord-Hollandsche Uitgevers Maatschappij, 1954)

Tiemann, Barbara, Fabel und Emblem. Gilles Corrozet und die französische RenaissanceFabel (Munich: Wilhem Fink, 1974)

Tijn, Th. van, "Pieter de la Court, zijn leven en zijn economische denkbeelden," Tijdschrift voor geschiedenis 69 (1956), 304-370

Till, Dietmar, Transformationen der Rhetorik. Untersuchungen zum Wandel der Rhetoriktheorie im 17. und 18. Jahrhundert (Tübingen: Max Niemeyer Verlag, 2004)

Tilmans, Karin, "Republican Citizenship and Civic Humanism in the BurgundianHabsburg Netherlands (1477-1566)," in Van Gelderen and Skinner (eds.), Republicanism, vol. I: $107-125$

Tracy, James D., The Founding of the Dutch Republic. War, Finance, and Politics in Holland, 1572-1588 (Oxford: Oxford University Press, 2008)

Tricaud, François, “'Homo homini Deus', 'Homo homini Lupus': Recherche des Sources des deux Formules de Hobbes," in Reinhart Koselleck and Roman Schnur (eds.), Hobbes-Forschungen (Berlin: Duncker \& Humblot, 1969), 63-71

— - "Hobbes's Conception of the State of Nature," in G.A.J. Rogers and Alan Ryan, Perspectives on Thomas Hobbes (Oxford: Clarendon Press, 1988), 107-123

Tuck, Richard, "Scepticism and Toleration in the Seventeenth Century," in Susan Mendus (ed.), Justifying Toleration. Conceptual and Historical Perspectives (Cambridge etc.: Cambridge University Press, 1988), 21-35

- "Grotius and Selden," in Burns and Goldie (eds.), Cambridge History of Political Thought, 499-529

—, Philosophy and Government, 1572-1651 (Cambridge: Cambridge University Press, 1993)

, "Hobbes and Democracy," in Brett et al. (eds.), Rethinking the Foundations, 171-19o

Veegens, D., "Johan de Witt als publicist," in Idem, Historische Studien, 2 vols. (The Hague: Van Stockum, 1884), vol. II: 30-67

Velema, Wyger, Enlightenment and Conservatism in the Dutch Republic. The Political Thought of Elie Luzac (1721-1796) (Assen: van Gorcum, 1993)

— - "'That a Republic is Better than a Monarchy': Anti-Monarchism in Early Modern Dutch Political Thought," in Van Gelderen and Skinner (eds.), Republicanism, vol. I: 9-25

, "Wijnand W. Mijnhardt on the Historiography of Republicanism," De Achttiende Eeuw 37 (2005), 193-202

—, Republicans. Essays on Eighteenth-Century Dutch Political Thought (Leiden: Brill, 2007)

Venturi, Franco, Utopia and Reform in the Enlightenment (Cambridge: Cambridge University Press, 1971)

Verbeek, Theo, Descartes and the Dutch: Early Reactions to Cartesian Philosophy, $1637-1650$ (Carbondale: Southern Illinois University Press, 1992) 
Versprille, Annie, "Het Leidse poorterschap," Leids Jaarboekje 36 (1944), 76-10o

Vickers, Brian, "Rhetoric and Poetics," in Charles B. Schmitt et al. (eds.), The Cambridge History of Renaissance Philosophy (Cambridge: Cambridge University Press, 1988), 715-745

- In Defence of Rhetoric (Oxford: Clarendon Press, 1989)

_ , "Some Reflections on the Rhetoric Textbook," in Mack (ed.), Renaissance Rhetoric, $81-102$

Viroli, Maurizio, From Politics to Reason of State. The Acquisition and Transformation of the Language of Politics 1250-16oo (Cambridge: Cambridge University Press, 1992)

_ Il Dio di Machiavelli e il problema morale dell'Italia (Bari: Laterza, 2005)

Visentin, Stefano, "Assolutismo e libertà. L'orizzonte repubblicano nel pensiero politico olandese del XVII secolo," Filosofia politica 12, 1 (1998), 67-85

_ - "Passioni collettive e leggi politiche nel repubblicanesimo olandese del XVII secolo: dai fratelli De la Court a Spinoza," Giornale di Storia Costituzionale 8 (2004), 239-258

__ , "Acutissimus o prudentissimus? Intorno alla presenza di Machiavelli nel Trattato politico diSpinoza," Etica \& Politica 6, 1 (2004), from http://www2.units.it/ etica/2004_1/ visentin.htm [retrieved May 13, 2011]

_ _ "La virtù dei molti. Machiavelli e il repubblicanesimo olandese della seconda metà del seicento," in Fillipo del Lucchese et al. (eds.) Machiavelli: immaginazione e contingenza (Pisa: ETS, 2006), 217-252

Visser, Pieter, Godtslasterlijck ende pernicieus. De rolvan boekdrukkers en boekverkopers in de verspreiding van dissidente religieuze en filosofische denkbeelden in Nederland in de tweede helft van de zeventiende eeuw (Amsterdam: AD\&L, 1996)

Vlist, Ed van der, "Een verstrooide brief van een verloren professor. Het eerewoord van Heereboord," Nieuw Letterkundig Magazijn 21 (2003), 40-48

Vogelaar, Christiaan, "Abraham van den Tempel," in Hollands Classicisme in de Nederlandse schilderkunst (Rotterdam: Museum Boijmans van Beuningen, 2000), 254-263

Voigt, Alfred, Über die Politica generalis des Johann Angelius v. Werdenhagen (Amsterdam 1632) (Erlangen, 1965)

Vries, Jan de and Ad van der Woude, The First Modern Economy. Success, Failure, and Perseverance of the Dutch Economy, 1500-1815 (Cambridge: Cambridge University Press, 1997)

Wagener, Hans-Jürgen, "Free Seas, Free Trade, Free People: Early Dutch Institutionalism," History of Political Economy 26, 3 (1994), 395-422

Walsham, Alexandra, Charitable Hatred. Tolerance and Intolerance in England, 1500-1700 (Manchester and New York: Manchester University Press, 2006)

Wansink, H., Politieke wetenschappen aan de Leidse Universiteit $1575^{ - \pm 1650}$ (Utrecht: HES, 1981)

_ , "De 'Sinryke Fabulen' van Pieter de la Court," in Blom and Wildenberg (eds.), Pieter de la Court, 185-193

Weber, Max, Die protestantische Ethik. Eine Aufsatzsammlung, ed.Johannes Winckelmann, 2d. ed. (München and Hamburg: Siebenstern, 1969)

Weber, Wolfgang, Prudentia gubernatoria. Studien zur Herrschaftslehre in der deutschen politischen Wissenschaft des 17. Jahrhunderts (Tübingen: Max Niemeyer, 1992)

_ , "'What a Good Ruler Should Not Do': Theoretical Limits of Royal Power in European Theories of Absolutism, 1500-1700," The Sixteenth Century Journal 26, 4 (1995), 897-915

Weststeijn, Arthur, "Mercury's Two Faces. Commercial Candour as the Key to Capability in the Dutch Golden Age," in Hartman et al. (eds.), Public Offices, Personal Demands, $15^{0-173}$

_ , "From the Passion of Self-Love to the Virtue of Self-Interest: The Republican Morals of the Brothers De la Court," European Review of History 17 (2010), 75-92

_ - "The Power of 'Pliant Stuff: Fables and Frankness in Seventeenth-Century Dutch Republicanism," Journal of the History of Ideas 72 (2011), 1-27

_ - "Republican Empire. Colonialism, Commerce and Corruption in the Dutch Golden Age," Renaissance Studies 26 (2012) 
Weststeijn, Thijs, The Visible World. Samuel van Hoogstraten's Art Theory and the Legitimation of Painting in the Dutch Golden Age (Amsterdam: Amsterdam University Press, 2008)

Wielema, Michiel, "Adriaan Koerbagh: Biblical Criticism and Enlightenment," in Wiep van Bunge (ed.), The Early Enlightenment in the Dutch Republic, 1650-1750 (Leiden: Brill, 2003), 61-80

Wijngaards, N., "Vondels Hollantsche Transformatie," De nieuwe taalgids 59 (1966), $302-312$

Wijnman, H.F., "De schilder Abraham van den Tempel," in Idem, Uit de kring van Rembrandt en Vondel. Verzamelde studies over hun leven en omgeving (Amsterdam: Noord-Hollandsche Uitgevers Maatschappij, 1959), 39-93

Wildenberg, Ivo W., "Appreciaties van de gebroeders De la Court ten tijde van de Republiek," Tijdschrift voor geschiedenis 98 (1985), 540-556

— Johan \& Pieter de la Court (1662-1660 \& 1618-1685). Bibliografie en receptiegeschiedenis (Amsterdam: APA-Holland University Press, 1986)

Withington, Phil, The Politics of Commonwealth. Citizens and Freemen in Early Modern England (Cambridge: Cambridge University Press, 2005)

Woltjer, J.J., Tussen vrijheidsstrijd en burgeroorlog (Amsterdam: Balans, 1994)

Wootton, David, "Leveller Democracy and the Puritan Revolution," in Burns and Goldie (eds.), Cambridge History of Political Thought, 412-442

- , "The True Origins of Republicanism: the Disciples of Baron and the CounterExample of Venturi," in Manuela Albertone (ed.), Il repubblicanesimo moderno. L'idea di repubblica nella riflessione storica di Franco Venturi (Napels: Bibliopolis, 2006), 271-304

(ed.), Republicanism, Liberty, and Commercial Society, 1649-1776 (Stanford: Stanford University Press, 1994)

Worden, Blair, "English Republicanism," in Burns and Goldie (eds.), Cambridge History of Political Thought, 434-475

, "Marchamont Nedham and the Beginnings of English Republicanism, 1649-1656," in Wootton (ed.), Republicanism; 45-81

"James Harrington and 'The Commonwealth of Oceana,' 1656," in Wootton (ed.), Republicanism, 82-110

- Literature and Politics in Cromwellian England. John Milton, Andrew Marvell, Marchamont Nedham (Oxford: Oxford University Press, 2007)

Wttewaall, B.W., Proeve uit een onuitgegeven staathuishoudkundig geschrift, het Welvaren der stad Leyden (Leiden, 1845)

Zuidervaart, H.J., "Het natuurbeeld van Johannes de Mey (1617-1678), hoogleraar filosofie aan de Illustere School te Middelburg," Archief. Mededelingen van het Koninklijk Zeeuwsch genootschap der Wetenschappen 99 (2001), 1-40

Zurbuchen, Simone, "Republicanism and Toleration," in Van Gelderen and Skinner (eds.), Republicanism, vol. II: 47-71 


\section{INDEX}

Act of Exclusion (1654) 47, 49-51, 64

Adams, Julia 162

\section{Ad Herennium 104}

adiaphora, indifferent matters of faith 301, 316, 333

Aesop, fables of 4, 114-116, 120, 123, 130, $132,235,353$

Aitzema, Lieuwe van 93 note 78,176 note 134, 257 note 217

Alberti, Leon Battista 201-203, 348

Alciato, Andrea 115

Althusius, Johannes 151, 274

ambition; see also: honour; self-love 80 , $87,142,170-172,176,184,186,192,196$, 200, 203-204, 213, 222, 246, 294-295, 313, 347,356

American Revolution 5-7, 13, 231, 354-355

amour-propre, see: self-love

Amsterdam 159, 185, 198, 232, 328, 344, 357

'Athenaeum Illustre' 71, 184, 187-188

Amyraut, Moyse 29

Anglo-Dutch War, First 47, 221

Anglo-Dutch War, Second 61, 233

anti-clericalism 109-110, 134-135, 147, 286, 291-298, 323-325, 331, 340, 343-344

aristocracy $35-36,52-53,76,101,151$, 264-270, 272-274, 279, 349, 355

Aristotle, Aristotelianism 5, 31-32, 63, 83, $150,158,167,185,190,250,255,265,269$,

272, 279, 357

Politics 26, 188, 247 note 171

Rhetoric $72-74$

on monarchy vs. tyranny $245^{-246}$

Arminian controversy 39, 43, 93, 95, 116, 298-299, 302

Arminianism 298-305, 307, 310, 314-315, $318-324,328,333$

Arnisaeus, Henning 36, 150, 262

Arnoldi, Henricus 320

Athens, Ancient 22-23, 52, 160, 206, 215-217, 219, 222, 224-225, 259, 269, 280, 282, 311, 348, 356

Augustine; see also: Senault, JeanFrançois 84-85, 143, 169-170, 178, 272, 346

Augustus 239-240, 246, $25^{8}$
Baardt, Petrus 271

Bacon, Francis 28, 115, 119, 133, 137-138, 354

Barlaeus, Caspar

Mercator sapiens 184-188, 190-191, 193-196

on Machiavelli 129

Batavian Myth $42-43,45,48,63-64,66$, 254-255, 257

Bayle, Pierre $317,336,353$

Becher, Johann Joachim $35^{\circ}$

Bentivoglio, Guido 33-34, 289

Berkel, Abraham van 148-149, 156, 341

Besold, Christoph 36

Bethel, Slingsby 2 note 3, 329-330, $35^{2}$

Beverwijck, Johan van 161

Blaeu editors 56, 130

Blom, Hans 14, 16-18, 146, 274

Boccalini, Traiano 64, 127, 129-132, 179, 239, 290, 295, 346

Bodin, Jean 41-42, 155, 242, 249, 300, 310

Bol, Ferdinand 197

Bonnel, Toby $35^{2}$

Botero, Giovanni 207, 221-222, 229, 346, 349

Bourgogne, Nicolas de 240 note 147

Boxhorn, Marcus Zuerius 31-38, 42, 70, $118,150-151,155$ note $54,189,217,245$ note 162, 262-264, 266, 271, 279, 289, 305

Braccioloni, Poggio 201, 291

Brandt, Gerard 323

Brazil, Dutch 233

Brett, Annabel 20-21

Browne, Thomas 149

Buchanan, George 246-247

Burgersdijk, Franco 31-35, 83, 158, 269 note $260,271,331$

Caesar 172, 246, 258

Calvinism 183, 203, 292-293, 296-299, $304-305,320-322,331,333,335^{-3} 6$, 340,344

Cappel, Louis 29

Captain-General, office of; see also:

Stadholderate $46,123,256,258,281$

Carthage 217, 259

Catholicism, toleration of 285,319 , 322-324, 329-332, 334-336, 347 
Cats, Jacob 105 note 101, 116, 137, 161-162, 199

Cattenbaert, Jasper 66

charity 170, 186, 189, 193, 306

Charles I, King of England 28, 37, 43, 47, $148,183,252$

Charron, Pierre $63,81-82$

Child, Josiah 227, 329, 351

Cicero 69, 72, 74, 93, 110, 114, 161, 168, 176, 180, 182, 184-185, 190, 193, 195-196, 225, 270, 357

De officiis 170, 186, 188-189, 243 moral philosophy of $170-171,347-348$ on res publica 261-263

citizenship

and immigration 159-161, 166, 216-217, 289

commercial 142, 190, 194, 196, 204 gender aspects of $161-163,166-167$ in Dutch urban context 21-22, 142, 157-159, 161-163, 204, 347 in republican tradition 200-204

civic militias 163-165, 219 civil society; see also: state of nature 44 , $142,144-145,150,153,156-158,160-161$, 172, 177-178, 182, 191, 203-204, 237, 269-270, 276, 285, 300, 305-307, 309, $313-315,325,333,346$

Cock, Gisbert 147 note 22

Colbert, Jean-Baptiste $35^{1}$

Collegiants $322,336,341$

colonialism 219-224, 249, 354

Comenius, Jan Amos 28-29, 31, 115

commerce; see also: free trade $1,4,10,16$, 18, 23, 45, 49, 93, 208-209, 212, 216-217, 219-222, 225, 227-234, 240, 242, 246, 248-250, 258-26o, 346, 348, 351-352 and democracy $276-279$ and rhetoric 139-140, 187-188 and toleration $285,324,327-329,337$ ethics of 184-196, 200-204, 241, 248, 346-348

Commines, Philippe de 106, 179

competition, economic 211, 213, 225-227, 231-232, 234-235, 277, 327

concord 23, 33-34, 124, 129, 185, 285-286, 288, 291-292, 295-296, 302, 305, 307, 309, 312, 317, 320-321, 323, 326-327, 332, $335,337,342,344,346-347$

conscience; see: freedom of conscience

Constans, Lucius Antistius, De jure ecclesiasticorum 312-314

Contarini, Gasparo 40 contract theory $22,142-146,152-154$, 156-157, 16o, 168, 204, 247, 251, 269, 305, 309

Contra-Remonstrants; see: Calvinism

Contzen, Adam 36

Coornhert, Dirck 188-190, 193, 326-328 corruption $85,125,143,181,183,185,190$, 192-193, 195, 200, 203, 291, 294, 308

court, courtiers 109-110, 112, 130, 134-135, 138-139, 179-181, 191-192, 241, 244-246, 248, 293-294, 315, 342-343

Cromwell, Oliver 47, 219, 253, 315, 329

Cunaeus, Petrus 184

Curaçao 233

Darby, John 345, 353-354

de factoism $64,129,149,157,263,286-287$

De la Court brothers

Politike Discoursen 53-54, 56, 59, 92, 96-97, 102-103, 145, 263, 291, 297, 305, 338-339, $35^{6}$

Politike Weeg-schaal 51-54, 56, 60, 81, 92-96, 100-103, 108, 132, 143-145, 152, 154, 165, 179-180, 216, 224, 237-239, 249-250, 254-255, 264, 266, 270, 272-275, 286, 338, 350, 355-356

Welvaren van Leiden $54-55,67,148$, 206-208, 210, 229, 232, 287

background of $25^{-27}$

textile firm of 205

De la Court, Johan

student years $27,30-33$

writings of $51-55,145,216,264,272-273$

De la Court, Johanna 88-90

De la Court, Nicolaas 233

De la Court, Pieter

Aanwysing 61-62, 81, 92, 96, 99, 103-104, 108, 129, 229, 232, 256-257, 287, 314, $327,336,339-340,350-35^{2}, 354$

Historie der gravelike regering 56-57, 6o, 92, 96, 98

Interest van Holland $56,59,61,66,69$, $92,96,113,141,229,232,235,256$, 267-268, 311, 329, 340, 351-352

Sinryke Fabulen 62, 117-127, 193, 250, 260, 278, 294, 344, 353

and Van der Voort brothers 232-233, $235^{-236,296,311,340}$

Grand Tour 27-30, 115, 154

in $16722-3,284$

last years $62,284-285,344$

letter to Harrington $1-2,252$

marriage to Tollenaar 55, 141-142, 196 
marriage to Van der Voort 197-198, 232 portraits of 196-199

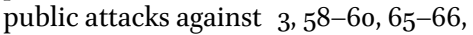
88-91, 315, 339 revisions by $52-56,100-103,132,145$, $148,15^{2}, 165^{-166,179-180,216,224,}$ 239, 255, 264, 266, 270, 273-275

De la Court sr, Pieter 25-27, 88, 142, 159, 199, 205

De la Court van der Voort, Magdalena 198

De la Court van der Voort, Pieter 28 note 16, 40, 198, 284

De Péréfixe, Hardouin 180-181, $25^{1}$ note 191

De Thou, Jacques-Auguste $330-331$

demagogy 22, 86, 110, 134, 272, 275-276, $295,302,305,307-308,316,320,344$

democracy $16,20,23,35-36,52,76,101$, $104,107,124,145,150-154,166-168,204$, 206, 215, 264, 268-275, 278-28o, 289, 310-311, 355-357

Descartes, René 29, 31-32, 80, 87, 118, 169, 339, 346, 356-357

Les passions de l'âme $82-85$

discipline 172, 177-184, 194, 244, 292, 353

Du Refuge, Eustache 181

Dutch republicanism 14-20, 42-50, 63-66, 82, 128-131, 147-149, 176-168, 214-215, 223-224, 240-241, 254-283, 310-312, 339, 346-349

Dutch Revolt 15, 46, 252, 286-287, 310, 320, 326,331

East India Company, Dutch (VOC) $232-236$

Eleman, Johannes 55, 141, 287

Elzevier publishers $40-41,44,70,82,84$, 146-147, 180-181, 215, 234

emblems 115-119, 121-127, 290

Emmius, Ubbo $215^{-216}$

Enden, Franciscus van den $57-58,128,167$, $278,342,355$

England $1-2,11,27-28,37,40,45,47,50$, $154,156,219,227,234,251-253,286$

English republicanism compared to Dutch republicanism 23 , 47, 129, 183-184, 206, 219, 223-224, $280-282,349,352-353$

historiography of $9,11-13,241$

Enlightenment 19-20, 23, 38, 279 reception of De la Courts in 349-357

Episcopius, Simon 302-303, 305, 311, 318-320, 332 equality $150-152,161,168,269,276-277$, 313-314

Erasmus, Desiderius 136, 138, 217, 286-287, 291, 296, 309, 319-320, 323, 337, $343-344,347$

Erastianism 300, 303, 305, 312, 314 ethics; see: commerce, ethics of

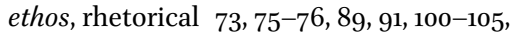
$264,272,287$

fables 22, 62, 111-133, 139-140, 238-239, 272, 289-290

Fajardo, Diego Saavedra 116-118, 180-181, 251 note 191, 257

Fernandez de Villareal, Manuel 234

Fijne, Passchier de 328

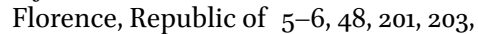
219, 239-240, 259, 262, 348

Foucault, Michel 140

France 29, 111-112, 138-139, 192, 251, 286, $351-35^{2}$

free trade; see also: commerce; monopolies; protectionism 49-50, 224-236, 348

freedom economic 209-213, 217, 226, 229, 236, $289,349,35^{1-} 35^{2}$

of conscience; see also: toleration 300$302,305,309-310,318-322,326$, 328-329, 333

of speech; see also: parrhèsia 138-139, 319, 337-343

religious; see: toleration republican; see: liberty, republican

Frijhoff, Willem 30

Further Reformation 292, 304

Geneva $30-31,67$

Genoa, Republic of 17, 48, 214, 266, 269

Gentillet, Innocent 129

German Imperial Cities 164, 288, 327

Ghistele, Joos van 254

Gianotti, Donato 40

Goldie, Mark 336

Gole, Jacob 117 note 142

Gordon, Thomas 353-354

Gournay, Vincent de 351

grandezza 207, 212, 221, 229, 277

Greenblatt, Stephen 21

Groot, Pieter de 55-56, 284, 323, 339

Grotius, Hugo 33, 35, 39, 42-43, 66, 70, 96 note $82,106,15^{2-153}, 155,160-161,184$, 230, 255, 309, 311, 313-315, 318, 333, 346-347 
De antiquitate 42, 49

De imperio 300-303, 307

on church and state 300-303, 305

on free trade and free seas

228-229, 236

on sovereignty $33,42-43,242,263$, 300-303, 305

Guicciardini, Francesco 106, 173, 176, 253-254

guilds, see also: monopolies 159, 161, 209, 211-212, 216, 234, 266, 278, 286, 289-290, 294, 298

Habermas, Jürgen 38

Hackius publishers 61

Haitsma Mulier, Eco 14, 16-18, 128, 266, 274

Harrington, James $1,6,10,17,64,130,156$, $158,201,215,219,249,277,280,282$, 329, 353

The Commonwealth of Oceana 6, 224, $25^{2-253}, 275^{-276}$

letter from De la Court to 1-2, $25^{2}$

Hartlib, Samuel 28

Hebrew Republic 44, 48, 183

Heereboord, Adriaan 28-32, 70, 87-91, 100-101, 113, 147

Hegel, Georg Wilhelm Friedrich 133

Heinsius, Daniel 26, 32, 72, 116

Heinsius, Nicolaas 26-28, 252

Henry IV, King of France 180, 315

Herodotus 215

Hill, Joseph 149

Hirschmann, Albert 173-174

Hobbes, Thomas $18,22,64,80,86$,

144-156, 178, 204, 242, 244, 287, 295,

303-304, 307, 346-347, 349-350,

356-357

Elements of Law 146, 151-152, 225 note 82

De cive 146-148, 150-152

Leviathan 146, 148-149, 152, 341

Dutch reception of $18,147-149$

on rhetoric 134-135

Holland, province of; see also: sovereignty, provincial 2-3, 23, 42-50, 55-62, 65-66, 71, 131, 149, 155, 158, 203, 216-217, 220-224, 226-232, 237, 240, 242, 244-245, 255-258, 26o, 266-269, 273, 277-278, 330-331, 333

honestum vs utile; see also: Cicero 186 , 188, 193

honour; see also: commerce, ethics of 22-23, 90-91, 142-143, 171-173, 184, 195-196, 200, 203-204, 270, 348
Hont, Istvan 226-227

Hoogstraten, Samuel van 199

Horace 113, 119

household 161-163

Hundert, E.G. 353

immigration 25, 141-142, 159-161, 222, 225-226, 229, 236, 267-268, 289, $327-328$

independence 161-168, 270, 355

interest of state; see also: reason of state; self-interest $4,11,41,45^{-46,64}, 66,231$, $236,242,258,35^{0}-35^{2}, 355$

irenicism 319-320, 323, 333

Israel, Jonathan 19-20, 321, 336

Italian republicanism; see also: Florence, Venice, Genoa, Lucca 11, 17, 44-45, 128, 201-203, 207, 214, 239-241, 259, 262, 288, 348

James I, King of England 130 James, Susan 83 jealousy of trade 226-229, 248 Jews, toleration of $301,323,332,334$ Juvenal 113,119

Kahn, Victoria 8-9, 128

Keckermann, Bartholomeus 72

Klinkhamer, Laurens 341

Koerbagh, Adriaen 149, 312, 340-342

Kossmann, Ernst $15^{-18}, 82,146,148,274$

La Rochefoucauld, François de 72

Laet, Johannes de 40

Latini, Brunetto 201

law, Roman 237-238, 241, 348

law, rule of 178-180, 183, 203, 248, 251

Le Clerc, Jean 353

Leibniz, Gottfried $345,35^{\circ}$

Leiden 22, 25, 54-55, 58, 88, 91, 189, 198, 207-208, 215-217, 220-226, 237, 269, 296, $321,328,339,35^{6}$

citizenship in $25,141-142,158-159,163$

city council (veertigraad) 141-142, 266-267, 278

economy and industry 205-213

Leiden University $30-32,37-38,54,70-71$, $87,207,212-213,215,296,313,353$

Lescaille, Jacob 215

Levellers 167

liberalism 6-8, 11, 241, 349

liberty, natural 210-211, 225, 243, 237, 333

liberty, republican $8,42,45-49,96,123$, 138-139, 206, 236-241, 255, 258, 263, 267, 282, 291, 308-309, 333, 339, 343, 346-349 
Limborch, Philippus van 323-324, 353

Lipsius, Justus 35,8 o note 42, 199, 285, $287,305,326-327,357$

Livy 218

Locke, John 115, 287, 317, 324, 329-330, 335, $35^{2}$

Louis XIV, King of France 1, 138, 180, $25^{0}$

Lucan 106, 172, 180, 218, 248

Lucassen, Jan 54

Lucca, Republic of 48, 164, 214, 219

Luther, Martin 136

luxury 10, 185-186, 192, 194, 217

Luzac, Elie 357

Macchiavelli, Niccolò $5-11,14-19,35,54$, 63-64, 126, 132, 16o, 179, 201, 215, 220, 227, 253-254, 262, 264-266, 284 note 2 , 291, 309, 346, 349, 354, 357

Discorsi $182,218,243^{-244}, 247$ note 171

anti-clericalism 291-292, 295

Dutch reception of 128-129

on civic militia $164-165$

on Rome 218-219, 240, 251, 291

Madison, James 354-355

Maissen, Thomas 11

Malcolm, Noel 18, 146, 307

Malvezzi, Virgilio 174

Malynes, Gerard de 228

Mamluk Sultanate 254

Mandeville, Bernard 353

Marquardus, Johannes 189-19o

Marsilius of Padua 298

Maurice of Orange, Stadholder 43, 93, 302

Mazarin, Cardinal 180

Meijer, Lodewijk 312-313

Menestrier, Claude François 116

mercator sapiens; see also: Barlaeus, Caspar 184-188, 196, 199, 204, 347-348

Meursius, Joannes 215

Mey, Johannes de 29

middle groups 39-40, 64, 66, 343

Milton, John $38,86,128,183,194$ note 196 , 223, 251-252, 280, 282, 287, 329-330, 338,353

Misselden, Edward 228

mixed constitution, regnum mixtum $35^{-36,44,47,49-50,52, ~ 155, ~ 247, ~}$ 254-255, 350

Monarchomachs 153, 247, 287

monarchy, anti-monarchism 2-4, 19, 20-23, 28, 35-36, 42-45, 47-49, 52,

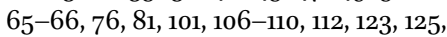
128, 130-132, 138-139, 151, 153-155, 172, 179-182, 206, 242, 244-254, 273, 279-280, $282,289,315,342-343,346,349,354-35^{6}$ monopolies; see also: guilds 232-236, 248, 351

Montaigne, Michel de 173, 288

Montesquieu, Charles de 351

More, Thomas 29, 63, 230

natural law 3, 14, 20, 145, 306, 309, 325-326, 337

Nedham, Marchamont 11, 156, 175, 215, 219, $253,275,280,282$

Nelson, Eric 231

Neostoicism; see also: Lipsius, Justus 17,83

Norbrook, David 9, 11, 106

Nyenborgh, Johan van 196

Ogilby, John $116-117,122$ note 156

Oglethorpe, James 354

oikeiosis $15^{2}$

Oldenbarnevelt, Johan van 302, 311, 315

oligarchy $50,56,212-213,266-269,273$, 278-279, 294

Orangism 2, 46-47, 49, 58, 64-66, 149, 254-255, 257-258, 287, 292-293, 296, 310-311

Orlers, Jan 208-209

ornatus, rhetorical $77_{-79,105^{-114}}$

Ottoman Empire 52, 249, 254, 259, 281-282

Overbeke, Aernout van 113 note 122

Owen, John 338

pacifism, peace $46-47,49-50,165$, 216-217, 219-221, 268

Paets, Adriaan 322

Palmieri, Matteo 201

pamphlets, pamphleteering 3, 37-41, 43-50, 58-6o, 64-65, 88-92, 196, 221, 227-228, 233, 292-293, 296, 303-304, $310-312,318-320,322-323,357$

Papal States 253

paradiastole; rhetorical redescription 79 , 108-109, 320

Parker, Henry 154-155, 210 note 20,233

Parkin, Jon 149-150

parrhèsia 100, 104-105, 112, 125,

133, 136-140, 167, 188, 261, 295, 337. 343, 347

Paruta, Paolo 54, 219-220

passions, affectus 72, 8o-87, 143, 162, 169, 172-173, 177-183, 193-194, 265, 281, 306, 308, 346

and rhetoric $71-81,85-87,89-91,108$, 123, 272-275, 294

patriarchy $161-163$ 
Peace of Westphalia (1648) 45-46, 208, 221

Pepys, Samuel $35^{2}$

Perpetual Edict (1667) 61, 256

persecution, religious $237,295,318$, 322-334

Pettegree, Andrew 318

Petty, Willliam 329

Pincus, Steven 10-11, 349

Plato 63, 134, 230-231, 357

Pocock, John $5^{-15}, 20,165,200-201,349$

politica, academic $34,44,52,67,103,150$, 261-262, 264, 271, 349

poorters; see: citizenship

popular government; see: democracy

Port Royal Logic 85

property, private $230-231$

protectionism, economic 209-213, 232

public church 301-302, 308-309, 316, 318-321, 332-334

public prayer, debate over $310-312$, 314, 341

Pufendorf, Samuel 154, 314, 350

Quintilian 69, 72, 114

Ragusa, Republic of 48, 164, 214, 219

Rahe, Paul 8, 349

Rampius, Janus 149

Ramus, Pierre $69-70$, note 2,73

reason of state $3,20,33,41,48,128$, 173-175, 206-207, 209-211, 220-221, 224-225, 227-228, 232, 236, 248, 264, 279, 282, 326-327, 336, 346-347, 349-350

reformation of manners $12,22,178,183$, 190, 195

Remonstrants; see: Arminianism

republic, res publica 239, 261-264

republicanism $5^{-23,168,241,345^{-3} 37}$

exclusivist 184, 281-282

in Dutch Republic; see: Dutch republicanism

in England; see: English republicanism

in Italian Renaissance; see: Italian republicanism

rhetoric; see also: fables; ornatus;

paradiastole; parrhèsia 21-22, 69-140, 199, 272-275, 289, 293-295, 297, 315, 337, 343-344, 346, 347-348

Aristotelian $72-74,77,85$

Vossius on $70-80$

ridicule $78,110-113$

Richelieu, Cardinal 234

Rieuwertsz, Jan 106
Robinson, Henry 228

Rohan, Duke of 54, 174, 207, 221, 346

Rome, Ancient; see also: Augustus; Caesar 23, 48, 160, 215, 217-219, 221, 223, 239-240, 258, 266, 269, 291, 348

Rubens, Peter Paul 199

Saadi, Gulistan 106-107

Saldenus, Guiljelmus 296 note 42

Sallust 286, 338

Salmasius, Claudius 38, 189, $25^{2}$

Sansovino, Francesco 166 note 96, 214

satire; see: ridicule

Saumur, Protestant Academy of 29-30

Savonarola, Girolamo 239-240

Schalcken, Godfried 199

Schama, Simon 189, 200

schuilkerken, clandestine churches

319, 335

schutterijen; see: civic militias

Scott, Jonathan $12-13,183,280-281$

Selden, John 228

self-interest; see also: interest of state 35 , 150, 168, 173-177, 183-184, 193, 200, 204, 211, 234-235, 243-244, 248, 264-265, 275, $277,279,282,294,348-349,353,356$

self-love $85-86,143-144,153,168-182$, 191-192, 194, 213, 222, 242-244, 270, 272,353

Senault, Jean-François $84-85,169-171,177$

Seneca 84, 199, 344

Sharpe, Kevin 9, 92

Sidney, Algernon 183, 219, 223, 280, 282, 352-353

Sidon, ancient republic of 259

skepticism 286-288, 336

Skinner, Quentin 8, 11-12, 241, 349

slavery; see: liberty, republican

Smith, Adam 354

Smith, Thomas 253 note 200

Socinianism 322, 339

Socrates 134, 198-199

Sommerville, Johann 12

Sorbière, Samuel 147

sovereignty 41-42, 263, 307 ecclesiastical 298-315, 318, 341

division of $145,148,155^{-156}$, 299-300, 312

popular $153^{-154,273,278}$

provincial 41-42, 64, 145, 149, 155

Spain 251

Sparta 44, 132, 16o, 215, 266

Spinoza, Baruch 14-15, 18-19, 57, 63, 8o, 106, 146-147, 184, 200, 312-314, 345,

355-357 
on democracy $167-168,271,279$, $356-357$

on freedom of speech 342

Stadholderate, debate over $33^{-}-34,4^{-}-5$, 65-66, 107-108, 206, 217, 239-240, 254-261, 286, 288-289, 347, 349

state of nature $143^{-145}, 15^{0-153}, 155^{-157}$, 172, 237, 269, 286-287, 306-307, 309, 313

Stevin, Simon 157,287

Streater, John 214, 219

Sweerts, Hieronymus 62

Switzerland, Swiss cantons; see also: Geneva 11, 44, 48, 164, 288, 311

Tacitus $33,36,42$, 101 note $88,106,117$, 129-130, 171, 179, 180, 218, 239, 266, 269, 342-343, 357

taxation $229-232,247-248,258,268,277$

Teelinck, Maximiliaen 292-293, 296

Tempel, Abraham van den 198, 208

textile industry; see also: Leiden economy and industry 205-206, 209-211

Thucydides 215

Thysius, Antonius 218

Toland, John 329, 353

toleration $23,29,160,184,285,303$, 316-337, 346, 349

Tollenaar, Elisabeth 55,141

Trigland, Jacob 303

Trenchard, John 353

Tuck, Richard 327

Turgot, Anne Robert Jacques $35^{1}$

tyranny $23,136,183,212,217,242,245,247$, $249^{-251}, 253,255^{-256}, 260-263,283$, $287,308,311$

Tyre, ancient republic of 259

Udemans, Godefridus 189, 193

Union of Utrecht 44,300

Uytenbogaert, Johannes 298-305, 318, $3^{20}-321,323$

Uythenhage de Mist, Johan 59-6o, 235

Valkenier, Petrus 66 note 142

Velthuysen, Lambert van 147, 303-305, $312,322-323$

Venice, Republic of $17,40,44,48,52,130$, $166,187,214,219,224,266$

Venturi, Franco 11
Veth, Adriaan $49^{-} 5^{0}$

virtue, virtù $6-11,14,18,82,84-85,88-89$, 91, 93, 105, 108-109, 129, 132, 134, 138, 169-172, 177-180, 182, 185, 187-190, 193-196, 200-204, 211, 243, 294, 300, 325,348

Visentin, Stefano 18

VOC, see: East India Company

Voetius, Gijsbert 304-305, 307, 311-312, $321-322$

Voltaire 337

Vondel, Joost van den 93-96, 116-117, 131 note $172,292,294,297,328$

Voort, Catharina van der 197-199, 232

Voort, Giovanni and Guglielmo van der 197-198, 232-233, 235-236, 296, 310-311, 340

Vossius, Gerard 70-72, 86, 89, 100, 102-103, $105,110-111,114-115,124,134,139-140$, 184,300

Rhetorices contractae $7 \mathbf{1}^{-79}$

Vossius, Isaac 252

Vranck, François 155

Walsham, Alexandra 336

Walwyn, William 234, 325 note 154

Wassenaer, Gerard van 57,80

Weber, Max 203

Werdenhagen, Johannes 36, 150, 262

West India Company, Dutch (WIC) 40

William II, Stadholder 43, 47, 49, 148, 254, 256, 259, 287, 292, 296, 303

William III, Stadholder 2, 50, 62, 100, 121, $123,132,179,261,353$

William the Silent, Stadholder 43, 46, 257, 259, 315

Willighen, Hendrik van 55

Wit, Johan de 233, 235 Public Gebedt $310-311,314$

Witt, Johan de 2-3, 61, 254-256, 267, 344-345, 347, 351, 353

Deductie 48-49

and De la Court 55-56, 59, 69, 268, 339

Wootton, David 12

Worden, Blair 11

Zeeland, province of 49-50, 55, 292

Zinkgref, Julius Wilhelm 117 